
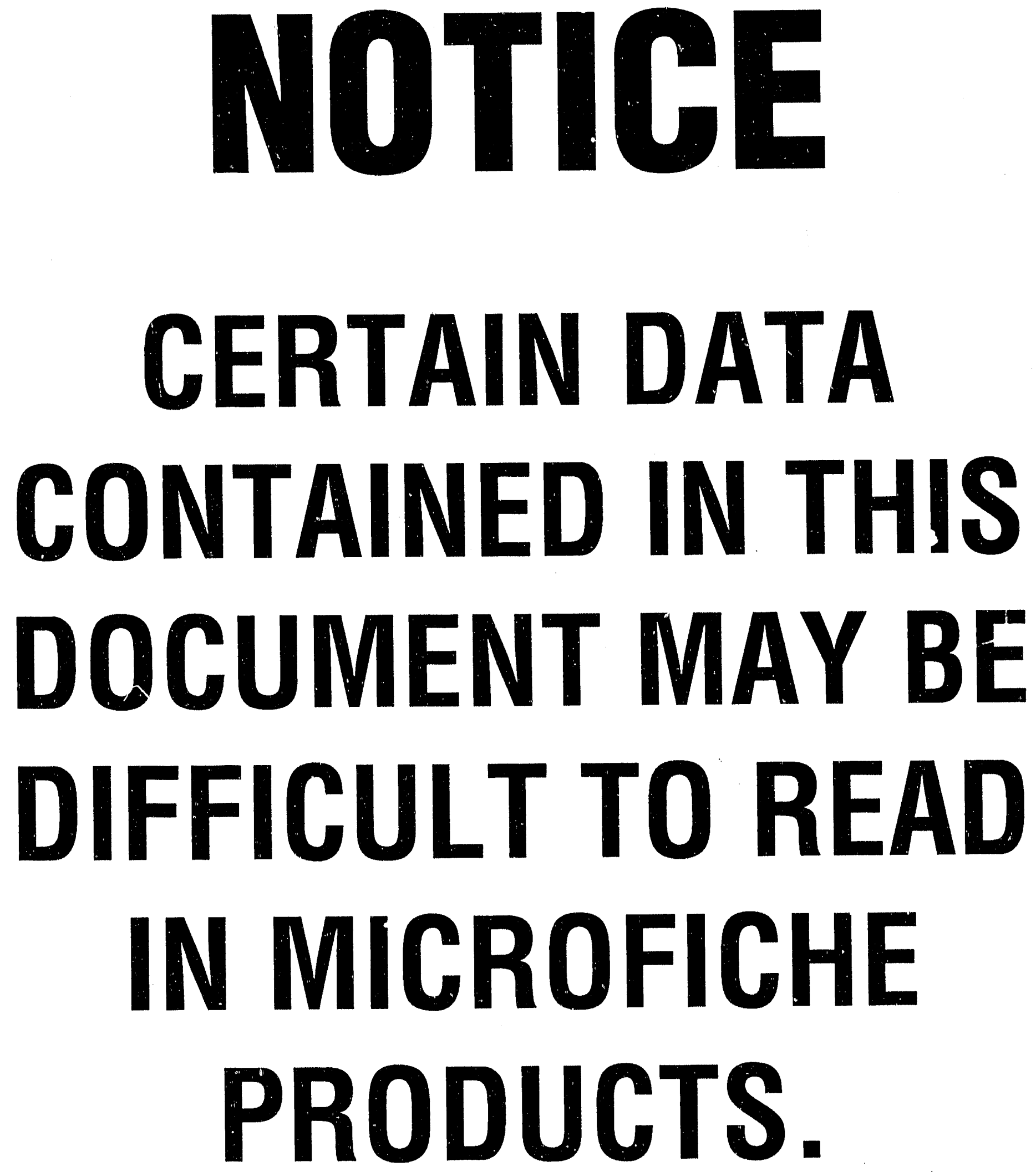


\title{
DATA USED IN PRELIMINARY PERFORMANCE ASSESSMENT OF THE WASTE ISOLATION PILOT PLANT (1990)
}

\author{
Rob P. Rechard \\ Harold Iuzzolino*, Jim S. Sandha** \\ Performance Assessment Division \\ Sandia National Laboratories \\ Albuquerque, New Mexico 87185
}

\begin{abstract}
This report documents the data available as of August 1990 and used by the Performance Assessment Division of Sandia National Laboratories in its December 1990 preliminary performance assessment of the Waste Isolation Pilot Plant (WIPP). Parameter values are presented in table form for the geologic subsystem, engineered barriers, borehole flow properties, climate variability, and intrusion characteristics. Sources for the data aid a brief discussion of each parameter are provided.
\end{abstract}

\section{MASTER}




\section{RELATED WIPP PERFORMANCE ASSESSMENT DOCUMENTS}

\section{PUBLISHED}

Bertram-Howery, S. G., and R. L. Hunter, eds. 1989. Plans for Evaluation of the Waste Isolation Pilot Plant's Compliance with EPA Standards for Radioactive Waste Management and Disposa1. SAND38-2871. Albuquerque, NM: Sandia National Laboratories.

Bertram-Howery, S. G., and R. L. Hunter, eds. 1989. Preliminary, Plan for Disposal-System Characterization and Long-Term Performance Evaluation of the Waste Isolation Pilot Plant. SAND89-0178. Albuquerque, NM: Sandia National Laboratories.

Bertram-Howery, S. G., and P. Swift. 1990. Status Report: Potential for Long-Term Isolation by the Waste Isolation Pilot Plant Disposal System, 1990. SAND90-0616. Albuquerque, NM: Sandia National Laboratories.

Bertram-Howery, S. G., M. G. Marietta, D. R. Anderson, K. F. Brinster, L. S. Gomez, R. V. Guzowski, and R. P. Rechard. 1989. Draft Forecast of the Final Report for the Comparison to 40 CFR Part 191, subpart B for the Waste Isolation Pilot Plant. SAND88-1452. Albuquerque, NM: Sandia Nationa1 La"poratories.

Pertram-Howery, S. G., M. G. Marietta, R. P. Rechard, P. N. Swift, D. R. Anderson, B. Baker, J. Bean, W. Beyeler, K. F. Brinster, R. V. Guzowski, J. Helton, R. D. McCurley, D. K. Rudeen, J. Scheiber, and P. Vaughn. 1990. Preliminary Comparison with 40 CFR Part 191, Subpart $B$ for the Waste Isolation Pilot Plant, December, 1990. SAND90-2347. Albuquerque, NM: Sandia National Laboratories.

Guzowsk1, R. V. 1990. Preliminary Identification of Scenarios That May Affect the Escape and Transport of Radionuclides From the Waste Isolation Pilot Plant, Southeastern New Mexico. SAND89-7149. Albuquerque, NM: Sandia National Laboratories.

Helton, J. C. 1990. Sensitivity Analys is Techniques and Results ir. Performance Assessment of the Waste Isolation Pilot Plant. SAND90-7103. Albuquerque, NM: Sandia National Laboratories.

Hunter, R. L. 1989. Events and Processes for Constructing Scenarios for the Release of Transuranic Waste from the Waste Isolation Pilot Plant, Southeastern New Mexico. SAND89-2546. Albuquerque, NM: Sandia National Laboratories.

Marietta, M. G., S. G. Bertram-Howery, D. R. Andersor, K. F. Brinster, R. V. Guzowski, H. J. Iuzzolino, and R. P. Rechard. 1989. Performance Assessment Methodology Demonstration: Methodology Development for Evaluating Compliance with EPA 40 CFR 191, Subpart B, for the Waste Isolation Pilot Plant. SAND89-2027. Albuquerque, NM: Sandia National Laboratories. 
Rechard, R. P. 1989. Review and Discussion of Code Linkage and Data Flow in Nuclear Waste Compliance Assessments. SAND87-2833. Albuquerque, NM: Sandia National Laboratories.

Rechard, R. P., H. J. Iuzzolino, J. S. Rath, R. D. McCurley, and D. K. Rudeen. 1989. Uiser's Manual for CAMCON: Compliance Assessment Methodology

Controller. SAND88-1496. Albuquerque, NM: Sandia National Laboratories.

Rechard, R. P., W. Beyeler, R. D. McCurley, D. K. Rudeen, J. E. Bean, and J. D. Schreiber. 1990. Parameter Sensitivity Studies of Selected Components of the Waste Isolation Pilot Plant Repository/Shaft System. SAND89-2030. Albuquerque, NM: Sandia National Laboratories.

Tierney, M. S. 1990. Constructing Probability Distributions of Uncertain Variables in the Models of the Performance of the Waste Isolation Pilot Plant. SAND90-2510. Albuquerque, NM: Sandia National Laboratories.

\section{IN PREPARATION}

Berglund, J., and M. G. Marletta. A Computational Model for the Direct Removal of Repository Material by Drilling. SAND90-2977. Albuquerque, NM: Sandia National Laboratories.

Brinster, K. F. Preliminary Geohydrologic Conceptual Model of the Los Medanos Region near the Waste Isolation Pilot Plant (WIPP) for the Purpose of Performance Assessment. SAND89-7147. Albuquerque, NM: Sandia National Laboratories.

Chen, Z., and H. L. Schreyer. Formulation and Computational Aspects of Plasticity in Damage Models for Geological Materials with Emphasis on Concrete. SAND90-7102. Albuquerque, NM: Sandia National Laboratories.

Guzowski, R. V. Applicability of Probability Techniques to Determining the Probability of Occurrence of Potentially Disruptive Intrusive Events at the Waste Isolation Pilot Plant. SAND90-7100. Albuquerque, NM: Sandia National Laboratories.

Hora, S., D. Scott, and K. Trauth. Expert Judgment on Inadvertent Human Intrusion into the Waste Isolation Pilot Plant. SAND90-3063. Albuquerque, NM: Sandia National Laboratories.

Marietta, M. G., D. R. Anderson, D. Scott, and P. Swift. Review of Parameter Sensitivity Studies for the WIPP. SAND89-2028. Albuquerque, NM: Sandia National Laboratories.

Marietta, M. G., P. N. Swift, B. L. Baker, K. F. Brinster, and P. J. Roache. Parameter and Boundary Conditions Sensitivity Studies Related to Climate Variability and Scenario Screening for the Waste Isolation Pilct Plant. SAND89-2029. Albuquerque, NM: Sandia National Laboratories. 
Marietta, M. G., R. P. Rechard, P. N. Swift, and others. Preliminary Probabilistic Safety Assessment of the Waste Isolation Pilot Plant. SAND90-2718. Albuquerque, NM: Sandia National Laboratories.

Rechard, R. P., A. P. Gilkey, D. K. Rudeen, J. S. Rath, W. Beyeler, R. Blaine, H. J. Iuzzolino, and R. D. McCurley. User's Reference Manual for CAMCON: Compliance Assessment Methodology Controller Version 3.0. SAND90-1983. Albuquerque, NM: Sandia National Laboratories.

Rechard, R, P., P. J. Roache, R. L. Blaine, A. P. Gilkey, and D. K. Rudeen. Quality Assurance Procedures for Computer Software Supporting Performance Assessments of the Waste Isolation Pilot Plant. SAND90-1240. Albuquerque, NM: Sandia National Laboratories.

Roache, P. J., R. Blaine, and B. L. Baker. SECO User's Manual. SAND90-7096. Albuquerque, NM: Sandia National Laboratories.

Tierney, M. S. Combining Scenarios in a Calculation of the Overall Probability Distribution of Cumulative Releases of Radioactivity from the Waste Isolation Pilot Plant, Southeastern New Mexico. SAND90-0838. Albuquerque, NM: Sandia National Laboratories. 


\section{PREFACE}

This report is a compilation of data and pertinent information used in the preliminary comparison of the Waste Isolation Pilot Plant (WIPP) with the Environmental Protection Agency's (EPA's) Environmental Standards for the Management and Disposal of Spent Nuclear Fuel, High-Level, and Transuranic Radioactive Wastes (40 CFR 191). The parameters reported herein will be updated as better information becomes available. Thus, this report is only a snapshot of the data as of August 1990. At a minimum, updated reports will be issued annually in conjunction with the comparison of the WIPP with 40 CFR 191. (Because of the many sensitivity studies planned for next year, two updates of the data report are currently planned for 1991.) The 1990 comparison and background information on the comparison are reported in:

Bertram-Howery, S. G., M. G. Marietta, R. P. Rechard, P. N. Swift, D. R. Anderson, B. Baker, J, Bean, W. Beyeler, K. F. Brinster, R. V. Guzowski, J. Helton, R. D. McCurley, D. K. Rudeen, J. Scheiber, and P. Vaughn. 1990. Preliminary Comparison with 40 CFR Part 191, Subpart B for the Waste Isolation Pilot Plant, December, 1990. SAND90-2347. Albuquerque, NM: Salidia National Laboratories.

Marietta, M. G., R. P. Rechard, P. N. Swift, and others. 1990. Preliminary Probabilistic Safety Assessment of the Waste Isolation Pilot Plant. SAND90-2718. Albuquerque, NM: Sandia National Laboratories. In preparation.

Berglund, J., and M. G. Marietta. 1990. A Computational Model for the Direct Removal of Repository Material by Drilling.

SAND90-2977. Albuquerque, NM: Sandia National Laboratories. In preparation.

Helton, J.C. 1990. Sensitivity Analysis Techniques and Results for Performance Assessment of the Waste Isolation Pilot Plant. SAND90-7103. Albuquerque, NM: Sandia National Laboratories.

Other compilations of data used by the WIPP project are reported in:

Bayley, S. G., M. D. Siegel, M. Moore, and S. Faith. 1990. Sandia Sorption Data Management System Version 2 (SSDMSII). SAND89-0371. Albuquerque, NM: Sandia National Laboratories.

Krieg, R. D. 1984. Reference Stratigraphy and Rock Properties for the Waste Isolation Pilot Plant (WIPP) Project. SAND83-1908. Albuquerque, NM: Sandia National Laboratories.

Munson, D. E., J. R. Ball, and R. L. Jones. 1990. "Data Quality Assurance Controls through the WIPP In Situ Data Acquisition, Analysis, and Management System" in Proceedings of the International High-Level Radioactive Waste Management Conference, Las Vegas, NV, April 8-12. Sponsored by American Nuclear Society and ASCE, New York, p. 1337-1350. 
A short companion document to this report is

Tierney, M. S. 1990. Constructing Probability Distributions of Uncertain Variables in the Models of the Performance of the Waste Isolation Pilot Plant (WIPP). SAND90-2510. Albuquerque, NM:

Sandia National Laboratories.

This report by Tierney presents the current procedures used to elicit data from researchers at Sandia, select appropriate distribution types, and construct empirical distributions. Although the discussion in Tierney (1990) is closely related to the information presented in this report, his report is being published separately to focus attention on the procedures used and perhaps elicit constructive comments.

Although the Performance Assessment (PA) Division is responsible for comparing the Waste Isolation Pilot Plant with the EPA Standard, $40 \mathrm{CFR}$ 191. Subpart B, the majority of data used for these comparisons is supplied by experimentors and analysts characterizing the disposal system and surrounding regional geology in the Fluid Flow \& Transport (6344), Disposal Room System (6345), and Repository Isolation Systems (6346) Divisions at Sandia National Laboratories. Supplying data as ranges and distributions to the PA Division is a major task. The contributions by R. L. Beauheim, P. B. Davies, M. D. Siegel, and B. M. Butcher are greatly appreciated.

Others who contributed data and information are A. C. Peterson (radionuclide inventory) and $M$. S. Tierney (human intrusion probability mode 1 ).

In addition to the individual contributors who established the current data (and are listed in Appendix $A$ of this report), earlier contributors are also acknowledged. Most of the earlier data is summarized in Systems Analysis Long-Term Radionuclide Transport, and Dose Assessments, Waste Isolation Pilot Plant (WIPP), Southeastern New Mexico; March 1989, edited by Lappin et al. (1989). Because of this report's wide circulation, we found it convenient to refer to this report as a data source, when in many cases it only summarized others' work. Its selection as a source was not meant to diminish the contributions of the original authors. However, Lappin et al. (1989) is also one of the first reports in which ranges were assigned for many parameters, so it does provide a primary reference for these ranges. Furthermore, some of the data have not yet been published and thus Lappin et al. (1989) series as the only source until the reports are complete.

We appreciate the time and suggestions supplied by the final peer reviewers: A. C. Peterson (6342) and A. M. LaVenue (INTERA, Inc.). Furthermore, J. M. Jamison's (New Mexico Engineering Research Institute) efforts in producing all the tables in this report from the database are greatly appreciated. In addition, the editorial help on the text and figures provided by J. Chapman and D. Pulliam, respectively, of Tech Reps, Inc., Albuquerque, New Mexico, greatly improved the report. 


\section{CONTENTS}

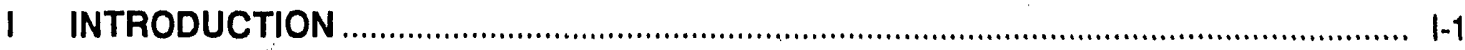

Purpose and Organization of Report..................................................................... I

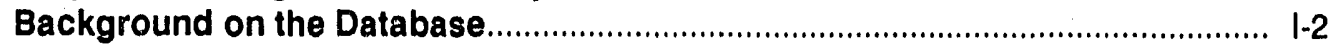

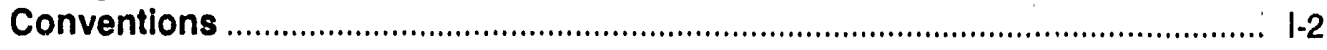

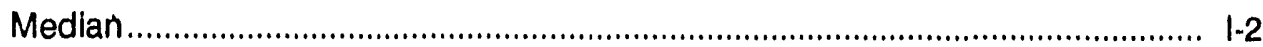

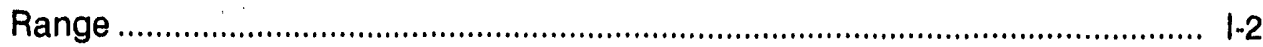

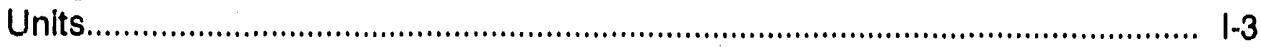

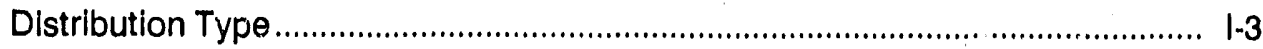

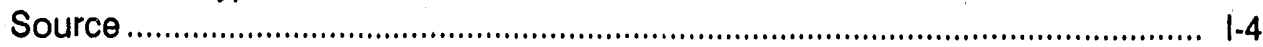

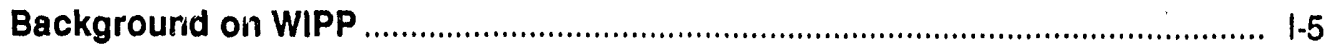

Purpose and Location......................................................................... $1-5$

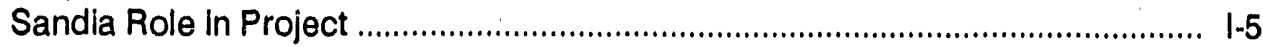

II GEOLOGIC SUBSYSTEM

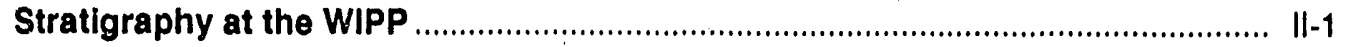

Parameters for Halite and Polyhalite within the Salado Formation...................... II-7

Capillary Pressure and Relative Permeability ....................................................... II-8

Salado Capacitance ..............................................................................................

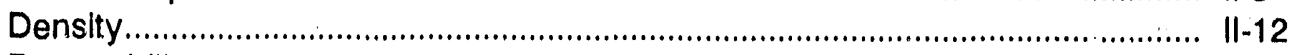

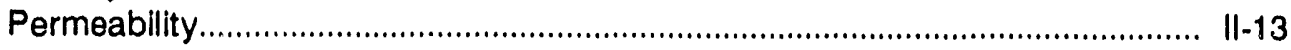

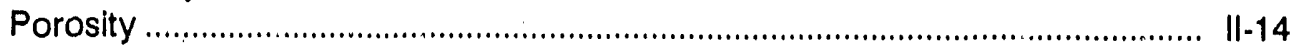

Brine Pressure at Repository Level .................................................................... $\|$ I-14

Parameters for Marker Bed 139 and Other Anhydrite Layers near Repository ... II-16

Capillary Pressure and Relative Permeabllity ..................................................... II-16

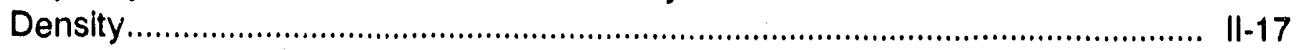

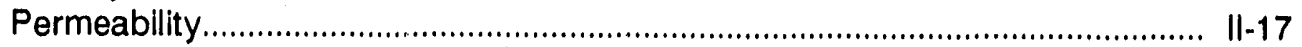

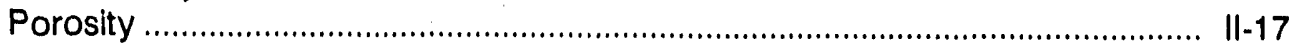

Thickness of Interbed .............................................................................. $\|$

Parameters for Castile Formation Brine Pocket .................................................. $\|$ I-21

Brine Pocket Model.............................................................................................

Location of Castile Brine Pocket below WIPP Disposal Area ............................. II-25

Parameters for Culebra Dolomite Member....................................................... II-28

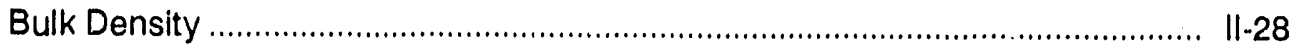

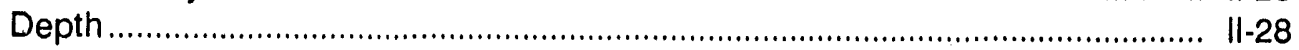

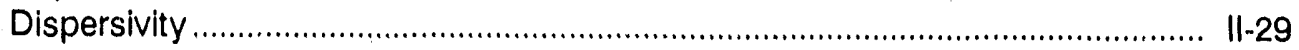

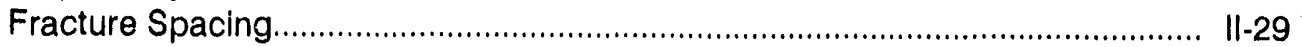

Fraction of Clay Filling in Fractures..................................................................

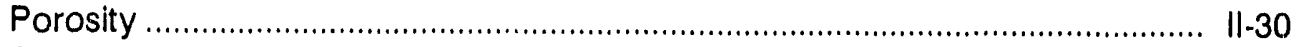

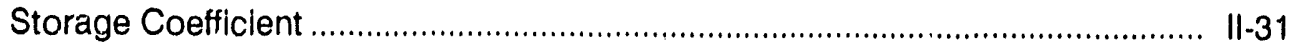

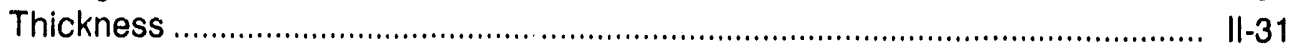

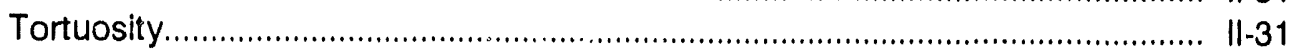

Partitioning Coefficients and Retardation ................................................... $\|$ I-31

Hydraulic Conductivities for Model Zones....................................................... II-38

Miscellaneous Geologic Material .................................................................. $\|$ I-61.

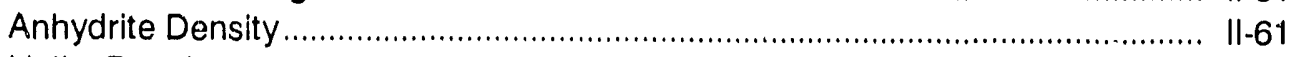

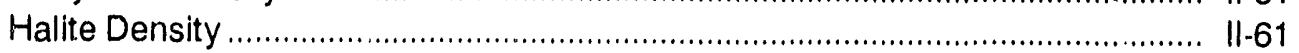




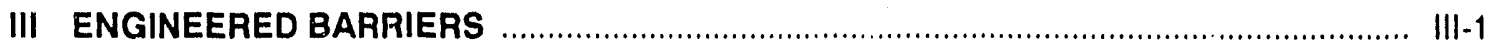

Seal Matarial Parameter Values for Crushed Salt.............................................. III-4

Parameter Values for Unmodified Waste Form Including Containers................. III-5

Capillary Pressure and Relative Permeability ................................................. III-5

Drilling Erosion Parameters .............................................................................. III

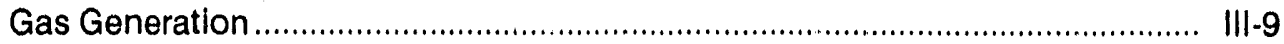

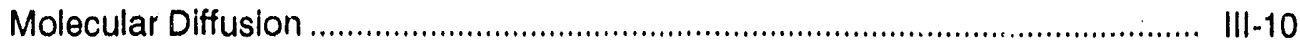

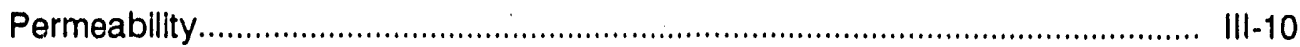

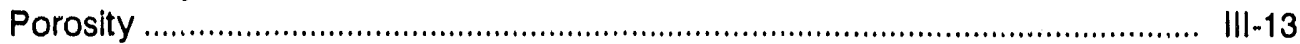

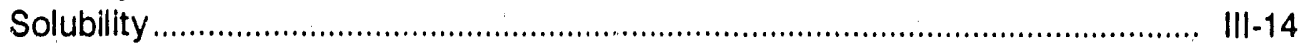

Parameter Values for Modific d Waste Form.................................................. $\quad|1|-17$

Permeability and Porosity................................................................................ $111-17$

Drilling Erosion Parameters.............................................................................. III-19

Solubility and Leachability .............................................................................. II-19

Parameter Values for Radionuclides ....................................................... III-20

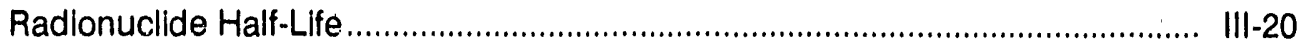

Inventory for Contact-Handled Waste.................................................................... III-20

Inventory for Remotely Handled Waste .......................................................... III-24

IV GLOBAL MATERIALS AND MISCELLANEOUS .................................................. IV-1

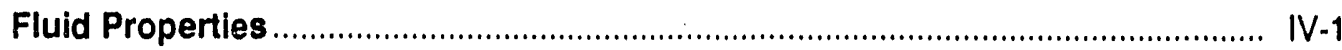

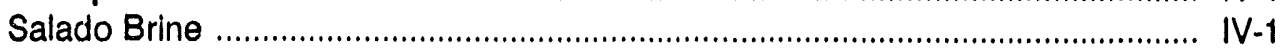

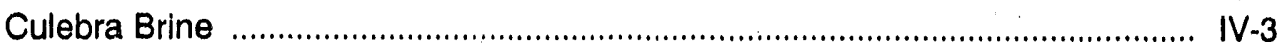

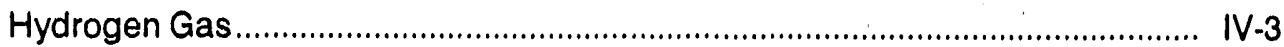

Climate Variability and Intrusion Characteristics ............................................ IV 6

Borehole Flow Properties .............................................................................. IV-7

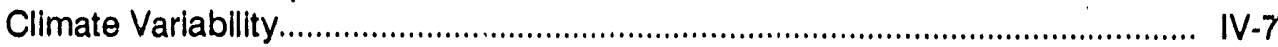

Drilling Characteristics................................................................................. IV-10

Intrusion Characteristics for Scenarios ........................................................... IV-12

Intrusion Cháacteristics for Multiple Intrusions ............................................... IV-17

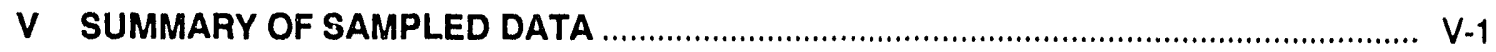

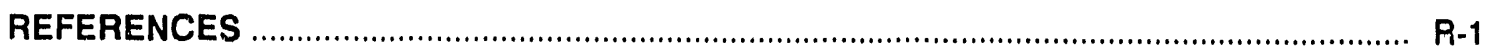

APPENDIX A: Memoranda and Letters Regarding Reference Data ................................. A-1

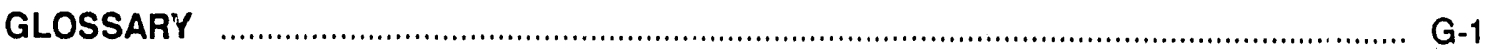

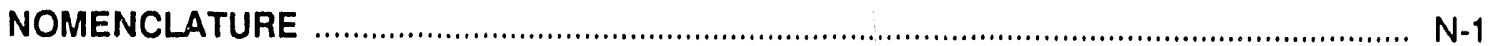




\section{FIGURES}

Figure

1-1 WIPP Location in Southeastern New Mexico.

$1-6$

1-2 Proposed WIPP Repository, Showing Both TRU Disposal Areas and Experimental Areas.

II-1 Level of WIPP Repository, Located in the Salado Formation

II-2 Stratigraphy at the Repository Horizon $11-3$

II-4 Marker Bed 139, One of Many Anhydrite Interbeds near the WIPP Repository Horizon

II-5 Assumed Capillary Pressure Curve for Salado Salt

$\| 10$

II-6 Relative Permeability Determined from Tight Gas Sands Analog for Halite Using Brooks and Corey Model.

II-7 Lognormal pdf and cdf for Salado Capacitance

$11-12$

II-8 Experimental pdf and cdf for Salado Permeability....

$11-13$

II-9 Uniform pdf and cdf for Brine Pressure at Repository Level.

II-15

II-10 Estimated Capillary Pressure Curve for Marker Bed 139 and Other Anhydrite Layers near Repository.

$11-18$

II-11 Estimated Relative Permeability for Marker Bed 139 and Other Anhydrite Layers near Repository.

II-12 Observation Wells in the WIPP Area.....

$11-22$

II-13 Conceptual Model of Castile Brine Pocket Repository and Borehole Requires a Specified Initial Brine Pocket Pressure and a Bulk Storage Coefficient.

II-14 pdf and cdf for Castile Brine Pocket Initial Pressura.

$11-25$

II-15 Uniform pdf and cdf for Castile Brine Pocket Initial Compressibility Volume ............. II-26

II-16 Contour Map of Depth to First Major Conductor below WiPP Disposal Area ............ $\quad$ II-27

$\|$ pdf and cdf for Culebra Fracture Spacing ...................................................... $\quad \|-30$

II-18 Variation of Culebra Member Thickness as Estimated by 10 Nearest Neighbors Using Inverse-Distance-Squared Weighting...................................................... $\quad \|-32$

II-19 pdf and cdf for Culebra Tortuosity

11-33 
II-20 Estimated pdf and cdf for Retardation Factor for Plutonlum ................................. $\quad$ II-39

II-21 Estimated pdf and cdf for Retardation Factor for Americium .................................. II-39

II-22 Estimated pdf and cdf for Retardation Factor for Neptunium ............................... $\quad \|-40$

II-23 Estimated pdf and cdf for Retardation Factor for Uranium................................... $\quad \|-40$

II-24 Estimated pdf and cdf for Fracture Retardation for Plutonium................................ $\quad \|-41$

II-25 Estimated pdf and cdf for Fracture Retardation for Americium.............................. $\quad \|-41$

II-26 Estimated pdf and cdf for Fracture Retardation for Neptunium ............................ $\quad \|-42$

II-27 Estimated pdf and cdf for Fracture Retardation for Uranium .............................. $\quad \| 1-42$

II-28 Transmissivity Zones based on Steady-State Transmissivity Wells without Pllot Points...................................................................................... $\quad 11-47$

11-29 Comparison of Initially Kriçad Log 10 Transmissivity Field with Trarismissivity Zones.....

II-30 Transmissivity Zones based on Steady-State Transmissivity Wells and Pllot Points.

II-31 Comparison of Transient Callbrated Log 10 Transmissivity Field with Transmissivity Zones...

II-32 SECO Regional Domain with Zones Based on Single Well Tests.....

II-51

II-33 SECO Regional Domain with Zones Based on Both Single Well iests snd Pilot Points.

II-34 pdf and cdf for Hydraulic Conductivity in Zone 1

pdf and cdf for Hydraulic Conductivity in Zone 2. pdf and cdf for Hydraulic Conductivity in Zone 3 
Figure

II-45 pdf and cdf for Hydraulic Conductivity in Zone G............................................. $\quad$ II-58

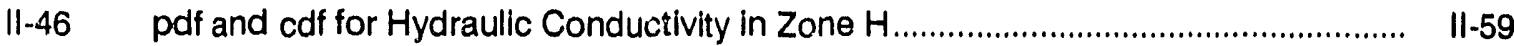

II-47 pdf and cdf for Hydraulic Conductivity in Zone I....................................................... II-59

II-48 pdf and cdf for Hydraulic Conductivity in Zone J................................................. $\quad 11-60$

II-49 pdf and cdf for Hydraulic Conductivity in Zone K ................................................. $\quad \|-60$

III-1 Dlagram of Typical Backfilled and Sealed Access Shaft............................................. III-2

III-2 Diagram of Typical Multicomponent Seals :......................................................... III-3

III-3 Diagram of Typical Multicomponent Seal for Drifts and Panels ............................... III-3

III-4 Estimated Capillary Pressure Curve for Unmodifled Waste......................................... III-7

III-5 Estimated Relative Permeability for Unmodified Waste .............................................. III-8

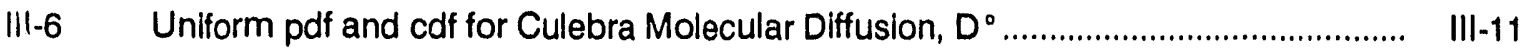

III-7 Loguniform cdf for Salado Solubility ..................................................................... III-16

IV-1 Formation Volume Factor for Salado Brine …...................................................... IV-2

IV-2 Formation Volume Factor for Hydrogen Gas................................................... IV-4

IV-3 Lognormal pdf and cdf for Borehole Permeability .............................................. IV

IV-4 Normal pdf and cdf for Borehole Porosity ......................................................... IV

IV-5 Normalized Closure for Shaft ............................................................................... IV

IV-6 Uniform Distribution for Precipitation............................................................. IV-9

IV-7 Unlform Distribution for Climate Boundary Condition Recharge Factor.................... IV-10

IV-8 Histogram Distribution for Drill Bit Cross Sectional Area......................................... IV-12

IV-9 Exponential Distribution for Time of Intrusion for E1, E2, and E1E2 Scenari, s......... IV-14

IV-10 Current Maximum Probability Values for Scenarios E1, E2, and E1E2 ................... IV-16

IV-11 Current Minimum Probability Values for Scenarios E1, E2, and E1E2 ..................... IV-16

IV-12 Histogram Distribution for Numiber of Intrusions for Multiple Hits........................... IV-18

IV-13 Uniform Distribution for Location of Intrusion (Room Number) .............................. IV-19

IV-14 Uniform Distribution for Global Time of Intrusion for Multiple Hits ............................ IV-20 


\section{TABLES}

Table

II-1 Depths of Stratigraphic Layers around Waste, Exhaust, and Salt Handling Shafts ... II-6

II.2 Parameter Values for Salado Formation near Repository ....................................... $\quad \|-7$

II-3 Probabillty Distributlon Function for Undisturbed Salado Permeabllity ..................... $\quad \| 1-7$

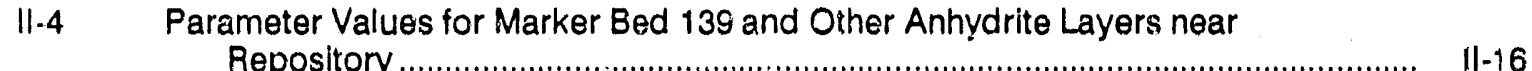

11-5 Parameter Values for Castile Formation Brine Pocket ........................................... $\quad \|-23$

II-6 Parameter Values for Culebra Dolomite Mernber of Rustler Formation..................... $\quad \| 1-29$

11-7 Cumulative Density' Function for Partition Coefficients for Culebra Dolomite

11-8 Cumulative Density Function for Partition Coefficients for Culebra Dolomite Member within Fracture Dominated liy Culebra Brine....................................... $\quad \| 1-35$

II-9 Hydraulic Conductivity for Zones in Culebra Dolomite Member ............................... $\quad$ II-44

II-10 Miscellancous Geologlc Material ............................................................... $\quad \|-61$

III-1 Parameter Values for Unmodifled TRU Waste...................................................... III-6

III-2 Preliminary Permeability Estimates for Individual Components ................................ III-11

III-3 Preliminary Porosity Estimates for Individual Components ..................................... III-13

III-4 Parameter Values for Salt-Packed Waste with Shredded Metal ................................ III-17

III-5 Estimated Permeability and Porosity Distributions ............................................... III-18

III-6 Inventory and Parameter Values for TRU Radionuclides....................................... III-21

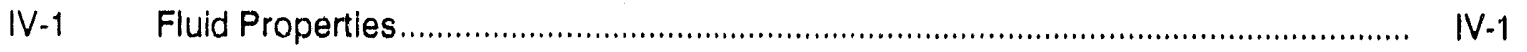

IV-2 Borehole Flow, Climate Var.ability, and Intrusion Characteristics........................... IV-6

IV-3 Discrete Probability of Drilling an Intrusion Borehole with a Speciflc Cross

IV-4 Probability of Mulitrie Hits into Disposal Area of Repository .................................. IV-18

V-1 Distributions of Sample Parameters in December 1990 WIPP Performance Assessment ................................................................................. 


\section{EXECUTIVE SUMMARY}

This report doruments the data available as of Avgust 1990, which were used by the Performance Assessment Division of Sandia National Laboratories in its December 1990 preliminary performance assessment of the Waste Isoialion Pilot Plant (WIPP). For the performance assessment task, Sandia has developed a methodology for controlling the data for evaluating long-term performance. As part of this methodology, a data base, called the secondary data base, contains interpreted data that are used to form a conceptual model of the disposal system. The data provided in this report are from the secondcry data base as of August 1990 and were used to ce' culate the December 1990 preliminary perforinance assessment of the WIPP.

The secondary database provides a set of parameter reference values (value, probability, and distribution type) and the source of these values. As batter information becomes available, the parameter values reported herein will be updated. Thus, this report is o.11y a snapshot of the data as of August 1990. At a minimum, updated data reports will be issued annually in conjunction with the Preliminary Comparison with $40 \mathrm{CFR}$ Part 191, Subpart B for the Waste isolation Pilot Plant (Bertram-Howery et al., 1990).

In this report, parameter values are presented in table form for the geologic subsystem, engineered barriers, borehole flow properties, climate variability, and intrusion characteristics. Sources for the data and a brief discussion of each parameter are provided. 


\section{INTRODUCTION}

\section{Purpose and Organization of Report}

Sandia National Laboratories is currently evaluating the long-term performance of the Waste Isolation Pilot Plant (WIPP), a geologic repository for transuranic radioactive waste. The WIPP must comply with the Environmental Protection 'gency's (EPA's) Environmental Standards for the Management and Dirposal of Spent Nuclear Fitel, High-Level, and Transuranic Radioactive Wastes (40 CFR 191) (hereaftar referred to as the Standard) (EPA, 1985). Performance assussment is defined by Subpart $B$ of the Standard as an analysis that (1) identifies the processes and events that might affect the disposal system, (2) examines the effects of these processes and events on the porformance of the disposal system, and (3) estimates the cumulative releases of radionuclides, considering the associated uncertainties, caused by all significant processes and events. These estimates are incorporated into an overall probability distribution of cumulative release to the extent practicable ( $40 \mathrm{CFR}$ $191.12(q))$.

The term "performance assessment" has come to refer to the prediction of all long-term performance, because the performance assessment methodology, with minor modifications, can also be used to assess compliance with the 1,000-year performance. This report refers to the assessment of compliance with both $\$ 191.13$ (a) of the Containment Requirements and the Individual Protection Requirements ( $\$ 191.15)$ as the "performance assessment."

The data used in the performance assessment of the WIPP are critical to generating a reasonable, well-founded estimate. This report documents what types of data are used, how they are organized, and the parameters currently in use by the Performance Assessment Division for the WIPF'.

The organization of this report is as follows:

- The remainder of Chapter I presents background information about the database, the conventions used in the data tables, and the WIPP.

- Chapter II provides parameters for the geologic subsystem.

- Chapter III gives the parameters for the engineered barriers.

- Chapter IV provides the parameters for fluid properties, Salado Formation brine compressibility, climate variability, and intrusion characteristics.

- Appendix A offers endorsements of the data currently in use. 


\section{Background on the Database}

For the performance assessment task, Sandia has developed a methodology for controlling the data used to evaluate long-term performance. As part of this methodology, a data base, called the secondary data base, contains interpreted data that are employed to form a conceptual model of the disposal system. The data provided in this report are from the secondary data base as of August 1.990 and were used to calculate the December 1990 preliminary performance assessment of the WIPP.

The secondary database provides a ser of parameter reference values (value, probability, and distribution type) and the source of these values. As better information becomes available, the parameter values reported herein will be updated. Thus, this report is only a snapshot of the data as of August, 1990. At a minimum, updated data reports will be issued annually in conjunction with the Preliminary Comparison with 40 CFR Part 191, Subpart B for the Waste Isolation Pilot Plant (Bertram-Howery et al., 1990). Currently, two updates to this data report are planned for 1991 because of the many sensitivity studies planned. In these updated reports, we may alter the text format so that the data become more accessible as reference material.

The major sources of the data are the task leaders in the Nuclear Waste Technology Department at Sandia. (The task leader is responsible for conducting activities described in the Sandia work plan. Although this position is called a principal investigator at Sandia, we refer to them as task leaders here so that the term cannot be confused with a principal investigator in a formal contract.) In particular, task leaders in the Performance Assessment, Fluid Flow and Transport, Disposal Room Systems, and Repository Isolation Systems Divisions established the data. The WIPP Test Phase Plan identified activities at Sandia for providing the data (U.S. DOE, 1990).

\section{Conventions}

The tables presented in Chapters II, III, and IV provide a median, a range, units, a distribution type, and a source for each parameter. These fields are defined as follows:

\section{MEDIAN}

The median represents the 0.5 quantile in the distribution.

\section{RANGE}

The range represents the 0.99 and 0.01 quantiles in the distribution. 


\section{UNITS}

The units indicate how the parameter is expressed quantitatively.

\section{DISTRIBUTION TYPE}

The distribution types are listed on the tables as either beta, constant, cumulative, density, histogram, normal, lognormal, uniform, loguniform, or table. A companion report (Tierney, 1990a) presents further information on selecting the appropriate distribution type and constructing the cumulative, density, and histogram distribution types.

\section{Beta}

Beta designatés the beta probability distribution function (pdf), which is a versatile density function that can take on numerous shapes in a specified interval a, b (Harr, 1987, p. 79; Miller and Freund, 1977, p. 119). Beta preserves maximum er, vropy when given the mean, coefficient of variation, and the minimum and maximum values (Harr, 1987, p. 93).

\section{Constant}

When a distribution is listed as constant, then no distribution type has been assigned and a constant value is used.

\section{Cumulative}

The cumulative distribution type refers to the piecewise linear cumulative distribution function (cdf) that employs the Maximum Entropy Formulism (see Tierney [1990a]). The cdf may be "empirical," i.e., the percentiles are based on measured data, or "subjective," i.e., the percentiles are subjectively estimated where data are sparse or absent.

\section{Density}

The density distribution type refers to "empirical" or "subjective" pdf. Although the cdf (integral of pdf) is preferred, the expert on the subject matter related to the parameter may, at his or her discretion, supply the pdf.

\section{Histogram}

The Histogram label indicates a cumulative distribution function where parameters nust be assigned discrete values, i.e., the distribution is not continuous. For example, the distribution type for the drill bit cross- 
sectional area cannot vary continuously between the minimum and maximum drill bit sizes, but must be the area of a bit that is actually available.

\section{Normal}

The normal pdf provides a good representation for many physical variables. By the central limit theorem, if a random variable represents the effect of many small causes (additions of errors), its pdf is normal. The distribution is truncated at the 0.99 and 0.01 quantiles. The mean and median are equal and uniquely defined by the distribution type.

\section{Lognormal}

Lognormal is a frequency distribution whose logarithm follows a normal distribution. The distribution is truncated at the 0.99 and 0.01 quantiles. The mean and median are uniquely defined by the distribution.

\section{Uniform}

Uniform means a distribution of a random variable in which each value has the same probability of occurrence. The mean and median are equal and uniquely defined by the distribution type.

\section{Loguniform}

Loguniform is a frequency distribution whose logarithm follows a uniform distribution. The mean and median are uniquely defined by the distribution.

\section{Table}

The last distribution type, Table, is not a distribution but a category that indicates the parameter varies with another property and the result is a tabulated value. For example, the distributions for capillary pressure and relative permeability are listed as Table.

\section{SOURCE}

The source indicates the document in which the value used was cited. 


\section{Background on WIPP}

\section{PURPOSE AND LOCATION}

The WIPP was authorized by Congress in 1979 as a research and development facility to demonstrate the safe management, storage, and eventual disposal of transuranic (TRU) waste generated by defense programs. Only after demonstrating compliance with the Standard and the Resource, Conservation, and Recovery Act of 1976 will the DOE dispose of TRU waste at the WIPP repository.

The WIPP is located in southeastern New Mexico, approximately $38 \mathrm{~km}$ (24 mi) east of Carlsbad, an area of low population density (Figure I-1). The location was chosen because of the underlying $600-\mathrm{m}(2,000-\mathrm{ft})$-thick Salado Formation of marine bedded salts, which are a desirable medium for nuclear waste disposal. The bedded salts consist of thick halite and interbeds of minerals such as clay and anhydrites of the late Permian period (Ochoan series) (approximately 255 million yr old)* that do not support flowing water.

The repository level is located within these bedded salts about $657 \mathrm{~m}(2,155$ $\mathrm{ft}$ ) below the surface and $390 \mathrm{~m}(1,300 \mathrm{ft})$ above sea level. The WIPP repository is composed of a single underground disposal level connected to the surface by four shafts (Figure I-2). The repository level consists of an experimental area at the north end and a disposal area at the south end.

\section{SANDIA ROLE IN PROJECT}

Besides the DOE project office in Carlsbad, NM, which oversees the project, the WIPP currently has two major participants: Sandia National Laboratories in Albuquerque, NM, which functions as scientific investigator; and Westinghouse Electric Company, which is responsible for the management of WIPP operations. The specific tasks of Sandia are (1) characterizing the disposal system and responding to specific concerns of the State of New Mexico, (2) carrying out performance assessment (i.e., ensuring regulatory compliance with 40 CFR 191, Subpart B, except the Assurance Requirements), (3) performing analytic, laboratory, field experiments, and applied research to support disposal system characterization and performance assessment relevant to nuclear waste disposal in salt, and (4) providing ad hoc scientific and engineering support (e.g., supporting environmental assessments). This report helps fulfill the performance assessment task, Task 2.

$\bar{*}$ This age reflects the revised 1983 geologic timetable (Palmer, 1983). 


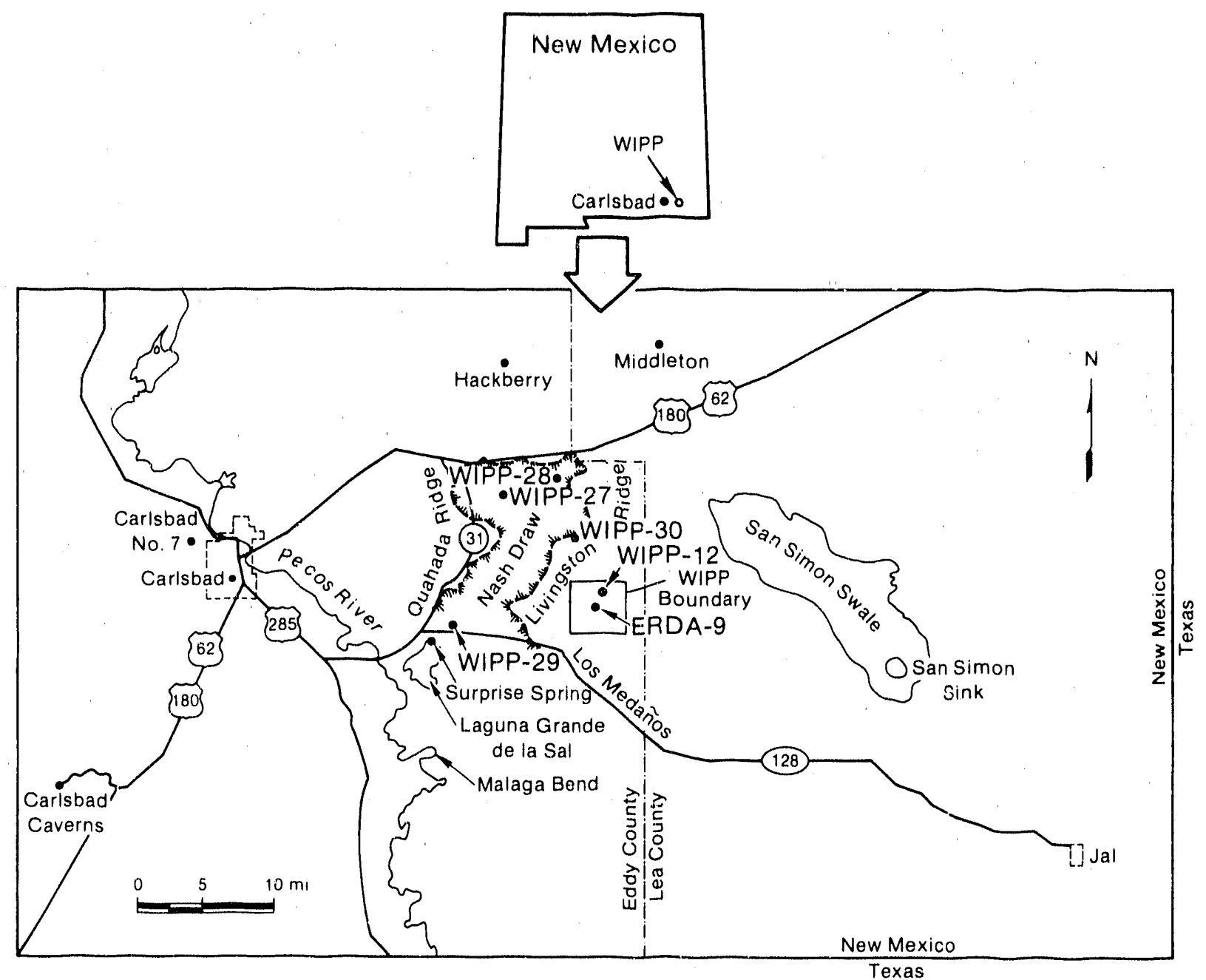

TRI-6334-53-2

Figure 1-1. WIPP Location in Southeastern New Mexico (Rechard, 1989). 


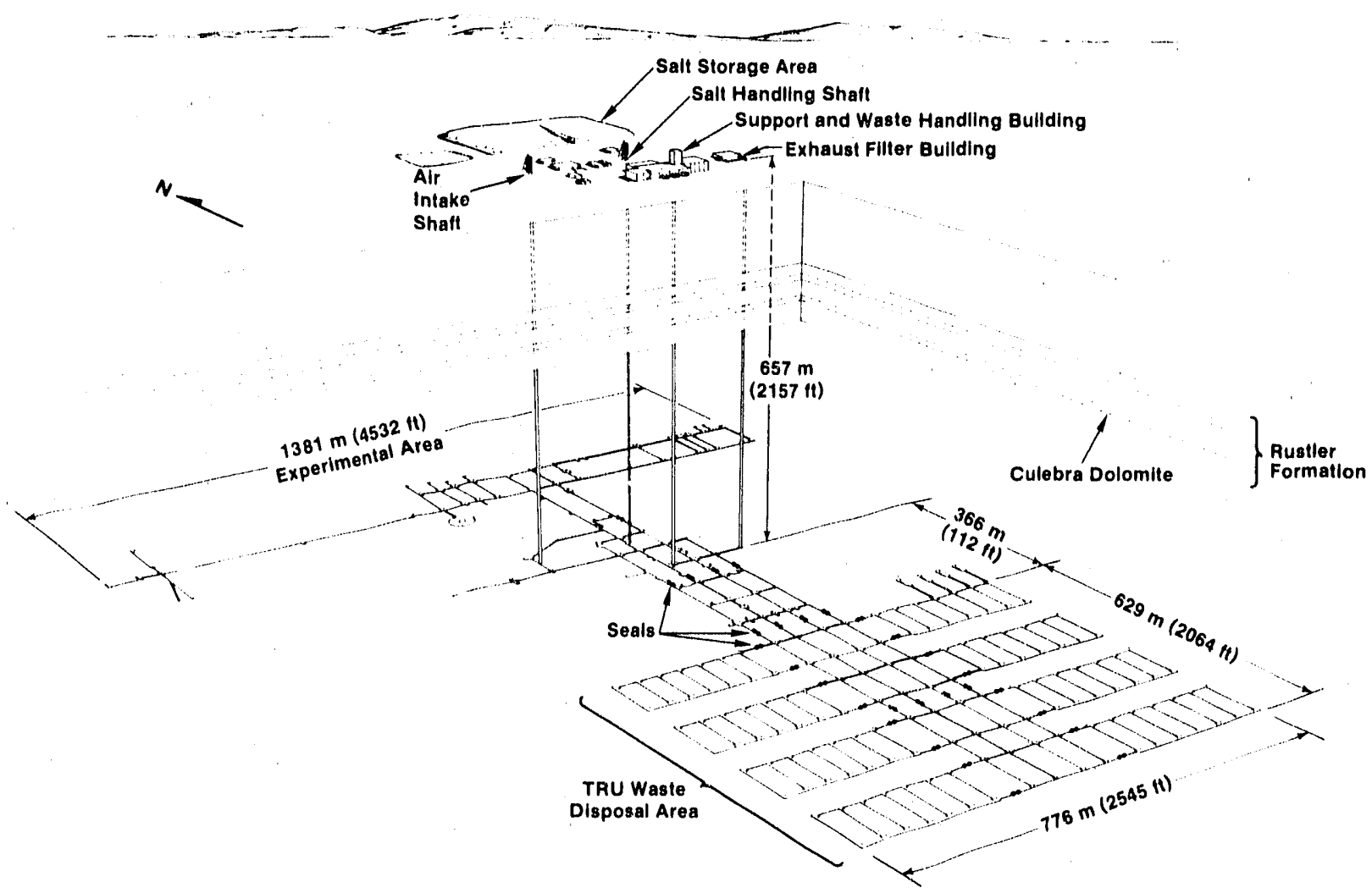

TR1-6346-59-1

Figure 1-2. Proposed WIPP Repository, Showing Both TRU Disposal Areas and Experimental Areas (Nowak et al., 1990). 


\section{GEOLOGIC SUBSYSTEM}

The Geologic Subsystem consists of the physical features of the repository, such as stratigraphy and geologic components.

\section{Stratigraphy at the WIPP}

The level of the WIPP repository is located within bedded salts about $657 \mathrm{~m}$ $(2,155 \mathrm{ft})$ below the surface and $390 \mathrm{~m}(1,300 \mathrm{ft})$ above sea level

(Figure II-1). The bedded salts consist of thick halite and interbeds of minerals such as clay and anhydrites of the late Permian period (Ochoan series) (approximately 255 million yr old) that do rot support flowing water (Figure II-2). An interbed that forms a potential 'ransport pathway, Marker Bed 139 (MB139), located about $1 \mathrm{~m}$ ( $3.3 \mathrm{ft}$ ) below the repository interval

(Figure II-2), is about $1 \mathrm{~m}$ ( $3.3 \mathrm{ft}$ ) thick (Figure $I \tau-3$ ), and is one of about 45 siliceous or sulfatic units within the Salado Forma ion consisting of polyhalitic anhydrite (Figure II-4) (Lappin, 1988; Tyler e'- a1., 1988). The depths of the stratigraphic layers around three main shafts are tabulated in Table II-1. 

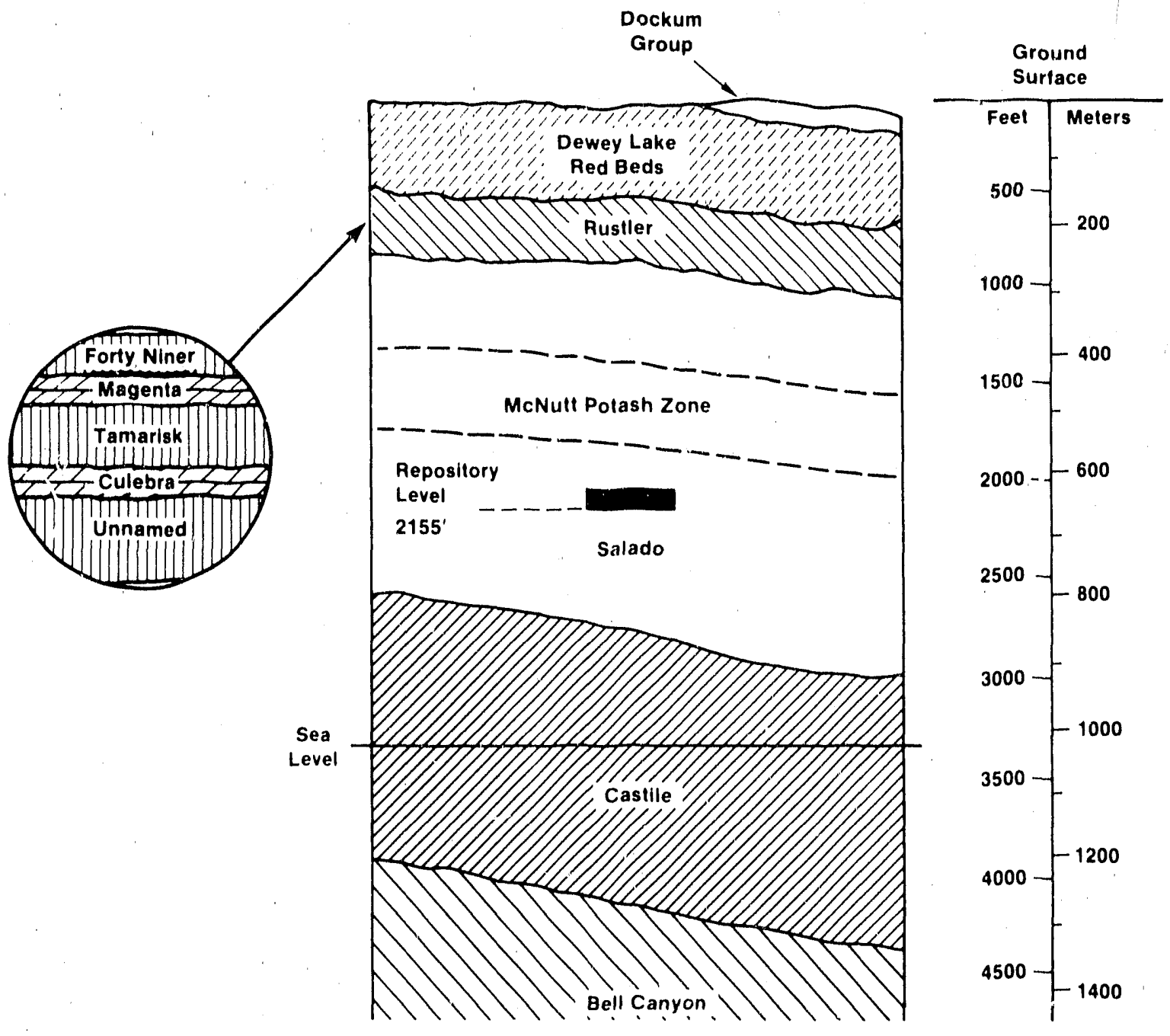

TR1-6334-49-0

Figure 11-1. Level of WIPP Repository, Located in the Salado Formation. The Salado Formation is composed of thick halite with thin Interbeds of clay and anhydrite deposited as marine evaporites about 255 million years ago (Permian period) (Rechard, 1989). 


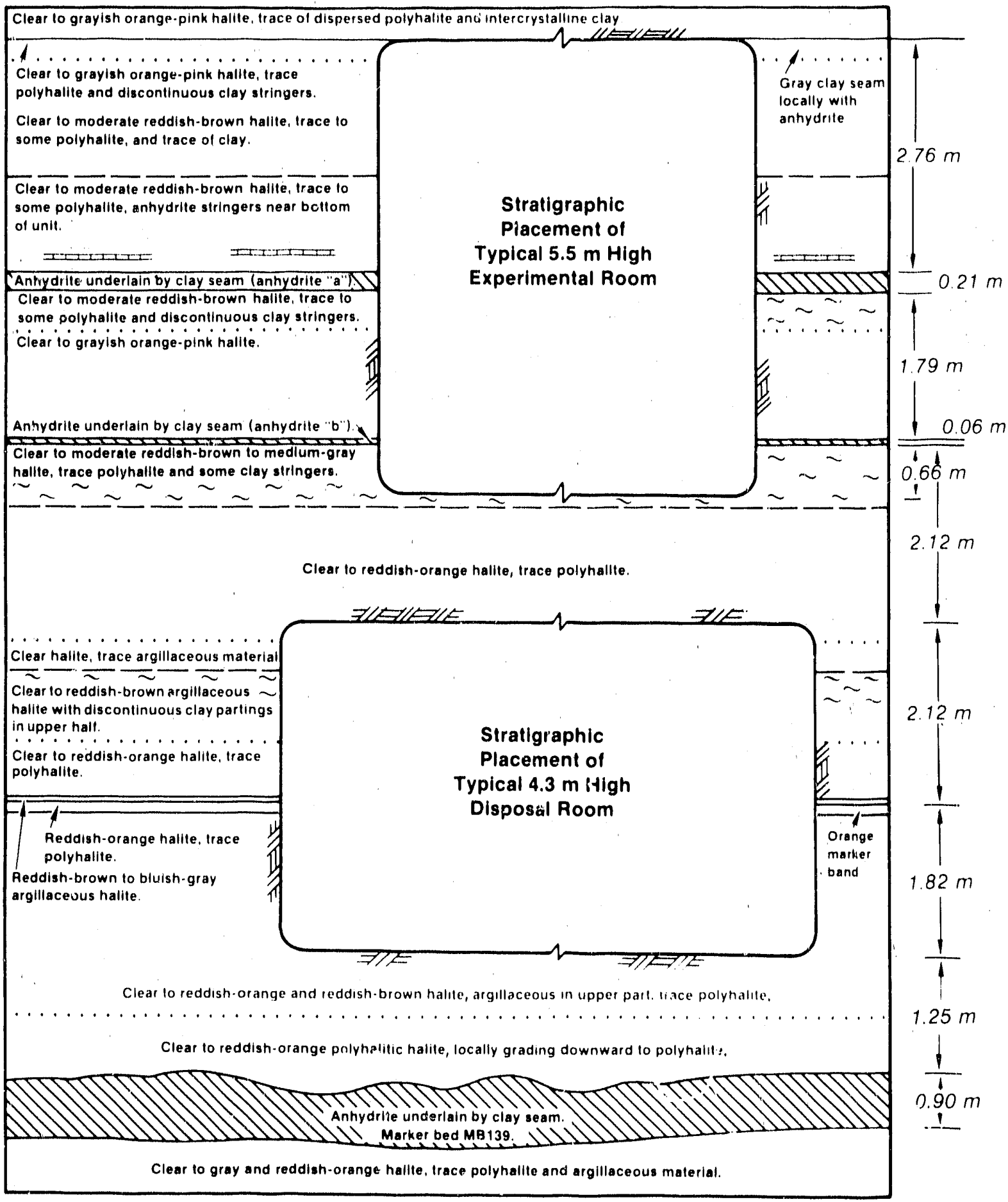

Interbeds Modeled within This Report

TRI-6334-257-0

Figure 11-2. Stratigraphy at the Repository Horizon (after Lappin et al., 1989). Units in the disposal area dip slightly to the south, but disposal excavations are always centered about the orange marked band (reddish-orange hallte). 


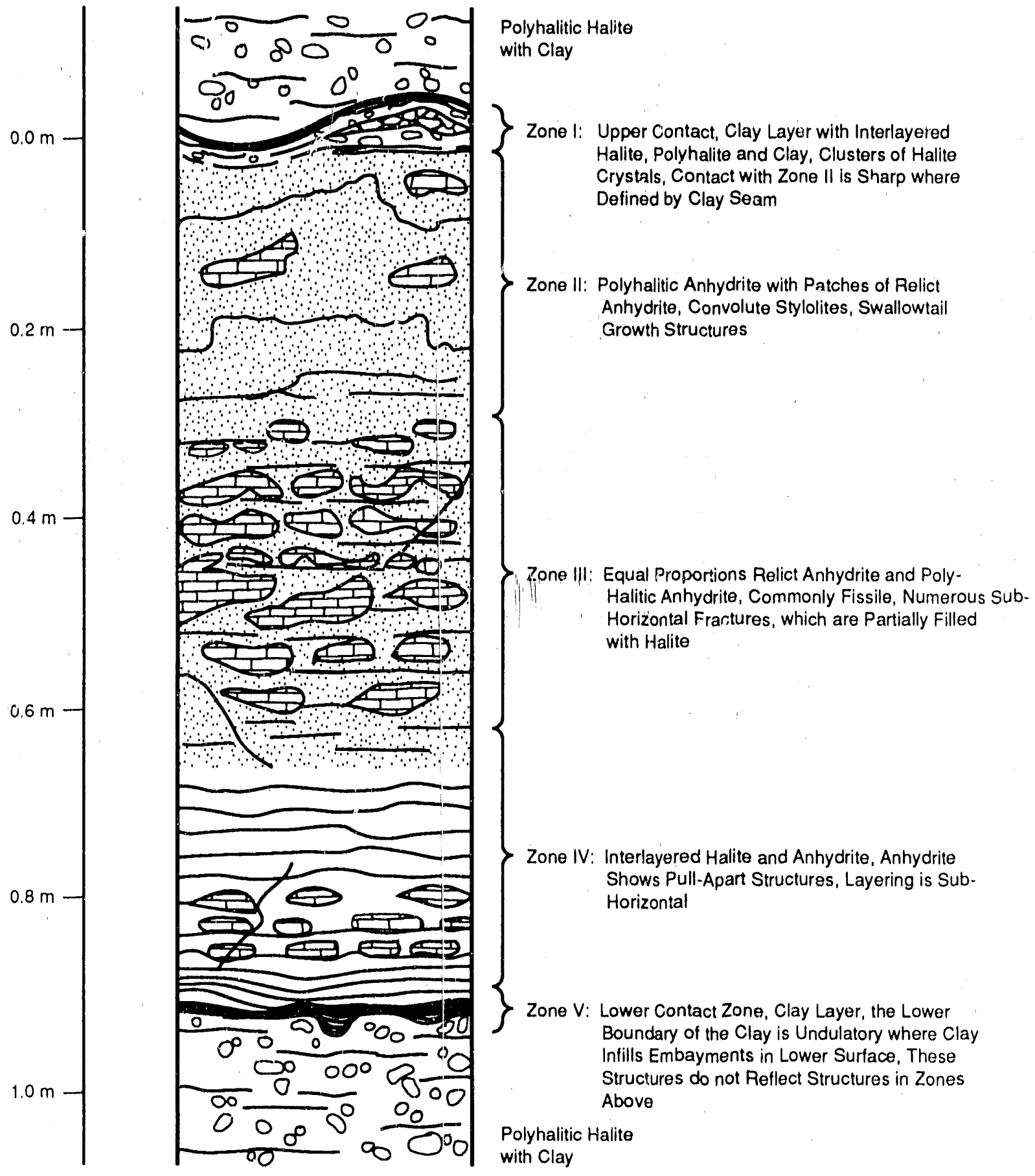

TRI.6334.220.0

Figure II-3. Generalized Cross Section of Marker Bed 139. The figure shows the internal variability of the unit and the character of both the upper and lower contacts (after Borns, 1985). 


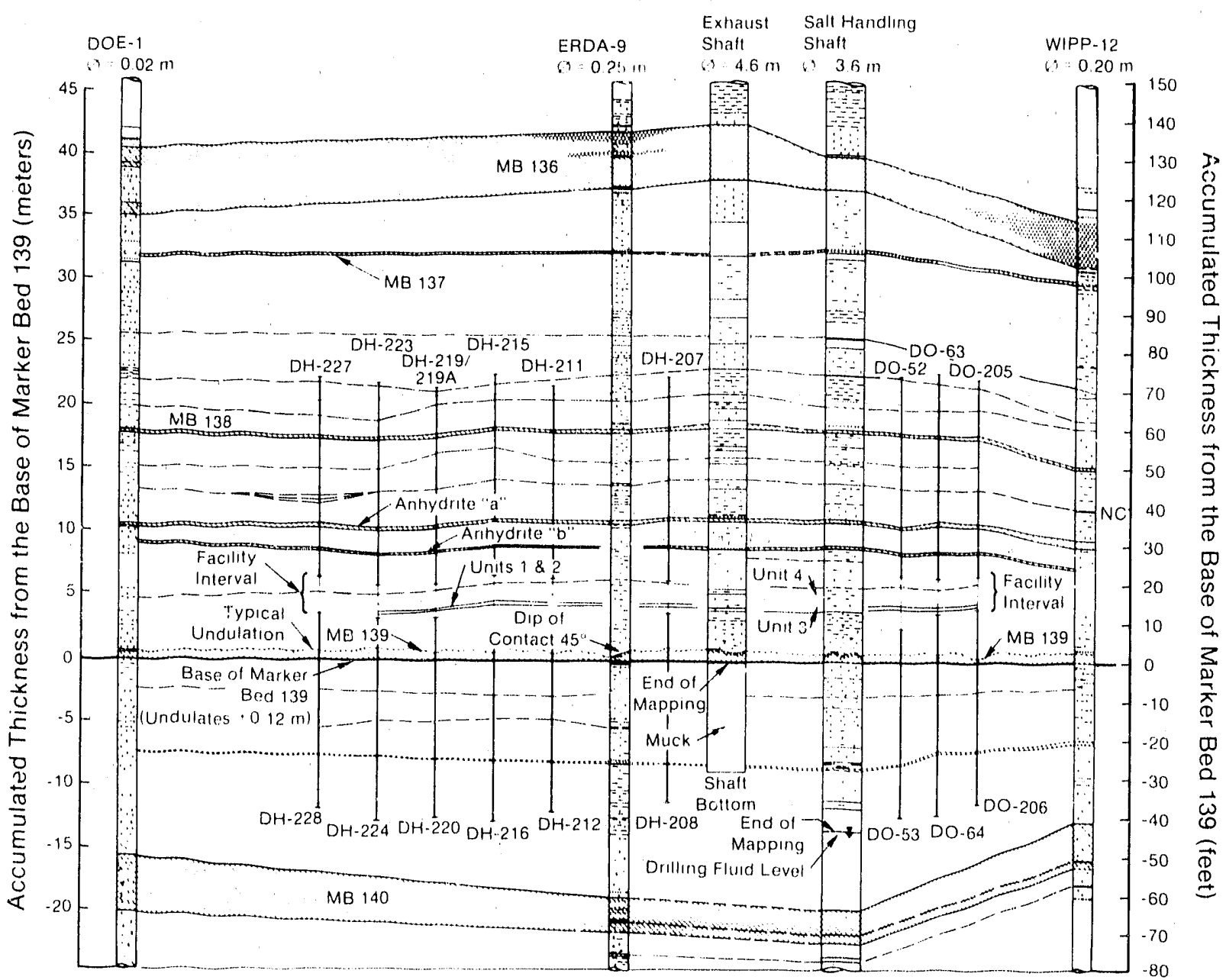

(Not Drawn to a Horizontal Scale)

MB - Marker Bed

$\mathrm{DH}$ - Drillholes South of the C\&SH Shaft

DO - Drillholes North of the C\&SH Shaft

Figure II-4. Marker Bed 139, One of Many Anhydrite Interbeds near the WIPP Repository Horizun. 
TABLE II-1. DEPTHS OF STRATIGRAPHIC LAYERS AROUND WASTE, EXHAUST, AND SALT HANDLING SHAFTS (after Nowak et al., 1990)

\begin{tabular}{|c|c|c|c|c|c|c|c|}
\hline \multirow[b]{2}{*}{ Layer } & \multirow{2}{*}{$\begin{array}{l}\text { Average } \\
\text { Depth } \\
\text { (m) }\end{array}$} & \multicolumn{2}{|c|}{ Waste } & \multicolumn{2}{|c|}{ Exhaust } & \multicolumn{2}{|c|}{ Salt Handling } \\
\hline & & $\begin{array}{l}\text { Depth } \\
(\mathrm{m})\end{array}$ & $\begin{array}{l}\text { Diameter } \\
\text { (m) }\end{array}$ & $\begin{array}{c}\text { Depth } \\
(\mathrm{m})\end{array}$ & $\begin{array}{l}\text { Diameter } \\
(\mathrm{m})\end{array}$ & $\begin{array}{l}\text { Depth } \\
(\mathrm{m})\end{array}$ & $\begin{array}{l}\text { Diameter } \\
\text { (m) }\end{array}$ \\
\hline Surface & 0.0 & 0.0 & N/A & 0.0 & $N / A$ & 0.0 & N/A \\
\hline Top of Magenta & $: 82.1$ & 182.0 & 7.0 & 183.8 & 5.0 & 180.4 & 3.6 \\
\hline Bottom of Magenta & 190.4 & 189.0 & 7.0 & 191.1 & 5.0 & 191.1 & 3.6 \\
\hline Top of Culebra & 216.3 & 214.9 & 7.0 & 217.6 & 5.0 & 216.4 & 3.6 \\
\hline Bottom of Culebra & 223.7 & 221.6 & 7.0 & 224.3 & 5.0 & 225.2 & 3.6 \\
\hline Rustler/Salado contact & 258.7 & 257.3 & 8.4 & 259.4 & 6.4 & 259.4 & 4.6 \\
\hline Top of Vaca Triste & 411.6 & 411.2 & 6.1 & 412.7 & 4.8 & 410.9 & 3.6 \\
\hline Bottom of Vaca Triste & 412.7 & 413.3 & 6.1 & 413.6 & 4.6 & 411.2 & 3.6 \\
\hline Top of station & 653.8 & 654.4 & 7.0 & 654.4 & 4.6 & 652.6 & 3.6 \\
\hline Station & 658.3 & 658.4 & N/A & 657.5 & $N / A$ & 659.0 & $N / A$ \\
\hline Top of sump & 558.7 & 658.4 & 7.0 & $N / A$ & N/A & 659.0 & 3.6 \\
\hline Bottom of sump & 694.7 & 696.8 & 7.0 & $N / A$ & $N / A$ & 692.5 & 3.6 \\
\hline
\end{tabular}




\section{Parameters for Halite and Poly isalite within the Salado Formation}

The WIPP repository is located in the Salado Formation. The Salado Formation is composed of thick halite with thin interbeds of clay and anhydrite deposited as marine evaporites about 255 million years ago (Permian period). The parameters for the Salado Formation near the repository are given in Table II-2. The pdf for salado permeability is given in Table II- 3 .

TABLE II-2. PARAMETER VALUES FOR SALADO FORMATION IVEARI REPOSITORY

\begin{tabular}{|c|c|c|c|c|c|c|}
\hline \multirow{2}{*}{ Parameter } & \multirow[b]{2}{*}{ Median } & \multicolumn{5}{|c|}{ Distribution } \\
\hline & & \multicolumn{2}{|c|}{ Range } & Units & Type & Source \\
\hline Capillary pressure $\left(p_{c}\right)$ & & 2.3 & $7.98 \times 10^{9}$ & $\mathrm{~Pa}$ & Table & $\begin{array}{l}\text { Brooks and Corey, 1964; Ward and } \\
\text { Morrow, } 1985\end{array}$ \\
\hline \multicolumn{7}{|l|}{ Relative } \\
\hline permeability $\left(k_{r w}\right)$ & & 0.0 & 1 & none & Table & $\begin{array}{l}\text { Brooks and Corey, 1964; Ward and } \\
\text { Morrow, } 1985\end{array}$ \\
\hline Capacitance (c) & $3.2 \times 10^{-11}$ & $1 \times 10^{-11}$ & $1 \times 10^{-10}$ & $\mathrm{~Pa}^{-1}$ & Lognormal & $\begin{array}{l}\text { Beauheim, 1990, Memo 3c (see } \\
\text { Appendix A) }\end{array}$ \\
\hline Density, average ( $\left.\rho_{\text {ave }}\right)$ & $2.3 \times 10^{3}$ & & & $\mathrm{~kg} / \mathrm{m}^{3}$ & Constant & Krieg, 1984, Table 4 \\
\hline Density, bulk ( $\left.\rho_{\text {bulk }}\right)$ & $2.14 \times 10^{3}$ & & & $\mathrm{~kg} / \mathrm{m}^{3}$ & Constant & Holcomb and Shields, 1987, p.17 \\
\hline \multicolumn{7}{|l|}{ Permeability (k) } \\
\hline Undisturbed & $3.5 \times 10^{-21}$ & $1 \times 10^{-22}$ & $3 \times 1 \%-20$ & $m^{2}$ & Density & Beauheim et al., 1990, Table 7-1 \\
\hline Disturbed & $1 \times 10^{-19}$ & $1 \times 10^{-20}$ & $1 \times 10^{-18}$ & $m^{2}$ & Lognormal & $\begin{array}{l}\text { Beauheim, 1990, Memo 3c (see } \\
\text { Appendix A) }\end{array}$ \\
\hline \multicolumn{7}{|l|}{ Porosity $(\phi)$} \\
\hline Undisturbed & $1 \times 10^{-2}$ & $1 \times 10^{-3}$ & $3 \times 10^{-2}$ & none & Cumulative & $\begin{array}{l}\text { Skokan ot al.,1988; Powers ot al.,1978; } \\
\text { Black ot al., } 1983\end{array}$ \\
\hline Disturbed & $6 \times 10^{-2}$ & & & none & Constant & Seo text. \\
\hline Repository pressure (p) & $1.10 \times 10^{7}$ & $7 \times 10^{6}$ & $1.5 \times 10^{7}$ & $\mathrm{~Pa}$ & Uniform & $\begin{array}{l}\text { Wawersik and Stcile, } 1985 ; z \cdot g \cdot \text { Pbrine: } \\
\text { Beauheim, 1990, Memo } 3 \mathrm{c} \text { (se日 } \\
\text { Appendix A) }\end{array}$ \\
\hline
\end{tabular}

TABLE II-3. PROBABILITY DISTRIBUTION FUNCTION FOR UNDISTURBED SALADO PERMEABILITY

\begin{tabular}{|c|c|c|c|c|c|c|}
\hline Median & & & Permeability & Density & Units & Source \\
\hline $3.5 \times 10^{-21}$ & $1 \times 10^{-22}$ & $3 \times 10^{-20}$ & $\begin{array}{l}1 \times 10^{-22} \\
2 \times 10^{-21 *} \\
2 \times 10^{-21} \\
3 \times 10^{-21} \\
4 \times 10^{-21} \\
5 \times 10^{-21} \\
3 \times 10^{-20}\end{array}$ & $\begin{array}{l}1.667 \times 10^{-1} \\
1.667 \times 10^{-1} \\
1.667 \times 10^{-1} \\
1.667 \times 10^{-1} \\
1.667 \times 10^{-1} \\
1.667 \times 10^{-1} \\
1.667 \times 10^{-1}\end{array}$ & $m^{2}$ & $\begin{array}{l}\text { Beauheim et al., } 1990 \text {, Table } \\
7-1\end{array}$ \\
\hline
\end{tabular}

\footnotetext{
* Experimental values are repeated with a probability of 0.1667 rather than entered once with a probability of 0.3333 to ensure that the exact value could be sampled. (See Figure 11.8 for latter method.)
} 


\section{CAPILLARY PRESSURE AND RELATIVE PERMEABILITY}

Capillary pressures and relative permeabilities for the Salado halite, the anhydrite layers, and waste have not been measured. As presented and discussed in Davies and LaVenue (1990, Memo 11 [Appendix A]), nat rral analogs were used to provide capillary pressure and relative permeability curves for these lithologies. The natural analogs consist of alternate materials that possess some of the same characteristics (i.e., permeability and porosity) as the anhydrite, halite, and waste room. The natu:al analogs applicable to the very low permeability of the halite and ankydrite were sands that were investigated during the Multiwell Tight Gas Sands Project (Ward and Morrow, 1985). The permeability for these sands typically ranges from $1 \times 10^{-16}$ to $1 \times 10^{-19} \mathrm{~m}^{2}\left(1 \times 10^{-1}\right.$ to $\left.1 \times 10^{-4} \mathrm{mD}\right)$. Although these permeabilities are higher than thuse of the annydrites and halites, the sand was the material found with the lowest permeability and also with measured capillary pressure and relative permeability curves. The natural analog used for the waste room was a poorly sorted, fragmented mixture of granulated clay, fragmented sandstone, and volcanic sand as presented in Brooks and Corey (1964).

Brooks and Corey observed that the effective saturation of a porous material, $s_{e}$, can be related to the capillary pressure, $p_{c}$, by

$$
s_{e}=\left[\frac{P_{t}}{P_{c}}\right]^{\lambda}
$$

where $\lambda$ and $p_{t}$ are characteristic constants of the material. $p_{t}$ is commonly referred to as the threshold displacement pressure. Brooks and Corey defined $s_{e}$ as

$$
s_{e}=\frac{s_{w}-s_{w r}}{1-s_{w r}}
$$

where $s_{\mathrm{w}}$ is the wetting phase saturation (brine) and $s_{\mathrm{wr}}$ is the residual saturation, below which the wetting phase no longer forms a continuous network through the pore network and therefore does not flow, regardless of the pressure gradient. This has been modified to account for residual gas saturation, sgc:

$$
s_{e}=\frac{s_{w i}-s_{w r}}{1-s_{g c}-s_{w r}}
$$


After obtaining the effective saturation from Eq. II-3 the relative permeability of the wetting phase $\left(k_{r w}\right)$ is obtained from

$$
\mathrm{k}_{\mathrm{rw}}=\mathrm{s}_{\mathrm{e}} \frac{2+3 \lambda}{\lambda}
$$

For the gas phase, the relative permeability $\left(\mathrm{k}_{\mathrm{rg}}\right)$ is

$$
k_{r g}=\left(1-s_{e}\right)^{2}\left(1-s_{e} \frac{2+\lambda}{\lambda}\right)
$$

Although none of the parameters that are used in Eq. II-5 has been measured for either the Salado halite, anhdyrites, or waste room, they were estimated from values that were obtained from the natural analogs (Davies and LaVenue, 1990, Memo 11 [Appendix A]). The following values have tentatively been selected for Salado halite; these values are preliminary and are likely to be changed as measurements are rade.

$$
\begin{aligned}
& \lambda=0.7 \\
& \mathrm{p}_{t}=23 \mathrm{MPa} \\
& s_{w r}=0.2 \\
& s_{g c}=0.2
\end{aligned}
$$

The resulting values for capillary pressure and relative permeability are shown in Figures II-5 and II-6, respectively. The values selected for the anhydrites and waste room are discussed in later sections.

\section{SALADO CAPACITANCE}

Capacitance (c) is defined as $c=\phi \beta_{\mathrm{W}}+\beta_{\mathrm{S}}$ where $\phi$ is Salado porosity, $\beta_{\mathrm{W}}$ is brine compressibility, and $\beta_{\mathrm{S}}$ is the Salado compressibility or, alternatively, the specific storativity divided by rock unit weight $\left(\mathrm{S}_{\mathrm{S}} / \gamma\right)$. For the PA compliance calculations, median values for porosity and brine compressibility were used. Salado compressibility varied depending upon the weighted average of compressibilities for individual rock types found near the repository (see Table II-11). The weighted values for capacitance vary between $1.5 \times 10^{-11}$ to $7.6 \times 10^{-11} \mathrm{~Pa}^{-1}$ (Beauheim et al., 1990; Beauheim, 1990, Memo 3c [Appendix A]). For the PA compliance calculations, this range was slightly expanded to $1 \times 10^{-11}$ and $1 \times 10^{-10} \mathrm{~Pa}^{-1}$ and a lognormal distribution was assigned (Figure II-7). 


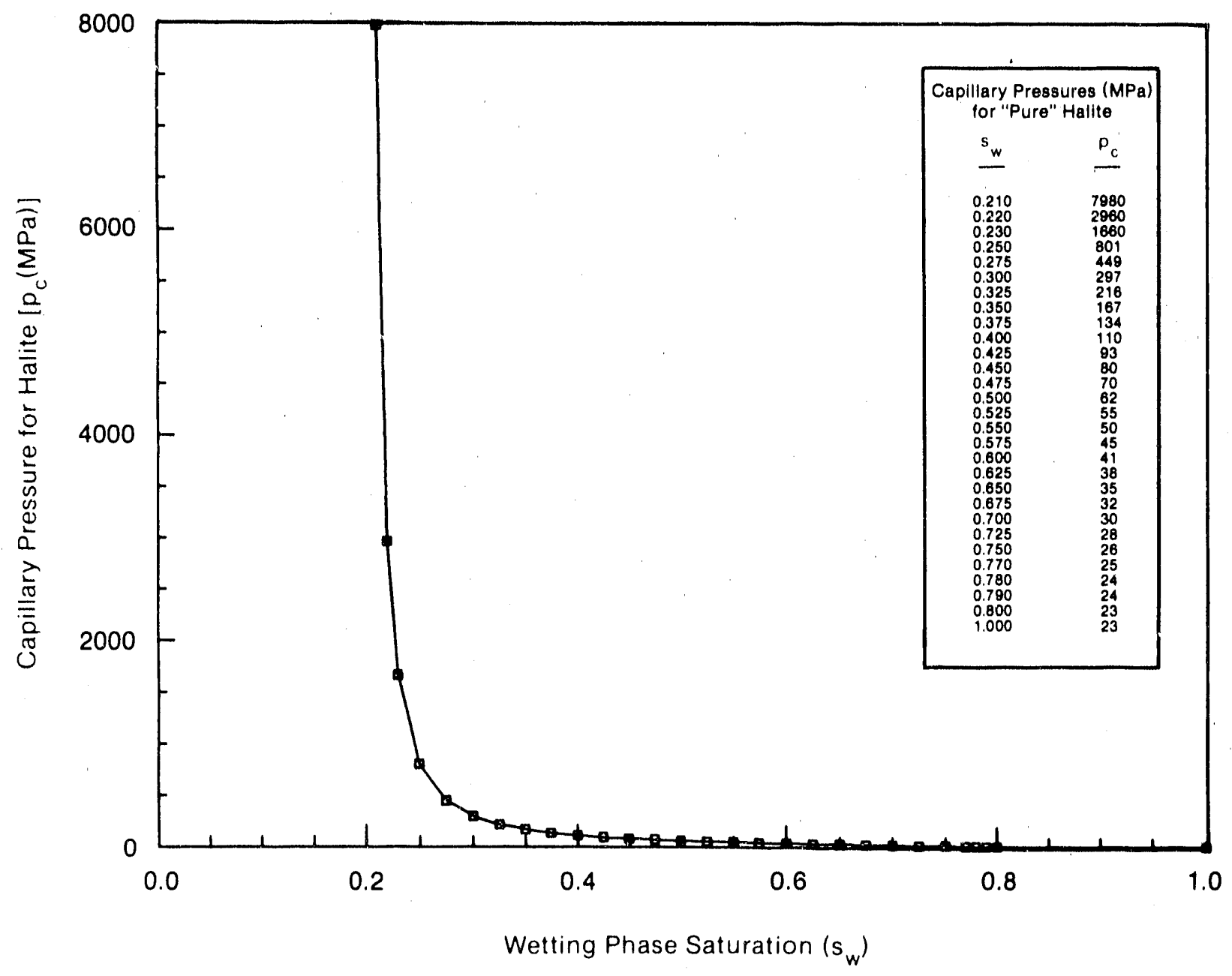

TRI-6342-622-0

Figure II-5. Assumed Capillary Pressure Curve for Salado Salt. 


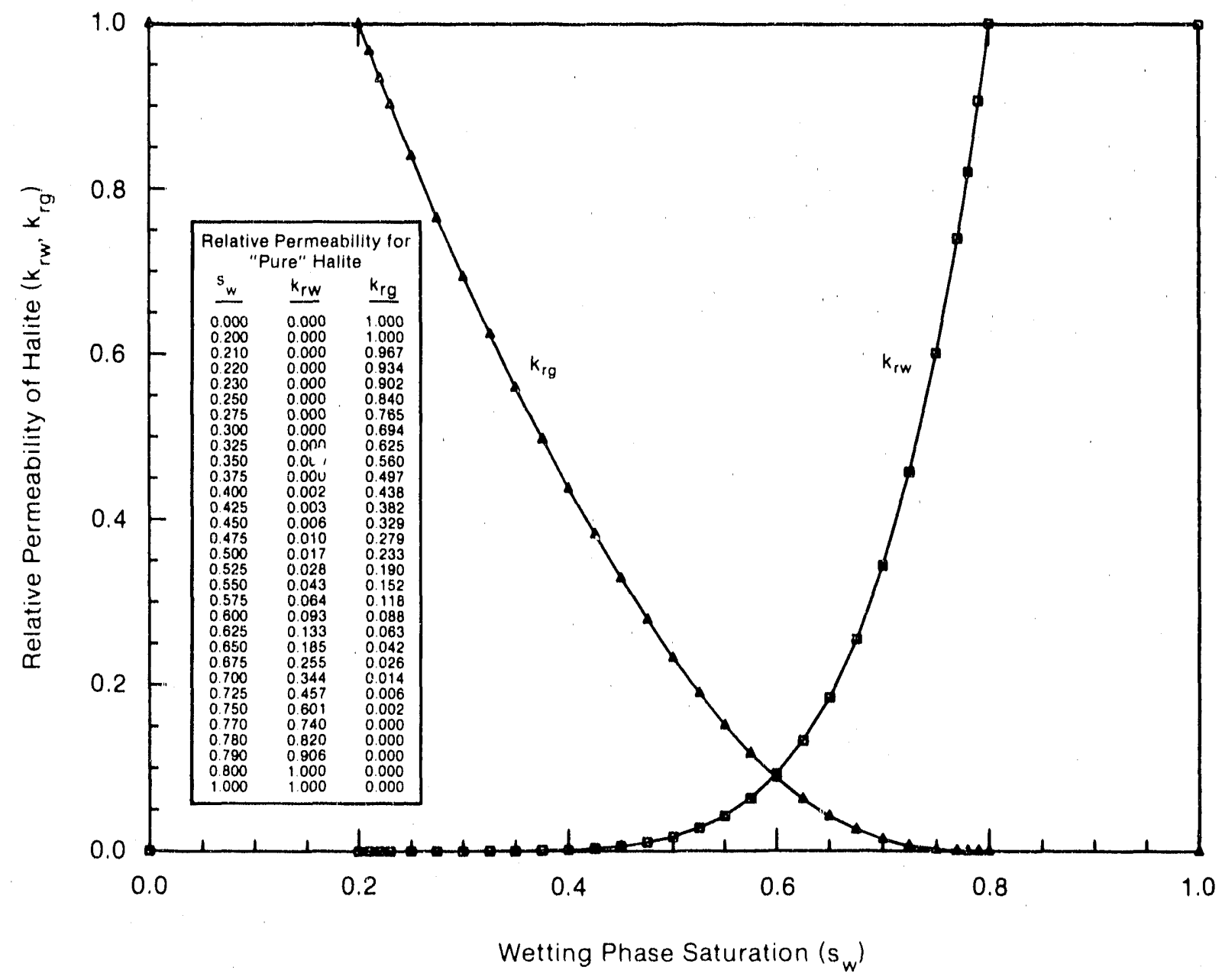

TRI-6342-619-0

Figure II-6. Relative Permeability Determined from Tight Gas Sands Analog for Halite Using Brooks and Corey Model. 


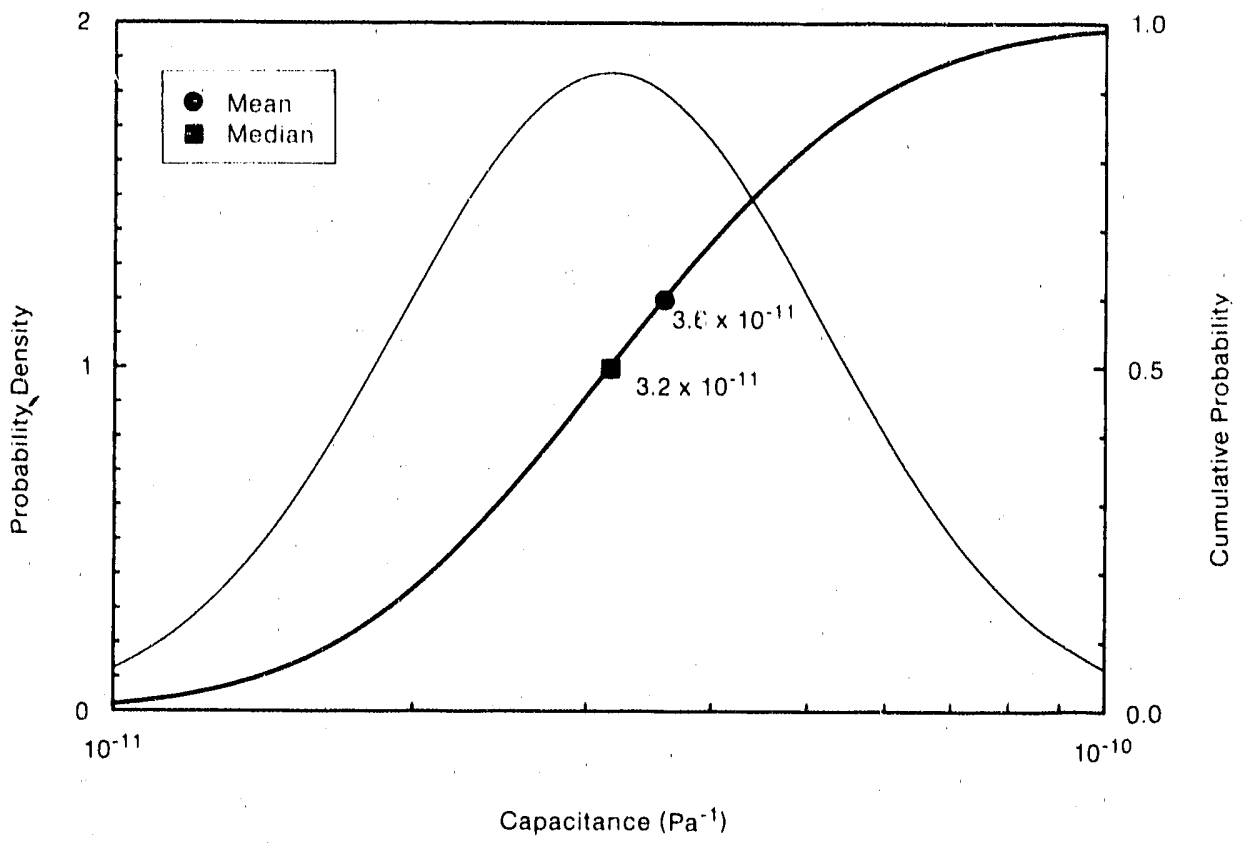

TR1-6342-668-D

Figure 11-7. Lognormal pdf and cdf for Salado Capacitance.

\section{DENSITY}

\section{Average Density Near Repository}

The average density of the Salado Formation in a 107.06-m (351.25-ft) interval straddling the repository is $2,300 \mathrm{~kg} / \mathrm{m}^{3}\left(143.6 \mathrm{lb} / \mathrm{ft}^{3}\right)$. The interval includes anhydrite marker beds, 134, 136, and 138 (above the repository) and anhydrite marker beds 139,140 , and polyhalite marker bed 141 (below the repository) (see Figure II-4). The sum of the thicknesses of all layers of halite and argillaceous halite is $90.92 \mathrm{~m}$ (298.29 ft). Assuming that 998 of this thickness is pure halite $(89.12 \mathrm{~m}$ [292.39 ft]) with a grain density of $2,163 \mathrm{~kg} / \mathrm{m}^{3}$ (135 $\left.\mathrm{lb} / \mathrm{ft}^{3}\right)$ (see Table II-10) and that the remaining thickness $(17.94 \mathrm{~m}[58.86 \mathrm{ft}])$ is anhydrite with a density of $2,963 \mathrm{~kg} / \mathrm{m}^{3}\left(185 \mathrm{lb} / \mathrm{ft}^{3}\right)$ (see Table II-10) yields a weighted average density of $2,300 \mathrm{~kg} / \mathrm{m}^{3}$ $\left(144 \mathrm{lb} / \mathrm{ft}^{3}\right)$ (Krieg, 1984, p. 14).

\section{Bulk Density of Halite in Salado}

The PA Division uses a bulk density of halite near the repository of 2,140 $\mathrm{kg} / \mathrm{m}^{3}\left(13.6 \mathrm{lb} / \mathrm{ft}^{3}\right)$ as reported by Holcomb and Shields (1987, p. 17). 


\section{PERMEABILITY}

\section{Undisturbed Permeability}

Experimental results were used to define permeabilities in the intact and disturbed Salado Formation (Table II-3) (Beauheim et al., 1990, Table 7-1). Six measurenents vere available for the intact Salado: Pure halite was below $1 \times 10^{-21} \mathrm{~m}^{2}\left(1 \times 10^{-6} \mathrm{mD}\right.$ ) (assumed as $1 \times 10^{-22} \mathrm{~m}^{2}\left[1 \times 10^{-1} \mathrm{mD}\right]$ herein but possibly as low as $1 \times 10^{-23} \mathrm{~m}^{2}$ [1 $\left.\left.1 \times 10^{-8} \mathrm{mD}\right]\right)$; argilleous halite was between $2 \times 10^{-21}$ and $3 \times 10^{-21} \mathrm{~m}^{2}\left(2 \times 10^{-6}\right.$ and $\left.3 \times 10^{-6} \mathrm{mD}\right)$ (four measurements); argilleous halite with a clay seam was between $5 \times 10^{-21}$ and $3 \times 10^{-20} \mathrm{~m}^{2}$ $\left(5 \times 10^{-6}\right.$ and $3 \times 10^{-5} \mathrm{mD}$ ) (Figure II-8), *

\section{Disturbed Permeability}

The disturbed permeability and porosity of the Salado Formation and interbeds vary from the intact properties to large, open fractures. These two disturbed properties also change as the stress field around the excavations change with time. Furthermore, the halite will likely heal to intact conditions over time (Lappin et al., 1989, p. 4-45; Sutherland and Cave, 1978). Often the PA

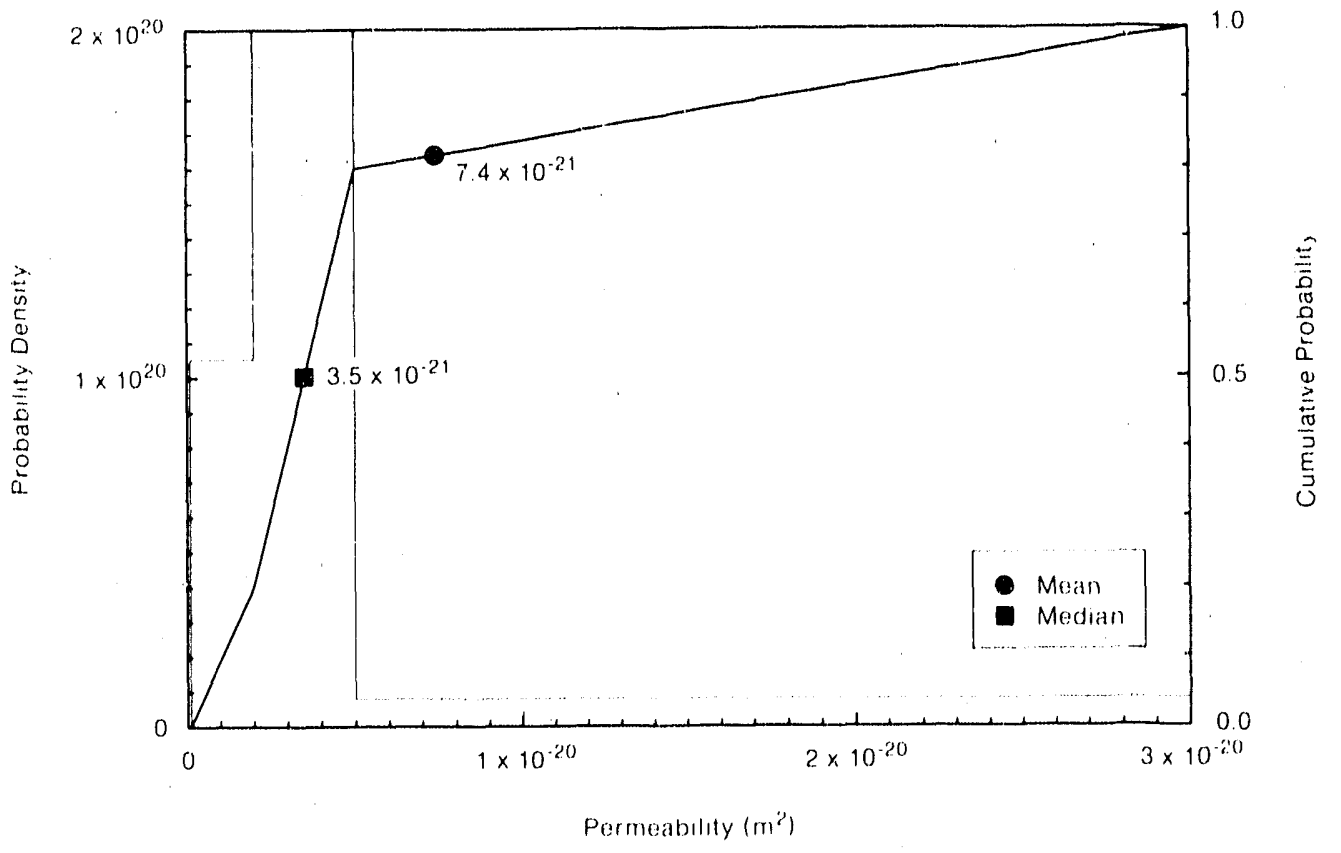

IfH1-6.342-6.69-()

Figure II-8. Experimental pdf and cdf for Salado Permeability.

*Refer to Tierney (1990a) for a discussion of how the density function shown in Figure II- 8 is constructed from Table II- 3 . 
Division does not model the disturbed zone when it is conservative to do so; however, when necessary the following values are typically used.

The disturbed permeability after consolidation and healing is assumed to vary between $1 \times 10^{-20} \mathrm{~m}^{2}\left(1 \times 10^{-5} \mathrm{mD}\right)$ (permeability at 0.95 of intact density [Holcomb and Shields, 1987, Figure 4] and the highest value measured. Beauheim et al. (1990, Table 7-1) reports one measurement from the disturbed rock zone in the Salado Formation of about $1 \times 10^{-18} \mathrm{~m}^{2}\left(1 \times 10^{-3} \mathrm{mD}\right)$. The median value was set about two orders of magnitude higher than the corresponding median value for the intact Salado Formation.

\section{POROSITY}

\section{Undisturbed Porosity}

The median porosity is assumed to be 0.01 based on electromagnetic and DC resistivity measurements (Skokan et a1., 1989). This median value is identical to that calculated from a grain density of $2,163 \mathrm{~kg} / \mathrm{m}^{3}\left(135 \mathrm{lb} / \mathrm{ft}^{3}\right)$ for halite (see Table II-11) and a bulk density of $2,140 \mathrm{~kg} / \mathrm{m}^{3}\left(133.6 \mathrm{lb} / \mathrm{ft}^{3}\right.$ ) $\left(\rho_{\mathrm{b}}=(1-\phi) \rho_{\mathrm{g}}\right)$ (see Table II-2). Although not varied in current PA calculations, the low of 0.001 is based on drying experiments (Powers et al., 1978), while the high of 0.03 is based on the low end of the DC resistivity measurements (Skokan et al, 1988).

\section{Disturbed Porosity}

The disturbed porosity of 0.06 (after consolidation and healing (Lappin et al., 1989, p. 4-45; Sutherland and Cave, 1978]) is calculated assuming that the final density is 0.95 of the intact density (Holcomb and Shields, 1987 , Figure 4) $\left(0.95 \rho_{\mathrm{b}}=(1-\phi) \rho_{\mathrm{g}}\right)$. Some early PA calculations arbitrarily used values of 0.03 without any noticeable influence on the results.

\section{BRINE PRESSURE AT REPOSITORY LEVEL}

In PA compliance calculations, brine pressure at the repository level is assumed to vary uniformly between $7 \mathrm{MPa}$ (69 atm) (about brine hydrostatic pressure) and $15 \mathrm{MPa}$ (148 atm) (1ithostatic pressure based on hydraulic fracturing experiments [Wawersik and Stone, 1985]) (Figure II-9). For a uniform distribution, the median and mean value is $11 \mathrm{MPa}$ (109 atm,) which corresponds to the maximum far-field pore-pressure measured in the Salado Formation (Beauheim, 1990, Memo 3c [Appendix A]). 


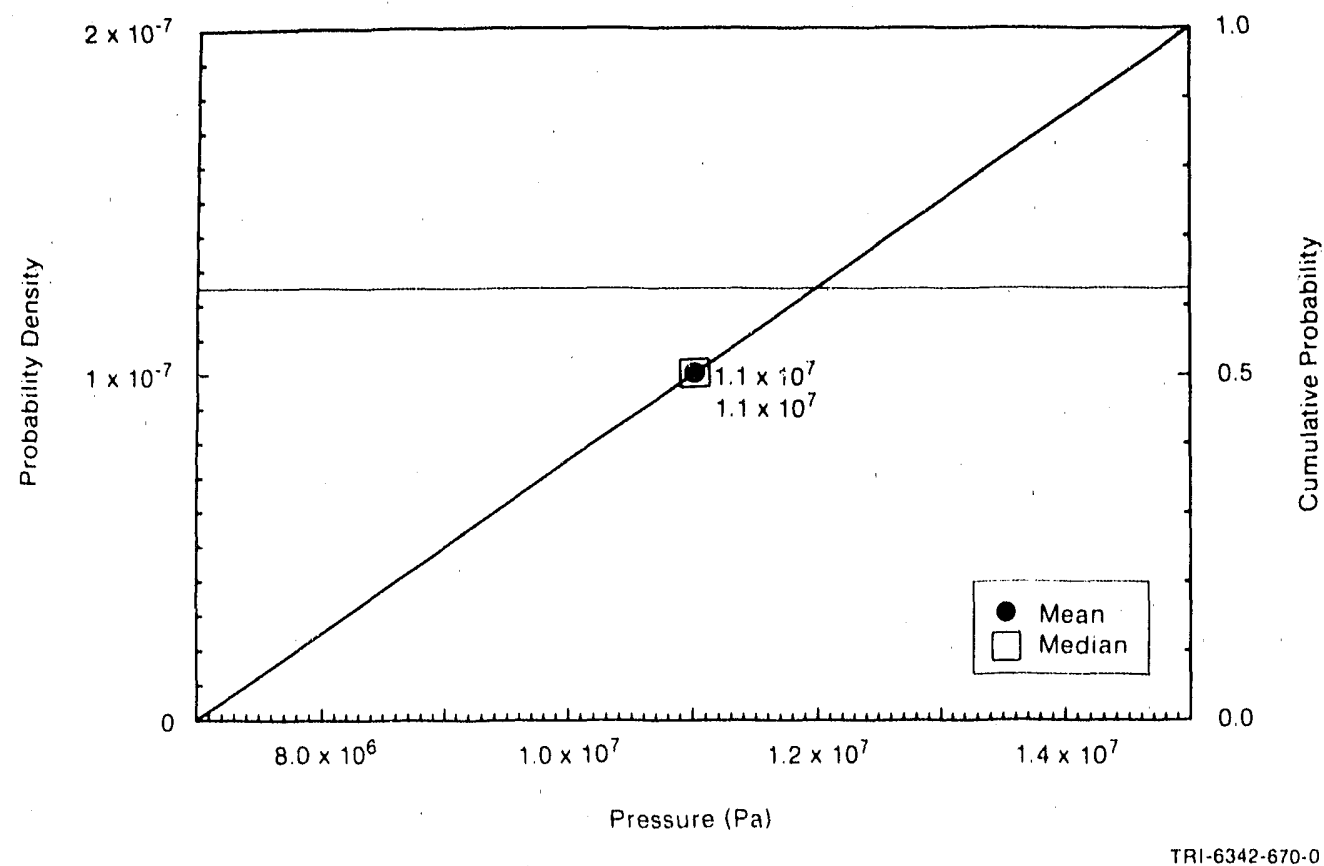

Figure II-9. Uniform pdf and cdf for Brine Pressiure at Repository Level. 


\section{Parameters for Marker Bed 139 and Other Anhydrite Layers near Repository}

Marker Bed 139 (MB139) is an interbed located about $1 \mathrm{~m}$ ( $3.3 \mathrm{ft}$ ) below the repository interval and a potential transport pathway. Table. II-4 provides the parameter values for Marker Bed 139.

TABLE $\|-4$, PARAMETER VALUES FOR MARKER BED 139 AND OTHER ANHYDRITE LAYERS NEAR REPOSITORY

\begin{tabular}{|c|c|c|c|c|c|c|}
\hline Parameter & Median & & Range & Uniro & $\begin{array}{c}\text { Distribution } \\
\text { Type }\end{array}$ & source \\
\hline Capillary pressure $\left(\mathrm{p}_{\mathrm{c}}\right)$ & & 0.3 & $1.04 \times 10^{8}$ & $P_{\mathbf{a}}$ & Table & $\begin{array}{l}\text { Brooks and Corey, 1964; Ward and } \\
\text { Morrow, } 1985\end{array}$ \\
\hline \multicolumn{7}{|l|}{ Relative } \\
\hline permeability $\left(x_{r w}\right)$ & & 0.0 & 1 & none & Table & $\begin{array}{l}\text { Brosks and Corey, 1964; Ward and } \\
\text { Morrow, } 1985\end{array}$ \\
\hline $\begin{array}{l}\text { Density, grain }\left(\rho_{\mathrm{g}}\right) \\
\text { Permeability }(k)\end{array}$ & $2.963 \times 10^{3}$ & & & $\mathrm{~kg} / \mathrm{m}^{3}$ & Constant & Se日 text (anhydrite) \\
\hline Undisturbed & $1 \times 10^{-19}$ & $1 \times 10^{-20}$ & $1 \times 10^{-18}$ & $m^{2}$ & Lognormal & Beauheim et al.,1990; DOE, 1989, 1.2 \\
\hline Disturbed & $1 \times 10^{-17}$ & $1 \times 10^{-19}$ & $1 \times 10^{-13}$ & $m^{2}$ & Cumulative & $\begin{array}{l}\text { Beauheim, 1990, Memo } 30 \text { (see } \\
\text { Appendix A) }\end{array}$ \\
\hline \multicolumn{7}{|l|}{ Porosity $(\phi)$} \\
\hline $\begin{array}{l}\text { Undisturbed } \\
\text { Disturbed }\end{array}$ & $\begin{array}{l}1 \times 10^{-2} \\
1 \times 10^{-1}\end{array}$ & $1 \times 10^{-3}$ & $3 \times 10^{-2}$ & $\begin{array}{l}\text { none } \\
\text { none }\end{array}$ & $\begin{array}{l}\text { Cumulative } \\
\text { Constant }\end{array}$ & $\begin{array}{l}\text { See text. } \\
\text { Lappin et al., 1989, Table D-2 }\end{array}$ \\
\hline Thlckness $(\Delta z)$ & $9 \times 10^{-1}$ & $4 \times 10^{-1}$ & 1.25 & $\mathrm{~m}$ & Cumulative & $\begin{array}{l}\text { Borns, 1985, Figure 3; DOE/WIPP } \\
89-009 \text {; Krieg, 1984, Table I }\end{array}$ \\
\hline
\end{tabular}

\section{CAPILLARY PRESSURE AND RELATIVE PERMEABILITY}

The correlations for these values were developed as discussed in the section, "Parameters for Halite and Polyhalite within the Salado Formation." Preliminary parameter values selected for MB139 and other anhydrite beds are the same as for Salado halite, except for a lower threshold displacement pressure $\left(p_{t}\right)$ and were taken from experimental data measured for the tight gas sands (Ward and Morrow. 1985).

$$
\begin{aligned}
& \lambda=0.7 \\
& \mathrm{p}_{t}=0.3 \mathrm{MPa} \\
& \mathrm{s}_{\mathrm{Wr}}=0.2 \\
& \mathrm{~s}_{\mathrm{gc}}=0.2
\end{aligned}
$$


Capillary pressures and relative permeabilities for these materials are given in Figures II-10 and II-11, respectively.

\section{DENSITY}

The grain density of anhydrite tabulated in Table II-4 is a value reported in the 1iterature (Clark, 1966, p. 46).

\section{PERMEABILITY}

\section{Undisturbed Permeability}

The general consensus for the permeability of anhydrite layers in general, and MB139 in particular, is a median value of $1 \times 10^{-19} \mathrm{~m}^{2}\left(1 \times 10^{-4} \mathrm{mD}\right)$ and a range of $1 \times 10^{-20}$ to $1 \times 10^{-18} \mathrm{~m}^{2}\left(1 \times 10^{-5}\right.$ to $1 \times 10^{-3} \mathrm{mD}$ ) (DOE, 1989, §1.2; Lappin et a1., 1989). Beauheim et al. (1990, Table 7-1) reports two measured permeabilities in MB139: $1 \times 10^{-18}$ and $6 \times 10^{-20} \mathrm{~m}^{2}\left(1 \times 10^{-3}\right.$ and $\left.6 \times 10^{-5} \mathrm{mD}\right)$, which fall within this range.

\section{Disturbed Permeability}

Following the logic described for permeability for the Salado halite, the disturbed permeability is assumed to vary between the median intact value and the highest measured value; the median value is set two orders of magnitude below the undisturbed median value. The highest permeability measured to date in MB139 is $3.2 \times 10^{-13} \mathrm{~m}^{2}\left(3.2 \times 10^{2} \mathrm{mD}\right.$ ) (Crawley, 1990) but was rounded down to $1 \times 10^{-13} \mathrm{~m}^{2}\left(1 \times 10^{2} \mathrm{mD}\right)$, the value used $\mathrm{fcr}$ unmodified TRU waste.

\section{POROSITY}

\section{Undisturbed Porosity}

PA calculations have assuned an undisturbed porosity similar to the undisturbed poros'ty of the Salado Formation as a whole.

\section{Disturbed Porosity}

The disturbed porosity of the anhydrite layers was set at 0.1 . This value is an order of magnitude increase above the undisturbed porosity. The reason for the increase is that the fractures that form within the brittle anhydrite beds during excavations will not heal completely. Shear displacement will likely cause abutment of asperities in the fractures which, in turn, will prop them open (Lappin et al., 1989, p. 4.62). 


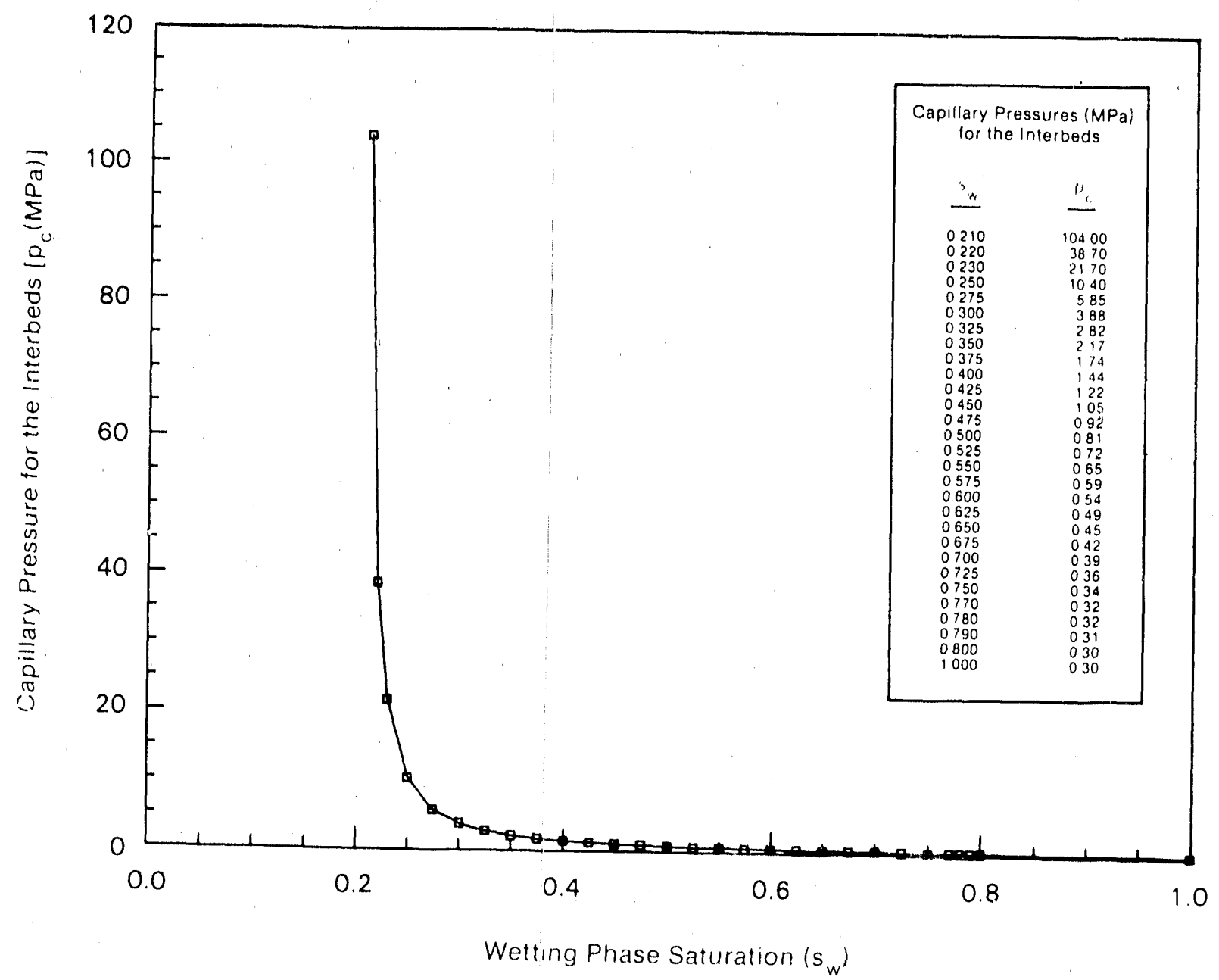

TR1.6342.623.0 Figure II-10. Estimated Capillary Pressure Cunve for Marker Bed 139 and Other Anhydrite Layers near
Repository. 


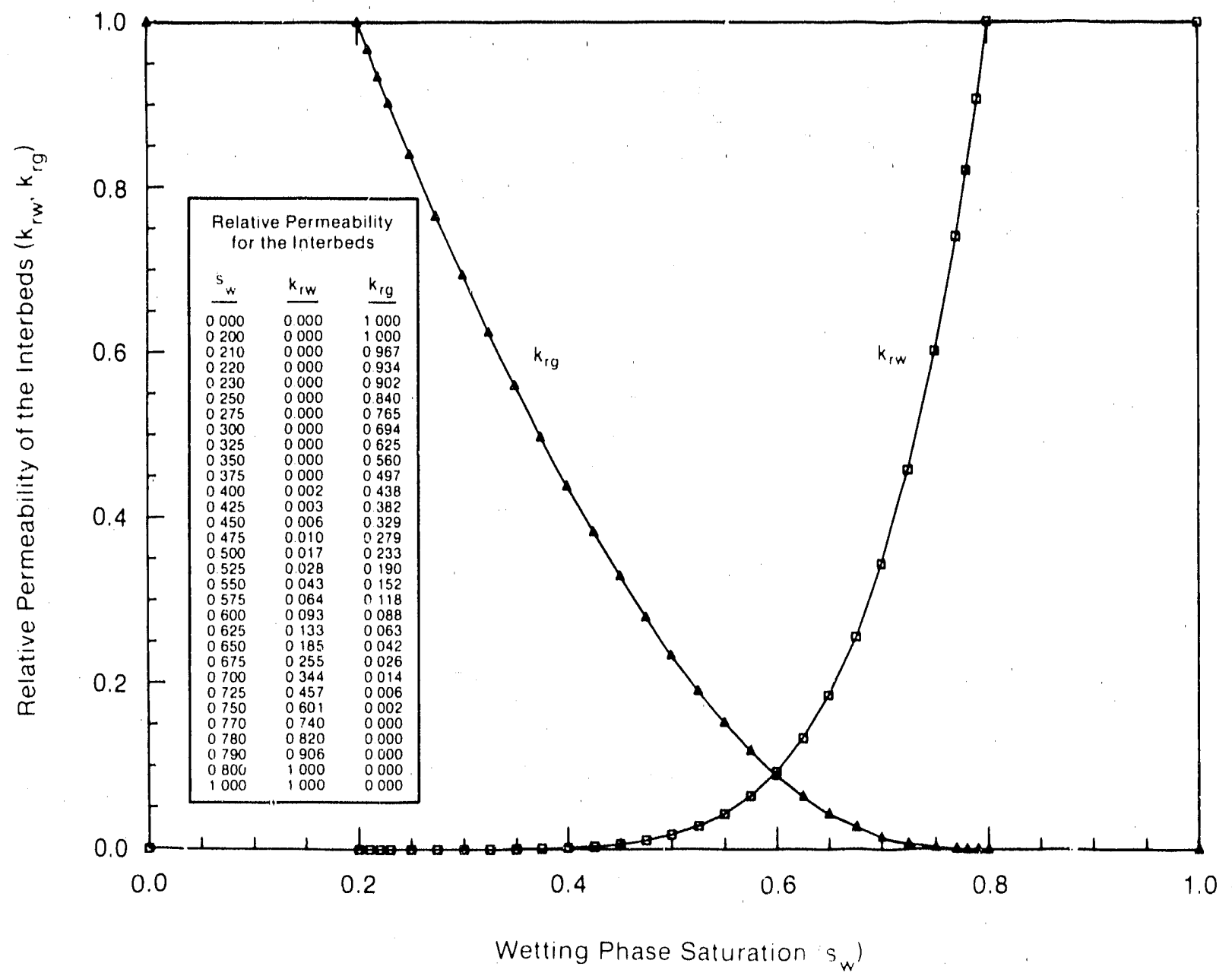

TRI-6342-620-0

Figure II-11. Estimated Relative Permeability for Marker Bed 139 and Other Anhydrite Layers near Repository. 


\section{THICKNESS OF INTERBED}

The thickness for MB139 in the generalized stratigraphy of the site is about $0.9 \mathrm{~m}$ (3 ft) (DOE/WIPP 89-009) and is used as the median value. Because the upper contact is irregular and undulates (caused from reworking of the interbed prior to further halite deposition), the thickness varies between 0.40 and $1.25 \mathrm{~m}(1.3$ and $4.1 \mathrm{ft}$ ) (Borns, 1985, Figure 3; Krieg, 1984, Table I). 


\section{Parameters for Castile Formation Brine Pocket}

Pressurized brine in the Castile Formation is known to be present at the WIPP-12 borehole north and at the Belco hydrocarbon borehole southwest of the WIPP (Figure II-12). During the past 50 years, a number of hydrocarbonexploration boreholes have encountered pressurized brine in the Castile Formation. Ceophysical studies that are correlated with the known occurrence of brine at WIPP-12 indicate the presence of brine to the south (Earth Technology Corp., 1988). Based on these studies and on borehole experience, the WIPP-12 brine pocket is assumed to extend underneath at least a portion of the waste-emplacement panels (Lappin et al., 1989; Lappin, 1988).

The origin of Castile brine pockets is not conclusively known. Present interpretations are that their origin is either local, by limited movement of intergranular brines from adjacent Castile halites, or regional, by the previous existence of a lateral hydraulic connection of the Castile Formation with tho Capitan reef (Lappin et al., 1989). The assumed presence of a Castile brine pocket beneath the repository is of concern only in the event of human intrusion. Hydraulic testing indicates that the WIPP-12 brine pocket is dominated by fracture flow in a very tight anhydrite matrix and that the brine pocket is limited in extent. A few laboratory estimates of permeability and porosity of the Castile anhydrite have been made. The permeability of the anhydrite core is less than $2 \times 10^{-19} \mathrm{~m}^{2}\left(2 \times 10^{-4} \mathrm{mD}\right)$ and the porosity values range from 0.008 to 0.002 (Popielak et al., 1983).

Table II-5 provides the parameter values for the Castile Formation Brine Pocket.

\section{BRINE POCKET MODEL}

The high effective transmissivity of the Castile brine pocket inferred from flow tests at the WIPP-12 borehole (Lappin et al., 1989; Popielak et al., 1983) implies that, in the event of its connection to the Culebra Dolomite through a sand-filled borehole, fluid flow rates from the brine pocket will be controlled by the conductivity of the borehole fill and the area of the borehole (Rechard et al., 1990; Reeves et al., 1990); hence, the pressure gradients within the brine pocket will be small. Therefore, the brine pocket state at any time can be characterized by a single pressure (the initial pressure, $p_{p}(0)$ is a logical value). 


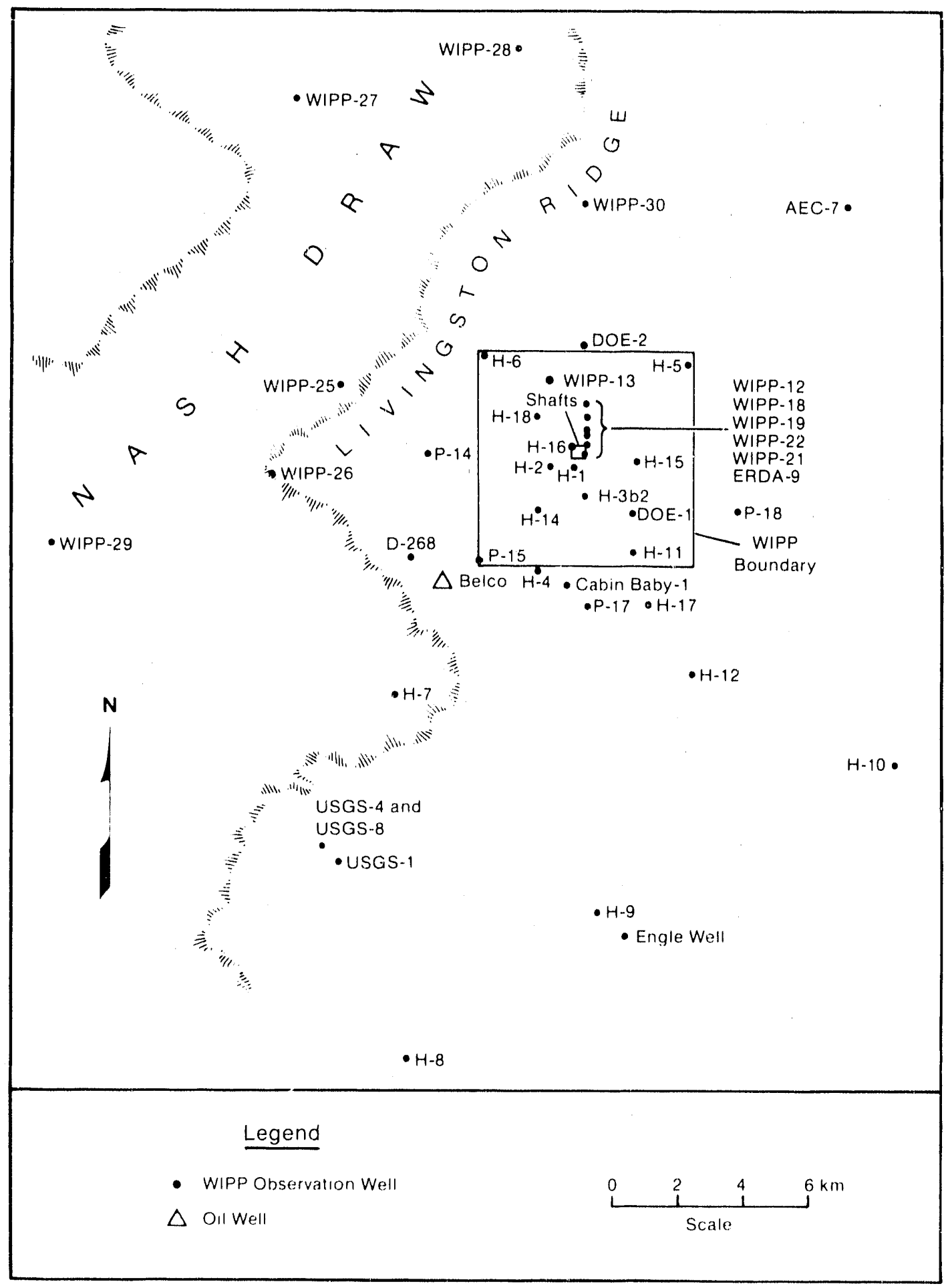

TRI-6342-303-1

Figure II-12. Observation Wells in the WIPP Area. 
TABLE $\|$-5. PARAMETER VALUES FOR CASTILE FORMATION BRINE POCKET

\begin{tabular}{|c|c|c|c|c|c|c|}
\hline Parameter & Median & & & Units & $\begin{array}{c}\text { Distribution } \\
\text { Typo }\end{array}$ & Source \\
\hline $\begin{array}{l}\text { Compressed } \\
\text { volume, initial }\left(v_{i}\right) \\
\text { Pressure, initial }\left(p_{i}\right)\end{array}$ & $\begin{array}{l}7 \times 10^{6} \\
1.27 \times 10^{7}\end{array}$ & $\begin{array}{l}4.8 \times 10^{3} \\
7 \times 10^{6}\end{array}$ & $\begin{array}{l}1.4 \times 10^{7} \\
1.74 \times 10^{7}\end{array}$ & $\begin{array}{l}\mathrm{m}^{3} \\
\mathrm{~Pa}\end{array}$ & $\begin{array}{l}\text { Uniform } \\
\text { Cumulative }\end{array}$ & $\begin{array}{l}\text { Lappin et al.,1989, Table 3-19 } \\
\text { Lappin et al.,1989, Table 3-19; } \\
\text { Poplelak et al.,1983 }\end{array}$ \\
\hline
\end{tabular}

Assuming constant compressibility of the brine pocket components (fluid, matrix, and gas), the pressure in the brine pocket will vary linearly with the volume of brine removed as follows: $d p / d V=1 / S_{b}$ where $d p$ is the change in brine pocket pressure, $\mathrm{dV}$ is the change in brine volume in the brine pocket, and $S_{b}$ is the bulk storage coefficient for the whole brine pocket.

Therefore, the essential characteristics of the brine pocket are contained in two parameters (Figure II-13): the initial pressure of the brine pocket, $p_{i}$, and the bulk storage coefficient, $s_{b}$.

\section{Initial Brine Pocket Pressure}

Lappin et al. (Table 3-19, 1989) estimated the initial brine pocket pressure from several wellhead measurements at WIPP-12 and other boreholes that encountered pressurized Castile brine the range was between 7.0 and $17.4 \mathrm{MPa}$ ( 69 and $172 \mathrm{~atm}$ ), with a median of $12.7 \mathrm{MPa}(125 \mathrm{~atm})$. The range between 7.0 and $9.4 \mathrm{MPa}$ ( 69 and $93 \mathrm{~atm}$ ) implies that should the Salado and Culebra be connected to the brine pocket, the fluid would flow down into the brine pocket. However, the range of pressures includes measurements in wells completed at various elevations, and the correction for elevation has not been made. A review of brine pocket pressure data is currently underway, but until the review is complete PA calculations assumed all downward flow as upward flow. The original sampling was done on a piecewise linear cumulative distribution function between 7.0 and $17.4 \mathrm{MPa}$ (69 and $172 \mathrm{~atm}$ ) with a median of $12.7 \mathrm{MPa}$ (125 atm) (Table II-5 and Figure II-14).

\section{Bulk Storage Coefficient}

The bulk storage coefficient $\left(S_{b}\right)$ can be estimated by examining the change in pressure with volume $(\Delta \mathrm{p} / \Delta \mathrm{V})$ for measurement of WIPP-12 and other boreholes that encounter pressurized Castile brine. A review of the data is currently underway. Until the review is complete, the bulk storage coefficient was estimated from the ratio of inital pressure and inital compressive volume 


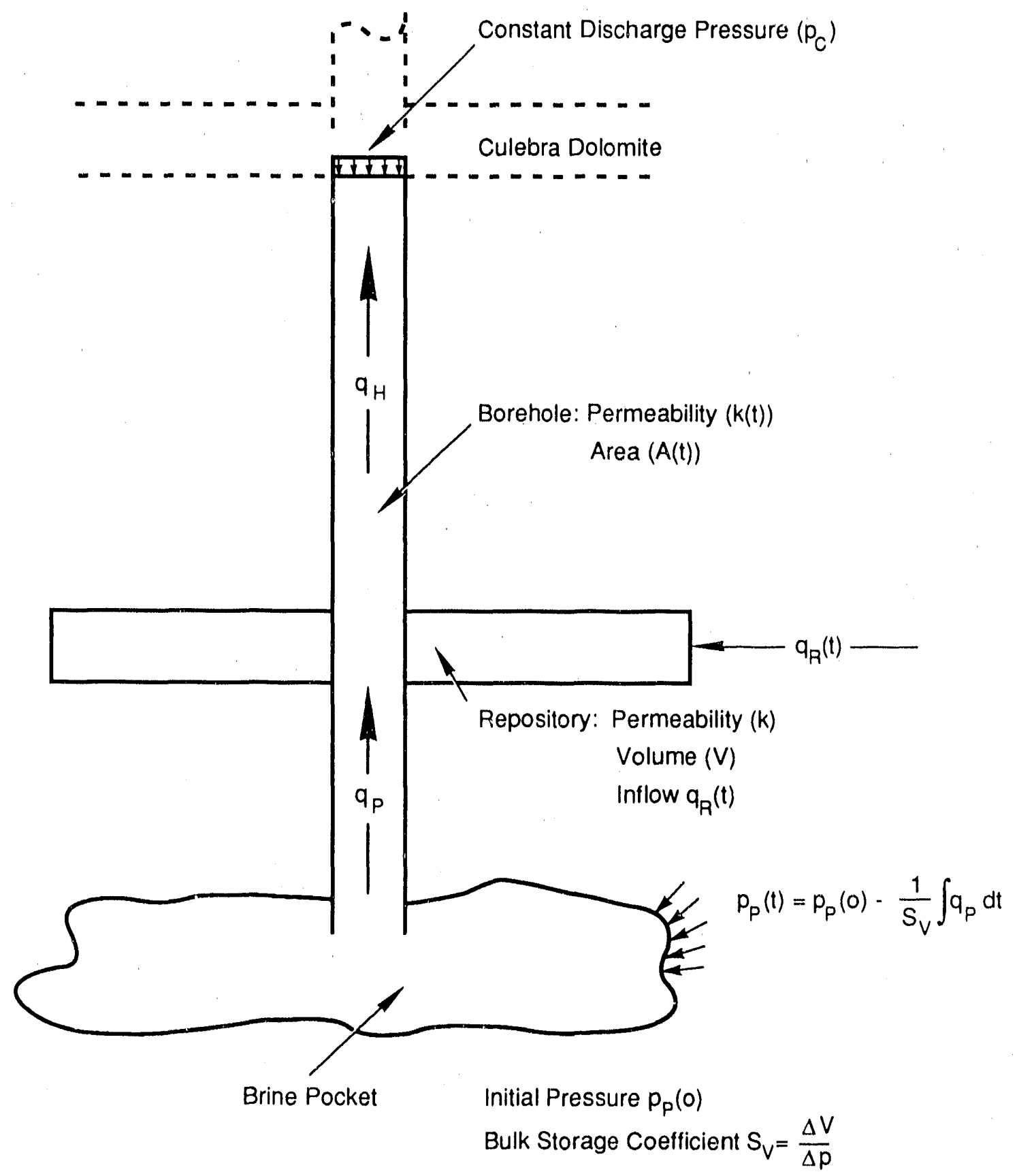

TR1.6342.393.1

Figure 11-13. Conceptual Model of Castile Brine Pocket Repository and Borehole Requires a Specified Initial Brine Pocket Pressure and a Bulk Storage Coefficient (Change in Discharge Volume with Change in Brine Pocket Pressure). 


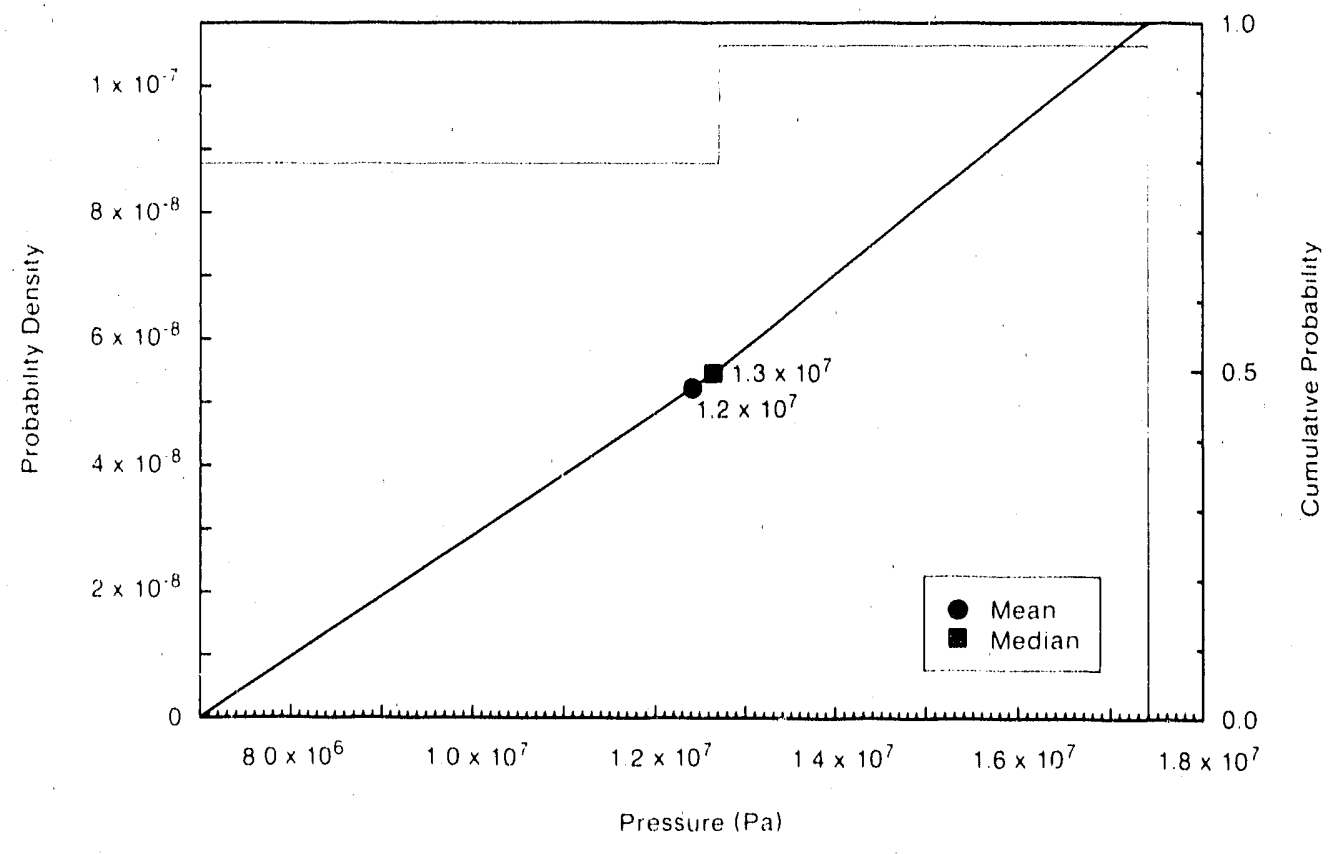

Figure II-14. pdf and cdf for Castile Brine Pocket Initial Pressure.

$\left(p_{i} / V_{i}\right)$, where $v_{i}$ (Table II-5) was defined as the amount of brint discharged in lowering the brine pocket potentiometric surface to the elevation of the Culebra Dolomite.

PA calculations sampled from a uniform distribution for $V_{\mathfrak{i}}$ with a range of 4.8 $\times 10^{3}$ to $1.4 \times 10^{7} \mathrm{~m}^{3}\left(1.7 \times 10^{5}\right.$ to $\left.4.9 \times 10^{8} \mathrm{ft}^{3}\right)$ (Figure II-15). The range for $V_{i}$ was estimated using the maximum values of radius and pressure defined for the brine pocket in Lappin et al. (1989) and the storage coefficent value used in calibrating the drill-stem test responses $\left(8.5 \times 10^{-5}\right)$. (It was assumed that brine was discharged from only the inner and middle zones in the brine pocket model described in Lappin et al., 1989).

\section{LOCATION OF CASTILE BRINE POCKET BELOW WIPP DISPOSAL AREA}

Pressurized brines in the northern Delaware Basin have been encountered in fractured anhydrites of the Castile Formation and in several hydrocarbon exploration boreholes both north and northeast of the WIPP. In addition, Castile brines were encountered southwest of the WIPP at the Belco Well, about $6.5 \mathrm{~km}(4 \mathrm{mi})$ from the center of the WIPP. During WIPP site characterization, Castile Formation brine pockets were encountered in the WIPP-12 borthole, about $1.6 \mathrm{~km}$ ( $1 \mathrm{mi}$ ) north of the center of the WIPP, and the ERDA-6 borehole, about $8 \mathrm{~km}$ ( $5 \mathrm{mi}$ ) northeast of the center of the WIPP. The pressurized brines 


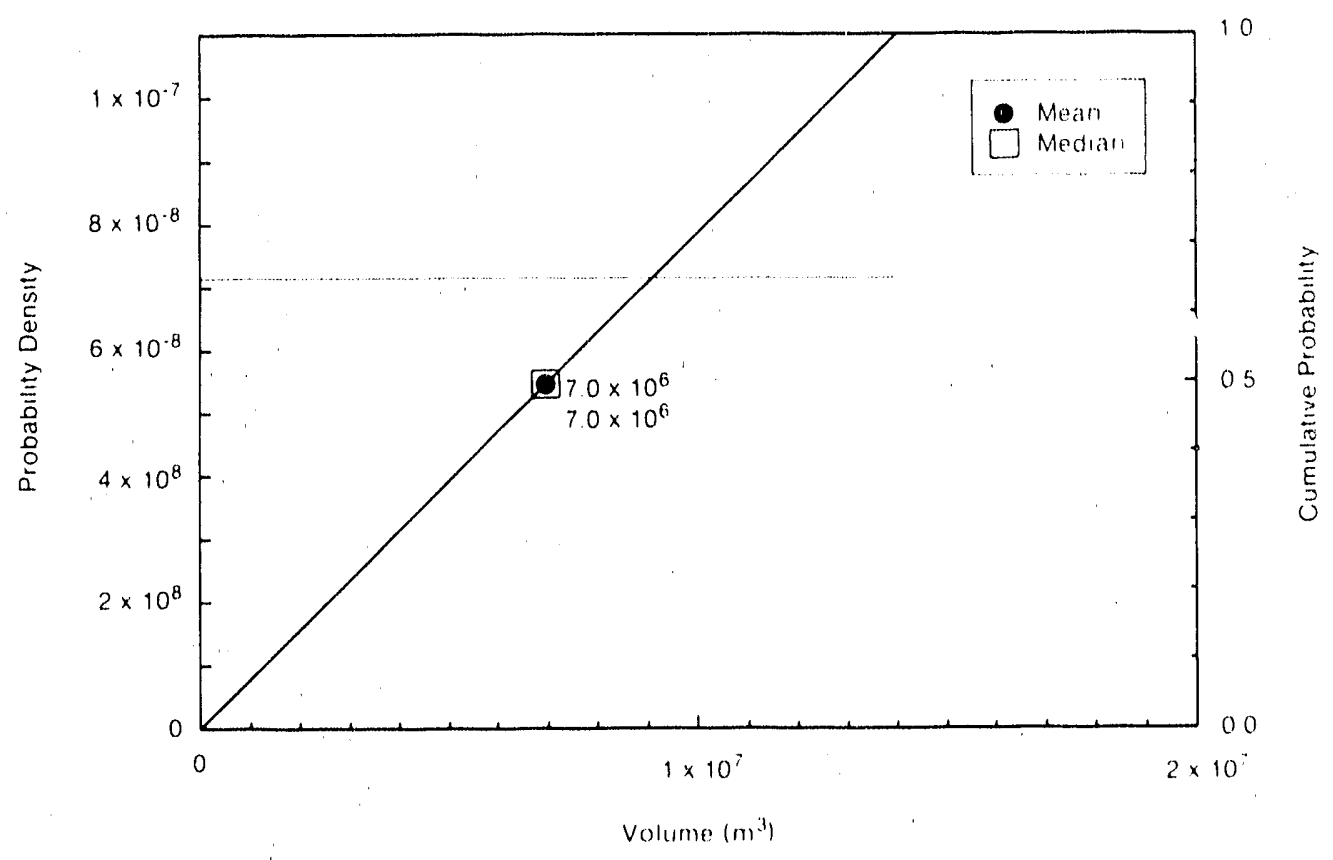

$191 \cdot 63.34 \cdot 6761$

Figure II-15. Uniform pdf and cdf for Castile Brine Pocket Initial Compressibility Volume.

were found only within the fractured portions of the anhydrite present in the Castile Formation (Lappin et al, , 1989).

A geophysical survey, using transient electromagnetic methods, was made in 1987 to determine the presence or absence of brines within the Castile Formation under the WIPP disposal area (Earth Technology Corp., 1988). Briefly, the electromagnetic method associates high electric conductivity with fluid. The entire Bell Canyon Formation directly beneath the Castile Formation (see Figure II-1) is a good conductor. However, in several places underneath the WIPP disposal area, the depth to the first major conducting media detected lay above the depth to the top of the Bell Canyon Formation $(1,250 \mathrm{~m}[4,100 \mathrm{ft}]$ in the ERDA-9 borehole and $1,230 \mathrm{~m}[4,035 \mathrm{ft}]$ in the Cabin Baby-1 borehole) but always below the botton of the Salado Formation (861 m [2,824 ft] in ERDA-9 and $821 \mathrm{~m}[2,694 \mathrm{ft}]$ in Cabin Baby-1) (Lappin et a1., $1.989)$.

The depth to the bottom of the anhydrite in the Castile Formation is $959 \mathrm{~m}$ $(3,117 \mathrm{ft})$ in Cabin Baby-1, and estimated at $950 \mathrm{~m}(3,146 \mathrm{ft})$ in ERDA-9. Assuming a maximum $75 \mathrm{~m}$ (246 ft) vertical uncertainty in the geophysical soundings implies that high conductors less than about $1,025 \mathrm{~m}(3,363 \mathrm{ft})$ 
could indicate brine within the anhydrite. Consequently, brine may be present only in the anhydrite beneath the northern and northeastern edges of the disposal area (Figure II-16) (Lappin et al, 1989). However, pressurized brine pockets cannot be entirely discounted until the Bell Canyon Formation is reached at about $1,250 \mathrm{~m}(4,100 \mathrm{ft})(1,200 \mathrm{~m}(3,937-\mathrm{ft})$ contour, (Figure II-16).

Current PA calculations use the $1,200 \mathrm{~m}(3,937 \mathrm{ft})$ contour for defining the locations of any brine pockets under the WIPP disposal area.

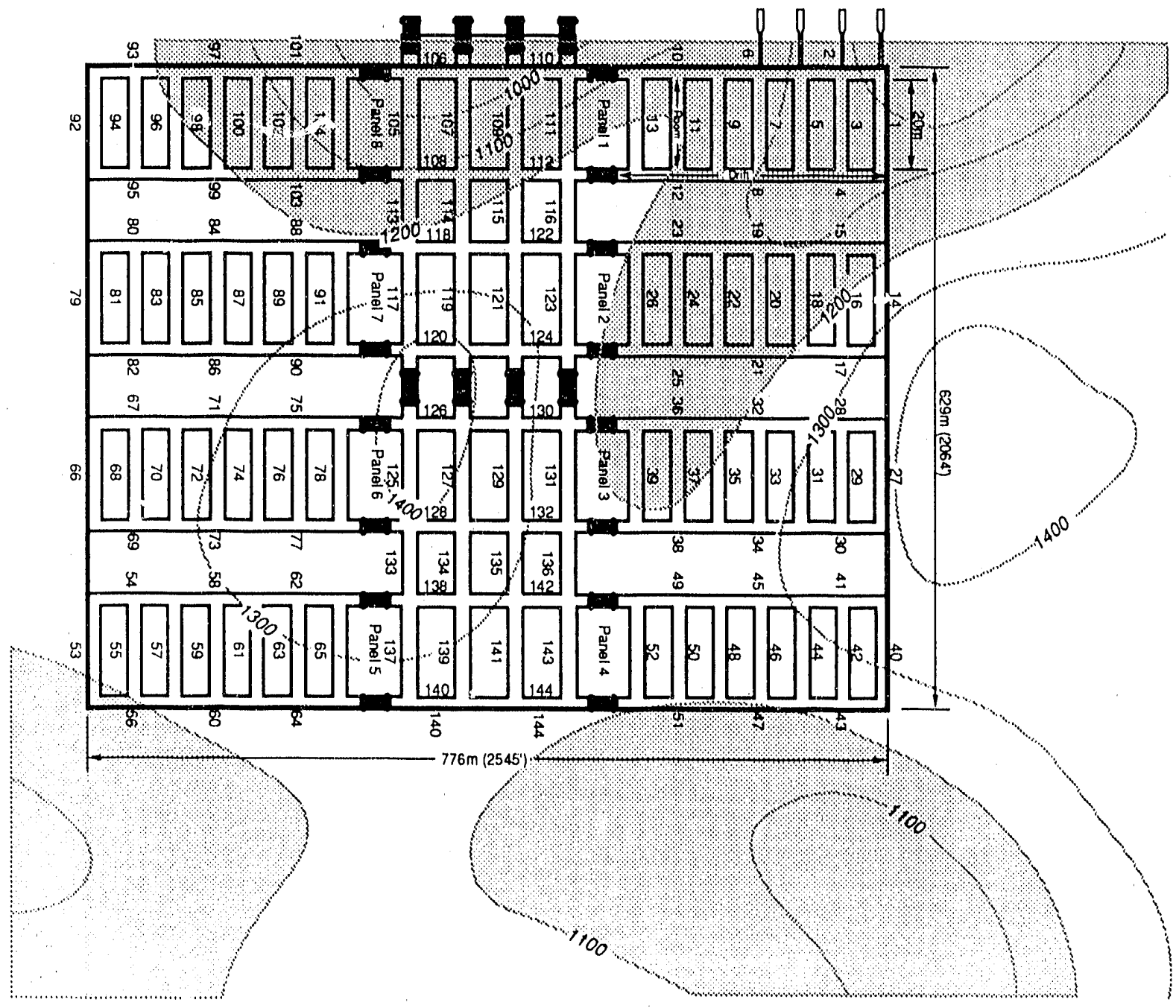

Assumed Location of Brine Pockets

TR1.6342-268-0

Figure II-16. Contour Map of Depth to First Major Conductor below WIPP Disposal Area (after Earth Technology Corp., 1987). 


\section{Parameters for Culebra Dolomite Member}

The Culebra Dolomite Member of the Rustler Formation is a finely crystalline, locally argillaceous (containing clay) and arenaceous (containing sand), vuggy dolomite ranging in thickness near the WIPP from $7 \mathrm{~m}$ (23 ft) (at DOE-1 and other locations) to $14 \mathrm{~m}(46 \mathrm{ft}$ ) (at H-7). The Culebra Dolomite is generally considered to provide the most important potential groundwater-transport pathway for radionuclides that are released to the accessible environment. Accordingly, the WIPP Project has devoted much attention to understanding the hydrogeology and hydraulic properties of the Culebra. (The Culebra Dolomite has been tested at 41 locations in the vicinity of the WIPP.)

One early observation (Mercer and Orr, 1979) was that the transmissivity of the Culebra Dolomite varies by six orders of magnitude in the vicinity of the WIPP. This variation in transmissivity appears to be the result of differing degrees of fracturing within the Culebra Dolomite. The cause of the fracturing, howeve $f$, is unresolved. Culebra transmissivities of about $3 . x$ $10^{-6} \mathrm{~m}^{2} / \mathrm{s}\left(0.93 \mathrm{ft}^{2} / \mathrm{d}\right)$ or greater appear to be related to fracturing. Where the transmissivity of the Culebra Dolomite is less than $1 \times 10^{-6} \mathrm{~m}^{2} / \mathrm{s}$ $\left(0.93 \mathrm{ft}^{2} / \mathrm{d}\right)$, few or no open fractures have been observed in core, and the Culebra's hydraulic behavior during pumping or slug tests is that of a singleporosity medium. Where transmissivities are between $1 \times 10^{-6} \mathrm{~m} / \mathrm{s}$ $\left(0.93 \mathrm{ft}^{2} / \mathrm{d}\right)$ and at least $1 \times 10^{-4} \mathrm{~m}^{2} / \mathrm{s}\left(93 \mathrm{ft}^{2} / \mathrm{d}\right)$, open fractures are observed in core, and the hydraulic behavior of the Culebra Dolomite during pumping tests is that of a dual-porosity medium (Lappin et al., 1989).

Parameter values for the Culebra Dolomite Member are given in Table II- 6 .

\section{BULK DENSITY}

The bulk density $\left(\rho_{\mathrm{b}}\right)$ of the Culebra Dolonite Member was evaluated for 73 core samples from 15 boreholes. The values vary between $2.78 \times 10^{3}$ and $2.84 \times 10^{3}$ $\mathrm{kg} / \mathrm{m}^{3}$ (174 and $178 \mathrm{lb} / \mathrm{ft}^{3}$ ) with an average of $2.82 \times 10^{3} \mathrm{~kg} / \mathrm{m}^{3}$ (176.7 $1 \mathrm{~b} / \mathrm{ft}^{3}$ ) (Lappin et al., 1989; Kelley and Saulnier, 1990). The bulk density $\left(\rho_{\mathrm{b}}\right)$ of the clays (gypsum and corrensite) lining the fractures of the Culebra Dolomite is $2.5 \times 10^{3} \mathrm{~kg} / \mathrm{m}^{3}$ (156 1b/ft ${ }^{3}$ ) (Siegel, 1990, Memo 3a [Appendix A]).

\section{DEPTH}

The reported depth is the average depth between the top and bottom of the Culebra Dolomite as measured in the three access shafts at the WIPP (see Table II - 1). 
TABLE II-6. PARAMETER VALUES FOR CULEBRA DOLOMITE MEMBER OF RUSTLER FORMATION

\begin{tabular}{|c|c|c|c|c|c|c|}
\hline Parameter & Median & Ran & & Unlts & $\begin{array}{l}\text { Dlstribution } \\
\text { Type }\end{array}$ & Source \\
\hline \multicolumn{7}{|l|}{ Density, bulk $\left(\rho_{\mathrm{b}}\right)$} \\
\hline Dolomite & $2.82 \times 10^{3}$ & $2.78 \times 10^{3}$ & $2.86 \times 10^{3}$ & $\mathrm{~kg} / \mathrm{m}^{3}$ & Normal & Lappln et al.,1789, Table E-6 \\
\hline Clay & $2.5 \times 10^{3}$ & & & $\mathrm{~kg} / \mathrm{m}^{3}$ & Constant & $\begin{array}{l}\text { Slegel, 1990, Memo 3a (see } \\
\text { Appendix A) }\end{array}$ \\
\hline Depth, average (z) & $2.20 \times 10^{2}$ & & & $m$ & Constant & Seo test (Stratlgraphy). \\
\hline \multicolumn{7}{|l|}{ Dispersivity, } \\
\hline longltudinal $\left(\alpha_{L}\right)$ & $1 \times 10^{2}$ & $5 \times 10^{1}$ & $3 \times 10^{2}$ & $m$ & Cumulative & Lappln et al.,1990, Table E-6. \\
\hline Fracture spacing (2B) & 2 & $2.50 \times 10^{-1}$ & 7 & m & Cumulative & $\begin{array}{l}\text { Lappin et al.,1989, Table 1-2, Table } \\
\text { E-6 }\end{array}$ \\
\hline Clay filling fraction $\left(b_{0} / b\right)$ & 0.5 & 0.1 & 0.9 & none & Normal & $\begin{array}{l}\text { Slegel, 1990, Memo 3a (see } \\
\text { Appendlx A) }\end{array}$ \\
\hline \multicolumn{7}{|r|}{ 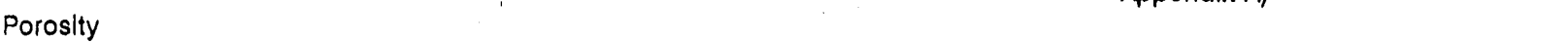 } \\
\hline Fracture $\left(\phi_{f}\right)$ & $1.5 \times 10^{-3}$ & $1.5 \times 10^{-4}$ & $1.5 \times 10^{-2}$ & none & Lognormal & $\begin{array}{l}\text { Lappin et al.,1989, Table 1-2, } \\
\text { Table E-6 }\end{array}$ \\
\hline Matrix $\left(\phi_{m}\right)$ & 15.2 & 0.028 & 0.303 & none & Density & Lappin et al.,1989 Table E-8 \\
\hline Storage coefficlent (S) & $2 \times 10^{-5}$ & $5 \times 10^{-6}$ & $5 \times 10^{-4}$ & none & Cumulative & $\begin{array}{l}\text { LaVenue et al.,1990, p. 2-18; Haug of } \\
\text { al.,1987 }\end{array}$ \\
\hline Thickness $(\Delta z)$ & $7.7 \times 10^{1}$ & & & $m$ & Constant & LaVenue et al., 1988, Table B-1 \\
\hline Tortuosity $(\tau)$ & $1.4 \times 10^{-1}$ & $3 \times 10^{-2}$ & $3.3 \times 10^{-1}$ & none & Density & Lappin et al., 1989 Table E-9 \\
\hline
\end{tabular}

\section{DISPERSIVITY}

For moderate travel distances (on the order of kilometers), longitudinal dispersivity $\left(\alpha_{L}\right)$ roughly varies between 0.01 and 0.1 of the mean travel distance of the solute (Lallemand-Barres and Peaudecerf, 1978; Pickens and Grisak, 1981). As first adopted by Lappin et al. (1989), the PA Division has assumed $\alpha_{\mathrm{L}}$ can vary between 50 and $300 \mathrm{~m}$ (164 and $984 \mathrm{ft}$ ) with a median value of $100 \mathrm{~m}$ (328 $\mathrm{ft})$.

In turn, transverse dispersivity $\left(\alpha_{\mathrm{T}}^{\prime}\right)$ is usually linearly related to $\alpha_{\mathrm{L}}$. The ratio of $\alpha_{\mathrm{L}}$ to $\alpha_{\mathrm{T}}$ has been reported to vary between 5 to 100 (de Marsily, 1986) and 10 to 20 (Bear and Verruijt, 1987). Similar to Lappin et al. (1989), $\alpha_{\mathrm{T}} \simeq 0.1 \alpha_{\mathrm{L}}$ for PA transport calculations.

\section{FRACTURE SPACING}

Both horizontal and vertical fracture sets have been observed in core samples, shaft excavations, and outcrops. A fracture spacing varying between 0.5 and $2.4 \mathrm{~m}$ ( 1.6 and $7.9 \mathrm{ft}$ ) has been interpreted for two travel paths at the $\mathrm{H}-3$ borehole (Kelley and Pickens, 1986). Preliminary evaluation of the breakthrough curves for the $\mathrm{H}-11$ borehole tracer test suggests a fracture spacing between 0.8 and $3 \mathrm{~m}(2.6$ and $9.8 \mathrm{ft}$ ) (Lappin et a1., 1989; Saulnier et al., 1989; Stensrud et al,, 1990). From these data, Lappin et al. (1989) 
suggested a minimum of $0.25 \mathrm{~m}(0.8 \mathrm{ft})$ and a maximum equiralent to the assumed uniform thickness of the Culebra $(7.7, \mathrm{~m}[25.3 \mathrm{ft}])$. Finally, the average fracture spacing at the two wells ( $\mathrm{H}-3$ and $\mathrm{H}-11)$ is $1.7 \mathrm{~m}(5.6 \mathrm{ft})$. Table II6 and Figure II-17 round these values to the first digit and uses the average of two wells as the median.

\section{FRACTION OF CLAY FILLING IN FRACTURES}

Within fractures of the Culebra Dolomite Member, gypsum and corrensite (alternating layers of chlorite and smectite) are observed. To evaluate the retardation of radionuclides within the fractures (caused by interaction with this material lining the fractures), the fraction of lining material ( $b_{c} / b$ ) is needed, where $b_{c}$ is the total thickness of clays and $b$ is fracture aperture. At present, data are not available to estimate the true range or distribution of $\mathrm{b}_{\mathrm{c}} / \mathrm{b}$ in the Culebra. Siegel (1990, Memo 3a [Appendix A]) recommended a normal distribution with a maximum of 0.9 and a minimum of 0.1 . Current PA calculations used a median of 0.5 to estimate the fracture retardation.

\section{POROSITY}

\section{Fracture Porosity}

The fracture porosities interpreted from the tracer tests at the $\mathrm{H}-3$ and $\mathrm{H}-11$ hydropads are $2 \times 10^{-3}$ (Kelley and Pickens, 1986) and $1 \times 10^{-3}$, respectively.

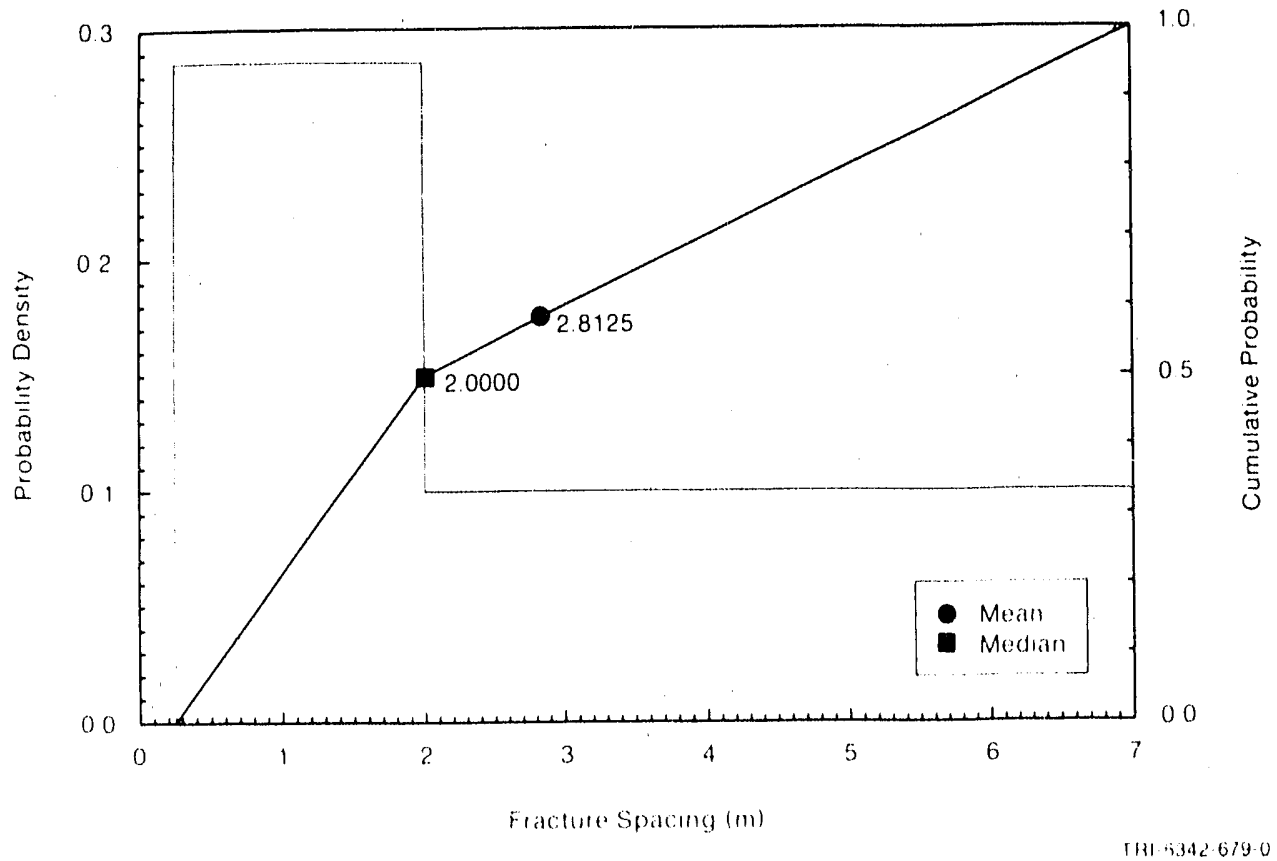

Figure II-17. pdf and cdf for Culebra Fracture Spacing. 
Both H-3 and H-11 lie near the expected transport pathway. Assuming that the porosity distribution is symmetrical, the average value was selected as the median ard used for PA calculations. Lappin et al. (1989) arbitrarily set the minimum and maximum one order of magnitude to either side of this median.

\section{Matrix Porosity}

Matrix porosity has been evaluated by the Boyles' law technique using helium or air on 82 core samples from 15 borehole or hydropad locations near the WIPP site and also by water-resaturation for 30 of the samples. From the Boyles' law technique, an average porosity of 0.152 was obtained, with a range of 0.03 to 0.30 (Lappin et a1., 1989, Table E-8; Kelly and Saulnier, 1990).

\section{STORAGE COEFFICIENT}

Model studies of the Culebra (LaVenue et a1., 1990, 1988; Haug et al., 1987) have used a storage coefficient (S) of $2 \times 10^{-5}$. The storage coefficient near the WIPP ranges over two orders of magnitude ( $5 \times 10^{-6}$ to $5 \times 10^{-4}$ ) and is the basis for the range in Table II-6. However, based on sparse well test data from 13 wells, the storage coefficient can range over four orders of magnitude $\left(1 \times 10^{-6}\right.$ to $1 \times 10^{-2}$ ) in the Culebra (LaVenue et al., 1990, p. 2-18).

\section{THICKNESS}

The Culebra thickness reported in Table II-6 is the constant thickness used in modeling studies reported by LaVenue et al. $(1988,1989)$ and used in PA calculations. Figure II-18 shows the spatial variation of thickness $(\Delta z)$ in the Culebra Dolomite Member estimated by interpolating using inverse-distance squared weighting from the 10 nearest neighbors.

\section{TORTUOSITY}

Tortuosity $(r)$ for the Culebra Dolomite Member was calculated from 15 core samples from 15 borehole locations using the helium porosity and the formation volume factor. The values range from 0.03 to 0.33 with an average of 0.14 (Lappin et a1., 1989, Table E-9) (Figure II-19).

\section{PARTITIONING COEFFICIENTS AND RETARDATION}

A partitioning or distribution coefficient $\left(K_{d}\right)$, which describes the intensity of sorption, is used to calculate the partitioning of species such as radionuclides between the groundwater and rock and, thereby, calculate the sorption capacity or retardation ( $R$ ). A $K_{d}$ value cannot be extrapolated with confidence to physiochemical conditions that differ from those under which the experimental data were obtained. 


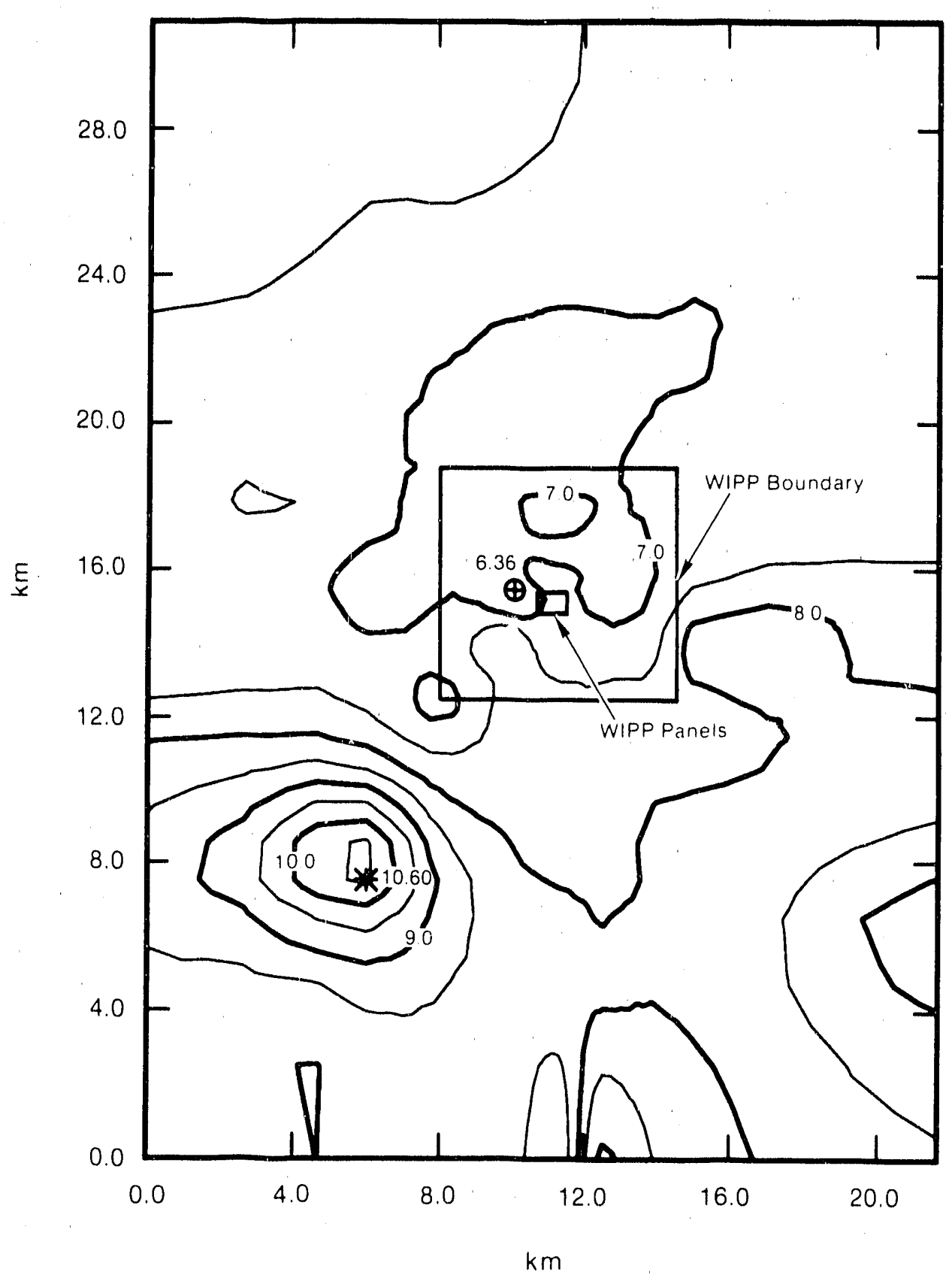

TRI-6342-646-0

Figure II-18. Variation of Culebra Member Thickness as Estimated by 10 Nearest Neighbors Using InverseDistance-Squared Weighting. 


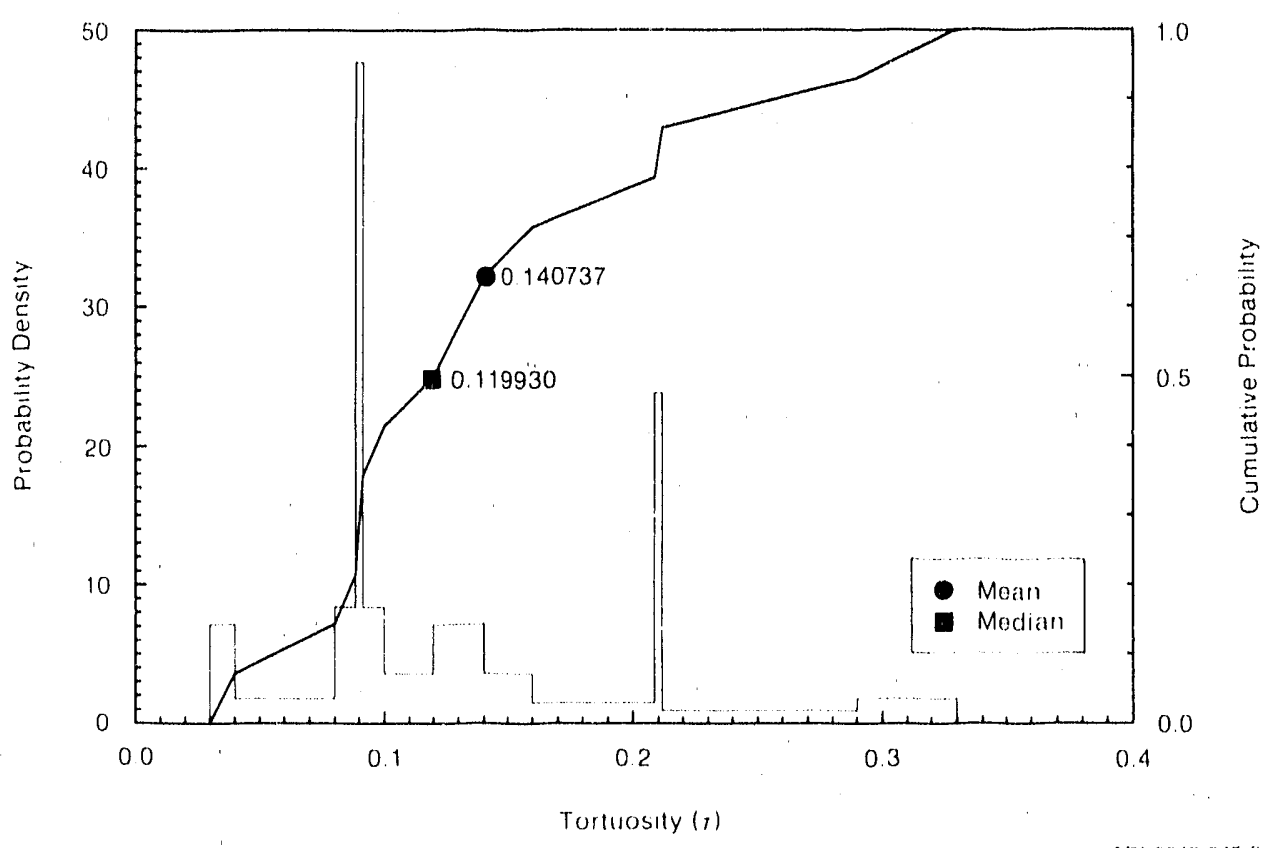

Flgure II-19. pdf and cdf for Culebra Tortuosity.

The choice of recommended $\mathrm{K}_{\mathrm{d}}$ cumulative distributions reported in Tables II-7 and II- 8 are considered to be realistic in light of available data, but require a number of subjective assumptions that ongoing experiments may invalidate. At present, data for thorium, radium, and lead are grouped with other values. In the future, we expect to have better data so that these values will be listed separately.

\section{General Rationale for Recommended Values}

The general rationale for selecting the $\mathrm{K}_{\mathrm{d}}$ value in each percentile of the cdf follows (Tables II-7 and II-8). Separate $k_{d}$ distributions are given for the dolomite matrix and the clays lining the fractures in the Culebra Dolomite Member. In general, the recommended $\mathrm{k}_{\mathrm{d}}$ values were reduced by several orders of magnitude from experimental $\mathrm{K}_{\mathrm{d}}$ data. Many of the $\mathrm{K}_{\mathrm{d}} \mathrm{s}$ reported for the actinides are in the range of 10,000 to $100,000 \mathrm{~mL} / \mathrm{g}$ (Lappin et al., 1989, Table 3-14). The following summarizes the discussion presented in Lappin et a1. (1989).

The uncertainties in the composition of water in the Culebra Dolomite that will be produced by mixing fluids from the repository and aquifer require that large ranges of $\mathrm{pH}$, Eh, organic content, and carbonate content of the groundwaters be considered in choosing $\mathrm{K}_{d}$ values. These possible variations 
TABLE II-7. CUMULATIVE DENSITY FUNCTION FOR PARTITION COEFFICIENTS FOR CULEBRA DOLOMITE MEMBER WITHIN MATRIX DOMINATED BY CULEBRA BRINE

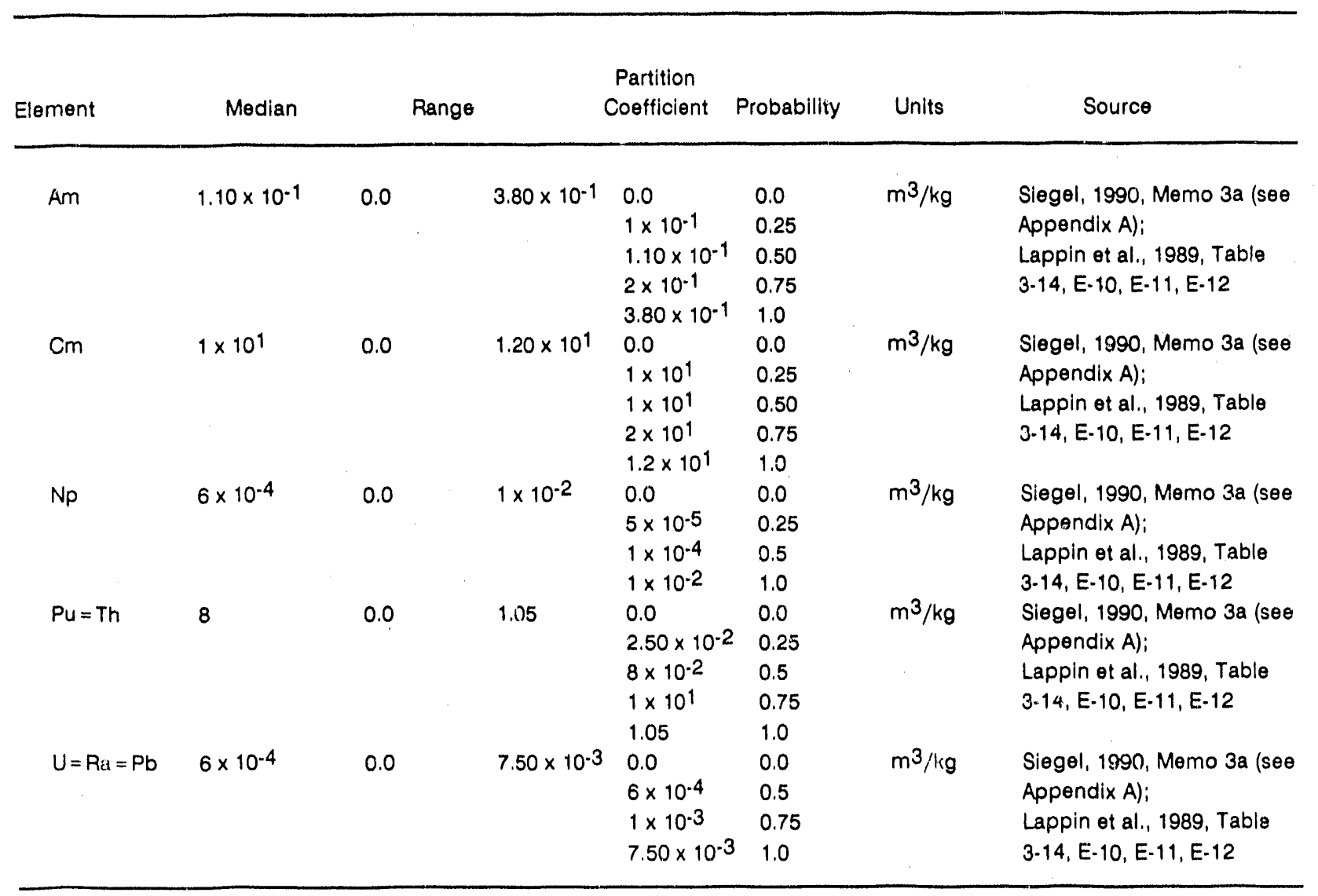


TABLE II-8. CUMULATIVE DENSITY FUNCTION FOR PARTITION COEFFICIENTS FOR CULEBRA DOLOMITE MEMBER WITHIN FRACTURE DOMINATED BY CULEBRA BRINE

\begin{tabular}{|c|c|c|c|c|c|c|c|}
\hline Element & Median & & ange & $\begin{array}{l}\text { Partition } \\
\text { Coefficient }\end{array}$ & Probability & Units & Source \\
\hline \multirow[t]{5}{*}{$\mathrm{Am}$} & $3 \times 10^{-1}$ & 0.0 & $4.10 \times 10$ & 0.0 & 0.0 & $\mathrm{~m}^{3} / \mathrm{kg}$ & Siegel, 1990, Memo 3a (see \\
\hline & & & & $2 \times 10^{-1}$ & 0.25 & & Appendix A); \\
\hline & & & & $3 \times 10^{-1}$ & 0.5 & & Lappin et al., 1989, Table \\
\hline & & & & $5 \times 10^{-1}$ & 0.75 & & $3-14, E-10, E-11, E-12$ \\
\hline & & & & 4.1 & 1.0 & & \\
\hline \multirow[t]{5}{*}{$\mathrm{Cm}$} & $5 \times 10^{-1}$ & 0.0 & $1.6 \times 10^{2}$ & 0.0 & 0.0 & $\mathrm{~m}^{3} / \mathrm{kg}$ & Slegel, 1990, Memo 3a (see \\
\hline & & & & $2 \times 10^{-1}$ & 0.25 & & Appendix A); \\
\hline & & & & $5 \times 10^{-1}$ & 0.5 & & Lappin et al., 1989, Table \\
\hline & & & & 2.7 & 0.75 & & $3-14, E-10, E-11, E-12$ \\
\hline & & & & $1.6 \times 10^{2}$ & 1.0 & & \\
\hline \multirow[t]{5}{*}{$\mathrm{Np}$} & $1 \times 10^{-2}$ & 0.0 & $5 \times 10^{-2}$ & 0.0 & 0.0 & $\mathrm{~m}^{3} / \mathrm{kg}$ & Slegel, 1990, Memo 3a (see \\
\hline & & & & $1 \times 10^{-3}$ & 0.25 & & Appendix A); \\
\hline & & & & $1 \times 10^{-2}$ & 0.5 & & Lappin et al., 1989, Table \\
\hline & & & & $2 \times 10^{-2}$ & 0.75 & & $3 \cdot 14, E \cdot 10, E \cdot 11, E \cdot 12$ \\
\hline & & & & $5 \times 10^{-2}$ & 1.0 & & \\
\hline \multirow[t]{5}{*}{$P u=T h$} & $3 \times 10^{-1}$ & 0.0 & $4 \times 10^{1}$ & 0.0 & 0.0 & $\mathrm{~m}^{3} / \mathrm{kg}$ & Slegel, 1990, Mems 3a (se日 \\
\hline & & & & $1 \times 10^{-1}$ & 0.25 & & Appendix A); \\
\hline & & & & $3 \times 10^{-1}$ & 0.5 & & Lappin et al., 1989, Table \\
\hline & & & & 2.3 & 0.75 & & 3-14, E-10, E-11, E-12 \\
\hline & & & & $4 \times 10^{1}$ & $1 \times 10$ & & \\
\hline \multirow[t]{5}{*}{$U=R a=P u$} & $1 \times 10^{-2}$ & 0.0 & $5 \times 10^{-2}$ & 0.0 & 0.0 & $m^{3} / \mathrm{kg}$ & Siegel, 1990, Memo 3a (see \\
\hline & & & & $1 \times 10.3$ & 0.25 & & Appendix $A)_{i}$ \\
\hline & & & & $1 \times 10^{-2}$ & 0.5 & & Lappin et al., 1989, Table \\
\hline & & & & $2 \times 10^{-2}$ & 0.75 & & 3-14, E-10, E-11, E-12 \\
\hline & & & & $5 \times 10^{-2}$ & 1.0 & & \\
\hline
\end{tabular}


in solution chemistry could result in order-of-magnitude changes of the $\mathrm{K}_{\mathrm{d}} \mathrm{s}$ from the values obtained in the experimental studies. The $\mathrm{K}_{\mathrm{d}}$ values chosen for each element are explained further below.

Culebra brine is assumed to dominate the groundwater chemistry. The Culebra brine is represented by the average composition of a brine sample from well $\mathrm{H}-2 \mathrm{~b}$ and $\mathrm{H}-2 \mathrm{c}$.

Plutonium, Americium, and Curium. $\mathrm{K}_{\mathrm{d}}$ values for plutonium are decreased from the values in Paine (1977), Dosch (1979), and Tien et al. (1983), because of the potential effect of carbonate complexation and competition for sorption sites by competing cations. $K_{d}$ values for americium are decreased from cited values because of the potential effects of organic complexation and competition. $\mathrm{K}_{\mathrm{d}}$ values for curium were decreased from the values listed in Tien et al. (1983) based on the assumption of behavior similar to americium and europium.

Uranium and Neptunium. In general, low $\mathrm{K}_{\mathrm{d}} \mathrm{s}$ for uranium and thorium have been measured in waters relevant to the WIPP repository. Low values $\left(\mathrm{K}_{\mathrm{d}}=1\right.$ or 10$)$ have been assumed here to account for the possible effects of complexation and competition.

Thorium. There are very few data for thorium under conditions relevant to the WIPP. Thorium $\mathrm{K}_{\mathrm{d}}$ values were estimated from data for plutonium, a reasonable homolog element for thorium (Krauskopf, 1986).

Radium and Lead. No $\mathrm{K}_{\mathrm{d}}$ data are available describing the sorption of radium or lead onto dolomite. This report assumes that these elements would sorb onto trace clay particles within the dolomite (comprising -38 by weight) and assumes that the behavior of radium and lead would be similar, based on hon slogous behavior in other environments (Tien et al., 1983). The PA calculations further assumed that the behavior would be similar to uranium.

\section{General Rationale for Constructing Cumulative Distributions}

The general rationale for selecting the $K_{d}$ value in each percentile of the cumulative distribution follows (Tables II-7 and II-8).

Dolomite Matrix. A description of distributions for dolomite matrix is given below.

100th percentile: The highest $\mathrm{K}_{\mathrm{d}}$ value for each radionuclide for the Culebra brine was used for the 100th percentile. If data for this brine were not available, the highest minimum value of the ranges from experiments carried out in WIPP Solutions A, B, and C (see Table 3-16 in Lappin et al., 1989) was 
used. The use of the minimum values introduces a degree of conservatism in the distributions. Data from experiments that include organic ligands were not consiciered.

75th percentile: The $\mathrm{K}_{\mathrm{d}}$ values for the 75 th percentile represent a compromise between the empirical data that show that sorption will occur under WIPPspecific conditions and theoretical calculations that suggest that many factors can decrease the extent of sorption significantly under other conditions that are possible in the Culebra. The values are identical to those used in Case I of Lappin et a1. (1989, Table E-10).

50th percentile: The lowest reported $\mathrm{K}_{\mathrm{d}}$ value for Culebra brine was used for the 50th percentile. If no data for Culebra brine were available, the lowest of the values reported for organic-free WIPP Solutions $A, B$, and $C$ was used.

25th percentile: The 25 th percentile represents conditions under which the solution chemistry is dominated by the influx of inorganic salts from the Salado and Castile Formations and includes the additional effects of organic ligands. The $\mathrm{K}_{\mathrm{d}}$ values are identical to those of Case IIB of Lappin et al. (1.989, Table E-10).

Oth percentile: The use of a $K_{d}$ value of zero increases the conservatism of the distribution because there is evidence some sorption will occur (Lappin et a1., 1989, Table 3-14).

Clay in Fractures. A description of distributions for clay in fractures is given below.

75th and 50th percentiles: The values in Table E-11 in Lappin et al. (1989) and the lowest value for Culebra brine were compared; the larger of the two values was used for the 75 th percentile. The smaller value was used for the 50th percentile. If no data for Culebra brine were available, the lowest value reported for WIPP Solutions A, B, and C (organic.free) was compared to the value in Table E-11, and the smaller value was used for the 50 th percentile.

25th percentile: The 25 th percentile represents conditions under which the solution chemistry is dominated by the influx of inorganic salts from the Salado and Castile Formations and includes the additional effects of organic ligands. The $K_{d}$ values are identical to those of Case IIB of Lappin et al. (1989, Table E-11).

Oth percentile: The use of a $\mathrm{K}_{\mathrm{d}}$ value of zero increases the conservatism of the distribution because there is evidence some sorption will occur (Lappin et al., 1989, Table 3-14). 


\section{Retardation}

The retardation for the Culebra Dolomite matrix was calculated using the standard expression for retardation in a porous matrix (Freeze and Cherry, 1979, p. 404):

$$
\mathrm{R}_{\mathrm{m}}=1+\rho_{\mathrm{b}} \mathrm{K}_{\mathrm{d}} / \phi_{\mathrm{m}}
$$

The retardation factor for the fractures was calculated from (Neretnieks and Rasmusson, 1984):

$$
\mathrm{R}_{\mathrm{f}}=1+\rho_{\mathrm{b}} \mathrm{K}_{\mathrm{d}} \mathrm{b}_{\mathrm{c}} / \mathrm{b}
$$

where

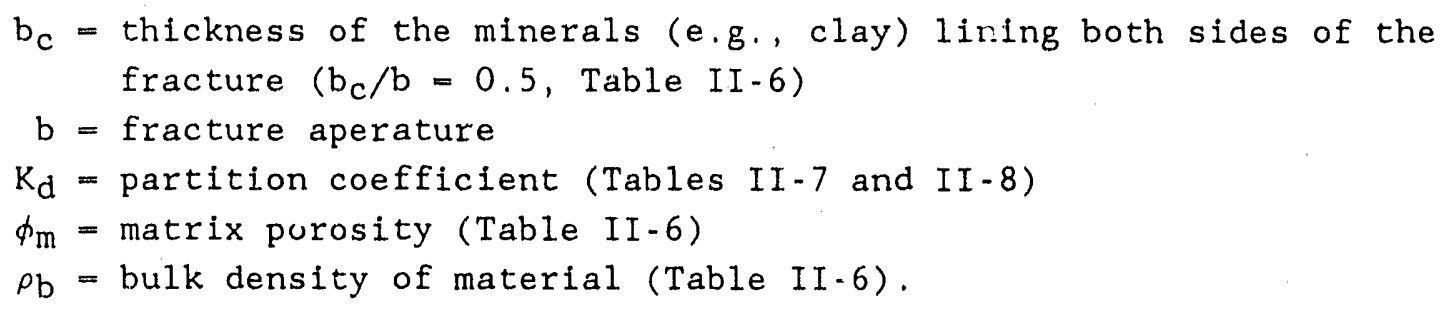

Figures II-20 through II-23 show the cumulative distributions for the matrix retardation factor for plutunium, americium, neptunium, and uranium. Figures II-24 through II-27 show the cumulative distribution for fracture retardation for the same elements.

\section{HYDRAULIC CONDUCTIVITIES FOR MODEL ZONES}

Previous modeling studies of the Culebra (LaVenue et al., 1988; Haug et al., 1978) carefully estimated the transmissivity field ( $T$ ) by calibration to undisturbed flow conditions within the Culebra. The most recent modeling study (LaVenue et al., 1990) presented a model in which the transmissivity field was estimated by the transient flow conditions generated by numerous regional and local scale tests conducted in the Culebra Dolomite. However, this most recent transmissivity field is possibly not unique because the calibration process is an inverse problem. Hence, there is some uncertainty associated with this field. Assigning uncertainty to this field is an important task that the PA Division will examine during 1991; the zone approach described below will not likely be used.

Until the study is complete, the PA Division chose to subdivide the Culebra into fixed zones with nonoverlapping uncertainty ranges and distinct median hydraulic conductivities $(K=\mathrm{T} / \Delta z)$, where $\Delta z$ is the thickness. The hydraulic conductivities were then sampled for each simulation (Table II-9) (interim zone approach). 


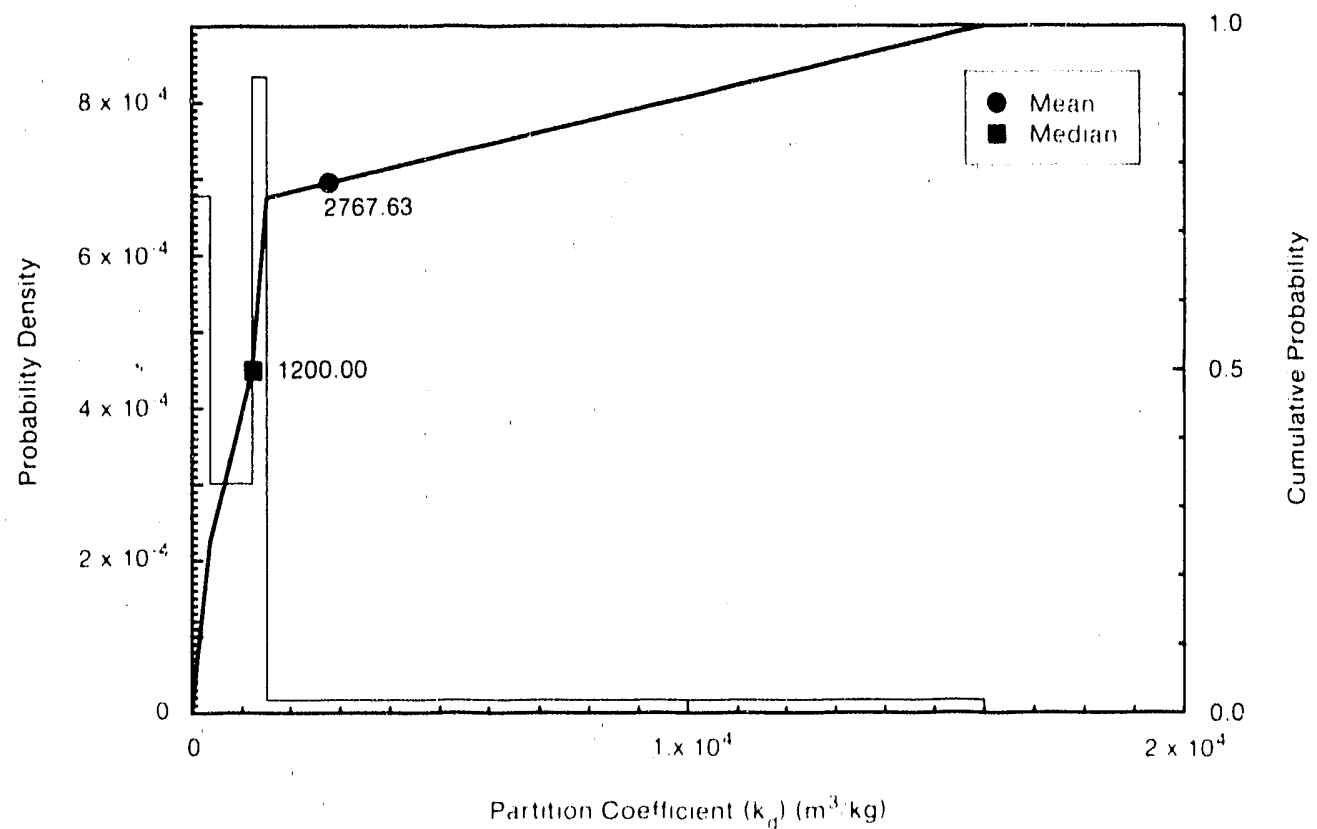

Figure II-20. Estimated pdf and cdf for Retardation Factor for Plutonium.

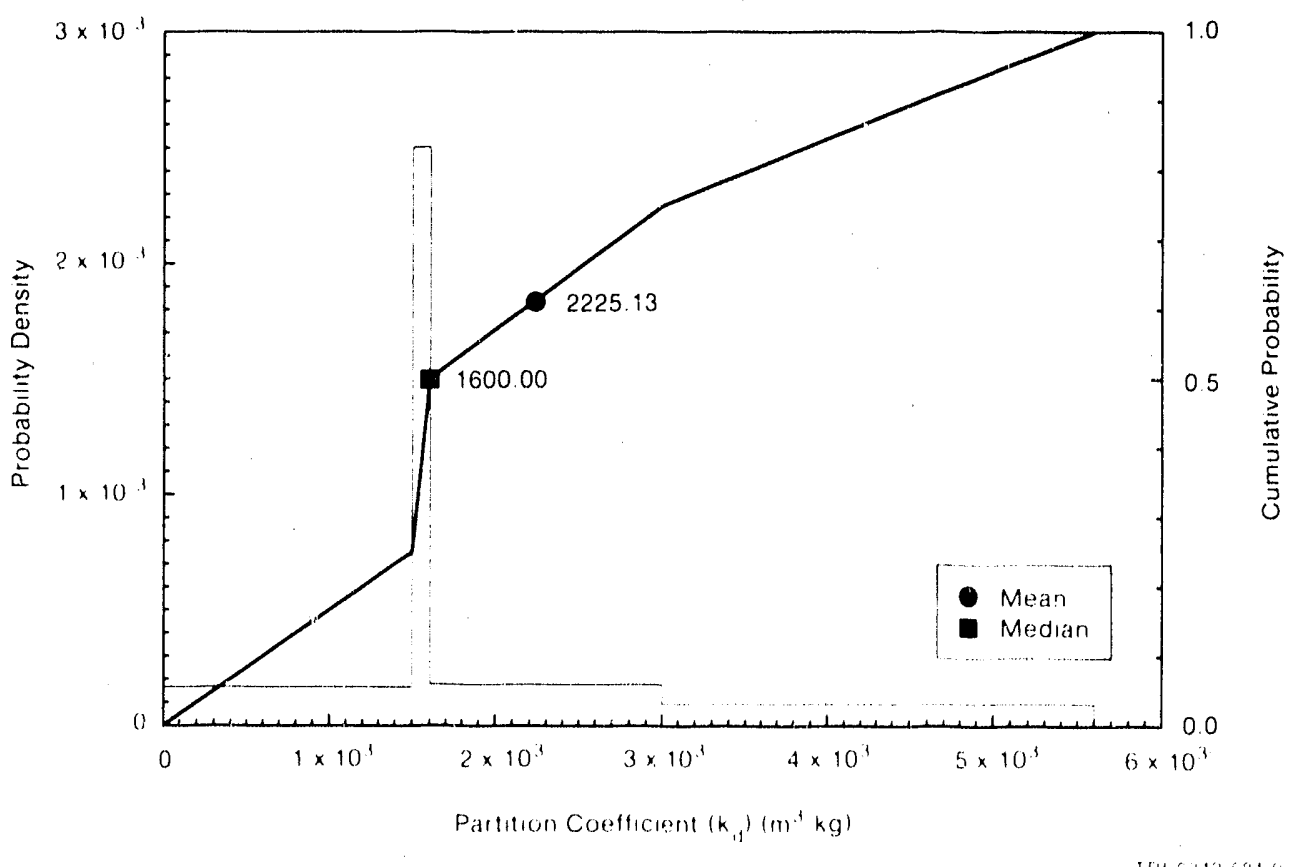

Figure 11-21. Estimated pdf and cdf for Retardation Factor for Americium. 


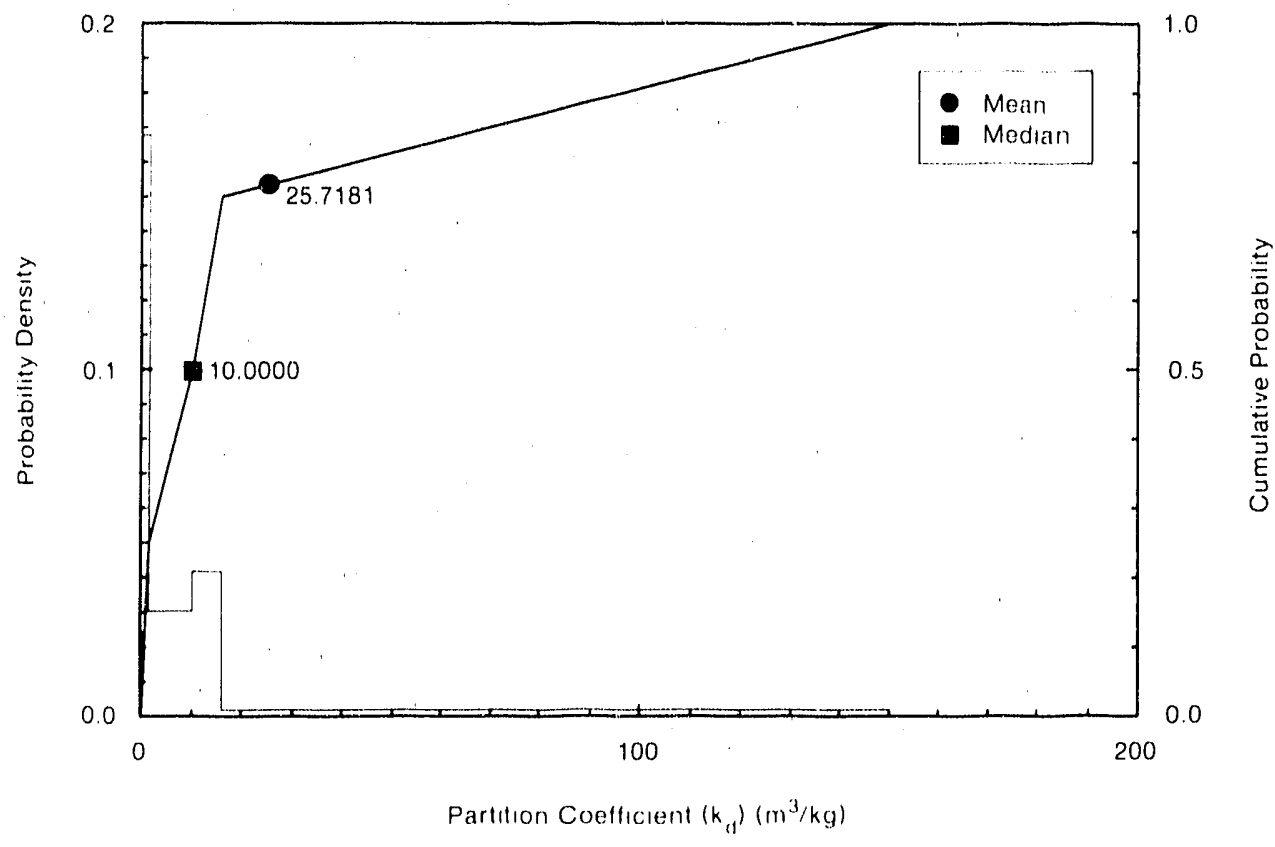

Figure II-22. Estimated pdf and cdf for Retardation Factor for Neptunium.

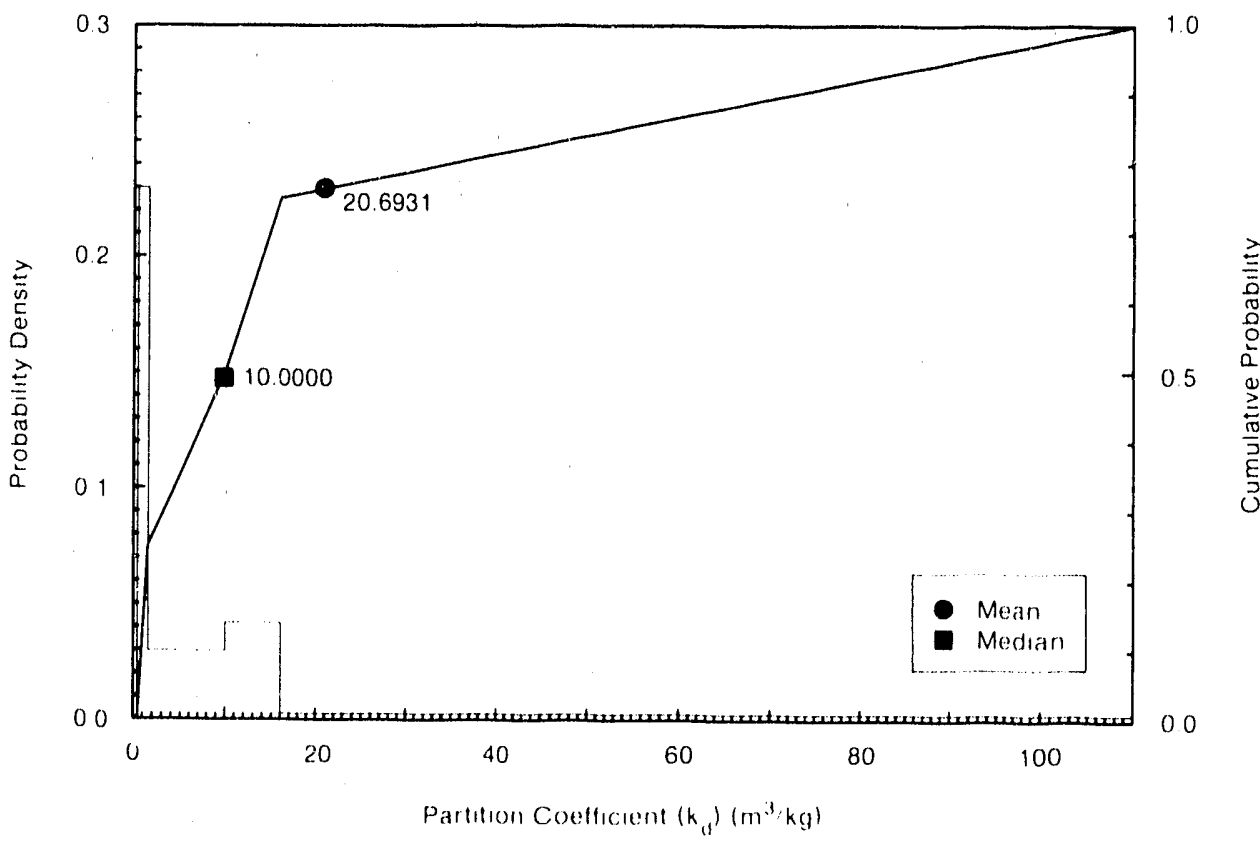

Figure 11-23. Estimated pdf and cdf for Retardation Factor for Uranium. 


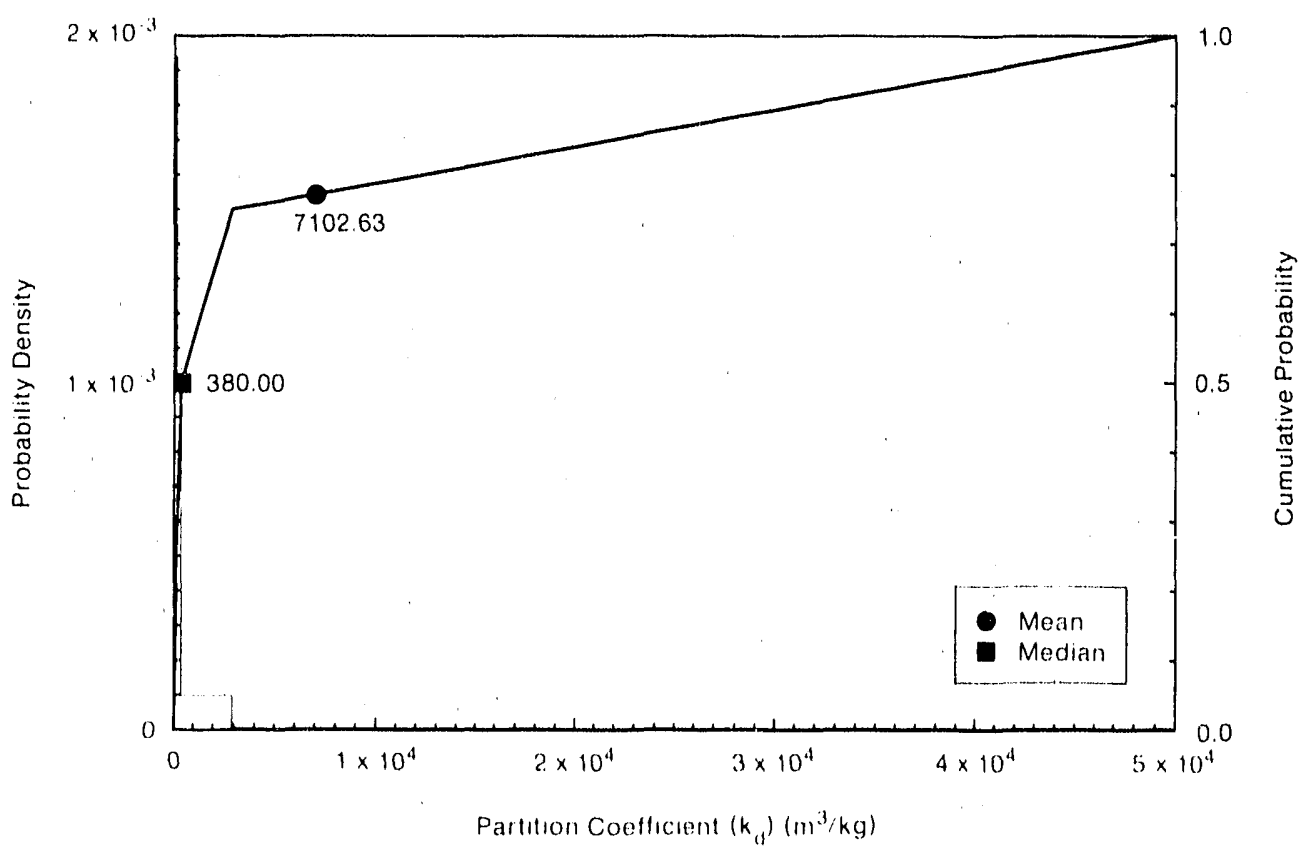

$1121 \cdot 634 \% \cdot 68 \% \cdot 0$

Figure 11-24. Estlmated pdf and cdf for Fracture Retardation for Plutonlum.

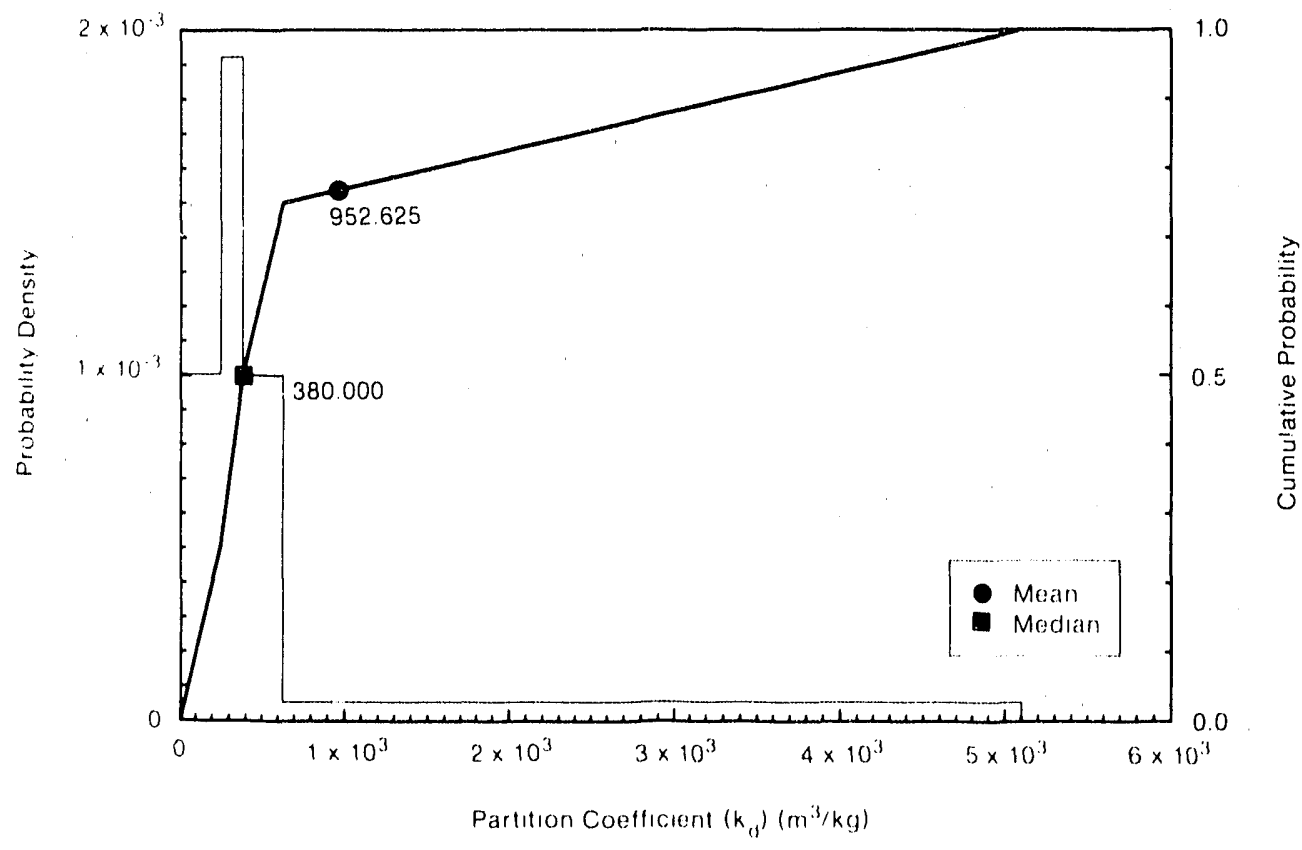

Figure II-25. Estimated pdf and cdf for Fracture Retardation for Americium. 


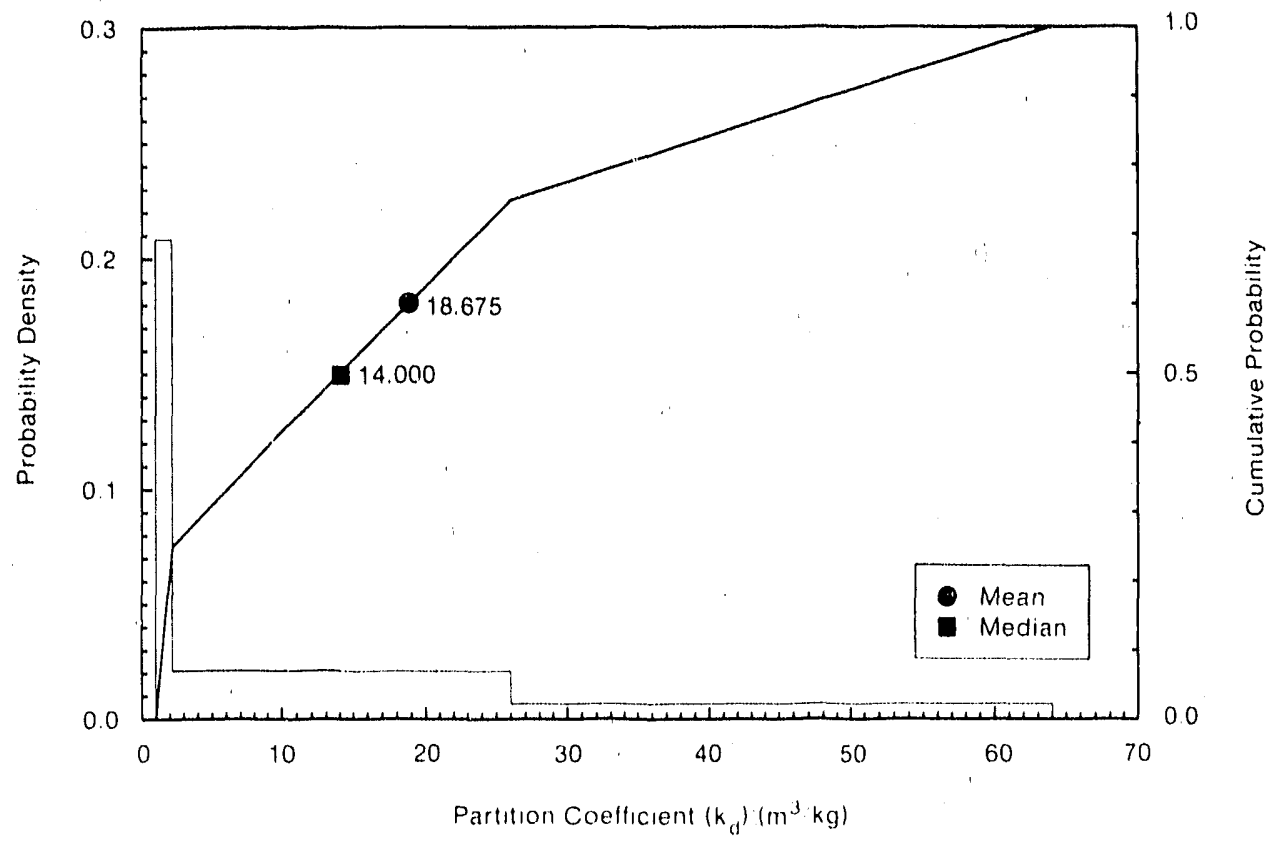

TR1.6342.689.0

Figure II-26. Estimated pdf and cdf for Fracture Retardation for Neptunlum.

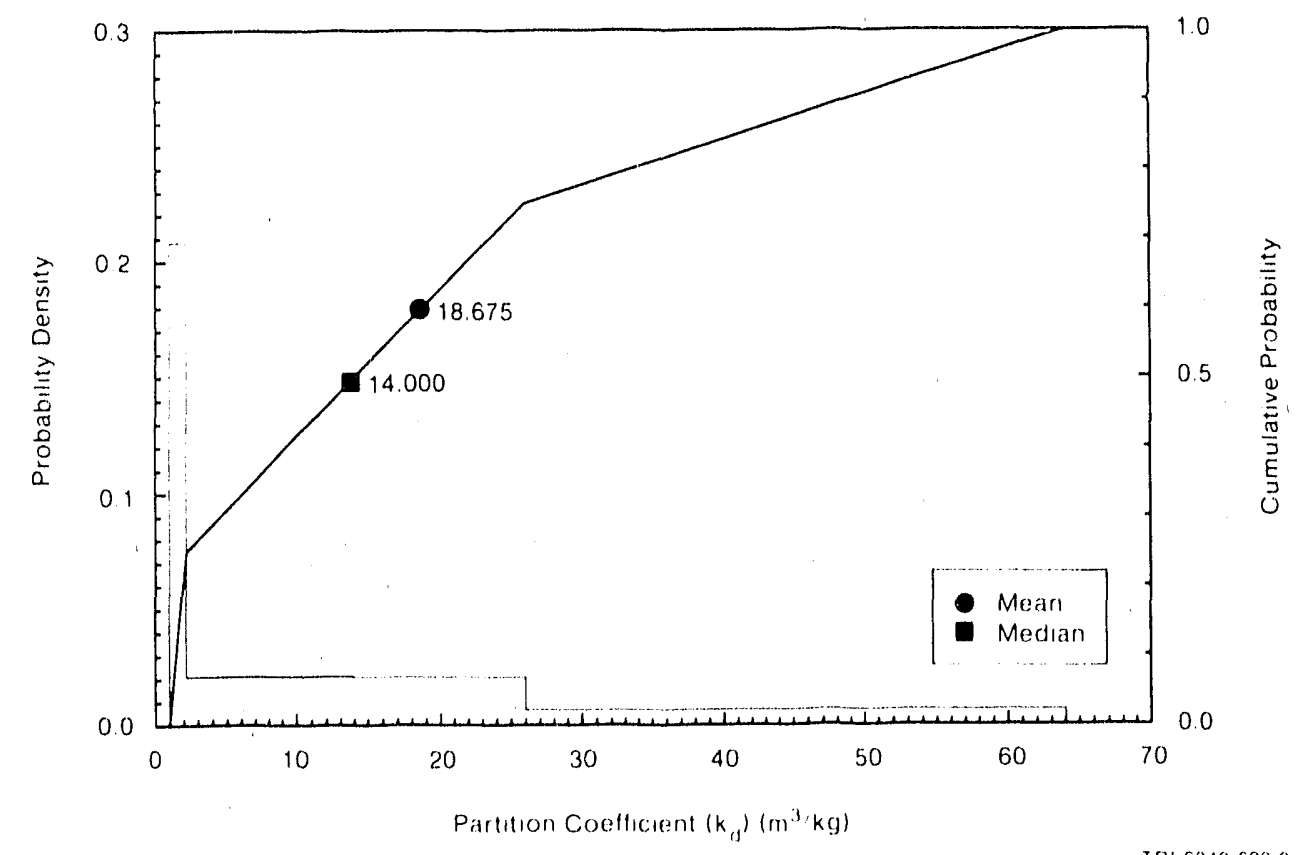

Figure 11-27. Estimated pdf and cdf for Fracture Retardation for Uranium. 
Selecting the location of the fixed zones was not straightforward. The current zone locations were chosen mechanically except that the general trend of progressively lower permeability when moving from west to east was maintained. Two zone definitions were made: one using only the single well transmissivity values (designated by numbers 1 to 8 ) and one using the single well and pilot point (synthetic data) transmissivity values (designated by letters $A$ to $M$ ) (Table II-9). The latter indirectly incorporates the calibration to transient well tests through the use of the pilot points.

The procedure for selecting zones consisted of (1) ordering the transmissivity well values (either with or without pilot points) from smallest to largest, (2) selecting "natural" break points to define groupings, and (3) selecting rectangular-shaped zones that enclose all the wells in each grouping.

Figures II-28 through II-31 show the resulting zones. No effort was made to condition the results on the steady state pressure heads or transient withdrawal tests (i.e., the resulting pressure heads from each transmissivity. field were not compared with the measured heads to reject those simulations that strayed too far from the measured heads).

Although not a fustification of this crude approach to incorporating uncertainty in the transmissivity field into the PA calculations, the PA results (Helton, 1990) were not greatly affected by abrupt changes in transmissivity between zones since the results are currently dominated by the wide range in solubilities for the waste (see Table III-1). The situation will likely change when the range of solubilities is decreased.

Figure II-29 compares the initially kriged Log10 transmissivity fleld (LaVenue et al., 1990, Figure 2.10a) with the zones based on single well tests. Figure II-31 compares the transient calibrated kriged Log10 field (LaVenue et a1., 1990, Figure 5.22a) with the interim zones based on both single well tests and pilot points.

PA models simulated groundwater flow in the Culebra Dolomite with a larger regional domain, called the SECO Regional Domain. Figure II-32 shows the zones without pilot points as defined for the regional domain. For these zones, the boundary lines from Figure II-28 (LaVenue domain [1990]) were extended as straight lines to the domain boundaries. Figure II-33 shows the zones based on both single well tests and pilot points as defined for the regional domain. Again, the zone boundary. lines from LaVenue (1990) were extended as straight lines to the domain boundaries.

Figures II-34 through II-49 represent the distributions for the hydraulic conductivities for model zones. 
TABLE 11-9. HYDRAULIC CONDUCTIVITY FOR ZONES IN CULEBRA DOLOMITE MEMBER

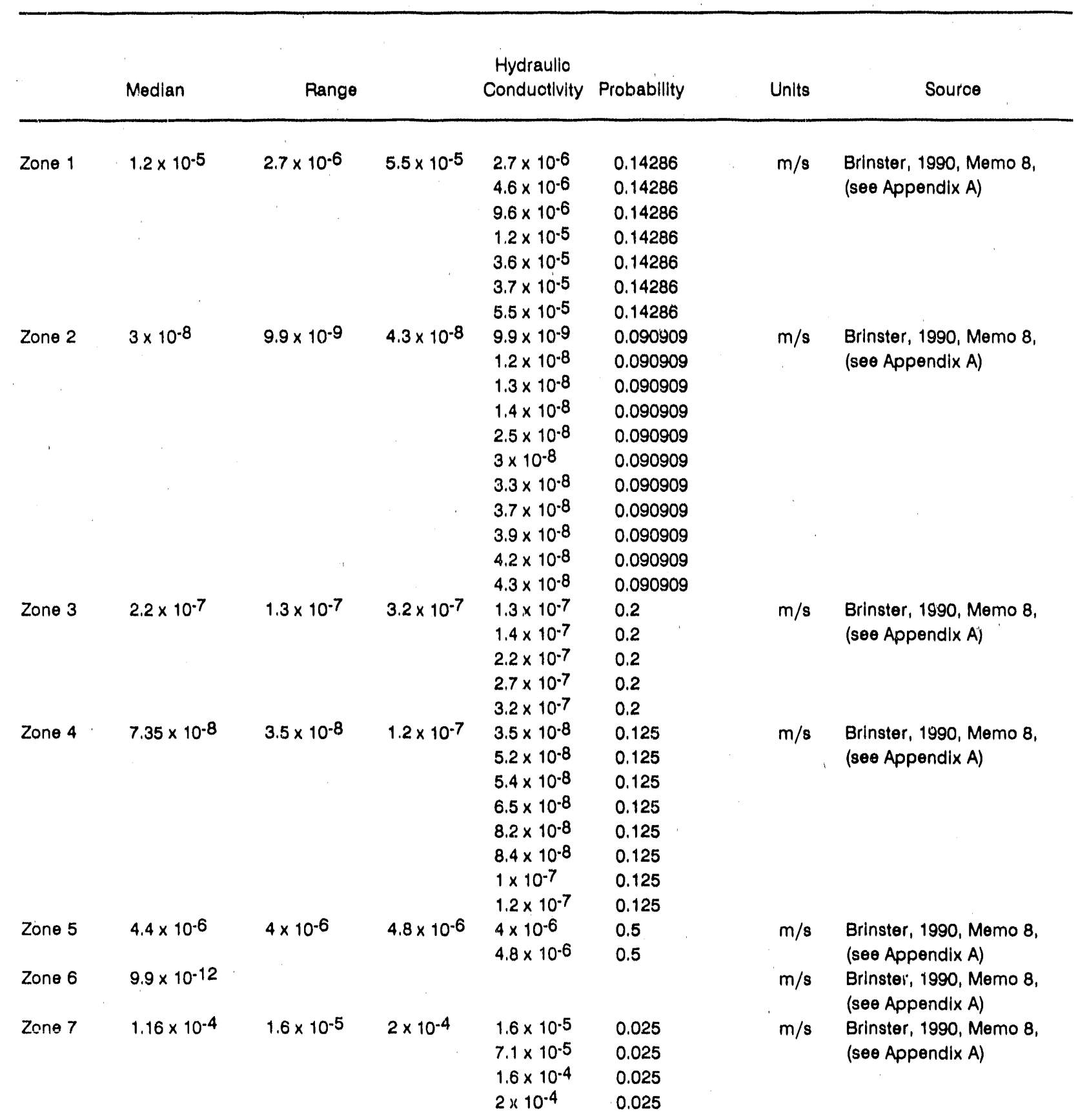


TABLE II-9. HYDRAULIC CONDUCTIVITY FOR ZONES IN CULEBRA DOLOMITE MEMBER (CONTINUED)

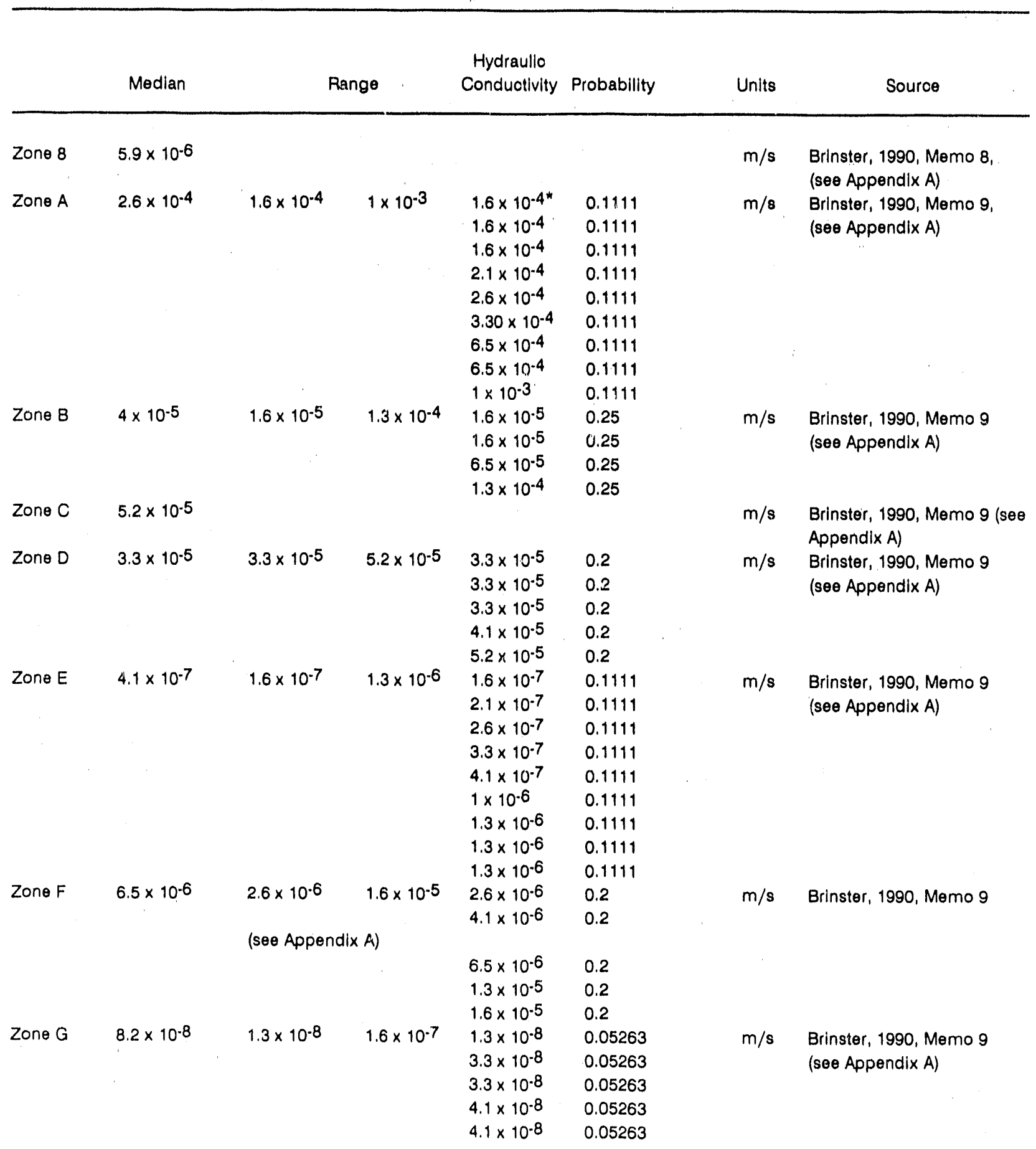

\footnotetext{
* Experimental values are repeated with a probability of 0.1111 rather than entered once with a probability of 0.3333 to ensure that the exact value can be reproduced during sampling. (See Figure II-38 for latter method.)
} 
TABLE II-9. HYDRAULIC CONDUCTIVITY FOR ZONES IN CULEBRA DOLOMITE MEMBER (CONCLUDED)

\begin{tabular}{|c|c|c|c|c|c|c|c|}
\hline & Median & \multicolumn{2}{|c|}{ Range } & Hydraullo & Probability & Units & Source \\
\hline \multirow{14}{*}{\multicolumn{2}{|c|}{ (Zone G concluded) }} & & & $5.2 \times 10^{-8}$ & 0.05263 & & \\
\hline & & & & $5.2 \times 10^{-8}$ & 0.05263 & & \\
\hline & & & & $5.4 \times 10^{-8}$ & 0.05263 & & \\
\hline & & & & $6.5 \times 10.8$ & 0.05263 & & \\
\hline & & & & $8.2 \times 10^{-8}$ & 0.05263 & & \\
\hline & & & & $8.2 \times 10^{-8}$ & 0.05263 & & \\
\hline & & & & $8.2 \times 10^{0.8}$ & 0.05263 & & . \\
\hline & & & & $1 \times 10^{-7}$ & 0.05263 & & \\
\hline & & & & $1.3 \times 10^{-7}$ & 0.05263 & & \\
\hline & & & & $1.3 \times 10^{-7}$ & 0.05263 & & \\
\hline & & & & $1.3 \times 10^{.7}$ & 0.05263 & & \\
\hline & & & & $1.3 \times 10^{.7}$ & 0.05263 & & \\
\hline & & & & $1.3 \times 10^{-7}$ & 0.05263 & & \\
\hline & & & & $1.6 \times 10^{-7}$ & 0.05263 & & \\
\hline \multirow[t]{3}{*}{ Zone $\mathrm{H}$} & $8.8 \times 10^{-7}$ & $3.3 \times 10^{-7}$ & $4.1 \times 10^{-5}$ & $3.3 \times 10^{.7}$ & 0.3333 & $\mathrm{~m} / \mathrm{s}$ & Brinster, 1990, Memo 9 \\
\hline & & & & $8.8 \times 10^{-7}$ & 0.3333 & & (see Appendix A) \\
\hline & & & & $4.1 \times 10^{-5}$ & 0.3333 & & \\
\hline \multirow[t]{2}{*}{ Zone 1} & $8.25 \times 10^{-10}$ & $6.5 \times 10^{-10}$ & $1 \times 10^{-9}$ & $6.5 \times 10^{-10}$ & 0.5 & $\mathrm{~m} / \mathrm{s}$ & Brinster, 1990, Memo 9 \\
\hline & & & & $1 \times 10^{-9}$ & 0.5 & & (seo Appendix A) \\
\hline \multirow[t]{5}{*}{ Zone J } & $4.1 \times 10^{-5}$ & $5.2 \times 10^{-6}$ & $7.3 \times 10^{-5}$ & $5.2 \times 10^{-6}$ & 0.2 & $\mathrm{~m} / \mathrm{s}$ & Brinster, 1990, Memo 9 \\
\hline & & & & $6.5 \times 10^{-6}$ & 0.2 & & (see Appendix A) \\
\hline & & & & $4.1 \times 10^{-5}$ & 0.2 & & \\
\hline & & & & $4.1 \times 10^{-5}$ & 0.2 & & \\
\hline & & & & $7.3 \times 10^{-5}$ & 0.2 & & \\
\hline \multirow[t]{7}{*}{ Zone $\mathrm{K}$} & $1.3 \times 10^{-8}$ & $2.6 \times 10^{.9}$ & $3.3 \times 10^{-8}$ & $2.6 \times 10^{-9}$ & 0.1429 & $\mathrm{~m} / \mathrm{s}$ & Brinster, 1990, Memo 9 \\
\hline & & & & $1 \times 10^{-8}$ & 0.1429 & & (seo Appendix A) \\
\hline & & & & $1.3 \times 10^{-8}$ & 0.1429 & & \\
\hline & & & & $1.3 \times 10^{-8}$ & 0.1429 & & \\
\hline & & & & $2.6 \times 10^{-8}$ & 0.1429 & & \\
\hline & & & & $3.3 \times 10^{-8}$ & 0.1429 & & \\
\hline & & & & $3.3 \times 10^{-8}$ & 0.1429 & & \\
\hline Zone L & $1.0 \times 10^{-11}$ & & & & & $\mathrm{~m} / \mathrm{s}$ & $\begin{array}{l}\text { Brinster, 1990, Merno } 9 \text { (see } \\
\text { Appendix A) }\end{array}$ \\
\hline Zone M & $6.5 \times 10^{-6}$ & & & & & $\mathrm{~m} / \mathrm{s}$ & $\begin{array}{l}\text { Brinster, 1990, Memo } 9 \text { (see } \\
\text { Appendix A) }\end{array}$ \\
\hline
\end{tabular}




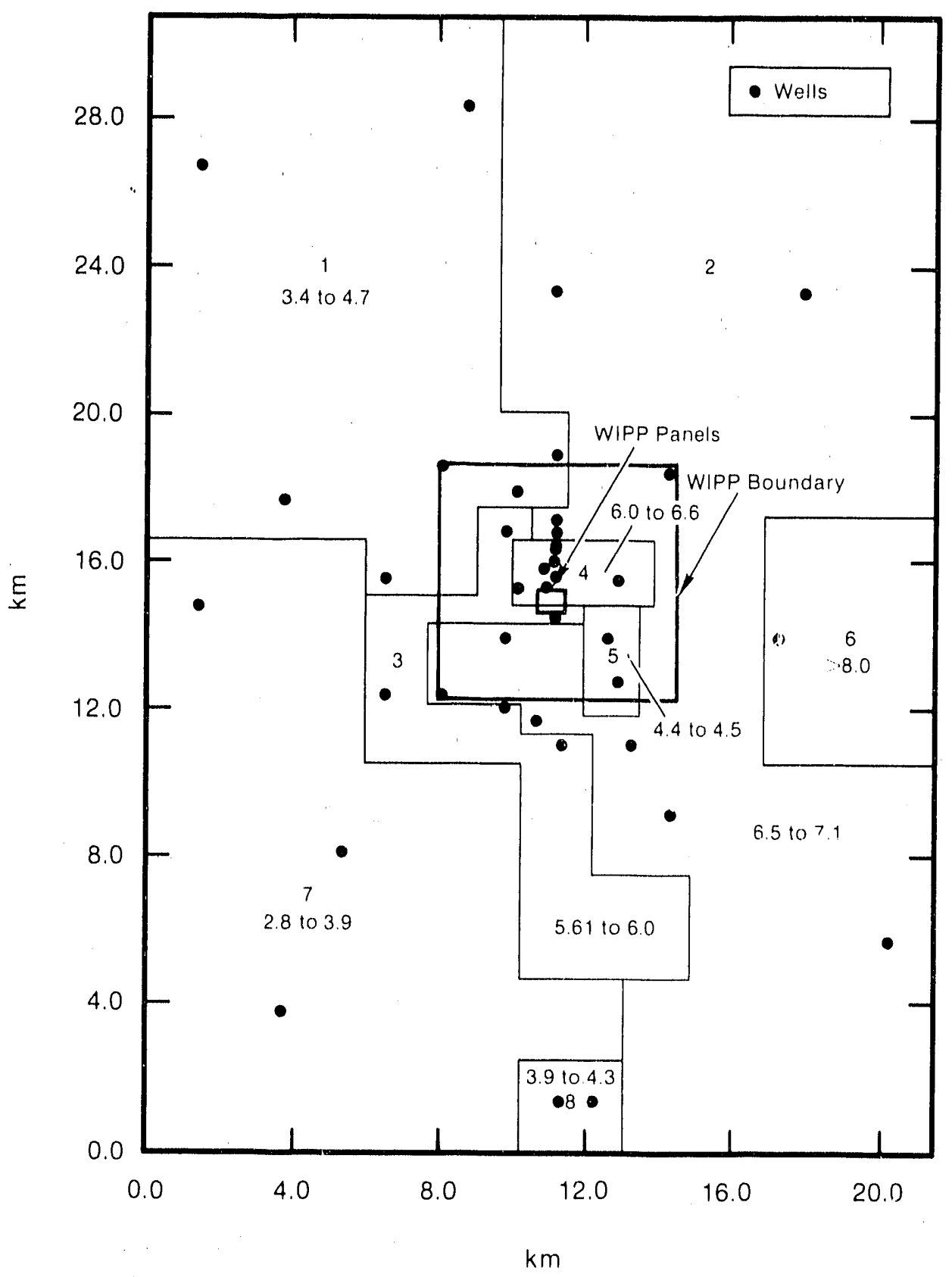

TRI-6342-643-0

Figure 11-28. Transmissivity Zones based on Steady-State Transmissivity Wells without Pilot Points (Adjusted Data). 

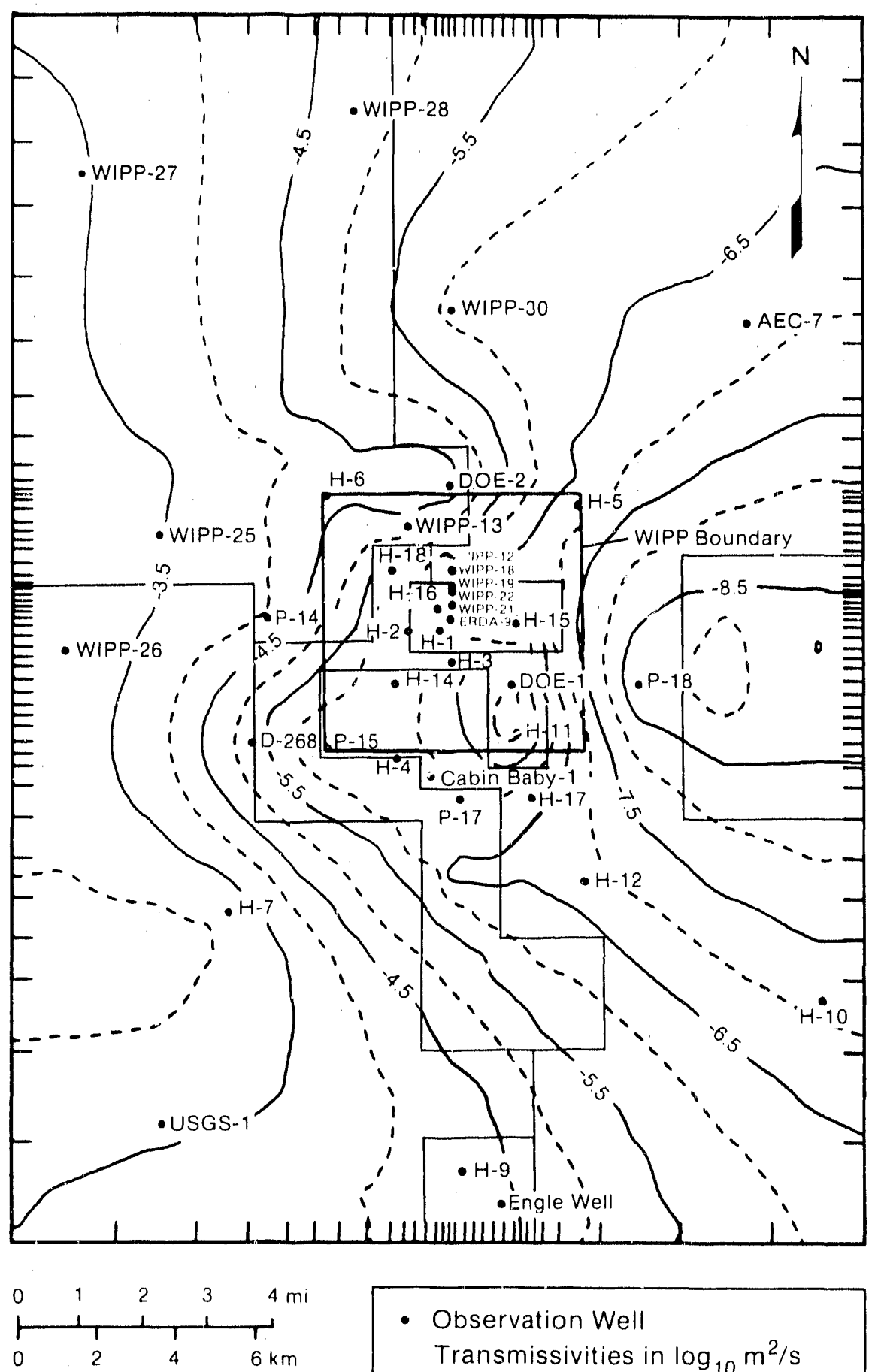

- Observation Well

Transmissivities in $\log _{10} \mathrm{~m}^{2} / \mathrm{s}$

Contour Interval: $0.5 \log _{10} \mathrm{~m}^{2} / \mathrm{s}$

TRI-6342-789-0

Figure II-29. Comparison of Initially Kriged Log $_{10}$ Transmissivity Field (La Venue et al., 1990, Fig 2.10a) with Transmissivity Zones. 


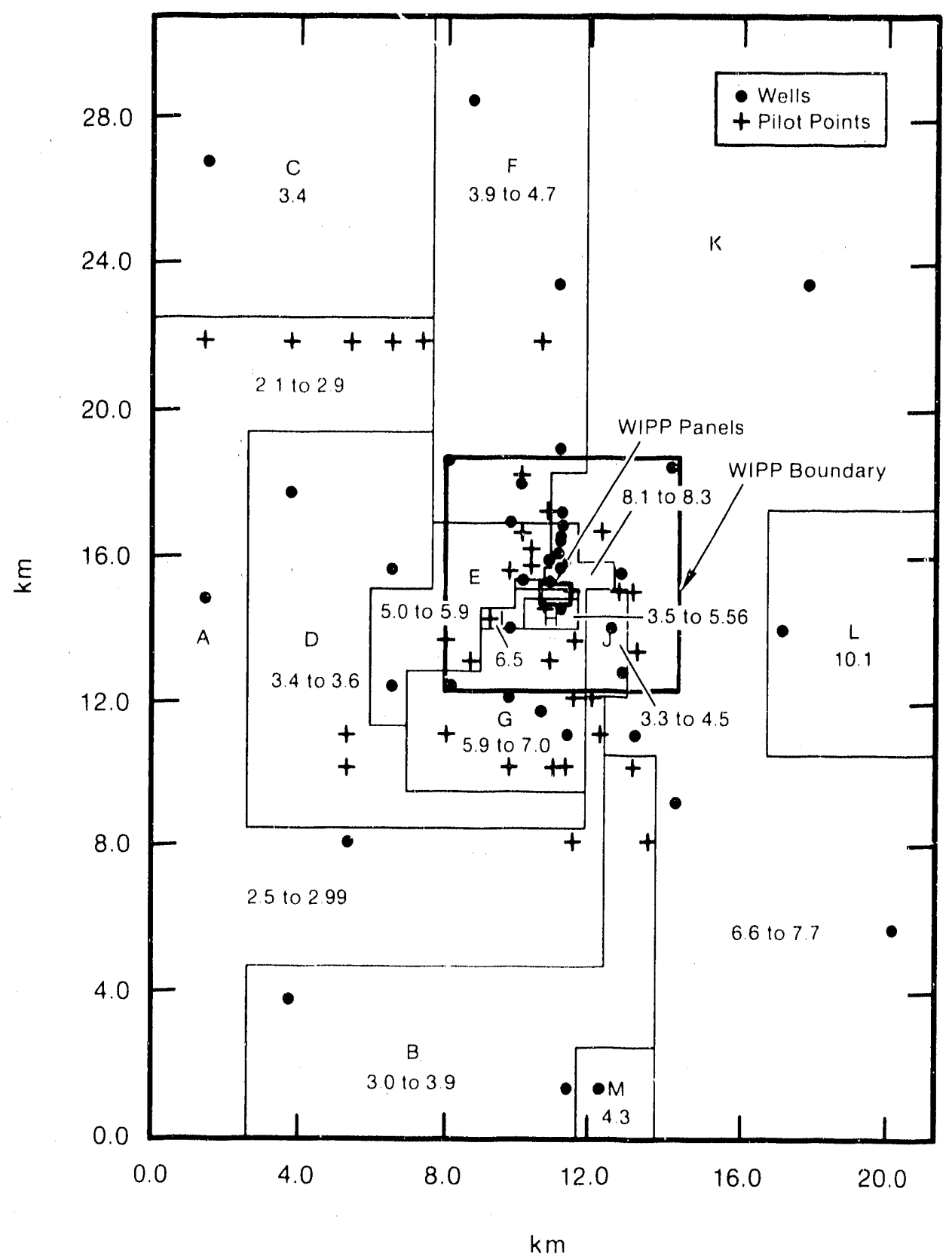

TRI-6342-644-0

Figure II-30. Transmissivity Zones based on Steady-State Transmissivity Wells and Pilot Poirits (Adjusted Data). 

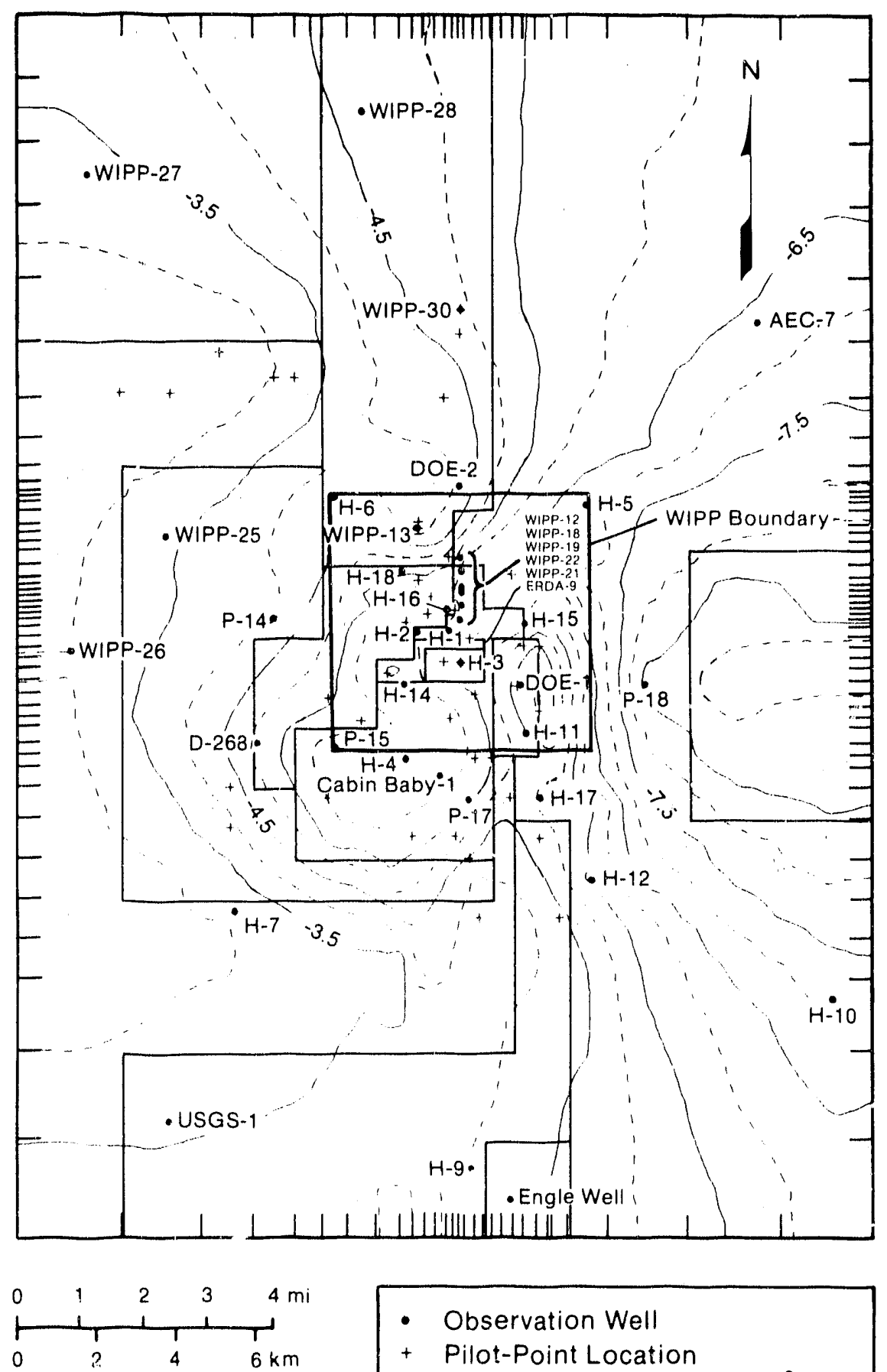

- Observation Well

+ Pilot-Point Location Transmissivities in $\log _{10} \mathrm{~m}^{2} / \mathrm{s}$ Contour Interval: $0.5 \log _{10} \mathrm{~m}^{2} / \mathrm{s}$

TRI-6342-634-2

Figure I1-31. Comparison of Transient Calibrated $\log _{10}$ Transmissivity Field (LaVenue et al., 1990, Fig. 5.22a) with Transmissivity Zones. 


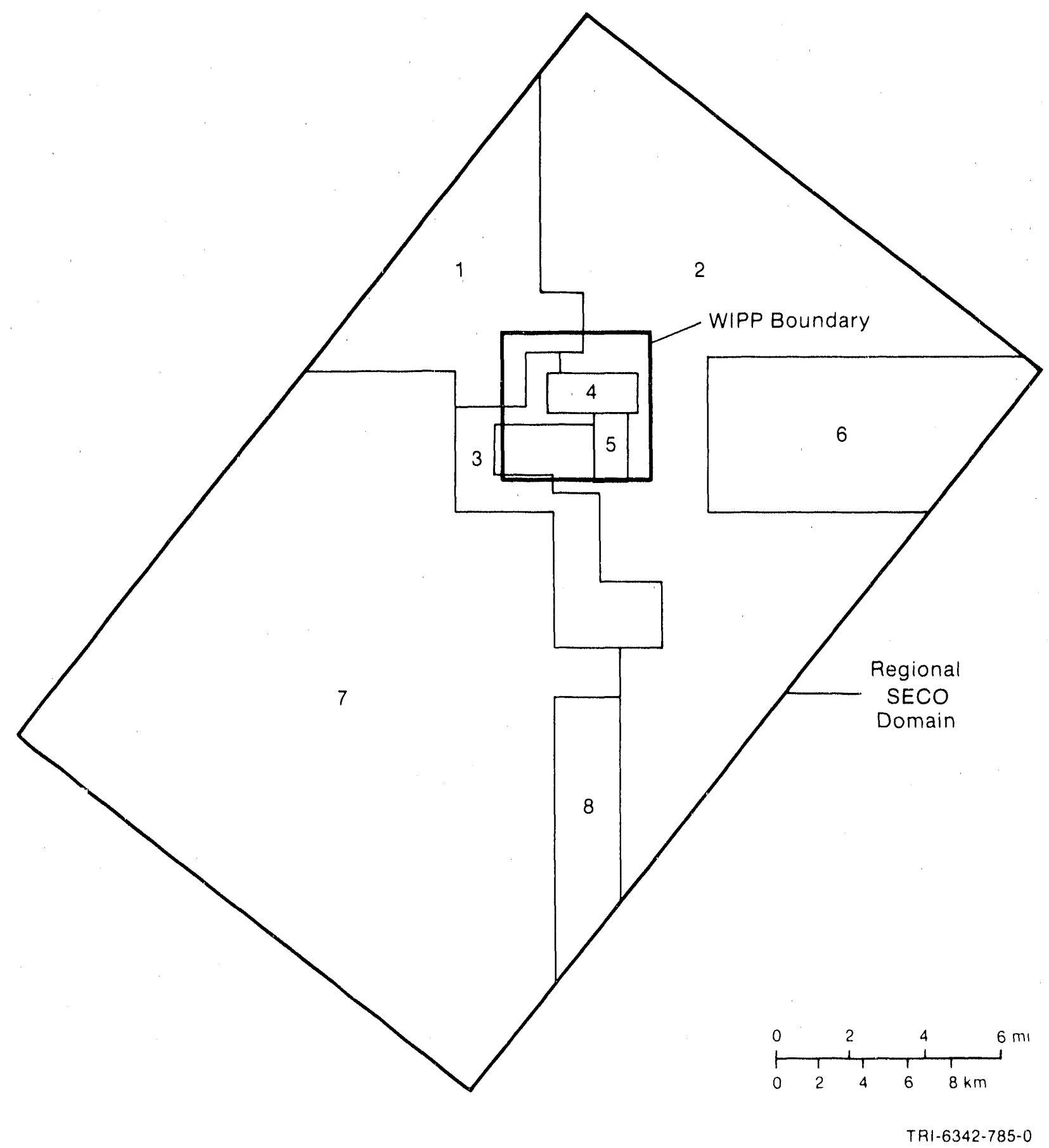

Figure II-32. SECO Regional Domain with Zones Based on Single Well Tests. 


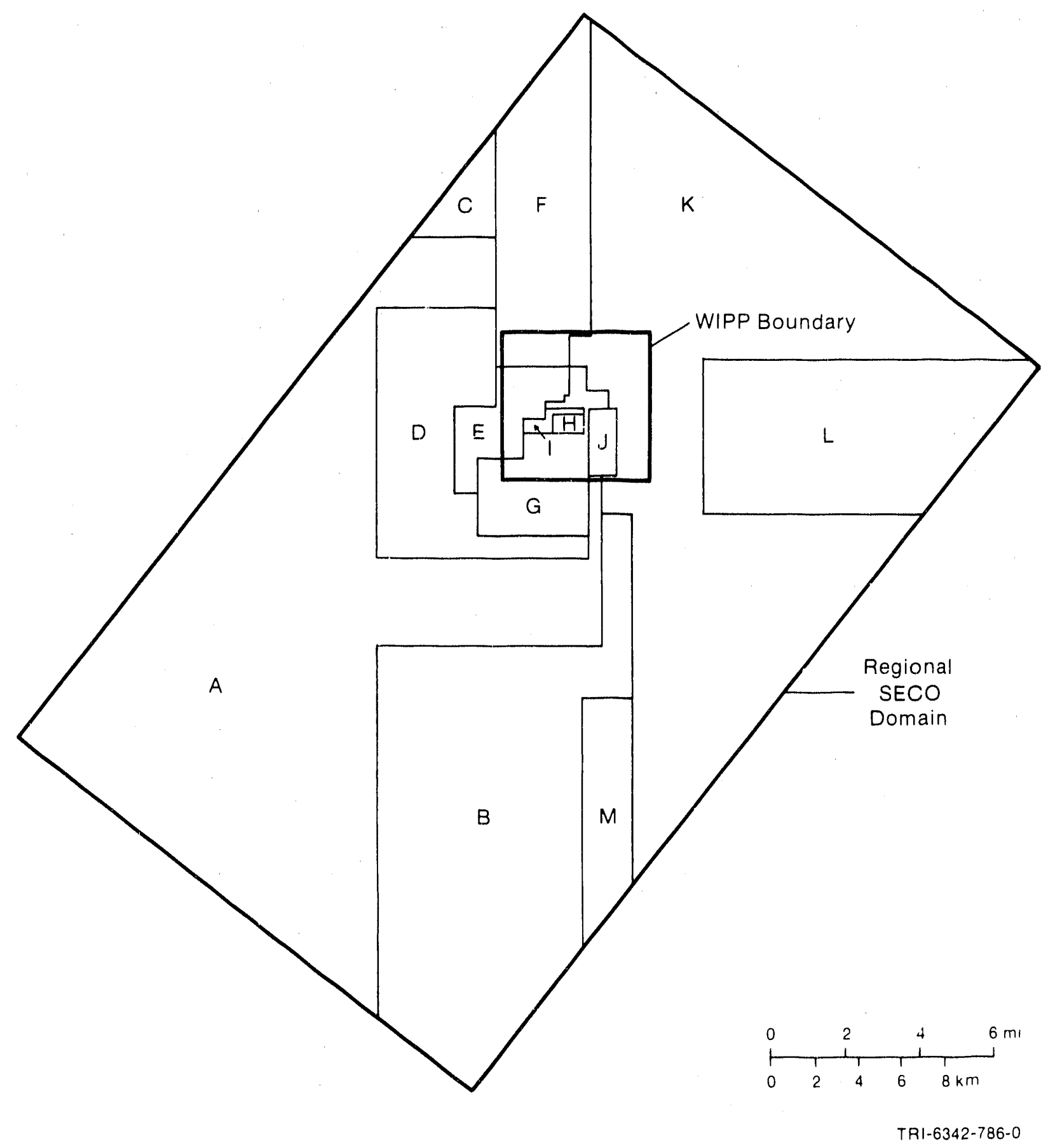

Figure II-33. SECO Regional Domain with Zones Based on Both Single Well Tests and Pilot Points. 


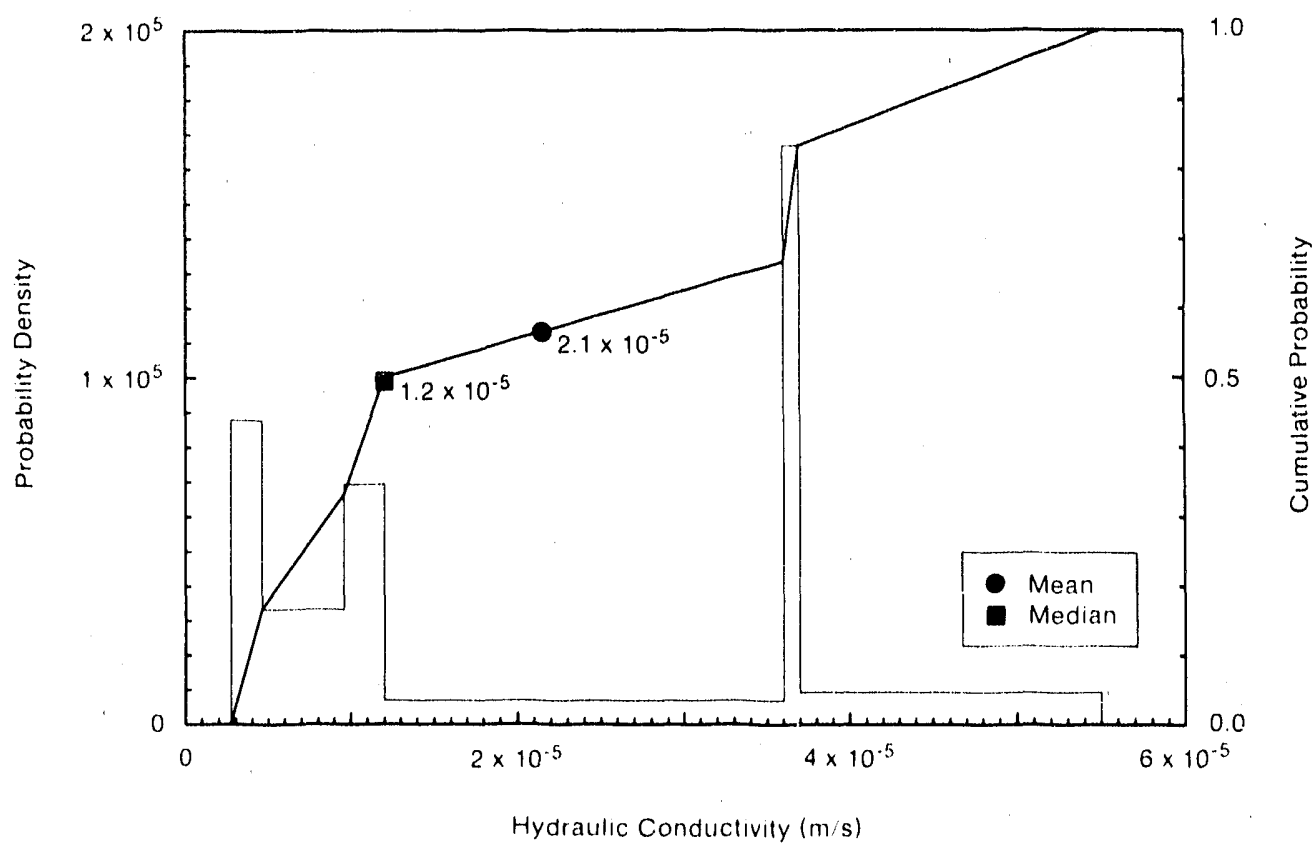

TRI-6342-691-0

Figure II-34. pdf and cdf for Hydraulic Conductlvity in Zone 1.

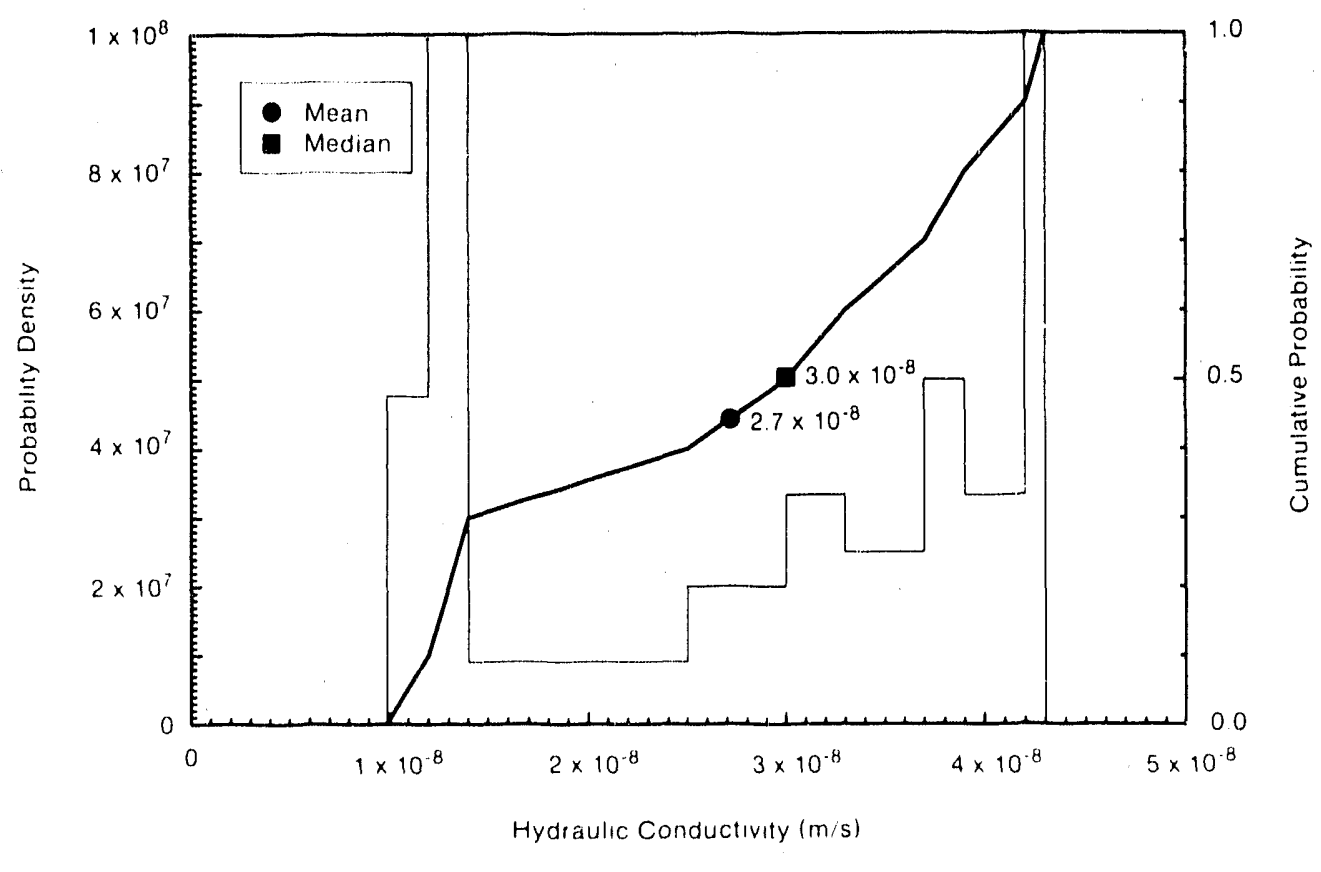

Figure II-35. pdf and cdf for Hydraulic Conductivity in Zone 2. 


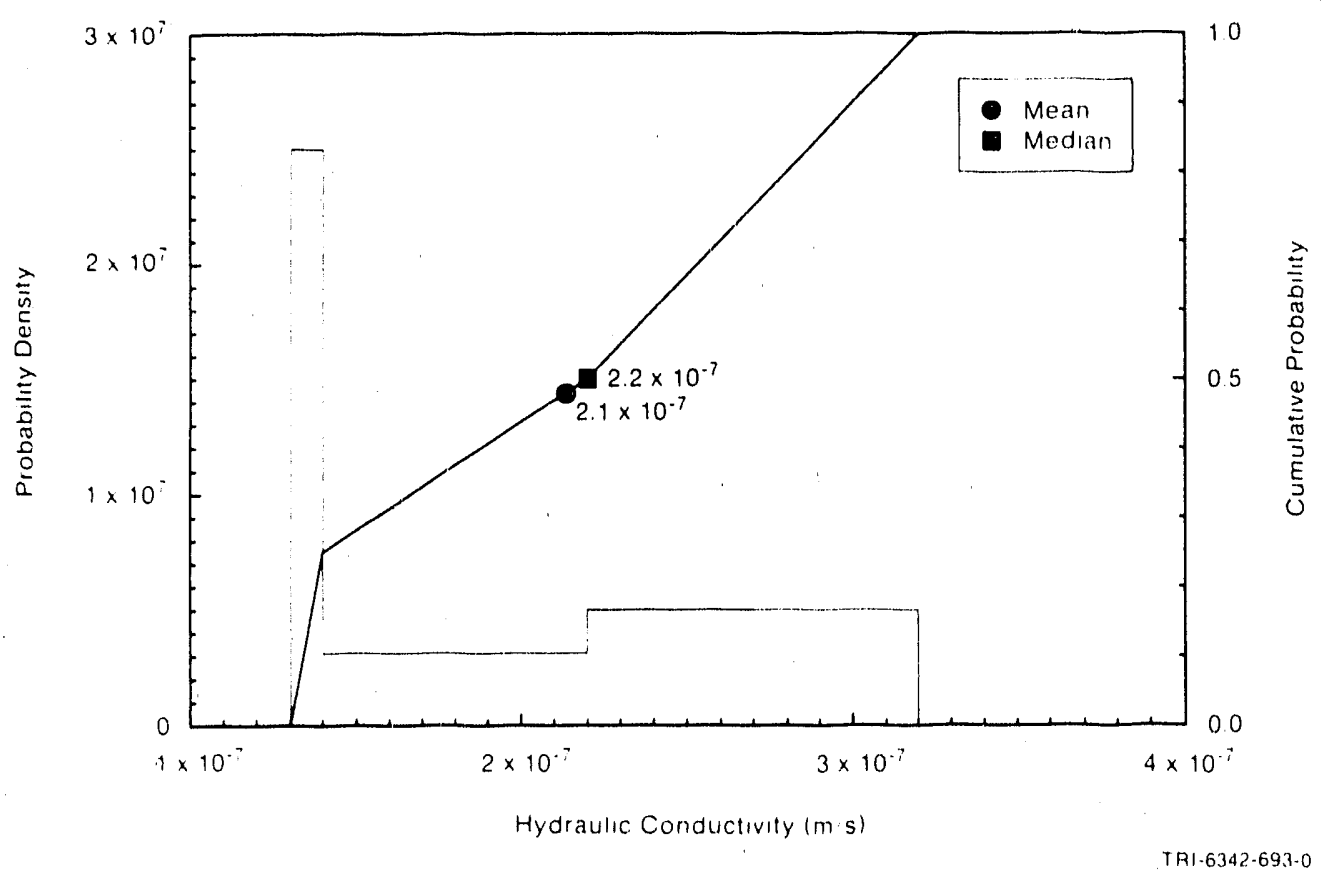

Figure II-36. pdf and cdf for Hydraulle Conductivity in Zone 3.

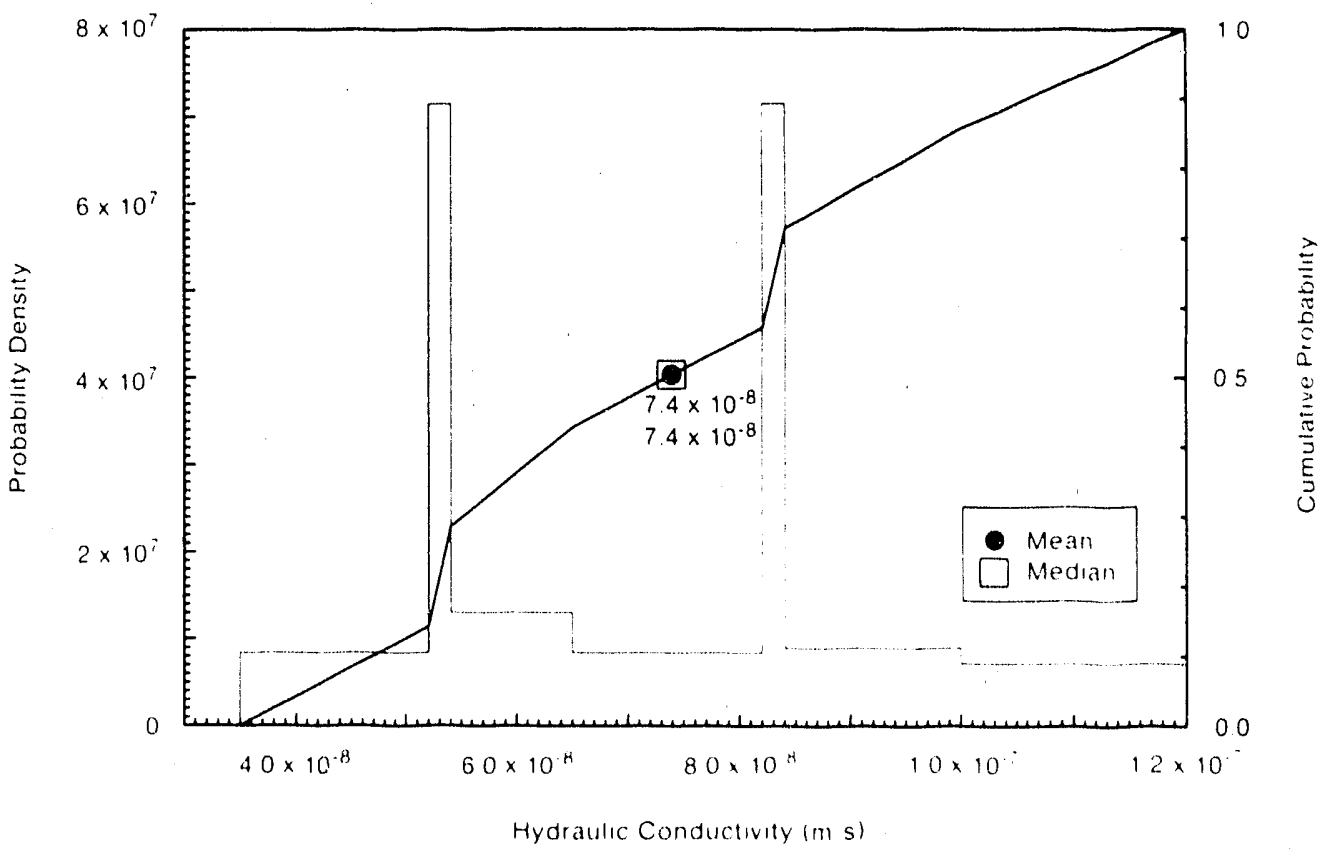

Figure II-37. pdf and cdf for Hydraulic Conductivity in Zone 4. 


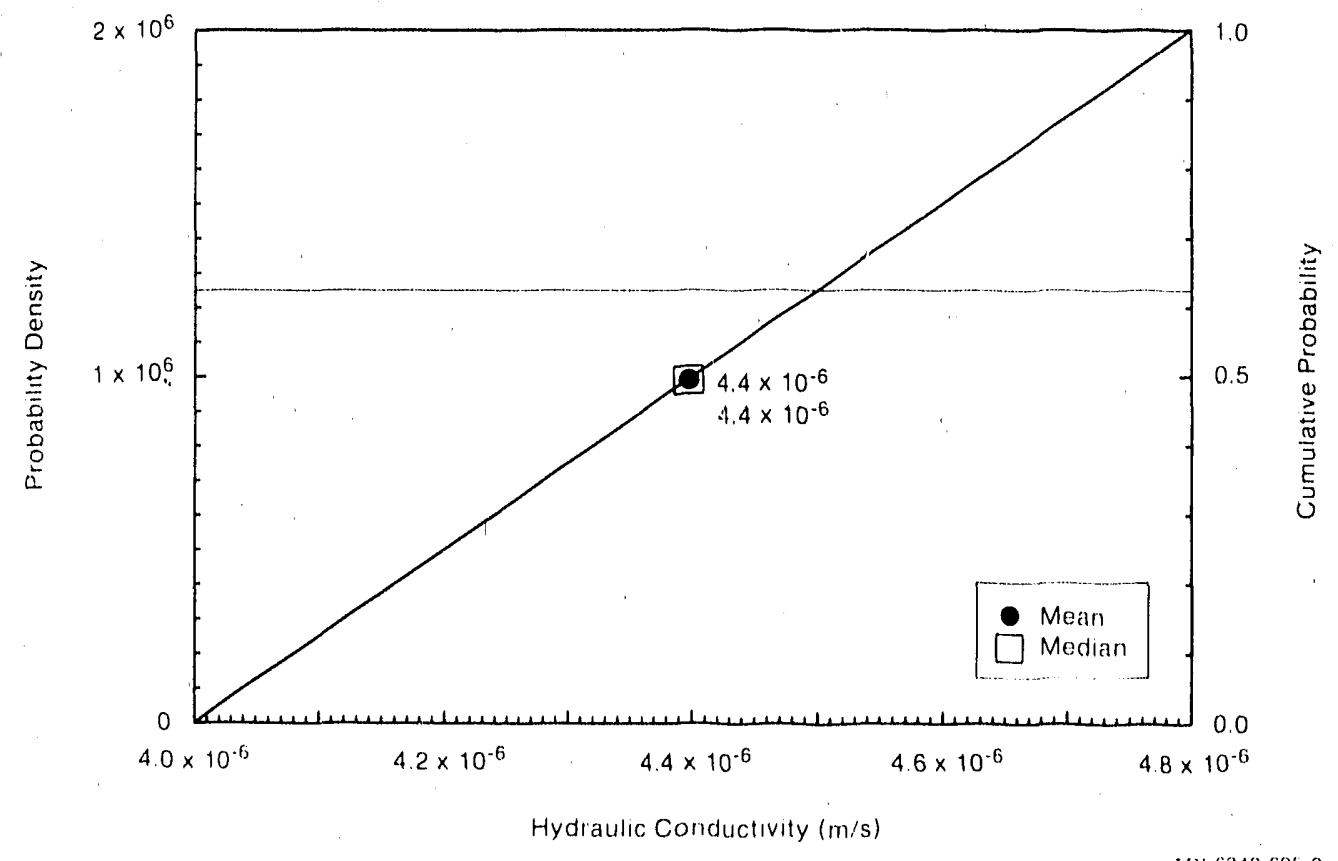

Figure II-38. pdf and cdf for Hydraullc Conductivity in Zone 5.

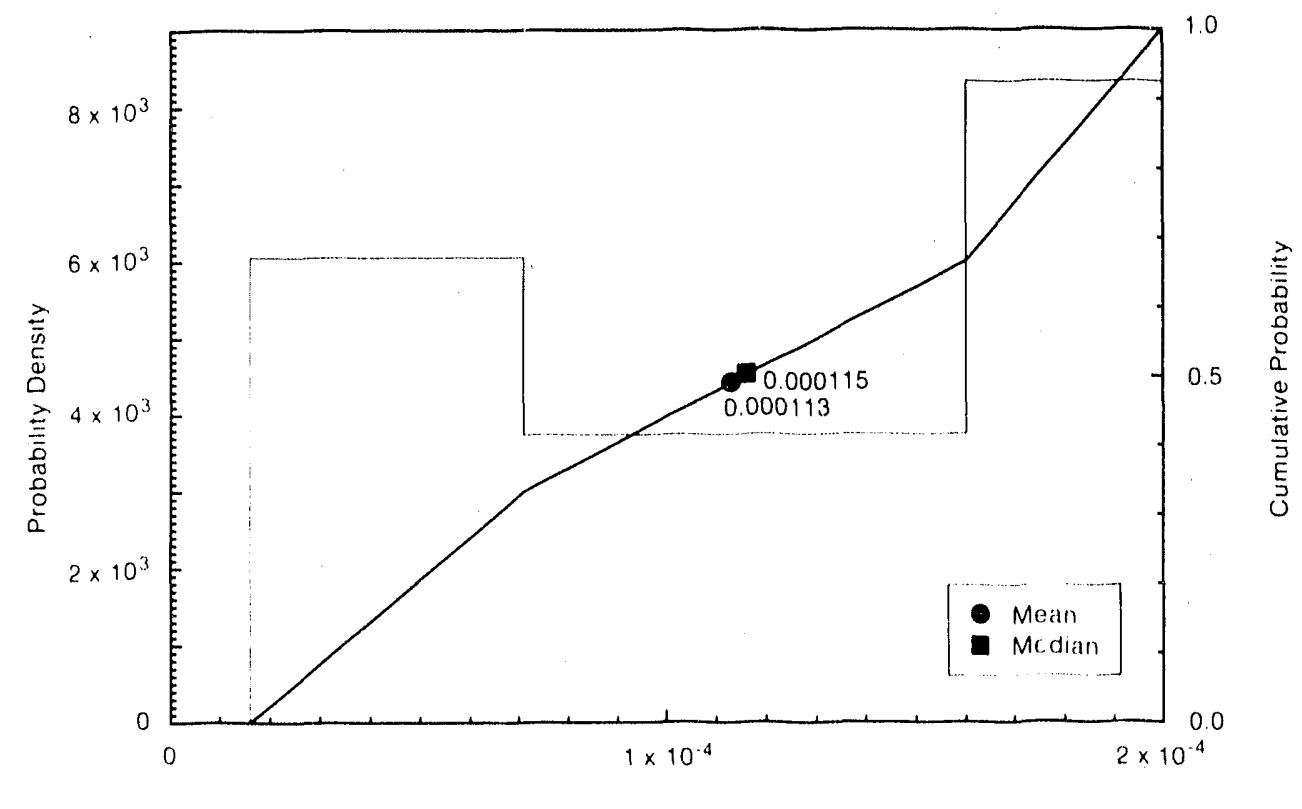

Hydraulic Conductivity $(\mathrm{m} / \mathrm{s})$

TR1. $6342 \cdot-696-0$

Figure II-39. pdf and cdf for Hydraulic Conductivity in Zone 7. 


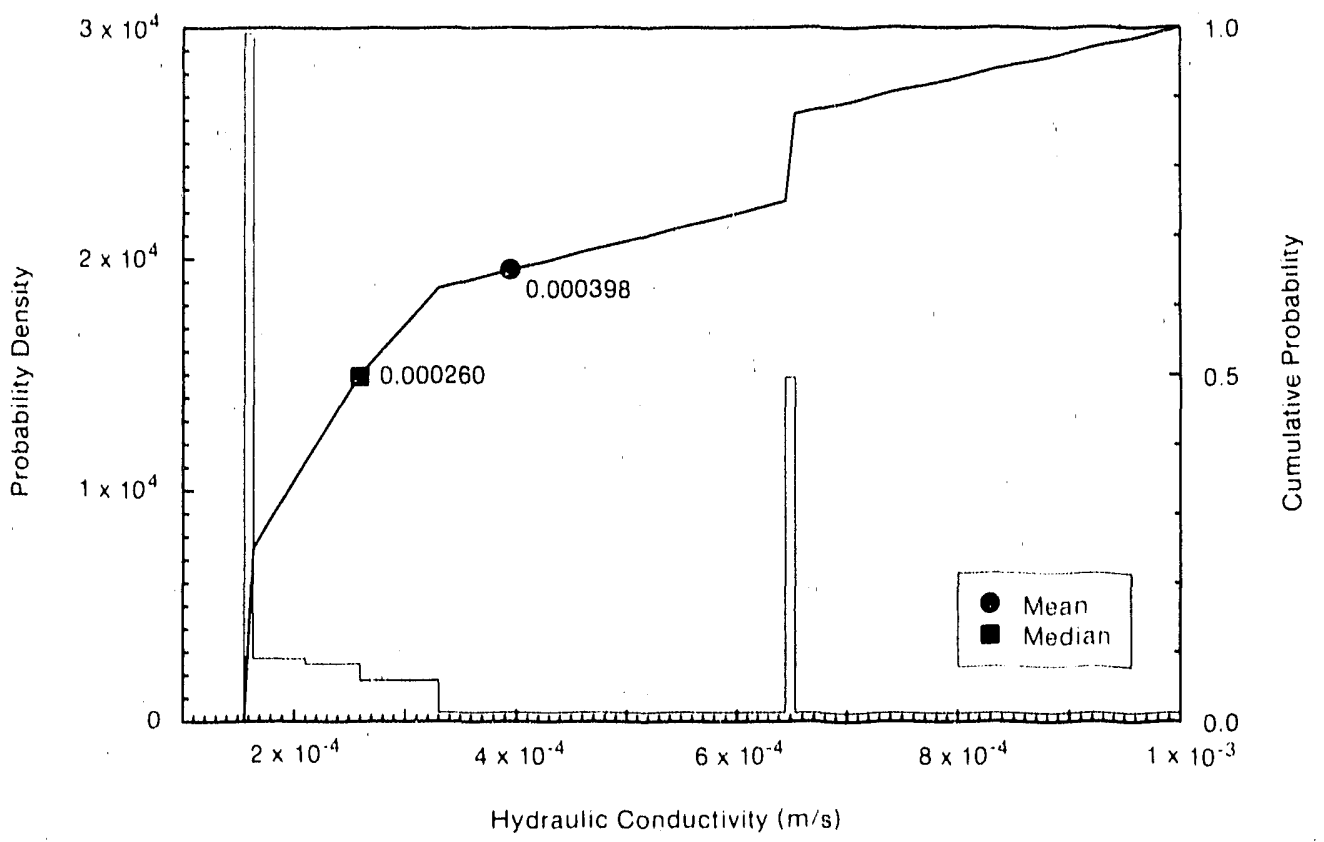

Figure II-40. pdf and cdf for Hydraulic Conductivity in Zone A.

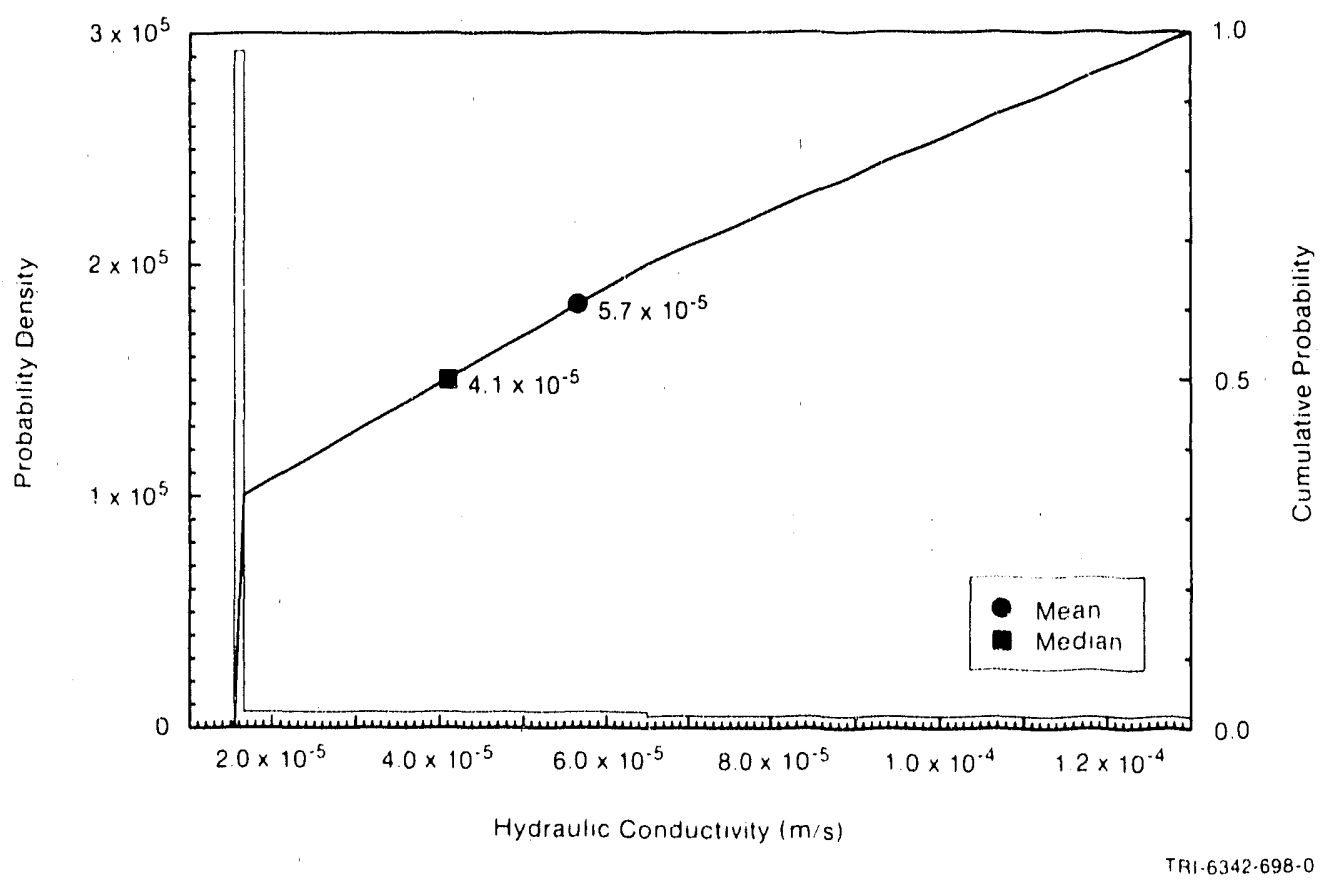

Figure II-41. pdf and cdf for Hydraulic Conductivity in Zone B. 


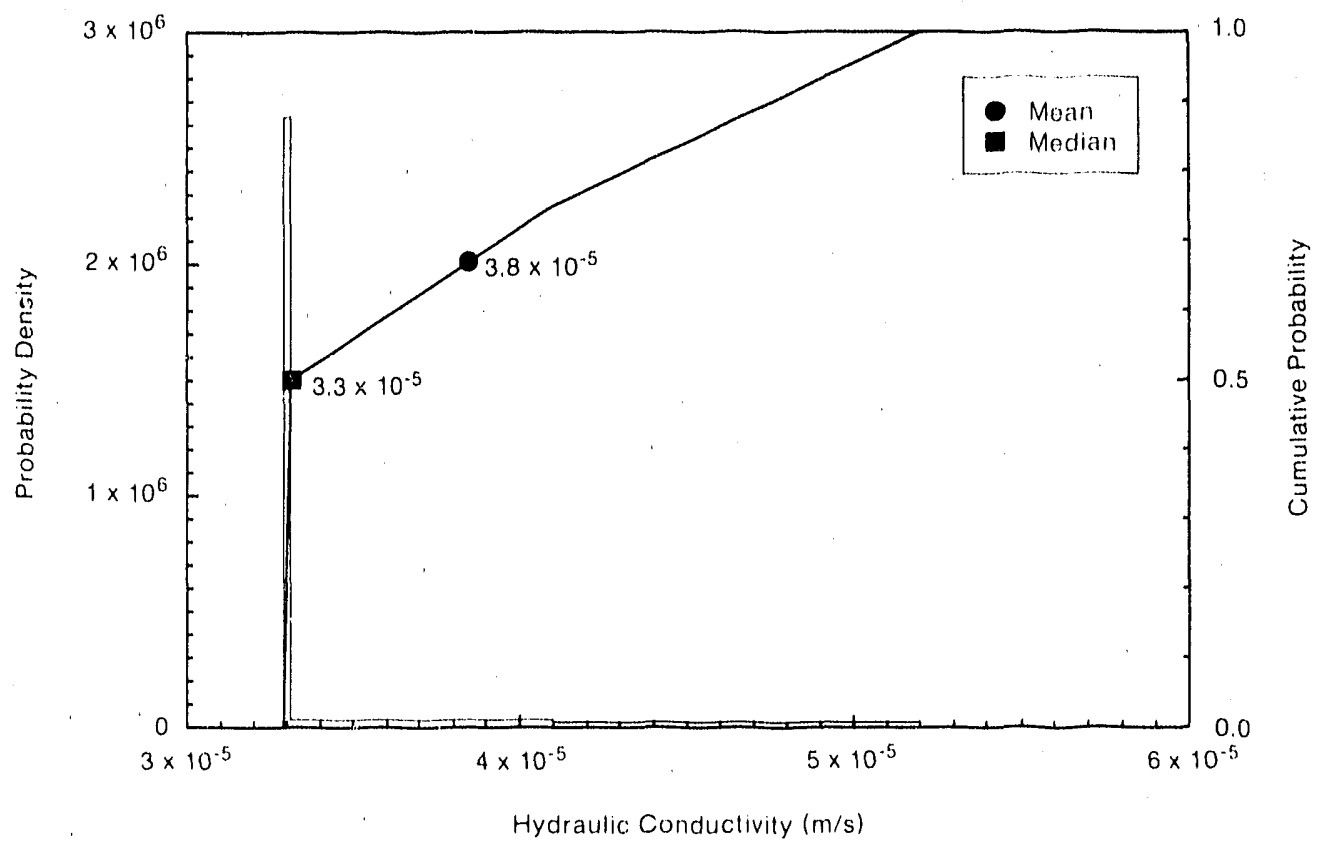

Figure II-42. pdf and cdf for Hydraulic Conductivity in Zone D.

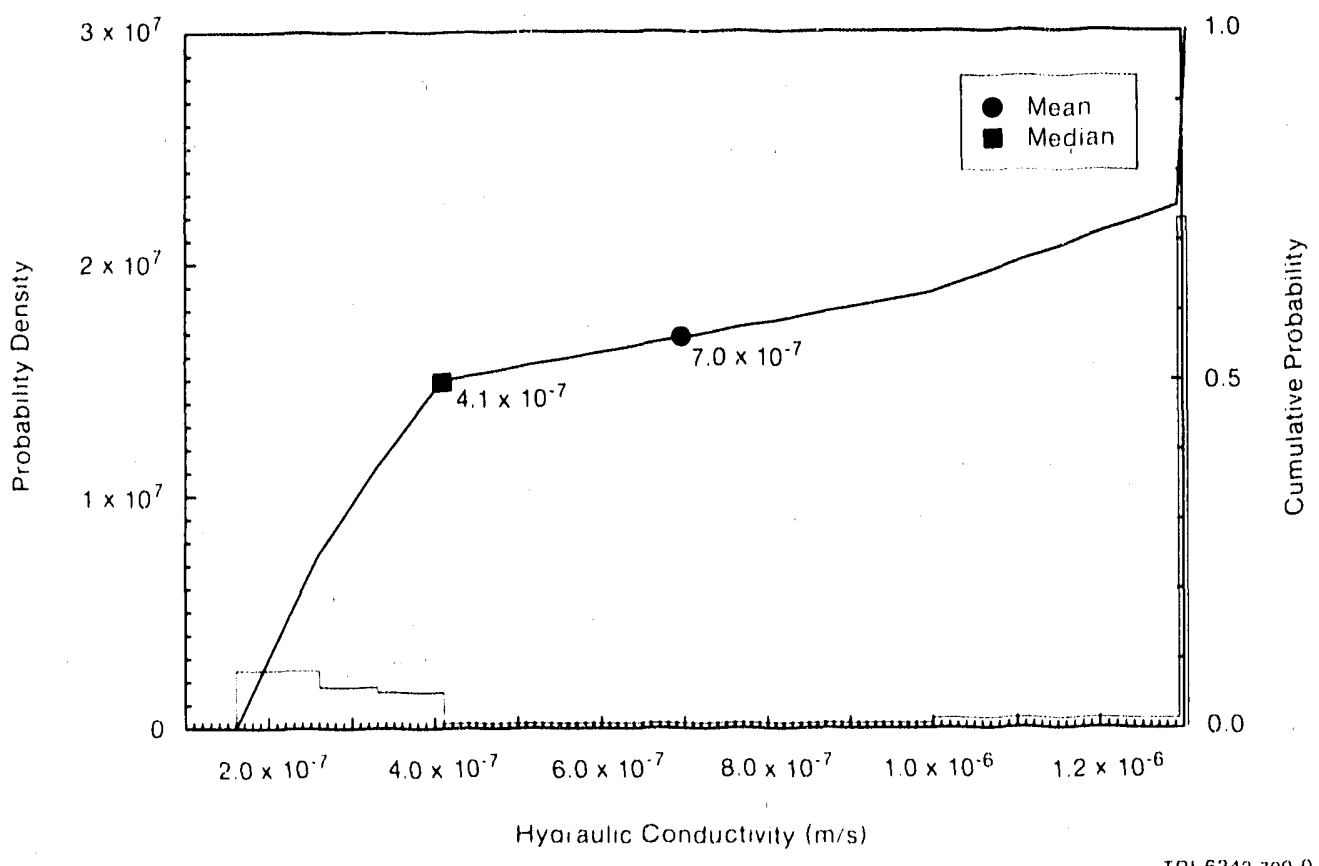

Figure II-43. pdf and cdf for Hydraulic Conductivity in Zone E. 


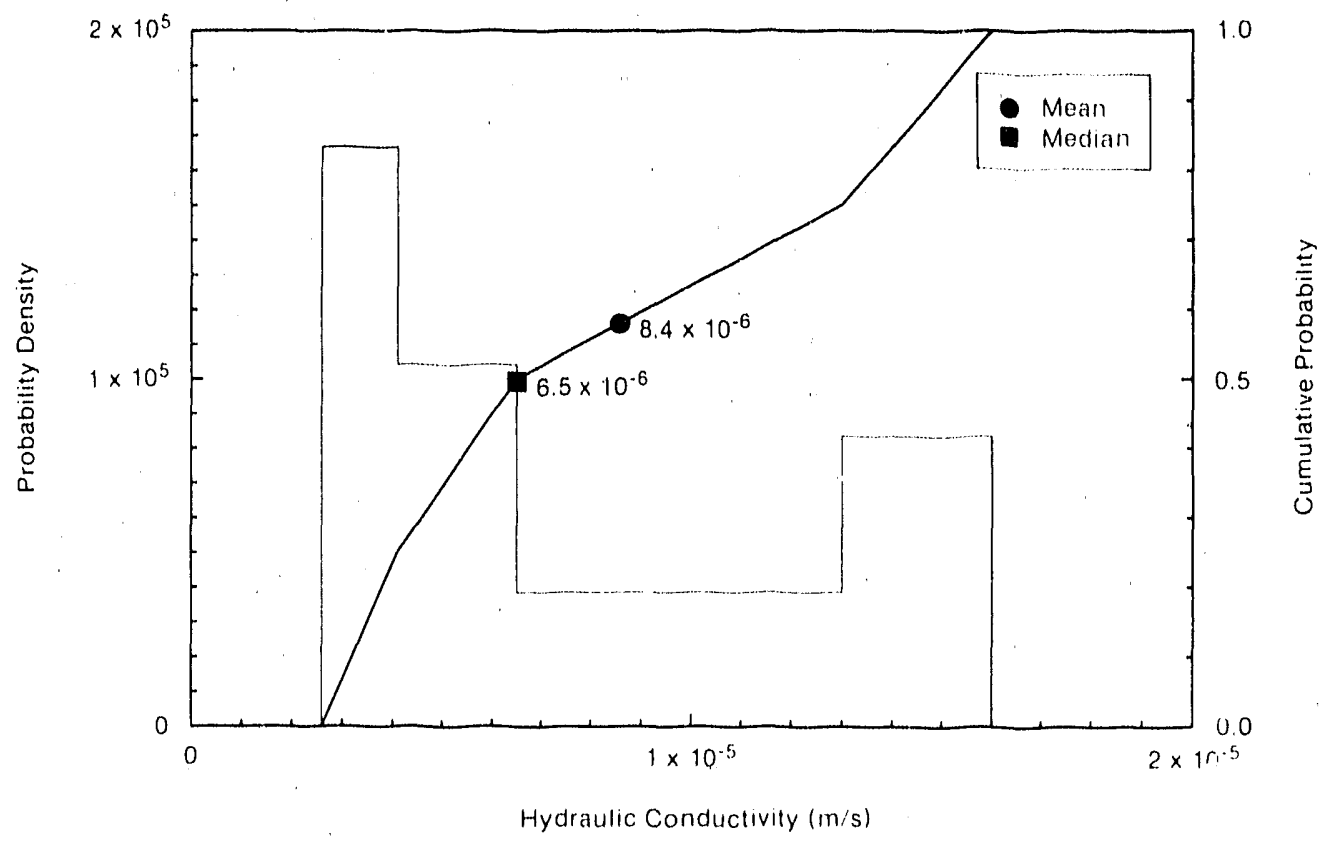

Figure II-44. pdf and cdf for Hydraulic Conductivity in Zone F.

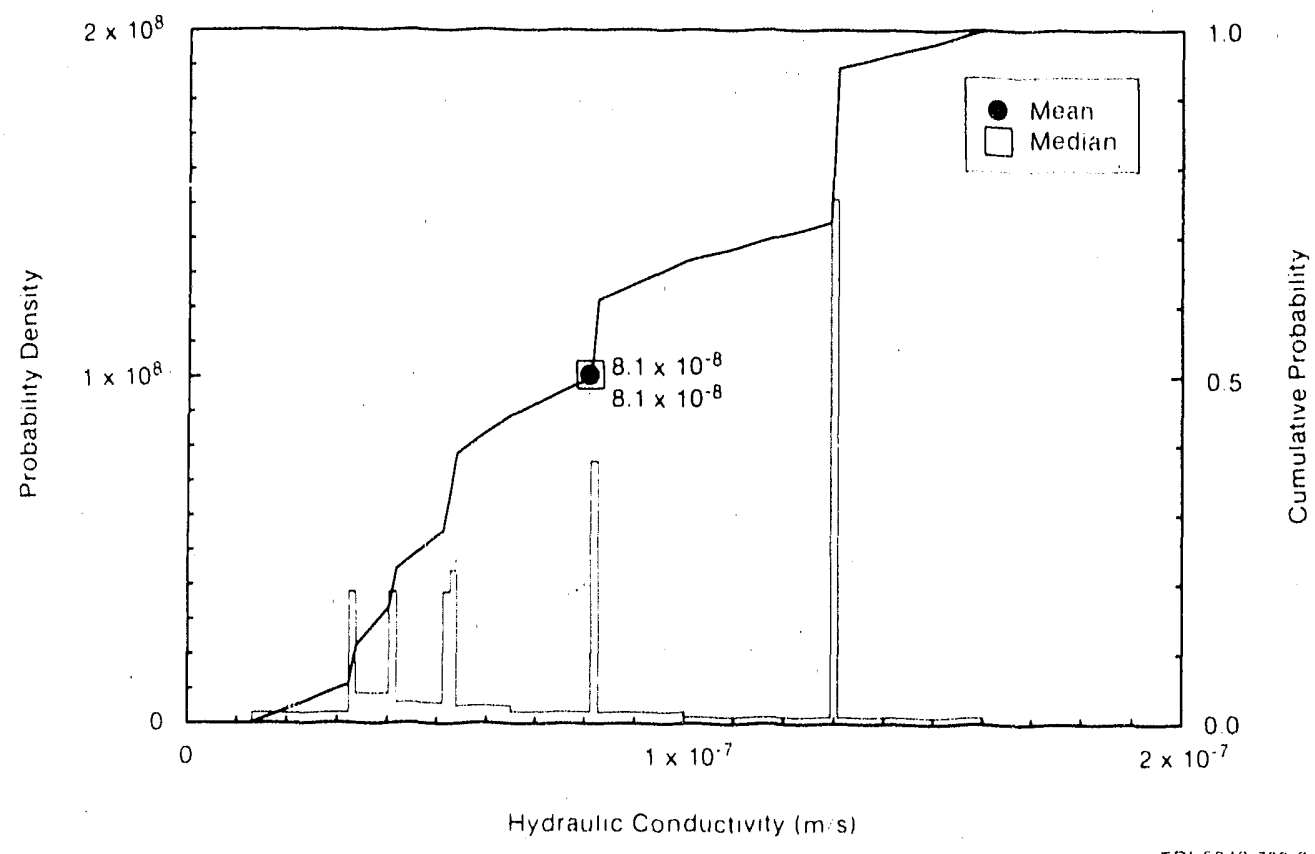

Figure II-45. pdf and cdf for Hydraulic Conductivity in Zone G. 


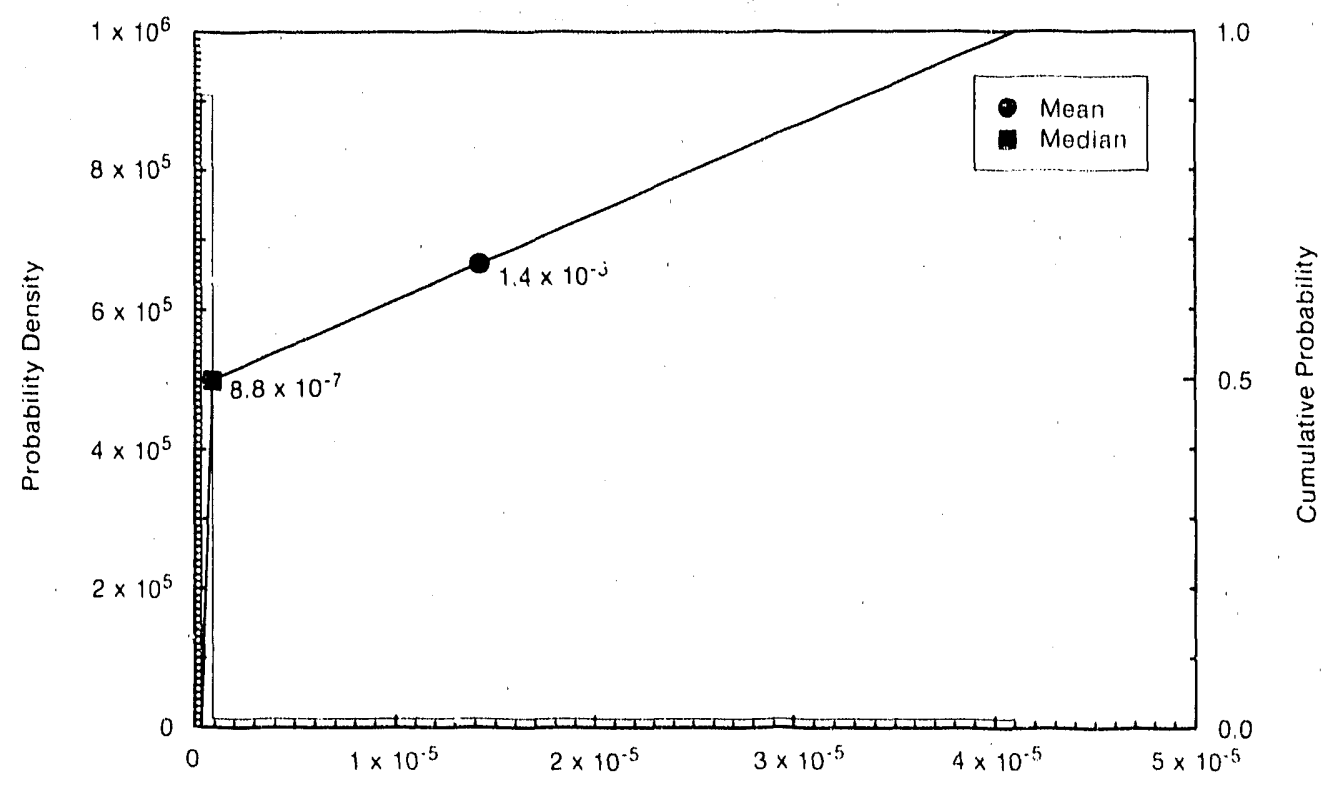

Hydraulic Conductivity $(\mathrm{m} / \mathrm{s})$

TRI-6342.703-0

Figure II-46. pdf and cdf for Hydraulic Conductlvity In Zone H.

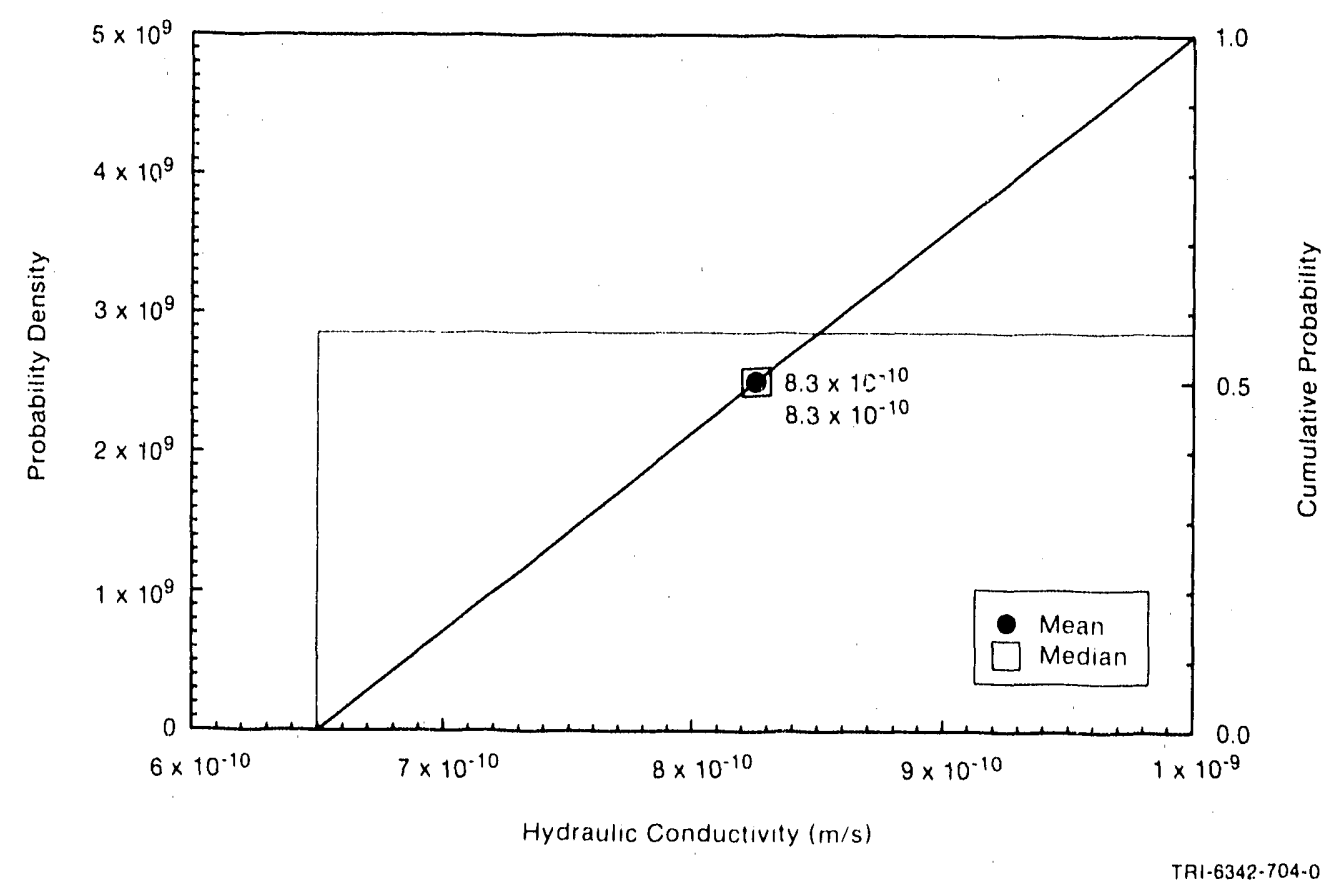

Figure I1-47. pdf and cdf for Hydraulic Conductivity in Zone I. 


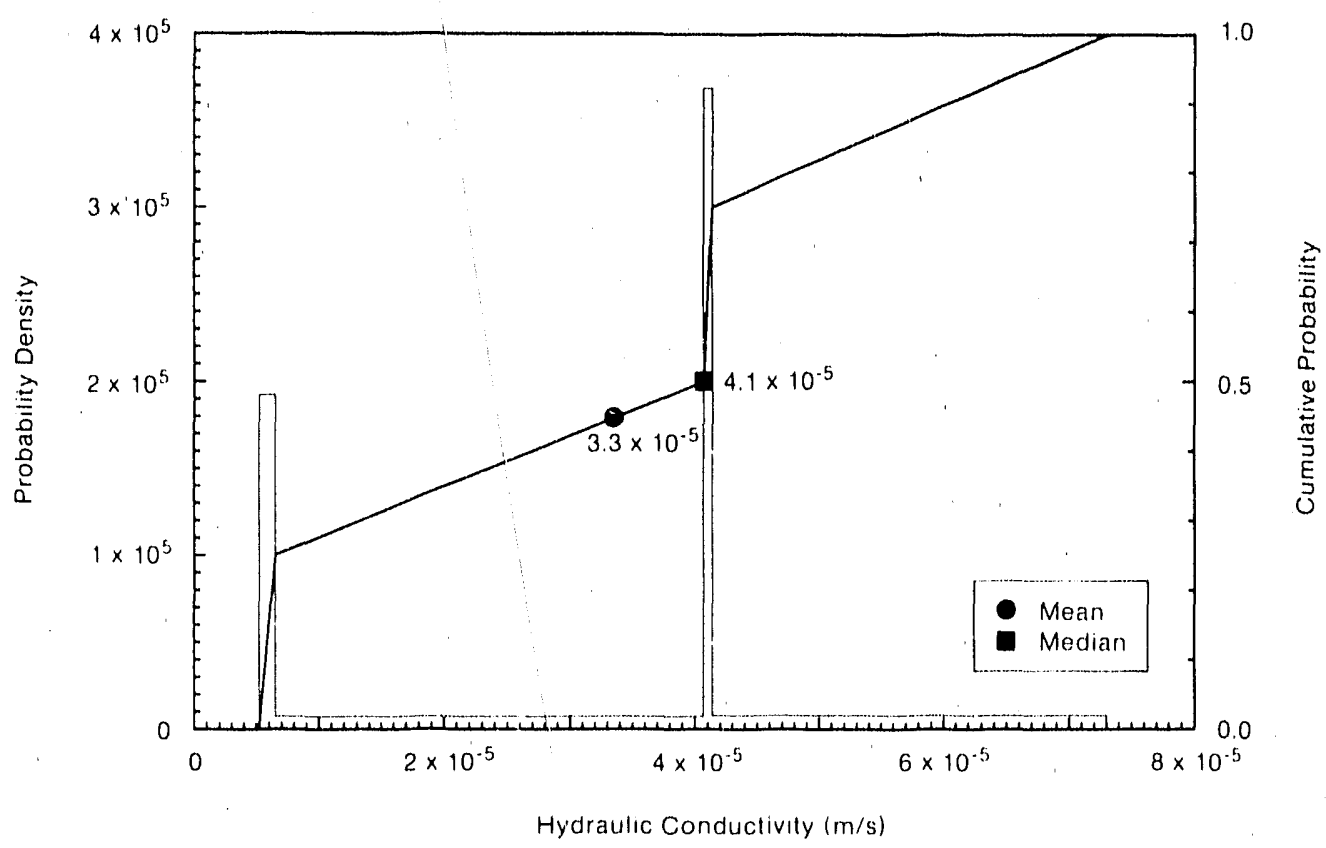

Figure II-48. pdf and cdf for Hydraulic Conductivity in Zone J.

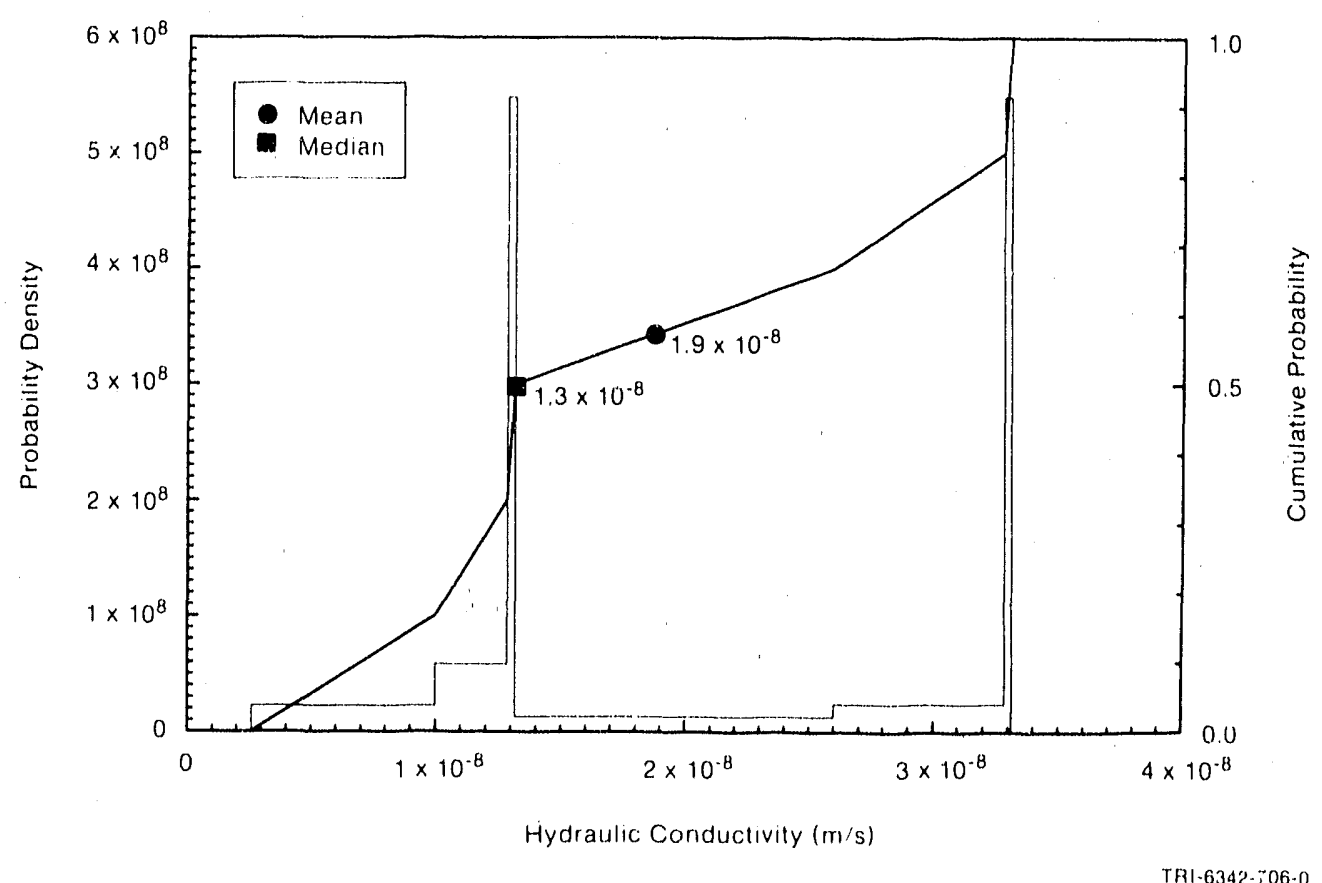

Figure II-49. pdf and cdf for Hydraulic Conductivity in Zone K. 


\section{Miscellaneous Geologic Material}

TABLE \|-10. MISCELLANEOUS GEOLOGIC MATERIAL

\begin{tabular}{|c|c|c|c|c|c|}
\hline Parameter & Medlan & Range & Units & $\begin{array}{l}\text { Distrlbution } \\
\text { Type }\end{array}$ & Source \\
\hline \multicolumn{6}{|l|}{ Anhydrite } \\
\hline Density, graln $\left(\rho_{\mathfrak{g}}\right)$ & $2.963 \times 10^{3}$ & & $\mathrm{~kg} / \mathrm{m}^{3}$ & Constant & Clark, 1966, p.46; Krieg, 1984, p.14 \\
\hline \multicolumn{6}{|l|}{ Hallte } \\
\hline Density, graln $\left(\rho_{\mathbf{g}}\right)$ & $2.163 \times 10^{3}$ & & $\mathrm{~kg} / \mathrm{m}^{3}$ & Constant & $\begin{array}{l}\text { Carmlchael, 1984, Table 2; Krleg, } \\
\text { 1984, p.14; Clark, 1966, p.44 }\end{array}$ \\
\hline
\end{tabular}

\section{ANHYDRITE DENSITY}

The published grain density of anhydrite $\left(\mathrm{CaSO}_{4}\right)$ is $2,963 \mathrm{~kg} / \mathrm{m}^{3}$ (185 $1 \mathrm{~b} / \mathrm{ft}^{3}$ ) (Clark, 1966, p. 46; Krieg, 1987, p. 14).

\section{HALITE DENSITY}

The published grain density of halite (NaCl) is $2,163 \mathrm{~kg} / \mathrm{m}^{3}$ (135 $1 \mathrm{~b} / \mathrm{ft}^{3}$ )

(Carmichael, 1984, Table 2; Krieg, 1987, p. 14; Clark, 1966, p. 44) 


\section{ENGINEERED BARRIERS}

The WIPP repository is composed of a single underground disposal level connected to the surface by four shafts. The repository level consists of an experimental area at the north end and a disposal area at the south end. The 100-acre disposal area contains all of the underground facilities for waste handling, waste disposal, operations, and inaintenance.

The four shafts are (1) the Air Intake Shaft, $5 \mathrm{~m}$ (16 ft) in diameter; (2) the Exhaust Shaft, $4 \mathrm{~m}(13 \mathrm{ft}$ ) in diameter, (3) the Salt Handling (C\&SH) Shaft, 3 $\mathrm{m}(10 \mathrm{ft})$ : jiameter, and (4) the Waste Shaft, $6 \mathrm{~m}(20 \mathrm{ft})$ in diameter. The Waste Sha. S designed to permit the transport of radioactive waste between the surface waste-handling facilities and the underground disposal area and also provides access for personnel, materials, large equipment, and diesel fuel. The shafts will be sealed upon decommissioning of the WIPP (Figures III-1. and III-2) (Nowak et al., 1990).

All of the underground openings are in the same stratigraphic interval, which aips slightly to the south, and are rectangular in cross section. The cistossal area drifts are generally $4 \mathrm{~m}$ (13 ft) high by $8 \mathrm{~m}$ (26 ft) wide; the disposal rooms are $4 \mathrm{~m}(13 \mathrm{ft}) \mathrm{high}, 10 \mathrm{~m}(33 \mathrm{ft}$ ) wide, and $91 \mathrm{~m}$ ( $300 \mathrm{ft}$ ) long. Other drifts range from about 2 to $4 \mathrm{~m}$ ( 7 to $13 \mathrm{ft}$ ) high and 4 to $8 \mathrm{~m}$ $(13$ to $26 \mathrm{ft}$ ) wide. The width of the pillars between rooms is $30 \mathrm{~m}$ (100 ft). The drift entries to the disposal areas will be sealed to isolate the disposal panels. The reference design uses a multiple-component seal approximately 40 m (131 ft) long (see Figures I-2 and II-16 for seal locations) (Nowak et al., 1990). The conceptual design for sealing MB139 directly underneath the disposal area envisions a salt-based grout, if sealing is necessary (Nowak and Tyler, 1989) (Figure III-3). 


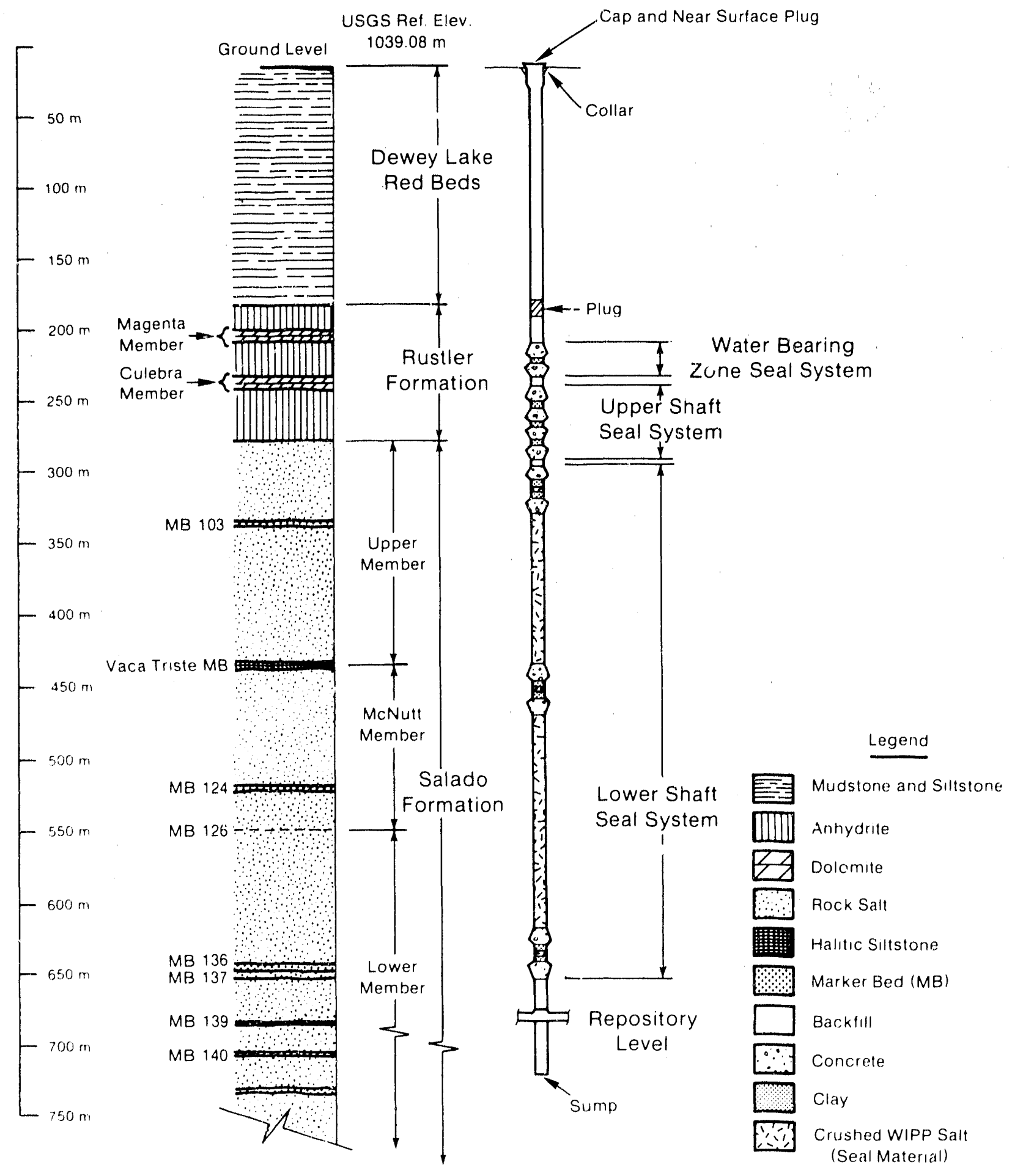

TRI-6342-311.1

Figure III-1. Diagram of Typical Backfilled and Sealed Access Shaft (after Nowak et al., 1990). 

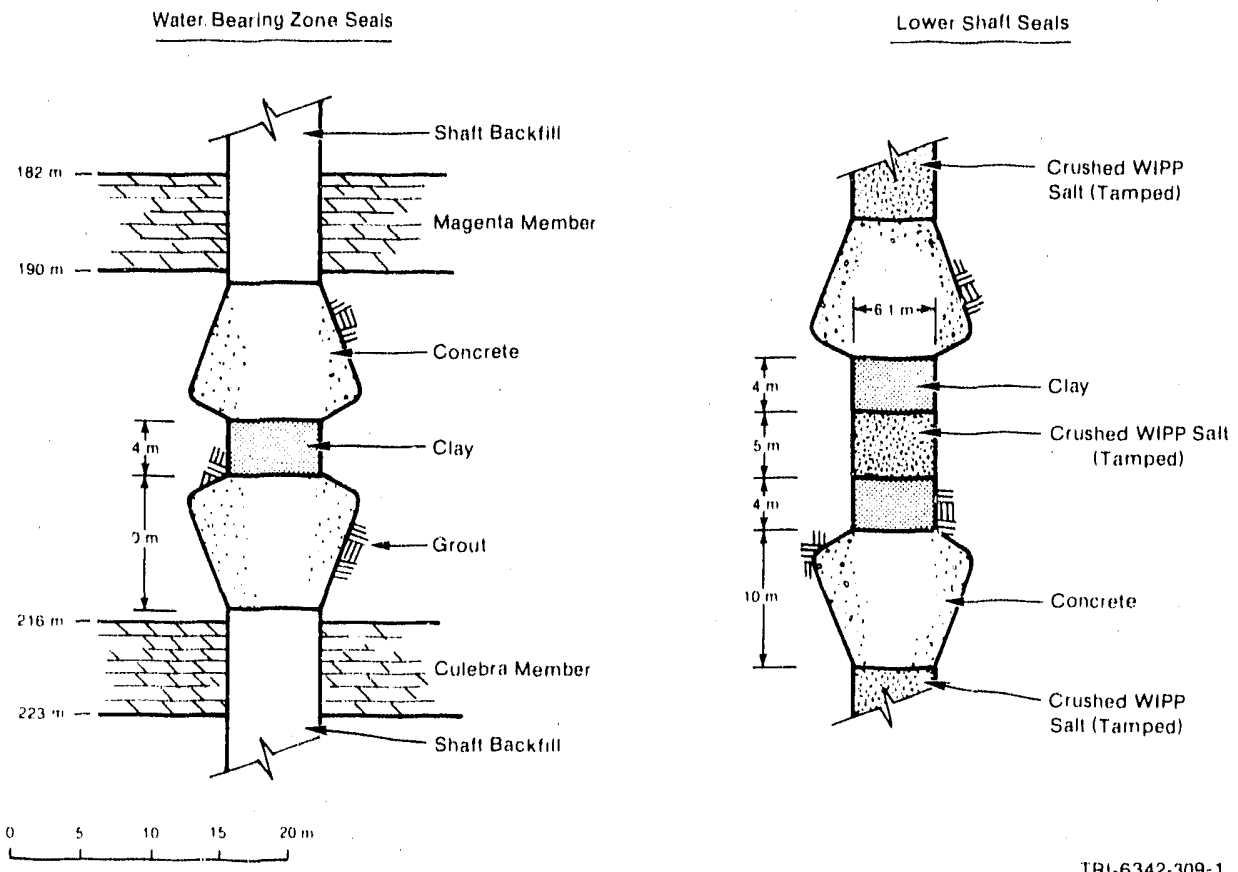

Figure III-2. Diagram of Typical Multicomponent Seals. The drawing shows a seal between water-bearing units (t.g. Culebra Dolomite) (upper left) and part of the Lower Shaft Short-Term Seal (e.g., at Vaca Triste) for Waste Shaft (upper right) (after Nowak et al., 1990).

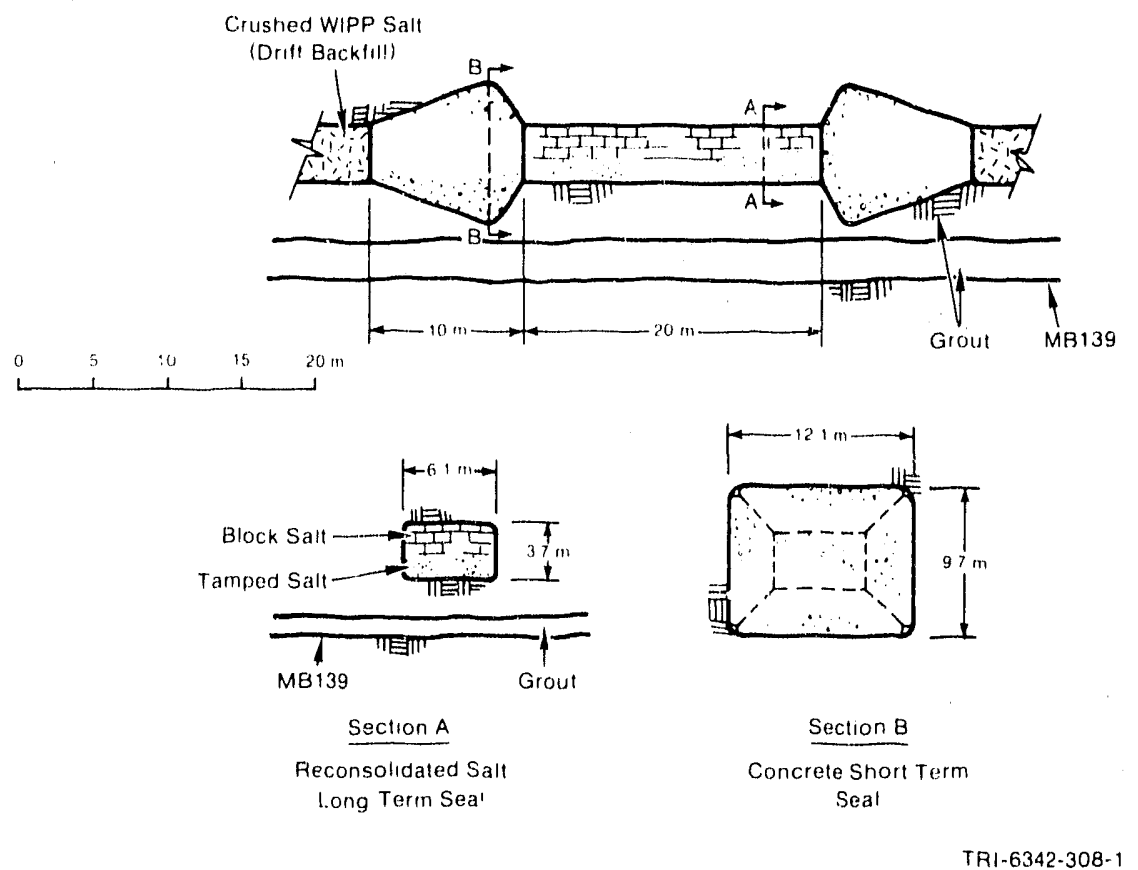

Figure III-3. Diagram of Typical Multicomponent Seal for Drifts and Panels (after Nowak et al., 1990). 


\section{Seal Material Parameter Values for Crushed Salt}

Sandia has developed a reference design for sealing and backfilling the WIPP lepository (the previous section presented a brief overview) (Nowak et al., 1990; Nowak and Tyler, 1989). The purpose of the reference design is to provide a common basis for calculations such as performance assessment and sensitivity analysis. The reference design is a starting point for developing experiments and analysis from which a detailed conceptual design will evolve.

The current PA calculations examine the human-intrusion scenario, not the undisturbed scenario. In a human-intrusion scenario, the borehole is assumed to bypass the seal material. Therefore, the current calculations did not use the data for the seals. The calculations for the undisturbed scenario were run earlier and reported in Rechard et al. (1990) and Marietta et al. (1989). The parameter values for the seal material are reported in Rechard et al. (1990, Appendix A). 


\section{Parameter Values for Unmodified Waste Form Including Containers}

The TRU waste, generated at defense-program facilities, consists of laboratory and production trash such as glassware, metal pipes, solvents, disposable laboratory clothing, cleaning rags, and solidified sludges. The trash is contaminated by alpha-emitting transuranic elenents with atomic numbers greater than uranium-92, half-lives greater than $20 \mathrm{yr}$, and curie contents greater than $100 \mathrm{nCi} / \mathrm{g}$. Other contaminants include radionuclides with halflives less than $20 \mathrm{yr}$, such as plutonium.

Approximately 608 of the waste may also be co-contaminated with waste considered hazardous under the RCRA, e.g., lead (WEC, 1989). Current plans specify that most of the TRU waste generated since 1970 will be placed in the WIPP repository, with the $r$ mainder to be disposed of at other DOE facilities.

Although only about one-third of the waste currently exists, the WIPP, if licensed, will ultimately dispose of about $1.2 \times 10^{5} \mathrm{~m}^{3}\left(4.2 \times 10^{6} \mathrm{ft}^{3}\right)$ of rRU waste. The design storage volume is $1.7 \times 10^{1} \mathrm{~m}^{3}\left(6.2 \times 10^{6} \mathrm{ft}^{3}\right)$ within the $4.3 \times 10^{5} \mathrm{~m}^{3}\left(1.5 \times 10^{7} \mathrm{ft}^{3}\right)$ of excavated volume. Radioactive waste emitting alpha radiation, although dangerous if inhaled or ingested, is not hazardous externally, and can be safely handled if confined in a sealed container (i.e., contact-handled $[\mathrm{CH}])$. The projected $\mathrm{CH}$.TRU waste consists of about 380,000 $0.21-\mathrm{m}^{3}$ (55-gal) steel drums, 6,000 $3.2-\mathrm{m}^{3}\left(113-\mathrm{ft}^{3}\right)$ steel and plywood boxes, and $13,5001.8-\mathrm{m}^{3}\left(64-\mathrm{ft}^{3}\right)$ steel boxes (IDB, 1988). The total curie content of the $\mathrm{CH}-\mathrm{TRU}$ waste is about $9.2 \times 10^{6} \mathrm{Ci}\left(2.5 \times 10^{-4} \mathrm{~Bq}\right)$. The value of 5.08 $\times 10^{6} \mathrm{Ci}\left[1.38 \times 10^{-4} \mathrm{~Bq}\right]$ was used to calculate the muitiplier (waste unit) for Table 1 in Appendix $A$ of 40 CFR 191. Although a room can ideally store 6,800 noncompacted drums stacked three deep, each of the 56 rooms and associated access drifts (about 63 room equivalents) will contain a repository average of 5,200 drum-equivalents.

A small portion of the TRU waste must be transported and handled in shielded casks (remotely handled $[\mathrm{RH}]$ ). The total curie content is being determined but must be less than $5.1 \times 10^{6} \mathrm{Ci}\left(1.39 \times 10^{-4} \mathrm{~Bq}\right)$ according to the agreement between DOE and the State of New Mexico (U.S. DOE/NM, 1984). The RH-TRU containers will be stored horizontally in the walls of the rooms. All CH- and RH-TRU waste must meet the WIPP Waste Acceptance Criteria (WEC, 1985) and be certified for shipment to the WIPP. Table III-1 provides the parameter values for unmodified waste.

\section{CAPILLARY PRESSURE AND RELATIVE PERMEABILITY}

The correlations for these values were developed as discussed in the Chapter II section, "Parameters for Halite and Polyhalite within the Salado Formation." Preliminary pd:ameter values were obtained from Brooks and Corey 
TABLE III-1. PARAMETER VALUES FOR UNMODIFIED TRU WASTE

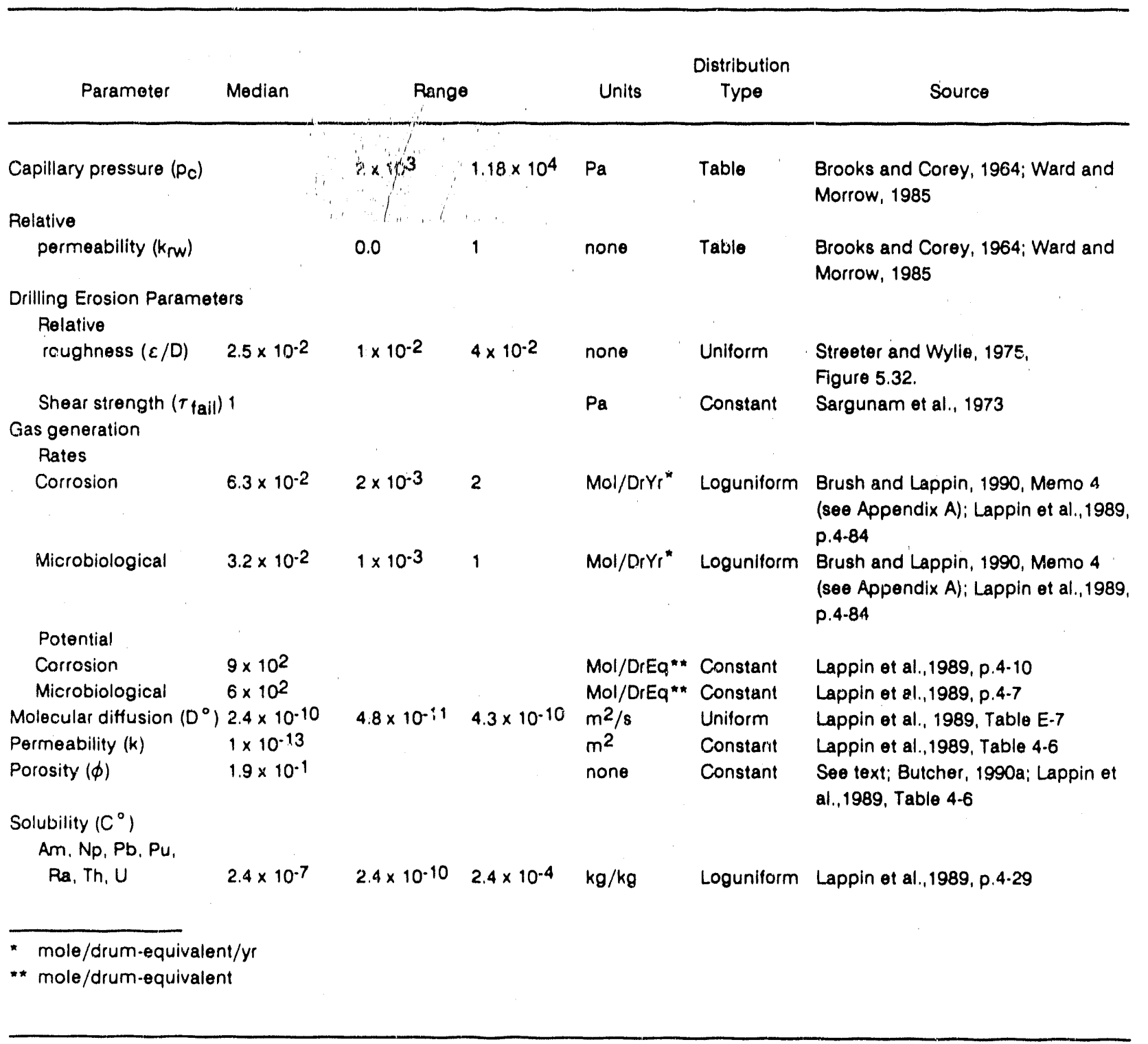

$$
\begin{aligned}
& \lambda=2.89 \\
& p_{t}=2.02 \mathrm{kPa} \\
& s_{r w}=0.276 \\
& s_{g C}=0.07
\end{aligned}
$$

Capillary pressures and relative permeabilities for waste are shown in Figures III-4 and III-5, respectively. 


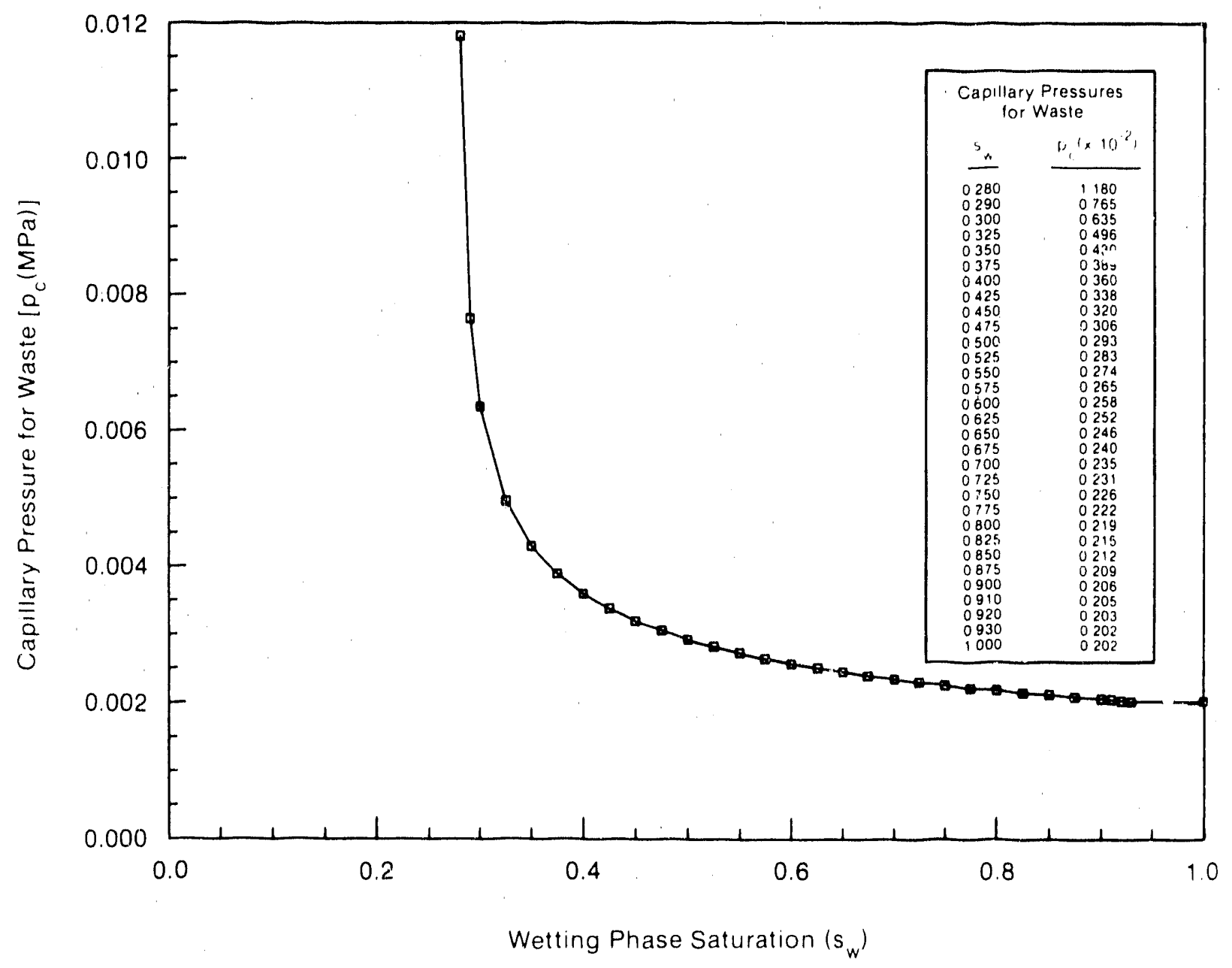

TRI-6342-624-0

Figure III-4. Estimated Capillarity Pressure Curve for Unmodifled Waste. 


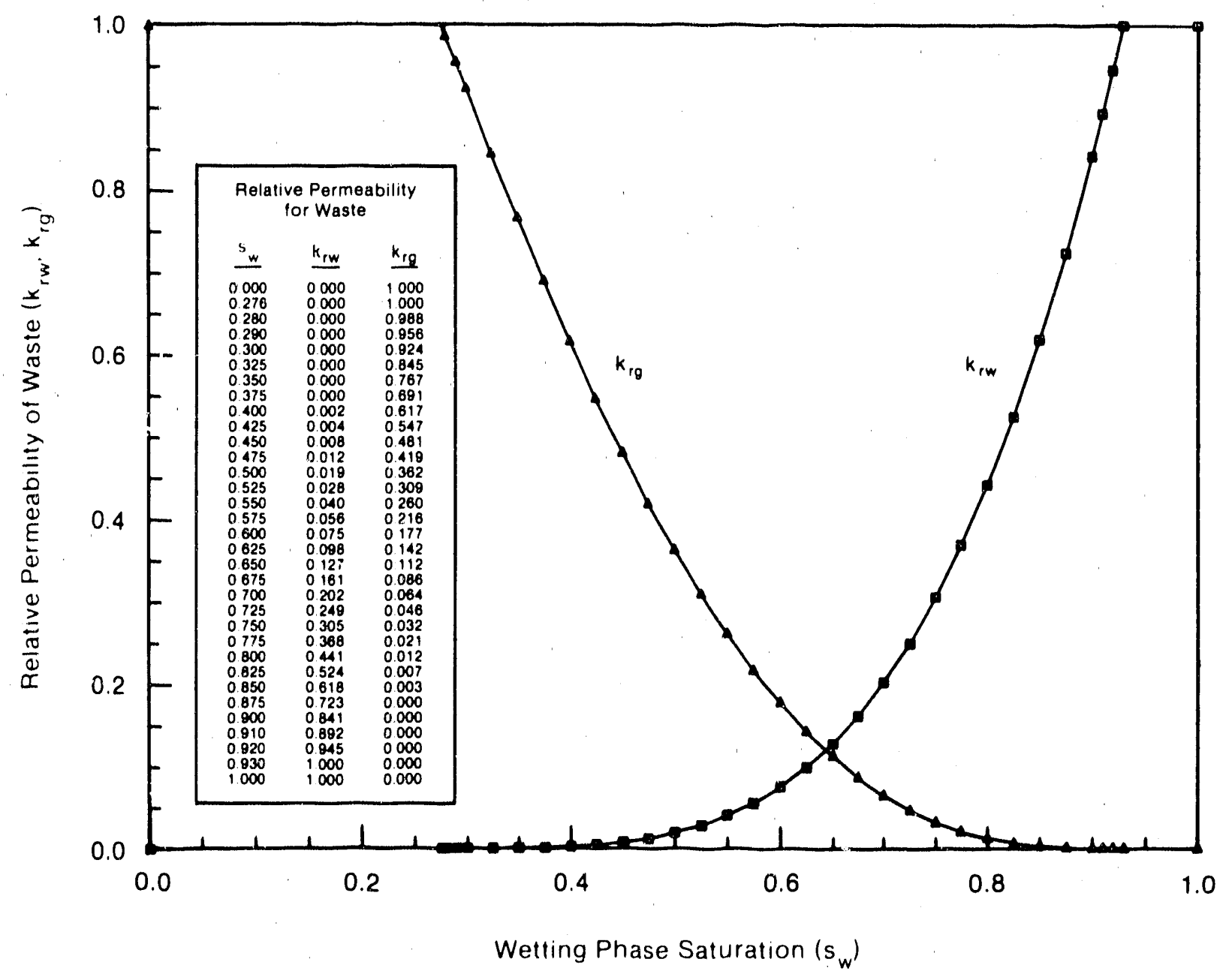

TRI-6342-621-0

Figure III-5. Estimated Relative Permeability for Unmodified Waste. 
(1964). Their experimental data for a "fragmented mixture of granulated clay, fragmented sandstone, and volcanic sand" are used.

\section{DRILLING EROSION PARAMETERS}

Two waste-dependent parameters influencing the amount of material that erodes from the borehole wall during drilling are shear stress generated by the drilling fluid (mud) and waste shear strength.

\section{Waste Relative Roughness}

For turbulent flow, the shear stress of the drilling fluid (mud) acting on the borehole wall is dependent upon the relative surface roughness $(\varepsilon / D)$ at the repository level. The current value chosen for PA calculations corresponds to riveted steel piping (Moody diagram) (Streeter and Wylie, 1975, Figure 5.32).

\section{Waste Shear Strength}

The PA Division assumed a shear strength ( $\tau_{\text {fal1 }}$ ) for the unmodified waste of 1 $\mathrm{Pa}\left(9.9 \times 10^{-6} \mathrm{~atm}\right)$, a value at the low end of the range for montmorillonite clay (Sargunam et al., 1973).

\section{GAS GENERATION}

\section{Gas Production Rates}

In Lappin et al. (1989, pp. 4-4 to 4-13), Brush estimated an upper bound on the rate of production of $\mathrm{H}_{2}$ from anoxic corrosion of iron and iron-based alloys as about 2 moles/drum equivalent/yr and production rate of various gases (e.g., $\mathrm{CO}_{2}, \mathrm{~N}_{2}, \mathrm{H}_{2} \mathrm{~S}$, and $\mathrm{CH}_{4}$ ) from microbial degradation of cellulosics as about 1 mole/drum equivalent/yr. ${ }^{*}$ The $\mathrm{H}_{2}$-generation rate assumes all the iron is $1.52 \mathrm{~mm}$ thick (less than 1/16 in.) and the iron is bathed in brine. (The wall thickness of drums is $1.52 \mathrm{~mm}$; drums comprise about 478 of $\mathrm{CH}$ iron waste). The microbial gases are assumed to arise from the degradation of cellulosic material and rubbers in waste. The 1 mole/drum equivalent/yr from microbial activity is estimated from $\mathrm{CO}_{2}$ generation in laboratory experiments conducted for 3 months usinir various cellulose matrices (e.g., paper, cloth, and plywood) (Molecke, 1979).

Brush and Lappin (1990, Memo 4 [Appendix A]) estimated a lower bound on the production of $\mathrm{H}_{2}$ from anoxic corrosion and various gases from microbial

*A1though more significar $=$ figures were reported in Lappin et al. (1989, p. 4-84) and Brush and Anderson (1989) for these rates, the natire of the estimates do not justify more significant digits. 
undisturbed Salado Formation. (Whether anoxic corrosion can occur without condensed $\mathrm{H}_{2} \mathrm{O}$ is still an open question and is being explored in laboratory experiments.) Furthermore, they proposed a loguniform distribution to sample equally in each decade of the three order of magnitude range (presumably when the amount of bxine in the waste is unknown.)

A test plan for laboratory experiments (Brush, 1990) and in-situ gas production experiments using real waste at the WIPP (Lappin et al., 1989) describe experiments currently planned to substantiate these speculations.

\section{Gas Generation Potential}

Wit'sut a detailed knowledge of the mechanisms by which gas may be produced, the gas generation potentials can only bo calculated based on the anount of waste received at the WIPP. Based on information in 1988 (IDB, 1988; Lappin et al., 1989, p. A-119), Sandia estimated a gas generation potential from corrosion of about 900 mole/drum equivalent and from microbial degradation of about 600 mole/drum equivalent. Because estimates of the volume of $\mathrm{CH}$ waste are decreasing, but the volume of $\mathrm{RH}$ waste is increasing, these values will change. To maintain consistency with previous Sandia calculations, the PA Division chose to use the 1988 numbers for the current calculations. Future work however, will incorporate newer estimates of total volume as well as results from experiments, which may place upper limits on the maximum potential of converting the estimated total volume into gas.

\section{MOLECULAR DIFFUSION}

Although molacular diffusion varies with each species and the concentration of ions (e.g., $\mathrm{Na}^{+}$from brackish water), most of the computer programs used by the PA Division use a single value. To be safe, molecular diffusion was assumed to be uniformly distributed (Figure III-6) with a range chosen to encompass the extremes for the radionuclides (Lappin et al., 1989, Table E-7) l:. $8 \times 10^{-11}$ to $4.3 \times 10^{-10} \mathrm{~m}^{2} / \mathrm{s}\left(4.5 \times 10^{-5}\right.$ to $\left.4.0 \times 10^{-4} \mathrm{ft}^{2} / \mathrm{d}\right)$ with a mean of $2.4 \times 10^{-10} \mathrm{~m}^{2} / \mathrm{s}\left(2.2 \times 10^{-4} \mathrm{ft}^{2} / \mathrm{d}\right)$.

\section{PERMEABILITY}

The permeability of the overall waste is estimated by combining the estimated individual permeabilities (on the scale of a barrel) of combustibles (plastic, gloves, pine wood, and rags), metal/glass (including corroded and uncorroded steel), and sludges (liquid waste mixed with cement). Preliminary estimates for the individual components from a few permeability tests are tabulated in Table III-2 (Butcher, 1990, Memo 5 [Appendix A]): 


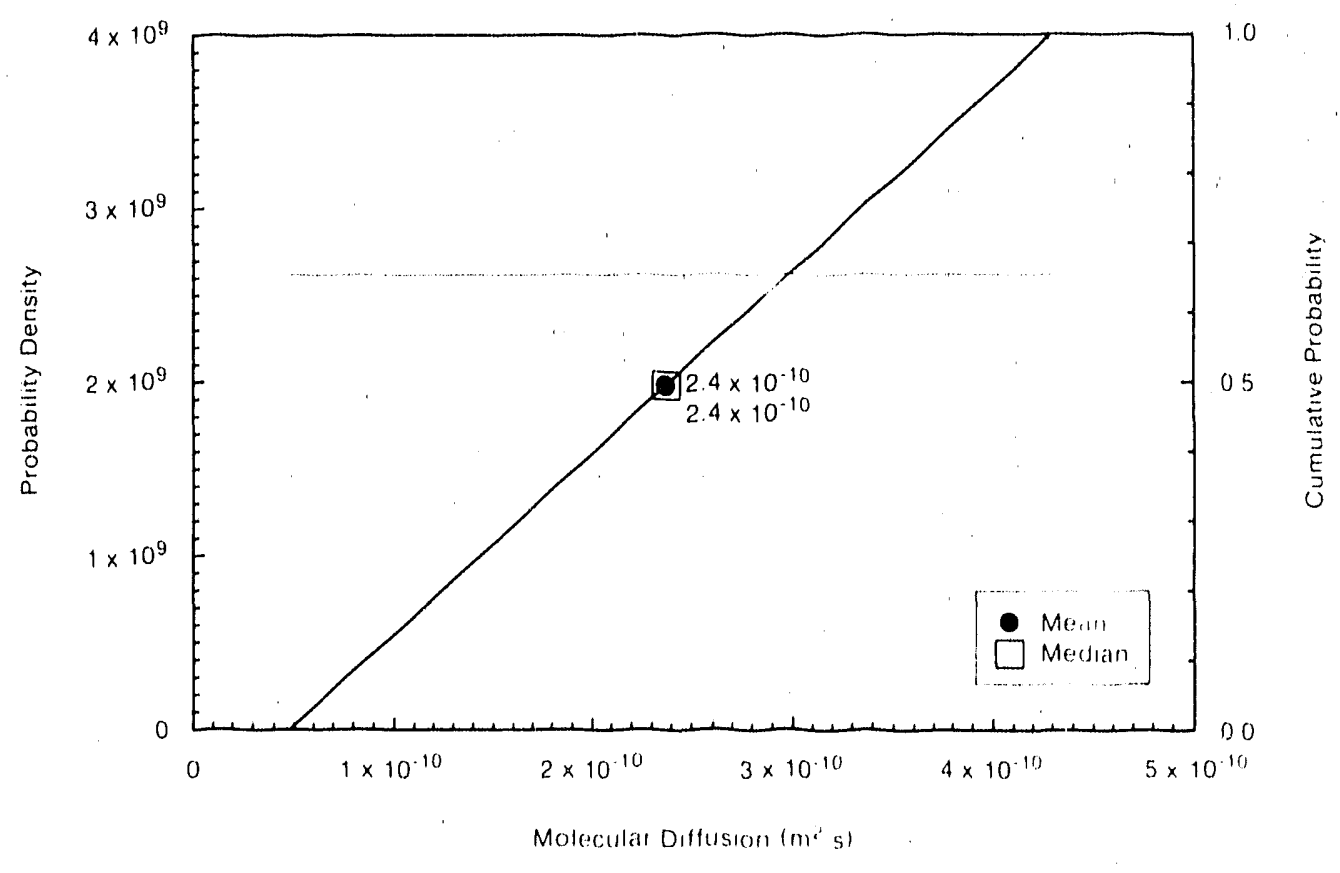

Figure III-6. Uniform pdf and cdf for Culebra Molecular Diffusion, $D^{\circ}$.

TABLE III-2. PRELIMINARY PERMEABILITY ESTIMATES FOR INDIVIDUAL COMPONENTS

\begin{tabular}{lcccc}
\hline Waste Component & Volume (\%) & Median (mD $)^{\star}$ & Range (mD) \\
\hline Combustibles & 40 & 17 & 2 & 200 \\
Metals/glass & 40 & 500 & 4 & 1200 \\
Sludges & 20 & 0.12 & 0.011 & 0.17 \\
& & & & \\
${ }^{\star} \mathrm{mD}=$ millidarcy; 1 darcy $=9.87 \times 10^{-3} \mathrm{~m}^{2}$ & & & \\
\hline
\end{tabular}

The permeability for the combustibles is estimated from a few tests on simulated waste. After crushing a mixture of 608 by weight of pine cubes and $40 \%$ of rags for 30 days at $14 \mathrm{MPa}$, the perneability started at $2 \times 10^{-13} \mathrm{~m}^{2}$ $(200 \mathrm{mD})$ and dropped to $2 \times 10-15 \mathrm{~m}^{2}(2 \mathrm{mD})$, which defined the rlaximum range for combustibles. (A similar test had a seady perineability of $1.3 \times 10^{-14} \mathrm{~m}^{2}$ $(13 \mathrm{mD})$; two tests on a mixture of 408 plastic bottles, 408 PVC parts, and $20 \%$ gloves had permeabilities of 0 and $2.5 \times 10^{-4} \mathrm{~m}^{2}[0$ and $25 \mathrm{mD}]$.) The median permeability of $1.7 \times 10^{-14} \mathrm{~m}^{2}$ ( $\left.17 \mathrm{mD}\right)$ for combustible waste was estimated from the average of two tests on a simulated waste inixture consisting of 458 
of the above plastics and 378 of the above wood mixture plus 98 -inch metal parts and 98 dry Portland cement.

The maximum and median values for permeability of the metals and glass component of the waste were estimated using 508 1-inch metal parts and 508 magnetite that were crushed for one day. The latter material represented the corroded metal. One test had an initial permeability of $5.0 \times 10^{-13} \mathrm{~m}^{2}$ ( $500 \mathrm{mD}$ ) (used as the median value), but dropped to $4 \times 10^{-15} \mathrm{~m}^{2}$ (4 inD) (used as the minimum value). (A second test had a steady permeability of $1.1 \mathrm{x}$ 10-14 $\mathrm{m}^{2}$ [11 $\left.\left.\mathrm{mD}\right].\right)$ The maximum permeability is the value estimated for uncorroded metal waste in Lappin et al. (1989, p 4-56).

Performance Assessment assumed that the permeabilities of each component were uniformly distributed among the minimum, median, and maximum values given above. Consequently, the distribution of local permeability (i.e., the effective permeability of a collapsed barrel) was the weighted sum of uniform distributions.

It is easily verified that the expected permeability ( $E(k)$ ) of the resulting probability density function on the scale of a barrel $\left(0.27 \mathrm{~m}^{3}\right.$ or $\left.9.5 \mathrm{ft}^{3}\right)$ is

$$
E(k)=\mu_{\text {perm }}=\int k f(\eta) \mathrm{d} \eta=1.7 \times 10^{-13} \mathrm{~m}^{2}
$$

and the coefficient of variation $[V(k)]^{1 / 2} / E(k)$ is

$$
\begin{aligned}
& \left([\mathrm{V}(\mathrm{k})]^{1 / 2} / \mathrm{E}(\mathrm{k})^{2}=\left(\sigma / \mu_{\text {perm }}\right)\right. \\
& \left.=\left(\int \mathrm{m}^{2} \mathrm{f}(\eta) \mathrm{d} \eta\right)^{1 / 2} / \mu_{\text {perm }}=\mathrm{E}(\mathrm{k}-\mu)^{2}\right]^{1 / 2} / \mu_{\text {perm }}-1.22
\end{aligned}
$$

where

$$
\begin{aligned}
& E(k)=\text { expectation of } k \\
& V(k)=\text { variance of } k
\end{aligned}
$$

Provided the fraction of waste components (combustibles, metal, and sludges) does not vary significantly or is spatially correlated, the central limit theorem guarantees that the probability density function on a repository scale will be normal. The permeability mean is (Tierney, 1990, Memo 6, [Appendix A])

$$
E\left(k_{\text {eff }}\right) \simeq \mu_{\operatorname{perm}}\left(1+\alpha^{2} / L\right) /\left(1+\alpha^{2}\right)=1.6 \times 10-13
$$

and the coefficient of variation is

$$
\left[\mathrm{V}\left(\mathrm{k}_{\mathrm{eff}}\right)\right]^{1 / 2} / \mathrm{E}\left(\mathrm{k}_{\mathrm{eff}}\right) \simeq \beta^{2}\left(1+\alpha^{2}\right) /\left[\mu_{\operatorname{perm}}\left(1+\alpha^{2}\right)\left(1+4 \alpha^{2}\right)\right]=1.2 \times 10^{-2}
$$


where

$$
\begin{aligned}
& \alpha^{2}=(\sigma / \mu)^{2} / \mathrm{MN} \\
& \beta^{2}=\sigma^{2} / \mathrm{MN} \\
& \mathrm{M}=\text { number of replications of the unit (waste barre1) across a room ( } 17) \\
& \mathrm{N}=\text { number of replications of the unit vertically (3) } \\
& \mathrm{L}=\text { number of replications of the unit down the length of the room }(\sim 150) .
\end{aligned}
$$

The mean varies only slightly with the permeability estimate in Lappin et al., 1989. To be consistent with this and other previous works, the PA Division usually used a value of $1 \times 10^{-13} \mathrm{~m}^{2}(100 \mathrm{mD}$ ). (In some cases, the permeability was decreased to $1 \times 10^{-15} \mathrm{~m}^{2}(1 \mathrm{mD})$ for numerical stability. This change has no noticeable effect on results [Rechard et al., 1989, Figure 4-2].)

Because the coefficient of variation is so small, the PA Division did not sample on waste permeability. This conclusion may change as information on the variability (variance) of the volume fraction of waste components in the repository and any spatial correlation become available. The variance of the volume fraction of waste components will add directly (not reduced by the central limit theorem) to the waste unit variance (expressed above in Eq. III4 as a coefficient of variation).

\section{POROSITY}

Similar to the permeability calculations presented above, the porosity of the overall waste was estimated by combining, by volume, the estimated individual porosities (on the scale of a barrel) of combustibles (plastic, gloves, pine wood, and rags), metal/glass (including corroded and uncorroded steel), and sludges ( 1 iquid waste mixed with cement). Preliminary estimates for the individual components from estimates of the density at $15 \mathrm{MPa}$ (148 atm) and without any porosity are tabulated in Table III-3 (Butcher, 1990, Memo 5 [Appendix A]).

TABLE III-3. PRELIMINARY POROSITY ESTIMATES FOR INDIVIDUAL COMPONENTS

\begin{tabular}{lllll}
\hline Waste Component & Volume (\%) & Median & \multicolumn{2}{c}{ Range } \\
\hline & & & & \\
Combustibles & 40 & 0.014 & 0.087 & 0.18 \\
Mecals/glass & 40 & 0.40 & 0.33 & 0.44 \\
Sludges & 20 & 0.11 & 0.01 & 0.22 \\
\hline
\end{tabular}


Performance Assessment assumed that the porosities of each component were uniformly distributed among the minimum, median, and maximum values given above. Cunsequently the distribution of local porosity (1.e., the effective porosity of a collapsod barrel) was the weighted sum of uniform distributions.

It is easily verified that the expected value $(E(\phi))$ of the resulting probability density function is

$$
E(\phi)=\mu_{\text {por }}=\int \phi \mathrm{f}(\eta) \mathrm{d} \eta-0.19
$$

and the variance $(V(\phi))$ is

$$
\begin{aligned}
& \mathrm{V}(\phi)=\sigma_{\text {por }}{ }^{2}=\int \phi^{2} \mathrm{f}(\eta) \mathrm{d} \eta=\mathrm{E}\left[(\phi-\mu)^{2}\right]=0.029 \\
& (\sigma=0.17, \sigma / \mu=0.59)
\end{aligned}
$$

Provided the fraction of waste components (combustibles, metal, and sludges) does not vary significantly or is spatially correlated, the central limit theorem guarantees that the probability density function on a repository scale will be normal with a mean of (Tierney, 1990, Memo 6, [Appendix A])

$$
E\left(\phi_{\text {eff }}\right)=\mu=0.19
$$

and a coefficient of variation of

$$
\mathrm{V}\left(\phi_{\text {eff }}\right) 1 / 2 / \mathrm{E}\left(\phi_{\text {eff }}\right)-\sigma /\left(\mathrm{MN} \mu_{\text {por }}\right)-2.0 \times 10^{-2}
$$

where

$M=$ number of replications of the unit (waste barre1) across a room ( 17 )

$N=$ number of replications of the unit vertically (3).

Because the coefficient of variation is so small, the PA Division did not sample on waste porosity. This conclusion may change as information on the variability (variance) of the volume fraction of waste components in the repository and any spatial correlation become available. The variance of the volume fraction of waste components will. add directly (not reduced by the central limit theorem) to the waste unit variance (expressed above in Eq. III8 as a coefficient of variatirn).

\section{SOLUBILITY}

The extreme range in solubility $\left(C^{\circ}\right)$ listed in Table III-1, $2 \times 10^{-10}$ to $2 \times 10^{-4} \mathrm{~kg} / \mathrm{kg}\left(1 \times 10^{-9}\right.$ to $1 \times 10^{-3}$ molar $)$ conservatively bounds the solubility of radionuclides that may occur within subregions of the barrels (Lappin et al., 1989, p. 4-29). The uncertainty in effective solubility 
results in part from the sparseness of data on radionuclide solubilities in the highly concentrated brines (about 6 molar) which may be present within the WIPP in the event of human intrusion (Brush, 1990). There is also potentially broad local variability in $\mathrm{Eh}$ and $\mathrm{pH}$ within the waste-emplacement rooms, especially for unmodified wastes, because of locally variable radionuclide concentrations and concentrations of organic matter. Therefore, for unmodified wastes, there may be a broad range of local solubilities within the repository, even at steady state. This variability is expected to occur over distances of centimeters (Brush, 1990). However, local variation does not translate into a lumped parameter variation unless there is specified correlation or wide variation in expected volumes of total metal/glass, combustibles, and sludges, because of the central limit theorem.

The currently estimated range in effective radionuclide solubilities is intended to include effects of possible colloid formation within the repository. The present conservative assumption is that colloidal materials would be completely transportable, i.e., that they would not be sorbed or precipitated within the repository.

At present, WIPP experts (Brush and Lappin, 1990, Memo 4 [Appendix A]) have conservatively chosen to use the "microscopic" range for the "macioscopic" lumped parameter. As in the past, the PA Division has sampled using a logun form distribution within this six order of magnitude range, which ensures that each order of magnitude of radionuclide solubility is equally represented in the simulations (Figure III-7). Furthermore, the same solubility was assigned to each radionuclide (i.e., the solubility of each radionuclide was assumed to be perfectly correlated). This assignment accentuated the effects at the extremes of solubility and elevated the importance of solubility on sensitivity results (see Helton, 1990). 


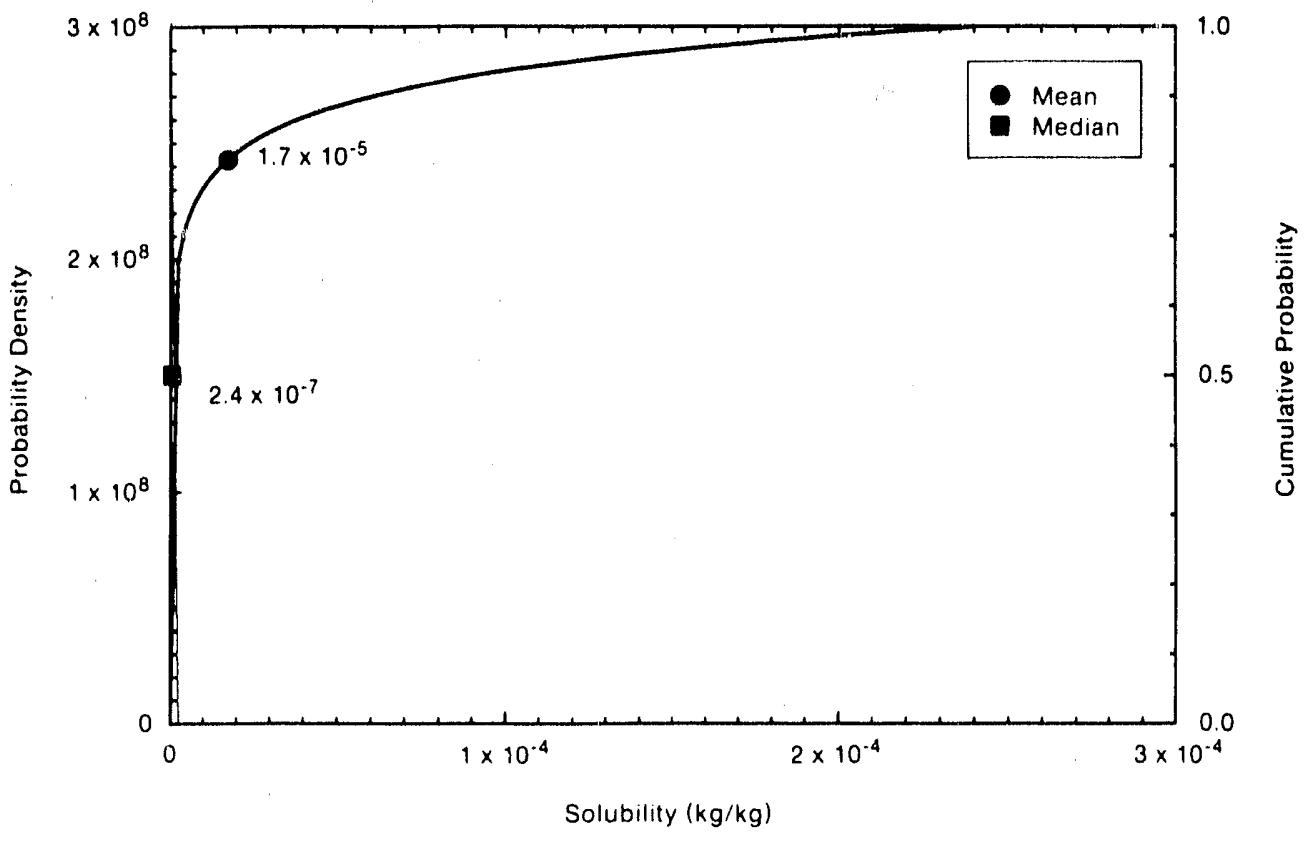

Figure III-7. Loguniform cdf for Salado Solubility. 


\section{Parameter Values for Modified Waste Form}

Preliminary calculations suggest compliance with 40 CFR 191, Subpart B can be achieved for the repository as currently designed (Bertram-Howery et a1., 1990; Marietta et al., 1991; Bertram-Howery and Swift, 1990). However, potential modifications to the present design of the repository and waste are being explored. In the current PA calculations, waste modification is simulated using modified values for waste permeability, porosity, and shear strength (Table III-4). These values correspond to hypothetical properties of combustible and metallic waste that has been shredded, mixed with crushed salt to reduce void space, and repackaged in new containers. All other parameters for the modified waste remaine identical to those of the unmodified waste (Table III-1).

TABLE III-4. PARAMETER VALUES FOR SALT-PACKED WASTE WITH SHREDDED METAL

\begin{tabular}{|c|c|c|c|c|c|c|}
\hline Parameter & Median & \multicolumn{2}{|c|}{ Range } & \multicolumn{2}{|r|}{$\begin{array}{c}\text { Distribution } \\
\text { Type }\end{array}$} & Source \\
\hline \multicolumn{7}{|l|}{ Drilling Erosion Parameters } \\
\hline Shear strength ( $\tau_{\text {fail }}$ ) & 5 & & & $\mathrm{~Pa}$ & Constant & Sargunam et al., 1973 \\
\hline Permeability(k) & $2.4 \times 10^{-17}$ & & & $m^{2}$ & Constant & Seo text \\
\hline Porosity $(\phi)$ & $8.5 \times 10^{-2}$ & & & none & Constant & See text; Butcher, 1990a \\
\hline \multicolumn{7}{|l|}{ Solubility $\left(\mathrm{C}^{\circ}\right)$} \\
\hline $\mathrm{Am}, \mathrm{Np}, \mathrm{Pb}, \mathrm{Pu}$ & & & & & & \\
\hline$R a, T h, U$ & $2.4 \times 10^{-7}$ & $2.4 \times 10^{-10}$ & $2.4 \times 10^{-4}$ & $\mathrm{~kg} / \mathrm{kg}$ & Logunlform & Lappin ot al, 1989, p. 4-29 \\
\hline
\end{tabular}

\section{PERMEABILITY AND POROSITY}

The permeability and porosity of the overall modified waste were calculated using the central limit theorem on the estimated distribution of permeability on a local scale (scale of a barrel). The hypothetical distributions used on the local scale are tabulated in Table III-5 as follows: 
TABLE III-5. ESTIMATED PERMEABILITY AND POROSITY DISTRIBUTIONS

\begin{tabular}{ccc}
\hline Permeability & Porosity & Probability \\
\hline $10^{-16}$ & 0.12 & 1.0 \\
$10^{-19}$ & 0.08 & 0.5 \\
$10^{-21}$ & 0.06 & 0.0 \\
\hline
\end{tabular}

It is easily verified that the expected permeability ( $\mu_{\text {perm }}$ ) and porosity ( $\mu_{\text {por }}$ ) of the resulting probability density function on the scale of a barrel $\left(0.27 \mathrm{~m}^{3}\right.$ or $\left.9.4 \mathrm{ft}^{3}\right)$ are

$$
\begin{aligned}
& \mu_{\text {perm }}=\int k f(\eta) \mathrm{d} \eta=2.4 \times 10.17 \mathrm{~m}^{2} \\
& \mu_{\text {por }}=0.085
\end{aligned}
$$

and the coefficients of variation $(\sigma / \mu)$ are

$$
\begin{aligned}
& (\sigma / \mu)_{\text {perm }}=1.29 \\
& (\sigma / \mu)_{\text {por }}=0.20
\end{aligned}
$$

Provided the fraction of waste components (combustibles, metal, and sludges) does not vary significantly or is spatially correlated, the central limit theorem guarantees that the probability density function on a repository scale will be normal. Consequently, porosity has a mean of (Tierney, 1990, Memo 6 [Appendix A])

$$
E\left(\phi_{\text {eff }}\right)=\mu_{\text {por }}=0.085
$$

and a coefficient of variation of

$$
V\left(\phi_{\text {eff }}\right)^{1 / 2 / E}\left(\psi_{\in} \in f\right)=\sigma_{\text {por }} /\left(\operatorname{MN} \mu_{\text {por }}\right)=2.5 \times 10-2
$$

where

$$
\begin{aligned}
& M=\text { number of replications of the unit (waste barrel) across a room }(-17) \\
& N=\text { number of replications of the unit vertically (3). }
\end{aligned}
$$

For permeability, the mean is (Tierney, 1990, Memo 6 [Appendix A])

$$
\mathrm{E}\left(\mathrm{k}_{\mathrm{eff}}\right) \simeq \mu_{\mathrm{por}}\left(1+\alpha^{2} / \mathrm{L}\right) /\left(1+\alpha^{2}\right)=2.4 \times 10^{-17} \mathrm{~m}^{2}
$$


and the coefficient of variation is

$$
\mathrm{V}\left(\mathrm{k}_{\mathrm{eff}}\right)^{1 / 2} / \mathrm{E}\left(\mathrm{k}_{\mathrm{eff}}\right) \approx \beta^{2}\left(1+\alpha^{2}\right) /\left[\mu_{\mathrm{por}}\left(1+\alpha^{2}\right)\left(1+4 \alpha^{2}\right)\right]=1.2 \times 10^{-2}
$$

where

$$
\begin{aligned}
& \alpha^{2}=(\sigma / \mu)^{2} / \mathrm{MN} \\
& \beta^{2}=\sigma^{2} / \mathrm{MN} \\
& M=\text { number of replications of the unit (waste barrel) across a room }(\sim 17) \\
& \mathbb{N}=\text { number of replications of the unit vertically }(3) \\
& \mathrm{L}=\text { number of replications of the unit down the length of the room }(-150) .
\end{aligned}
$$

Because the coefficient of variation is so small, the PA Division did not sample on either waste permeability or porosity. This conclusion may change as information on the variability (variance) of the volume fraction of waste components in the repository and any spatial correlation become available.

\section{DRILLING EROSION PARAMETERS}

\section{Waste Shear Strength}

The PA Division assumed a shear strength ( $\tau_{\text {fail }}$ ) for the modified waste of 5 $\mathrm{Pa}$ (49 atm), a value at the upper end of the range for montmorillonite clay (Sargunam et al., 1973).

\section{SOLUBILITY AND LEACHABILITY}

The solubility and leachability of the radionuclides will likely change; however, quantifying this change is difficult and has not yet been attempted for the PA calculations. Consequently, as with the unmodified, reference waste, the overall solubility ranges are the same as the extreme local scale (subregions within the barrel) solubility; the leach rate from the contaminated material is assumed infinite. 


\section{Parameter Values for Radionuclides}

Current analyses have used projected inventories in the calculations for contact-handled $(\mathrm{CH})$ and remotely handled (RH) TRU waste. The projected inventories can vary from year to year based on input to the Integrated Data Base. To avoid these fluctuations, future work may shift to using the design inventory. (The design inventory assumes that the repository is filled to maximum capacity.)

Table III- 6 provides the parameters for TRU radionuclides.

\section{RADIONUCLIDE HALF-LIFE}

The half-lives for each radionuclide listed was the value as reported in the literature by ICRP Publication 38 (ICRP, Pub 38, 1983).

\section{INVENTORY FOR CONTACT-HANDLED WASTE}

The projected inventory of radionuclides in waste that can be safely handled if confined in sealed containers (i.e., contact-handled [ $\mathrm{CH}]$ ) is the same as reported in Lappin et al. (1989). The projected total curie content is about $9.2 \times 10^{6} \mathrm{Ci}\left(2.5 \times 10^{-4} \mathrm{~Bq}\right.$ ) (of which $5.08 \times 10^{6} \mathrm{Ci}\left[1.38 \times 10^{-4} \mathrm{~Bq}\right]$ is regulated). This inventory was based on input to the 1987 Integrated Data Base (IDB) (IDB, 1987). The input to the IDB does not contain the inventory of each radionuclide. Rather, the inventory of each radionuclide was calculated based on knowledge about the $\mathrm{mix}$ of waste streams that was reported. The projected total curies in the 1990 IDB (IDB, 1990) has decreased by about 208 from the 1987 IDB values currently used in PA calculations. The projected total volume has decreased by about 308 .

This initial inventory is used for source-term calculations in the PANEL module of CAMCON (Rechard et al., 1991) (i.e., PANEL). In this module, PANEL calculates all daughters from this initial inventory (the complete chains). However, abbreviated chains derived by eliminating all radionuclides with half-1ives less than a few hours and Th-234, which has low radiologic toxicity, are shown below for reader reference. 
TABLE III-6. INVENTORY AND PARAMETER VALUES FOR TRU RADIONUCLIDES

\begin{tabular}{|c|c|c|c|}
\hline Parameter & Value & Units & Source \\
\hline \multicolumn{4}{|l|}{ Am241 } \\
\hline $\begin{array}{l}\text { Half-life }\left(t_{1} / 2\right) \\
\text { Inventory, projected }\end{array}$ & $1.364 \times 10^{10}$ & s & ICRP, Pub 38, 1983 \\
\hline Contact Handled $(\mathrm{CH})$ & $6.3 \times 10^{5}$ & $\mathrm{Cl}$ & $\begin{array}{l}\text { IDB, 1987; DOE/WIPP 88-005; Lappin et al., 1989, } \\
\text { Table 4-2a }\end{array}$ \\
\hline Remote Handled (RH) & $1.3 \times 10^{3}$ & $\mathrm{Cl}$ & $\begin{array}{l}\text { IDB, 1990; Peterson, 1990, Memo } 7 \text { (see Appendix } \\
\text { A) }\end{array}$ \\
\hline \multicolumn{4}{|r|}{ P } \\
\hline $\begin{array}{l}\text { Half-life }\left(t_{1} / 2\right) \\
\text { Inventory, projected }\end{array}$ & $8.325 \times 10^{8}$ & 8 & ICRP, Pub 38, 1983 \\
\hline Contact Handled $(\mathrm{CH})$ & $2.0 \times 10^{3}$ & $\mathrm{Cl}$ & $\begin{array}{l}\text { IDB, 1987; DOE/WIPP 88-005; Lappin ot al., 1989, } \\
\text { Table 4-2a }\end{array}$ \\
\hline Remote Handled (RH) & $2.4 \times 10^{3}$ & $\mathrm{Ci}$ & $\begin{array}{l}\text { IDB, 1990; Peterson, 1990, Memo } 7 \text { (see Appendix } \\
\text { A) }\end{array}$ \\
\hline \multicolumn{4}{|r|}{ r } \\
\hline $\begin{array}{l}\text { Half-life }\left(t_{1} / 2\right) \\
\text { Inventory, projected }\end{array}$ & $5.715 \times 10^{8}$ & $\mathbf{s}$ & ICRP, Pub 38, 1983 \\
\hline Contact Handled $(\mathrm{CH})$ & $1.3 \times 10^{4}$ & $\mathrm{Cl}$ & $\begin{array}{l}\text { IDB, 1987; DOE/WIPP 88-005; Lappin et al.,1989, } \\
\text { Table 4-2a }\end{array}$ \\
\hline Remote Handled (RH) & $8.8 \times 10^{3}$ & $\mathrm{Cl}$ & $\begin{array}{l}\text { IDB, 1990; Peterson, 1990, Memo } 7 \text { (see Appendix } \\
\text { A) }\end{array}$ \\
\hline \multicolumn{4}{|l|}{ Cs 137} \\
\hline \multicolumn{4}{|l|}{ inventory, projected } \\
\hline Remote Handled (RH) & $3.3 \times 10^{5}$ & $\mathrm{Cl}$ & $\begin{array}{l}\text { IDB, 1990; Peterson, 1990, Memo } 7 \text { (see Appendix } \\
\text { A) }\end{array}$ \\
\hline \multicolumn{4}{|r|}{ 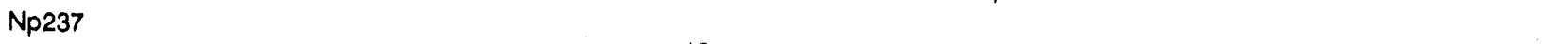 } \\
\hline $\begin{array}{l}\text { Half-life }\left(t_{1} / 2\right) \\
\text { Inventory, projected }\end{array}$ & \multicolumn{3}{|c|}{ Inventory, projected } \\
\hline Contact Handled $(\mathrm{CH})$ & 8.0 & $\mathrm{Cl}$ & $\begin{array}{l}\text { IDB, 1987; DOE/WIPP 88-005; Lappin et al.,1989, } \\
\text { Table 4-2a }\end{array}$ \\
\hline Remote Handled (RH) & $7.0 \times 10^{-1}$ & $\mathrm{Cl}$ & $\begin{array}{l}\text { IDB, 1990; Peterson, 1990, Memo } 7 \text { (see Appendix } \\
\text { A) }\end{array}$ \\
\hline \multicolumn{4}{|l|}{$\mathrm{Pb} 210$} \\
\hline $\begin{array}{l}\text { Half-life }\left(t_{1 / 2}\right) \\
\text { Pm147 }\end{array}$ & $7.037 \times 10^{8}$ & $\mathbf{s}$ & ICRP, Pub 38, 1983 \\
\hline $\begin{array}{l}\text { Half-life }\left(t_{1} / 2\right) \\
\text { Inventory, projected }\end{array}$ & $8.279 \times 10^{7}$ & s & ICRP, Pub 38, 1983 \\
\hline Remote Handled (RH) & $3.2 \times 10^{5}$ & $\mathrm{Cl}$ & $\begin{array}{l}\text { IDB, 1990; Peterson, 1990, Memo } 7 \text { (seo Appendix } \\
\text { A) }\end{array}$ \\
\hline \multicolumn{4}{|r|}{ r } \\
\hline $\begin{array}{l}\text { Half-life }\left(t_{1} / 2\right) \\
\text { Inventory, projected }\end{array}$ & $2.769 \times 10^{9}$ & s & ICRP, Pub 38, 1983 \\
\hline Contact Handled $(\mathrm{CH})$ & $3.9 \times 10^{6}$ & $\mathrm{Cl}$ & $\begin{array}{l}\text { IDB, 1987; DOE/WIPP 88-005; Lappin et al., 1989, } \\
\text { Table 4-2a }\end{array}$ \\
\hline Remote Handled (RH) & $5.1 \times 10^{2}$ & $\mathrm{Cl}$ & $\begin{array}{l}\text { IDB, 1990; Peterson, 1990, Memo } 7 \text { (see Appendix } \\
\text { A) }\end{array}$ \\
\hline
\end{tabular}


TABLE III-6. INVENTORY AND PARAMETER VALUES FOR TRU RADIONUCLIDES (CONTINUED)

\begin{tabular}{|c|c|c|c|}
\hline Parameter & Value & Units & Source \\
\hline \multicolumn{4}{|l|}{ Pu239 } \\
\hline Half-life $\left(t_{1} / 2\right)$ & $7.594 \times 10^{11}$ & $\mathbf{s}$ & ICRP, Pub 38, 1983 \\
\hline \multicolumn{4}{|l|}{ Inventory, projected } \\
\hline Contract Handled $(\mathrm{CH})$ & $4.2 \times 10^{5}$ & $\mathrm{Cl}$ & $\begin{array}{l}\text { IDB, 1987; DOE/WIPP 88-005; Lappin et al., } 1989 \\
\text { Table 4-2a }\end{array}$ \\
\hline Remote Handled (RH) & $1.4 \times 10^{3}$ & $\mathrm{Ci}$ & $\begin{array}{l}\text { IDB, 1990; Peterson, 1990, Memo } 7 \text { (see Appendlx } \\
\text { A) }\end{array}$ \\
\hline \multicolumn{4}{|r|}{ r } \\
\hline Half-life $\left(t_{1} / 2\right)$ & $2.063 \times 10^{11}$ & s & ICRP, Pub 38, 1983 \\
\hline \multicolumn{4}{|l|}{ Inventory, projected } \\
\hline Contact Handled $(\mathrm{CH})$ & $1.0 \times 10^{5}$ & $\mathrm{Ci}$ & $\begin{array}{l}\text { IDB, 1987; DOE/WIPP 88-005; Lappin et al.,1989, } \\
\text { Table 4-2a }\end{array}$ \\
\hline Remote Handled (RH) & $2.9 \times 10^{2}$ & $\mathrm{Ci}$ & $\begin{array}{l}\text { IDB, 1990; Peterson, 1990, Memo } 7 \text { (see Appendix } \\
\text { A) }\end{array}$ \\
\hline \multicolumn{4}{|r|}{ N } \\
\hline $\begin{array}{l}\text { Half-life }\left(t_{1} / 2\right) \\
\text { Inventory, projected }\end{array}$ & $4.544 \times 10^{8}$ & \multicolumn{2}{|c|}{ Inventory, projected } \\
\hline Contact Handled (CH) & $4.1 \times 10^{6}$ & $\mathrm{Cl}$ & $\begin{array}{l}\text { IDB, 1987; DOE/WIPP 88-005; Lappin et al., 1989; } \\
\text { Table 4-2a }\end{array}$ \\
\hline Remote Handled (RH) & $1.3 \times 10^{4}$ & $\mathrm{Ci}$ & $\begin{array}{l}\text { IDB, 1990; Peterson, 1990, Memo } 7 \text { (see Appendix } \\
\text { A) }\end{array}$ \\
\hline \multicolumn{4}{|r|}{ N } \\
\hline \multicolumn{3}{|l|}{ Inventory, projected } & ICRP, Pub 38, 1983 \\
\hline Contact Handled $(\mathrm{CH})$ & $1.8 \times 10^{1}$ & $\mathrm{Cl}$ & $\begin{array}{l}\text { IDB, 1987; DOE/WIPP 88-005; Lappin et al.,1989, } \\
\text { Table 4-2a }\end{array}$ \\
\hline Remote Handled $(\mathrm{RH})$ & $3.3 \times 10^{-3}$ & $\mathrm{Cl}$ & $\begin{array}{l}\text { IDB, 1990; Peterson, 1990, Memo } 7 \text { (see Appendix } \\
\text { A) }\end{array}$ \\
\hline \multicolumn{4}{|r|}{ S } \\
\hline Half-life $\left(t_{1} / 2\right)$ & $5.049 \times 10^{10}$ & s & ICRP, Pub 38, 1983 \\
\hline \multicolumn{4}{|l|}{ Sr90 } \\
\hline \multicolumn{3}{|l|}{ Inventory, projected } & ICRP, Pub 38, 1983 \\
\hline Remote Handlet $(\mathrm{RH})$ & $2.8 \times 10^{5}$ & $\mathrm{Cl}$ & $\begin{array}{l}\text { IDB, 1990; Peterson, 1990, Memo } 7 \text { (see Appendix } \\
\text { A) }\end{array}$ \\
\hline \multicolumn{4}{|r|}{ n) } \\
\hline Half-life $\left(t_{1 / 2}\right)$ & $2.316 \times 10^{11}$ & s & ICRP, Pub 38, 1983 \\
\hline \multicolumn{4}{|l|}{ Th230 } \\
\hline Half-life $\left(t_{1} / 2\right)$ & $2.430 \times 10^{12}$ & $\mathbf{s}$ & ICRP, Pub 38, 1983 \\
\hline \multicolumn{4}{|l|}{ Th232 } \\
\hline Half-life $\left(t_{1} / 2\right)$ & $4.434 \times 10^{17}$ & s & ICRP, Pub 38, 1983 \\
\hline \multicolumn{4}{|l|}{ Inventory, projected } \\
\hline Contact Handled $(\mathrm{CH})$ & $2.7 \times 10^{-1}$ & $\mathrm{Cl}$ & $\begin{array}{l}\text { IDB,1987; DOE/WIPP 88-005; Lappin et al.,1989, } \\
\text { Table 4-2a }\end{array}$ \\
\hline Remote Handled (RH) & $2.3 \times 10^{-3}$ & $\mathrm{Cl}$ & $\begin{array}{l}\text { IDB, 1990; Peterson, 1990, Memo } 7 \text { (see Appendix } \\
\text { A) }\end{array}$ \\
\hline
\end{tabular}


TABLE III-6. INVENTORY AND PARAMETER VALUES FOR TRU RADIONUCLIDES (CONCLUDED)

\begin{tabular}{|c|c|c|c|}
\hline Parameter & Value & Units & Source \\
\hline \multicolumn{4}{|l|}{ U233 } \\
\hline $\begin{array}{l}\text { Half-life }\left(t_{1} / 2\right) \\
\text { Inventory, projected }\end{array}$ & $5.002 \times 10^{12}$ & $s$ & ICRP, Pub 38, 1983 \\
\hline Contact Handled $(\mathrm{CH})$ & $7.7 \times 10^{3}$ & $\mathrm{Cl}$ & $\begin{array}{l}\text { IDB, 1987; DOE/WIPF' 88-005; Lappin et al.,1989, } \\
\text { Table 4-2a }\end{array}$ \\
\hline Remote Handled (RH) & $2.8 \times 10^{1}$ & $\mathrm{Cl}$ & $\begin{array}{l}\text { IDB, 1990; Peterson, 1990, Memo } 7 \text { (see Appendix } \\
\text { A) }\end{array}$ \\
\hline \multicolumn{4}{|r|}{ N } \\
\hline Half-life $\left(t_{1 / 2}\right)$ & $7.7157 \times 10^{12}$ & s & ICRP, Pub 38, 1983 \\
\hline \multicolumn{4}{|l|}{ U235 } \\
\hline $\begin{array}{l}\text { Half-life }\left(t_{1} / 2\right) \\
\text { Inventory, projected }\end{array}$ & $2.221 \times 10^{16}$ & s & ICRP, Pub 38, 1983 \\
\hline Contact Handled $(\mathrm{CH})$ & $3.7 \times 10^{-1}$ & $\mathrm{Cl}$ & $\begin{array}{l}\text { IDB, 1987; DOE/WIPP 88-005; Lappin et al., 1989, } \\
\text { Table 4-2a }\end{array}$ \\
\hline Remote Handled (RH) & $1.2 \times 10^{-2}$ & $\mathrm{Cl}$ & $\begin{array}{l}\text { IDB, 1990; Peterson, 1990, Memo } 7 \text { (see Appendix } \\
\text { A) }\end{array}$ \\
\hline \multicolumn{4}{|r|}{ i } \\
\hline $\begin{array}{l}\text { Half-llfe }\left(t_{1} / 2\right) \\
\text { Inventory, projected }\end{array}$ & $1.41 \times 10^{17}$ & s & ICRP, Pub 38, 1983 \\
\hline Contact Handled (CH) & 1.5 & $\mathrm{Cl}$ & $\begin{array}{l}\text { IDB, 1987; DOE/WIPP 88-005; Lappin et al, 1989, } \\
\text { Table 4-2a }\end{array}$ \\
\hline Remote Handled (RH) & $7.8 \times 10^{-2}$ & $\mathrm{Cl}$ & $\begin{array}{l}\text { IDB, 1990; Peterson, 1990, Meno } 7 \text { (see Appendix } \\
\text { A) }\end{array}$ \\
\hline
\end{tabular}

(1)

$$
244 \mathrm{Cm} \rightarrow 240 \mathrm{Pu} \rightarrow 236 \mathrm{U} \rightarrow 232 \mathrm{Th}+228 \mathrm{Ra}
$$

$\uparrow$

$$
252 \mathrm{Cf} \rightarrow 248 \mathrm{Cm} \rightarrow 244 \mathrm{Pu}
$$

(2) $241 \mathrm{Pu} \rightarrow 241_{\mathrm{Am}} \rightarrow 237_{\mathrm{Np}} \rightarrow 233_{\mathrm{U}} \rightarrow 229 \mathrm{Th}$

(3) $242 \mathrm{Pu} \rightarrow 238 \mathrm{U}+234 \mathrm{U}+230_{\mathrm{Th}} \rightarrow 226_{\mathrm{Ra}}+210_{\mathrm{Pb}}$

$\uparrow$

$$
238 \mathrm{Pu}
$$

(4) $239 \mathrm{Pu} \rightarrow 235 \mathrm{U} \rightarrow 231 \mathrm{~Pa}$ 
For PA transport calculations, the four decay chains were reduced and simplified by eliminating those short-lived radionuclides in the inventory that decay into long-lived daughters. (Although all radionuclides in the chains were output by the panel module, only those radionuclides needed for the transport calculations were transferred to the transport code. These simplified chains are shown below:

$$
\begin{aligned}
& \text { (1) } 240 \mathrm{Pu} \rightarrow 236 \mathrm{U} \\
& \text { (2) } 241 \mathrm{Am} \rightarrow 237 \mathrm{~Np} \rightarrow 233 \mathrm{U} \rightarrow 229 \mathrm{Th} \\
& \text { (3) } 238 \mathrm{Pu} \rightarrow 234 \mathrm{U} \rightarrow 230 \mathrm{Th} \rightarrow 226 \mathrm{Ra}+210 \mathrm{~Pb} \\
& \text { (4) } 239 \mathrm{Pu}
\end{aligned}
$$

\section{INVENTORY FOR REMOTELY HANDLED WASTE}

The inventory of TRU waste that must be transported and handled in shielded casks (remotely handled waste $[\mathrm{RH}]$ ) is being determined. The preliminary estimates reported in Table III- 6 are based on input to the 1990 Integrated Data Base (IDB, 1990) yet to be issued. The current total curie content is about $1.3 \times 10^{6} \mathrm{Ci}\left(3.5 \times 10^{-5} \mathrm{~Bq}\right)$ but will likely increase. Similar to the $\mathrm{CH}$ waste inventory, the IDB does not contain the inventory of each radionuclide, but instead is estimated from knowledge about the waste streams and mix of fission products at the generator sites. For example, the activity of the waste canisters coming from Hanford, Washington assume a uniform source that produces an external dose rate of $8.3 \times 10^{-5} \mathrm{~Sv} / \mathrm{s}$ (30 rem/hr). After submitting tha for the 1990 IDB, Oak Ridge National Laboratory increased their estimated RH inventory. The $1989 \mathrm{IDB}$ indicated that the total inventory would be approximately 4,500 canisters $\left(4,005 \mathrm{~m}^{3}\left[141,436 \mathrm{ft}^{3}\right]\right)$. This increase is included in Table III-6. More details of the TRU waste inventory will be documented in a future report authored by $H$. Batchelder of Westinghouse Electric Company, Carlsbad, NM.

In general, the 1990 data indicates an inventory of about 7,600 canisters $\left(6,765 \mathrm{~m}^{3}\left[238,906 \mathrm{ft}^{3}\right]\right)$. This number of canisters approaches the capacity of $7,080 \mathrm{~m}^{3}\left(250,000 \mathrm{ft}^{3}\right)$ for placing $\mathrm{RH}$ TRU waste in the WIPP using the current placement technique in which one canister is empiaced horizontally every $2.4 \mathrm{~m}$ ( $8 \mathrm{ft}$ ) into the drift and room walls. The source of this additional waste is metaliic components removed from the Hanford double shell tanks. 


\section{GLOBAL MATERIALS AND MISCELLANEOUS}

This chapter contains parameters for fluid properties, climate variability, and intrusion characteristics.

\section{Fluid Properties}

The fluid parameters tabulated in Table IV-1 include Salado and Culebra brine, drilling mud, and hydrogen gas.

TABLE IV-1. FLUID PROPERTIES

\begin{tabular}{|c|c|c|c|c|c|c|}
\hline Parameter & Median & \multicolumn{2}{|c|}{ Range } & \multicolumn{2}{|r|}{$\begin{array}{l}\text { Distribution } \\
\text { Type }\end{array}$} & \multirow[t]{2}{*}{ Source } \\
\hline Brine, Salado & & & & & & \\
\hline Density $\left(\rho_{\uparrow}\right)$ & $1.20 \times 10^{3}$ & & & $m^{2}$ & Constant & Stein and Krumhansl, 1986 \\
\hline Formation volume factor & & 1.0059 & 1.0043 & none & Table & $\begin{array}{l}\text { HP, 1984; Numbere ot al.,1977, p.16; } \\
\text { Craft and Hawkins, 1959, p.131 }\end{array}$ \\
\hline Viscosity $(\mu)$ & $1.60 \times 10^{-3}$ & & & $\mathrm{~Pa} \cdot \mathrm{s}$ & Constant & Kaufman, 1960, p. 622 \\
\hline \multicolumn{7}{|l|}{ Brine, Culebra } \\
\hline Viscosity $(\mu)$ & $1 \times 10^{-3}$ & & & $\mathrm{~Pa} \cdot \mathrm{s}$ & Constant & Haug ot al., 1987, p.3-20 \\
\hline \multicolumn{7}{|l|}{ Hydrogen } \\
\hline Formation volume factor & & $2.50 \times 10^{-3}$ & 1 & none & Table & See text (hydrogen gas). \\
\hline Viscosity $(\mu)$ & $9.32 \times 10^{-6}$ & $8.84 \times 10^{-6}$ & $9.80 \times 10^{-6}$ & $\mathrm{~Pa} \cdot \mathrm{s}$ & Density & $\begin{array}{l}\text { Buddenberg and Wilke, 1949; Streeter } \\
\text { and Wylle, 1975, Figure C-1 }\end{array}$ \\
\hline \multicolumn{7}{|l|}{ Drilling Mud Properties } \\
\hline Viscosity (0 shear vel.) & $2.1999 \times 10^{-2}$ & $1 \times 10^{-2}$ & $6 \times 10^{-2}$ & $\mathrm{~Pa} \cdot \mathrm{s}$ & Bota & $\begin{array}{l}\text { Pace, 1990, Letter 10 (see } \\
\text { Appendix A) }\end{array}$ \\
\hline Oldroyd viscosity param. & $1.6510 \times 10^{-6}$ & $2.89 \times 10^{-7}$ & $2.0810 \times 10^{-6}$ & none & Beta & $\begin{array}{l}\text { Fredrickson, 1960, p.252; Savins ot al., } \\
\text { 1966; Pace, 1990, Letter 1b (see } \\
\text { Appendix A) }\end{array}$ \\
\hline Density, mud $\left(\rho_{f}\right)$ & 1211 & 1139 & 1378 & $\mathrm{~kg} / \mathrm{m}^{3}$ & Beta & $\begin{array}{l}\text { Pace, 1990, Letter 1b (see } \\
\text { Appendix A) }\end{array}$ \\
\hline
\end{tabular}

\section{SALADO BRINE}

\section{Density}

The density in the Salado Formation at the repository level was reported by Stein and Krumhans 1 (1986) as $1,200 \mathrm{~kg} / \mathrm{m}^{3}\left(75 \mathrm{lb} / \mathrm{ft}^{3}\right)$. 


\section{Salado Brine Formation Volume Factor}

Figure IV-1 shows the formation volume factor for Salado brine. The formation volume factor of Salado brine at various pressures was evaluated from the following empirical correlations used in the petroleum industry (HP, 1984). The formation volume factor is defined as the ratio of the brine volume at brine pocket conditions to the volume at reference conditions $(303.15 \mathrm{~K}$ $\left.\left[30^{\circ} \mathrm{C}\right], 101.325 \mathrm{kPa}[1 \mathrm{~atm}]\right)$.

Empirical Correlations

$$
\mathrm{BW}\left(\mathrm{H}_{2} \mathrm{O}\right)=\mathrm{a}+\mathrm{bp}+\mathrm{cp} \mathrm{p}^{2}
$$

Gas-Free Water:

$$
\begin{aligned}
& a=0.9947+5.8\left(10^{-6}\right) \overline{\mathrm{T}}+1.02(10-6) \overline{\mathrm{T}}^{2} \\
& \mathrm{~b}=4.228\left(10^{-6}\right)+1.8376\left(10^{-8}\right) \overline{\mathrm{T}}-6.77\left(10^{-11}\right) \overline{\mathrm{T}}^{2} \\
& \mathrm{c}=1.3\left(10^{-10}\right)-1.3855(10-12) \overline{\mathrm{T}}+4.285(10-15) \overline{\mathrm{T}}^{2}
\end{aligned}
$$

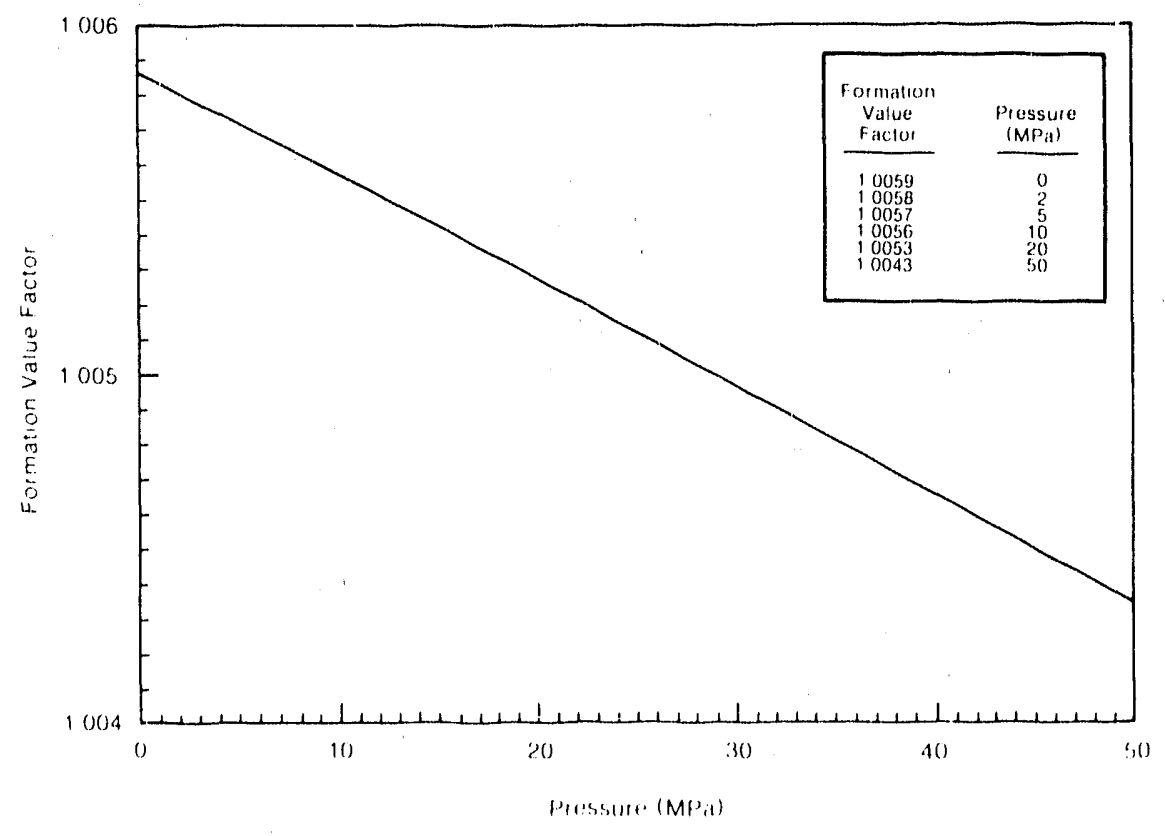

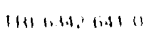

Figure IV-1. Formation Volume Fáctor for Salado Brine. 
Gas-Saturated Water:

$a=0.9911+6.35\left(10^{-5}\right) \overline{\mathrm{T}}+8.5\left(10^{-7}\right) \overline{\mathrm{T}}^{2}$

$b=-1.093\left(10^{-6}\right)-3.497(10-9) \bar{T}+4.57(10-12) \bar{T}^{2}$

$c=-5(10-11)+5.429(10-13) \bar{\top}-1.43(10-15) \overline{\mathrm{T}}^{2}$

Salinity Correction:

$$
\begin{aligned}
\mathrm{BW} \text { (brine) } & =\mathrm{BW}\left(\mathrm{H}_{2} \mathrm{O}\right)\left[\left(5.1\left(10^{-8}\right) \mathrm{p}\right.\right. \\
& +\left[5.47\left(10^{-6}\right)-1.95\left(10^{-10}\right) \mathrm{p}\right](\overline{\mathrm{T}}-60) \\
& \left.+\left[-3.23\left(10^{-8}\right)+8.5\left(10^{-13}\right) \mathrm{p}\right](\overline{\mathrm{T}}-60)^{2} ; \% \mathrm{NaCl}+1\right]
\end{aligned}
$$

\section{Range of Validity}

$$
\begin{aligned}
& 100<\overline{\mathrm{T}}<250 \mathrm{~F} \\
& 1000<\mathrm{p}<5000 \text { ps } 1 \\
& 0 \leq 8 \mathrm{NaCl}<25
\end{aligned}
$$

\section{Viscosity}

A literature value for brines at the density in the Salado Formation is $1.6 \times 10^{-3} \mathrm{~Pa} \cdot \mathrm{s}\left(1.1 \times 10^{-3} \mathrm{lb} / \mathrm{s} \cdot \mathrm{ft}\right)$ (Kaufman, 1960, p. 622).

\section{CULEBRA BRINE}

\section{Viscosity}

Similar to other modeling studies of the Culebra Dolomite (LaVenue et al., 1990, 1988; Haug et al., 1987), PA calculations assume that the Culebra Brine viscosity is identical to pure water, $1.0 \times 10^{-3} \mathrm{~Pa} \cdot \mathrm{s}\left(6.7 \times 10^{-4} \mathrm{lb} / \mathrm{s} \cdot \mathrm{ft}\right)$.

\section{HYDROGEN GAS}

\section{Hydrogen Formation Volume Factor}

Figure IV-2 shows the formation volume factor for hydrogen gas. The formation volume factor is the ratio of tine volume at reservoir conditions to the volume at reference conditions $\left(303.15 \mathrm{~K}\left[25^{\circ} \mathrm{C}\right], 101.325 \mathrm{kPa}[1 \mathrm{~atm}]\right)$. The molar 

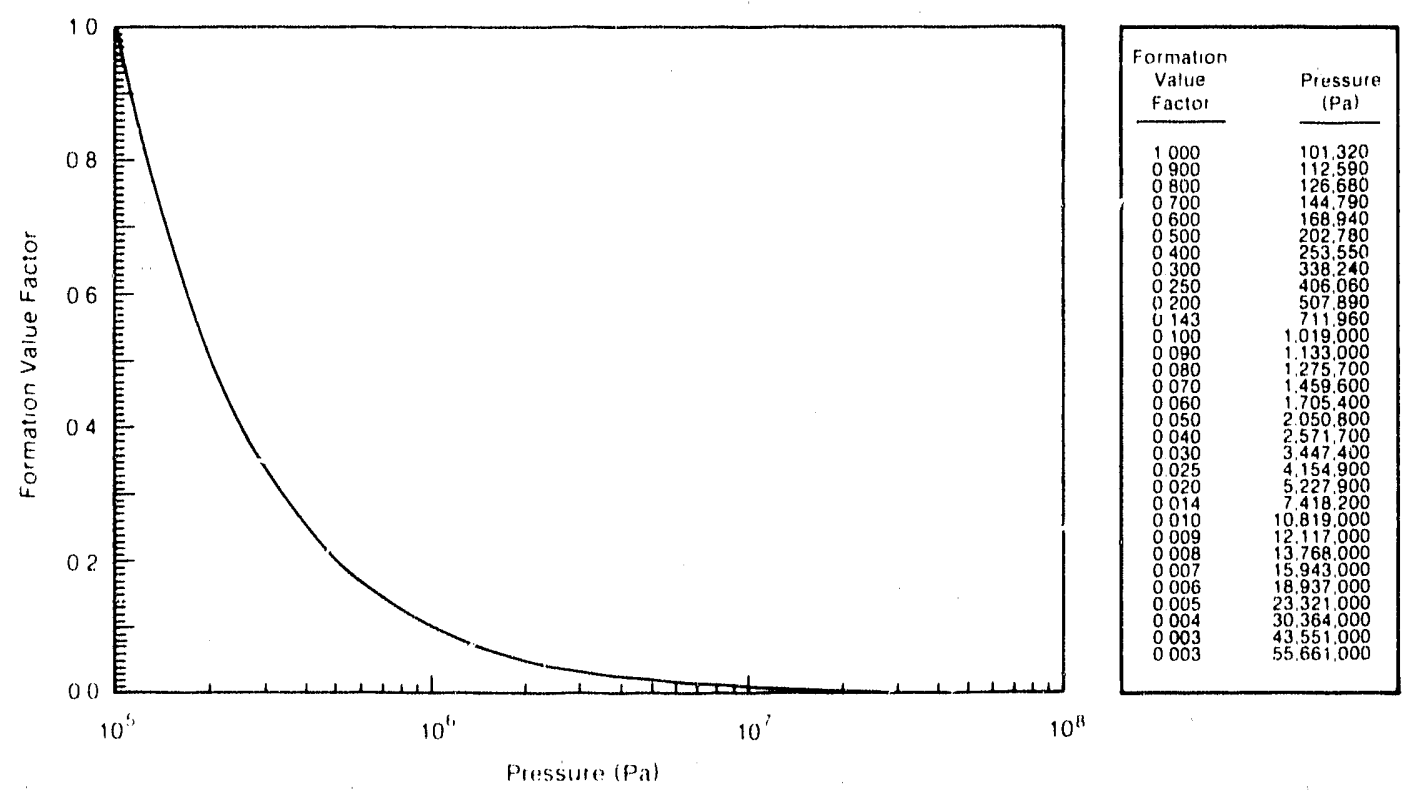

IHI - $334 \div \div 6420$

Figuire IV-2. Formation Volume Factor for Hydrogen Gas.

volume of hydrogen gas is computed using the Redlich-Kwong-Soave equation of state (Walas, 1985):

$$
\mathrm{z}=\frac{\mathrm{pu}}{\mathrm{RT}}=\frac{v}{v-\mathrm{b}} \cdot \frac{\mathrm{a} \alpha}{\overline{\mathrm{R} T}(u+\mathrm{b})}
$$

where

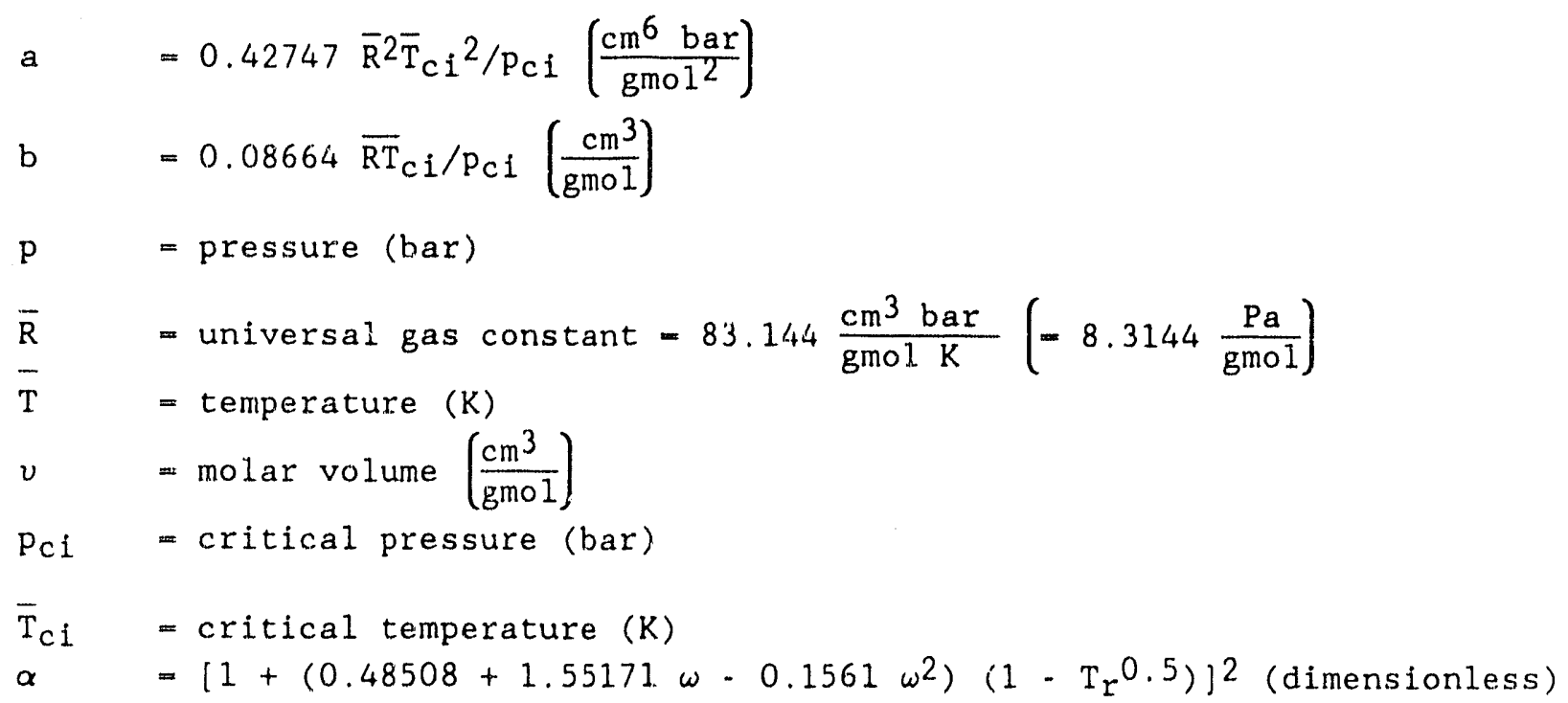




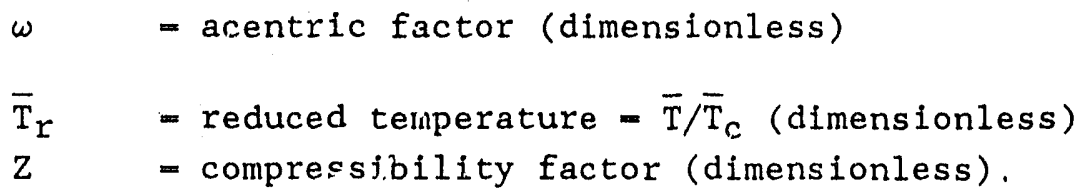

For rydrogen:

$$
\begin{aligned}
\mathrm{T}_{C i} & =\frac{43.6}{1+\frac{21.8}{\mathrm{TM}}}(\mathrm{K}) \\
\mathrm{p}_{C i} & =\frac{20.47}{1+\frac{44.2}{\mathrm{TM}}} \text { (bar) } \\
\mathrm{M} & =\text { molecular weight }=2.01594 \mathrm{~g} / \mathrm{gmol} \\
\alpha & =1.202 \mathrm{exp}(-0.30288 \mathrm{Tr}) \\
\omega & =0.0
\end{aligned}
$$

Note that temperature-dependent effective critical properties are used for hydrogen (Prausnitz, 1969). Hydrogen also requires a special expression for (a) (Graboski and Daubert, 1979), and an acentric factor of zero (Knapp et al., 1982).

Equation IV-9 is solved numerically for molar volume, $v$, at the reference condition and at reservoir conditions to provide the values used to calculate the formation volume factor (Figure IV-2).

\section{Viscosity}

The literature value for the viscosity of hydrogen gas ranges betweel $8.84 \mathrm{x}$ $10^{-6}$ and $9.8 \times 10^{-6} \mathrm{~Pa} \cdot \mathrm{s}\left(5.9 \times 10^{-6}\right.$ and $6.6 \times 10^{-6} \mathrm{lb} / \mathrm{s} \cdot \mathrm{ft}$ ) (Buddenberg and Wilke, 1949; Streeter and Wylie, 1975, Figure C-1). The PA Division uses the average of $9.32 \times 10^{-6} \mathrm{~Pa} \cdot \mathrm{s}\left(6.26 \times 10^{-6} \mathrm{lb} / \mathrm{s} \cdot \mathrm{ft}\right)$.

\section{Drilling Mud Properties}

When drilling through salt in the Delaware Basin, the drilling fluid is most likely to be brine with the original brine density maintained when transporting cuttings by adding an emulsified oil (Pace, 1990, Letter 1b [Appendix A]). The density, viscosity at zero shear rate (assuming a Bingham Plastic fluid), and viscosity parameters for oldroyd type drilling fluid (01droyd, 1958) of $1,200 \mathrm{~kg} / \mathrm{m}^{3}\left(75 \mathrm{lb} / \mathrm{ft}^{3}\right), 0.02 \times 10^{-3} \mathrm{~Pa} \cdot \mathrm{s}(0.01 \mathrm{x}$ $\left.10^{-3} \mathrm{lb} / \mathrm{s} \cdot \mathrm{ft}\right)$, and $1.65 \times 10^{-6}$, respectively, assumed this drilling fluid. 


\section{Climate Variability and Intrusion Characteristics}

Climate variability and human intrusion parameters are characteristics that define the future state of the disposal system. A major uncertainty arises from human intrusion; however, the guidelines in 40 CFR 191, Appendix B provide upper bounds on the severity of the human intrusion. These upper bounds were used to establish the parameters in Table IV-2.

TABLE IV-2. BOREHOLE FLOW, CLIMATE VARIABILITY, AND INTRUSION CHARACTERISTICS

\begin{tabular}{|c|c|c|c|c|c|c|}
\hline Parameter & Median & Range & & Units & $\begin{array}{c}\text { Distribution } \\
\text { Type }\end{array}$ & Source \\
\hline \multicolumn{7}{|l|}{ Borehole Flow Properties } \\
\hline Density, average $\left(\rho_{\text {ave }}\right)$ & $2.30 \times 10^{3}$ & & & $\mathrm{~kg} / \mathrm{m}^{3}$ & Constant & See text (Salado). \\
\hline Density, bulk ( $\rho_{\text {bulk }}$ ) & $2.14 \times 10^{3}$ & & & $\mathrm{~kg} / \mathrm{m}^{3}$ & Constant & Seo text (Salado). \\
\hline Permeability, initial ( $k$ ) & $3.16 \times 10^{-12}$ & $1 \times 10^{-14}$ & $1 \times 10^{-11}$ & $m^{2}$ & Lognormal & $\begin{array}{l}\text { Freeze and Cherry, Table } 2.2 \\
\text { (silty sand) }\end{array}$ \\
\hline Porosity $(\phi)$ & $3.75 \times 10^{-1}$ & $2.50 \times 10^{-1}$ & $5 \times 10^{-1}$ & none & Normal & $\begin{array}{l}\text { Freeze and Cherry, Table } 2.4 \\
\text { (sand) }\end{array}$ \\
\hline Creep & & 0.02 & 0.8 & none & Table & Sjaardema and Krleg, 1987 \\
\hline \multicolumn{7}{|l|}{ Climate Characteristics } \\
\hline Boundary recharge factor & 1 & 0 & 2 & none & Uniform & Marietta of al., 1991 \\
\hline Precipitation climate factor & 1 & 0 & 2 & none & Uniform & Marietta ot al., 1991 \\
\hline \multicolumn{7}{|l|}{ Drilling Characteristics } \\
\hline $\begin{array}{l}\text { Drill bit cross sectional } \\
\text { area }(\mathrm{A})\end{array}$ & $3.1420 \times 10^{-2}$ & $1.1430 \times 10^{-2}$ & $1.5518 \times 10^{-1}$ & $\mathrm{~m}^{2}$ & Histogram & $\begin{array}{l}\text { Brinster, 1990, Memo } 10 \text { (see } \\
\text { Appendlx A) }\end{array}$ \\
\hline \multicolumn{7}{|l|}{ Drili string angular } \\
\hline \multicolumn{7}{|l|}{ Drilling mud uphole } \\
\hline velocity $(\gamma)$ & 1.36 & $9.90 \times 10^{-1}$ & 1.73 & $\mathrm{~m} / \mathrm{s}$ & Uniform & $\begin{array}{l}\text { Pace, 1990, Letter 1b (see } \\
\text { Appendix A) }\end{array}$ \\
\hline \multicolumn{7}{|c|}{ Scenario Intrusion Characteristics } \\
\hline Time of intrusion & $7 \times 10^{10}$ & $3.156 \times 10^{9}$ & $3.156 \times 10^{11}$ & $\mathbf{s}$ & Exponential & Tlerney, 1990b, Appendix C \\
\hline \multicolumn{7}{|l|}{ Scenario probability } \\
\hline$P\{E 1\}$ & $3.6914 \times 10^{-2}$ & $3.2786 \times 10^{-3}$ & $7.055 \times 10^{-2}$ & & Uniform & $\begin{array}{l}\text { Guzowskl, 1990; Marietta ot } \\
\text { al., } 1989\end{array}$ \\
\hline$P\{E 2\}$ & $8.1014 \times 10^{-2}$ & $6.4786 \times 10^{-3}$ & $1.5555 \times 10^{-1}$ & & Uniform & $\begin{array}{l}\text { Guzowski, 1990; Marietta et } \\
\text { al., } 1989\end{array}$ \\
\hline$P\{E 1 E 2\}$ & $7.2357 \times 10^{-3}$ & $2.145 \times 10^{-5}$ & $1.445 \times 10^{-2}$ & & Uniform & $\begin{array}{l}\text { Guzowskl, 1990; Marietta ot } \\
\text { al., } 1989\end{array}$ \\
\hline$P\{$ bas $\theta$ cas $\theta\}$ & $8.7484 \times 10^{-1}$ & $9.90221 \times 10^{-1}$ & $7.5945 \times 10^{-1}$ & & Uniform & $\begin{array}{l}\text { Guzowski, 1990; Niarietta ot } \\
\text { al., } 1989\end{array}$ \\
\hline \multicolumn{7}{|c|}{ Multiple Intrusion Characteristics } \\
\hline Number of intrusions & 3 & 1 & $1.30 \times 10^{1}$ & $m^{2}$ & Poisson & Tierney, 1990b, Appendix C \\
\hline Room ID & $7.20 \times 10^{1}$ & 1 & $1.44 \times 10^{2}$ & none & Uniform & $\begin{array}{l}\text { See text (Location of } \\
\text { intrusion). }\end{array}$ \\
\hline Time of intrusion & $1.5936 \times 10^{11}$ & $3.156 \times 10^{9}$ & $3.156 \times 10^{11}$ & & Uniform & Tierney, 1990b, Appendix C \\
\hline
\end{tabular}




\section{BOREHOLE FLOW PROPERTIES}

The EPA Standard ( 40 CFR 191, Appendix B) states that the PA process "... need not assume consequences of an inadvertent intrusion to be more severe than...the creation of a ground water flow path with a permeability typical of a borehole filled by the soil or gravel that would normally settle into an open hole over time--not the permeability of a carefully sealed borehole." The PA process assumes that degrading concrete plugs and uncompacted salt initially present in the hole would have a permeability (Figure IV-3) and porosity (Figure IV-4) of silty sand (Freeze and Cherry, 1979), but with a bulk and average density equal to that of the Salado Formation (Table IV-2). The permeability and porosity were assumed to vary lognormally and normally, respectively, between the typical range for silty sand, typical of distributions of the parameters in the literature (Harr, 1987).

Salt "would normally settle into an cipen hole" and naturally seal the hole shut. The numerically predicted creep closure used in PA calculations is shown in Figure IV-5 (Sjaardema and Krieg, 1987).

\section{CLIMATE VARIABILITY}

The PA Division will evaluate effects of climate variability, particularly long-term increases in precipitation, on the performance of the WIPP. Field data from the American Southwest and global climate models indicate that the coolest and wettest conditions in the past at the WIPP occurred when the North American ice sheet reached its southern 1 imit (roughly $1,200 \mathrm{~km}$ (745 $\mathrm{mi}$ ) north of the WIPP during the last glacial maxima 18,000 to 22,000 years before present); under these conditions, the jet stream's nominal position was much further south than its present location. The average precipitation in the Southwest increased to about twice its present value. Wet periods have occurred since the retreat of the ice sheet, but none has exceeded glacial limits. Data from deep-sea sediments indicate that fluctuations in global climate corresponding to glaciation and deglaciation of the northern hemisphere have been regular in both frequency and amplitude for at least 780,000 years. Using this data, modeling of glacial periodicity suggest that, barring human disruption by the greenhouse effect, the next glacial maximum may occur in about 60,000 years. Furthermore, global models of the greenhouse effect suggest no significant increase in precipitation at the WIPP (Marietta et a1., 1991).

Therefore, the PA model evaluating precipitation changes uses a linear increase of precipitation to twice the present value in 60,000 years. Figure IV-6 shows the distribution for precipitation, and Figure IV-7 provides the distribution for the boundary condition recharge factor. 


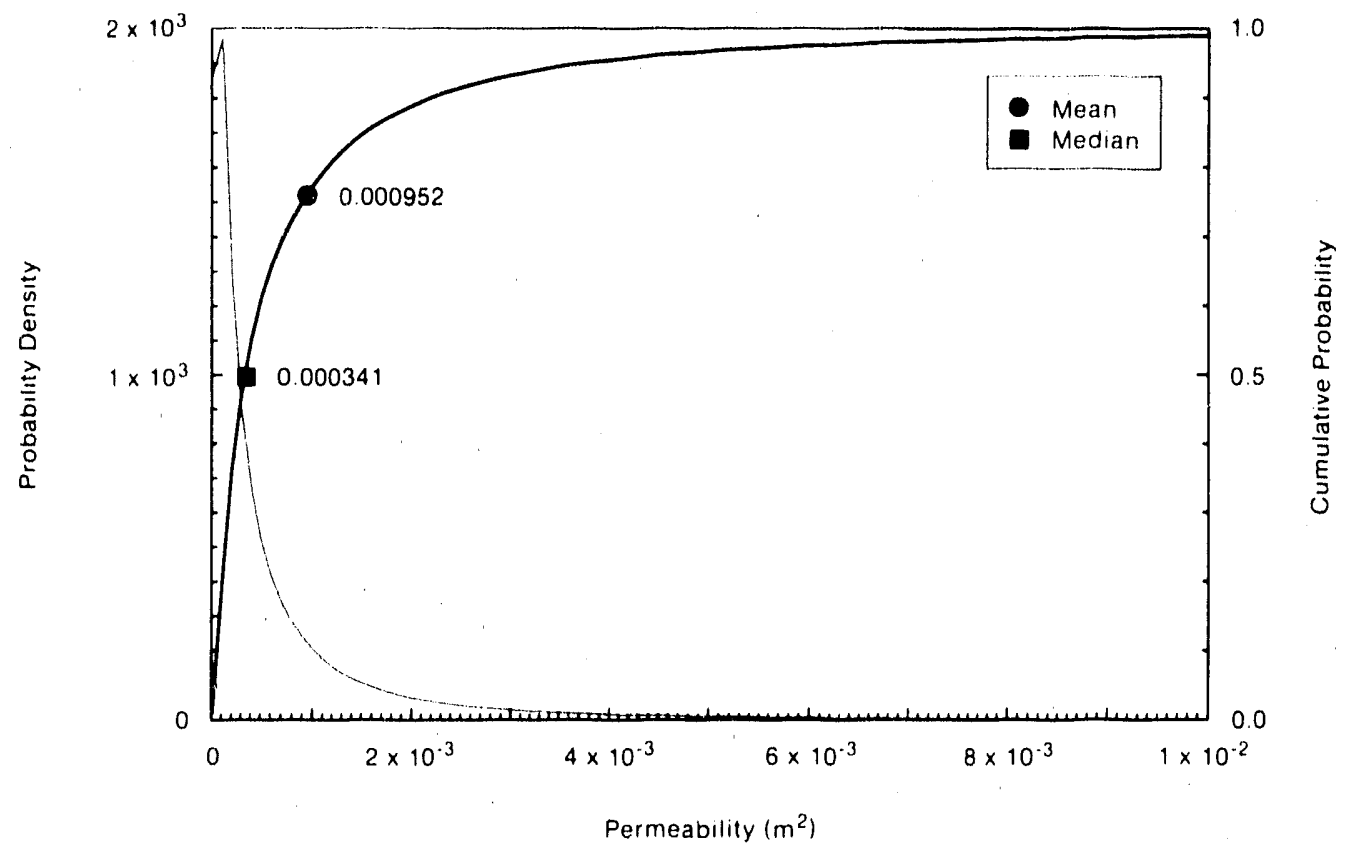

Figure IV-3. Lognormal pdf and cdf for Borehole Permeability.

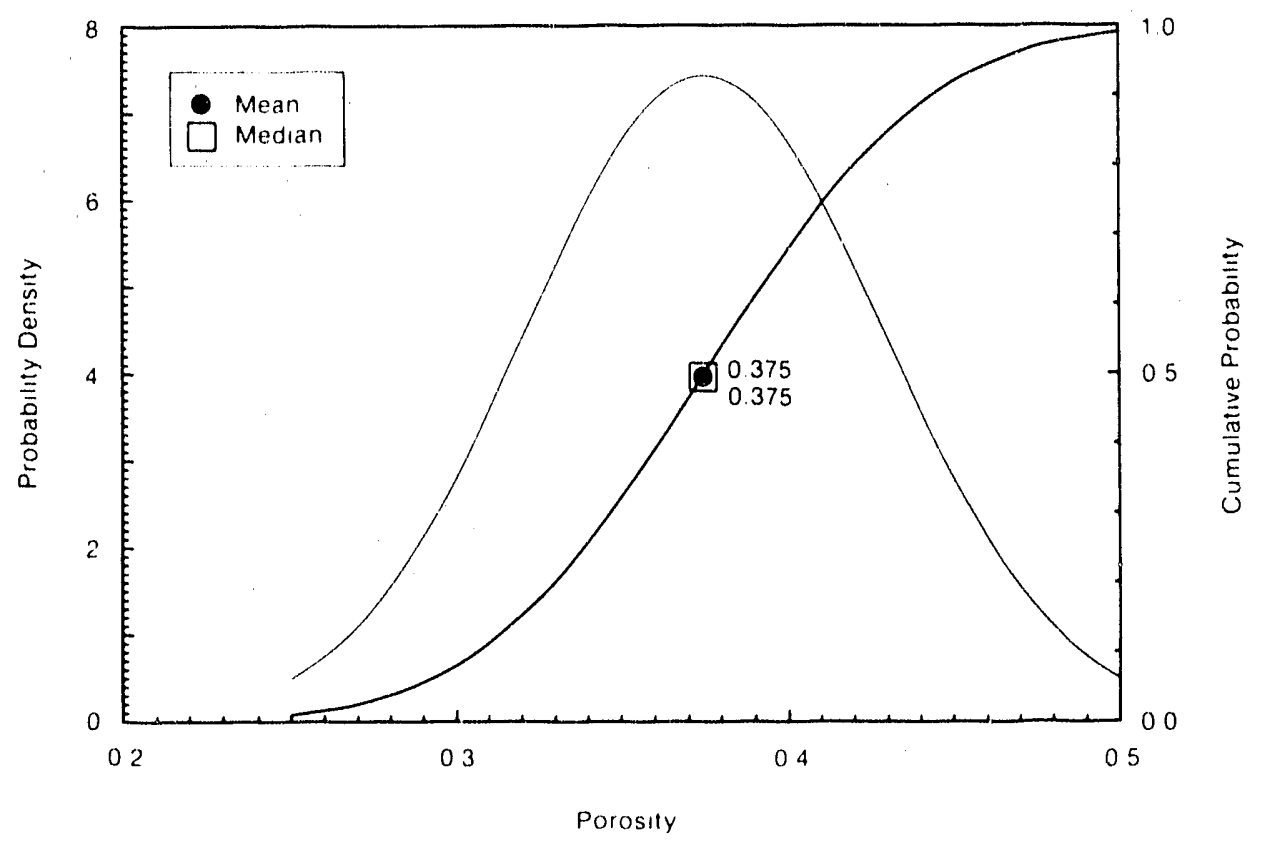

Figure IV-4. Normal pdf and cdf for Borehole Porosity. 


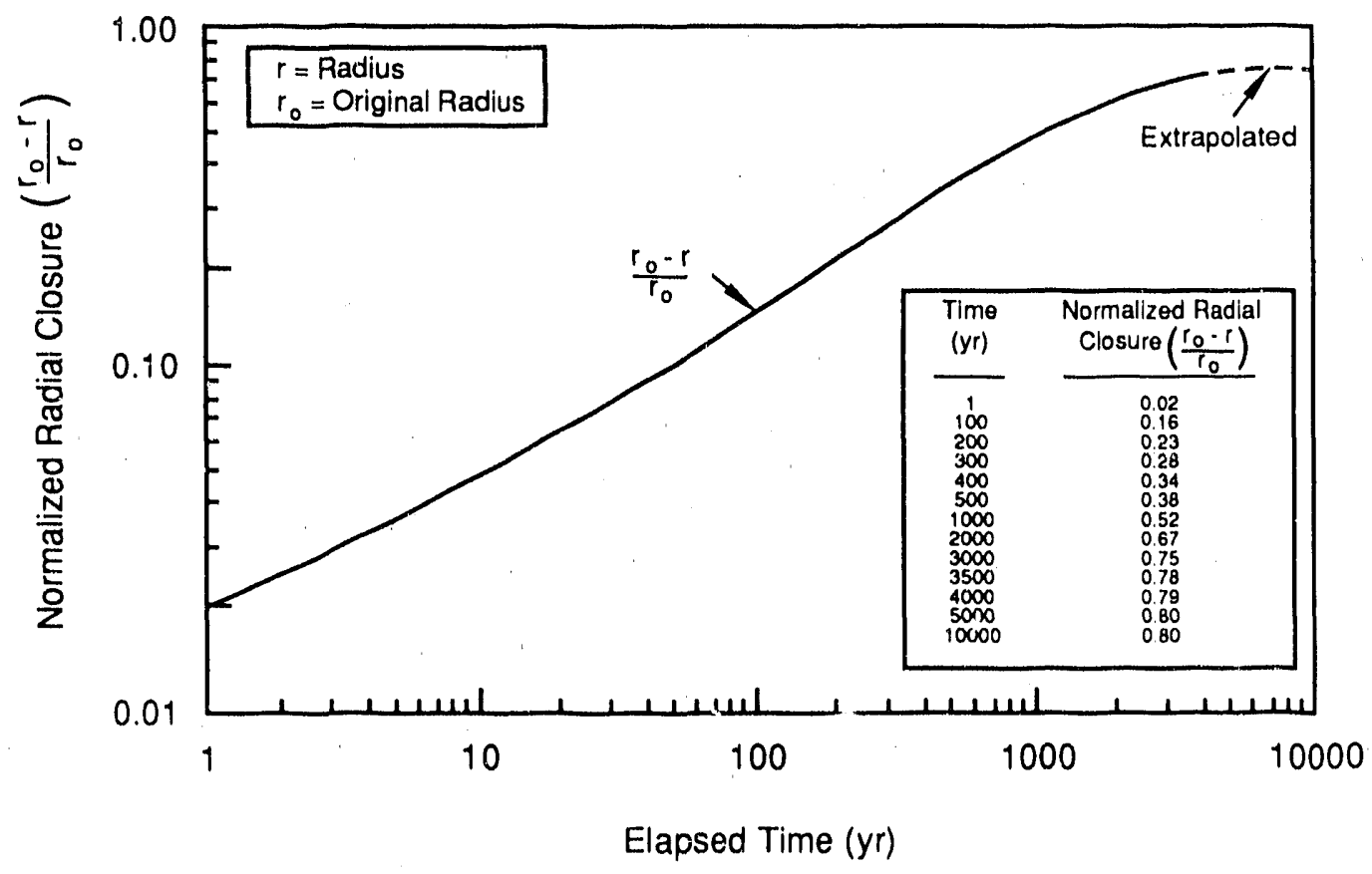

TRI.6342.59.0

Figure IV-5. Normalized Closure for Shaft (Sjaardema and Krieg, 1987).

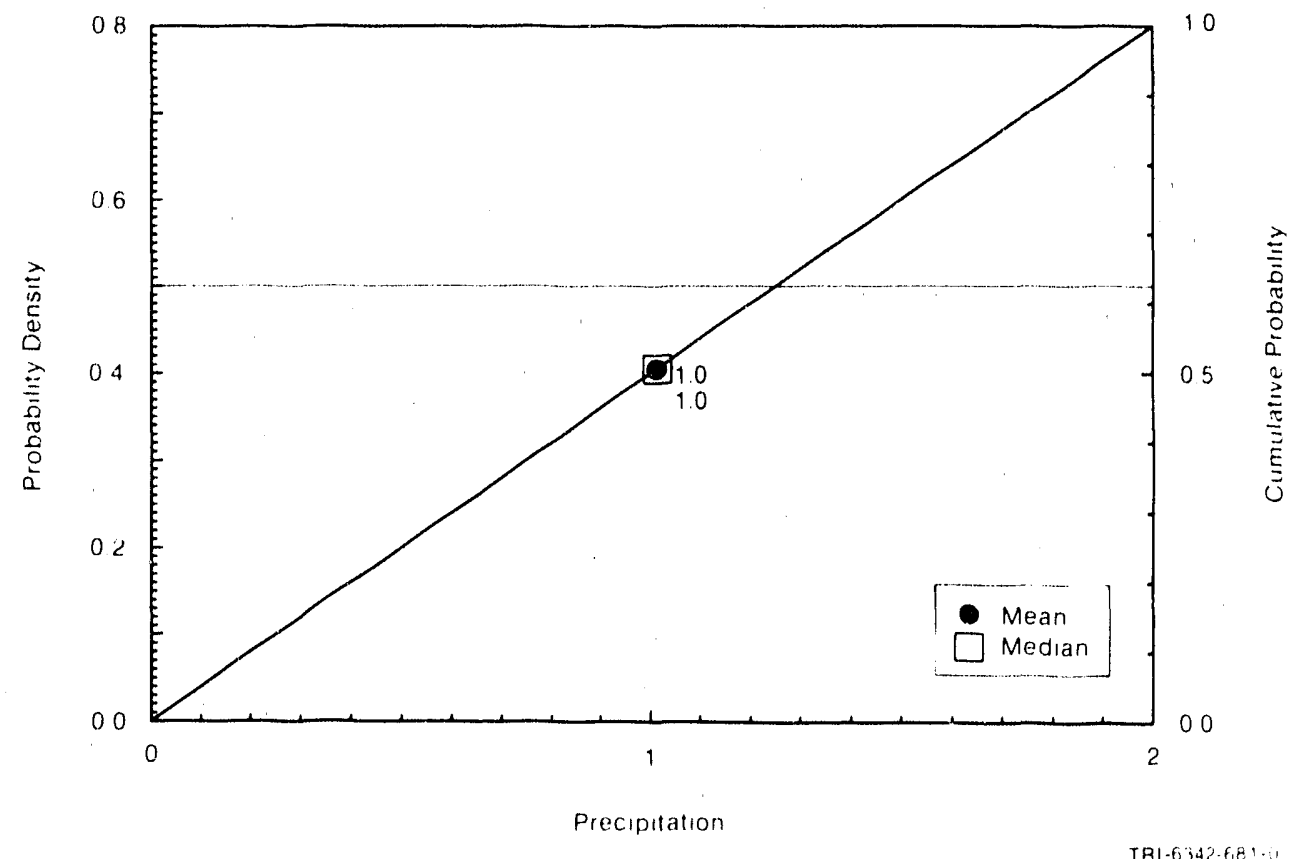

Figure IV-6. Uniform Distribution for Precipitation. 


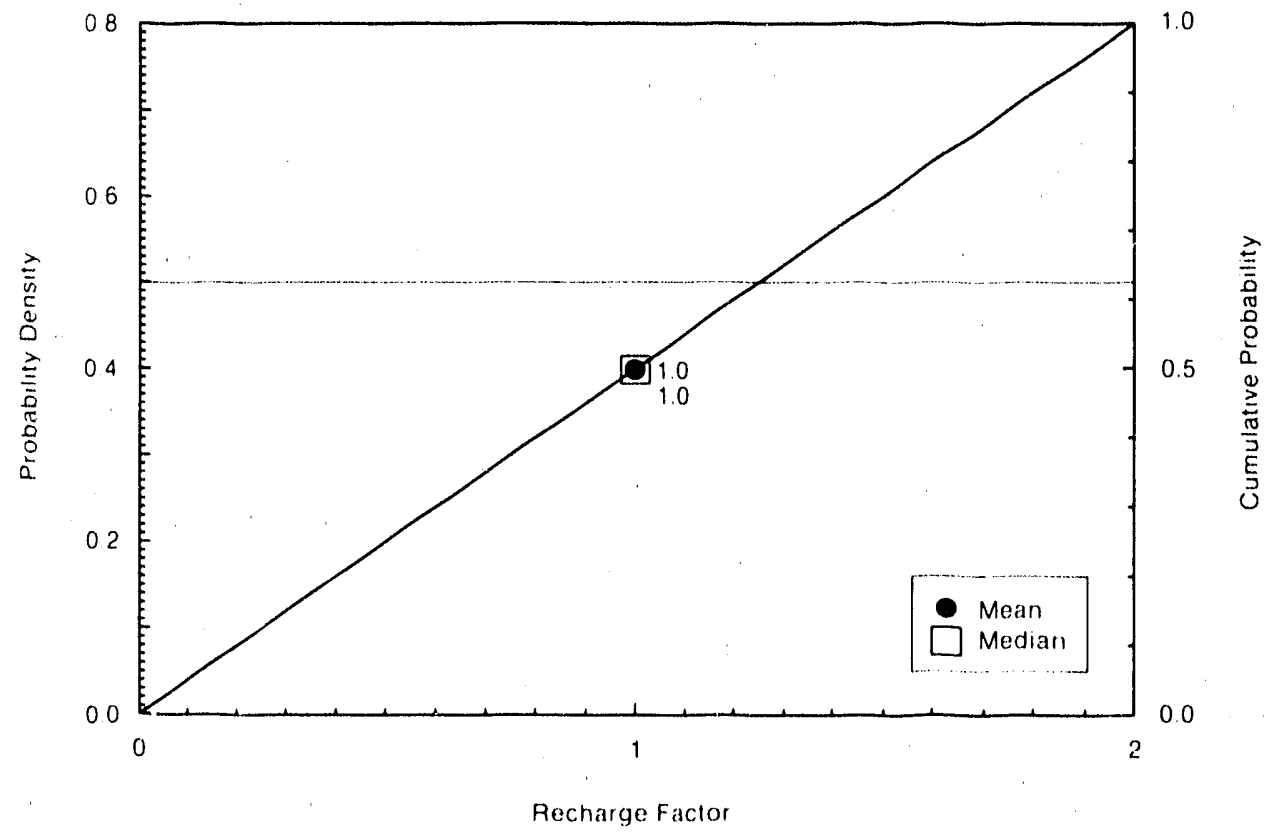

TA1 $6342 \cdot 690-0$

Figure IV-7. Uniform Distribution for Climate Boundary Condition Recharge Factor.

\section{DRILLING CHARACTERISTICS}

\section{Cross-Sectional Area of Intrusion Drill Bit}

The histogram of a bit cross-sectional area (calculated from the bit diameter) comes from records of bit diameters used in the Delaware Basin for oil and gas exploration. PA calculations used a discrete histogram; thus, bit crosssectional areas cannot vary continuously between the minimum of $0.01143 \mathrm{~m}^{2}$ $\left(0.1230 \mathrm{ft}^{2}\right)$ and the maximum of $0.15518 \mathrm{~m}^{2}\left(1.670 \mathrm{ft}^{2}\right)(0.1206 \mathrm{~m}$ and $0.4445 \mathrm{~m}$ diameter or 4-3/4 in. and 17-1/2 in., respectively), but must be the area of a bit that was actually used (Brinster, 1990, Memo 10 [Appendix A]). The median bit cross-sectional area is $0.03142 \mathrm{~m}^{2}\left(0.3382 \mathrm{ft}^{2}\right)(0.2000 \mathrm{~m}$ or $7-7 / 8 \mathrm{in}$. diameter) (Table IV-3 and Figure IV-8).

From the bit cross-sectional area, the drilled area through the waste is predicted based on strength properties of the waste (e.g., shear strength) and angular velocity of the drillstring, viscosity of the drilling fluid, fluid density, and annular uphole fluid velocity (Berglund, 1990; Rechard et al., 1991). Shear strength and surface roughness of the waste also influence the drilled area and are discussed with waste properties. 
TABLE IV-3. DISCRETE PROBABILITY OF DRILLING AN INTRUSION BOREHOLE WITH A SPECIFIC CROSS SECTIONAL AREA

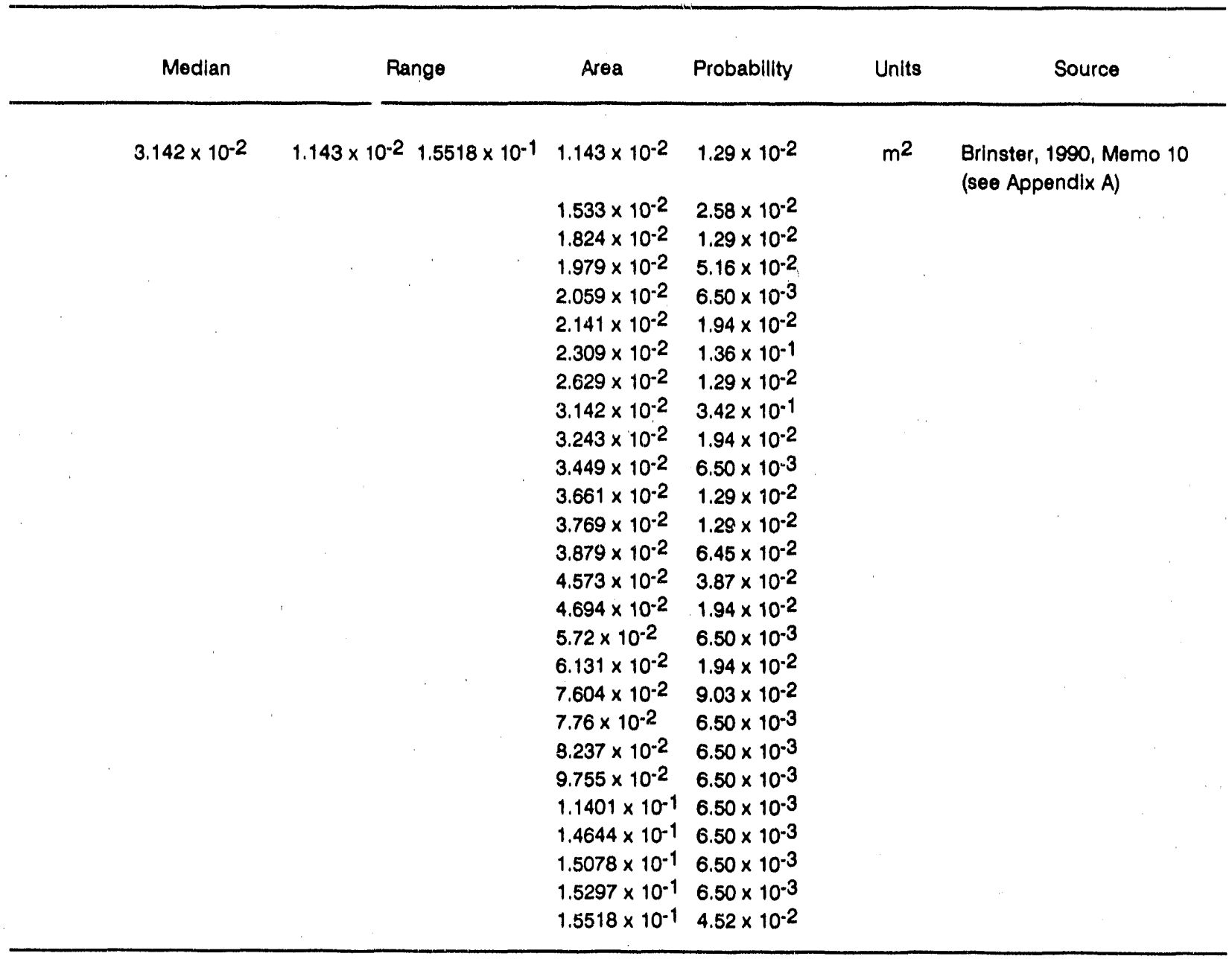




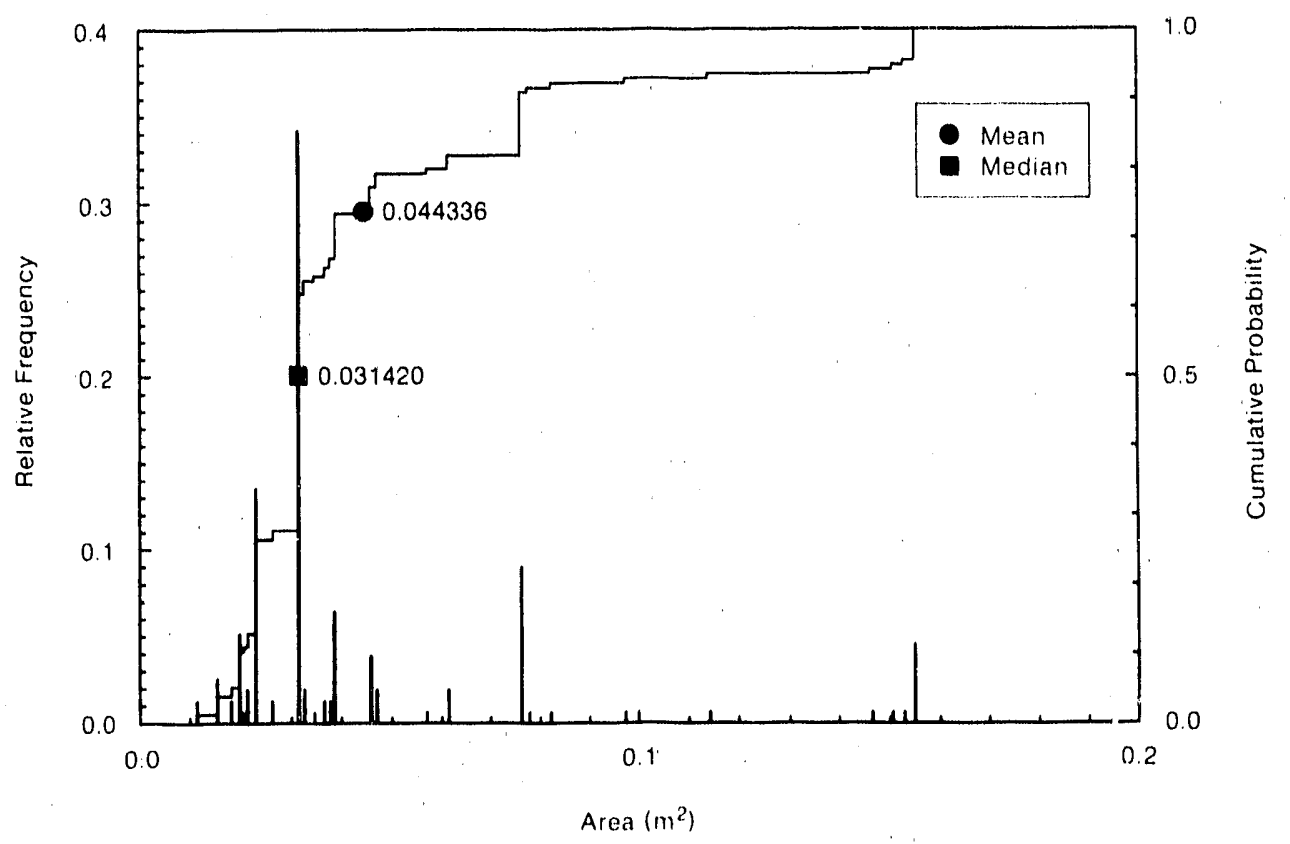

Figure IV-8. Histogram Distribution for Drill Bit Cross-Sectional Area.

\section{Angular Drillstring Velocity}

For drilling through salt, the drillstring angular velocity $(\theta)$ can vary between 4.18 and $23 \mathrm{rad} / \mathrm{s}$ ( 3.8 and $220 \mathrm{rpm}$ ) (Austin, 1983), with the most probable speed about $7 \mathrm{rad} / \mathrm{s}$ ( $70 \mathrm{rpm}$ ) (Pace, 1990, Letter 1b [Appendix A]).

\section{Annular Uphole Velocity}

Flowrates of the drilling fluid usually vary between $5 \times 10^{-5}$ and $8 \times 10^{-5}$ $\mathrm{m}^{3} / \mathrm{s} / \mathrm{m}$ of drill diameter ( 30 and $50 \mathrm{gal} / \mathrm{min} / \mathrm{in.}$ ) (Austin, 1983). PA calculations assumed that the annulus between the drill collar and borehole was initially about $2.5 \mathrm{~cm}$ ( $1 \mathrm{in.}$ ). Thus, for the minimum and maximum diameters typically used in the drilling near the WIPP, the uphole velocity varies between 0.99 and $1.73 \mathrm{~m} / \mathrm{s}\left(2.8 \times 10^{5}\right.$ and $\left.4.9 \times 10^{5} \mathrm{ft} / \mathrm{d}\right)$.

\section{INTRUSION CHARACTERISTICS FOR SCENARIOS}

The EPA Standard requires a study of scenarios in which the WIPP is hypothetically intruded by humans doing exploratory drilling. The current mathematical interpretation of this requirement is examined by Tierney (1990b, Appendix C) from which the following discussion is summarized. 


\section{Time of First Intrusion for Scenarios}

The current probability model for determining the time of the first intrusion for scenarios is based upon the fallure rate function $(r(t))$ :

$$
r(t)= \begin{cases}0 & 0<t<t_{0} \\ -d / d t \ln [1-F(t)], & t_{0}<t\end{cases}
$$

where

t = time elapsed since disposal system placed in operation

to - time when active governuant control ceases (100 yr [40 CFR 191])

$F(t)=$ cumulative distribution for first time of disturbing event.

Integrating to evaluate $F(t)$ yields

$$
F(t)=1-\exp \left[-\int_{t_{0}}^{t} r(\tau) d \tau\right]
$$

Currently, PA calculations assume $r(t)$ is a constant $(\lambda)^{*}$, thus $F(t)$ is a cumulative exponential distribution (Figure IV-9)

where

$$
\begin{aligned}
F(t) & = \begin{cases}0 & , \text { if } 0<t<t_{0}\end{cases} \\
& =p(\text { time of hit }<t)
\end{aligned}
$$

$1 / \lambda+t_{0}-$ the average time one must wait until the first drilling occurs.

The EPA Standard places an upper bound on the failure rate function from which $\lambda$ can be evaluated:

... the Agency assumes that the likelihood of such inadvertent and intermittent drilling need not be taken to be greater than 30 boreholes per square kilometer per 10,000 years for geologic repositories in proximity to sedimentary rock formations...

* Though conservative, the constant failure rate is unrealistic because the effects of markers (required by the EPA Standard to warn of the presence of the repository) is ignored. 


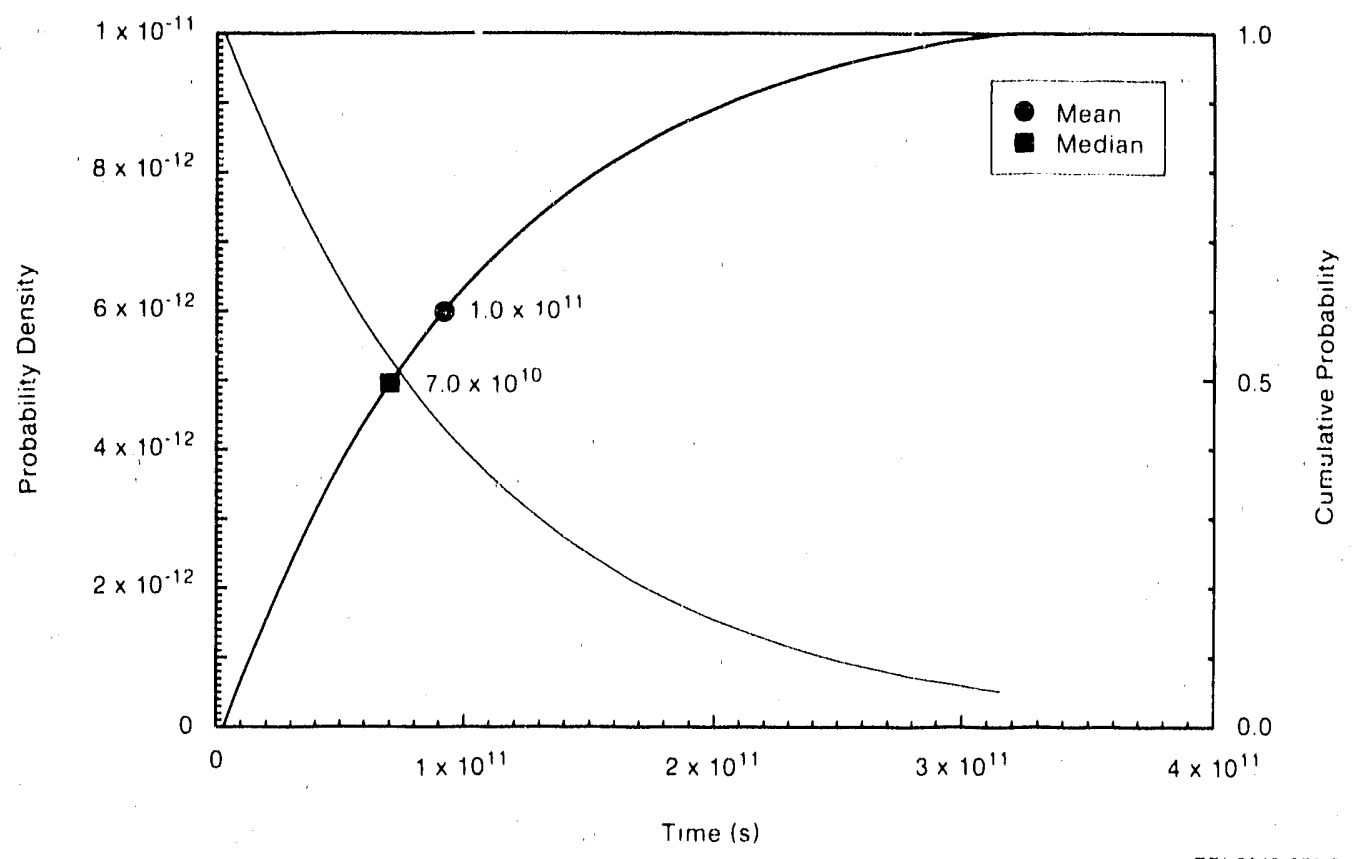

Figure IV-9. Exponentlal Distribution for Time of Intrusion for E1, E2, and E1E2 Scenarios.

or

$$
\lambda=\frac{30 \text { boreholes }}{10^{6} \mathrm{~m}^{2} 10^{4} \mathrm{yr}} \cdot \text { area of excavated disposal region }
$$

Hence, for WIPP $\lambda=3.28 \times 10^{-4} \mathrm{y}^{-1}$ assuming an excavated disposal region of about $1.09 \times 10^{5} \mathrm{~m}^{2}\left(1.1 \times 10^{6} \mathrm{ft}^{2}\right)$. The mean time of the first intrusion is $1 / \lambda$ or about $3,000 \mathrm{yr}$. However, the time for each simulation is sampled from an exponential distribution.

Because the PA Division grouped the occurrence of human intrusion into a separate scenario class, PA calculations used the conditional probability. The conditional probability on the time when drilling will occur given that drilling occurs at least once before $t>t_{1}$, where $t_{1}$ is the regulatory period of 10,000 years is (Miller and Freund, 1977)

$$
\begin{aligned}
& P\left(\text { time of hit }<t \mid \text { time of hit }<t_{1}\right) \\
& =P(\text { time of hit }<t\} / P\left(t i m e \text { of hit }<t_{1}\right)
\end{aligned}
$$


where

$$
\text { P\{time of hit } 1-\exp \left[-\lambda\left(t_{1}-t_{0}\right)\right]
$$

Hence,

$$
\begin{aligned}
& P\left(t i m e \text { of hit }<t \mid \text { time of hit }<t_{1}\right) \\
& =\left\{1-\exp \left[-\lambda\left(t-t_{0}\right)\right]\right\} /\left(1-\exp \left[-\lambda\left(t_{1}-t_{0}\right)\right]\right\}
\end{aligned}
$$

\section{Scenario Probability}

Undisturbed Performance Scenario. As defined in the EPA Standard, "undisturbed performance" means the predicted behavior of a disposal system, including the consideration of the uncertainties in predicted behavior, if the disposal system is not disrupted by human intrusion or the occurrence of unlikely natural events. The undisturbed performance is the base case for scenario development (Guzowski, 1990). For the PA calculations, the base case probability is one minus the sum of the human intrusion probabilities described below.

Human Intrusion Scenarios. The EPA Standard requires $\varepsilon n$ analys is of the consequences of humans intruding into the repository (e.g., drilling an exploratory borehole through the repository). For the WIPP disposal system, screening has reduced the initial list of events and processes for scenario development to three (Hunter, 1989; Guzowski, 1990; Bertram-Howery, 1990): (1) conventional or solution mining of potash beyond the disposal system resulting in areas of subsidence that act as areas of recharge to underlying aquifers (designated as Transport/Subsidence or TS); (2) intrusion of a borehole through a disposal room or drift and into a pressurized brine pocket (reservoir) in the Castile Formation (designated as Event 1 or E1); and (3) intrusion of a borehole into a disposal room or drift (Event 2 or E2). Current calculations have not included the TS process; hence, the probability values are calculated from a truncated Logic diagram (Figures IV-10 and IV-11).

Final probability assignments for events of the compliance assessment will likely rely on expert judgment. However, rough estimates were made when demonstrating the Sandia Compliance Methodology (Marietta et al., 1989, Figure 4-16). The estimated values for scenarios involving only events E1, $\mathrm{E} 2$, and E1E2 $(0.0705,0.1556$, and 0.0144 , respectively) are the current maximum values (Figure IV-10). Possible approaches to assigning probabilities to the events were more thoroughly reviewed and new estimates made by Guzowski. (1990). The newly proposed probabilities for scenarios E1, E2, and E1E2 $(0.00328,0.00648$, and 0.00002$)$ are the current minimum values (Figure IV-11). 


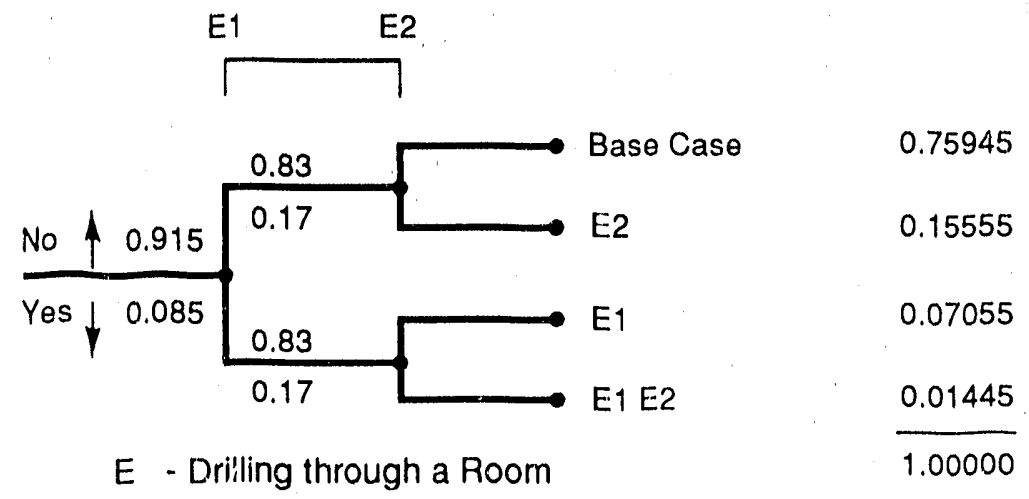

Figure IV-10. Current Maximum Probability Values for Scenarios E1, E2, and E1E2.

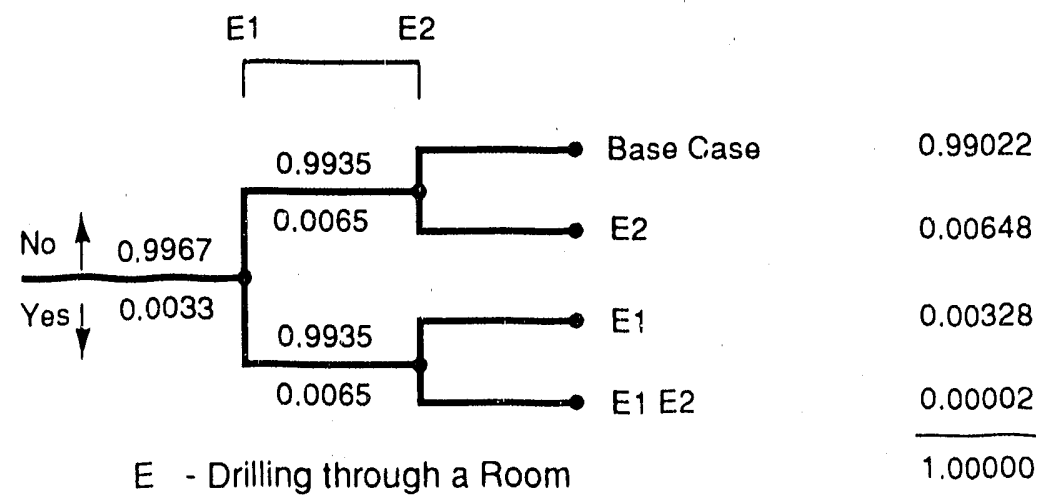

Figure IV-11. Current Minimum Probability Values for Scenarios E1. E2. and E1E2.

TRI-6342-768-0 
Both ends of this probability range were included in PA compliance calculations reported by Bertram-Howery et al. (1990). Helton (1990) reports on a compliance calculation of the complementary cumulative distribution function (CCDF) where the probability of the scenarios for each simulation were randomly sampled between the two limits assuming a uniform pdf.

\section{INTRUSION CHARACTERISTICS FOR MULTIPLE INTRUSIONS}

\section{Number of Intrusions}

Assuming that the times of attempted drilling are independent of each other, the probability that drilling will occur more than once is given by the Poisson distribution (Ross, 1985, Chapter 7):

$$
P\{N=n\}=\left[(\lambda t)^{n} / n !\right] \exp (-\lambda t)
$$

where

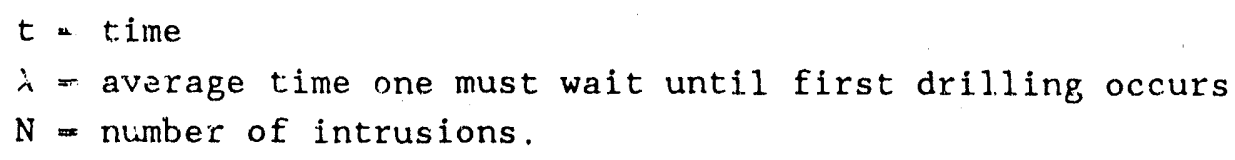

Because the PA Division grouped the occurrence of human intrusion into a separate scenario class, PA calculations used the conditional probability. The conditional probability that drilling will occur more than once $(N>0)$ is

$$
P\{N=n \mid N>0\}=P\{N=n\} / P\{N>0\}
$$

where

$$
P(N>0)=1-P(N=0\}=1-\exp (-\lambda t)
$$

Hence,

$$
P(N=n \mid N>0\}=\{[(\lambda t) n / n !] \exp (-\lambda t)\} /[1-\exp (-\lambda t)\}
$$

The discrete probability of intrusion, $P(N=n \mid N>0)$, is given in Table IV-4 and Figure IV-12 for between 1 and 13 intrusions.

\section{Location of Intrusion}

The waste disposal area was subdivided intu 144 "rooms" approximately $100 \mathrm{~m}$ (300 ft) long. The location of an intrusion was then randomly selected from these 144 "rooms" using a uniform distribution (Figure IV-13). Multiple intrusions into the same room were permitted. 
TABLE IV-4. PROBABLITY OF MULTIPLE HITS INTO DISPOSAL AREA OF REPOSITORY

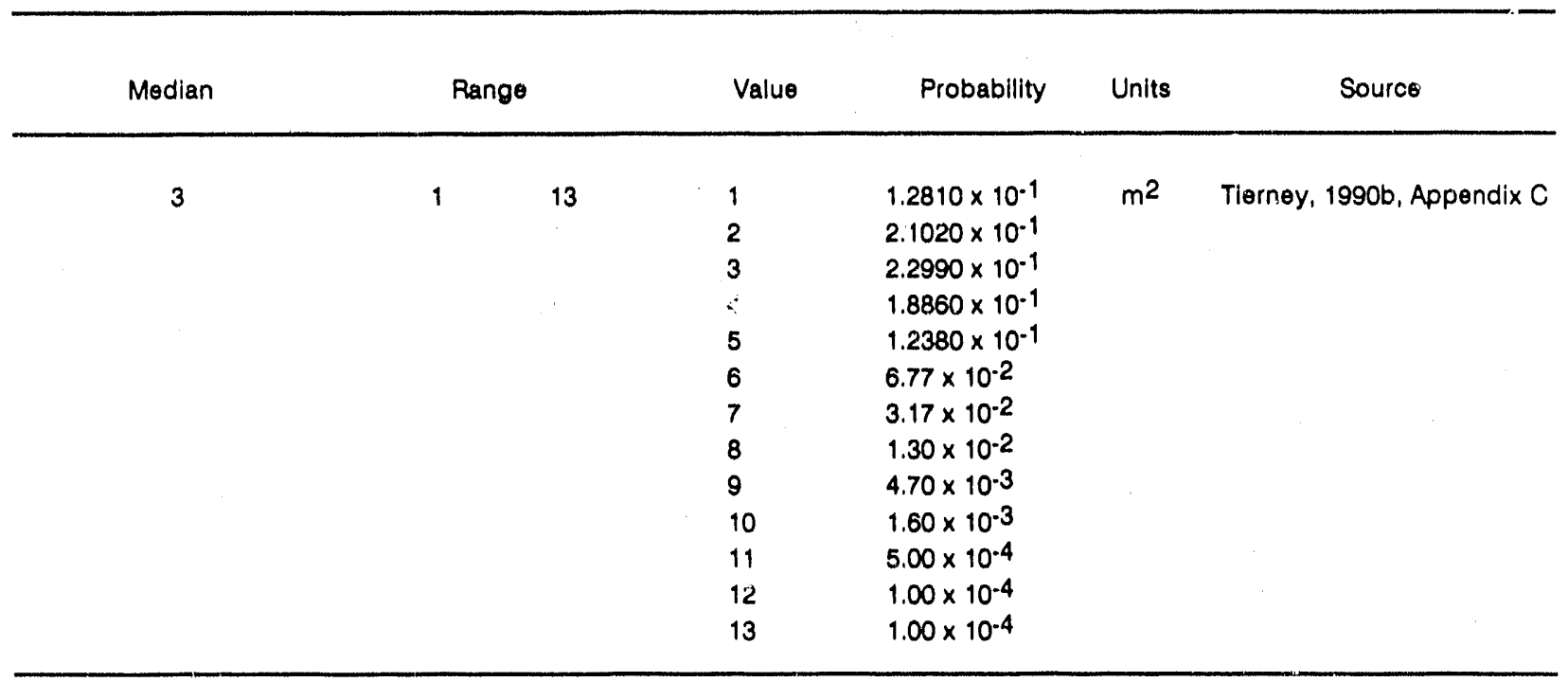

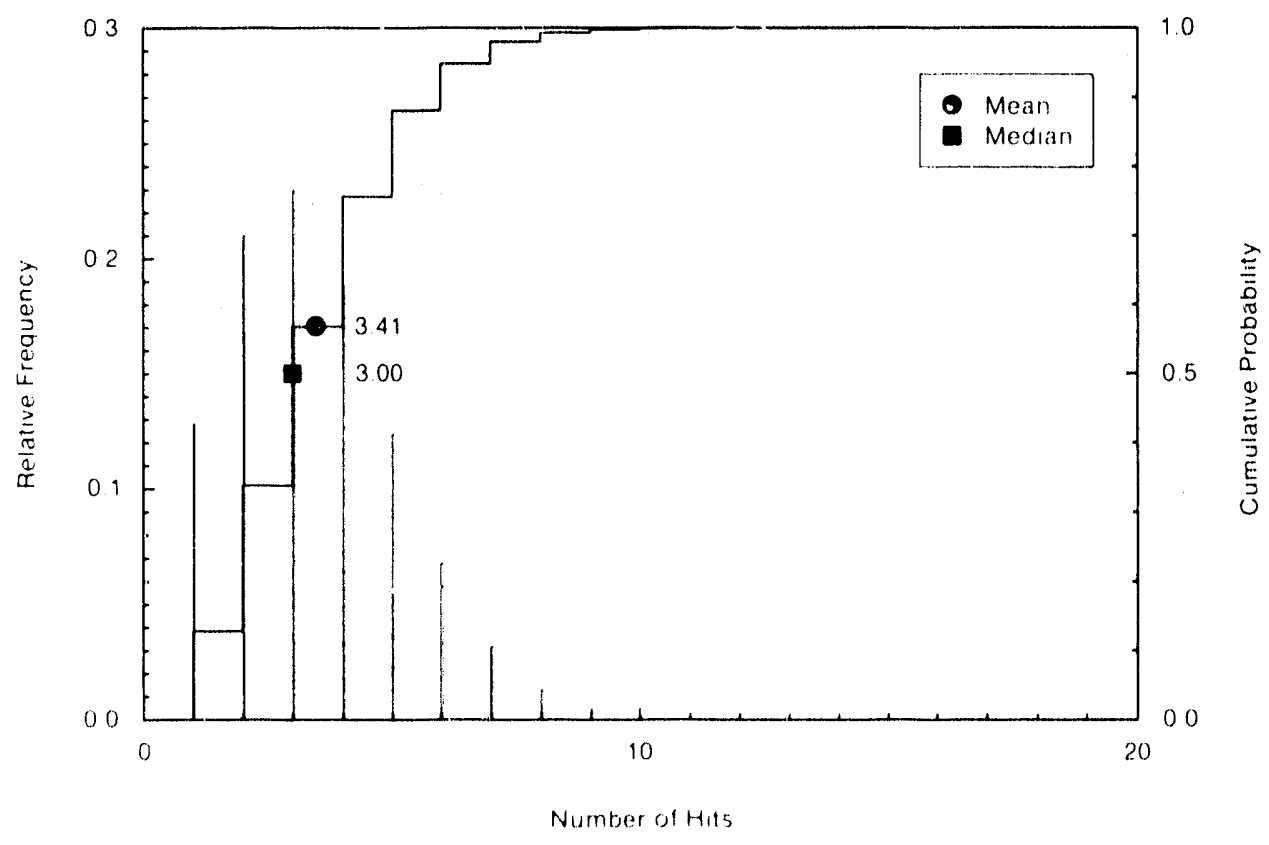

Figure IV-12. Histogram Distribution for Number of Intrusions for Multiple Hits. 


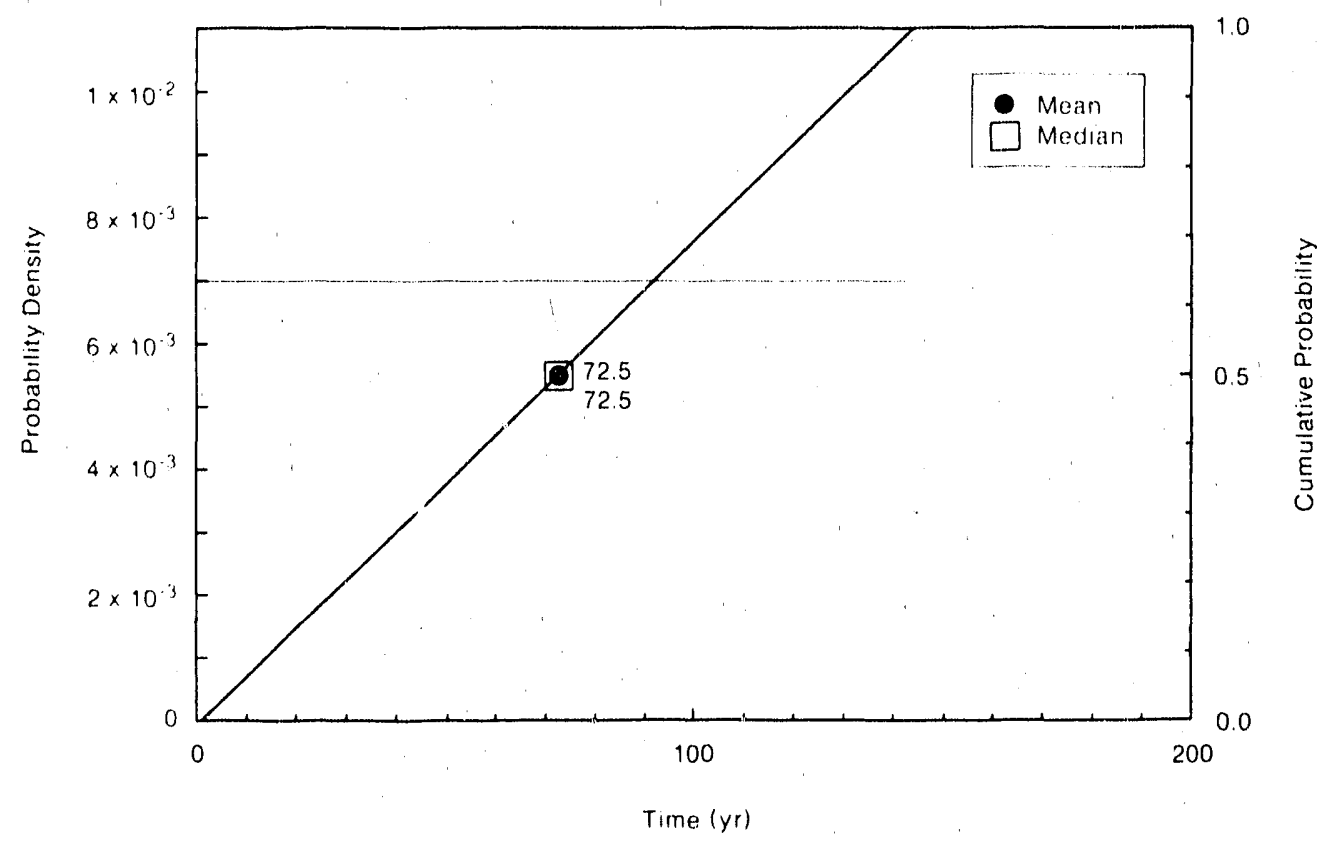

TRI-6342-707-0

Figure IV-13. Uniform Distribution for Location of Intrusion. (Room Number).

There were 13 equivalent rooms in each side panel, and 20 rooms in each northern and southern equivalent panel (see Figure II-16). The "rooms" of the northern and southern equivalent panels were slightly shorter, which resulted in more rooms and consquently a slightly greater probability of hitting the northern and southern equivalent panels. Refinements in the subdivision of the waste disposal area so that the probability of an intrusion more closely equals the surface area will be considered in future work.

\section{Times of Multiple Intrusions}

The times of the $\mathrm{N}$ intrusions are evaluated from a uniform distribution between 100 and 10,000 years* (Figure IV-14). The $N$ random samples from the uniform distribution are then ordered from the smallest to the largest. Identical times for intrusions are permitted. It can be shown that for a Poisson process, the waiting time between successive intrusions have exponential distributions. Consequently, the mean time of intrusion (or mean time between intrusions) is $1 / \lambda+t_{0}$ or about $3,000 \mathrm{yr}$, as for the scenarios.

* For compliance calculations, 100 years is the time period after which active government control of the WIPP must be assumed to stcp ( 40 CFR 191); 10,000 years : the end of the regulatory period. 


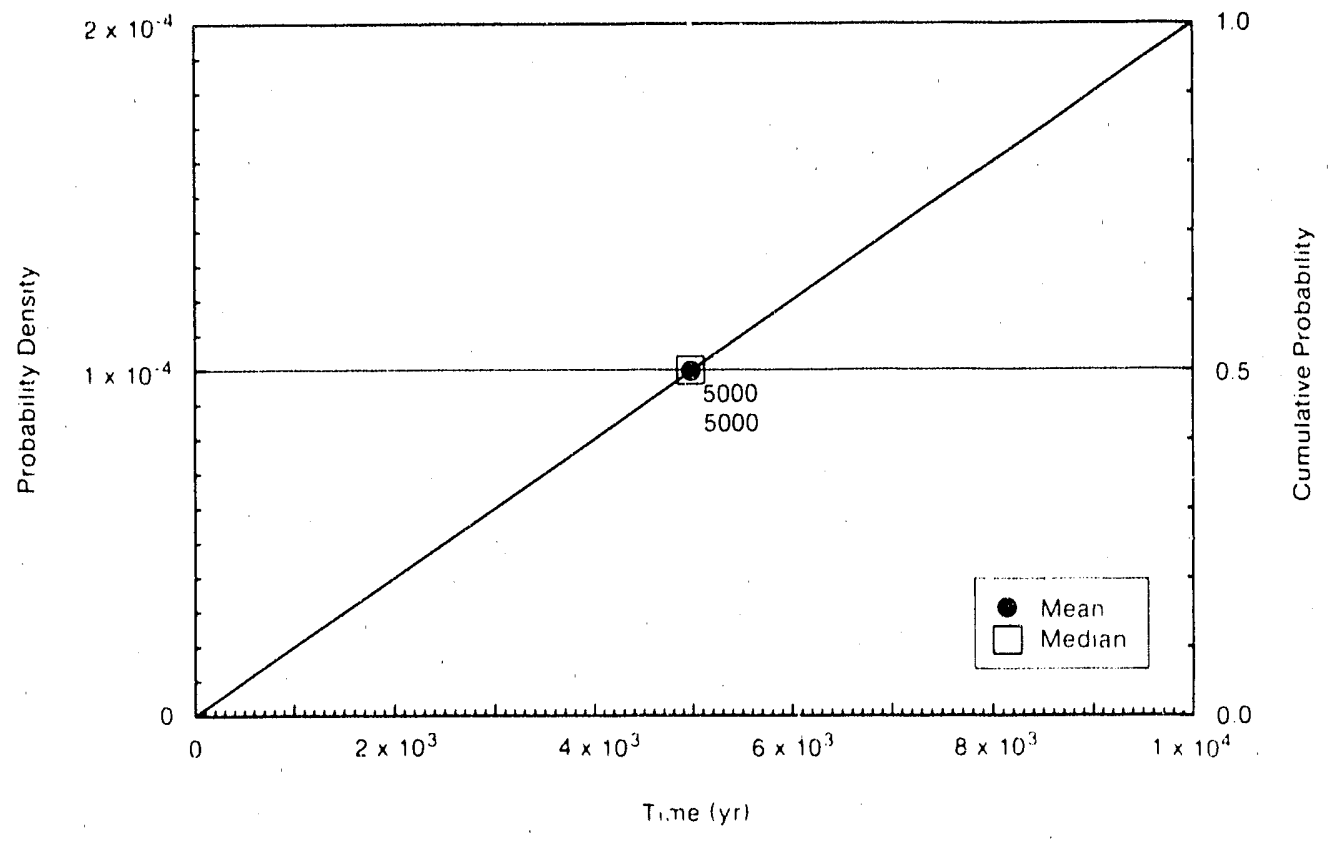

Figure IV-14. Uniform Distribution for Global Time uf Intrusion for Multiple Hits. 


\section{SUMMARY OF SAMPLED DATA}

Table V-1 is a summary of data sampled using Latin Hypercube Sampling as reported in the Performance Assessment report, Bertram-Howery et al., 1990, Preliminary Comparison with 40 CFR Part 191, Subpart B for the Waste Isolation Pilot Plant, December 1990, SAND90-2347. Albuquerque, NM: Sandia National Laboratories. For all parameters not sampled, the median value was used unless stated otherwise. 
TABLE V-1. DISTRIBUTIONS OF SAMPLE PARAMETERS IN DECEMBER 1990 WIPP PERFORMANCE ASSESSMENT

\begin{tabular}{|c|c|c|c|c|c|c|}
\hline Parameter & Median & \multicolumn{2}{|c|}{ Range } & \multicolumn{2}{|r|}{$\begin{array}{l}\text { Distribution } \\
\text { Type }\end{array}$} & Source \\
\hline Salado Formation & & & & & & \\
\hline Capacitance & $3.2 \times 10^{-11}$ & $1 \times 10^{-11}$ & $1 \times 10^{-10}$ & $\mathrm{~Pa}^{-1}$ & Lognormal & $\begin{array}{l}\text { Beauheim, 1990, Memo 3c (see } \\
\text { Appendix A) }\end{array}$ \\
\hline $\begin{array}{l}\text { Permeability } \\
\text { Pressure at }\end{array}$ & $3.5 \times 10^{-21}$ & $1 \times 10^{-22}$ & $3 \times 10^{-20}$ & $m^{2}$ & Density & Beauheim ot al., 1990 \\
\hline repository level & $1.1 \times 10^{7}$ & $7 \times 10^{6}$ & $1.5 \times 10^{7}$ & $\mathrm{~Pa}$ & Uniform & $\begin{array}{l}\text { Wawersik and Stone, 1985; } \\
z \cdot g \cdot \text { Pbrine; Beauheim, 1990, } \\
\text { Memo } 3 c \text { (see Appendix A) }\end{array}$ \\
\hline \multicolumn{7}{|c|}{ Castile Formation Brine Pocket } \\
\hline Initial pressure & $1.27 \times 10^{7}$ & $7 \times 10^{6}$ & $1.74 \times 10^{7}$ & $\mathrm{~Pa}$ & Cumulative & $\begin{array}{l}\text { Lappln et al, 1989, Table 3-19; } \\
\text { Poplelak et al., } 1983\end{array}$ \\
\hline $\begin{array}{l}\text { Initial compressive } \\
\text { volume }\end{array}$ & $7 \times 10^{6}$ & $4.8 \times 10^{3}$ & $1.4 \times 10^{7}$ & $m^{3}$ & Unlform & Lappin et al, 1989, Table 3.19 \\
\hline \multicolumn{7}{|l|}{ TRU Waste } \\
\hline $\begin{array}{l}\text { radionuclides } \\
\text { Molecular diffusion }\end{array}$ & $2.4 \times 10^{7}$ & $2.4 \times 10.10$ & $2.4 \times 10^{-4}$ & $\mathrm{~kg} / \mathrm{kg}$ & Loguniform & Lappin ot al., 1989, p. $4-29$ \\
\hline coefficient & & $4.8 \times 10^{-11}$ & $4.3 \times 10^{-10}$ & $\mathrm{~m}^{2} / \mathrm{s}$ & Uniform & Lappin et al., 1989, Table E-7. \\
\hline \multicolumn{7}{|c|}{ Drilling Characteristics of Intrusion Borehole } \\
\hline Drill bit area & $3.142 \times 10^{-2}$ & $1.143 \times 10^{-2}$ & $1.5518 \times 10^{-1}$ & $m^{2}$ & Histogram & $\begin{array}{l}\text { Brinster, 1990, Memo } 10 \text { (see } \\
\text { Appendix A) }\end{array}$ \\
\hline \multicolumn{7}{|c|}{ Multiple Intrusion Time and Location } \\
\hline $\begin{array}{l}\text { Time of Intrusion } \\
\text { Number of hits }\end{array}$ & $5 \times 10^{3}$ & $1 \times 10^{2}$ & $1 \times 10^{4}$ & $y r$ & Uniform & 40 CFR 191, Subpart B \\
\hline $\begin{array}{l}\text { (multiple intrusions) } \\
\text { Room number }\end{array}$ & 3 & 1 & $1.3 \times 10^{1}$ & $m^{2}$ & Poisson & Tierney, 1990b, Appendix C \\
\hline $\begin{array}{l}\text { of intrusions } \\
\text { Scenario Intrusion Time }\end{array}$ & $\begin{array}{l}7.2 \times 10^{1} \\
3 \times 10^{3}\end{array}$ & $1 \times 10^{2}$ & $\begin{array}{l}1.44 \times 10^{2} \\
1 \times 10^{4}\end{array}$ & $\begin{array}{l}\text { none } \\
y r\end{array}$ & $\begin{array}{l}\text { Uniform } \\
\text { Exponential }\end{array}$ & $\begin{array}{l}\text { See text (Chapter IV) } \\
\text { Tierney, 1990b, Appendix C }\end{array}$ \\
\hline \multicolumn{7}{|c|}{ Intrusion Borehole Flow Parameters } \\
\hline Permeability & $3.16 \times 10^{-12}$ & $1 \times 10^{-14}$ & $1 \times 10^{-11}$ & $m^{2}$ & Lognormal & $\begin{array}{l}\text { Freeze and Cherry, Table } 2.2 \\
\text { (clean sand) }\end{array}$ \\
\hline Porosity & $3.7 \times 10^{-1}$ & 0.25 & 0.5 & none & Norrinal & $\begin{array}{l}\text { Freeze and Cherry, Table } 2.4 \\
\text { (sand) }\end{array}$ \\
\hline \multicolumn{7}{|c|}{ Culebra Dolomite Member of Rustler Formation } \\
\hline Fracture spacing & 2 & $2.5 \times 10^{-1}$ & 7 & $m$ & Cumulative & $\begin{array}{l}\text { Lappin et al., 1989, Table 1-2, } \\
\text { Table E-6 }\end{array}$ \\
\hline \multicolumn{7}{|c|}{ Matrix partition coefficient } \\
\hline Am & $1.1 \times 10^{-1}$ & 0 & $3.8 \times 10^{1}$ & $\mathrm{~m}^{3} / \mathrm{kg}$ & Cumulative & $\begin{array}{l}\text { Slegel, 1990, Memo 3a (see } \\
\text { Appendix A); Lappin et al., 1989, } \\
\text { Table 3-14, E-10, E-11, E-12 }\end{array}$ \\
\hline $\mathrm{Np}$ & $6 \times 10^{-4}$ & 0 & $1 \times 10^{-2}$ & $\mathrm{~m}^{3} / \mathrm{kg}$ & Cumulative & $\begin{array}{l}\text { Slegel, } 1990, \text { Memo 3a (see } \\
\text { Appendix A); Lappin et al., } 19,39 \text {, } \\
\text { Table 3-14, E-10, E-11, E-12 }\end{array}$ \\
\hline$P u=T h$ & $8 \times 10^{-2}$ & 0 & 1.05 & $\mathrm{~m}^{3} / \mathrm{kg}$ & Cumulative & $\begin{array}{l}\text { Siegel, 1990, Memo 3a (see } \\
\text { Appendix A); Lappin et al., 1989, } \\
\text { Table 3-14, E-10, E-11, E-12 }\end{array}$ \\
\hline$U=R a=P b$ & $6 \times 10^{-4}$ & 0 & $7.50 \times 10^{-3}$ & $\mathrm{~m}^{3} / \mathrm{kg}$ & Cumulative & $\begin{array}{l}\text { Slegel, 1990, Memo 3a (see } \\
\text { Appendix A); Lappin et al., 1989, } \\
\text { Table 3-14, E-10, E-11, E-12 }\end{array}$ \\
\hline
\end{tabular}




\section{TABLE V-1. DISTRIBUTIONS OF SAMPLE PARAMETERS IN DECEMBER 1990 WIPP PERFORMANCE} ASSESSMENT (CONCLUDED)

\begin{tabular}{|c|c|c|c|c|c|c|}
\hline \multirow{2}{*}{ Parameter } & \multirow[b]{2}{*}{ Medlan } & \multicolumn{5}{|c|}{ Distribution } \\
\hline & & \multicolumn{2}{|c|}{ Range } & \multirow[t]{2}{*}{ Units } & \multirow[t]{2}{*}{ Type } & \multirow[t]{2}{*}{ Source } \\
\hline \multicolumn{4}{|c|}{ Fracture partition coefficient } & & & \\
\hline Am & $3 \times 10^{-1}$ & 0 & 4.10 & $\mathrm{~m}^{3} / \mathrm{kg}$ & Cumulative & $\begin{array}{l}\text { Slegel, 1990, Memo 3a (see } \\
\text { Appendix A); Lappin et al., } 1989 . \\
\text { Table 3-14, E-10. E-11, E-12 }\end{array}$ \\
\hline $\mathrm{Np}$ & $1 \times 10^{-2}$ & 0 & $5 \times 10^{-2}$ & $\mathrm{~m}^{3} / \mathrm{kg}$ & Cumulative & $\begin{array}{l}\text { Slegel, 1990, Memo 3a (see } \\
\text { Appondix A): Lappin et al., 1989, } \\
\text { Table 3-14, E-10, E-11, E-12 }\end{array}$ \\
\hline $\mathrm{Pu}=\mathrm{Th}$ & $3 \times 10^{-1}$ & 0 & $4 \times 10^{1}$ & $\mathrm{~m}^{3} / \mathrm{kg}$ & Cumulative & $\begin{array}{l}\text { Slegel, 1990, Memo 3a (see } \\
\text { Appendix A), Lappin et al., 1989, } \\
\text { Table 3-14, E-10, E-11, E-12 }\end{array}$ \\
\hline$U=R a=P b$ & $1 \times 10^{-2}$ & 0 & $5 \times 10^{-2}$ & $\mathrm{~m}^{3} / \mathrm{kg}$ & Cumulative & $\begin{array}{l}\text { Slegel, } 1990 \text {, Memo 3a (se日 } \\
\text { Appendlx A); Lappin et al., } 1989 \text {, } \\
\text { Table 3-14, E-10, E-11, E-12 }\end{array}$ \\
\hline \multicolumn{7}{|c|}{ Hydraulic Conductivity } \\
\hline Zone 1 & $1.2 \times 10^{-5}$ & $2.7 \times 10^{-6}$ & $5.5 \times 10^{-5}$ & $\mathrm{~m} / \mathrm{s}$ & Density & $\begin{array}{l}\text { Brinster, 1990, Memo } 8 \text { (see } \\
\text { Appendlx A) }\end{array}$ \\
\hline Zone 2 & $3 \times 10^{-8}$ & $9.9 \times 10^{-9}$ & $4.3 \times 10^{-8}$ & $\mathrm{~m} / \mathrm{s}$ & Density & $\begin{array}{l}\text { Brinster, } 1990, \text { Memo } 8 \text { (see } \\
\text { Appendlx A) }\end{array}$ \\
\hline Zone 3 & $2.2 \times 10^{-7}$ & $1.3 \times 10^{-7}$ & $3.2 \times 10^{-7}$ & $\mathrm{~m} / \mathrm{s}$ & Density & $\begin{array}{l}\text { Brinster, 1990, Memo } 8 \text { (see } \\
\text { Apperidix A) }\end{array}$ \\
\hline Zone 4 & $7.35 \times 10^{-8}$ & $3.5 \times 10^{-8}$ & $1.2 \times 10^{-7}$ & $\mathrm{~m} / \mathrm{s}$ & Density & $\begin{array}{l}\text { Brinster, 1990, Memo } 8 \text { (see } \\
\text { Appendix A) }\end{array}$ \\
\hline Zone 5 & $4.4 \times 10^{-6}$ & $4 \times 10^{-6}$ & $4.8 \times 10^{-6}$ & $\mathrm{~m} / \mathrm{s}$ & Density & $\begin{array}{l}\text { Brlnster, 1990, Memo } 8 \text { (see } \\
\text { Appendix A) }\end{array}$ \\
\hline Zone 7 & $1.16 \times 10^{-4}$ & $1.6 \times 10^{-5}$ & $2 \times 10^{-4}$ & $\mathrm{~m} / \mathrm{s}$ & Density & $\begin{array}{l}\text { Brinster, 1990, Memo } 8 \text { (see } \\
\text { Appendix A) }\end{array}$ \\
\hline \multicolumn{7}{|c|}{ Multiple Intrusions: } \\
\hline Zone A & $2.6 \times 10^{-4}$ & $1.6 \times 10^{-4}$ & $1 \times 10^{-3}$ & $\mathrm{~m} / \mathrm{s}$ & Density & $\begin{array}{l}\text { Brinster, 1990, Memo } 9 \text { (see } \\
\text { Appendix A) }\end{array}$ \\
\hline Zone B & $4 \times 10^{-5}$ & $1.6 \times 10^{-5}$ & $1.3 \times 10^{.4}$ & $\mathrm{~m} / \mathrm{s}$ & Density & $\begin{array}{l}\text { Brinster, 19९), Memo } 9 \text { (see } \\
\text { Appendix A) }\end{array}$ \\
\hline Zone D & $3.3 \times 10^{-5}$ & $3.3 \times 10^{-5}$ & $5.2 \times 10^{-5}$ & $\mathrm{~m} / \mathrm{s}$ & Density & $\begin{array}{l}\text { Brinster, 1990, Memo } 9 \text { (see } \\
\text { Appendix A) }\end{array}$ \\
\hline Zone E & $4.1 \times 10^{-7}$ & $1.6 \times 10^{-7}$ & $1.3 \times 10^{-6}$ & $\mathrm{~m} / \mathrm{s}$ & Density & $\begin{array}{l}\text { Brinster, 1990, Memo } 9 \text { (see } \\
\text { Appendix A) }\end{array}$ \\
\hline Zone F & $6.5 \times 10^{-6}$ & $2.6 \times 10^{-6}$ & $1.6 \times 10^{-5}$ & $n_{1} / \mathrm{s}$ & Density & $\begin{array}{l}\text { Brinster, 1990, Memo } 9 \text { (see } \\
\text { Appendix A) }\end{array}$ \\
\hline Zone G & $8.2 \times 10^{-8}$ & $1.3 \times 10^{-8}$ & $1.6 \times 10^{-7}$ & $m_{1} / s$ & Density & $\begin{array}{l}\text { Brinster, 1990. Memo } 9 \text { (see } \\
\text { Appendix A) }\end{array}$ \\
\hline Zone $\mathrm{H}$ & $8.8 \times 10^{-7}$ & $3.3 \times 10^{-7}$ & $4.1 \times 10^{-5}$ & $\mathrm{~m} / \mathrm{s}$ & Density & $\begin{array}{l}\text { Brinster, 1990, Memo } 9 \text { (see } \\
\text { Appendix A) }\end{array}$ \\
\hline Zone I & $8.25 \times 10^{-10}$ & $6.5 \times 10^{-10}$ & $1 \times 10^{-9}$ & $\mathrm{~m} / \mathrm{s}$ & Density & $\begin{array}{l}\text { Brinster, 1990, Memo } 9 \text { (see } \\
\text { Appendix A) }\end{array}$ \\
\hline Zone J & $4.1 \times 10^{-5}$ & $\therefore 2 \times 10^{-6}$ & $7.3 \times 10^{-5}$ & $\mathrm{~m} / \mathrm{s}$ & Density & $\begin{array}{l}\text { Brinster, 1990, Memo } 9 \text { (see } \\
\text { Appendix A) }\end{array}$ \\
\hline Zone K & $1.3 \times 10^{-8}$ & $2.6 \times 10^{-9}$ & $3.3 \times 10^{-8}$ & $\mathrm{~m} / \mathrm{s}$ & Density & $\begin{array}{l}\text { Brinster, 1990, Memo } 9 \text { (see } \\
\text { Appendix A) }\end{array}$ \\
\hline
\end{tabular}




\section{REFERENCES}

Austin, E. H. 1983. Drilling Engineering Handbook. Boston MA: International. Human Resources Development Corporation.

Bear, J. and A. Verruijt. 1987. Modeling Groundwater Flow and Pollution. Boston, MA: D. Reidel Publishing Company, p. 126.

Beauheim, R. L. 1987. Interpretations of Single-We1l Hydraulic Tests Conducted At and Near the Waste Isolation Pilot Plant (WIPP) Site, 1983-1987. SAND87-0039. Albuquerque, NM: Sandia National Laboratories.

Beauheim, R. L. 1990. "Review of Parameter Values to be used in Performance Assessment," memorandum to E. Gorham (July 31). Albuquerque, NM: Sanlia National Laboratories.

Beauheim, R. L., G. J. Saulnier, and J. D. Avis. 1990. Interpretation of Brine-Permeability Tests of the Salado Formation at the Waste Isolation Pilot Plant Site: First Interim Report, SAND90-0083. Albuquerque, NM: Sandia National Laboratories.

Berglund, J., M. G. Marielta, B. L. Baker, and B. Butcher, 1990. Sensitivity Studies of the Removal of Cuttings and Eroded Particles During a Hypothetical Human-Instrusion Event for WIPP Performance Assessment, SAND number not yet assigned. Albuquerque, NM: Sandia National Laboratories. In preparation.

Bertram-Howery, S. G. and P. Swift. 1990. Status Report: Potential for Long-Term Isolation by the Waste Isolation Pilot Plant Disposal System, 1990. SAND90-0616. Albuquerque, NM: Sandia National Laboratories.

Bertram-Howery, S. G., M. G. Marietta, R. P. Rechard, P. N. Swift, D. R. Anderson, B. Baker, J. Bean, W. Beyeler, K, F. Brinster, R. V. Guzowski, J. Helton, R. D. McCurley, D. K. Rudeen, J. Scheiber, and P. Vaughn. 1990. Preliminary Comparison with 40 CFR Part 191, Subpart B for the Waste Isolation Pilot Plant, December 1990. SAND90-2347. Albuquerque, NM: Sandia National Laboratories.

Black, S. R., R. S. Newton, and D. K. Shukla, eds, 1983. "Brine Content of the Facility Interval Strata" in Results of the Site Validation Experiments, Vol II, Supporting Document 10. Waste Isolation Pilot Plant, U.S. Department of Energy.

Borns, D. J. 1985. Marker Bed 139: A Study of Drillcore From a Systematic Array. SAND85-0023. Albuquerque, NM: Sandia National Laboratories.

Bredehoeft, J. D. 1988. "Will Salt Repositories be Dry?" in EOS, Transactions of the American Geophysical Society, 69: 121-124.

Brooks, R. H. and A. T. Corey. 1964. "Hydraulic Properties of Porous Media," Hydrology Papers, No. 3. Fort Collins, CO: Colorado State University. 
Brush, L. H. 1990. Test Plan for Laboratory and Modeling Studies of Repository and Radionuclide Chemistry for the Waste Isolation Pilot Plant. SAND90-0266. Albuquerque, NM: Sandia National Laboratories.

Brush, L. H., and A. R. Lappin. 1990. "Additional Estimates of Gas Production Rates and Radionuclide Solubility for Use in Models of WIPP Disposal Rooms," memorandum to D. R. Anderson (August 1). Albuquerque, NM: Sandia National Laboratories.

Buddenberg, J. W., and C. R. Wilke. 1949. Ind. Eng. Chem. 41: 1345-1347.

Butcher, B. M. 1990a. Mechanical Compaction of WIPP Simulated Waste. SAND90-1206. Albuquerque, NM: Sandia National Laboratories. In preparation.

Butcher, B. M. 1990b. Preliminary Evaluation of Potential Engineered Modifications for the Waste Isolation Pilot Plant (WIPP). SAND89-3095. Albuquerque, NM: Sandia National Laboratories.

Carmichae1, R. S., ed. 1984. CRC Handbook of Physical Properties of Rocks, Vol III. Boca Raton, FL: CRC Press, Inc.

Clark, S. P. 1966. Handbook of Physical Constants. New York, NY: The Geological Society of America, Inc.

Craft, B. C. and M. F. Hawkins. 1959. Applied Petroleum Reservoir Engineering. Englewood Cliffs, NJ: Prentice-Hall, Inc. 130.

Crawley, M. E. 1990. Hydraulic Testing of Marker Bed 139 at the Waste Isolation Pilot Plant, Southeastern New Mexico. Carlsbad, NM: Westinghouse Electric Company for U. S. Department of Energy. In preparation.

Darley, H. C. H., and G. R. Gray, 1988. Composition and Properties of Drilling and Completion Fluids. Houston, TX: Gulf Publishing Company.

de Marsily, G. 1986. Quantitative Hydrogeology. Orlando, FL: Academic Press, Inc., Harcourt Brace Jovanovich. 238.

Dosch, R. G. 1979. "Radionuclide Migration Studies Associated with the WIPP Site in Southern New Mexico" in G. J. McCarthy, ed., Scientific Basis for Nuclear Waste Management. New York: Plenum Publishing Company, 1: 395-398.

Driscoll, F. G., ed. 1986. Groundwater and Wells, 2nd ed., St. Paul, MN: Jonson Divison.

Earlougher, R. C. 1977. Advances in Well Test Analysis. Dallas TX: Society of Petroleum Engineers of American Institute of Mining Engineers. 232.

Earth Technology Corp. 1987. Final Report for Time Domain Electromagnetic (TDEM) Surveys of the WIPP. SAND87-7144. Albuquerque, NM: Sandia National Laboratories. 
Frederickson, A. G. 1960. "Helical Flow of an Annular Mass of Visco-Elastic Fluld." Chemical Engineering Science, Vol. II. 252-259.

Freeze, R, A. and J, C. Cherry. 1979. Groundwater. Englewood Cliffs, NJ: Prentice-Hall, Inc.

Graboski, M. S. and T. E. Daubert. 1979. "A Modified Soave Equation off State for Phase Equilibrium Calculations. 3. Systems Containing Hydrogen" in Ind. Eng. Chem. Process Des. Dev. vol. 18, no. 2. 300-306.

Gulick; C. W. and L. D. Wakeley. 1990. Reference Properties of Cement-Based Plugging and Sealing Materials for the Waste Isolation Pilot Plant.

SAND87-2817. Albuquerque, NM: Sandia National Laboratories. In preparation.

Guzowski, R. V. 1990. Preliminary Identification of Scenarios that May Affect the Release and Transport of Radionuclides from the Waste Isolation Pilot Plant, Southeastern New Mexico. SAND89-7149. Albuquerque, NM: Sandia National Laboratories.

Harr, M. E. 1987. Reliability Based Design in Civil Engineering. New York: McGraw Hill Book Co.

Haug, A., V. A. Kelley, A. M. LaVenue, and J. F. Pickens. 1987. Modeling of Groundwater Flow in the Culebra Dolomite at the Waste Isolation Pilot Plant (WIPP) Site: Interim Report. Contractor Report SAND86-7167. Albuquerque, NM: Sandia National Laboratories.

Holcomb, D. J. and M. Shields. 1987. Hydrostatic Creep Consolidation of Crushed Salt with Added Water. SAND87-1990. Albuquerque, NM: Sandia National Laboratories.

HP (Hewlett-Packard). 1984. Petroleum Fluids PAC for HP-41C. Corvallis, OR: Hewlett-Packard.

ICRP, Pub 38. 1983. Radionuclide Transformations Energy and Intensity of Emissions, ICRP Publication 38, Annals of the International Commission on Radiological Protection (ICRP), Vol 11-13.

IDB (Integrated Data Base). 1987. 1987 Integrated Data Base: Spent Fuel and Radioactive Waste Inventories, Projection and Characteristics, DOE/RW-0006 Revision 3. Oak Ridge, TN: Oak Ridge National Laboratory for U.S. Department of Energy.

IDB (Integrated Data Base). 1988. 1988 Integrated Data Base: Spent Fuel and Radioactive Waste Inventories, Projection and Characteristics, DOE/RW-0006 Revision 4. Oak Ridge, TN: Oak Ridge National Laboratory for U.S. Departinent of Energy.

IDB (Integrated Data Base). 1990. 1990 Integrated Data Base: Spent Fuel and Radioactive Waste Inventories, Projection and Characteristics. DOE/RW-0006 Revision 6. Oak Ridge, TN: Oak Ridge National Laboratory for U.S. Department of Energy. 
Kaufman, D. W. ed. 1960. Sodium Chloride, the Production and Properties of Salt and Brine, Monograph No. 145. Washington, DC: American Chemical Society.

Kelley, V. A., and J. F. Pickens. 1986. Interpretation of the ConvergentFlow Tracer Tests Conducted in the Culebra Dolomite at the $\mathrm{H}-3$ and H-4 Hydropads at the Waste Isolation Pllot Plant (WIPP) Site. SAND86-7161. Albuquerque, NM: Sandia National Laboratories.

Kelley, V. A., and G. J. Saulnier, Jr. 1990. Core Analysis for Selected Samples from the Culebra Dolomite at the Waste Isolation Pilot Plant Site. SAND90-7011. Albuquerque, NM: Sandia National Laboratories.

Krauskopf, K. B. 1986. "Thorium and Rare-Earth Metals as Analogs for Actinide Elements" in Chemical Geology 55:323-336.

Krieg, R. D. 1984. Reference Stratigraphy and Rock Properties for the Waste Isolation Pilot Plant (WIPP) Project. SAND83-1908. Albuquerque, NM: Sandia National Laboratories.

Lallemand-Barres, and P. Peaudecerf, 1978. Recherche des Relations Entre les Valeurs Mesurésde la Dispersivité Macroscropique d'un Milieu Aquifére, Ses Autres Charactéristiques et ales Conditions de Mesure. Eude Bibliograaphique. Rech. Bul1. Bur. Geol. Min. Sér. 2, Sec. III, 4-1978, 277-284.

Langmuir, D., and J. S. Herman. 1980. "The Mobility of Thorium in Natural Waters at Low Temperatures." Geochimica et Cosmochimica Acta 44: 1753-1766.

Langmuir, D., and.A. C. Riese. 1985. "The Thermodynamic Properties of Radium." Geochimica et Cosmochimica Acta 49: 1593-1601.

Lappin, A. R. 1988. Summary of Site Characterization Studies Conducted from 1983 through 1987 at Waste Isolation Pilot Plant (WIPP) Site, Southeastern New Mexico. SAND88-0157. Albuquerque, NM: Sandia National Laboratories.

Lappin, A. R., R. L. Hunter, D. P. Garber, and P. B. Davies, eds. 1989. Systems Analysis Long-Term Radionuclide Transport, and Dose Assessments, Waste Isolation Pilot Plant (WIPP), Southeastern New Mexico; March 1989. SAND 89-0462. Albuquerque, NM: Sandia National Laboratories.

LaVenue, A. M., A. Haug, and V. A. Kelley. 1988. Numerical Simulation of Ground-Water Flow in the Culebra Dolomite at the Waste Isolation Pilot Plant (WIPP) Site: Second Interim Report. SAND88-7002. Albuquerque, NM: Sandia National Laboratories.

LaVenue, A. M., T. L. Cauffman, and J. F. Pickens, 1990. Ground-water Flow Modeling of the Culebra Dolomite, Volume I: Model Calibration. SAND89-7068/1. Albuquerque, NM: Sandia National Laboratories. 
Marietta, M. G., S. G. Bertram-Howery, D. R. Anderson, K. F. Brinster, R. V. Guzowski, H. J. Iuzzolino, and R. P. Rechard. 1989. Performance Assessment Methodology Demonstration: Methodology Development for Purposes of Evaluating Compliance with EPA 40 CFR 191, Subpart B, for the WIPP. SAND89-2027. Albuquerque, NM: Sandia National Laboratories:

Marietta, M. G., P. Swift, and B. L. Baker. 1991. Parameter and Boundary Condition Sensitivity Studies Related to Climate Variability and Scenario Screening for the WIPP. SAND89-2029. Albuquerque, NM: Sandia National Laboratories. In preparation.

Mercer, J. W., and B. R. Crr. 1979. Interim Data Report on the Geohydrology of the Profosed Waste Isolation Pilot Plant Site, Southeastern New Mexico. USGS Water-Resources Investigations 79-98. Albuquerque, NM: U.S. Geological Survey.

Miller, I. and J. E. Freund. 1977. Probabilities and statistics for Engineers. Second edition. Englewood Cliffs, NJ: Prentice-Hall.

Molecke, M. A. 1979. Gas Generation from Transuranic Waste Degradation: Data Summary and Interpretation. SANL79-1245. Albuquerque, NM: Sandia National Laboratories.

Munson, D. E. 1989. "Proposed New Structural Reference Stratigraphy, Law, and Properties," memorandum to Distribution (August 22). Albuquerque, NM: Sandia National Laboratories.

Neretnieks, I., and A. Rasmussen. 1984 "An Approach to Modeling Radionuclide Migration in a Medium with Strongly Varying Velocity and Block Sizes along the Flow Path," Water Resources Research, vol. 20, no. 12: 1823-1836.

Nowak, E. J. and L. D. Tyler. 1989. "The Waste Isolation Pilot Plant (WIPP) Seal System Performance Program," Proceedings of the Joint NEA/CEC

Repositories, Braunschweig, FRG, May 22-25, 1989.

Nowak, E. J., J. R. Tillerson, and T. M. Torres. 1990. Initial Reference Seal System Design: Waste Isolation Pilot Plant (WIPP). SAND90-0355.

Albuquerque, NM: Sandia National Laboratories.

Numbere, D., W. E. Grigham, and M. B. Standing. 1977. Correlations for Physical Properties of Petroleum Reservoir Brines. Palo Alto, CA: Petroleum Research Institute, Stanford University. 17.

Oldroyd, J. G. 1958. Proceedings of the Royal Society (London) A245: 278.

Pace, R. O. 1990. Manager, Technology Exchange Technical Services, Baroid Driling Fluids, Inc., $3000 \mathrm{~N}$. Sam Houston Pkwy. E., Houston, Texas. (Expert Opinion). Letter of 18 September 1990.

Paine, R. T. 1977. Chemistry Related to the WIPP Site, Draft Final Report, Sandia Contract GTK/07-1488. Albuquerque, NM: Chemistry Departmint, University of New Mexico. 
Palmer, A. R. 1983. The Decade of North American Geolng 1983 Geologic Time Scale, Geological Society of America.

Pickens, J. F., and G. E. Grisak. 1981. Modeling of Scale-Dependent Dispersion in Hydrolgeologic Systems. Water Resources Research, vol. 17, no. 6, pp. 1701-11.

Popielak, R. S., R. L. Beauheim, S. R. Black, W. E. Coons, C. T. Ellingson, and R. L. Olsen. 1983. Frine Reservoirs in the Castile Fm., Waste Isolation Pilot Plant (WIPP) Project, Southeastern New Mexico. TME-3153. Carlsbad, NM: U.S. Department of Energy.

Powers, D. W., S. J. Lambert, S. E. Shaffer, L. R. Hill, and W. D. Weart, ed. 1978. Geological Characterization Report, Waste Isolation Pilot Plant (WIPP) Site, Southeastern New Mexico. SAND78-1596, vol. 1 and 2. Albuquerque, NM: Sandia National Laboratories.

Prausnitz, J. M. 1969. Molecular Thermodynamics of Fluid-Phase Equilibria. Englewood Cliffs, NJ: Prentice-Hall, Inc.

Rechard, R. P. 1989. Review and Discussion of Code Linkage and Data Flow in Nuclear Waste Compliance Assessments. SAND87-2833. Albuquerque, NM: Sandia National Laboratories.

Rechard, R. P., W. Beyeler, R. D. McCurley, D. K. Rudeen, J. E. Bean, and J. D. Schreiber. 1990. Parameter Sensitivity Studies of Selected Components of the Waste Isolation Pilot Plant Repository/Shaft System. SAND89-2030. Albuquerque, NM: Sandia National Laboratories.

Rechard, R. P., H. J. Iuzzolino, J. S. Rath, A. P. Gilkey, R. D. McCurley, and D. K. Rudeen. 1991. User's Manual for CAMCON: Compliance Asessment Methodology Controler. SAND88-1496. Albuquerque, NM: Sandia National Laboratories.

Reeves, M., G. Freeze, V. Kelley, J. Pickens, D. Upton, and P. Davies. 1990. Regional Double-Porosity Solute Transport in the Culebra Dolomite under BrineReservoir-Breach Release Conditions: An Analysis of Parameter Sensitivity and Importance. SAND89-7069. Albuquerque, NM: Sandia Nationa1 Laboratories. In preparation.

Riese, A. C. 1982. "Adsorption of Radium and Thorium onto Quartz and Kaolinite: A Comparison of Solution/Surface Equilibria Models, " Ph.D. Thesis, Colorado School of Mines, Golden, CO.

Ross, S. M. 1985. Introduction to Probability Models, 3rd ed. New York: Academic Press, Inc.

Sargunam, A., P. Riley, K. Arulanadum, and R. B. Krone. 1973. "PhysicoChemical Factors in Erosion of Cohesive Soils." Journal of the Hydraulics Division, American Society of Civil Engineers 99: 555-558.

Saulnier, G., T. Cauffman, V. Kelley, J. Pickens, and W. Stensrud. 1989. "Practical Aspects of Design and Implementation of a Convergent Flow Tracer Test," presented at NWWA Conference on Tracers in Hydrology: Principles, 
Problems, and Practical Applications, Houston, TX, October 30-November 1 , 1989. Abstract in Groundwater, vo1, 27, no. 5: 728.

Savins, J. G., and G. C. Wallick. 1966. "Viscosity Profiles, Discharge Rates, Pressures, and Torques for a Rheologically Complex Fluid in Helical Flow." A.I.Ch.E. Journal, vol. 12, no. 2, March 1966.

Shakoor, A, and H. R. Hume, 1981. Physical Properties Data for Rock Salt: Chapter 3, Mechanical Properties, NBS Monograph 167. Washington DC: Nationa1 Bureau of Standards, pp. 103-203.

Sjaardema, G. D. and R. D. Krieg. 1987. A Constitutive lodel for the Consolidation of WIPP Crushed Salt and Its Use in Analysis of Backfilled Shaft. and Drift Configurations. SAND87-1977. Albuquerque, NM: Sandia National Laboratories.

Skokan, C., J. Starrett, and H. T. Andersen, 1988. Final Report: Feasibility Study of Seismic Tomography to Monitor Underground Pillar Integrity at the WIPP Site. SAND88-7096. Albuquerque, NM: Sandia National Laboratories.

Stein, C. L., and J. L. Krumhans1. 1986. Chemistry of Brines in Salt from the Waste Isolation Pilot Plant (WIPP), Southeastern New Mexico: A Preliminary Investigation. SAND85-0897. Albuquerque, NM: Sandia National Laboratories.

Stensrud, W. A., M. A. Bame, K. D. Lantz, J. B. Palmer, and G. J. Saulnier, Jr. 1990. WIPP Hydrology Program, Waste Isolation Pilot Plant, Southeastern New Mexico, Hydrologic Data Report No. 8. SAND87-7056. Albuquerque, NM:

Sandia National Laboratories.

Streeter, V. L., and E. B. Wylie. 1975. Fluid Mechanics. Sixth Edition. New York, NY: McGraw-Hill Book Co.

Sutherland, H. J. and S. Cave. 1978. Gas Permeability of SENM Rock Salt. SAND78-2287. Albuquerque, NM: Sandia National Laboratories.

Tien, P. L., F. B. Nimick, A. B. Muller, P. A. Davis, R. V. Guzowski, L. E. Duda, and R. L. Hunter. 1983. Repository Site Data and Information in Bedded Salt: Palo Duro Basin, Texas. SAND82-2223, NUREG/CR-3129. Albuquerque, NM:

Sandia National Laboratories.

Tierney, M. S. 1990a. Constructing Probability Distributions o: Uncertain Variables in the Models of the Performance of the Waste Isolation Pilot Plant (WIPP). SAND90-2510. Albuquerque, NM: Sandia National Laboratories.

Tierney, M. S. 1990b. Combining Scenarios in a Calculation of the Overall Probability Distribution of Cumulative Releases of Radioactivity from the Waste Isolation Pilot Plant, Southeastern New Mexico. SAND90-0838.

Albuquerque, NM: Sandia National Laboratories.

Tyler, L. D., R. V. Matalucci, M. A. Molecke, D. E. Munson, E. J. Nowak, and J. C. Stormont. 1988. Summary Report for the WIPP Technology Development 
Program for Isolation of Radioactive Waste. SAND88-0844. Albuquerque, NM: Sandia National Laboratories.

U.S. Department of Energy. 1987. DOE/WIPP-88-005. Carlsbad, NM: U.S. Department of Energy.

U.S. Department of Energy. 1989. Addendum to No-Migration Variance Petition for Waste Isolation Pilot Plant. DOE/WIPP-89-003. U.S. Department of Energy, Carlsbad, NM, §2.1.

U.S. Department of Energy. 1990. WIPP Test Phase Plan: Performance Assessment. DOE/WIPP 89-011, Rev. 0. Carlsbad, NM.

U.S. Department of Energy/State of New Mexico. 1984. U.S. Department of Energy and State of New Mexico, 1981, First Modification to the July 1, 1981 "Agreement for Consultation and Cooperation" on WIPP by the State of New Mexico and U.S. Department of Energy, November 30, 1984.

U.S. Environmental Proteclion Agency. 1985. Environmentrl Radiation Protection Standards for Management and Disposal of Spent Nuclear Fuel, HighLeve1, and Transuranic Radioactive Wastes. (40 CFR 191). Federal Register, 50: $38066-38089$.

Walas, S. M. 1985. Phase Equilibrium in Chemical Engineering. Boston, MA: Butterworth Publishers. 52-54.

Ward, J. S., and N. R. Morrow. 1985. "Capillary Pressures and Gas Permeabilities of Low-Permeability Sandstone." SPE/DOE 13882. Paper presented at the SPE/DOE 1985 Low Permeability Gas Reservoirs, Denver, CO., May 19-22, 1985 .

Wawersik, W. R., and C. M. Stone. 1985. Application of Hydraulic Fracturing to Determine Virgin In Situ Stress Around Waste Isolation Pilot Plant--In Situ Measurements. SAND85-1775. Albuquerque, NM: Sandia National Laboratories.

WEC (Westinghouse Electric Corporation). 1985. TRU Waste Acceptance Criteria for the Waste Isolation Pilot Plant, Revision 2. WIPP-DOE-069-Rev. 2. Carlsbad, NM: Westinghouse Electric Corporation.

WEC (Westinghouse Electric Corporation). 1989. Waste Isolation Pilot Plant No-Migration Variance Petition, Vol. 1. DOE/WIPP 89-003. Prepared for U.S. Department of Energy. Carlsbad, NM: Westinghouse Electric Corporation. 


\section{APPENDIX A: \\ MEMORANDA AND LETTERS REGARDING REFERENCE DATA}

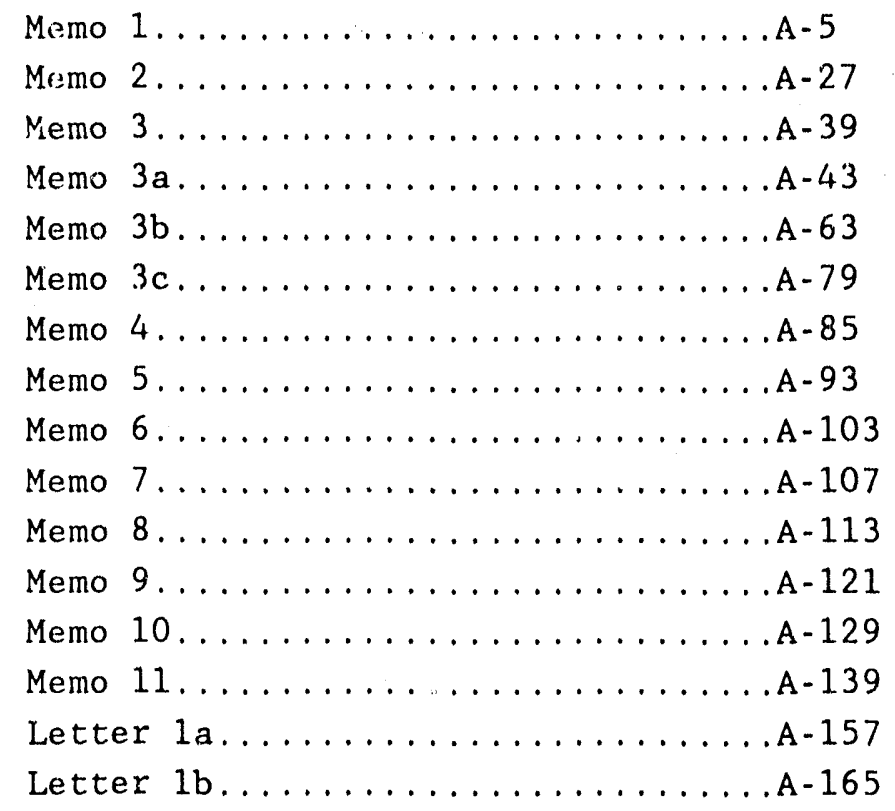

A- $1 / 2$ 


\section{APPENDIX A: MEMORANDA AND LETIERS REGARDING REFERENCE DATA}

The memoranda provided are as follows:

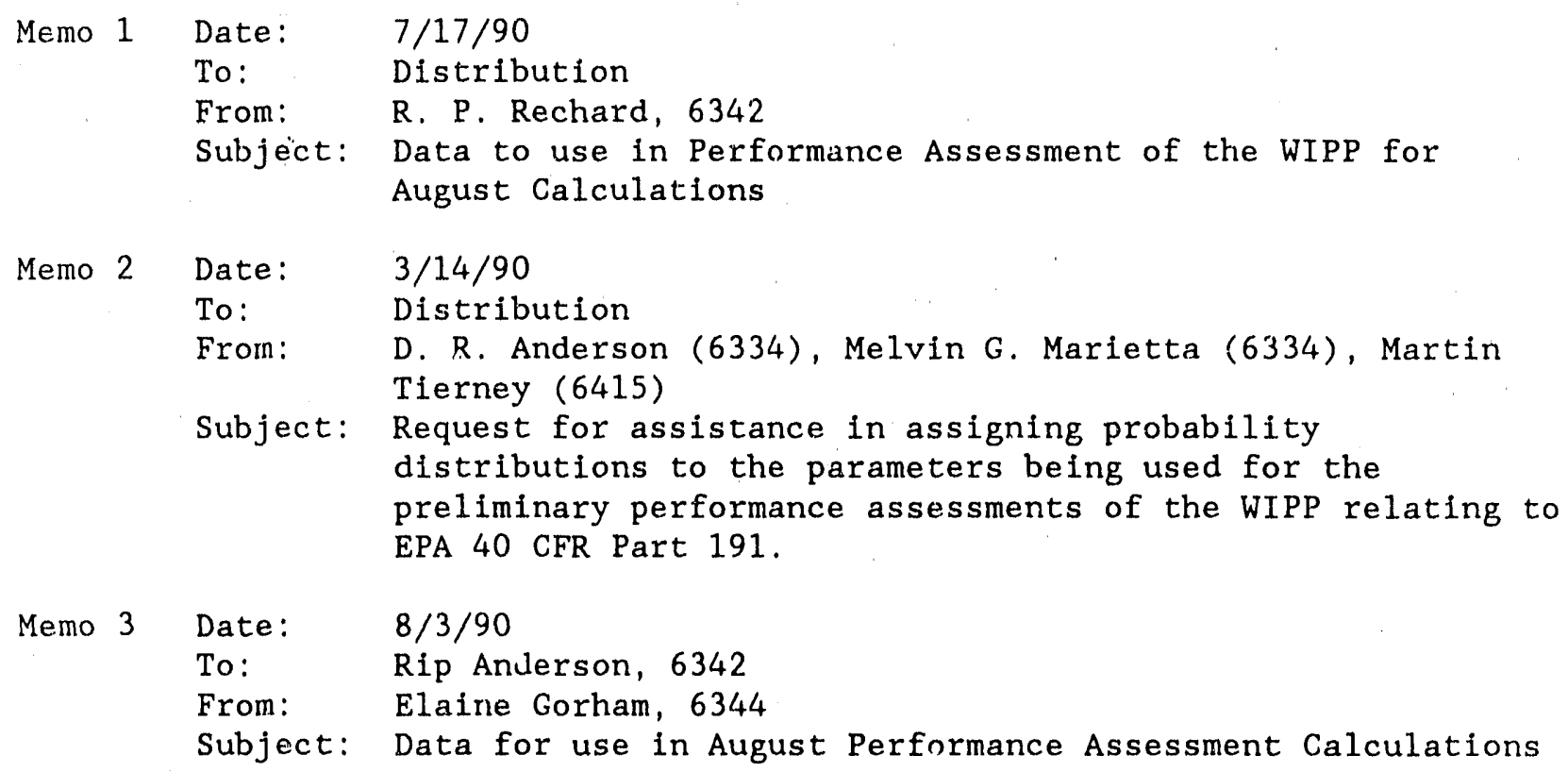

NOTE: Memo 3 includes the following memos:

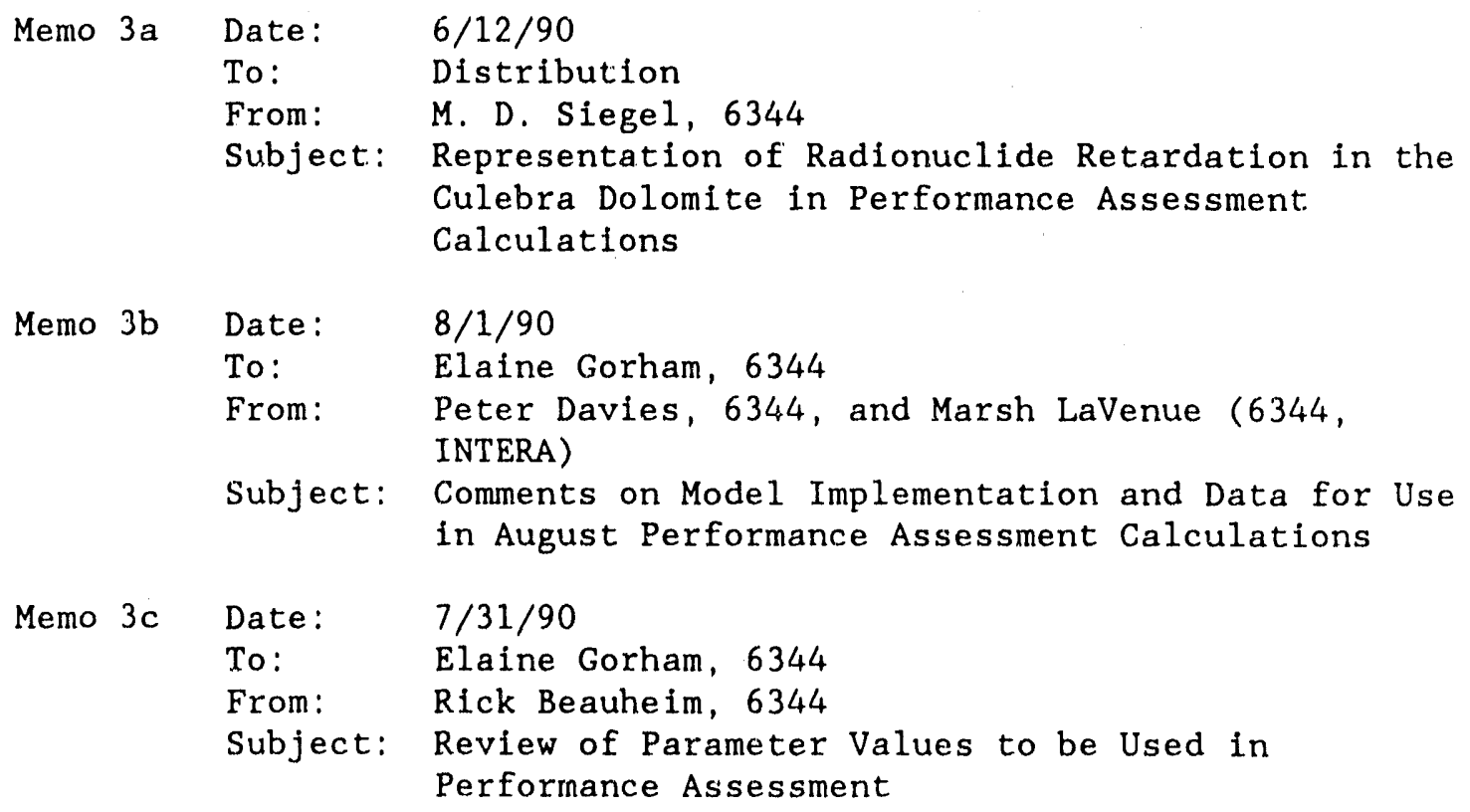




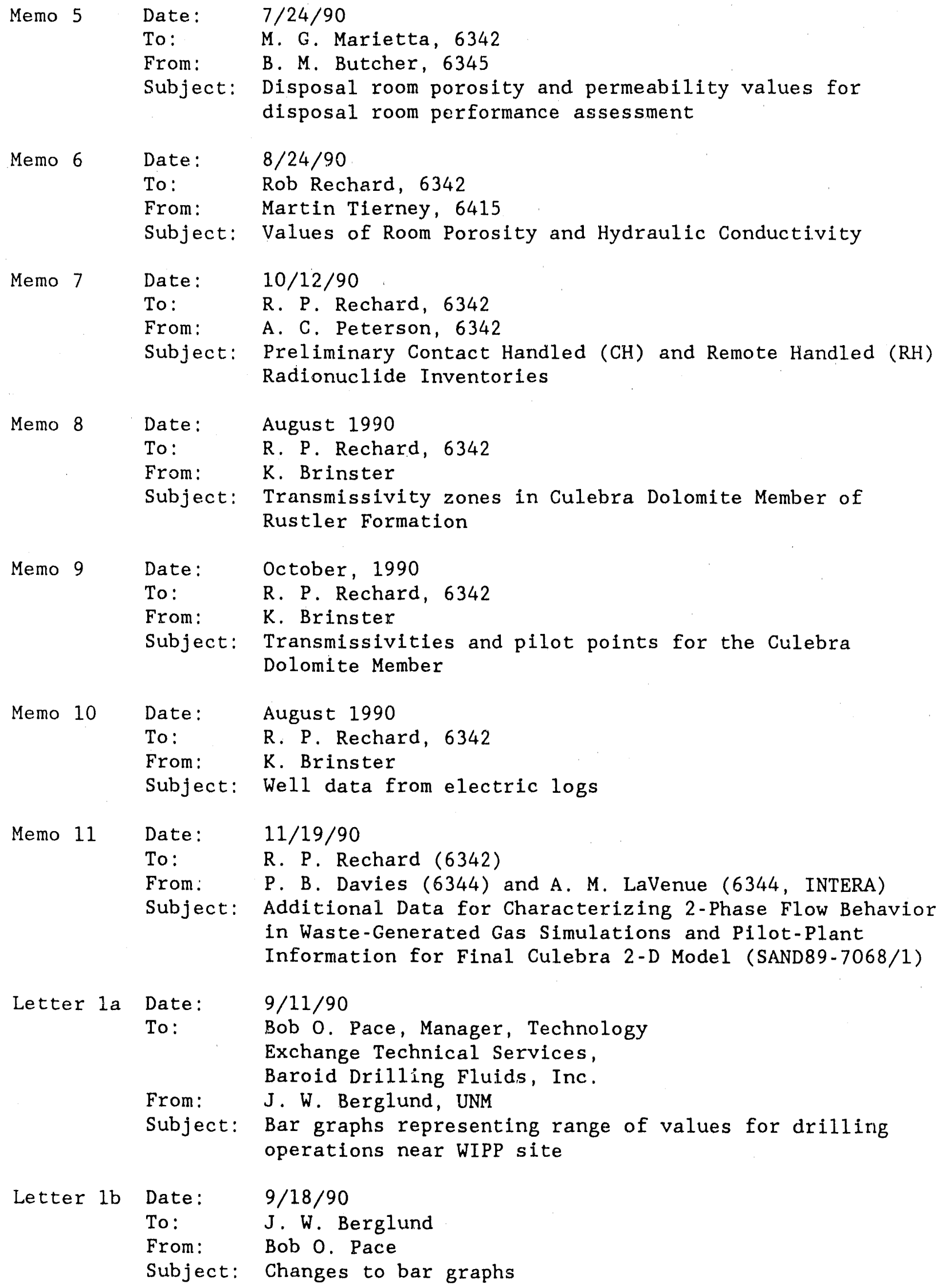




\section{Memo 1}

Date: $\quad 7 / 17 / 90$

To: $\quad$ Distribution

From: R. P. Rechard, 6342

Subject: Data to use in Performance Assessment of the WIPP for August Calculations 


\section{Sandia National Laboratories}

date: July 17,1990

Albuquerque, New Mexico 87185

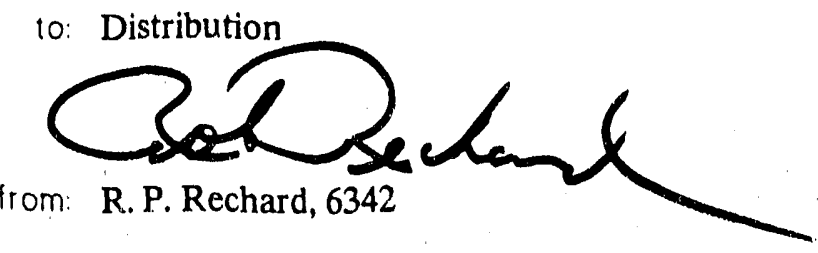

subject: Data to use in Performance Assessment of the WIPP for August Calculations

As indicated in the meetings on July 13, the data reported in Appendix A of SAND89-2030 (Rechard et al., 1990) is being used as a starting point for data to use in the August calculations. These calculations will be documented in a SAND report and presented at the December NAS meeting. Appendix A is part of the attachments of this memo. Data highlighted in Appendix $A$, is data that will actually be sampled for uncertainty analysis. For all other data needed, the median value will be used. (After the discussion on July 13, you all indicated that the value listed under "expected value" in Appendix A should be treated as the median value by the PA division.)

In addition to Appendix $A$, the conceptual models for the Culebra Dolomite member, the Salado Formation around the repository, and the brine pocket are included. For the Culebra, permeability data for the zones shown will be sampled. For the Brine Pocket, the initial brine pocket pressure and volume release per unit decrease in brine pocket pressure will be sampled. (The conceptual model for the brine pocket will be discussed this Friday, July 20 at the Rustler Working Group Meeting.)

Clearly, the median values of all data, and the ranges on data to sample nust be approved by you. We would also appreciate your examination of ranges on other data. Please indicate your approval or changes to as much of the data as possible in a memo to your supervisor. Your supervisor will then collect the individual memos and pass them on to Rip or me.

Because this is the first time and because of our lack of time before the PA calculations must begin, the data collection is process is a little rough. For future data requests, we hope to hand out a data form with current estimates of distributions on data, the plots of the distributions, space for changes, space for indicating your approval on each data item, and figures on conceptual models.

The PA division greatly appreciates the time spent in delivering data to us.

RPR:6342:rpr

Copy w/ attachments:

6342 M. G. Marietta

6342 R.P. Rechard

6344 R. L. Beauheim

6344 P. B. Davies

6344 S. J. Finley

6344 S. M. Howarth

6344 C. F. Novak

6345 L. M. Brush

6345 B. M. Butcher

6346 J. E. Nowak
Copy w/o attachments:

6341 R. C. Lincoln

6342 S. G. Bertram-Howery

6342 A. C. Peterson

6343 T. M. Schultheis

6344 E. D. Gorham

6345 A. R. Lappin

6346 J. R. Tillerson 


\section{APPENDIX A}

\section{MATERIAL PROPERTY VALUES}

The tables in this appendix contain the material properties that are used in the calculations described in this report. Any exceptions to these values are specifically noted in the descriptions of the simulations (Chapters 3 and 4). The sources of the data are noted in the tables. The primary source of information is the deterministic disposal system analysis by Lappin et al. (1989). However, an important addition to the data is an expanded range for the capacitance (i.e., specific storativity divided by specific weight) for the Salado Formation, which is three orders of magnitude larger than the expected value of Lappin et al. (1989) (McTigue, 1989). A significant revision might occur in this capacitance value, but it currently provides an upper bound. Also included are data for two-phase properties to account for waste-generated gas. These later parameter values are rough estimates, and significant revisions are expected in the future. 
TABLE A-1. PARAMETER VALUES FOR SALADO FORMATION

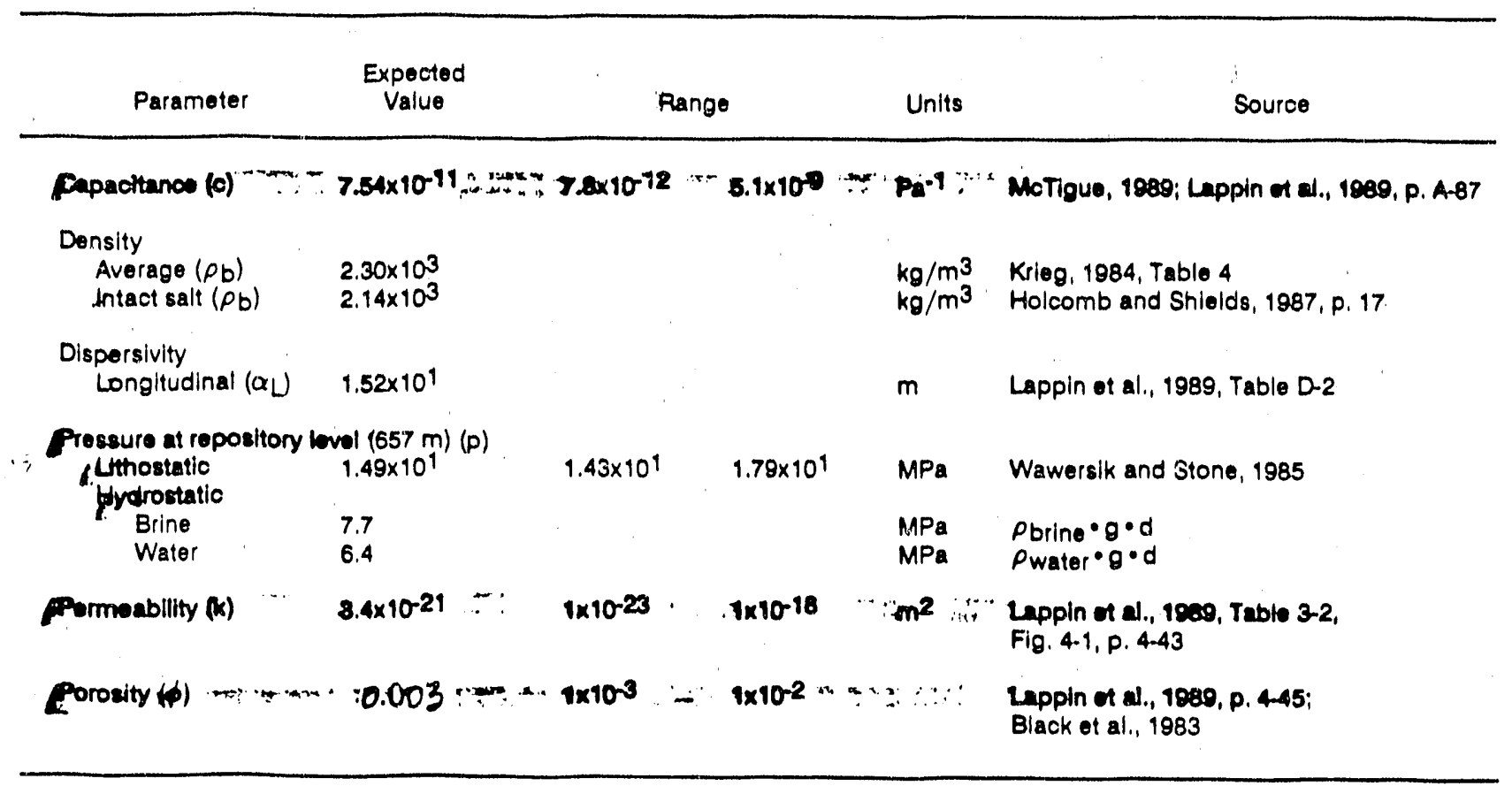


Appendix A

TABLE A.2. PARAMETER VALUES FOR MARKER BED $139 \frac{1}{1} A_{n}, f$ \&

\begin{tabular}{|c|c|c|c|c|c|}
\hline Parameter & $\begin{array}{l}\text { Expocted } \\
\text { Value }\end{array}$ & \multicolumn{2}{|c|}{ Range } & Units & Source \\
\hline Density, rock $(\rho)$ & \multicolumn{4}{|c|}{ (See Table A-9, anhydrite.) } & \\
\hline $\begin{array}{l}\text { Permeability }(k) \\
\text { Porosity }(\phi) \\
\text { Fracture }\end{array}$ & $\begin{array}{l}3.3 \times 10^{-7} \\
1.0 \\
1 \times 10^{-1}\end{array}$ & & & $m^{2}$ & $\begin{array}{l}\text { Lappin of al., 1989, Table D-2 } \\
\text { Lappin of al., 1989, Table D-2 } \\
\text { Lappin ot al., 1989, p. } 4-62\end{array}$ \\
\hline $\begin{array}{l}\text { Pondtion, undisturtoed } \\
\text { Permeabillty }(k)\end{array}$ & $1 \times 10^{-19}$ & $1 \times 10^{-20}$ & $1 \times 10^{-18}$ & $m^{2}$ & DOE, $1989, \S 1,2$ \\
\hline Thickness & $9.0 \times 10^{-1}$ & $6.5 \times 10^{-1}$ & 1.05 & $m$ & Berns, 1985, Flg. 3 \\
\hline
\end{tabular}


TABLE A-3. PARAMETER VALUES FOR CULEBRA DOLOMITE MEMBER OF RUSTLER FORMATION

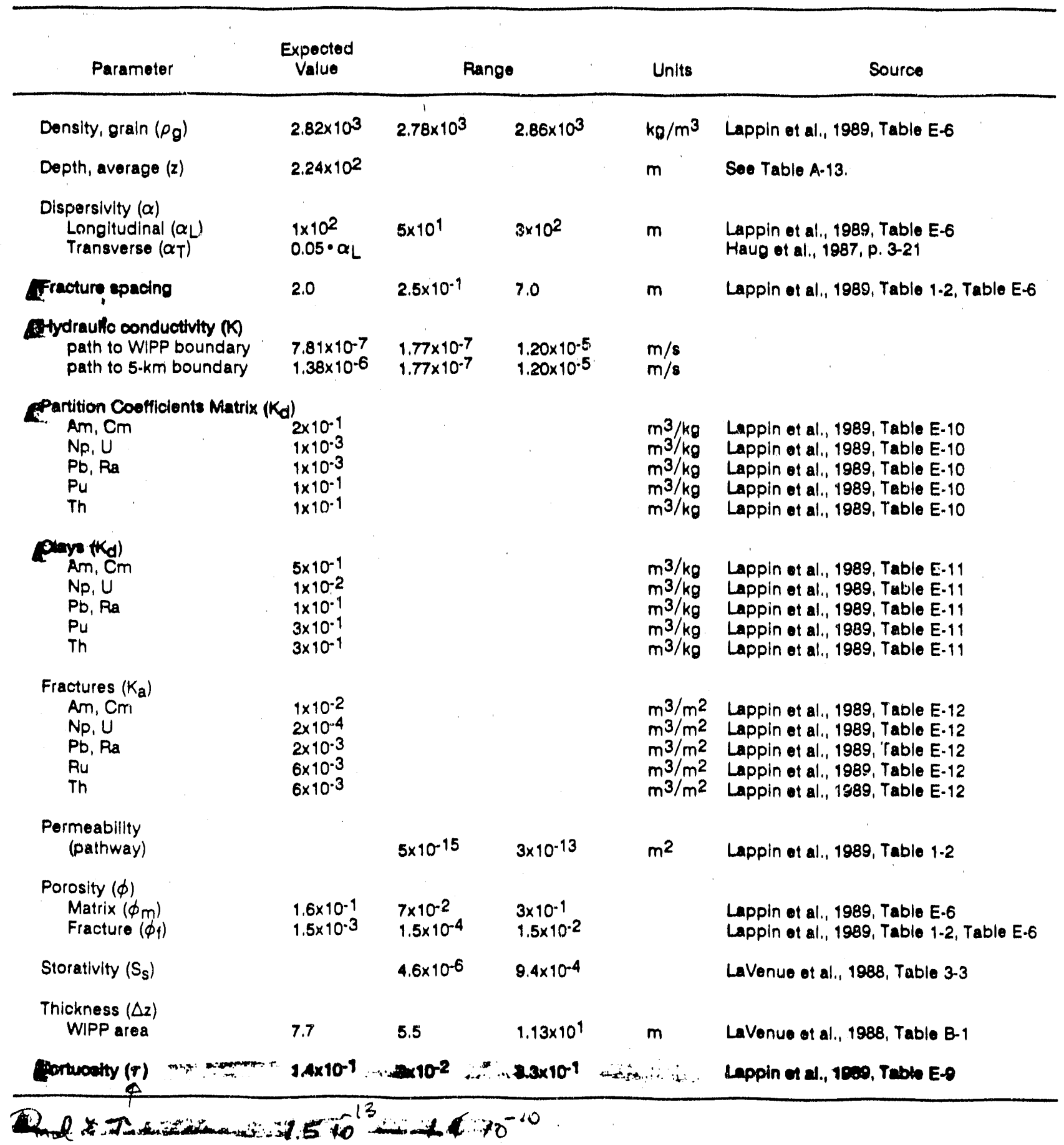


TABLE A-4. PARAMETER VALUES FOR CASTILE FORMATION BRINE POCKET

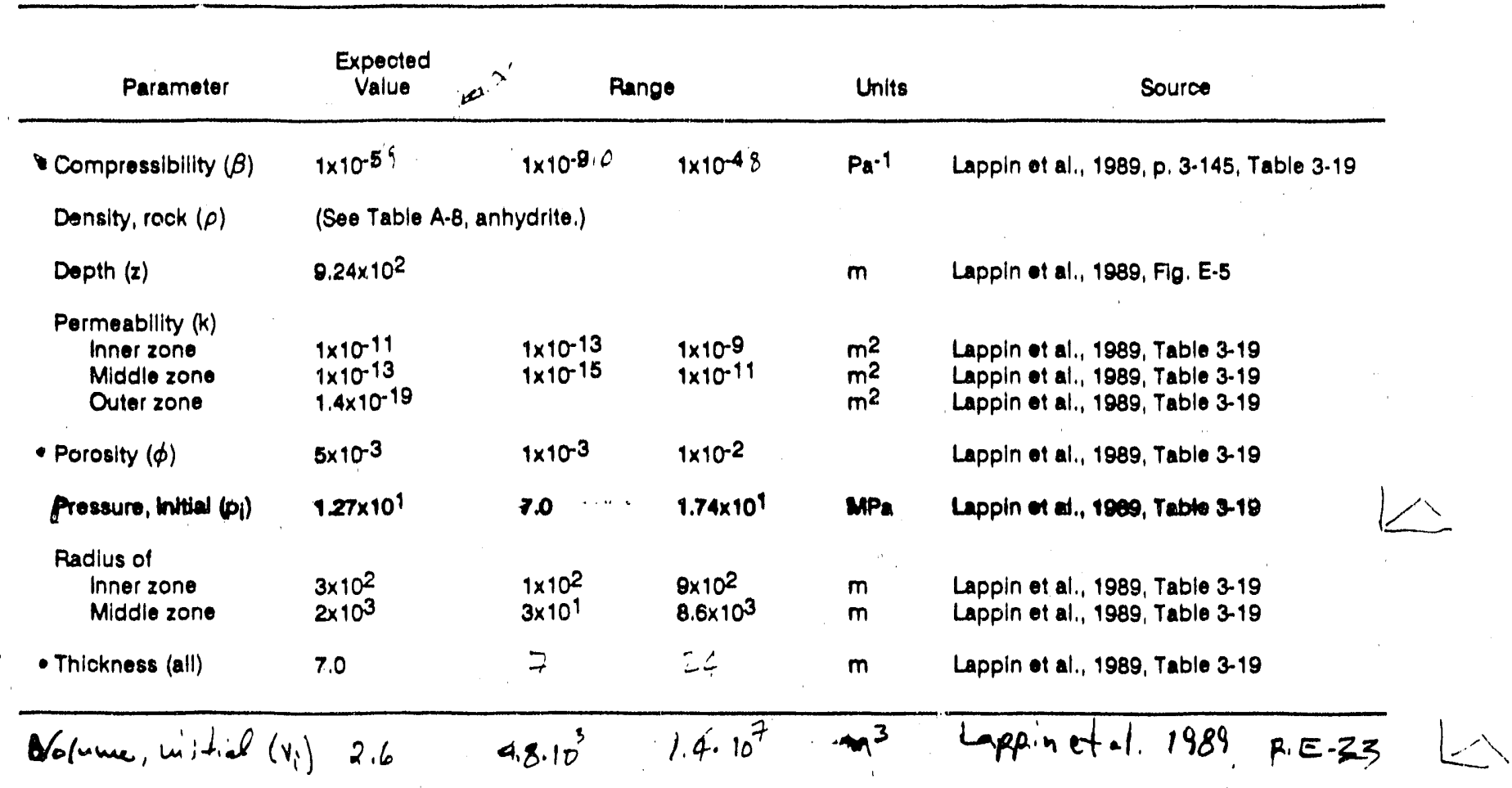


TABLE A-5. RELATIVE PERMEABILITIES FOR TYPICAL SALT (Rough Estimates)

\begin{tabular}{llll}
\hline $\begin{array}{c}\text { Saturation } \\
\text { (S) }\end{array}$ & $\begin{array}{c}\text { for water } \\
\left(\mathrm{k}_{\mathrm{rw}}\right)\end{array}$ & $\begin{array}{c}\text { Saturation } \\
(\mathrm{S})\end{array}$ & $\begin{array}{c}\text { for gas } \\
\left(\mathrm{k}_{\mathrm{rg}}\right)\end{array}$ \\
\hline 0.275 & 0.0 & 0.0 & 0.0 \\
0.2875 & $4.600 \times 10^{-8}$ & 0.035 & 0.0 \\
0.30 & $8.525 \times 10^{-7}$ & 0.0425 & $2.554 \times 10^{-6}$ \\
0.35 & $8.718 \times 10^{-5}$ & 0.05 & $2.032 \times 10^{-5}$ \\
0.40 & $7.497 \times 10^{-4}$ & 0.10 & $1.59 \times 80^{-3}$ \\
0.50 & $8.915 \times 10^{-3}$ & 0.20 & $2.408 \times 10^{-2}$ \\
0.60 & $4.195 \times 10^{-2}$ & 0.30 & $9.154 \times 10^{-2}$ \\
0.70 & $1.299 \times 10^{-1}$ & 0.40 & $2.177 \times 10^{-1}$ \\
0.80 & $3.163 \times 10^{-1}$ & $0.059 \times 10^{-1}$ \\
0.90 & $6.592 \times 10^{-1}$ & 0.60 & $6.485 \times 10^{-1}$ \\
0.95 & $9.116 \times 10^{-1}$ & 0.65 & $7.850 \times 10^{-1}$ \\
0.9575 & $9.550 \times 10^{-1}$ & $0.276 \times 10^{-1}$ \\
0.965 & 1.000 & 0.7125 & $9.638 \times 10^{-1}$ \\
& & 0.725 & 1.0000 \\
\hline
\end{tabular}




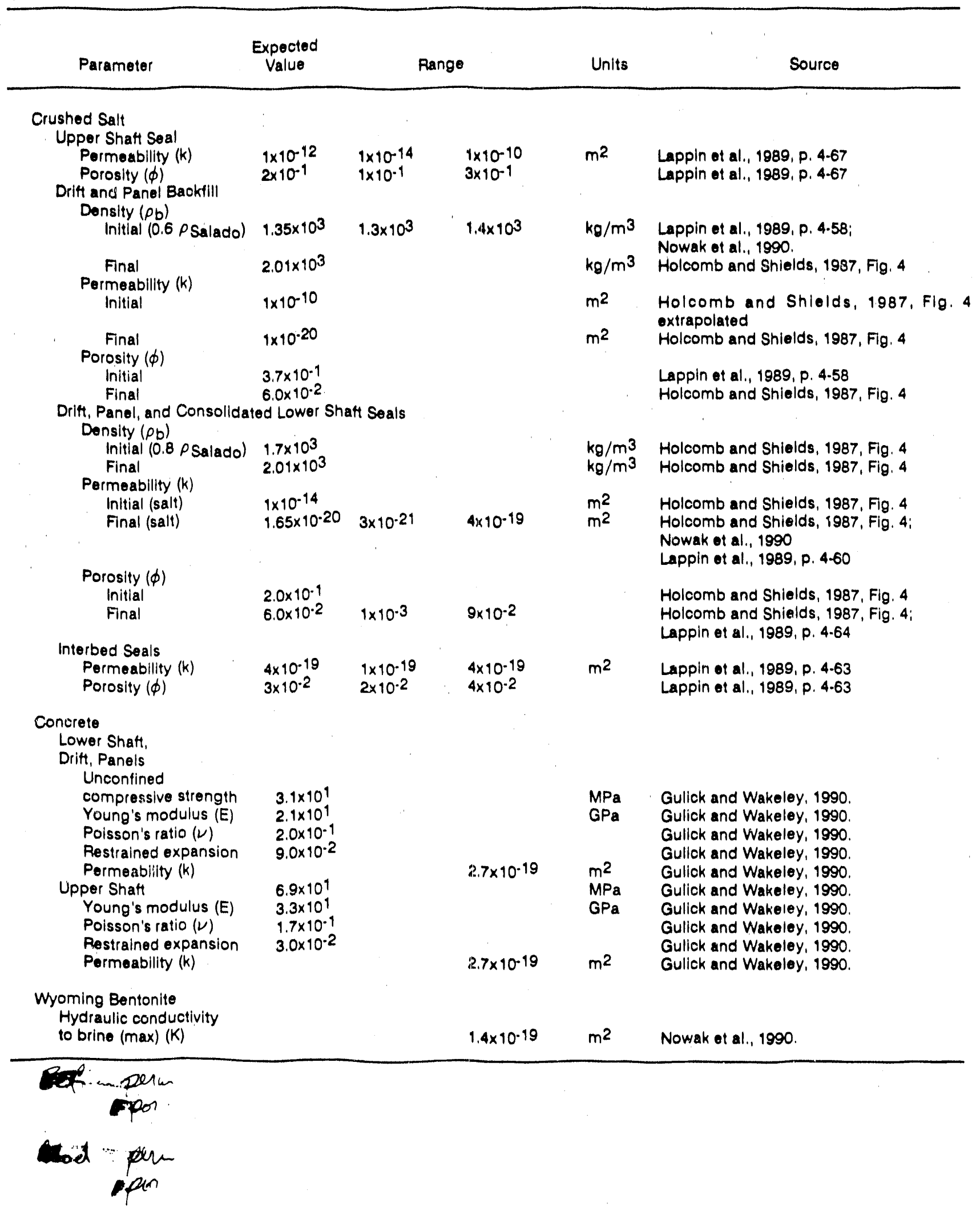


TABLE A-7. PARAMETER VALUES FOR UNMODIFIED AVERAGE WASTE

\begin{tabular}{|c|c|c|c|c|c|}
\hline Parameter & $\begin{array}{l}\text { Expected } \\
\text { Value }\end{array}$ & , & ange & Units & Source \\
\hline Compressibility $\left(\beta_{8}\right)$ & $1 \times 10^{-9}$ & & & $\mathrm{~Pa}^{-1}$ & $\begin{array}{l}\text { Author's opinion, based on Freeze and } \\
\text { Cherry, 1979, Table } 2.5 \text {. }\end{array}$ \\
\hline $\begin{array}{l}\text { Pes generation } \\
\text { Corrosion }\left(\mathrm{H}_{2}\right) \\
\text { Miorobiological } \\
\text { Potential } \\
\text { Corrosion }\left(\mathrm{H}_{2}\right) \\
\text { Microblological }\end{array}$ & & $\begin{array}{l}0 \\
0 \\
0 \\
0\end{array}$ & $\begin{array}{l}1.7 \\
8.5 \times 10^{-1} \\
8.9 \times 10^{2} \\
6.0 \times 10^{2}\end{array}$ & $\begin{array}{l}\text { mole/drum } / y r \\
\text { mole/drum } / \mathrm{yr}^{\mathrm{r}} \\
\text { mole/drum-eq } \\
\text { mole/drum-eq }\end{array}$ & $\begin{array}{l}\text { Lappin ot al., 1989, p. 4-84 } \\
\text { Lappin ot al., 1989, p. 4-84 } \\
\text { Lappin of al., 1989, p. 4-78 } \\
\text { Lappin ot al., 1989, p. 4-78 }\end{array}$ \\
\hline $\begin{array}{l}\text { Permeability (k) } \\
\text { Initial } \\
\text { Final }\end{array}$ & $\begin{array}{l}5 \times 10^{-11} \\
1 \times 10^{-15}\end{array}$ & $1 \times 10^{-18}$ & $1 \times 10^{-13}$ & $m^{2}$ & $\begin{array}{l}\text { Holcomb and Shields, 1987, Fig. 4, } \\
\text { oxtrapolated } \\
\text { Lappin ot al., 1989, Table 4-6 }\end{array}$ \\
\hline $\begin{array}{l}\text { Porosity }(\phi) \\
\text { Initial } \\
\text { Final } \\
\text { Solubility (S) }\end{array}$ & $\begin{array}{l}6.8 \times 10^{-1} \\
1.8 \times 10^{-1} \\
1 \times 10^{-6}\end{array}$ & $\begin{array}{l}1.5 \times 10^{-1} \\
1 \times 10^{-9}\end{array}$ & $\begin{array}{l}2.1 \times 10^{-1} \\
1 \times 10^{-3}\end{array}$ & Molar & $\begin{array}{l}\text { Lappin of al., 1989, Fig. 4-8 } \\
\text { Lappin of al., 1989, Table 4-6 } \\
\text { Lappin of al., 1989, p. } 4-29\end{array}$ \\
\hline
\end{tabular}


TABLE A-8. PARAMETER VALUES FOR SPECIFIC MATERIALS

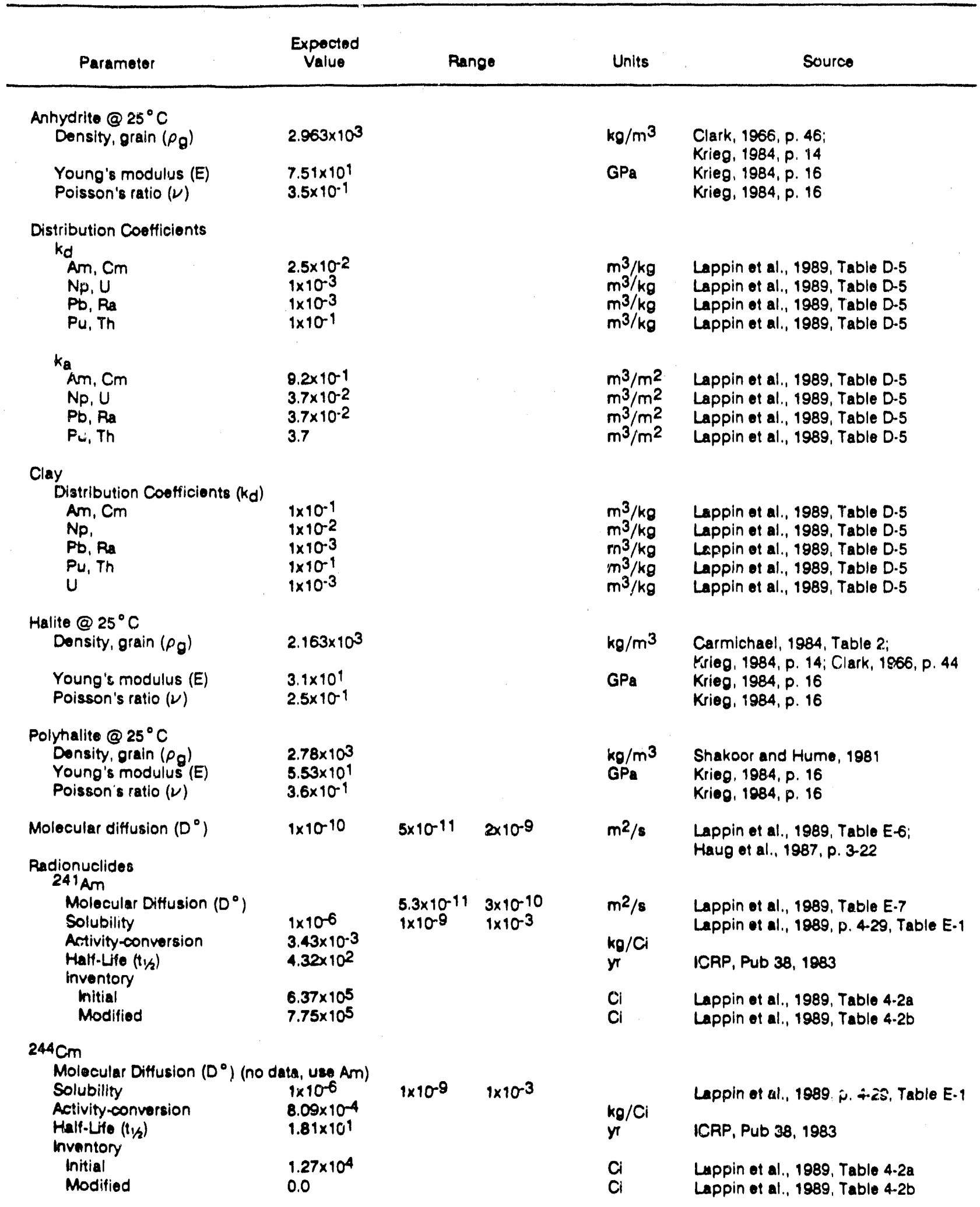


TABLE A-8. PARAMETER VALUES FOR SPECIFIC MATERIALS (Continued)

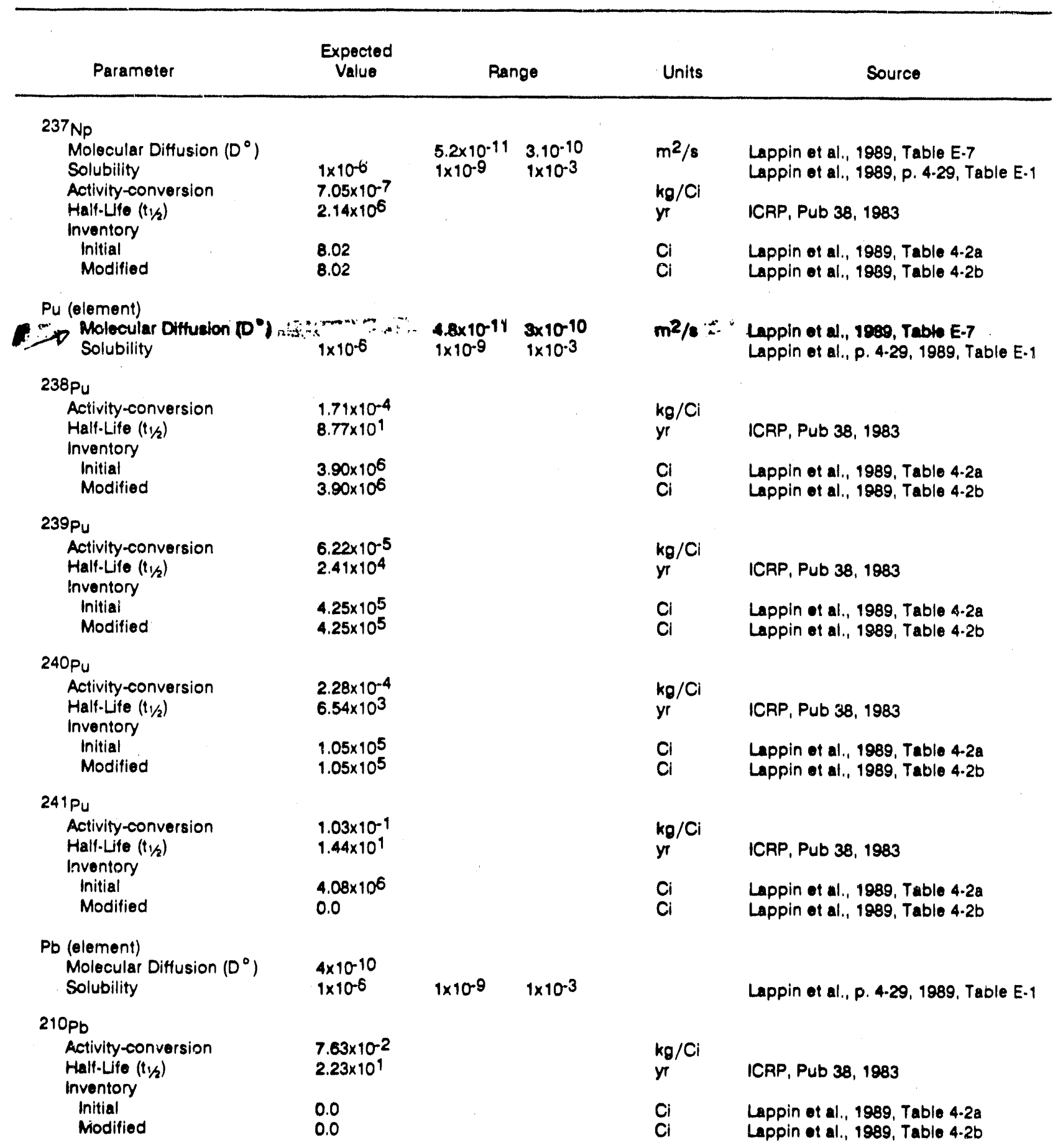


TABLE A-8 PARAMETER VALUES FOR SPECIFIC MATERIALS (Conciuded)

\begin{tabular}{|c|c|c|c|c|c|}
\hline Parameter & $\begin{array}{l}\text { Expected } \\
\text { Value }\end{array}$ & \multicolumn{2}{|c|}{ Range } & Units & Source \\
\hline $\begin{array}{l}\text { Molecular Diffusion }\left(D^{\circ}\right) \\
\text { Solubility } \\
\text { Activity-conversion } \\
\text { Half-Life }(1 / 2) \\
\text { Inventory } \\
\text { Initial } \\
\text { Modified }\end{array}$ & $\begin{array}{l}7.5 \times 10^{-6} \\
1 \times 10^{-6} \\
9.89 \times 10^{-4} \\
1.60 \times 10^{-3} \\
0.0 \\
0.0\end{array}$ & $1 \times 10^{-9}$ & $1 \times 10^{-3}$ & $\begin{array}{l}\mathrm{kg} / \mathrm{Ci} \\
\mathrm{yr}\end{array}$ & $\begin{array}{l}\text { Lappin of al., 1889, p. 4-29, Table E-1 } \\
\text { ICRP, Pub 38, 1983 } \\
\text { Lappin ot al., 1989, Table 4.2a } \\
\text { Lappin of al., 1989, Table 4.2b }\end{array}$ \\
\hline $\begin{array}{l}\text { 232Th } \\
\text { Molecular Diffusion }\left(D^{\circ}\right) \\
\text { Solubility } \\
\text { Activity-conversion } \\
\text { Half-Life }(t / 2) \\
\text { Inventory } \\
\text { Initial } \\
\text { Modified }\end{array}$ & $\begin{array}{l}1 \times 10^{-6} \\
1.10 \times 10^{10} \\
1.41 \times 10^{10} \\
2.74 \times 10^{-1} \\
0.0\end{array}$ & $\begin{array}{l}5 \times 10^{-11} \\
1 \times 10^{-9}\end{array}$ & $\begin{array}{l}1.5 \times 10^{-10} \\
1 \times 10^{-3}\end{array}$ & $\begin{array}{l}\mathrm{m}^{2} / \mathrm{s} \\
\mathrm{kg} / \mathrm{Ci} \\
\mathrm{rr} \\
\mathrm{Ci} \\
\mathrm{Ci}\end{array}$ & $\begin{array}{l}\text { Lappin of al., 1989, Table E-7 } \\
\text { Lappin of al., 1989, p. 4-29, Table E.1 } \\
\text { ICRP, Pub 38, } 1983 \\
\text { Lappin of al., 1989, Table 4-28 } \\
\text { Lappin ot al., 1989, Table 4-2b }\end{array}$ \\
\hline $\begin{array}{l}\text { U (element) } \\
\text { Molecular Diffusion }\left(D^{\circ}\right) \\
\text { Solubility }\end{array}$ & $1 \times 10^{-6}$ & $\begin{array}{l}1.1 \times 10^{-10} \\
1 \times 10^{-9}\end{array}$ & $\begin{array}{l}4.3 \times 10^{-10} \\
1 \times 10^{-3}\end{array}$ & $\mathrm{~m}^{2} / \mathrm{s}$ & $\begin{array}{l}\text { Lappin of al., 1889, Table E-7 } \\
\text { Lappin of al., 1989, p. 4-29, Table E-1 }\end{array}$ \\
\hline $\begin{array}{l}233 U \\
\text { Activity-sonversion } \\
\text { Half-Lifo (t } 1 / 2) \\
\text { Inventory } \\
\text { Initial } \\
\text { Modified }\end{array}$ & $\begin{array}{l}9.68 \times 10^{-6} \\
1.59 \times 10^{5} \\
7.72 \times 10^{3} \\
7.72 \times 10^{3}\end{array}$ & & & $\begin{array}{l}\mathrm{kg} / \mathrm{Ci} \\
\mathrm{yr} \\
\mathrm{Ci} \\
\mathrm{Ci}\end{array}$ & $\begin{array}{l}\text { ICRP, Pub 38, } 1983 \\
\text { Lappin ot al., 1989, Table 4.2a } \\
\text { Lappin of al.。 1889, Table 4-2b }\end{array}$ \\
\hline $\begin{array}{l}235 \\
\text { Activity-conversion } \\
\text { Half-Life }\left(t_{1} / 2\right) \\
\text { Inventory } \\
\text { Initial } \\
\text { Modified }\end{array}$ & $\begin{array}{l}2.16 \times 10^{-9} \\
7.40 \times 10^{8} \\
3.7 \times 10^{-1} \\
3.7 \times 10^{-1}\end{array}$ & & & $\begin{array}{l}\mathrm{kg} / \mathrm{Ci} \\
\mathrm{yr} \\
\mathrm{Ci} \\
\mathrm{Ci}\end{array}$ & $\begin{array}{l}\text { ICRP, Pub 38, } 1983 \\
\text { Lappin ot al., 1989, Table 4.2a } \\
\text { Lappin of al., 1989, Table 4.2b }\end{array}$ \\
\hline $\begin{array}{l}238 \text { Uctivity-conversion } \\
\text { Half-Life }\left(t_{1 / 2}\right) \\
\text { Inventory }\end{array}$ & $\begin{array}{l}3.36 \times 10^{.10} \\
4.47 \times 10^{9}\end{array}$ & & & $\begin{array}{l}\mathrm{kg} / \mathrm{Ci} \\
\mathrm{yr}\end{array}$ & ICRP, Pub 38, 1883 \\
\hline $\begin{array}{l}\text { Initial } \\
\text { Modified }\end{array}$ & $\begin{array}{l}1.47 \\
0.0\end{array}$ & & & $\begin{array}{l}\mathrm{Ci} \\
\mathrm{Ci}\end{array}$ & $\begin{array}{l}\text { Lappin of al., 1989, Table 4-2a } \\
\text { Lappin of al, 1989, Table 4-2b }\end{array}$ \\
\hline
\end{tabular}


TABLE A-9. FLUID PROPERTIES

\begin{tabular}{|c|c|c|c|c|c|}
\hline Parameter & $\begin{array}{l}\text { Expected } \\
\text { Value }\end{array}$ & & Range & Units & Source \\
\hline $\begin{array}{l}\text { Brine, Culebra } \\
\text { Donsity }(\rho f) \\
\text { Dittusivity }\left(D^{\circ}\right) \\
\text { Viscosity }(\mu)\end{array}$ & $\begin{array}{l}1.092 \times 10^{3} \\
2 \times 10^{-9} \\
1.0 \times 10^{-3}\end{array}$ & & & $\begin{array}{l}\mathrm{kg} / \mathrm{m}^{3} \\
\mathrm{~m}^{2} / \mathrm{s} \\
\mathrm{Pa}-\mathrm{s}\end{array}$ & $\begin{array}{l}\text { Marietta of al., 1989, Table } 3-9 \\
\text { Haug of al., 1987, p. 3.22 } \\
\text { Haug of al., 1987, p. 3-20 }\end{array}$ \\
\hline $\begin{array}{l}\text { Brine, Castile Reservoir } \\
\text { Density }\left(\rho_{f}\right)\end{array}$ & $1.24 \times 10^{3}$ & & & $\mathrm{~kg} / \mathrm{m}^{3}$ & Lappin ot al., 1889, Table 3-10 \\
\hline $\begin{array}{l}\text { Brine, Salado, } 1.013 \times 105 \\
\text { Density }(\rho f) \\
\text { Compressibility }\left(\beta_{f}\right) \\
\text { Viscosity }(\mu)\end{array}$ & $\begin{array}{l}@ 28^{\circ} \mathrm{C} \\
1.2 \times 10^{3} \\
2.7 \times 10^{-10} \\
1.6 \times 10^{-3}\end{array}$ & & & $\begin{array}{l}\mathrm{kg} / \mathrm{m}^{3} \\
\mathrm{~Pa}^{-1} \\
\mathrm{~Pa}-\mathrm{s}\end{array}$ & $\begin{array}{l}\text { Stoin and Krumhansl, } 1886 \\
\text { Kaufman, 1960, p. } 609 \\
\text { Kaufman, 1960, p. } 622\end{array}$ \\
\hline $\begin{array}{l}\text { Gas, } 100 \% \mathrm{H}_{2}, 1.013 \times 10^{5} \\
\quad \text { Viscosity }(\mu)\end{array}$ & . $@ 25^{\circ} \mathrm{C}$ & $8.84 \times 10^{-6}$ & $9.8 \times 10^{-6}$ & Pa.s & $\begin{array}{l}\text { Buddenbero and Wilke, 1949; } \\
\text { Strooter and Wylie, 1975, Fig. C-1 }\end{array}$ \\
\hline $\begin{array}{l}\text { Water @ } 25^{\circ} \mathrm{C} \\
\text { Compressiblity }\left(\beta_{f}\right) \\
\text { Density }\left(\rho_{f}\right) \\
\text { Viscosity }(\mu)\end{array}$ & $\begin{array}{l}4.53 \times 10^{-10} \\
9.971 \times 10^{2} \\
8.90 \times 10^{-4}\end{array}$ & & & $\begin{array}{l}\mathrm{Pa} \cdot 1 \\
\mathrm{~kg} / \mathrm{m}^{3} \\
\mathrm{~Pa} \cdot \mathrm{s}\end{array}$ & $\begin{array}{l}\text { Haug of al, 1987, p. 3-17 } \\
\text { Weast, 1974, p. F-11 } \\
\text { Woast, 1974, p. F-49 }\end{array}$ \\
\hline
\end{tabular}


Appendix A

TABLE A-10. SALADO BRINE COMPRESSIBILITY (Rough Estimates)

\begin{tabular}{ccc}
\hline $\begin{array}{c}\text { Pressure } \\
(\mathrm{MPa})\end{array}$ & $\begin{array}{c}\text { Compressibility }\left(\beta_{t}\right) \\
\left(\mathrm{Pa}^{-1} \times 10^{-10}\right)\end{array}$ & $\begin{array}{c}\text { Formation } \\
\text { Volume Factor }\end{array}$ \\
\hline 0.1 & 2.70 & 1.00000 \\
1.0932 & 2.70 & 0.99954 \\
2.0 & 2.70 & 0.99912 \\
5.0 & 2.69 & 0.99773 \\
10.0 & 2.69 & 0.99541 \\
20.0 & 2.68 & 0.99077 \\
50.0 & 2.64 & 0.97685 \\
100.0 & 2.57 & 0.95365 \\
\hline
\end{tabular}




\section{TABLLE A-11. CLIMATE VARIABILITY AND INTRUSION CHARACTERISTICS}

\begin{tabular}{|c|c|c|c|c|c|}
\hline Parameter & $\begin{array}{l}\text { Expected } \\
\text { Value }\end{array}$ & \multicolumn{2}{|c|}{ Range } & Units & Source \\
\hline $\begin{array}{l}\text { Climate Varlabufiry } \\
\text { Glaciastori noxt) } \\
\text { Peak procipitation }\end{array}$ & $\begin{array}{l}8 \times 10^{4} \\
6 \times 10^{1}\end{array}$ & $\begin{array}{l}4 \times 10^{4} \\
4.5 \times 10^{1}\end{array}$ & $\begin{array}{l}1.2 \times 10^{5} \\
9.0 \times 10^{1}\end{array}$ & $\begin{array}{l}\mathrm{yr} \\
\mathrm{cm} / \mathrm{yr}\end{array}$ & $\begin{array}{ll}\text { Marietta et al., } & 1990 \\
\text { Marietta of al., } & 1990\end{array}$ \\
\hline 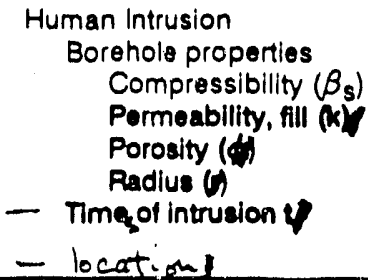 & $\begin{array}{l}1 \times 10^{-8} \\
1 \times 10^{-12} \\
2 \times 10^{-1} \\
1.67 \times 10^{-1} \\
3.15 \times 10^{10}\end{array}$ & $\begin{array}{l}1 \times 10^{-7} \\
1 \times 10^{-13} \\
1 \times 10^{-1} \\
8.89 \times 10^{-2} \\
3.15 \times 10^{9}\end{array}$ & $\begin{array}{l}1 \times 10^{-9} \\
1 \times 10^{-11} \\
3 \times 10^{-1} \\
2.54 \times 10^{-1} \\
3.15 \times 10^{11}\end{array}$ & $\begin{array}{l}\mathrm{Pa}^{-1} \\
\mathrm{~m}^{2} \\
\mathrm{~m}\end{array}$ & $\begin{array}{l}\text { Freeze and Cherry, 1979, Table } 2.5 \\
\text { Lappin ot al., 1989, Table 1.2, Table C-1 } \\
\text { Marietta ot al., 1989, Table 3-10 } \\
\text { Lappin ot al,, 1989, Table C-1; well logs } \\
\text { Marietta of al., 1989, Table 3-10 }\end{array}$ \\
\hline
\end{tabular}


Appendix A

Zone

$K(\mathrm{~m} / \mathrm{s})$

$\angle N D$

$1 \times 10^{-4}$ to $1 \times 10^{-3}$

n

(A)

$1 \times 10^{-4}$

$2 \times 10^{-4}$

expinipate tron allumio

(B)

$2 \times 10^{-5}$

$1 \times 10^{-4}$

3

(c)

$6 \times 10^{-6}$

$1 \times 10^{-5}$

5

(D)

$1 \times 10^{-7}$

$4 \times 10^{-6}$

(E)

$4 \times 10^{-8}$

$1 \times 10^{-7}$

po

(F)

$2 \times 10^{-8}$

$3 \times 10^{-8}$

4

(r)

$1 \times 10^{-9}$

$1 \times 10^{-8}$

3

代

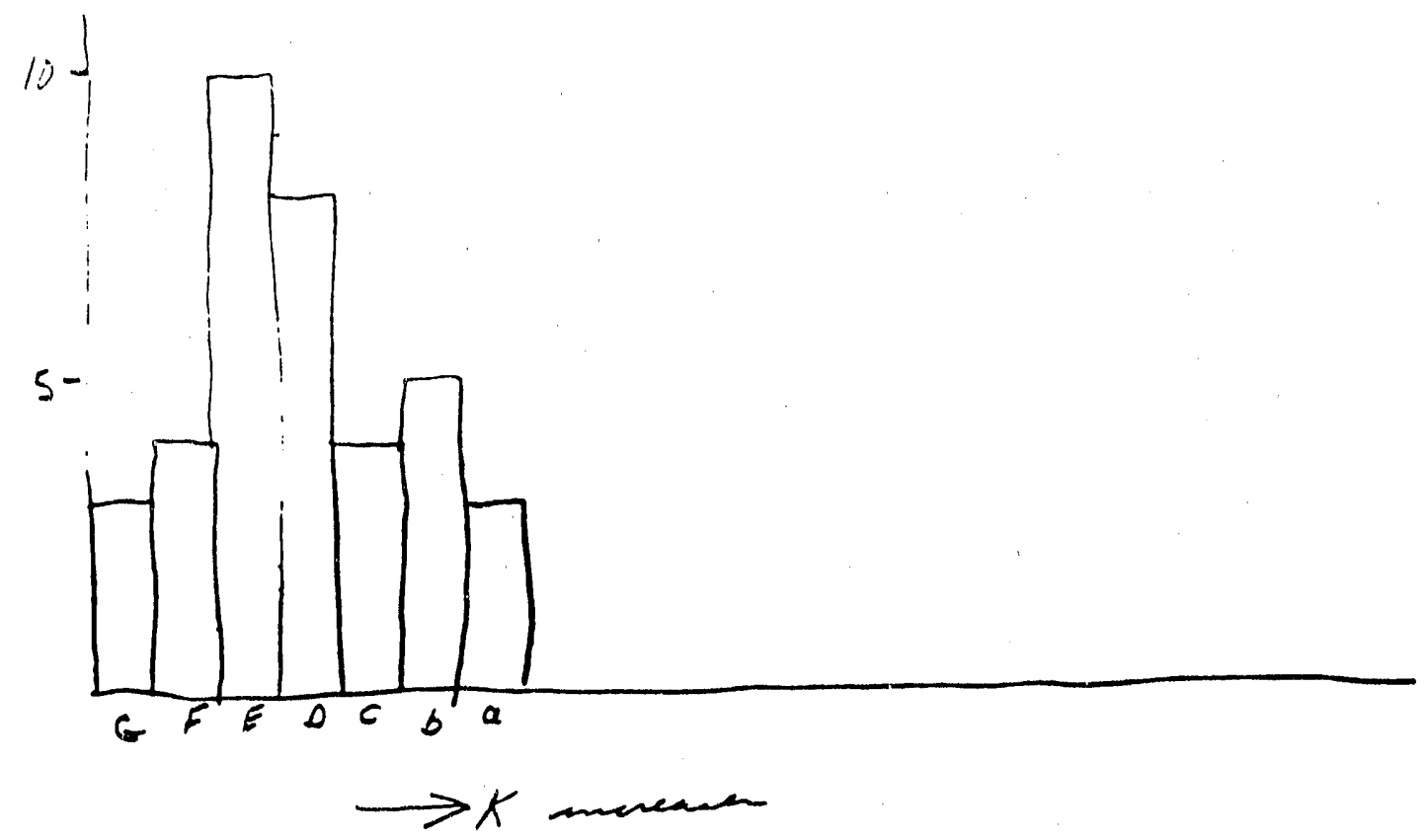

$\hat{n}-22$ 


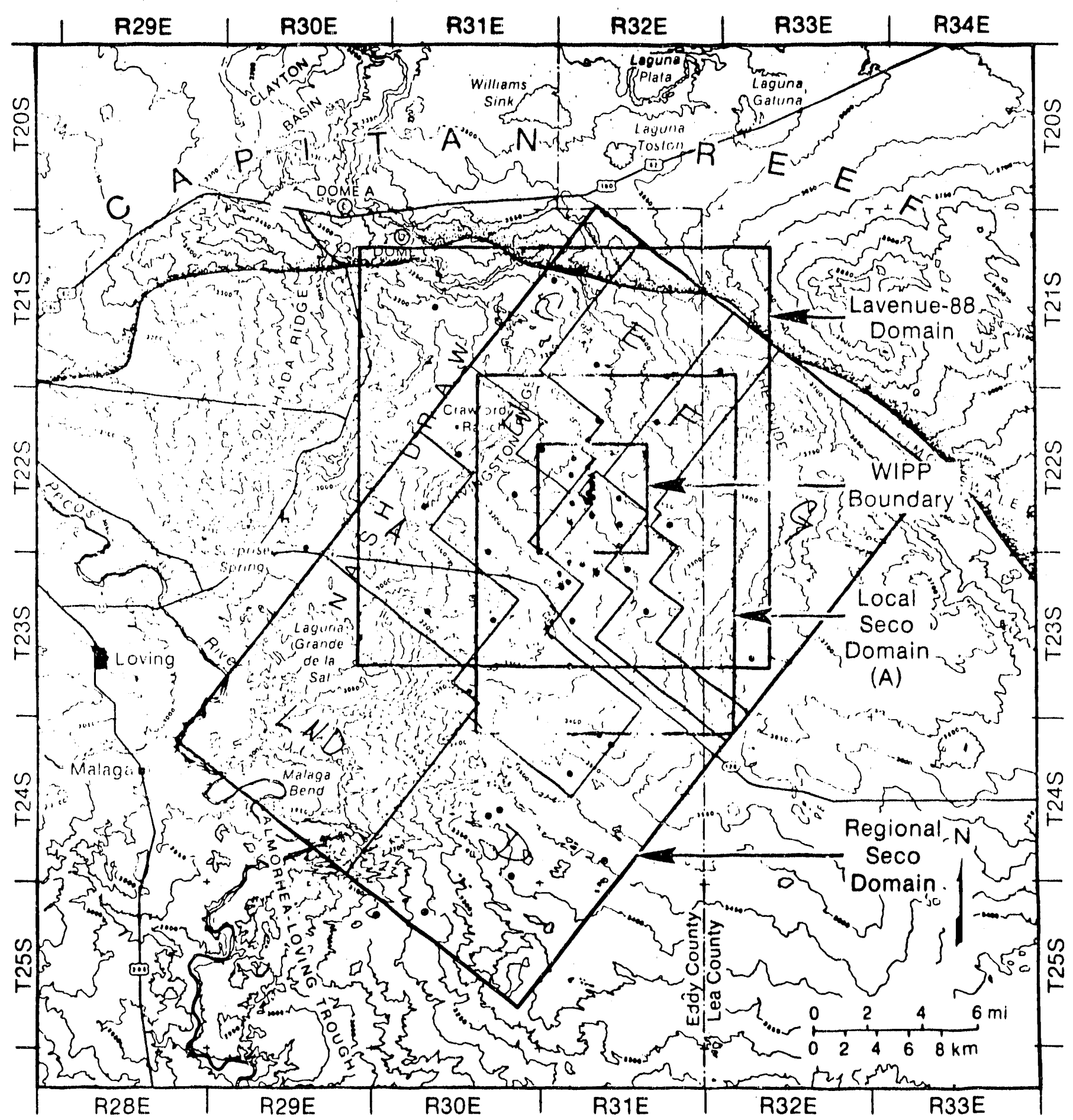


Appendix A

Conceptual model for Salado around repository

(1)

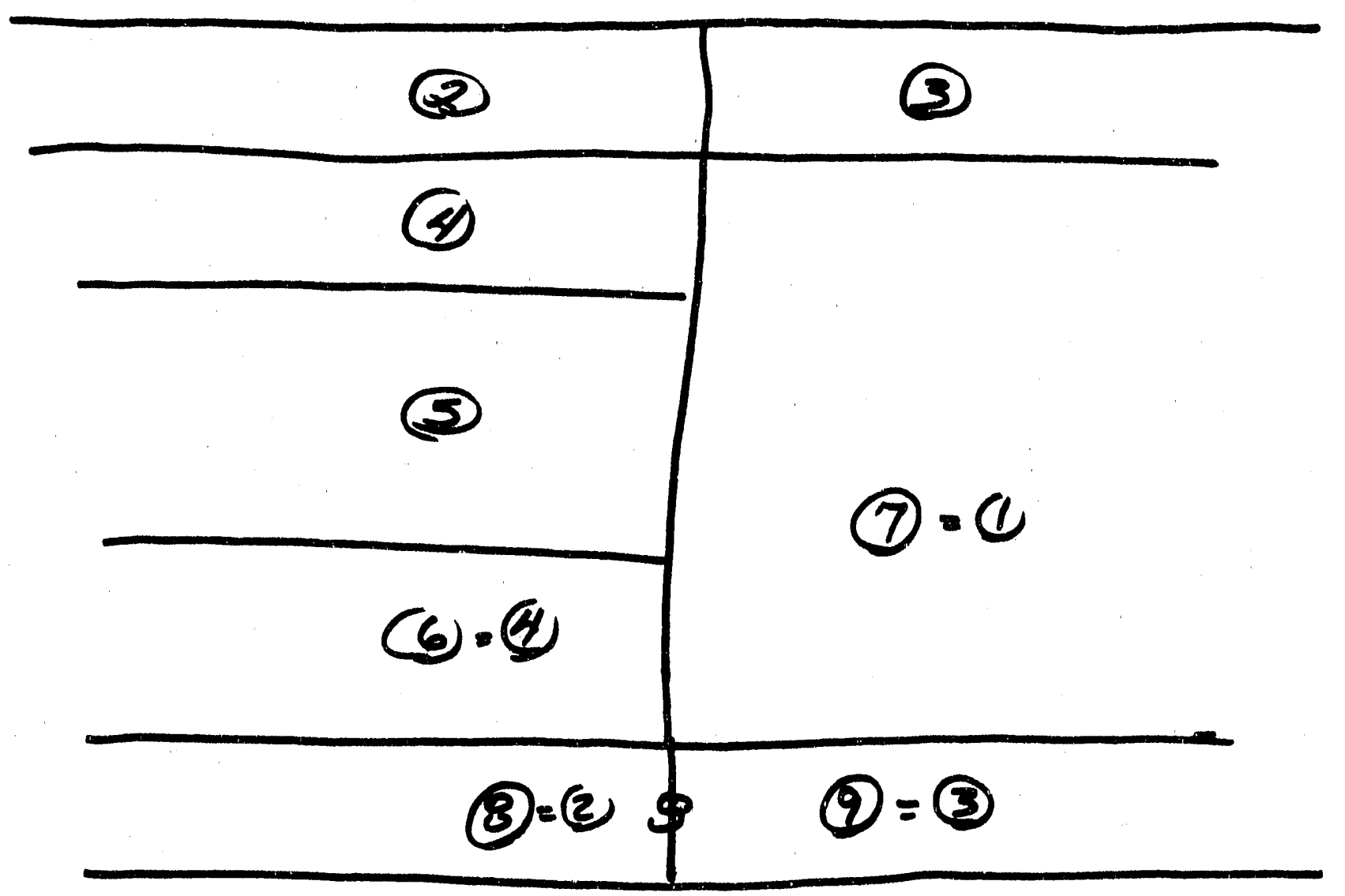

1. Salado

2. disturbed

3. anhydrite

parameter

median min mar $k$ $3 \times 10^{-21}$

0.03

ф

$10^{-17}$

0.10

$10^{-19}$

0.03

4. Salado DR k

$10^{-18}$

5. waste

0.03

$10^{-18}$

A -24

$k$

0.18

6. Same as 4 ;

7. same as 1 ;

8. Same e as 2 
Memo 1
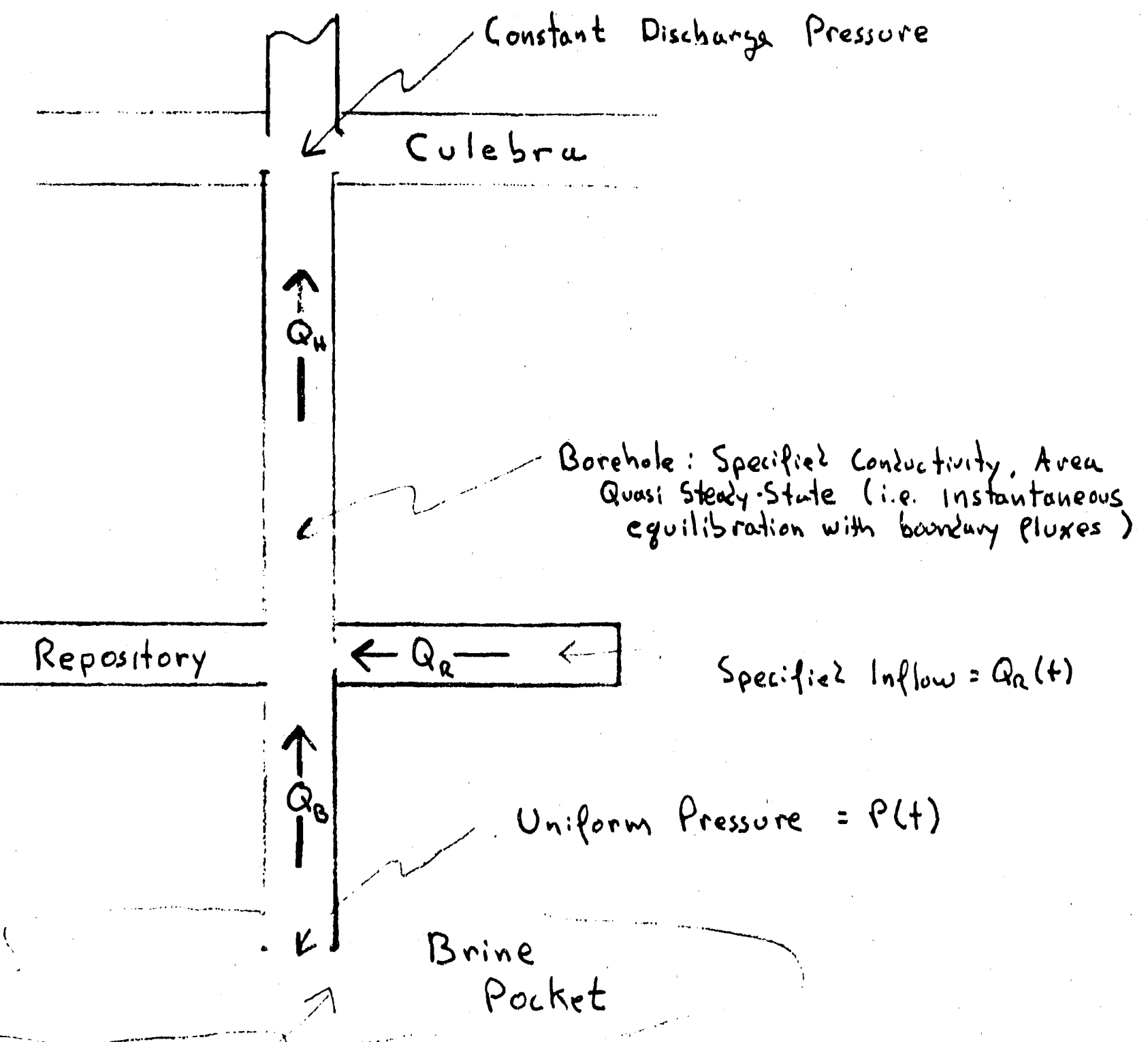

Finite Volume, Quasi Steady. State (ie infinite conductivity)

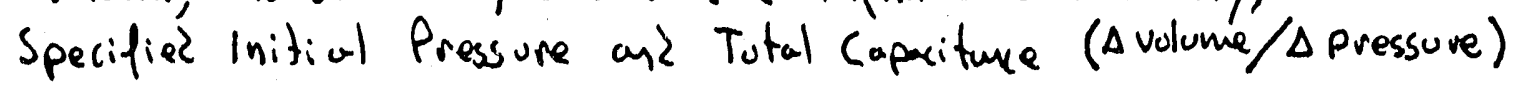

Conceptual Model of Brine Pocket Discharge Process Following Ploy Degradation

$A-25, A-26$ 


\section{Memo 2}

Date: $\quad 3 / 14 / 90$

To: Distribution

From: D. R. Anderson (6334), Melvin G. Marietta (6334), Martin Tierney (6415)

Subject: Request for assistance in assigning probability distributions to the parameters being used for the preliminary performance assessments of the WIPP relating to EPA 40 CFR Part 191. 
Date: $\quad$ March 14, 1990
To:
Distributiom
From:
1) $R$ Hivining
$\mu h(i$
U. R. Anderson, Melvin G. Marietta, 6334; Martin Tierney 6415
Subject: Request for assistance in assigning probability distributions to the parameters being used for the preliminary performance assessments of the WIPP relating to EPA 40 CFR Part 191.

\begin{abstract}
ie are requesting investigators on the distribution list to assist us in croating probability distributions associated with the hydrologic and geocheinical properties listed on Attachment A (Tables 3-9 and 3-10, Marietta et a 1., 1989) and in Appendix A, Rechard et al., 1990 (already circulated). The probability distributions of these parameters will be used in simulations of release scenarios in the next round of preliminary pelformance assessinents of the WIPP relating to EPA 40 CFR Part 191.
\end{abstract}

The ne:t set of calculations will be presented to the NAS at the June 7.8 reeting. The calculations will be repeated and fully documented for the December NAS meeting. The set of uncertain input parameters that will be s.ripled for these calculations will not be the same as listed in Tables $3-9$ and 3-10. Brine pocket, intrusion borehole, and more Culebra and room viareters will be added. The set of parameters to be sampled will clearly 10 include everything in Appendix $A$, yet unsampled parameter values must be ruined too. This memo is concerned with constructing probability models 'fol : hose parameters that will be sampled.

The linds of information being requested:

$\because$ ate not asking that investigators supply probability estimates directly; instead, we ask those investigators most familiar with the data associated $\therefore$ th a parameter to please record (in a short memo) any information they may have concerning the numerical values likely to be taken on by that parameter in the context of the WIPP. The forms this information might take are listed be low in order of decreasing usefulness in the construction of probability cistributions that could reflect the real conditions at the WIPP.

1. A table of measured values of the parameter.

2. Reasoned estimates of percentile points for the parameter: For example, provide statements like " 90 percent of the solubility values lie below $10^{-4}$ Molar." 
3. Reasoned estimates of the mean value and standard deviation of the parameter (quantities that usually apply to spatially inhomogeneous hydrologic and geochemical parameters such as porosity, conductivity and sorption coefficlents $\left.\left[K_{d} s\right]\right)$. In other words, what we are seeking here are measures of the "clustering" and "spread" of a spatially inhomogeneous quantity.

4. Reasoned estimates of only the mean value of the parameter.

5. At the minimum, and in addition to information of types 1 through 4 , we need reasoned estimates of the maximum and minimum values (the range) that the parameter can take in the context of the WIPP.

In providing information about the parameters in Attachment $A$, investigators are urged to indicate the size of the reference volume to which the data or estimates apply and to provide any other qualifications they may believe are necessary for an understanding of their data.

How the information will be used:

If a table of measured values of the parameter is provided, the entries from the table may be used to create an empirical cumulative distribution function (CDF). An example of an empirical CDF is shown on Attachment $B$; this example shows the normalized frequency of the diameters of boreholes that have been taken from well logs in the vicinity of the WIPP. The resulcing empirical CDF will be used as the sampling distribution for the parameter in the performance-assessment simularions. An example of a Latin Hypercube Sample is also shown on Attachment B.

If information of types 2 through 4 (see above) are the only types of information about a parameter that can be supplied at this time, then these kinds of information may be used as ingredients in the Maximum Entropy Formalism (MEF; see Jaynes 1982, or Cook and Unwin, 1986) to construct a CDF for the parameter. Examples: If only the range, $[a, b]$, of a parameter can be estimated, then application of the MEF will yield a uniform distribution on the interval $[a, b]$. If estimates of the range and mean are provided, then application of the MEF will yield a truncated exponential distribution. If estimates of the range, the mean and the standard deviation are provided, then application of the MEF will yleld a truncated normal distribution on the interval $[a, b]$. Finally, if percentile points are provided, then application of the MEF yields a piecewise Linear CDF. 
Brief meetings with investigators from each division would be useful to answer any questions about how data will be used and to educate PA on correct data interpretation. We suggest that information transfer to PA can be accomplished by short memos, but complete documentation by investigators for the PA data base manager will still be required on a regular basis. A Eormal procedure for this process should be implemented.

\section{REFERENCES}

Cook, Ian and S. D. Unwin, 1986, "Controlling principles for prior probability assignments in nuclear risk assessment, "Nuclear Science and Engineering: 94, 107-119.

Jaynes, Edwin T., 1982, "On the rationale of maximum entropy methods," Proc. IEEE: $70,939-952$.

Marietta, Melvin G., et al. 1989, "Performance assessment methodology demonstration: methodology development for evaluating compliance with EPA 40 CFR Part 191, Subpart B, for WIPP," SAND89-2027.

Rechard, Robert P., et al. 1990, "Parameter sensitivity studies of selected components of the WIPP repository system," SAND89-2030. In preparation. 
Attachment A

Page 1 of 4

TABLE 3-9. REFERENCE DATA BASE FOR NEFTRAN SIMULATION OF UNDISTURBED CONDITIONS

\begin{tabular}{|c|c|c|c|c|}
\hline$\underline{\text { Variable }}$ & Distribution & Range & Units & $\begin{array}{l}\text { Expected Value* } \\
\text { or Median** }\end{array}$ \\
\hline \multicolumn{5}{|c|}{ Marker Bed 139 Pathway: Sampled Parameters } \\
\hline Room Pressure & Uniform & {$[6.0,15.0]$} & $\mathrm{MPa}$ & 10.5 \\
\hline Solubility & Loguniform & {$\left[10^{-9}, 10^{-3}\right]$} & Molar & $10^{-6}$ \\
\hline Room Conductivity & Beta & {$\left[10^{-11}, 10^{-6}\right]$} & $\mathrm{m} / \mathrm{s}$ & $10^{-7}$ \\
\hline MB139 Seal Conductivity & Lognormal & {$\left[10^{-12}, 4 \times 10^{-10}\right]$} & $\mathrm{m} / \mathrm{s}$ & $2 \times 10^{-11}$ \\
\hline MB139 Seal Porosity & Normal & {$[0.02,0.04]$} & & 0.03 \\
\hline Lower Shaft Seal Conductivity & Lognormal & {$\left[3 \times 10^{-14}, 10^{-11}\right]$} & $\mathrm{m} / \mathrm{s}$ & $5 \times 10^{-12}$ \\
\hline Lower Shaft Seal Porosity & Beta & {$[0.001,0.08]$} & & 0.05 \\
\hline Upper Shatt Seal Conductivity & Lognormal & {$\left[10^{-7}, 10^{-3}\right]$} & $\mathrm{m} / \mathrm{s}$ & $10^{-5}$ \\
\hline Upper Shaft Seal Porosity & Normal & {$[0.1,0.3]$} & & 0.20 \\
\hline M8139 Retardation (Pu,Th) & Beta & {$[1.0,10.0]$} & & 4.7 \\
\hline MB139 Retardation (Am) & Beta & {$[1.0,10.0]$} & & 1.9 \\
\hline $\begin{array}{l}\text { Lower Shaft Seal Retardation } \\
(\mathrm{Pu}, \mathrm{Th}, \mathrm{Am})\end{array}$ & Beta & {$[1.0,10.0]$} & & 5.2 \\
\hline Lower Shaft Seal Retardation (Np) & Beta & {$[1.0,10.0]$} & & 1.4 \\
\hline $\begin{array}{l}\text { Ufper Shaft Seal Retardation } \\
\text { (Pu,Th,Am) }\end{array}$ & Beta & {$[1.0,10.0]$} & & 1.7 \\
\hline \multicolumn{5}{|c|}{ Marker Bed 139 Pathway: Unsampled Parameters } \\
\hline $\begin{array}{l}\text { MB139 Retardation } \\
(U, \mathrm{~Np}, \mathrm{Ra}, \mathrm{Pb})\end{array}$ & & & & 1.0 \\
\hline $\begin{array}{l}\text { Lower Shaft Seal Retardation } \\
\quad(U, \mathrm{Ra}, \mathrm{Pb})\end{array}$ & & & & 1.0 \\
\hline $\begin{array}{l}\text { Upper Shatt Seai Retardation } \\
\text { (Np) }\end{array}$ & & & & 1.1 \\
\hline $\begin{array}{l}\text { Upper Shaft Seal Retardation } \\
\text { (U,Ra,Pb) }\end{array}$ & & & & 1.0 \\
\hline
\end{tabular}


Attachment A

Page 2 of 4

TABLE 3-9. REFERENCE DATA BASE FOR NEFTRAN SIMULATION OF UNDISTURBED CONDITIONS (Concluded)

\begin{tabular}{|c|c|c|c|c|c|c|c|c|c|}
\hline \multicolumn{2}{|l|}{ Variable } & \multicolumn{3}{|c|}{ Distribution } & \multicolumn{2}{|c|}{ Range } & Uni's. & \multicolumn{2}{|c|}{$\begin{array}{l}\text { Expected Value* } \\
\text { OrMedian }\end{array}$} \\
\hline \multicolumn{10}{|c|}{ Salado Pathway Parameters } \\
\hline \multicolumn{2}{|l|}{ Salado Conductivity } & & & & \multicolumn{2}{|c|}{$2.9 \times 10^{-14}$} & $\mathrm{~m} / \mathrm{s}$ & & \\
\hline \multicolumn{2}{|l|}{ Salado Porosia } & & & & & & & \multicolumn{2}{|r|}{0.001} \\
\hline \multicolumn{2}{|l|}{$\begin{array}{l}\text { Salado Retardation } \\
\text { (Pu,Am,Th) }\end{array}$} & & & & & & $m^{2}$ & \multicolumn{2}{|r|}{231.0} \\
\hline \multicolumn{2}{|c|}{ Salado Retardation (Np) } & & & & & & $m^{2}$ & \multicolumn{2}{|r|}{24.0} \\
\hline \multicolumn{2}{|l|}{$\begin{array}{l}\text { Salado Retardation } \\
\text { (U,Ra,Pb) }\end{array}$} & & & & & & $m^{2}$ & \multicolumn{2}{|r|}{3.3} \\
\hline \multicolumn{10}{|c|}{ Marker Bed 139 Pathway Constant Parameter Values } \\
\hline Legs: & Repository & $\begin{array}{c}\text { Marker } \\
\text { Bed } \\
\text { Seal } \\
\end{array}$ & $\begin{array}{c}\text { Marker } \\
\text { Bed } \\
\end{array}$ & $\begin{array}{l}\text { Lower } \\
\text { Shaft } \\
\text { Seal } \\
\end{array}$ & $\begin{array}{l}\text { Upper } \\
\text { Shaft } \\
\text { Seal } \\
\end{array}$ & $\begin{array}{l}\text { Culebra } \\
\text { Leg. }\end{array}$ & $\begin{array}{c}\text { Culebra } \\
\text { Leg } \\
\end{array}$ & $\begin{array}{c}\text { Culebra } \\
\text { Leg }\end{array}$ & $\begin{array}{l}\text { Culebra } \\
\text { Upgradient }\end{array}$ \\
\hline Length (m) & 91.4 & 30 & 366 & 200 & 200 & 430 & 1030 & 3444 & 400 \\
\hline Area $\left(m^{2}\right)$ & 38.9 & 5.57 & 5.57 & 29.2 & 29.2 & 800 & 800 & 800 & 800 \\
\hline Roc:k Density $\left(\mathrm{kg} / \mathrm{m}^{3}\right)$ & 2720 & 2720 & 2720 & 2720 & $27 \approx 0$ & 2720 & 2720 & 2720 & 2720 \\
\hline Fluid Density $\left(\mathrm{kg} / \mathrm{m}^{3}\right)$ & 1186 & 1186 & 1186 & 1186 & 1186 & 1092 & 1092 & 1092 & 1092 \\
\hline
\end{tabular}


Attachment A

Page 3 of 4

TABLE 3-10. REFERENCE DATA BASE FOR NEFTRAN SIMULATION OF HUMAN INTRUSION SCENARIOS

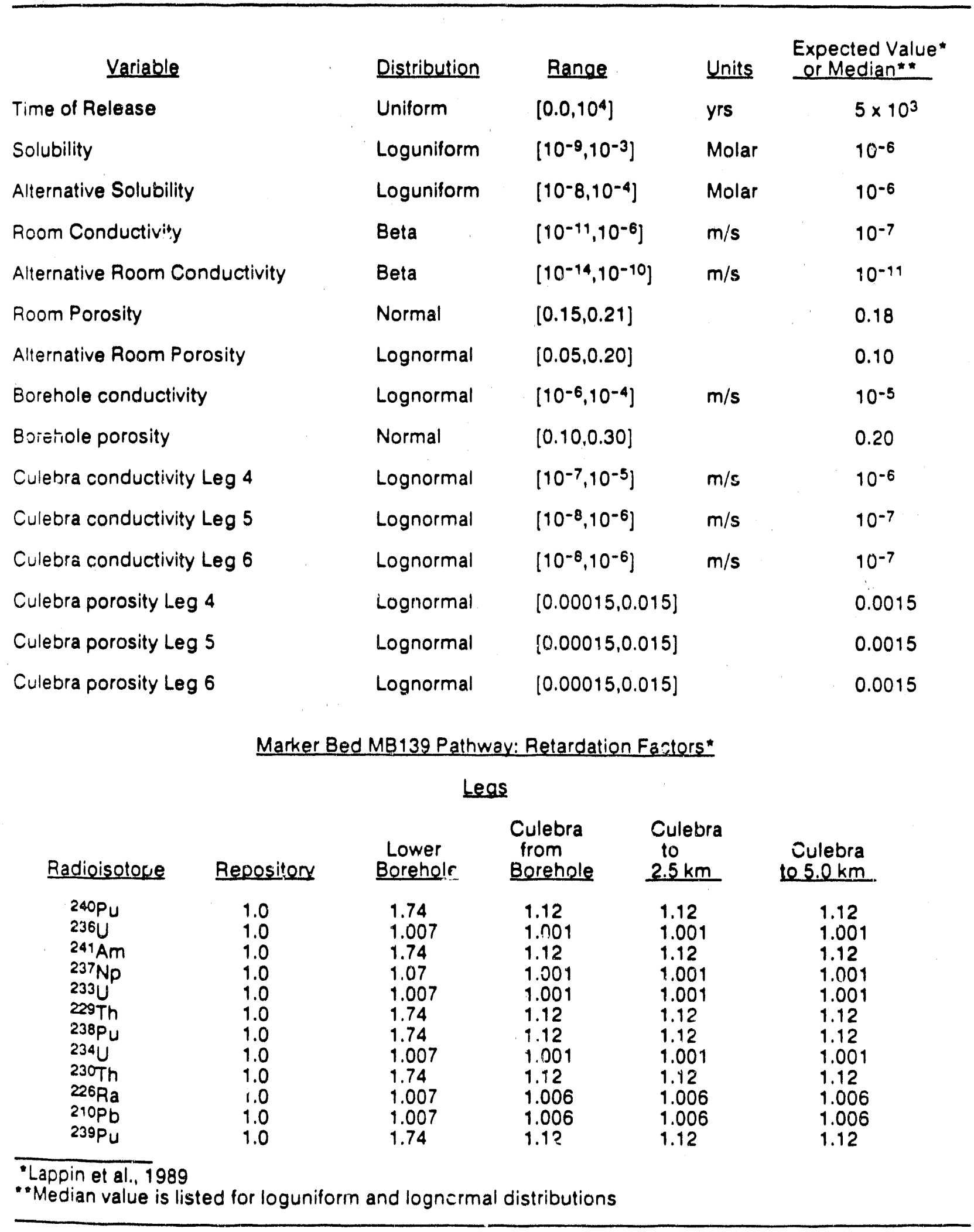


Attachment $A$

Page 4 of 4

TABLE 3-10. REFERENCE DATA BASE FOR NEFTRAN SIMULATION OF HUMAN INTRUSION SCENARIOS (Concluded)

\begin{tabular}{|c|c|c|c|c|c|c|}
\hline \multicolumn{7}{|c|}{ Marker Bed MB139 and Salado Formation Pathway Constant Parameter Values" } \\
\hline Legs: & Repository & $\begin{array}{c}\text { Lower } \\
\text { Borehole }\end{array}$ & $\begin{array}{c}\text { Upper } \\
\text { Borehole }\end{array}$ & $\begin{array}{l}\text { Culebra } \\
\text { Lea } 1\end{array}$ & $\begin{array}{l}\text { Culebra } \\
\text { to } 2.5 \mathrm{~km} \\
\end{array}$ & $\begin{array}{l}\text { Culebra } \\
\text { te } 5.0 \mathrm{~km}\end{array}$ \\
\hline Length $(m)$ & 300.0 & 270.0 & 440.0 & 300.0 & 2140.0 & 2560.0 \\
\hline Area $\left(m^{2}\right)$ & 38.9 & 0.01 & 0.02 & 800.0 & 800.0 & 800.0 \\
\hline $\begin{array}{l}\text { Rock Density } \\
\left(\mathrm{kg} / \mathrm{m}^{3}\right)\end{array}$ & 2720 & 2720 & 2720 & 2720 & 2720 & 2720 \\
\hline $\begin{array}{l}\text { Fluid Density } \\
\mathrm{kg} / \mathrm{m}^{3}\end{array}$ & 1186 & 1186 & 1186 & 1092 & 1092 & 1092 \\
\hline Node Pressure: & \multicolumn{3}{|c|}{$\begin{array}{l}\text { 10.5 MPa Repository } \\
16.0 \mathrm{MPa} \text { Castile Brine Occurrence } \\
0.92 \mathrm{MPa} \text { Culebra at } 5 \mathrm{~km}\end{array}$} & & & \\
\hline "Lappin et al., & & & & & & \\
\hline
\end{tabular}




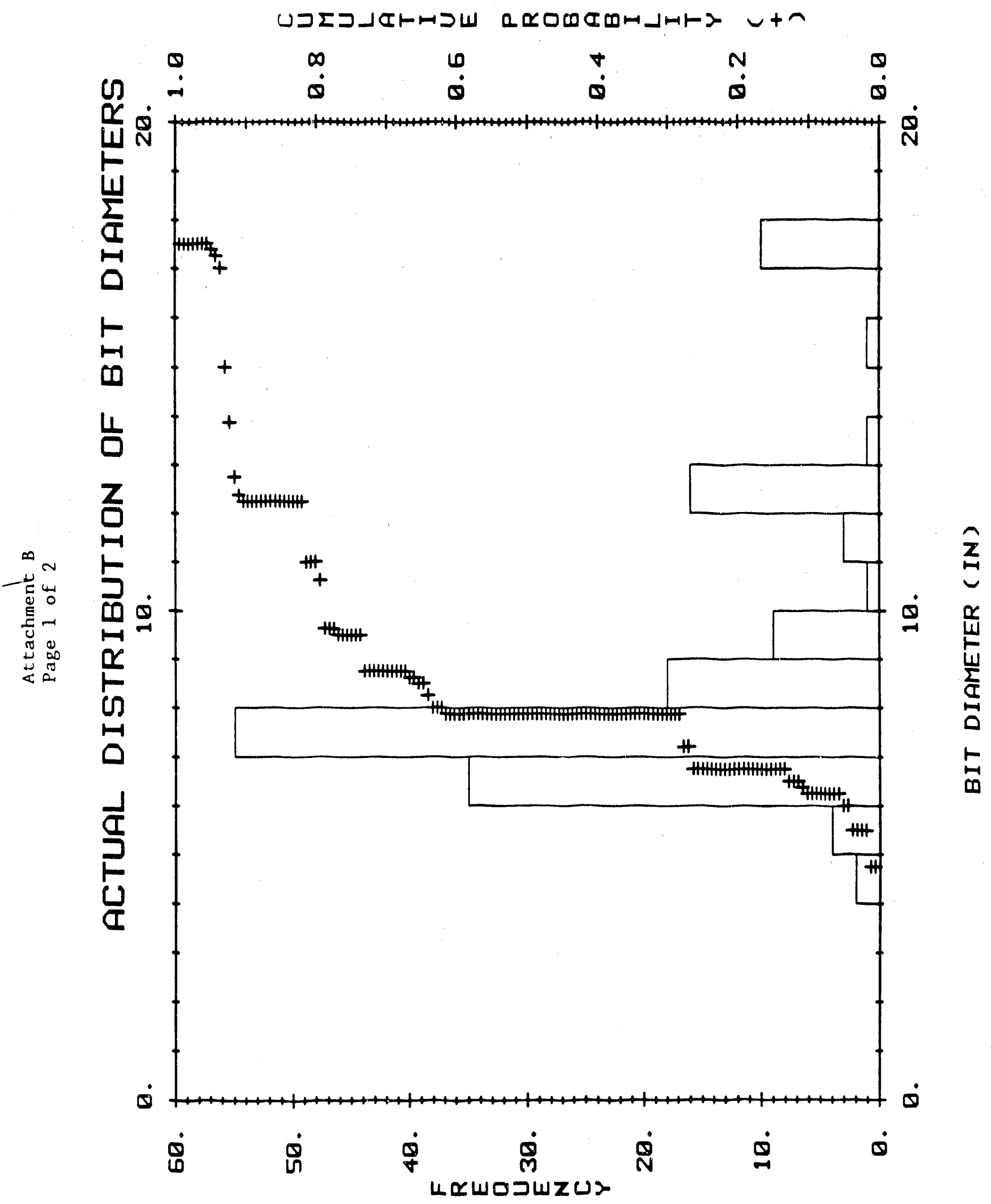




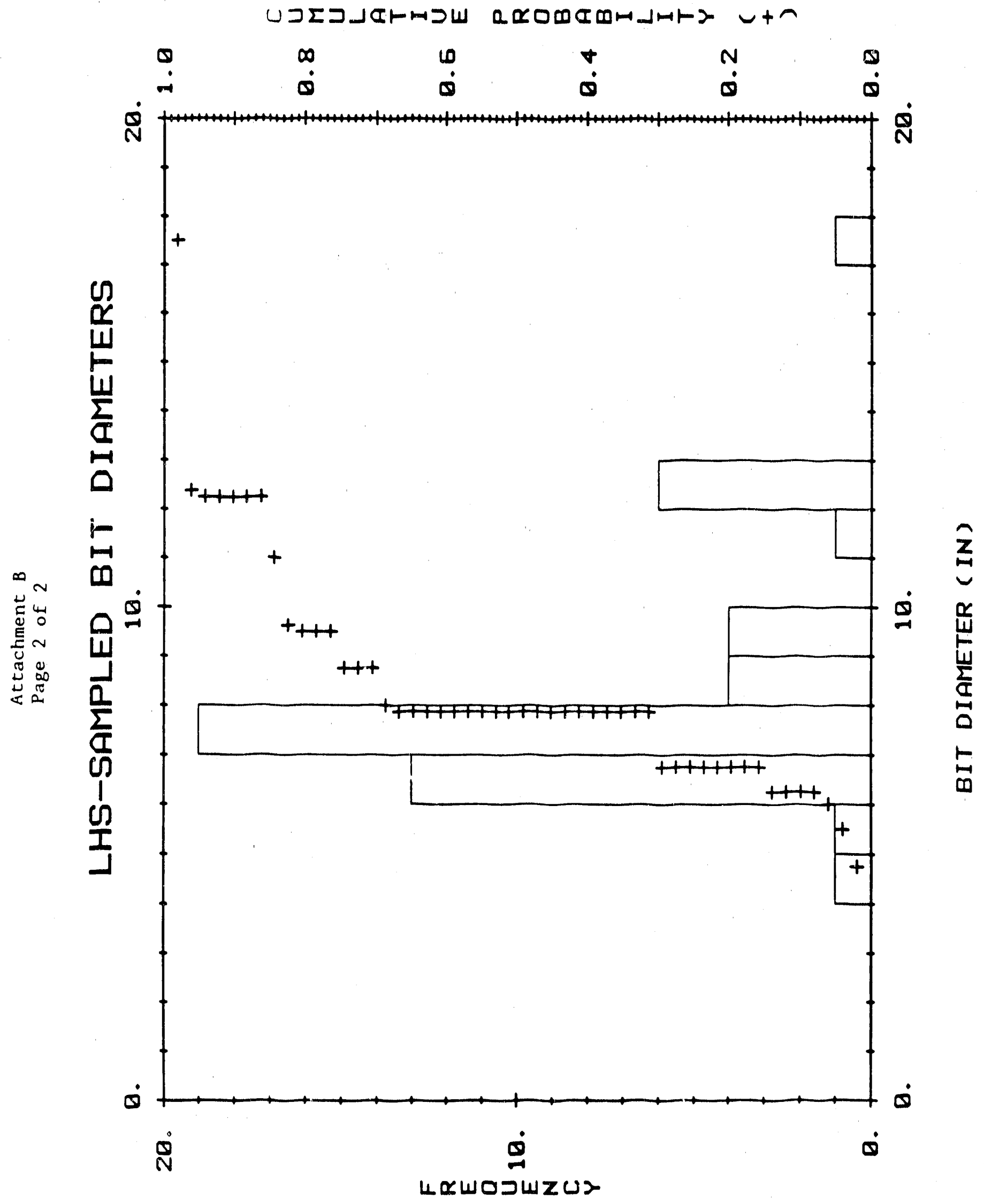

A- $37, A-38$ 
Memo 3

Memo 3

Date: $\quad 8 / 3 / 90$

To: $\quad$ Rip Anderson, 6342

From: Elaine Gorham, 6344

Subject: Data for use in August Performance Assessment Calculations 
date August 3, 1990

to Rip Anderson, 6342

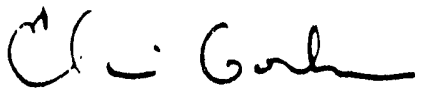

from Elaine Gorham, 6344

\section{Sandia National Laboratories}

Albuquerque. New Mexico 87185

subject Data for use in August Performance Assessment calculations

Attached are three memos which will, along with comments in this memo, supply all the information that is needed by performance assessment to perform the December calculations.

As you will see after reading the memos, there are suggestions for making model changes. I support those suggestions, although I am aware that implementation of the suggested changes may not be possible in the time available.

In a few cases Rick and Peter have suggested slightly different distributions for hydrologic model parameters. I have deliberately not asked them to devise a consensus distribution. Where the distributions differ, you should implement the average distribution. Calculation of the averages should be simple and straightforward. I will be willing to construct them myself if you wish.

The memo from Malcolm siegel should be used to define PA transport parameters. It currently represents the judgement of both Malcolm and Craig.

A source of values for $K_{d} s$ appropriate to the backfill were supplied to Barry Butcher by Craig Novak. Barry will include those values and their rationale in a memo from him.

Finally, I will work with my staff to generate final write-ups for inclusion in the PA documents due out in December. I'm not sure how to handle Peter's suggestions for you to change your Culebra modeling approach if you don't have time to make the changes. Maybe this is one of the things we can work out in our Quality Team sessions.

Copies:
6340 Weart
6344 Beauheim
6344 Davies
6344 Finley
6344 Howarth
6344 LaVenue
6344 Novak
6315 Siegel 


\section{Memo 3a}

\section{Date: $\quad 6 / 12 / 90$}

To: Distribution

From: $\quad$ M. D. Siegel, 6344

Subject: Representation of Radionuclide Retardation in the Culebra Dolomite in Performance Assessment

Calculations 


\section{Sandia National Laboratories}

date: June 12,1990

Albuquerque, New Mexico 87185

10: Distribution

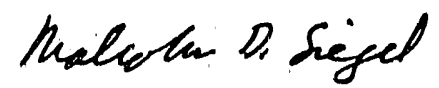

from: M. D. Siegel, 6344

subject: Representation of Radionuclide Retardation in the Culebra Dolomite in Performance Assessment Calculations

Summary

The purpose of this memo is to describe probability distribution functions for $k_{d}$ values for use in the next round of performance assessment calculations. The paucity of relevant site-specific data necessitated the use of conservative (low) $K_{d}$ values in the Final Supplemental Environmental Impact Statement (cf. Lappin et al., 1989) and in the performance assessment calculations described in SAND89-2027 (Marietta et al., 1989). In this memo, higher $K_{d}$ values, chosen from a distribution of $K_{d} s$, are recommended as a result of work carried out during 1989 - 1990. The most important of these results include: 1) the observation that the clay mineral, corrensite comprises up to 258 by weight of material scraped from open fractures in the Culebra Dolomite; 2) demonstration that corrensite adsorbs large fractions of the uranium in solution at $\mathrm{pH}$ ranges (6.5-7.5) typical of the Culebra; and 3 ) evidence that uranyl-carbonate and uranyl-EDTA complexes are adsorbed by corrensite and iron oxyhydroxides.

A second objective of the memo is to provide some guidance in the representation of radionuclide retardation in the Culebra Dolomite. Previous transport calculations have considered retardation in either the fractures or the dolomite matrix but not both. Marietta et al. used a retardation factor of 1.12 for transport of plutonium within fractures in the Culebra and concluded that the Culebra was not an effective barrier to radionuclide migration. In contrast, using the data and equations described in this memo, retardation factors for plutonium transport ranging from 76 to 676 , and 625 to 2000 in the fracture and matrix respectively are calculated at the midpoint of the recommended $K_{d}$ distribution function. These results suggest that a dual porosity transport model should be used in the next round of performance assessment calculations. 


\section{Background}

Radionuclide distribution coefficients $\left(K_{d} s\right)$ and retardation factors are important in calculations of radionuclide migration. $K_{d}$ values describe the intensity of sorption; retardation factors provide information about the sorption capacity of the rock. As discussed below, two recently published SAND reports used identical $k_{d}$ values but different approaches to calculate retardation factors and consequently produced very different results and conclusions.

Transport calculations described in SAND89-2027 (Performance Assessment Methodology Demonstration: Methodology Development for Evaluating Compliance with EPA 40 CFR 191 . Subpart B, for the Waste Isolation Pilot Plant) (Marietta et al., 1989) considered retardation only in the fractures of the Culebra and ignored any retardation in the dolomite matrix. This calculation strongly contrasts with the transport calculations done in SAND89-0462 (Systems Analysis, Long Term Radionuclide Transport, and Dose Assessments, Waste Isolation Pilot Plant (WIPP). Southeastern New Mexico) (Lappin et al., 1989). In the 1.itter report, retardation was assumed to occur only in the matrix and the calculated retardation factors were much higher than those used by Marietta et al.

In Lappin et al. (1989), the sorption capacities of fractures and matrix were calculated using their respective surface areas. A conservative single porosity retardation factor for the fractures (i.e., assuming sorption will occur only in the fractures) was calculated using the surface area of smooth fractures calculated from an estimated fracture porosity. Similarly, the sorption capacity of the matrix was calculated using the intergranular surface area of the matrix from studies of dolomite powders.

Lappin et al. ignored retardation in the fractures because the calculated single porosity matrix retardation factor was much larger than the calculated single porosity fracture retardation factor. SAND89-2027 (Marietta et al., 1989) however, used the single porosity fracture retardation factors calculated in Lappin et al. to represent all retardation in the Culebra Dolomite and ignored retardation in the matrix. The implicit conclusion of Marietta et al. that retardation in the Culebra Dolomite provides little or no barrier to radionuclide migration is a direct consequence of this choice.

The use of a dual porosity model would provide a more realistic estimate of the ability of the Culebra Dolomite to retard radionuclide migration to the accessible environment. In this approach, the volume of the fracture-coating minerals would be used to to calculated the sorption capacity and retardation factor of the fracture. The retardation factor for the matrix would be calculated separately. For this reason, separate probability distribution functions are given for the $k_{d} s$ in the fracture and dolomite matrix in this memo. 


\section{Some Caveats Concerning the Use of $K_{d} s$ in Transport Calculations}

Radionuclide distribution coefficients $\left(K_{d}\right)$ are used in transport codes to calculate the partitioning of radioelements between the groundwater and rock. The definition, underlying assumptions and limitations of the use of a $K_{d}$ to estimate radionuclide retardation have been reviewed in Lappin et al. (1989; section 3.3.4). As discussed in that section, a $K_{d}$ value cannot be extrapolated with confidence to physicochemical conditions that differ from those under which the data were obtained. In addition, the use of a $K_{d}$ to calculate radionuclide partitioning is theoretically valid only if: 1) chemical equilibrium exists among all aqueous species containing the solute; 2) reversible, linear sorption is the dominant process controlling exchange of the solute between the groundwater and the rock; and 3) transport of the solute by particulates (colloids) is insignificant. It remains to be demonstrated if these assumptions are valid for radioelement transport in the Culebra or if deviations from these conditions will produce errors that are significant for performance assessment calculations.

In the following sections, the assumptions used in estimating defensible probability distribution functions for $k_{d} s$ are described. The choice of "recommended" $K_{d}$ distributions required a large number of subjective assumptions which cannot be supported rigorously. The values given in Tables 1-2 are considered to be the realistic in light of available data; however, research in progress may produce results that will invalidate the logic and recommendations presented below.

Compositions of Groundwaters in the Culebra Dolomite

Measured $\mathrm{K}_{\mathrm{d}} \mathrm{s}$ can be strongly dependent on the composition of the groundwater (c.f. Section 3.3.4 in Lappin et al. 1989 and cited references). The composition of radionuclide-bearing solutions at various locations within the Culabra will depend upon the composition and volume of the solution from the repository that reaches the aquifer. Separate ranges of $k_{d} s$ are given for two extreme scenarios.

In Case $I$, the ratio of the flux of the repository fluid to the flux of Culebra water is very small; therefore, the major solute composition of the resultant fluid is assumed to be similar to that of the undisturbed Culebra. $\mathrm{K}_{\mathrm{d}}$ data obtained in the "Culebra $\mathrm{H}_{2} \mathrm{O}$ " described in Lappin et al. (1989; Table 3-16) are most relevant for this scenario. This solution represents an average composition of waters sampled in well H-2B (sampled $2 / 77$ ) and $\mathrm{H}-2 \mathrm{C}$ (sampled $3 / 77$ ). This water is similar in composition to the AISin reference water which has been modified (by reducing the $\mathrm{Ca}$ content by 25\%) for use in Pu speciation and sorption studies being carried out at Lawrence Berkeley Laboratory and for $U$ sorption studies that are being carried out at SNL. The $K_{d}$ distribution for Case 1 is described in Table 1. The composition of the AISin water is described in Table 3 . 
In Case 2, the mixing ratio (as repository fluid/Culebra fluid) is high and the resultant composition resembles that of the repository fluid. In Case 2, radionuclide sorption in the Culebra is assumed to be affected by the high salinity of the Castille and Salado brines and organic ligands from the waste. The information needed to construct the distribution functions for these conditions are given in Table 2. Data obtained in Brines $A$ and $B$ plus added organic complexants (Lappin et al., 1989; Table 3-16) were used for this scenario.

The $k_{d}$ ranges for Case 2 are very speculative; the compositions of Brine $A$ and Brine $B$ may not be representative of the water in the facility horizon. The addition of organic and metal-containing waste, cement and backfill additives will change the solution $\mathrm{pH}$, dissolved organic carbon speciation, dissolved oxygen content and concentrations of metal ions. At present, no reliable estimate of the organic composition of the repositoty fluids is available. The inorganic composition of fluids resulting from the mixing of salado and Castille waters has been estimated with the PHRQPITZ code. Table 3 describes the compositions of two reference brines obtained from these calculations.

Estimation of Parameters Defining Cumulative Probability Distribution Functions for $\mathrm{K}_{\mathrm{d}}$ Values

Separate $K_{d}$ distributions are given for the dolomite matrix and the clays lining the fractures in the Culebra in this section. The use of these data to calculate retardation factors is discussed in a later section of this memo.

The cumulative probability distribution functions for the $k_{d}$ values are defined by values for the $08,258,508,758,958$ and 1008 intervals. Data from $K_{d}$ measurements and predictions based on theoretical calculations were used to obtain the recommended $k_{d}$ distribution functions.

Tables 3-14 and 3-15 in Lappin et al. (1989) contain a compilation of ranges of $k_{d}$ values obtained under chemical conditions that were similar in some way to those expected for a variety of mixing ratios in the Culebra Dolomite. The sources for these data are identified in that report and will not be repeated here. Data from parametric studies or theoretical calculations for simple well-constrained systems were used to estimate the magnitude of the change in the $K_{d}$ that might be related to differences between the actual experimental conditions and the range of conditions postulated for the WIPP.

The meaning of each of the points along the probability distribution functions is given below: 
CASE 1 (Tables $1 \mathrm{~A}$ and $1 \mathrm{~B}$ ):

100 percentile: The highest vaiue for the Culebra $\mathrm{H}_{2} \mathrm{O}$ was used. If data for this water were not avallable, the highest minimum value of the ranges from experiments carried out in WIPP Solutions $A, B$, and $C$ (see Tables 3-14 to 3-16 in Lappin et al., 1989) was used. The use of the minimum values introduces a degree of conservatism in the distributions. Data from experiments which include organic ligands were not considered.

75 percentile: (dolomite matrix) The values for Case I in Table E-10 in Lappin et al. (1989) were used. These $K_{d}$ values represent a compromise between the empirical data that show that sorption will occur under. WIPP-specific conditions and theoretical calculations that suggest that many factors can decrease the extent of sorption significantly under other conditions that are possible in the Culebra.

50 percentile: (dolomite matrix) The lowest reported value for Culebra $\mathrm{H}_{2} \mathrm{O}$ was used. If no data for Culebra $\mathrm{H}_{2} \mathrm{O}$ were available, the lowest of the values reported for organic-free WIPP $A, B$, and $C$ Solution was used.

75 percentile and 50 percentile (clays):

The values in Table E-11 in Lappin et a1. (1989) and the lowest value for Culebra $\mathrm{H}_{2} \mathrm{O}$ were compared; the larger of the two values was used for the 75 percentile. The smaller value was used for the 50 percentile. If no data for Culebra $\mathrm{H}_{2} \mathrm{O}$ were available, the lowest value reported for WIPP $A, B$, and $C$ Solutions (organic-free) was compared to the value in Table E-11.

25 percentile: The value for Case IIB in Tables E-10 (dolomite) or E-11 (clay) was used. The choice of this value reflects the possible effect of organics on retardation.

0 percentile: The use of a $k_{d}$ value of zero increases the conservatism of the distributions. 
CASE 2 (Tables $2 A$ and $2 B$ ):

100 percentile: The lowest maximum of the ranges of values for Brine $B$ with organics was used. Brine $\mathrm{B}$ is a saline $\mathrm{NaCl}$ brine which is qualitatively similar to Castille Brine, the dominant fluid in scenarios wherein fiuid composition is controlled by solut ions from the repository (see Table $3)$. The concentrations of organics in the Brine $B+$ organics experiments may be higher than would be expected in the PA scenarios. If data for this water were not available, the lowest maximum of the ranges of values from other data for inorganic Brine $B, A$ or other saline waters (see Table 3-14 in Lappin et al., 1989) was used. The use of the minimum values introduces a degree of ronservatism in ti.: distributions.

95 percentil. (dolomite matrix) The lowest maximum of ranges of value for organic-rich Brine $B$ was used. If no data for this solution were available, the lowest maximum of ranges of the values reported for organic-free Brine $B$ was used.

50 percentile: (dolomite matrix) The values for Case IIB in Table E-10 in Lappin et al. (1989) were used. These $K_{d}$ values represent a compromise between the empirical data that show that sorption will occur under WIPP-specific conditions and theoretical calculations that suggest that many factors can decrease the extent of sorption significantly under other conditions that are possible in the Culebra.

95 percentile and 50 percentile (clays):

The values in Table E-11 for Case 2B in Lappin et aI. (1989) and the highest minimum for ranges of values for Brine B (Table 3-14) were compared; the larger of the two values was used for the 95 percentile. The smaller value was used for the 50 percentile. If no data for Brine $B$ available, the lowest value reported for Brine $A$ and other saline solutions in Tabie 3-14 was compared to the value in Table $\mathrm{E}-11$.

0 percentile: The use of a $k_{d}$ value of zero increases the conservatism of the distributions. 
Calculation of Retardation Factors for Dual Porosity Transport in the Culebra Dolomite

Data provided in this mewo can be used to model dual porosity transport in the Culebra. In this model, retardation in the matrix and fractures provide separate barriers to radionuclide migration. The mineralogy of the Culebia has been described in Siegel et al. (1990). The dominant mineral in the matrix is a fairly pure dolomite. Clay, gypsum and calcite are distributed heterogeneously, both vertically and horizontally in the matrix. Clay and quartz together comprise ubout 38 by weight of the matrix on average.

In the dolomite inatrix, both the clay and dolomite can sorb radionuclides; however, I have not attempted to differentiate between the independent contributions of these two sliostrates to the overall sorption in the matrix. Table $1 B$ and $2 B$ provide the bulk matrix $K_{d} s$ for Case 1 and Case 2, respectively. The retardation factors can be calculated for the bulk matrix using the standard expression tor retardation in a porous medium (Eq. 1) and used to model the extent of matrix diffusion In Eq. 1. $\rho$ and $\phi$ are the grain density and porosity of the matrix respectively.

$$
R=1+K_{d} \rho(1-\phi) / \phi
$$

Radionuclide transport within the fractures will be retarded by interactions with fracture-lining minerals. The concentration of a radionuclide in the fracture is coupled to matrix diffusion in the calculations of a dual porosity transport model. Within the fractures, gypsum and corrensite, a mixed-layer chlorite/smectite are most commonly observed. Material scraped from the surfaces of open (?) fractures contains up to $258(\mathrm{gm} / \mathrm{gm})$ clay. The retardation factors for le fractures can be calculated from the following expression:

$$
R=1+\rho_{c} K_{d c}\left(\delta_{c} / \delta\right)
$$

where $K_{d c}$ is the distribution coefficient for the clay given in Tables $1 B$ and $2 \mathrm{~B} ; \rho_{\mathrm{c}}$ is the density of the clay $(2.5 \mathrm{gm} / \mathrm{cc}) ; \delta_{c}$ is the thickness of the clay coating the fracture and $\delta$ is the fracture aperture (see Neretnieks and Rasmusson, 1984).

At present, data are not available to estimate the true range or distribution of $\delta_{c} / \delta$ in the Culebra. A normal distribution with a maximum value of 0.9 and a minimum value of 0.1 could be used for the current set of performance assessment calculations. Using these values and $a K_{d}$ of $300 \mathrm{ml} / \mathrm{gm}$ for plutonium (cf. Table 1B, retardation factors for the fracture ranging from 76 to 676 can be calculated. A retardation factor of 2000 can be calculated for the dolomite matrix using Eq. 1 , with a $k_{d}$ of $80 \mathrm{ml} / \mathrm{gm}$ ( $c f$. Table $1 \mathrm{~A}$ ), a density of $2.8 \mathrm{gm} / \mathrm{cc}$ and porosity of 0,1 . 
Researchers from the University of New Mexico are currently measuring the thickness of clay fracture coatings in Culebra core samples. The WIPP hydrologists should be asked to provide an estimate of the distribution of fracture apertures. From these two sets of data, a more defensible distribution for $\delta_{c} / \delta$ can be obtained for the next round of PA calculations.

There is no reason to assume a priori that matrix diffusion will not be significant in the Culebra. The amount of matrix diffusion and the proper model for transport in dual porosity media depends on the relative rates of transport through the fractures and diffusion in the matrix. Several iumerical criteria that can be used to determine the validity of alternative approximations for transport in porous fractured media are presented by Erickson et al. (1986). A previous application of the criteria to transport in the Culebra is described in Attachment 1 to this memo. The parameter values used in the memo (written in 1986) are not be the most current estimates of the properties of the Culebra; however the calculations are significant because they show that matrix diffusion can be important even if the travel time to the accessible environment is less than 20 years. The method to calculate the criteria is straightforward and can be applied to more recent data.

On the Conservative Nature of the Recommended $k_{d}$ Distributions

In general, the bulk of the values sampled from the recommended $k_{d}$ distributions will be lower than those 1 isted in Tables $3-14$ and $3-15$ of Lappin et al. (1989). Nany of the $\mathrm{K}_{d} s$ for the actinides reported in the literatule are in the range $10,000-100,000 \mathrm{ml} / \mathrm{gm}$. Such high values were not allowed to dominate the shape of the distribution functions recommended in this memo. In general, $\mathrm{K}_{\mathrm{d}} s$ are calculated solely from the loss of radioactivity from solution; therefore, small errors in the measurement of a trace amount of radionuciide remaining in solution could lead to large errors in the calculated $K_{d}$. Review of experimental procedures used to obtain the values, suggests that the results could be compromised by unrecognized precipitation; this error would lead to high $\mathrm{K}_{\mathrm{d}} \mathrm{s}$ that wouid overestimate the extent of sorption.

Experimental data obtained during 1989-1990, and qualitative predictions about che surface properties of the clays, however, do suggest that actinides could be strongly adsorbed onto both fixed-charge ion exchange sites and surface hydroxyl groups of clays in the presence of carbonate complexation, high ionic strength, competition for sorption sites by other cations such as $\mathrm{Mg}^{+2}$ and $\mathrm{Ca}^{+2}$, and organic complexation. The results of work carried out at Stanford University in support of this project suggest that ac inide carbonate complexes and organo-actinide complexes will be sorbed by clays in the $\mathrm{pH}$ ranges typical of the undisturbed Culebra Dolomite. The effect of mixing of water from the repository and Culebra waters on sorption remains to be evaluated. 
The $K_{d}$ values presented in Tables 1 and 2 were based on consideration of experimental data obtained under oxic conditions. The sorption behavior of the radioelements under anoxic conditions that may be present in the repository cannot be extrapolated with these data. Some observations have been made of radionuclide partitioning between soils, solutions and organic matter that suggest that the $\mathrm{K}_{\mathrm{d}} s$ of the radioelements in their lower oxidation states might be lower than those reported for the oxidized forms.

\section{Additional References}

Erickson, K. L., et al., 1986, "Approximate Methods to Calculate Radionuclide Discharges for Performance Assessment of HLW Repositories in Fractured Rock," in Waste Management 86 , Vol, 2, P. G. Post, ed., University of Arizona.

Siegel. M. D., Lambert, S. J. and Robinson, K., 1990, Hydrogeochemical Studies of the Rustler Formation and Related Rocks in the WIPP Area, Southeastern New Mexico, SAND88-0196 (in press).

Neretnieks, I., and Rasmusson, A., 1984, "An Approach to Modelling Radionuclide Migration in a Medium with Strongly Varying Velocity and Block Sizes Along the Flow Path," Water Resources Research, Vol. 20, pp. $1823-1836$.

Distribution:

J. Carr, WPO/DOE

V. Daub, WPO/DOE

J. C. Helton, 6413

M. Tierney, 6415

W. D. Weart, 6340

R. C. Lincoln, 6341

D. R. Anderson, 6342

S. G. Bertram-Howery, 6342

L. S. Gomez, 6342

M. G. Marietta, 6342

R. P. Rechard, 6342

E. D. Gorham, 6344

P. B. Davies, 6344

A. M. LaVenue, 6344

C. F. Novak, 6344

A. R. Lappin, 6345

L. H. Brush, 6345 
Table 1A. Probability Distribution Functions for $K_{d}$ Values (ml/g) for Culebra Dolomite Matrix (Case 1).

\begin{tabular}{rrrrrrr} 
Bercent1le & Pu & Am & Cm & U & Np \\
\cline { 6 - 7 } 1008 & 1050 & 380 & $(12000)$ & 7.5 & $(10)$ \\
758 & 100 & 200 & $(200)$ & 1 & $(1)$ \\
508 & 80 & 110 & $\mathrm{ng}$ & 0.6 & $(0.6)$ \\
258 & 25 & 100 & $(100)$ & $\mathrm{ng}$ & $\mathrm{ng}$ \\
08 & 0 & 0 & 0 & 0 & 0
\end{tabular}

Table 1B. Probability Distribution Functions for $K_{d}$ Values (ml/g) for Fracture Clays of the Culebra Dolomite (Case 1)

\begin{tabular}{crrrrr} 
Percent1le & Pu & Am & Cm & D.Np \\
\cline { 1 - 2 } 1008 & 40000 & 4100 & $1.6 E 5$ & 50 \\
758 & 2300 & 500 & 2700 & 20 \\
508 & 300 & 300 & $(50 C)$ & 10 \\
258 & 100 & 200 & $(200)$ & $(1)$ \\
08 & 0 & 0 & 0 & 0
\end{tabular}

() - value poorly constrained by avallable data; estimated by assumption of similar behavior to homolog element.

ng - not given 
Table 2A. Probability Distribution Functions for $K_{d}$ Values (ml/g) for Culebra Dolomite Matrix (Case 2).

\begin{tabular}{rrrrrr} 
Percentile & Pu & Am & Um & U & Np \\
\cline { 2 - 5 } & 6000 & $5.7 E$ & $(5.7 E / 4)$ & 7.1 & 28 \\
758 & 560 & $2.8 E 4$ & $(2.8 E 4)$ & 1.5 & 10 \\
508 & 25 & 100 & $(1.00)$ & 1 & 1 \\
08 & 0 & 0 & 0 & 0 & 0
\end{tabular}

Table 2B. Probability Distribution Functions for $K$ Values (ml/g) for Fracture Clays of the Culebra Dolomite (Case 2)

\begin{tabular}{crrrrrr} 
Percentile & Pu & Am & $\mathrm{Cm}$ & U & Np \\
\cline { 5 - 6 } & 1008 & $1.0 E 4$ & 1000 & $(1.0 E 4)$ & 50 & 2000 \\
958 & 300 & 100 & $(300)$ & $\mathrm{ng}$ & 5 \\
508 & 100 & 90 & $(100)$ & 1 & 1 \\
08 & 0 & 0 & 0 & 0 & 0
\end{tabular}

() - value poorly constrained by available data; estimated by assumption of similar behavior to homolog element.

ng - not given 
TABLE 3. COMPOSITIONS OF REFERENCE BRINES AND MIXTURES

\begin{tabular}{|c|c|c|c|}
\hline \multirow[t]{2}{*}{ SOLUTE } & \multicolumn{3}{|c|}{ SOLUTIONS 1} \\
\hline & $\underline{\mathrm{SB}-1 \mathrm{ah}}$ & ERDA- 6 & AISin \\
\hline $\mathrm{Ca}^{2+}(\mathrm{mmol})$ & 10.5 & 13.2 & 22.8 \\
\hline $\mathrm{Mg}^{2+}(\mathrm{mmol})$ & 1171 & 20.8 & 21.5 \\
\hline $\mathrm{Na}^{+}$(mol) & 3.92 & 5.35 & 0.61 \\
\hline $\mathrm{K}^{+}$(mmol) & 586 & 107 & 8.2 \\
\hline $\mathrm{Cl}^{-}$(mol) & 6.42 & 5.27 & 0.57 \\
\hline $\mathrm{SO}_{4}^{2-}(\mathrm{mmol})$ & 186 & 187 & 80 \\
\hline $\mathrm{TIC}^{2}$ (mmol) & 0.4 & 17.5 & 1.74 \\
\hline $\operatorname{logpCO}_{2}(\mathrm{~atm})$ & -2.4 & -0.69 & -2.75 \\
\hline $\mathrm{pH}$ & 6.08 & 6.17 & 7.46 \\
\hline I $($ mol $)$ & 8.20 & 5.82 & 0.84 \\
\hline
\end{tabular}

${ }^{1}$ The ERDA- 6 brine is the average composition calculated for 10 samples from the ERDA-6 we11. The SB-lah brine is a composition calculated from a reference Salado brine composition (PAB1 in Lappin et al. (1989); Tále 3-4) which has been brought to equilibrium with anhydrite and halite in a PHRQPITZ simulation. The AISin brine is a composition calculated from a reference composition for samples from the WIPP Air Intake Shaft which has been brought to equilibrium with calcite by adding $\mathrm{CO}_{2}$ in a PHRQPITZ simulation.

${ }^{2}$ Total Inorganic Carbon 
MEMORANDUM

DATE:

SUBJECT :

FROM :

TO:
August 12, 1986

Approximate Methods to Calculate Solute Transport in Fractured Porous Media: Application to the WIPP

M.D. Siegel, Div. 6431

Distribution

Erickson and others (1986) have evaluated three approximate methods for calculating radionuclide discharges in homogeneous systems of fractured, porous rock. The approximations are: (1) a semi-infinite medium approximation where radionuclide diffusion rates into the porous matrix are calculated assuming a semi-infinite matrix (Crank, 1975); (2) a linear-driving-force approximation where radionuclide diffusion rates into t? $\mathrm{e}$ matrix are proportional to the difference between bulk concentrations in the fracture fluid and in the matrix pore water; and ( 3 ) an equivalent-porous-medium approximation where it is assumed that the time rate of change of radionuclide concentrations in the matrix is proportional to that of radionuclides in the fracture fluid. An evaluation of the accuracy of these approximations and derivation of criteria for their application were made for simple systems (see Figure 1.) in which the following assumptions are valid:

(1) the formation is a saturated, porous rock containing 1 set of uniform, parallel, evenly-spaced fractures,

(2) fluid flow occurs only in 1 direction in the fractures,

(3) bulk diffusion in the matrix pore waters occurs only perpendicular to the direction of fluid flow,

(4) radionuclide sorption is reversible and isotherms are linear.

(5) radionuclides exist as single chemical species,

(6 fluid flow in the porous matrix, hydrodynamic dispersion, radioactive production and decay, and colloidal transport of radionuclides are all negligible.

Radionuclide transport in this system can be described by coupled material balances for the fracture fluid and the matrix. The equations are coupled through the expression for the radionuclude concentrations in the matrix pore water. The three approximations are derived from this exact solution by replacing this term with simpler expressions. Criteria for application of these approximations are based on the the error in the calculated radionuclide concentration in the matrix. For the purposes of performance assessment calculations Erickson and others (1986) suggested that errors on the order of 208 were acceptable. The criteria were expressed in terms of the following fundamental parameters: fracture porosity ( $\phi f)$, matrix porosity $(\phi m)$, the lonic diffusivity in the pore water (D), the tortuosity/constrictivity of the matrix $(a)$, the fracture spacing (2B), the interstitial velocity $(v)$, and the travel path length $(x)$. 
For systems in which the fracture porosity is small and less than the matrix porosity, the numerical criteria are expressed as follows:

Define $X-[(D / \alpha)(1-\phi f) \phi m x] / v B^{2} \phi f$

then:

$X \leq 1$ for the semi-infinite-medium approximation,

$\mathrm{X} \geq 0.2$ for the linear-driving-force approximation,

$X \geq 50$ for equivalent-porous-medium approximation.

Figure 2 illustrates the application of these criteria to data from the WIPP site. Lines representing $X$ values of $0.2,1$, and 50 divide the graph into regions within which at least one of the approximations will give acceptable results (ie. errors $<208$ when compared to the exact solution). The data plotted were chosen such that the $y$-coordinates correspond to parameter values which gave the best fit to early SWIFT-2 simulations of the H-3 tracer test ('average values'), and to the extrema of parameter values considered reasonable for the site ('best case' and 'worst case' values). The $x$-coordinates correspond to the breakthrough times observed at the $\mathrm{H}-3$ tracer test ( 0.9 and 3.8 days) and the extrapolated travel times to the accessible environment ( 2.9 and 18.2 years). It can be seen that for the 'average' and 'worst case' values, the semi-infinite-medium approximation would be valid for the tracer test if the geochemical and hydrogeological assumptions listed above were valid. The lineardriving-force approximation would give acceptable results for regional-scale transport modeling for the 'best case' and 'average' values of $X$ if these same assumptions held throughout the whole region. Under such conditions, the computer code NWFT/DVM (Campbe11, 1981) could be used for transport modeling. Figure 2 also shows that for 'best case' values of $x$, the equivalent-porous-medium approximation could be used for a fracture system that was homogeneous on a regional-scale. Under 'worst-case' conditions, only the exact solution or the semi-infinite-medium approximation would give acceptable results for the tracer test or the regional-scale modeling.

Several important questions remain to be addressed before the results of this type of analysis can be applied with confidence to the WIPP site:

1. What is the effect of geometry on the numerical values of the criteria for the approximations? The effects of different shaped matrix blocls, heterogeneities in fracture spacing and aperture, and anisotropy must be examined before the use of a porous-medium approximation can be evaluated for the site. Can the effects of heterogeneity be bounded by the appropriate choice of parameter values for a homogeneous system which produces the same discharge?

2. What are the effect of nonlinear and irreversible sorption on the numerical values of the criteria? 
3. In the analysis presented above it was assumed that neither the rates of sorption or diffusion through the boundary layer at the fracture/matxix interface imited the rate of mass transfer into the matrix. Is this reasonable for the rapid flow rates obtained from the tracer test?

4. Can the analysis presented above be applied to a system of discrete fractures or highly fractured zones with a relatively impermeable matrix?

5. Radioactive decay and production were not considered in the analysis presented above. How will these processes affect the criteria for the approximations?

The major ur.ertainty in the analysis is fracture geometry. It should be noted that a dual-porosity conceptual model using SWIFT-2 may also be subject to the same uncertainty; both the SWIFT-2 analysis and the simple analysis described above assume a homogeneous fractured media. Additional field data is needed to improve the analysis.

Some follow-up activities to this analysis are listed below. These suggestions are based in part on discussions with $K$. L. Erickson, R. Rechard, and P. Davis and are designed to address some of the questions raised above.

1. Examine the effect of different geometries (prisms vs spheres vs flat plates) on the exact solution of the transport equation using the RAINBOW code. Comparison of elution curves for media with different geometries but similar fracture porosities would provide some insight into the sensitivity of this analysis to geometric effects.

2. Derive the criteria for the three approximations for other geometries. This work is nearly complete for spheres; it would probably be considerably more difficult for prisms than the analysis for flat plates.

3. Examine ways to represent heterogeneous systems by 'equivalent' homogeneous systems by using representative elementary volumes (REV's) of appropriate geometry.

4. Examine the validity of the criteria for a system composed of a zone of high permeability within an impermeable matrix (ie. what is the error introduced by edge effects at the boundary of the permeable zone?)

5. Obtain additional field data to further constrain the fracture geometry used in the conceptual models. 


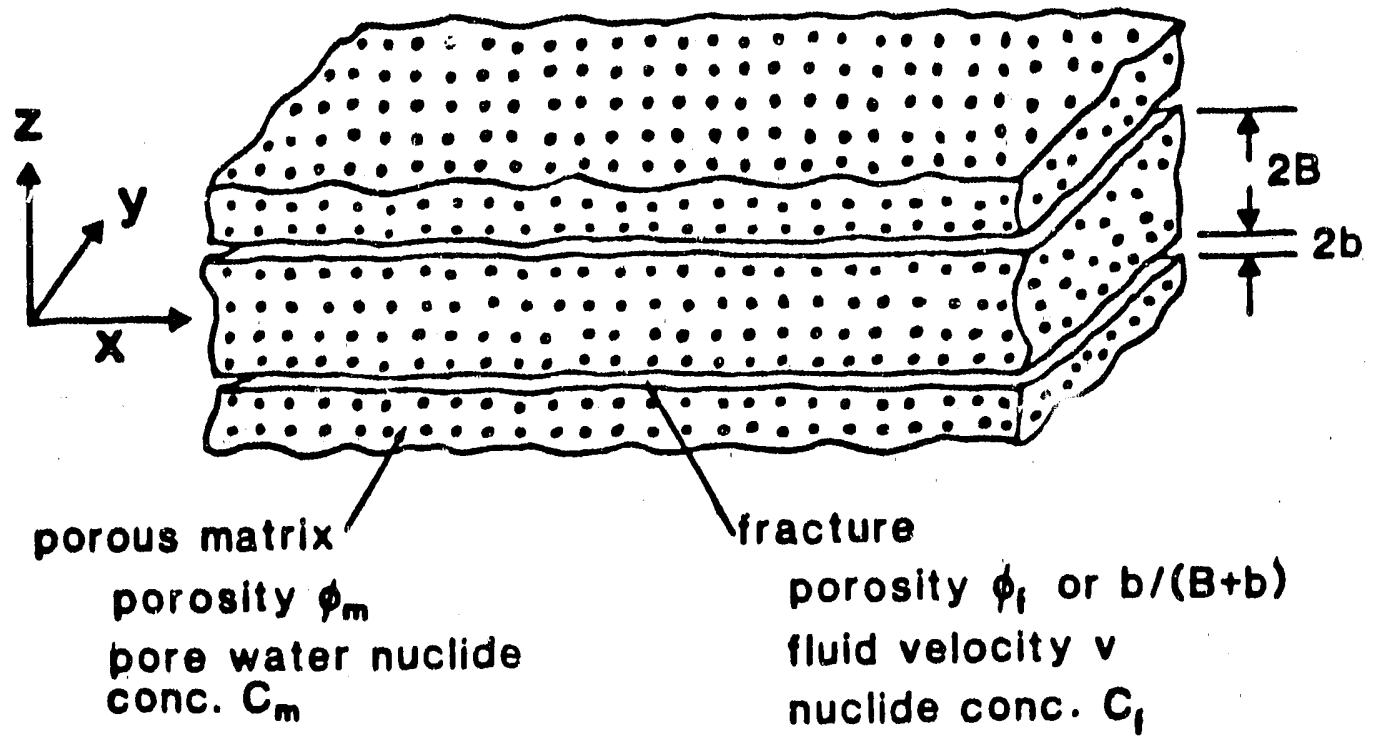

Figure 1. Schematic representation of fractured, porous rock.

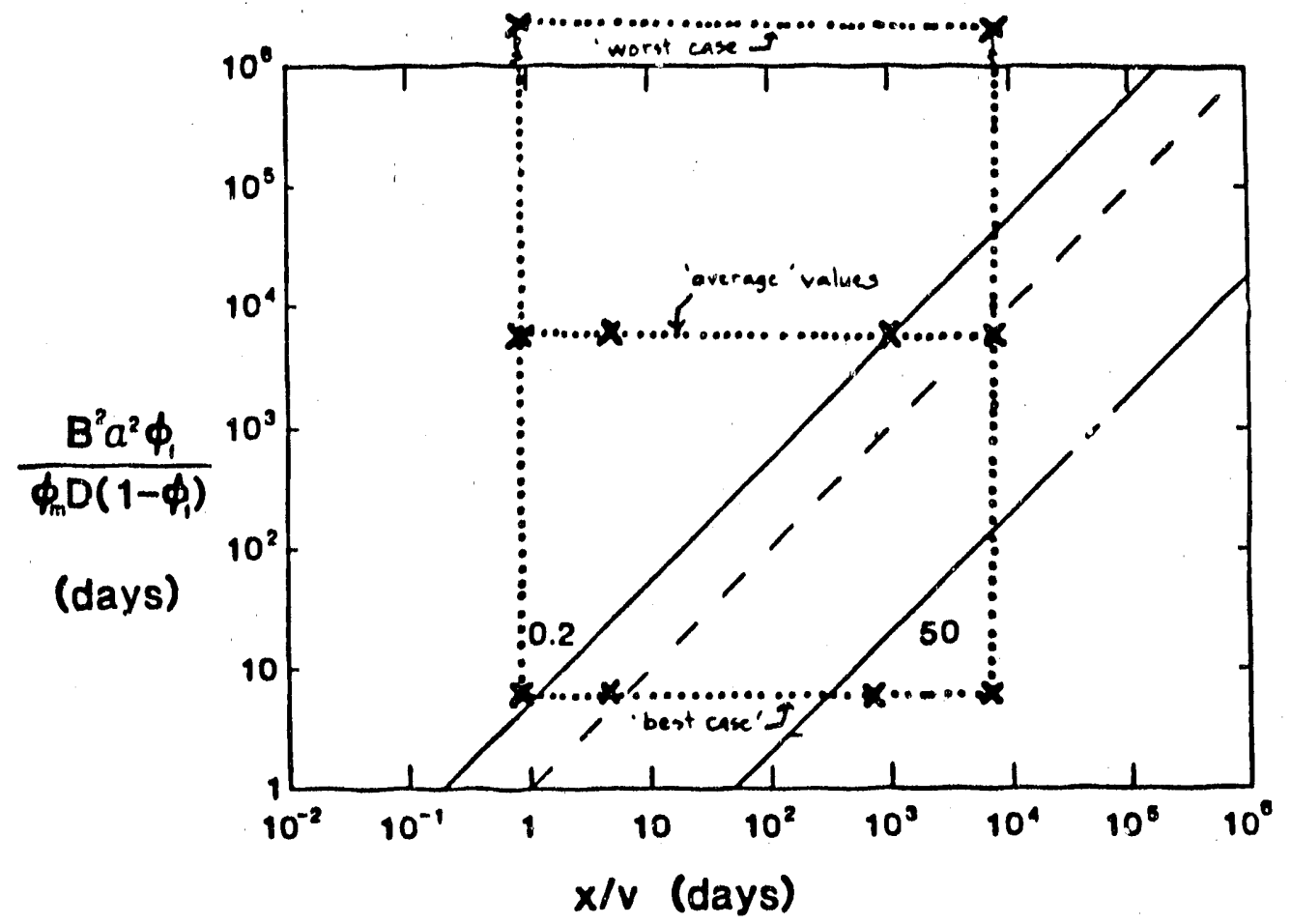

Figure 2. Application of criteria to selected hydrulogical and chemical parameters for the WIPP site. 
Table 1. Parameter Values Used in WIPP Analysis

$\begin{array}{lccc} & \text { 'Best Case' } & \text { Average } & \text { 'Worst Case' } \\ \text { Matrix porosity } & 25 & 208 & 28 \\ \text { Fracture Porosity } & 0.018: & 0.188 & 28 \\ \begin{array}{l}\text { Fracture Spacing } \\ \text { 2B (ft) }\end{array} & 2 & 4 & 4 \\ \begin{array}{l}\text { Diffusivity } \\ \text { D/a }\left(\mathrm{cm}^{2} / \mathrm{sec}\right)\end{array} & 1.3 \mathrm{E}-6 & 7.0 \mathrm{E}-7 & 1.4 \mathrm{E}-7\end{array}$




\title{
Memo 3b
}

\author{
Date: $\quad 8 / 1 / 90$ \\ To: Elaine Gorham, 6344 \\ From: Peter Davies, 6344, and Marsh LaVenue (6344, \\ INTERA) \\ Subject: Comments on Model Implementation and Data for Use \\ in August Performance Assessment Calculations
}


DATE:

TO:

FROM:

SUBJECT:
August 1, 1990

Elaine Gorham (6344)
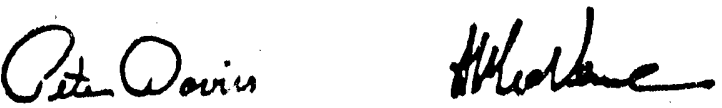

Peter Davies (6344) and Marsh LaVenue (6344, INTERA)

Comments on Model Implementation and Data for Use in August Performance Assessment Calculations

The following material is our response to the recent request from Division 6342 for input on data, distributions, and feedback on model implementation. This material is divided into the following three categories: 1) comments about model implementation for brine reservoir, Culebra flow, Culebra transport, and 2-phase flow; 2) general comments about data distributions for uncertainty analysis; and 3) specific data and uncertainty distribution recommendations.

Our understanding of the model, data, and data-distribution needs of the Performance Assessment Group is derived primarily from two sources: July 13th meeting with PA in which model implementation and data needs for the August calculations were described in a general fashion and Rob Rechard's July 17 th memo which provided tables and schematics of specific data weeds. PA has requested that all information be provided by August 1st.

\section{Cemments oe Medel Implementation for PA Calculations}

One of the most challenging tasks that PA faces is implementing flow and transport models that are simple enough to run efficiently in the CANCOM, multi-run/uncertainty-sampling framework, yet complete enough to capture essential system behavior. In order to accomplish this balance, simplifying assumptions must be consistent with the importance, quality, and extent of the available data, and simplified models must be tested against more rigorous models. With these objectives in mind, we have the following comments concerning model implementation for the current round of PA calculations:

- Brize-Reserveir Medel: As discussed in detail at the July 20th Rustler Working Group Meeting, the simplified exponential decay model proposed by PA for the brine resirvoir is fully supportea by the detailed, brine-reservoir analysis that was recently comnleted by Mark Reeves and others at INTERA. This simplified model should result in significant savings in computational effort. We think that characterization of the "cotal capacitance" term in this simplified model will require additional model unalyses based on the parameters values presented in Table A -4 .

- Culebn Elow Model: Our understunding of the approach to Culebra now modeling as presented in the July 13 th meeting and the July 17 th memo is that the model is to be divided into regional and local flow models. Also, the regional-scale model is broken into 8 transmissivity zones, with the transmissivity of each zone assigned based solely ou the single well, small-scale test data. The transmissivity zones from the regional model are carried 
directly to the local-scale model. The motivation for this regional/local model approach is to use the regional model to calculate the impact of climate change, and then impose the resulting now-system change as boundary conditions on the local model.

As we have already expressed in verbal communications to PA, we do not think that this approach should be taken for the present PA calcuiations. The reason for our concern is as follows: The Culebra is a highly heterogeneous unit and the transmissivity distribution in the immediate site ares plays a very important role in controlling offsite contaminant transport. The combination of strong heterogeneity and large impact of this parameter has been the primary motivation behind the extensive Culebra field testing and analysis program, and in particular, is the primary motivation behind the large scale multi-pad pumping tests and associated transient model calibration to those tests. Limiting the regional model to only eight zones and then carrying those same cones into the local model results in an uarealistic bomogenization of the transmissivity distribution in the immediate vicinity of the site. Also, basing the zones solely on small-scale, single-well transmissivities essentially throws out the valuable information that was obtained from the inge-scale, multi-pad tests and associated transient model calibration.

As we understand it, the motivation behind the regional model and associated coarse zonation is the use of the regional model to calculate the impact of climate change. Compared to our knowledge of the Culebra transmissivity distribution in the site area, our current understandine of how chanses in minfall at the cround surface propasate to the Culebra is extremely orimitive. Also, the Culebra flow system is likely to be significantly more sensitive to transmissivity than it is to climate change. Therefore in our opinion. the preseninoproach makes a tradeoff of usine an overly primirive representation of a very imoertan earameter (transmissivity) in order to add representation of a relatively low impact orocess that we do not yes know how 10 model in a defendable fashion.

What can be done given the current schedule for calculations? It is our opinion that the localscale model needs a more detailed zonation, and that sampling for uncertainty should focus on this scale. We recommend that the transmissivity and zonation for the site-scale model be based on the calibrated transmissivisy distribution from the transient-calibrated model of LaVenue et al. (1990), which directly incorporates the important information from the largescale multi-pad tests. Relative to climate change, our first approach would be to recognize up froat that we can not yet model climate impact on the Culebra in a meaningful fashion and drop the regional model. If PA feels that it is absolutely necessary to have climate change, even though we do not have a defensible model for the pertinent processes, then we suggest that climate change be imposed directly on the local-scale model, as we do not think that the regional-scale model provides much additional benefit at the present stage of model development. In reaching this conclusion, we do not mean to imply that the regional scale model will not be necessary for future calculations. Once we have a reasonable model for evaluating Culebre recharge and once inclusion of the regional scale does not require unacceptable compromises to the local-scale model, then a dual-scale approach to modeling Culehra now may be quite useful.

More detailed recommendations for zoning and uncereninty of Culebra transmissivity is presented in the third segment of this memo.

- Culeber Innsporr In order to provide defensible transport calculations, duni-porosity processes should be included. If health effects calculations are to be included, then transport modeling will require a two-dimensional approsch (because lateral dispersion will sienificantly impact contaminant concentration at a point source such as a well). If only 
cumulative release is to be culculated, the our recent sensitivity studies sugsest that a onedimensional approach may be sufficient, as long as dual-porosity processes are adequately implemented in the $1-D$ model. It is our understanding that PA is currently interested in both integrated release and health effects. We recommend that PA consider the simplified uniform now field approach for the transport segment of the calculation (essentially $1-D$ flow and 2-D transport) that was developed for the FSEIS and brine-reservoir-breach aensitivity aimulations. This approach should be checked against the current PA approach of fully 2dimensional now and transport. In the long-term, we think that this alternate approach will provide a computationally efficient, yet defensible simplification to transport.

2-Phnse Modeling: Based on the presentations of PA 2-phase modeling at the July 11 th Salado Working Group Meeting and the July 13th PA meeting, we think that the most important step toward improving the PA 2-phase breach model is to fully implement aon-zero capillary pressures and the capability to handle dissolved gas in the BOAST code.

\section{Geoeral Comments About Den Distributions for Uncertainty Aonlysis}

Our first gederal comment is that the time and resources available to address this request are clearly not adequate to carry out a thorough and rigorous response, particularly with respect to data distributions for uncertainty analysis. While this is presumably recognized by all parties involved, we are quite concerned that once the data values and distributions 80 into the calculations, the questionable validity of the uncertainty distributions may be forgotten. Therefore, we think that it is extremely important that all future model discussions (both written and verbal) carry explicit cavears about the questionable validity of uncertainty information utilized in these calculations.

Given the limited time, we sugsest the following approach for assigning uncertainty distributions. Unless stated otherwise, we interpret the "expected"/"base-case" values cited in the SEIS (Lappin et al., 1989), in Rechard et al. (1990), and in this memo as representing median values and the endpoints of the "range" as representative of the 1 st and $99 \mathrm{th}$ percentile on a cumulative probability plot. Clearly there are some parameters for which there exist sufficient data to construct more realistic cumulative probability distributions, and for such parameters, PA is encouraged to construct and use these distributions in place of the lst and 99 th percentile approach taken in this memo.

Finally, we think that it is quite important that PA and the WIPP project as a whole recognize that obtaining truly meaningful uncertainty distributions will be a maior task. We have some parameters for which we do not have (and never will have) adequate data to construct meaningful distributions, which will require expert panels to derive distributions (e.8. Culebra dispersivity). We have other parameters for which we have sufficient quantities of dats to directly construct distributions (e.8. Culebra matrix potosity). However, the task of organizing data and constructing the distributions will require significant time to complete and document. And finally, we have come very important parameters for which the data are insufficient to construct meaningful distributions, but for which alternate analytic approaches may yield very useful uncertainty information (e.g. using kriging and pilot points to generate information about the uncertainty in the Culebra transmissivity distribution). None of these are small tasks. Few of these are likely to be carried out well by staff members as a peripheral activity. The bottom line is thes construction of uncertninty distributions is a maior task thrs needs to be resosnized as a explicil activity. with nopropriate fundine and staffins. 
Appendix A

\section{Spedific Comments on the Current PA Dnin Bese}

- Attention needs to be paid 10 significant figures. For most data, 1 significant figure is all that is justified. For some parameters, 2 significant figures may be appropriate, while for others, only order of magnitude values are justified.

- A second broader issue concerns many of the citations in the Appendix $A$ tables given in the 7-17-90 Rechard memo. In the long run, parameter values and rationales should be referenced back to their original sources, not to some intermediate SAND report. Ultimately, it probably would be very useful to publish a separate parameter data-base report that rigorously documents this information. A first attempt has been made in this memo to cite original references where that is possible, but time limitations have prevented rigorous tracking down of all original citatioas. We have appended a copy of the reference list from Lappin et al., 1989, as this is the most comprehensive list of original literature available at this time.

\section{IABLEA-L SALADQSALT PROPERTIES}

- Capacitance: It is not clear how this capacitance value, and its range are derived for the cited source (McTigue, 1987). We suggest that a median capacitance value be derived directly from the rock properties cited in Krieg's (1984, p. 16) reference rock properties report and a brine (water) compressibility from the CRC Handbook of Chemistry of Physics. For the upper end of the range ( $99 \mathrm{th}$ percertile) we suggest increasing the capacitance value by two orders of magnitude as a very rough approximation of the impact of dissolved gas in the Salado brine as suggested by Bredehoeft, 1988 (EOS paper). We suggest this upper end only for calculations that are limited to a single (brine) phase. For the lower end of the range, we suggest computing a capacitance based on an assumption of totally incompressible matrix. Also note that the capacitance term is sometimes constructed differently in different flow codes, and therefore, this parameter is some what code specific (see additional comments under TABLE A-3).

- Dispersivity. No rationale is given in Lappin et al., 1989 for the cited value (Table D-2) for dispersivity in the Salado. For the present time, one could use a parameter rationale similar to that used for the Culebra dispersivity. For the Culebra, dispersivity is expressed as a function of the trunsport distance of interest. However, the rationale behind the Culebra dispersivity is based on actual transport observations in relatively permeable media reported in the literature. No relevant solute transport data exists for very low permeability media such as the Salado. Therefore, at present, we see no basis for making a defensitic es:imate of dispersivity in the Salado.

Bressure 1 the Repositery Level: We sugsest a median value of $11 \mathrm{MPa}$, based on the maximum far-field pore-pressure mensured to dare (personal communications from R.L. Beauheim and E. Peterson). For the upper end of the range ( 99 th percentile), we suggest a pressure equal to lithostutic, 15 MPa based on Wawersik and Stone's (1985) hydraulic fracturing study. For the lower end of the range (lst percentile), we suggest a pressure equal to brine hydrostatic (6 MPa, based on Nowak et al., 1988, p.6).

Rermenbility. In our opinion, Salado salt permeability should be considered only on an order of magnitude basis. We base the following recommendation on the early brine inflow work summarized in Nowak et al. (1988) and on discussions with R.L. Beauheim on the preliminaly 
results of his ongoing in-situ Salado permenbility testing program. We sugsest a median value of $1 e-20 \mathrm{~m}^{2}$, with an upper end (99th percentile of $1 \mathrm{e}-19 \mathrm{~m}^{8}$ and a lower end (1st percentile) of $1 e-23 \mathrm{~m}^{2}$. It is our opinion that the person best qualified to provide permeability values and distribution is R.L. Beauheim, and his estimates should be siven the highest weight.

- Rorosity. We sugsest a median value of 0.01 based on the electro-magnetic and DC resistivity mensurements of Skokan et al. (1989). For the upper end of the range (99th percentile), we suggest a value of 0.03 based on the low ead $(10 \mathrm{ohm})$ of the DC resistivity range of Skokan et al. (1989). For the lower end of the range (1st percentile), we suggest 0.001 bused on drying experiments reported in Powers et al. (1978).

\section{TABLE A-2, SALADO INTERBED PROPERTTES}

- Interbed Thickness: Use the reference stratigraphy presented DOE, 1989 (Geotechnical Field Dats and Analysis Report, DOE/WIPP 89-009).

- Undisturbed Interbed Permeability. Based on discussions with R.L. Beauheim on the preliminary results of his Salado permeability messurement program we suggest a median value of $1 \mathrm{e}-19 \mathrm{~m}^{2}$. For the upper end of the range ( $99 \mathrm{th}$ percentile), we susgest $1 \mathrm{e}-18 \mathrm{~m}^{2}$, and for the lower end of the range (Ist percentile) $1 e-20 \mathrm{~m}^{2}$. It is our opinion that the person best qualified to provide permeability values and distribution is R.L. Beauheim, and his esvimates should be given the highest weight.

- Disturbed Interbed Permeability. No rationale is given in Lappin et al. (1989) for the cited value (Table D-2) for disturbed interbed permeability. Disturbed interbed permeability will change with time as the stress field around the WIPP excavations changes with time. We know from observations of fracturing (e.8. Borns, 1985) that permeability is likely to be quite high in some locations at some times. However, at this point in time, we have no reliable measurements of disturbed interbed permeabilities. Given that fractured interbeds are likely to have significantly higher permeabilities, we recommend a median value that is two orders of magnitude higher than the median value for intact interbeds, i.e. $1 \mathrm{e}-17 \mathrm{~m}^{2}$. The permeability for intact interbeds provides a lower bound (Ist percentile) of $1 e-19 \mathrm{~m}^{2}$. Based on an arbitrary spread of 2 orders of magnitude, an upper bound ( $99 \mathrm{th}$ percentile) value is le$15 \mathrm{~m}^{2}$. Observations of large, open fractures at eome locations beneath older excavations suggests that the upper bound permeability could locally be orders of magnitude higher that $1 \mathrm{e}-15 \mathbf{m}^{2}$. 


\section{IABLEA-3. CULFBRA DQLOMITE PROPERTIES}

- Dispertivity: A review of literature analyzing tracer tests at various scales and the development of contamiannt plumes in permeable, water-bearing units, at various scales (see Lappin et al., 1989, p. E-51), dispersivity for moderate travel distances (on the order of a kilometers), dispersivity can be expressed as a function of travel distance. In seneral, dispersivity ranges from about one percent to about ten percent of the travel path length. Given that the PA calculations are on the ame scale (a few kilometers) as the SEIS caleulations, we susgest applying the same median value of 100 meters for longitudinal dispersivity.

The magnitude of hateral dispersivity is generally considered to be related to longitudinal dispersivity. Reported ntios of longitudinal to transverse dispersivity mase from 5 to 100 (de Marsily, 1986) and 10 to 20 (Bear and Verruijt, 1987). Given these ranges, a ratio of 10 was specified for the SEIS (Lappin et a., 1989, p. E-23) and is recommended as the median value to be used for the August PA calculations.

- Encture Spacins (Matrix Block Leneth): The values and rationale presented in Lappin et al., 1989 (Table E-6, and p. E-50 to E-51) are the best basis for this parameter, i.e. 2 meters for the median value, 7 meters for the upper end ( 99 th percentile) and 0.25 meter for the low end (Ist percentile).

- Hydraulic Conductivity: Primary guidance for hydraulic conductivity should be taken from the transient-calibrated transmissivity distribution of LaVenue et al. (1990). This transmissivity distribution has utilized the greatest breadth of hydraulic information available, including both local-scale well tests and large-scale transient tests. (Note that if the LaVenue et $\mathbf{a}$. (1990) transmissivity is to be converted to hydraulic conductivity for PA calculations, the Culebra thickness assumed by LaVenue et al. (1990) is 7.7 meters.)

If a zoning approach is to be used, we recommend that I order of magnitude zones be created directly from the LaVenue et al. (1990, Fig. 5-22a,b) transient-calibrated transmissivity distribution. For a median value in eash zone, we suggest an area weighted mean of gridblock log-T values, i.e.:

$$
\log T_{\text {apoe }}-\frac{\sum A_{i} 108 T_{i}}{A_{i}}
$$

where $A_{1}$ and $T_{1}$ are the area and transmissivity of a given grid-block within the zone and $A_{8}$ is the total area of the zone. Uncertainty within each zone can be estimated from the standard deviations of the estimation errors (LaVenue et al., 1990, Fig. 2.10b) calculated by kriging the $\mathrm{DB}_{10}$ transmissivity data from hydraulic testing. Using a similar aren-weighted average for each zone produces an average standard deviation for the zone, i.e.:

$$
-\frac{\sum A_{1} q_{1}}{A_{4}}
$$


where $a_{i}$ is the standard deviation of the estimation error for a given grid block and opne is the area weighted standard deviation for a given zone. In order to facilitate construction of this zoning and the corresponding uncertainty distributions, we have attached a floppy disk containing the erid-block transmissivity values and grid-block estimation errors from the LaVenue et al. (1990) model. PA should be aware that this is only at first cut at estimating uncertainty distributions for Culebra transmissivity and that additional consideration should be given on how to better handle these distributions in future calculations.

- Brrtition Coefficients (Kd): Because Kd's are beyond the realm of our expertise, we have no further input. We sugsest that Malcolm Siegel is the best source for input on this parameter.

- Mntrix Porosity. Lappin et al., 1989 (Table E-8 and p. E-45 to E-48) provides a good review of the available matrix porosity measurements on Culebra core. The mean value for matrix porosity is 16 percent. While no distribution has been requested for this parameter, there are probably enough measurements to construct a rensonable distribution if this becomes necessary at some point. While no distribution has been requested for this parameter, it should be noted that the low end value for Culebra porosity is 0.03 as reported in Kelley and Saulnier (SAND90-7011, in prep).

- Eracture Porosity. Fracture porosity values are derived from the interpretation of tracer tests at the H-3 and H-11 hydropads. As discussed in Lappin et 1. ., 1989 (p. E-48 to E-50), the current expected/median value for fracture porosity is 0.0015 . No distribution has been requested for this parameter.

Storativity: The recommended value for median storativity is $2 e-5$, which is based on sparse well test data from 13 wells (see LaVenue et al., 1990, Table 2.5). This is the value that was used by LaVenue et al. (1990, 1988) and by Haug et al. (1987). PA modelers should note that this value has been used for SWIFT II simulations and that storativity in SWIFT II is defined as follows:

$$
S \cdot p \& b(\alpha+\beta)
$$

where:

$$
\begin{aligned}
& \text { - - porosity } \\
& \text { p - Iuid density } \\
& \text { - Eravity } \\
& \text { b - squifer thickaess } \\
& \text { - - rock compressibility }
\end{aligned}
$$


This definition is different from the definition of storativity used in many other groundwater models. The more common definition for storativity is as follows:

$$
S-p b(a+\infty)
$$

Note that the difference between these two equations rolates to the defiaition of rock compressibility (defined with respect to pore volume in the first equation and with respect to bulk volume in the second equation).

No distribution has been requested for this parameter.

- Thickness: An extensive Culebra thickness data base is presented in Appendix B of Cauffman et al. (1990, volume II of the recent Culebra modeling report). The mean value for thickness is 7.7 meters. No distribution hes been requested for this parameter.

- Tortuesity: Tortuosity data is derived primarily from electrical resistivity measurements on Culebra core as summarized in Lappin et al., 1989 (Table E-9 and p. E-48). We recommend the use of a mean value of 0.14 from this data set. The upper end of the range ( $99 \mathrm{th}$ percentile) is 0.33 , and the lower end of the range (Ist percentile) is 0.03 . 
- Expected and range values for brine reservoir parameters and rationales are well summarized in Lappin et al., 1989 (Table E-4 and p. E-25 to E-34). As stated previously, we interpret the expected/base-case values as being representative of the median and the endpoints of the range as being representative of the Ist and 99th percentile. Note that there is one typo in Lappin et al., 1989 Table E-4. The upper end of the transmissivity of the intermediate zone is $7 e-4 \mathrm{~m}^{2} / \mathrm{s}$, not $7 e-2 \mathrm{~m}^{2} / \mathrm{s}$. In the July 20 th Rustler Working Group meeting on brinereservoir-breach modeling, PA presented a simplified approach for modeling the brine reservoir. Derivation of the parameters aeeded for that approach more detailed parameters cited above should be documented.

- Comoressibilitr. The expected values and range given in Table A-4 (le-5 and le-9 to le-4, respectively) are not the values given in the cited Table 3-19 in Lappin et al. (1989). The correct values are an expected/median value of le-9 $\mathrm{Pa}^{-1}$ and a range of $1 \mathrm{e}-10$ to le-8 $\mathrm{Pa}^{-1}$.

- Permeability. The permeability values in Table A-4 have been calculated from transmissivities given in Lappin et al., 1989. The original reference for these permeabilities is Popielak et al. (1983), which gives value for permeability of intact Castile anhydrite as less than $2 e-4$ millidarcy $\left(<2 e-19 \mathrm{~m}^{2}\right)$.

\section{TABLE A-S. RELATIVE PERMEABILITY FOR SALT}

Measured data for the relative permeability of salt do not exist. At the present time our approach to this parameter is to use test data from the lowest permeability material that we could find for which relative permeability measurements have been made. The following relative permeability table has been derived by applying a modified Brooks and Corey model to data from a tight (on the order of 10 microdarcy) gas sand from the Multi-Well project.

$\begin{array}{lll}S_{\text {water }} & k_{\text {rw }} & k_{\text {rE }} \\ 0.200 & 0.00 E+0 & 1.00 E+0 \\ 0.220 & 2.23 E-9 & 9.34 E-1 \\ 0.250 & 4.78 E-7 & 8.40 E-1 \\ 0.300 & 2.77 E-5 & 6.94 E-1 \\ 0.350 & 2.98 E-4 & 5.60 E-1 \\ 0.400 & 1.60 E-3 & 4.38 E-1 \\ 0.450 & 5.93 E-3 & 3.29 E-1 \\ 0.500 & 1.73 E-2 & 2.33 E-1 \\ 0.525 & 2.76 E-2 & 1.90 E-1 \\ 0.550 & 4.26 E-2 & 1.52 E-1 \\ 0.575 & 6.37 E-2 & 1.18 E-1 \\ 0.600 & 9.30 E-2 & 8.79 E-2 \\ 0.650 & 1.85 E-1 & 4.19 E-2 \\ 0.675 & 2.55 E-1 & 2.58 E-2 \\ 0.700 & 3.44 E-1 & 1.40 E-2 \\ 0.725 & 4.57 E-1 & 6.29 E-3 \\ 0.750 & 6.01 E-1 & 1.98 E-3 \\ 0.770 & 7.40 E-1 & 4.49 E-4 \\ 0.790 & 9.06 E-1 & 1.74 E-5 \\ 0.800 & 1.00 E+0 & 0.00 E+0\end{array}$


TABLE A-6. ENGINEERED MATERIALS

We have no recommendations in the ares of engir eered materials.

\section{TABLE A-7. UNMODIFIED AVERAGE HASTE}

We have no recommendations in the area of unmodified average waste.

\section{IABLEA-8. PARAMETER YALUES FOR SPECIFIC MATERIALS}

We have no recommendations in the area of specific materials.

\section{TABLEA-9. FUUID PROPEBTIES}

Culebre Fluid Density: Table A-9 cites a single value $\left(1.092 e+3 \mathrm{~kg} / \mathrm{m}^{2}\right)$ for Culebra nuid density, referencing Marietta et al., 1989, Table 3-9. Fluid density in the Culebra is highly variable, ranging from freshwater to relatively dense brine $\left(1.00 e+3\right.$ to $\left.1.15 e+3 \mathrm{~kg} / \mathrm{m}^{3}\right)$. The citation of a single fluid density for the Culebra in this table takes the Marietta et al., 1989 value out of context (it was used to specify fuid density along NEFTRAN legs in the Culebra) and is misleading. Clearly there is no single value that characterizes Culebra fluid density. Values chosen for specific analyses must be chosen carefully. We recommend that if there is a need for Culebra fluid density in this data base, that either able of wells with associated density values or a contour plot is the best way to present this data in a manner that will minimize potential misunderstandings by anyone who is not familiar with the Culebra.

Water $22^{\circ} \mathrm{C}:$ State that these are reference properties for fresh water.

\section{IABLE A-10, SALADO BRINE COMPRESSIBILITY}

The purpose of this table is not clear. Salado brine compressibility (essentially the same value) is specified in Table A-9. 


\section{IABLE A-U CLIMATE YARIABILITY AND INTRUSION CHARACTERISTICS}

- Climase Vuriability. Where is this information coming from and how is climate variability (i.e. changes in peak precipitation) going to be implemented in the model? The WIPP project bas done relatively little work on climate variability and very little, if any, relevant data on how precipitation reaches and impacts the Culebra has been collected. See additional comments under the discussion of model implementation.

- Intrusion Borehole Properties: The reference given for the cited porosity values is Marietta et al., 1989, Table 3-10, which in turn cites a penexistent value in Lappin et al., 1989. The model for the degraded borehole (driven by the regulation) is unconsolidated sand. If that is the model, then a consistens set of bydrologic data for unconsolidated sand needs to be used. Possibilities include:

Freeze and Cherry (1979) - a widely cited, but yery Ber.eral reference $\rightarrow$

$\begin{array}{lll}\text { Permeability: } & 10^{-9} \text { to } 10^{-14} \mathrm{~m}^{2} & \text { (silty and clean sand) } \\ \text { Porosity: } & 0.25 \text { to } 0.50 & \text { (sand) } \\ \text { Compressibility } & 10^{-7} \text { to } 10^{-0} & \text { (sand) }\end{array}$

An alternative sources that are worth checking are:

Mercer et al . 1982: Parameters and Variables Appearing in Repository Siting Models, NUREG/CR-3066.

Touloukian and Ho, ed., 1981: Physical Properties of Rocks and Minerals (?), McGraw-Hill/Cindas Data Series on Material Properties.

Note that it is not clear why porosity and compressibility are needed for the intrusion borehole, as borehole transmissibility does not depend on these parameters. Note that Lappin et al (1989) and Table A-11 cite a range of le-13 to le-11 $\mathrm{m}^{2}$ for borehole permeability. The range used for sensitivity calculations in the recent Reeves et al. sensitivity study is $1 e-14$ to $1 e-10 \mathrm{~m}^{2}$. Clearly we have no real data for this very important parameter. Ultimately we may need to seek regulatory guidance on how to characterize the range for this parameter (in particular, the upper end of the range). 


\author{
Appendix A \\ cc: W.D. Weart (6340) \\ D.R. Anderson (6342) \\ M.G. Marietta (6342) \\ R.P. Rechard (6342) \\ R.L. Beauheim (6344) \\ S.J. Finley (6344) \\ S.M. Howarth (6344) \\ C.F. Novak (6344) \\ S.W. Webb (6344) \\ File 5.2
}


Note: The reference list mentioned on page 4 of this memo has not been appended here. For the list of references, please consult

Lappin, A. R., R. L. Hunter, D. P. Garber, and P. B. Davies, eds. 1989. Systems Analysis Long-Term Radionuclide Transport, and Dose Assessments, Waste Isolation Pilot Plant (WIPP), Southeastern New Mexico; March 1989.

SAND89-0462. Albuquerque, NM: Sandia National Laboratories. 


\section{Memo 3c}

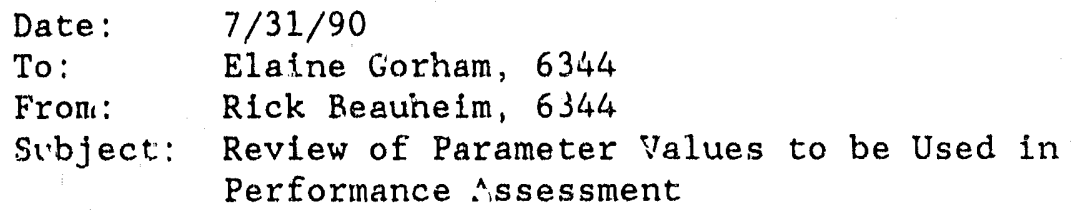


Date: July 31,1990

To: Elaine Gorham, 6344

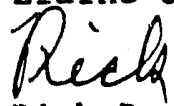

From: Rick Beauheim, 634,4

Subject: Review of Paramecer Values to be Used in Performance Assessment

With reference to Rob Rechard's memo to distribution of July 17, 1990, I have reviewed the data reported in Appondix A of SANr:9-2030. My comments on the data selection, in those areas where I either provide or use similar data, are presented below.

Table A.1

capacitance - the term that Dave $M=T i g u e$ describes as capacitance (c) is a lumped parameter defined as $c-n c_{w}+c_{x}$, where $n$ is porosity, $c_{w}$ is fluid compressibility, and $c_{r}$ is rock compreisibility. In my test interpretations, I input values for those three parameters separately. My base case porosity is 0.01 (18), base case brine compressibility is $3.1 \times 10^{-10} \mathrm{~Pa}^{-1}$ and rock compresibility depends on rock type, ranging from $1.9 \times 10^{-9} \mathrm{~Pa}^{-1}$ for claystone to $4.8 \times 10^{-11} \mathrm{~Pa}^{-1}$ for halite to $1.2 \times 10^{-11} \mathrm{~Pa}^{-1}$ for anhydrite. The rock compressibility values for halite and anhydrite come from Krieg (1984; SAND83-1908), and are the inverse of the bulk moduli presented in his Table $V$. The value for claystone comes from Touloukian et al. (1981.). The actual value of rock compressibility I use in a given simulation is a weighted average depending on the percentage of each rock type in a particular test interval. These values have ranged from $1.2 \times 10^{-11} \mathrm{pa}^{-1}$ to $7.3 \times 10^{-11} \mathrm{~Pa}^{-1}$, with associated capacitances ranging from $1.5 \times 10^{-11} \mathrm{~Pa}^{-1}$ to $7.6 \times 10^{-11} \mathrm{~Pa}^{-1}$. I consider an appropriate range on capacitance to be from $1 \times 10^{-11} \mathrm{~Pa}^{-1}$ to $1 \times 10^{-10} \mathrm{~Pa}^{-1}$. I have tried to fit some of my tests using McTigue's high values of capacitance, and cannot do it. I suggest that McTigue's high values are more of an apparent capacitance than a real capacitance, and must include factors/mechanisms in addition to those in the formal definition of capacitance. These may include dewatering, gas drive, or creep effects. If $P A$ is going to use McTigue's high values, they should be careful in their wording of what the parameter includes.

pressure at repository level - values presented are okay, although I wonder about the significance of the hydrostatic values? How are they to be used?

permeability .. my values for permeability range from $<10^{-23} \mathrm{~m}^{2}$ to $3 \times 10^{-20}$ $\mathrm{m}^{2}$. The "expected value" in the table of $3.4 \times 10^{-21} \mathrm{~m}^{2}$ is reasonable, but extending the range to $10^{-18} \mathrm{~m}^{2}$ is at least an order of magnitude too much.

porosity . the range in porosity I obtain from the same references given in the table is 0.001 to 0.03 . I always use a base case value of 0.01 in my calculations. I think the "expected value" is a little low, but as long as they sample uver the entire range, they should be okay. 
T'able A-2

disturbed permeability -. the "expected value" presented is entirely

synthetic, ard does not reflect any actual measurements. The highest value ever measured is six orders of magnitude lower, $3.2 \times 10^{-13} \mathrm{~m}^{2}$ (Crawley, in preparation). I would go with the measured value rather than the synthetic value.

disturbed porosity .. vilues are okay

undisturbed permeabilfty -. my measured values (all two of them) are $1 \mathrm{x}$ $10^{-18}$ and $5 \times 1 C^{-20} \mathrm{~m}^{2}$, so the values presented are okay.

Tables $A-3$ and $A-4$

any comments I would make here would be based on exactly the same reports and interpretations as Peter's comments

Table A-5

I'd find a real reference before presenting anything here.

Tables $A-6, A-7$, and $A-8$

no comments

Table A-9

Culebra brine density .. expected value is a function of position. They should use a range from 1000 to $1150 \mathrm{~kg} / \mathrm{m}^{3}$ based on data in the WQSP reports.

Culebra brine viscosity .. viscosity is a function of pressure, temperature, and dissolved solids concentration. They could very easily use a correlation chart such as Figure D.35 in Earlougher (1977) to relate viscosity to density. Viscosity is not, however, an important factor.

Castile brine density .. okay

Salado brine density .. okay

Salado brine compressibility -. value presented is slightly low for brine with no dissolved gas. A better value would be $2.9 \times 10^{-10} \mathrm{~Pa}^{-1}$. For brine saturated with gas (which is probably the case), compressibility should be about $3.1 \times 10^{-10} \mathrm{~Pa}^{-1}$.

Salado brine viscosity -. okay

Water compressibility, density, viscosity - okay, but what are distilled water properties ever used for?

Table A-10

Salado brine compressibility - compressibilities at low pressures are too low, and compressibilities at high pressures are too high. The range should be more like $2.9 \times 10^{-10}$ to $1.7 \times 10^{-10} \mathrm{~Pa}^{-1}$, higher if gas saturation is taken into account. What is the reference for these values?

Salado brine formation volume factor -. all values are slightly low, 
particularly if gas saturation is taken into account, and the range is too great. What is the reference for these values?

Table A-11

no comments

With respect to the zoning of the Culebra, and the hydraulic conductivities assigned to the zones, a greater effort needs to be made to make this model agree with the final LaVenue et al. (1990) model. I see the desirability of using a simple model for the PA calculations, but if a simplified model produces results vastly different from those that would be obtained with the LaVenue model, then the simple model is misleading and unreliable. I think $\mathrm{PA}$ is really going to have to bite the bullet on this one, and invest the time and effort it will take to come up with a reliable simplified version of the LaVenue model (if it can be done at all). I would not present any results from the simplified model as it now stands. The NAS or any other review group would be likely to ask 1) why we invested so much time and energy in producing the LaVenue model if we aren't going to use it, and 2) why we think we can produce reliable results with an uncalibrated model.

With respect to the conceptual model for the Salado around the repository, the zoning and parameters seem okay for a first cut. If the ranges from Tables $A-1$ and $A-2$ are to be used here, I would keep the disturbed anhydrite "a" and "b" permeability below $10^{-15} \mathrm{~m}^{2}$.

no comments on conceptual model of brine pocket discharge

I believe that PA is familiar with all of the references $I$ have cited above. If not, I'll be happy to provide them to them.

I hope they find these comments useful. 


\title{
Memo 4
}

\author{
Date: $\quad 8 / 1 / 90$ \\ To: $\quad$ D. R. Anderson, 6342 \\ From: L. H. Brush and A. R. Lappin, 6345 \\ Subject: Additional Estimates of Gas Production Rates and \\ Radionuclide Solubilities for Use in Models of WIPP \\ Disposal Rooms
}




\section{Sandia National Laboratories}

dale: August 1, 1990

Albuquerque, New Mexico 87185

10: D. R. Anderson. 6342

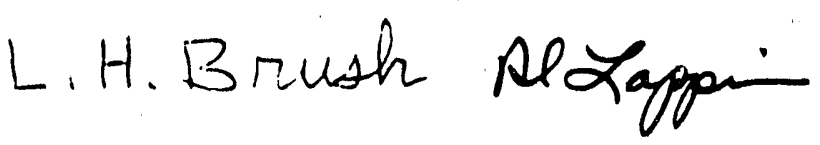

from: L. H. Brush and A. R. Lappin, 6345

subjecl: Additional Estimates of Gas Production Rates and Radionuclide Solubilities for Use in Models of WIPP Disposal Rooms

This memo provides: (1) estimates of the ranges and distributions of the rates of gas production from anoxic corrosion and microbial activity under humid conditions; (2) estimates of the range and distribution of the rate of gas production from radiolysis of brine; (3) an estimate of the distribution of radionuclide solubilities within the previously estimated range of $1 \mathrm{nM}$ to $1 \mathrm{mM}$.

\section{ESTIMATES FOR ANOXIC CORROSION AND MICROBIAL ACTIVITY UNDER HUMID CONDITIONS}

Brush and Anderson (1989) estimated the rate of production of $\mathrm{H}_{2}$ from anoxic corrosion of $\mathrm{Fe}$ and $\mathrm{Fe}$-base alloys and the production rate of various gases from microblal degradation of cellulosics under inundated conditions in Wl.PP disposal rooms for Lappin et al. (1989). (I use "inundated" to specify direct contact between brine and corroding metallic surfaces or cellulosics undergoing microbial degradation. This is equivalent to the term "saturated," as used in soil mechanics, or "partially saturated," if a thin film of brine coats metals and cellulosics.) The estimated rates were 1.70 and 0.85 mole per equivalent drum of waste per year for anoxic corrosion and microbial activity, respectively. After J. D. Bredehoeft of the NAS WIPP Panel correctly pointed out that the use of more than one significant figure for such estimates is inappropriace, Brush (1990) revised these estimates to 2 and 1 mole per drum per year.

Because the $\mathrm{H}_{2} \mathrm{O}$ content of WIPP disposal rooms could affect the rates of anoxic corrosion and microbial activity significantly, $R$. E. Westerman and D. Grbic-Galic are carrying out studies at Pacific Northwest Laboratory and Stanford University, respectively, to quantify these processes under humid and inundated conditions. (I use "humid" to specify that $\mathrm{H}_{2} \mathrm{O}$ vapor in void spaces is in equilibrium with $\mathrm{H}_{2} \mathrm{O}$ in brine on the floor, in the disturbed rock zone, or in the undisturbed Salado $\mathrm{Fm}$. At equilibrium, the thermodynamic activity of $\mathrm{H}_{2} \mathrm{O}$ vapor is equal to its activity in the brine, about 0.7 , and the relative 
humidity is $70 \%$. If condensation induced by thermal gradients or "wicking" of brine throughout the rooms deposits a thin film of brine on metals or cellulosics, I refer to these conditions as "inundated," not "humid." )

In lieu of results from these studies, I propose a range of 0.002 to 2 and 0.001 to 1 mole per drum per year for the gas production rates from anoxic corrosion and microbial activity under humid conditions, respectively. I also propose a log-uniform distribution of the rates within these ranges. The maximum value of each of these ranges might be expected if the concentration of $\mathrm{H}_{2} \mathrm{O}$ did not affect the rate of anoxic corrosion or microbial activity significantly. This situation could occur if the rate of the anoxic corrosion reaction itself were the rate-limiting step instead of transport of $\mathrm{H}_{2} \mathrm{O}$ to sites of reaction. The minimum value could occur if the rate of the anoxic corrosion reaction were fast relative to $\mathrm{H}_{2} \mathrm{O}$ transport. However, I must stress that, until experimental results become available, specification of these ranges and a log-uniform distribution is arbitrary.

\section{ESTIMATES FOR RADIOLYSIS OF BRINE}

Reed (1989) calculated a total gas production rate of about 0.1 mole of $\mathrm{H}_{2}$ and $\mathrm{O}_{2}$ per equivalent drum of waste per year from radiolysis of WIPP, brine by dissolved Pu. He neglected brine radiolysis by particulate $P u$ because, to a first approximation, the short range of $\alpha$ particles in solids and the resulting self absorption of energy by Pu-bearing particles would probably prevent significant brine radiolysis in the absence of dissolution. He assumed an average loading of $10 \mathrm{~g}$ of ${ }^{239} \mathrm{Pu}$ per drum (he neglected other isotopes), 7,000 drums per room, $106 \mathrm{~m}^{3}$ of brine per room (see below for an explanation of the selection of this value and a discussion of other possible choices), and a dissolved Pu concentration of $1 \mathrm{mM}$, the maximum solubility of $\mathrm{Pu}$ in WIPP brines estimated by Brush and Anderson (1989) for Lappin et al. (1989). The following equation from Reed (1989) extends this rate to the minimum and intermediate estimates of $\mathrm{Pu}$ solubilities estimated by Brush and Anderson (1989), $1 \mathrm{nM}$ and $1 \mu \mathrm{M}$, respectively:

$$
R=9.2 \cdot(\mathrm{Pu}) \cdot \mathrm{G} \text {. }
$$

In this equation, $R$ is the gas production rate $i_{1}$ moles of $\mathrm{H}_{2}$ and $\mathrm{O}_{2}$ per drum per year, $(\mathrm{Pu})$ is the dissolved $\mathrm{Pu}$ concentration in $\mathrm{g}$ per $\mathrm{L}$, and the last term is the $G$ value in molecules per $100 \mathrm{eV}$, about 0.04 to 0.05 according to Reed (1989). Assuming a molecular weight of 239 $\mathrm{g} /$ mole for $\mathrm{Pu}$, the gas production rates are $1 \cdot 10^{-7}$ and $1 \cdot 10^{-4}$ mole of gas per drum per year for Pu solubilities of $1 \mathrm{nM}$ and $1 \mu \mathrm{M}$, respectively. The maximun estimate remains $1 \cdot 10^{-1}$ mole per drum per year. Reed will carry out a study at Argonne National Laboratory to measure gas production rates for a radiolysis of representative WIPP 
brines with various dissolved $P u$ concentrations and calculate gas production rates for particulate Pu. Pending results from this study, specification of a log-normal distribution for rates of gas production from radiolysis of brine is consistent with a log-normal distribution for radionuclide solubilities within the previously estimated range of $1 \mathrm{nM}$ to $1 \mathrm{mM}$ (see below).

I suggested that Reed (1989) assume $106 \mathrm{~m}^{3}$ of brine per room because I used this value for other estimates, such as the concentrations of organic and inorganic ligands in any brine present in WIPP disposal rooms (see Brush, 1990). In lieu of results from a model of brine inflow that includes the effects of gas production, pressurization, and room closure, I obtained a value of $106 \mathrm{~m}^{3}$ by assuming that brine could eventually resaturate all of the residual void volume of a room. Lappin et al. (1989) provided an intermediate estimate of 3.08 of the initial room volume of $3,640 \mathrm{~m}^{3}$ for the residual void volume by assuming that the residual porosity of the room contents will be 188 .

Because Reed (1989) assumed $106 \mathrm{~m}^{3}$ of brine per room to derive the equation given above, quantities of brine other than $106 \mathrm{~m}^{3}$ per room will require revisions of the estimated range of $1 \cdot 10^{-7}$ to $1 \cdot 10^{-1}$ mole of gas per drum per year for brine radiolysis. Smaller quantities of brine should decrease the rate estimated for any given dissolved $\mathrm{Pu}$ concentration by a factor equal to the quantity of brine in $\mathrm{m}^{3}$ divided by $106 \mathrm{~m}^{3}$. Larger quantities should increase these rates until the entire quantity of $\mathrm{Pu}$ present in the room dissolves. Reed and I are recalculating rates normalized to the quantity of brine instead of drums of waste and will provide them as required. However, these rates are quite low relative to current estimates of rates of gas production from anoxic corrosion and microbial activity under inundated conditions, especially for quantities of brine less than $106 \mathrm{~m}^{3}$ per room, and may not be worth including in integrated models of WIPP disposal rooms. Reed and I will also estimate gas-production rates from radiolysis of brine by solid-phase $\mathrm{Pu}$, but these rates will probably be very low too.

Although these rates are low relative to the estimated rates of gas production from anoxic corrosion and microbial activity under inundated conditions, radiolysis of brine would continue, if sufficient brine were present, until the rate of gas consumption by various back reactions equals the rate of gas production. Experimental and modeling results obtained for Permian Basin brines by Gray and Simonson (1984) suggest an equilibrium pressure of 300 atm for brine radiolysis. Because this pressure is high enough to raise concern about the integrity of the repository, Reed will soon start a study to determine the pressure at which net radiolytic gas production ceases.

It is impossible to estimate the gas production potential from radiolysis of brine at this time because it depends on: (1) how much brine is available; (2) the equilibrium pressure; (3) the void volume of WIPP disposal rooms at the time the equilibrium pressure is 
attained. These factors do not preclude estimation of gas production potentials for anoxic corrosion and microbial activity because pressures of a few hundred atmospheres would probably be insufficient to stop these processes (see Brush, 1990).

Reed (personal communication) belleves that the gas production rate from radiolysis of $\mathrm{H}_{2} \mathrm{O}$ vapor will be much lower than from radiolysis of brine. Furthernore, the rate of scavenging of $\mathrm{O}_{2}$ may equal or even exceed its rat of production from radiolysis of $\mathrm{H}_{2} \mathrm{O}$ vapor. If so, radiolysis of $\mathrm{H}_{2} \mathrm{O}$ vapor would not result in net gas production. Therefore, I propose a rate of 0 moles per drum per year for gas production from radiolysis of $\mathrm{H}_{2} \mathrm{O}$ vapor.

\section{ESTIMATES OF RADIONUCLIDE SOLUBILITIES}

Brush and Anderson (1989) estimated the solubilities of radionuclides in any brine present in WIPP disposal rooms for Lappin et al. (1989). They estimated a minimum value of $1 \mathrm{nM}$, an intermediate value of $1 \mu \mathrm{M}$, and a maximum value of $1 \mathrm{mM}$, but did not specify a distribution for the values within this range.

There are very few thermodynamic data (stability constants for complexes between $\mathrm{Pu}, \mathrm{Am}, \mathrm{Th}$, and $\mathrm{U}$ and organic or inorganic ligands, or solubility products for solids containing these elements) for high ionic-strength aqueous solutions such as WIPP brines. Therefore, G. R. Choppin is carrying out a study at Florida State University to quantify the speciation of $\mathrm{Pu}, \mathrm{Am}, \mathrm{Th}$, and $\mathrm{U}$ in concentrated solutions (see Brush, 1990). This study, which will take a few years to complete, will provide input data for solubility calculations under a wide range of conditions. He is also conducting a study to determine the solubilities of these elements directly over the next few months under selected combinations of conditions (see Brush, in prep.).

These studies will almost certainly demonstrate that, for designbasis TRU waste, radionuclide solubilities will vary by several orders of magnitude among closely spaced microenvironments with different values of $\mathrm{Eh}$ and $\mathrm{pH}$, and different concentrations of organic and inorganic ligands (see Brush, 1990). Quantification of the distribution of radionuclide solubilities will require: (1) calculation and, in some cases, experimental determination of radionuclide solubilities as a function of $\mathrm{Eh}, \mathrm{pH}$, and 1 igand concentrations; (2) predictions of the Eh, $\mathrm{pH}$, and 1 igand concentrations for each type of waste after reaction with any brine present in WIPP disposal roons; (3) estimation of the quantities of each type of waste in the WIPP inventory.

In lieu of these results, I propose a log-normal distribution for radionuclide solubilities within the range of $1 \mathrm{nM}$ to $1 \mathrm{mM}$. Specification of this distribution is arbitrary. 
Brush, L. H. (1990). Test Plan for Laboratory and Modeling Studie: of Repository and Radionuclide Chemlstry for the Waste Isolation Pilot Plant, SAND90-0266, Sandia National Laboratorles, Albuquerque, NM.

Brush, L. H. Test Plan for Laboratory and Modeling Studies of Repository and Radionuclide Chemistry for the Waste Isolation P1lot Plant, Adóendum 1, in preparation.

Brush, L. H., and D. R. Anderson (1989). Estimates of Gas Production Rates, Potentials, and Periods, and Dissolved Radionucilide Concentrations for the WIPP Supplemental Environmental Impact Statement, unpublished memorandum to B. M. Butcher, February 14 , 1989. Sandia National Laboratories, Albuquerque, NM.

Gray, W. J., and S. A. Simonson (1985). Gamma and Alpha Radiolysis of Brines. In C. M. Jantzen, J. A. Stone, and R. C. Ewing, Eds., Sclentific Basis for Nuclear Waste Management VIII, Symposium held November 26-29, Boston, Massachusetts, U. S. A., Materials Research Soclety Symposia Proceedings, Vol. 44, Materials Research Society, Pittsburgh, PA, pp. 623-630.

Lappin, A. R., R. L. Hunter, D. P. Garber, and P. B. Davies, Eds. (1989). Systems Analys1s, Long-Term Radionuclide Transport, and Dose Assessments, Waste Isolation Pilot Plant (WIPP), Southeastern New Mexico; March, 1989. SAND89-0462, Sandia National Laboratories, Albuquerque, NM.

Reed, D. T. (1989). Unpublished letter to L. H. Brush, November 21, 1989. Argonne National Laboratory, Argonne, IL.

Distribution:

6340 W. D. Weart

6341 R. C. Lincoln

6341 SWCF (6): XXXRC, XXXRC/AC, XXXRC/MA, XXXRC/R, XXXRNC, XXXRNC/SOL

6342 Staff

6343 T. M. Schultheis

6344 E. D. Gorham

6344 P. B. Davies

6345 Staff

6346 J. R. Tillerson 


\section{Memo 5}

Date: $\quad 7 / 24 / 90$

To: M. G. Marietta, 6342

From: B. M. Butcher, 6345

Subject: Disposal ruom porosity and permeabjlity values for disposal room performance assessment 
10: M. G. Marietta, 6342

$$
\text { B.M. Bate }
$$

from: B. M. Butcher, 6345

subject: Disposal room porosity and permeability values for disposal room performance assessment

The foliowing information has been prepared as input for material property value distributions for performance assessment. Four types of uncertainty are identified with the porosity and permeability values.

1) Data variation from test to test of supposediy identical samples. This source of uncertainty is considered small and has not been included in the data variations reported in this memo.

2) Variations because of material variability from waste unit to waste unit. For example, the nature of plastic material may vary from drum to drum, one drum containing primarily polyethylene, whereas another drum may contain primarily PVC parts. In other words, a though generically similar, different plastics compact slightiy differently. Another example would be various mixes of different types of metals. In view of the iack of precise definition of the waste composition, this type of variability will be assumed to dominate all other sources of uncertainty, and is the basis for the ranges in data values quoted in this memo.

3) How much of each component of waste (plastics, cellulosics, sorbents, etc.) exists in various categories of waste is also variable. For example, the assumption has been made, based on the INEL waste inventory study, that combustible waste is composed of $9 \%$ by weight metals, $45 \%$ plastics, $37 \%$ cellulosics, and $9 \%$ sorbents. While drum contents are likely to differ from this mix, this uncertainty has not been included in the absence of any information.

4) Finally, there is the uncertainty with regard to how much of the various categories of waste will actually be stored in the repository. For the present, the assumption is that $28 \%$ by weight of the repository is metal and glass, $28 \%$ is combustible, and the remainder, $44 \%$, is siudge. Any change in this mix would change the range quoted for the various properties, a factor that has not been included in the quoted values. 
At present, the best estimate for the repository-wide average porosity of waste :ompacted to lithostatic pressure (14.8 MPa) is 0.186 , with a miniinum of 0.15 and a maximum of 0.27 . These values are interpreted as an estimated $10 \%$ probability that the porosity is less than 0.15 , 50\% probability that the porosity is less than 0.186 , and a $90 \%$ probability that the porosity is less than .27 . These values do not include any adjustment for intrusion of sait into the voids of the metallic materials within the wasie. When $50 \%$ intrusion is considered, the repository average drops to a porosity of 0.14 (50\% probability), with a minimum of 0.095 ( $<10 \%$ probability) and a maximum of 0.23 (<90\% probability). This value was computed from the ranges of values for the various waste components listed in Tables 1 and 2 .

The range of permeability values for waste in the repository is more difficult to define because less experimental information is available (Table 3). Additional data is anticipated shortiy. Recommended values for the permeabilities of the various types of waste, are compared in Table 4 with values assumed for DSEIS analysis. The recommended values for combustibles are taken directly from the experimental data: the minimum $<10 \%$ probability) is from the second test on material "2 (Table 3 ), the recommended ( $<50 \%$ prubability) is the average of the two tests on material \#4, which is the mixture representing simulated combustible waste, and the maximuin ( $<90 \%$ probability) is the average of the second test on material \#2, a less well-founded assumption.

The rationale for estimating the permeability of metallic waste in this memo is different from that used for the DSEIS analysis. The value for the DSEIS assumed uncorroded metal. The new values, quoted in Table 4, are made with the assumption that some corrosion has occurred, and that its consequence is a 50-50 mixture of uncorroded metals and inagnetite. The minimum permeability for metals is therefore assumed to be the minimum value observed in the second test on mixture \$7 (Table 3 ), the maximum value is the value quoted for the DSEIS assuming uncorroded metal, and the recommended is the maximum value of 500 millidarcy observed during the second test on mixture 7 . Perhaps a less conservative approach would be to use 11 millidarcy as a value for the recommended permeability - the permeability observed in the first test on mixture 17 (Table 3). Additional experiments to verify the results of the mixture permeabilities must be obtained, however, before these new values for metallic waste are finalized.

Permeability values for simulated sludge can be determined, but no results are available yet. The recommended value remains the DSEIS value. An indication of a range of values is possible, however, from the values of the physical properties of cementitious grout quoted in Table 3.1 of the SKB report on "Potentially Useful Materials for Sealing Nuclear Waste 
Repositories"! On the basis of this information, a minimum value for sludge is that of ordinary portland cement (CSA Type 10) cured for 130 days, and the value for a high alumina cement with fly ash is used for the maximum value.

1. State-of-the Art Report on Potentially Useful Materials for Sealing Nuclear Waste Repositories, $w$, Coons, A. Bergstrom, P. Gnirk, M. Gray, B. Knecht, R. Pusch, J. Steadman, B. Stillborg, M. Tokonami, M. Vaajasaari, SKB Stripa Project Technical Report 8712 , Swedish Nuclear Fuel and Waste Management Co. (SKB), Box 5864, S-102 48 Stockholm, Sweden, June, 1987. 
Cellulosics:

Minimum Recommended Maximum

Density at $14.8 \mathrm{MPa} \quad 870 \mathrm{~kg} / \mathrm{m}^{3} \quad 940 \mathrm{~kg} / \mathrm{m}^{3} \quad 1310 \mathrm{~kg} / \mathrm{m}^{3}$ No-void density $\quad 940 \mathrm{~kg} / \mathrm{m}^{3} \quad 1100 \mathrm{~kg} / \mathrm{m}^{3} \quad 1490 \mathrm{~kg} / \mathrm{m}^{3}$

Plastics:

Density at $14.8 \mathrm{MPa} \quad 1010 \mathrm{~kg} / \mathrm{m}^{3} \quad 1090 \mathrm{~kg} / \mathrm{m}^{3} \quad 1100 \mathrm{~kg} / \mathrm{m}^{3}$ No-void density $\quad 940 \quad 1200 \mathrm{~kg} / \mathrm{m}^{3} \quad 1350 \mathrm{~kg} / \mathrm{m}^{3}$

Metals:

Density at $14.8 \mathrm{MPa} \quad 2090 \mathrm{~kg} / \mathrm{m}^{3} \quad 2740 \mathrm{~kg} / \mathrm{m}^{3} \quad 3200 \mathrm{~kg} / \mathrm{m}^{3}$ $\mathrm{Nc}$-void density $\quad 6420 \mathrm{~kg} / \mathrm{m}^{3} \quad 7110 \mathrm{~kg} / \mathrm{m}^{3} \quad 8200 \mathrm{~kg} / \mathrm{m}^{3}$

Sorbents:

Density at $14.8 \mathrm{MPa} \quad 1160 \mathrm{~kg} / \mathrm{m}^{3} \quad 2050 \mathrm{~kg} / \mathrm{m}^{3} \quad 2495 \mathrm{~kg} / \mathrm{m}^{3}$ No-void density $\quad 2200 \mathrm{~kg} / \mathrm{m}^{3} \quad 3000 \mathrm{~kg} / \mathrm{m}^{3} \quad 3000 \mathrm{~kg} / \mathrm{m}^{3}$

Sludge:

Density at $14.8 \mathrm{MPa}$

$1975 \mathrm{~kg} / \mathrm{m}^{3} \quad 2330 \mathrm{~kg} / \mathrm{m}^{3}$

No-void density

$2200 \mathrm{~kg} / \mathrm{m}^{3} \quad 3000 \mathrm{~kg} / \mathrm{m}^{3}$ 
Table 2: Density and Porosity Estimates for Combustible, Metallice and Siudge Waste

$\begin{array}{lll}\text { Minimum } & \begin{array}{l}\text { Recommended } \\ \text { Porosity }\end{array} & \text { Maximum } \\ \text { Porosity } & \text { Porosity }\end{array}$

Combustible:

$\begin{array}{llll}\text { Density at } 14.8 \mathrm{MPa} & 1010 \mathrm{~kg} / \mathrm{m}^{3} & 1132 \mathrm{~kg} / \mathrm{m}^{3} & 1291 \mathrm{~kg} / \mathrm{m}^{3} \\ \text { No-void density } & 1106 \mathrm{~kg} / \mathrm{m}^{3} & 1310 \mathrm{~kg} / \mathrm{m}^{3} & 15.11 \mathrm{~kg} / \mathrm{m}^{3} \\ \text { Porosity } & 0.087 & 0.136 & 0.178\end{array}$

Metallic:

Density at $14.8 \mathrm{MPa} \quad 2308 \mathrm{~kg} / \mathrm{m}^{3} \quad 2068 \mathrm{~kg} / \mathrm{m}^{3} \quad 1657 \mathrm{~kg} / \mathrm{m}^{3}$

No-void density $\quad 3923 \mathrm{~kg} / 3 \quad 3440 \mathrm{~kg} / \mathrm{m}^{3} \quad 2949 \mathrm{~kg} / \mathrm{m}^{3}$

$\begin{array}{llll}\text { Porosity } & 0.33^{* *} & 0.40 & 0.44^{* *}\end{array}$

Sludge:

Density at $14.8 \mathrm{MPa}$

$1907 \mathrm{~kg} / \mathrm{m}^{3} \quad 2216 \mathrm{~kg} / \mathrm{m}^{3}$

No-void density

$2150 \mathrm{~kg} / \mathrm{m}^{3} \quad 2827 \mathrm{~kg} / \mathrm{m}^{3}$

Interconnected

Porosity barre

$0.1^{*}$

0.113

0.216

Average Repository:

Porosity

0.15

0.186

0.27

Average Repository with $50 \%$ of the metal voids filled with salt:
Porosity
0.095
0.143
0.23

- estimated

* These values were computed using the recommended no-void density of $4260 \mathrm{~kg} / \mathrm{m}^{3}$ was used to compute these values because of inconsistency between the estimated no-void densities and the estimated values at $14.8 \mathrm{MPa}$ 
Table 3: Measured Simulated-Waste Permeability Values

\begin{tabular}{|c|c|c|c|}
\hline$\underset{n}{\text { Material }}$ & Descriotion & $\begin{array}{c}\text { Days at } \\
14 \mathrm{MPa} \\
\text { (two tests) }\end{array}$ & $\begin{array}{c}\text { Permeability } \\
\text { millidarcy } \\
\text { (two tests) }\end{array}$ \\
\hline 1 & $\begin{array}{l}\text { 40\% PE botties } \\
\text { 40\% PVC Parts } \\
20 \% \text { Gloves }\end{array}$ & $\begin{array}{l}30 \\
30\end{array}$ & $\begin{array}{l}\text { No flow at } 1000 \mathrm{psi} \\
25\end{array}$ \\
\hline 2 & $\begin{array}{l}\text { 60\% Pine Cubes } \\
\text { 40\% Rags }\end{array}$ & $\begin{array}{l}30 \\
30\end{array}$ & 203 dropped to 2 \\
\hline 4 & $\begin{array}{l}\text { 45\% Mat1. \#1 } \\
37 \% \text { Mat1. } 2 \\
9 \% \text { 1" metals } \\
9 \% \text { Dry Port Iand }\end{array}$ & $\begin{array}{l}30 \\
30\end{array}$ & $\begin{array}{l}19 \\
15\end{array}$ \\
\hline 7 & $\begin{array}{l}50 \% \text { Magnetite } \\
50 \% 1^{n} \text { Metals }\end{array}$ & $\begin{array}{l}24 \mathrm{hr} \\
24 \mathrm{hr}\end{array}$ & 500 dropped to 4 \\
\hline
\end{tabular}


Table 4: Hydraulic Conductivity and Permeability Estimates for Combustible, Metallice and Sludge Waste

\section{Minimum Recommended Maximum}

(millidarcy) (millidarcy) (millidarcy)

\begin{tabular}{|c|c|c|c|}
\hline $\begin{array}{c}\text { Combustible: } \\
\text { millidarcy } \\
10^{-9} \mathrm{~m} / \mathrm{s} \\
10^{-16} \mathrm{~m}^{2}\end{array}$ & $\begin{array}{l}2 \\
17 \\
20\end{array}$ & $\begin{array}{l}17 \\
141 \\
168\end{array}$ & $\begin{array}{l}100 \\
830 \\
990\end{array}$ \\
\hline DSEIS value & $V / s$ & 10 & \\
\hline $\begin{array}{c}\text { Metallic: } \\
\text { millidarcy } \\
10^{-9} \mathrm{~m} / \mathrm{s} \\
10^{-16} \mathrm{~m}^{2}\end{array}$ & $\begin{array}{r}11 \\
91 \\
109\end{array}$ & $\begin{array}{r}500 \\
4150 \\
4950\end{array}$ & $\begin{array}{r}1200 \\
10000 \\
12000\end{array}$ \\
\hline DSEIS value & $n / s$ & 10000 & \\
\hline $\begin{array}{l}\text { Sludge: } \\
\text { mi } 11 \text { idarcy } \\
10-9 \mathrm{~m} / \mathrm{s} \\
10^{-16} \mathrm{~m}^{2}\end{array}$ & $\begin{array}{l}0.011 \\
0.0013 \\
0.0016\end{array}$ & $\begin{array}{l}0.12 \\
1.0 \\
1.2\end{array}$ & $\begin{array}{l}0.1 \\
1.4 \\
1.6\end{array}$ \\
\hline DSEIS value & $n / s$ & 1.0 & \\
\hline
\end{tabular}




Appendix A
$\begin{array}{ll}\text { Distribution: } \\ 6340 & \text { H. D. Weart } \\ 6340 & \text { SWCF/XXXDRM (5 years) } \\ 6340 & \text { S. Y. Pickering } \\ 6341 & \text { R. C. Lincoln } \\ 6342 & \text { D. R. Anderson } \\ 6343 & \text { T. M. Schultheis } \\ 6344 & \text { E. D. Gorham } \\ 6344 & \text { P. B. Davies } \\ 6345 & \text { A. R. Lappin } \\ 6345 & \text { L. H. Brush } \\ 6345 & \text { B. M. Butcher } \\ 6345 & \text { F. T. Mendenhall } \\ 6345 & \text { M. A. Molecki } \\ 6346 & \text { J. R. Tillerson } \\ 6415 & \text { M. S. Tierney }\end{array}$


Memo 6

\section{Memo 6}

Date: $\quad 8 / 24 / 90$

To: Rob Rechard, 6342

From: Martin Tierney, 6415

Subject: Values of Room Porosity and Hydraulic Conductivity 


\section{Sandia National Laboratories}

date: August 24, 1990

Albuquerque, New Mexico 87185

10: Rob Rechard, 6342

from: Martin Tierney, 6415 Martin \&. Tiensey

subject: Values of Room Porosity and Hydraulic Conductivity

I suggest that the following values be used (no sampling) in current PA calculations

\section{Porosity, $\varepsilon$ Hydraulic Conductivity $(\mathrm{K}, \mathrm{m} / \mathrm{s})$}

$\begin{array}{lll}\text { Reference }^{(1)} & 0.19 & 1.2 \times 10^{-6} \mathrm{~m} / \mathrm{s} \\ \begin{array}{l}\text { Engineered } \\ \text { Alternative }\end{array} & 0.09 & 1.8 \times 10^{-10} \mathrm{~m} / \mathrm{s}\end{array}$

(1) Reference-case values are consistent with recommendation made in memo from Butcher and Lappin (6345), dated 7/24/90.

(2) There is no change in engineered-alternative case since no change in \% by volume of waste components is indicated in the new Table 4.1 (Tru-waste Inventory Analysis) provided by Butcher in his note of $8 / 13 / 90$; presumably, the same curve of permeability versus fractional density that was provided by Butcher on $5 / 18 / 90$ still applies. [Note: Butcher may want to give a new range and central value to permeability for this case, but I have been unable to contact him.]

We may have to sample room porosity and hydraulic conductivity if the uncertainty in waste composition, i.e. \% by volume of metallic, combustible and sludge components, proves to be large. So far, only one set of numbers has been provided for the $\%$ by volume:

$\begin{array}{ll}\text { Metals \& glass } & 40 \% \\ \text { Combustibles } & 419 \% \\ \text { Sludge } & 19 \%\end{array}$

The volume contributions of steel containers, polyethylene liners, PVC liners, bugs and wood/fiberboard are apparently ignored. 


\section{Memo 7}

Date: $\quad 10 / 12 / 90$

To: $\quad$ R. P. Rechard, 6342

From: A. C. Peterson, 6342

Subject: Preliminary Contact Handled (CH) and Remote Handled (RH) Radionuclide Inventories 
date: October 12,1990

Albuquerque, New Mexico 87185

10: R. P. Rechard, 6342

trom: A. C. Peterson, 6342

subsecl: Preliminary Contact Handled (CH) and Remote Handled (RH) Radionuclide Inventories

A preliminary $\mathrm{CH}$ radionuclide inventory is tabulated in Table 1 . This inventory was based on input to the "1987 Integrated Data Base: Spent Fuel and Radioactive Waste Inventories, Projection and Characteristics," DOE/RW-0006 Rev 3, September 1987. The input to the Integrated Data Base (IDB) does not contain the inventory of each radionuclide. A draft report, DOE/WIPP 88-005, was the source of the information that is contained in Table 1. The inventories were calculated based on the isotopic mix, weight per cent, of the waste weights that were reported by the generator sites. In addition, standard plutonium mixes were used to calculate radionuclide distributions for sites that referenced standard mixes. To my knowledge the calculations of the radionuclide inventories have not been closely reviewed, however, this inventory appears to currently be the most applicable that is available.

A preliminary RH radionuclide inventory is tabulated in Table 2 . This inventory was based on input to the "1990 Integrated Data Base: Spent Fuel and Radioactive Waste Inventories, Projections, and Characteristics," DOE/RE-0006, Rev 6, to be issued. The inventory was based on knowledge about the waste that was reported by each generator site. For instance assumptions were made about the distribution of radionuclides in the mixed fission products that were reported at some of the sites. The activity of the Hanford canisters was based on a calculation using a uniform source to produce an external dose rate of $30 \mathrm{R} / \mathrm{Hr}$. Subsequent to the 1990 IDB submittal, Oak Ridge National Laboratory transmitted an update to their RH inventory that increased their inventory from the value reported in the 1990 IDB. This change in the 0ak Ridge inventory was included in the inventory listed in Table 2. These results will be documented in a report to be authored by Hank Batchelder at WIPP/WID. To my knowledge these results have not been reviewed and should be considered preliminary.

It is of interest to note that the projected annual volume in the $\mathrm{CH}$ inventory reported in the 1990 IDB decreased by about one half from the values in the 1987 IDB; whereas, the projected annual volume in the RH inventory increased by about a factor of three.

Copy to:

6342 D. R. Anderson

6342 M. G. Marietta

6344 E. D. Gorham

6345 A. R. Lappin 
Table 1

Syste. CH Fiadionuclide Suamary

\begin{tabular}{|c|c|c|c|c|c|c|c|c|c|c|c|c|}
\hline Nuclide & $\begin{array}{c}\text { Kaiflite } \\
\text { (Yri) }\end{array}$ & $\begin{array}{r}A N L-E \\
(C i)\end{array}$ & $\begin{array}{l}\text { HANF } \\
\text { (Ci) }\end{array}$ & $\begin{array}{l}\text { INEL } \\
|\mathrm{Ci}\rangle\end{array}$ & $\begin{array}{l}\text { LANL } \\
\text { (Ci) }\end{array}$ & $\begin{array}{l}\text { LLNL } \\
\langle C i\rangle\end{array}$ & $\begin{array}{l}\text { HOUND } \\
\text { (Ci) }\end{array}$ & $\begin{array}{l}\text { NTS } \\
\text { (Ci) }\end{array}$ & $\begin{array}{l}\text { OFiNL } \\
\text { (Ci) }\end{array}$ & $\begin{array}{l}\text { RFP } \\
(C i)\end{array}$ & $\begin{array}{l}\text { SRS } \\
\text { (Ci) }\end{array}$ & $\begin{array}{l}\text { Syster } \\
\text { Total } \\
\text { (Ci) }\end{array}$ \\
\hline-232 & $=+10$ & +60 & & & & & & & & & & \\
\hline $4-233$ & $1.390 E+105$ & $0.0010 E+00$ & $0.000 E+00$ & $5.756 E+0.2$ & $5.067 E+01$ & $0.0005+00$ & $0.000 \mathrm{DE}+00$ & $0.000 E+00$ & $7.070 E+0.5$ & $0.000 E+00$ & $0.000 E+100$ & \\
\hline $11-265$ & $7.04 \mathrm{UE}+\hat{U} \theta$ & $0.000 E+000$ & $0.0001 E+00$ & $2.174 E-02$ & $1.402 E-U !$ & $0.000 E+00$ & $0.000 E+00$ & $0.000 E+00$ & $2 .\lfloor|1 E-0| 1$ & O. OUOE +OO & $0.000) E+00$ & 3. \\
\hline $12-230$ & $4.17 \mathrm{UE}+1.9$ & 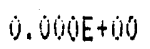 & U. OUUUE+00 & $3.652 E-\cup 2$ & b. $\| J E-01$ & $0.000 E+100$ & $0.000 E+00$ & $0.000 E+00$ & $8.453 E-0.1$ & J. $000 E+00$ & $0.000 E+00$ & \\
\hline$p u-639$ & $2.410 E+04$ & $4.414 E+11$ & $9.002 E+04$ & $2.217 E+014$ & $1.462 E+0 j 5$ & $3.341 E+0.3$ & $3.544 E-01$ & $4.1300+01$ & $2.278 E+\dot{0} 4$ & $1.354 E+0.5$ & $4.287 E+03$ & 4.2 \\
\hline F山ー240 & $5.560 E+13$ & $2.023 E+01$ & $3.201 E+14$ & $5.40 .5 E+0.3$ & $3.379 E+144$ & $8.516 E+02$ & $2.391 E-101$ & $9.9013 E+100$ & $0.000 E+00$ & $3.691 E+04$ & $E+113$ & 1. \\
\hline$F u-241$ & 1. $+4 U E+U 1$ & $4.6275+02$ & $1.629 E+06$ & $1.717 E+05$ & $1.138 E+06$ & $3.186 E+04$ & $2.165 E-001$ & $3.726 E+02$ & $0.000 E+00$ & $9.65 E E+05$ & 1.29 & 4. \\
\hline$i u-242$ & $3.750 E+15$ & O. OUUE + GU & $7.240 E+100$ & 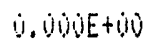 & $\dot{0} .34 J E+\dot{Q} 0$ & $5.243 E-1.2$ & $\dot{v} \cdot \dot{v} \dot{v} \theta \mathrm{E}+0 \dot{0}$ & U. $000 E+00$ & O. OQUEE+OUO & $2.7600+100$ & $1.4015 E+00$ & 1.8 \\
\hline $\operatorname{Hin}-241$ & $4.327 E+02$ & 1.E3UE+02 & 0. $000 E+00$ & $1.465 E+05$ & $4.761 E+05$ & $2.120 E+0.3$ & $0.000 \mathrm{E}+00$ & $0.000 E+00$ & $1.911 E+03$ & $0.42 E E+U .3$ & 3.54 & 6.3 \\
\hline & & & & & & & & & & & & \\
\hline
\end{tabular}

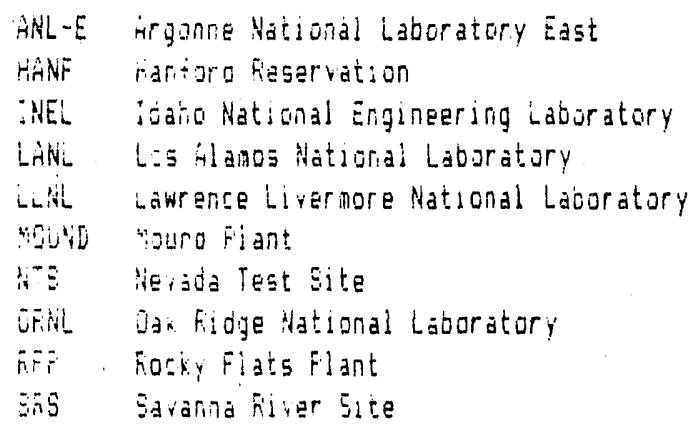


Table 2

System Rit Radionuclide Sunnary

\begin{tabular}{|c|c|c|c|c|c|c|c|c|c|}
\hline Nibcidide & $\begin{array}{c}\text { Haitlite } \\
(r r)\end{array}$ & $\begin{array}{l}\text { HiNL }-E \\
(C i)\end{array}$ & $\begin{array}{l}\text { HANF } \\
\text { (Ci) }\end{array}$ & $\begin{array}{l}\text { INEL } \\
\text { iCj) }\end{array}$ & $\begin{array}{l}\text { LANL } \\
\text { (Ci) }\end{array}$ & $\begin{array}{l}\text { OFNL } \\
(C i)\end{array}$ & $\begin{array}{r}\text { Systen } \\
\text { Total } \\
\text { (Ci) }\end{array}$ & $\begin{array}{l}\text { Systen } \\
\text { Total } \\
\text { (Grams) }\end{array}$ & $\begin{array}{c}\text { FH } \\
\text { Radionucide } \\
\text { Inventory } \\
\text { (C1) }\end{array}$ \\
\hline $\mid r-5]$ & 7. $380 E-0.2$ & (10)+100 & $0.000 E+000$ & $1.976 E+02$ & $0,000 \mathrm{E}$ & 10 & $\sqrt{6} 6$ & $35 E-103$ & \\
\hline $4 n-54$ & $8.560 \mathrm{E}-01$ & 0. GUQUE+UO & $0,000 E+00$ & 1. $21 \mathrm{EE}+04$ & $0.000 \mathrm{E}$ & $0,000 E+00$ & $1.213 E+04$ & $1.567 E+00$ & \\
\hline$[0-38$ & $1,7+0 E-01$ & $0.000 E+00^{\circ}$ & $0.000 E+00$ & $7.759 E+03$ & $0,000 E+00$ & $0.000 E+1 M$ & $7.759 E+03$ & $2.444 E+100$ & \\
\hline$F 0-5 \overline{4}$ & $1,20 \mathrm{U}-01$ & G. BGUE+ & $0,000 E+00$ & $1.975 \overline{B E}+1 \mathrm{Z}$ & 1. $1000 \bar{E}+000$ & $\dot{B}, 0 \cup G E+0 \dot{0}$ & $1.976 E+02$ & $3.975 E-03$ & \\
\hline [E-6i) & $5,270 E+00$ & 0. $400+00$ & $1,556 E+03$ & $1.559 E+03$ & $0,006 E+000$ & $4,794 E+1,3$ & B. $209 E+113$ & $7.254 E+100$ & \\
\hline 5 & Z.Y YIEE+Q1 & $4.761 E+Z_{2}$ & $2.2 \mathrm{i}+4 E+05$ & $1.55 \bar{E}+64$ & 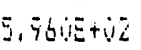 & $1.728 E+15$ & $4.209 E+15$ & S USUE+0O & $4,207 E+105$ \\
\hline $\mid-7 i]^{\prime}$ & $7.3 C 6 E-103$ & $4.761 E+12$ & $2.314 E+0 E$ & 0, yoletọ & $5,900 E+192$ & $0,000 E+000$ & $2.355+05$ & $4,272 E-i 1]$ & \\
\hline BD-75 & $9.0 .0 E-1 i$ & $0.640 E+00$ & $1.629 E+03$ & $8.965 E-011$ & Q. OUUE + 00 & $0.000 E+000$ & 1. $0.00+03$ & $4.167 E-022$ & \\
\hline $70-106$ & $1, \quad 310 E+60$ & $\dot{0}$, GUOE +lü & $7.575 E+014$ & $0.900 E+00$ & Q. OUUE + 00 & $0.000 E+00$ & $7.575 E+104$ & $2.206 E+0.1$ & \\
\hline $8 \pi-100$ & $9.45: E-67$ & $0.600 E+00$ & $7,575 \mathrm{E}+\mathrm{U14}$ & U. MUME+UO & Q. MUOE + & Q. GUOE + Uं & $7.575 E+04$ & $2.12 B E-1.5$ & \\
\hline $62-125$ & $2,77 . \mathrm{E}+10$ & $0.600 E+00$ & $1.755 E+04$ & $0,000 E+00$ & 0. COOE+ +OO & W. OQOE +WO & $1.365 E+1.4$ & $1.35 E+01$ & \\
\hline$E \equiv-i 34$ & Z, Bbuetii & Q. CubE+iot & $8.910 E+03$ & T. GEUE $+0 \mathrm{~S}$ & $0,000 E+60$ & G OOOE + UOO & $1.659 E+04$ & $1.200 E+01$ & \\
\hline $6=-37$ & $5, G Q E+11$ & $3,571 E+02$ & $3: 245+15$ & $\therefore .84 B E+64$ & $4,470 E+1.2$ & $1.827 E+105$ & $5.344 E+15$ & $5,90 \mathrm{EE}+13$ & $5.144 E+1 . j$ \\
\hline $5 a-37 \pi$ & $4, E 5 E-06$ & $\therefore 174 E+10$ & $2,740 E+15$ & 1. & $\bar{B}, 57.3 E+19$ & G. $600 \mathrm{E}+0 \mathrm{O}$ & $2.950 E+15$ & $5.484 E-04$ & \\
\hline $22-144$ & T.7SUE-01 & W MGNE+UO & & $5.795 E+04$ & 1. $100 E+00$ & $0.000 E+00$ & & $9.172 E+011$ & \\
\hline$B r-144$ & $3.29 \overline{G E-i j}$ & A. WWUE+UG & $2.53 j E+45$ & U. $\quad 000 E+0 \dot{0}$ & Q. MUDE+OU. & $0.000 E+00$ & $Z .531 E+05$ & $3.345 E-i\}$ & \\
\hline$=9-147$ & 2. & $\therefore \bar{B} I E+02$ & $3.144 E+05$ & 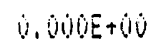 & $4.470 E+0 Z$ & U. Uं00E+UO & $3.152 E+45$ & $3.397 \bar{E}+1, \bar{Z}$ & $3.5 Z E+1.5$ \\
\hline$E:-15 i$ & 1. SUE +QU1 & U. QUVE +00 & $1.149 E+11$ & 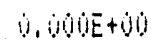 & Q. QUOEE + 00 & $2.397 E+14$ & $2.398 E+04$ & $1.355 E+1.2$ & \\
\hline$E_{w}-154$ & E. EUOE+QU & U. WUUE+OU & $1.6017 E+0.5$ & 0. GUUE+U0 & O. OUUE + IlO & $2,4 E E E+04$ & $1.399 E+i 4$ & $0.055 E+01$ & \\
\hline$E u-155$ & $4,95 \mathrm{~b}+0 \mathrm{u}$ & A BuUe+ou & $2.9375+0103$ & $\dot{0}, \quad$ QUUE +00 & G. OOUE+OQ & Q. 1000 +00 & $2.9395+0$. & $6.314 E+000$ & \\
\hline$T h-232$ & $1 .+1 E E+10$ & O. OUUE +100 & $2,395 E-113$ & $0 . \quad 00 \mathrm{E}+00$ & Q. UOUE + & $3.644 E+10$ & $5.346 E+00$ & $\xi_{1} 162 E+117$ & $5, B A E+10 \dot{0}$ \\
\hline $9-23$ & L. & G GUVE+TO & Q. UUUE + & i. GUUE +Uं & 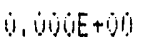 & 1.785 & $1,955 E+02$ & $2.0 \Xi E \tilde{E}+04$ & $1.995 E+02$ \\
\hline $1-235$ & $7.646 E+6 E$ & $\because, 391 E-144$ & $4.307 E-03$ & 1.7 & 3.162 & 5.67 & $1.27 b E-10$ & 5. 9U1E+05 & $1,2 \pi E-i 2$ \\
\hline-52 & $4,4 B Q E+i \overline{9}$ & 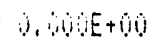 & 7.7 & $3 E-14$ & $2,7,1 E-64$ & $1.055 E-05$ & 3.95 & $2.357 E+V_{5}$ & $7.929 E-62$ \\
\hline $4 \bar{y}-35$ & $\therefore$ II UUE & 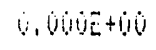 & 6.9 & $O E+C i$ & 0.1 & 1.88 & 8.367 & $1.257 E+1.4$ & $8.307 E-1.1$ \\
\hline $8 u-230$ & $\overline{3}, 770 E+01$ & b. GQUE+vi & $B E+02$ & 0. & . & $\overline{8} .5$ & 1.32 & $7.746 E+\dot{U} 1$ & $1.328 E+0 \overline{1}$ \\
\hline $8 u-239$ & $2,4 U E+14$ & $\therefore, \cup(4 E+11]$ & $5.391 E+0.12$ & $2,406 E+02$ & (i) & 3.390 & 1.165 & $1.876 E+(14$ & $1.165 E+13$ \\
\hline $5-240$ & 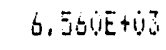 & $\therefore 13 E+00$ & $2.749 E+12 Z$ & $1.627 E+\dot{0} 0$ & $\bar{Z} . \mathrm{E}(0 \mathrm{GE}+00$ & 4.49 & 2.590 & 1.27 & $2.890 \bar{U}+\mathrm{U}^{2}$ \\
\hline$[1-241$ & $1.440 E+01$ & Q. OOUE+100 & $1,28 J E+14$ & $E+i i j$ & 5.72 & 1,0 & 1.3 & 1.2 & 1. $31 \bar{E}+1+4$ \\
\hline$F_{4}-242$ & $\therefore 75 U E+105$ & $0.900 E+00$ & $E-03$ & $E+00$ & 1.6 & 0,000 & 3.3 & 2.3 & $3.3060 E-13$ \\
\hline rifi- $24 i$ & $4.527 E+02$ & O. OQUOE+ & $9.409 E+1.2$ & 20. OUDEE+00 & $0.0000+00$ & 6.48 & 1. Wibe+i & 2,53 & 1. DQEetio \\
\hline$-\pi-244$ & $1.310 E+11$ & $0,600 E+00$ & $2.209 E+00$ & $\because 1.001 E+00$ & Q. UDOUE+00 & $4.26 i$ & 4.2 & $5.260 \bar{E}+\dot{0} 1$ & $4.262 E+103$ \\
\hline$[t-i 52$ & 2. DEEE+OO & $0.600 \mathrm{E}+000$ & $\dot{U}, \dot{100 E+}+\dot{0}$ & 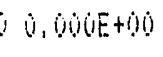 & $0.000 E+00$ & 2.629E+1.1] & $E+0$ & 1. GUSE-(1) & E.r.9E+(1) \\
\hline Turals & & 2 & $i$ & h & (1) & $404 E+\angle 5$ & .. & 17 & $1.272 \mathrm{E}+i \mathrm{i}$ \\
\hline 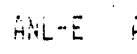 & gonin & 10 ond LaOar & ary-tas & & & & & & \\
\hline & rariturd fess & invation & & & & & & & \\
\hline 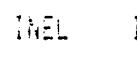 & Hano Natso & nal Engifie & & & & & & & \\
\hline - - itit & Ds Hitucs & inetionad & tory & & & & & & \\
\hline & & & & & & & & & \\
\hline
\end{tabular}


Memo 3

\section{Memo 8}

Date: August 1990

To: R. P. Rechard, 6342

From: $\quad K$. Brinster

Subject: Transmissivity zones in Culebra Dolomite Membe $c$ of Rustler Formation 


\section{Sandia National Laboratories}

date: August 1990

Albuquerque, New Mexico 87185

10: Rob Rechard

from:

Brinster

subjecl: Transmissivity zones in Culebra Dolomite Member of Rustler Formation

Enclosed is a map (from LaVenue, 1988) showing 8 transmissivity (T) zones in the WIPP vicinity and a listing of the T's for each zone. The average Culebra thickness is about $7.7 \mathrm{~m}$ (from LaVenue, 1988). 
REGION CULEBRA1:

LOG (TRANSMISSIVITY)

$-4.68$

$-4.45$

$-4.13$

$-4.02$

$-3.56$

$-3.54$

$-3.37$

REGION CULEBRA2:

LOG (TRANSMISSIVITY)

$-7.12$

$-7.04$

$-7.01$

$-6.97$

$-6.71$

$-6.64$

$-6.60$

$-6.55$

$-6.52$

$-6.49$

$-6.48$

REGION CULEBRA3:

LOG (TRANSMISSIVITY)

$-6.00$

$-5.97$

$-5.78$

$-5.69$

$-5.61$

REGION CULEBRA4:

LOG (TRANSMISSIVITY)

$-6.57$

$-6.40$

$-6.38$

$-6.30$

$-6.20$

$-6.19$

$-6.11$

$-6.03$

REGION CULEBRA5:

LOG (TRANSMISSIVITY)

$-4.51$

$-4.43$

REGION CULEBRA6:

LOG (TRANSMISSIVITY)

$-10.12$

REGION CULEBRA7:

LOG (TRANSMISSIVITY)

$-3.90$

$-3.26$

$-2.91$

$-2.81$

REGION CULEBRA8:

LOG (TRANSMISSIVITY)

$-4.34$

$$
\text { A }-116
$$

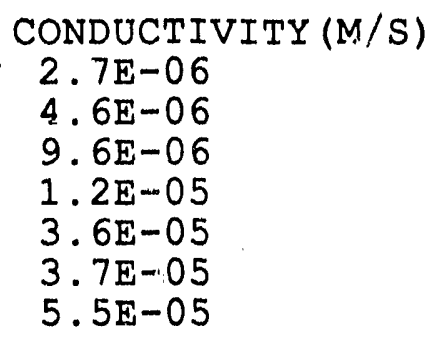

CONDUCTIVITY (M/S)
9. $9 \mathrm{E}-09$
1. $2 \mathrm{E}-08$
1. $3 \mathrm{E}-08$
1. $4 \mathrm{E}-08$
2. $5 \mathrm{E}-08$
3. $0 \mathrm{E}-08$
3. $3 \mathrm{E}-08$
3. $7 \mathrm{E}-08$
3. $9 E-08$
4. $2 \mathrm{E}-08$
4. $3 E-08$

CONDUCTIVITY (M/S)

$$
\begin{aligned}
& 1.3 E-07 \\
& 1.4 E-07 \\
& 2.2 E-07 \\
& 2.7 E-07 \\
& 3.2 E-07
\end{aligned}
$$

CONDUCTIVITY (M/S)

$$
\begin{aligned}
& \text { 3. } 5 E-08 \\
& 5.2 E-08 \\
& 5.4 E-08 \\
& 6.5 E-08 \\
& 8.2 E-08 \\
& 8.4 E-08 \\
& 1.0 E-07 \\
& 1.2 E-07
\end{aligned}
$$

CONDUCTIVITY (M/S)

4. $0 \mathrm{E}-06$

4. $8 \mathrm{E}-06$

CONDUCTIVITY (M/S)

$$
\text { 9. } 9 \mathrm{E}-12
$$

CONDUCTIVITY (M/S)

$$
\begin{aligned}
& 1.6 \mathrm{E}-05 \\
& 7.1 \mathrm{E}-05 \\
& 1.6 \mathrm{E}-04 \\
& 2.0 \mathrm{E}-04
\end{aligned}
$$

CONDUCTIVITY (M/S)

5. $9 \mathrm{E}-06$ 
$r \operatorname{lom}_{\text {appendix } A}^{\sigma^{0} v^{0}}$

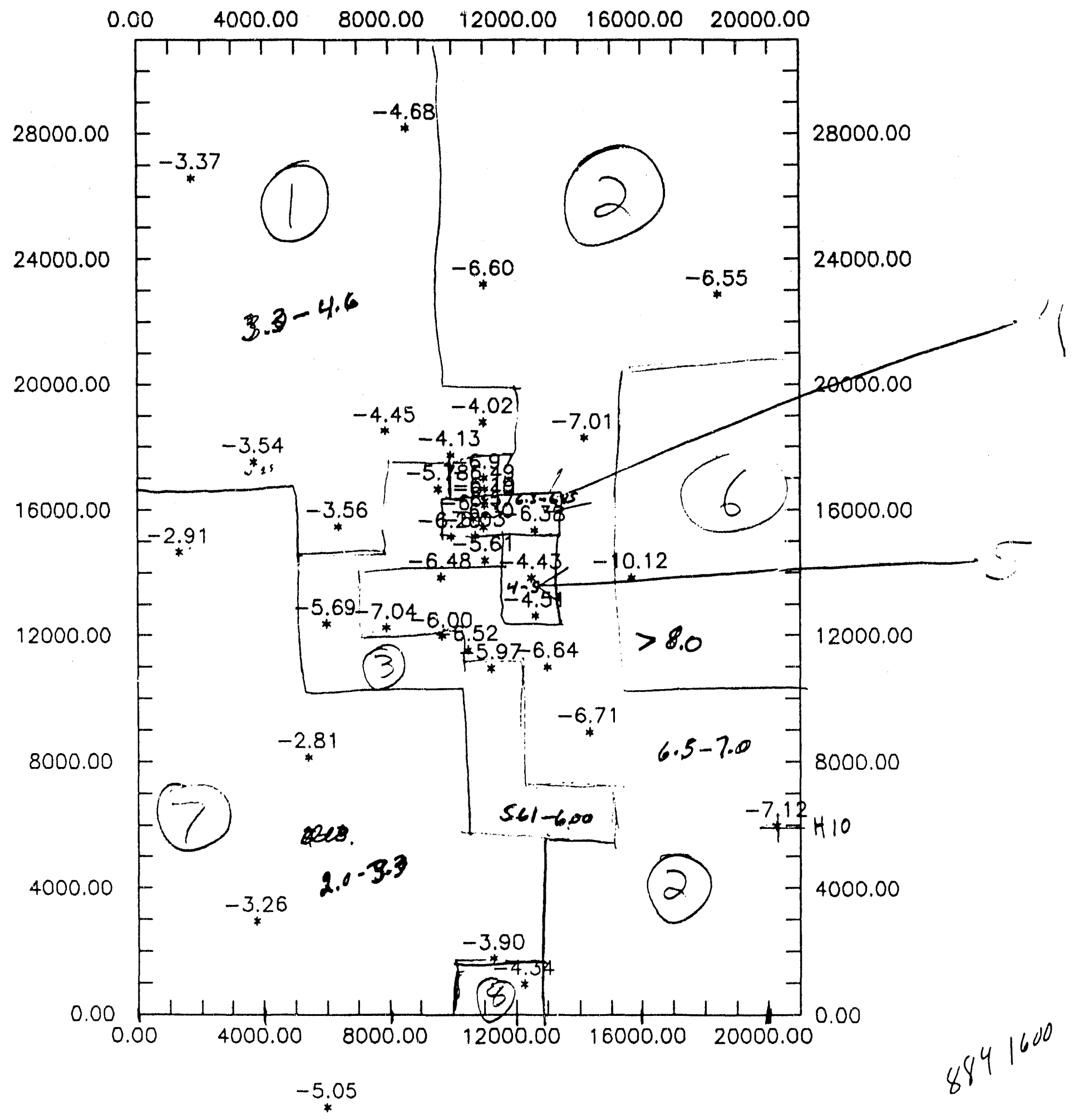




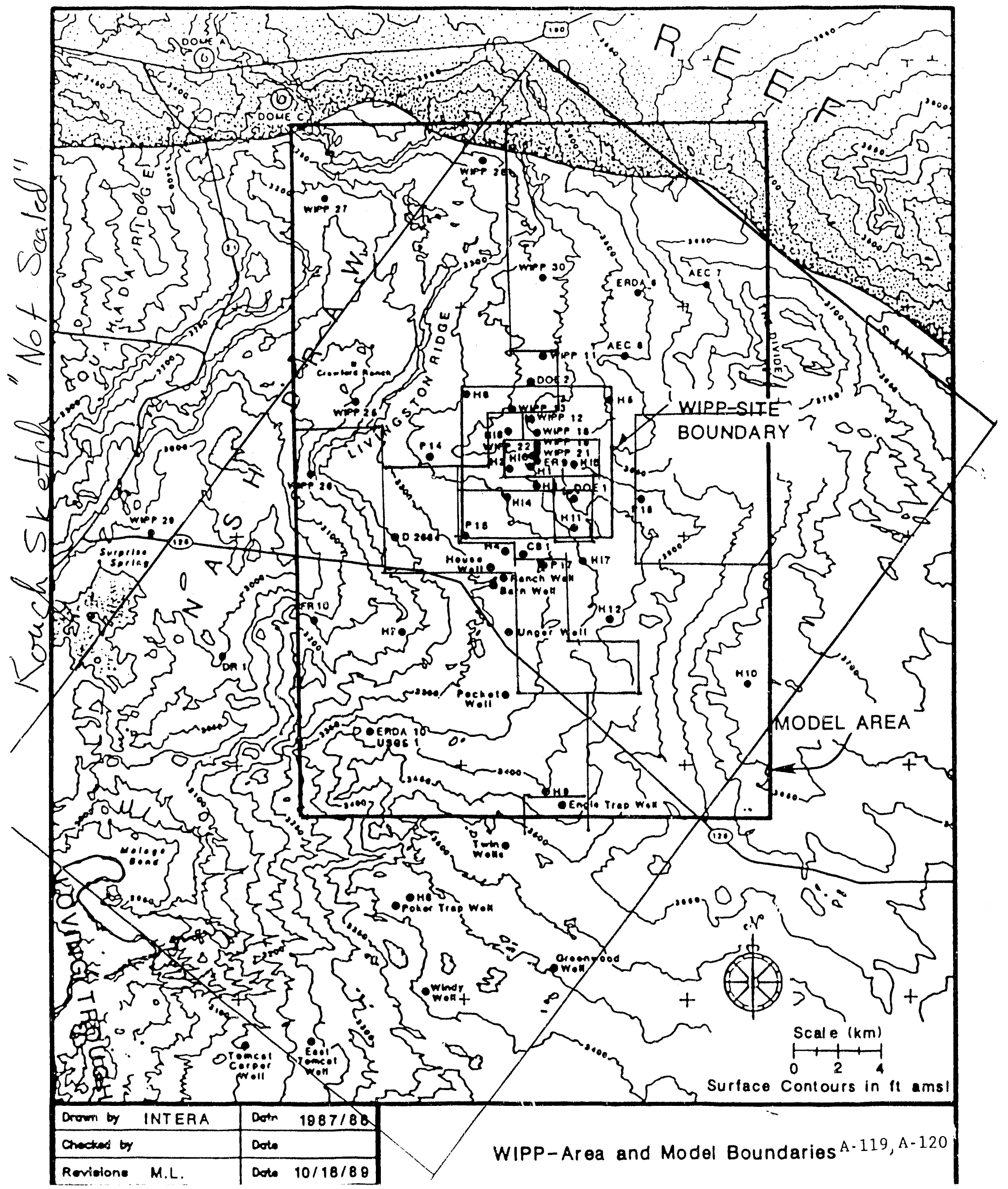


Memo 9

Date: October, 1990

To: R. P. Rechard, 6342

From: $\quad K$. Brinster

Subject: Transmissivities and pilot points for the Culebra Dolomite Member 


\section{Sandia National Laboratories}

date: October 1990

Albuquerque, New Mexico 87185

10: Rob Rechard

from:

Brinster/ $/ \mathrm{km}$

subject: Transmissivities and pilot points for the Culebra Dolomite Member.

Enclosed is a listing of transmissivities from the Culebra Dolomite Member for actual wells and for the pilot points used by LaVenue 1990. The accompanying plot of the points shows their locations. The Culebra Dolomite Member is $7.7 \mathrm{~m}$ thick. 


\section{Appondix A}

CULEBRA TRANSMISSIVITY MEASUREMENTS AND PILOT POINTS,

AND CALCULATED HYDRAULIC CONDUCTIVITY $(=10 * * \log (\mathrm{T}) / 7.7)$

REGION CULEBRAA:

LOG (TRANSMISSIVITY) CONDUCTIVITY (M/S)

$-2.9$

$-2.9$

$-2.9$

$-2.8$

$-2.7$

$-2.6$

$-2.3$

$-2.3$

$-2.1$

1. $6 \mathrm{E}-4$

1. $6 \mathrm{E}-4$

1. $6 \mathrm{E}-4$

2. $1 \mathrm{E}-4$

2. $6 \mathrm{E}-4$

3. $3 \mathrm{E}-4$

6. $5 \mathrm{E}-4$

6. $5 \mathrm{E}-4$

1. $O E-3$

REGION CULEBRAB :

LOG (TRANSMISSIVITY) CONDUCTIVITY (M/S)

$-3.9$

$-3.9$

$-3.3$

$-3.0$

1. $6 \mathrm{E}-5$

1. $6 \mathrm{E}-5$

$6.5 \mathrm{E}-5$

1. $3 E-4$

REGION CULEBRAC :

LOG (TRANSMISSIVITY)

$-3.4$

CONDUCTIVITY (M/S)

$5.2 \mathrm{E}-5$

REGION CULEBRAD :

LOG (TRANSMISSIVITY) CONDUCTIVITY (M/S)

$-3.6$

$-3.6$

$-3.6$

$-3.5$

$-3.4$

3. $3 E-5$
3. $3 E-5$
3. $3 E-5$
$4.1 E-5$
$5.2 E-5$

REGION CULEBRAE:

LOG (TRANSMISSIVITY)

$-5.9$

$-5.8$

$-5.7$

$-5.6$

$-5.5$

$-5.1$

$-5.0$

$-5.0$

$-5.0$

CONDUCTIVITY $(\mathrm{M} / \mathrm{S})$

1. $6 \mathrm{E}-7$

2. $1 \mathrm{E}-7$

2. $6 \mathrm{E}-7$

3. $3 E-7$

4. $1 \mathrm{E}-7$

1. $0 \mathrm{E}-6$

1. $3 \mathrm{E}-6$

1. $3 \mathrm{E}-6$

1. $3 \mathrm{E}-6$

REGION CULEBRAF :

LOG (TRANSMISSIVITY)

$-4.7$

$-4.5$

$-4.3$

$-4.0$

$-3.9$

CONEUCTIVITY $(\mathrm{M} / \mathrm{S})$

2. $6 \mathrm{E}-6$

4. $1 E-6$

6. $5 \mathrm{E}-6$

1. $3 E-5$

1. $6 \mathrm{E}-5$ 
REGION CULEBRAG:

LOG (TRANSMISSIVIT'Y)

$-7.0$

$-6.6$

$-6.6$

$-6.5$

$-6.5$

$-6.4$

$-6.4$

$-6.38$

$-6.3$

$-6.2$

$-6.2$

$-6.2$

$-6.1$

$-6.0$

$-6.0$

$-6.0$

$-6.0$

$-6.0$

$-5.9$
CONDUCTIVITY (M/S)

1. $3 E-8$

3. $3 E-8$

3. $3 E-8$

4. $1 E-8$

4. $1 \mathrm{E}-8$

5. $2 \mathrm{E}-8$

5. $2 \mathrm{E}-8$

5. $4 \mathrm{E}-8$

6. $5 \mathrm{E}-8$

8. $2 \mathrm{E}-8$

8. $2 \mathrm{E}-8$

8. $2 \mathrm{E}-8$

1. $0 \mathrm{E}-7$

1. $3 E-7$

1. $3 E-7$

1. $3 \mathrm{E}-7$

1. $3 \mathrm{E}-7$

1. $3 \mathrm{E}-7$

1. $6 \mathrm{E}-7$

REGION CULEBRAH :

LOG (TRANSMISSIVITY)

$-5.6$

$-5.17$

$-3.5$

CONDUCTIVITY (M/S)

3. $3 E-7$

8. $8 \mathrm{E}-7$

4. $1 E-5$

REGION CULEBRAI :

LOG (TRANSMISSIVITY)

$-8.3$

$-8.1$

CONDUCTIVITY (M/S)

6. $5 E-10$

1. $O E-9$

REGION CULEBRAJ :

LOG (TRANSMISSIVITY)

$-4.4$

$-4.3$

$-3.5$

$-3.5$

$-3.25$

CONDUCTIVITS (M/S)

$$
\begin{aligned}
& 5.2 \mathrm{E}-6 \\
& 6.5 \mathrm{E}-6 \\
& 4.1 \mathrm{E}-5 \\
& 4.1 \mathrm{E}-5 \\
& 7.3 \mathrm{E}-5
\end{aligned}
$$

REGION CULEBRAK:

LOG (TRANSMISSIVITY)

$-7.7$

$-7.1$

$-7.0$

$-7.0$

$-6.7$

$-6.6$

$-6.6$

CONDUCTIVITY (M/S)

2. $6 \mathrm{E}-9$

1. $0 \mathrm{E}-8$

1. $3 E-8$

1. $3 \mathrm{E}-8$

2. $6 \mathrm{E}-8$

3. $3 \mathrm{E}-8$

3. $3 E-8$

REGION CULEBRAL:

LOG (TRANSMISSIVITY) CONDUCTIVITY (M/S)

$-10.1$

1. $0 \mathrm{E}-11$

REGION CULEBRAM:

LOG (TRANSMISSIVITY)

$-4.3$

CONDUCTIVITY $(\mathrm{M} / \mathrm{S})$

$6.5 E-6$ 


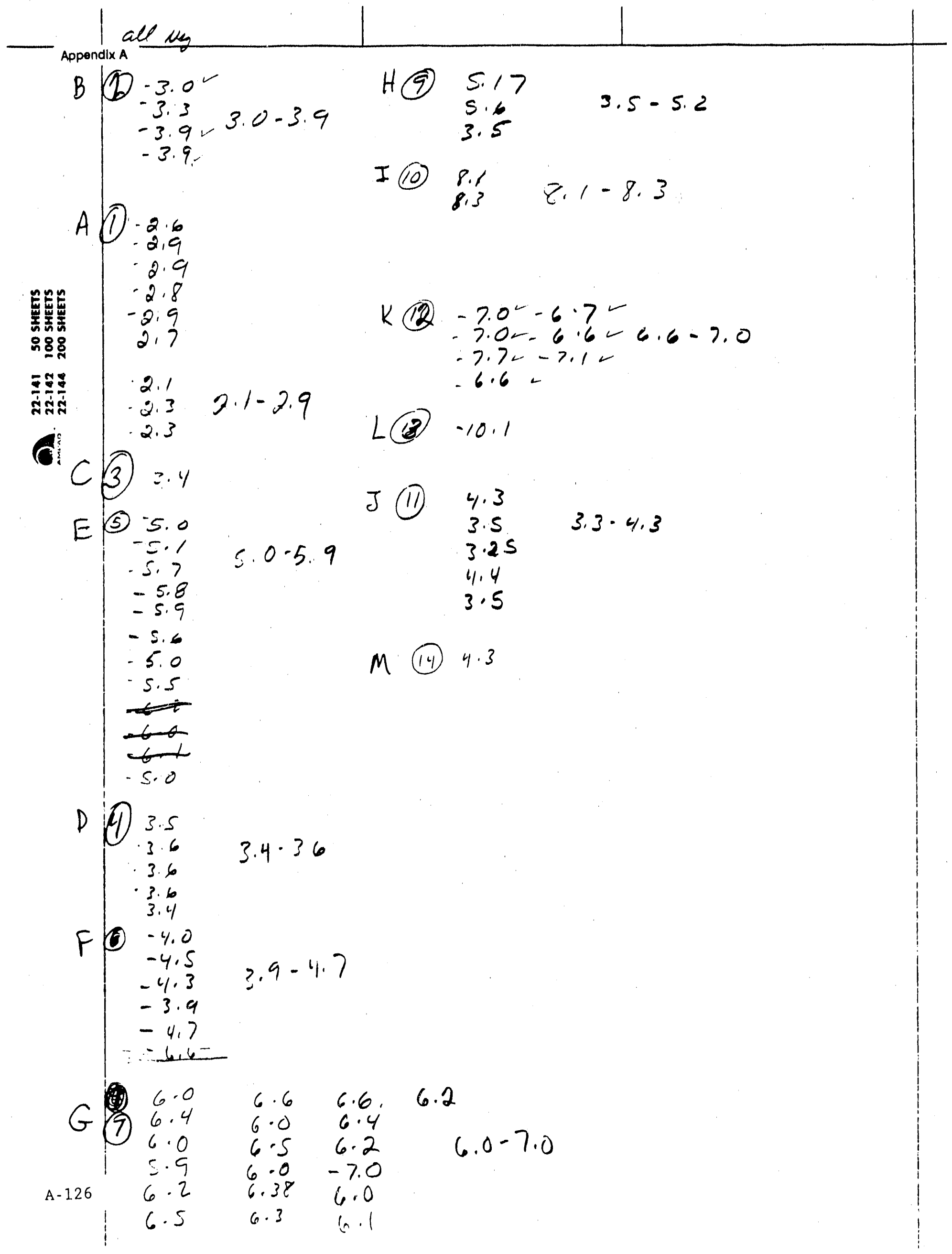




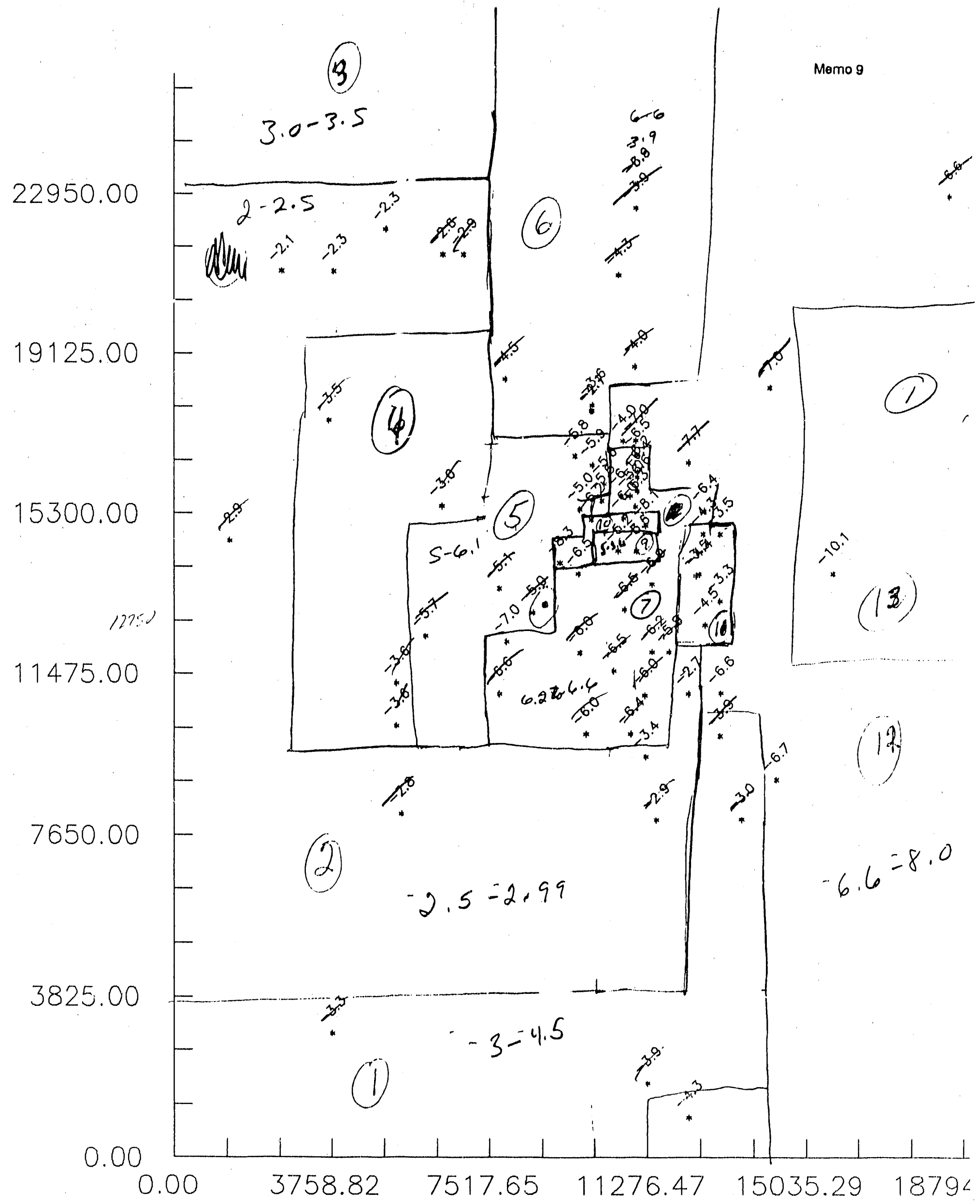


Memo 10

Date: August 1990

To: R. P. Rechard, 6342

From: $\quad K$. Brinster

Subject: Well data from electric logs 


\section{Sandia National Laboratories}

date: August 1990

Albuquerque, New Mexico 87185

10: Rob Rechard

from:

$\mathrm{K}$

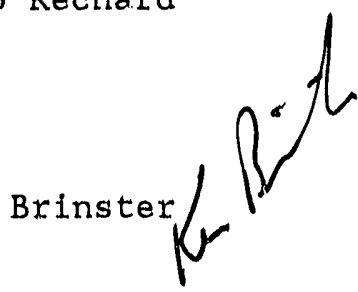

subject: We11 data from electric logs

The accompanying 1isting of wells and bit diameters is compiled from well logs found in the WIPP library at SNL and from the USGS well log library in Denver. The logs have been copied and are kept in a folder in my office, at present, but will eventually be kept in the WIPP library. 
WELL NG. LOCATION Sec. T. Fi
DEF'TH

to
BIT DIA. EIT DIA. WELL, CUUNT IN. @ 2150

\begin{tabular}{|c|c|c|c|c|c|c|c|}
\hline \multirow[t]{2}{*}{ WELL NO. } & LOCATI DN & \multicolumn{2}{|r|}{$\begin{array}{l}\text { DEF'TH } \\
\text { to }\end{array}$} & \multirow{2}{*}{$\begin{array}{c}\text { EIT IIA. } \\
\text { IN. }\end{array}$} & \multirow{2}{*}{$\begin{array}{l}\text { EIT DIA. } \\
\text { (a } 2150^{\circ}\end{array}$} & \multirow[t]{2}{*}{ WELLL } & \multirow[t]{2}{*}{ COUN } \\
\hline & Sec. & fram & to & & & & \\
\hline$W F-0,908-1$ & 202231 & 0 & 510 & 7.875 & 0 & & 0 \\
\hline$W F-(0) 1908-2$ & $2022=1$ & 510 & 900 & 11 & 0 & & 0 \\
\hline$W F-02084-1$ & 172231 & 0 & $10 \Omega 7$ & 7.875 & 0 & & 0 \\
\hline$W F-02084-2$ & 17227 & 10,77 & \pm 868 & 7.875 & 7.875 & & 1 \\
\hline$W F-0.48 E$ & 152231 & 0 & 1025 & 7.875 & 0 & & 0 \\
\hline$W F-0.521$ & $2 \pi \quad 24 \quad 30$ & 0 & 735 & 7.875 & 0 & & 0 \\
\hline$W F-0.528$ & $0424 \quad \Xi 1$ & 0 & 785 & 7.875 & 0 & & 0 \\
\hline$W F-0.99: 9-1$ & 112231 & 0 & 10.56 & $7.20 \pi$ & 0 & & 0 \\
\hline$W F-03939-2$ & $1122 \quad 1$ & $10: 6$ & 3028 & 7.205 & $7.20 \pi$ & & 1 \\
\hline$W F-04448-1$ & $1020 \quad 5$ & 0 & 2622 & 17.5 & 17.5 & & 1 \\
\hline$W F-04448-2$ & $1020 \quad 52$ & 2622 & 9996 & 12.25 & 0 & & 0 \\
\hline$W F-04448-3$ & 102032 & 9996 & 142010 & 8.75 & 0 & & 0 \\
\hline$W F-04448-4$ & 102022 & 14200 & $14: 47$ & 7.75 & 0 & & 0 \\
\hline$W F-04470$ & 062129 & 0 & 11575 & 7.875 & 7.875 & & 1 \\
\hline$W F-04472-1$ & 182129 & 0 & 3006 & 12.25 & 12.25 & & 1 \\
\hline$W F-04472-2$ & 182129 & 3006 & 12977 & 8.75 & 0 & & 0 \\
\hline$W F-04476-1$ & 222129 & 0 & 3501 & 8.75 & 8.75 & & 1 \\
\hline$W F^{\prime}-04476-2$ & 222129 & 2501 & 6990 & 8.75 & 0 & & 0 \\
\hline$W F-04476-I$ & 222129 & 6990 & 1300 & 8.75 & 0 & & 0 \\
\hline$W F-04485$ & $\$ 42129$ & 0 & 135 & 7.975 & 7.875 & & 1 \\
\hline$W F-04491-1$ & $26 \quad 21 \quad 30$ & 0 & 11187 & 10.625 & $1 \% .625$ & & 1. \\
\hline$W F^{\prime}-04491-2$ & $2621 \quad 0$ & 11187 & 1362 & 7.875 & 0 & & () \\
\hline$W F-04492-1$ & 352130 & 0 & 3638 & 15 & 15 & & 1. \\
\hline$W F^{\prime}-04492-2$ & 55215 & 36.88 & 11287 & 9.5 & 0 & & 0 \\
\hline$W F-04.49 \Xi-\Xi$ & 552120 & 11287 & 1.800 & 6.75 & 0 & & 0 \\
\hline$W F-04499-1$ & 01215 & 0 & 4000 & 12.25 & 12.25 & & 1 \\
\hline$W F-04499-2$ & o) $21 \quad 2$ & 4000 & 11300 & 8.5 & 0 & & 0 \\
\hline$W F^{\prime}-04499-\Xi$ & 01215 & 1.300 & 14515 & 6.5 & 0 & & 0 \\
\hline$W F-04504$ & 022132 & 0 & 14500 & 7.875 & 7.875 & & 1 \\
\hline$W F-04505-1$ & 022132 & 0 & 1125 & 12.25 & 12.25 & & 1 \\
\hline$W F-04505-2$ & 022152 & 11.25 & 14250 & 8.75 & 0 & & 0 \\
\hline$W F^{\prime}-045015-3$ & 022152 & 14250 & 14400 & 8.75 & 0 & & 0 \\
\hline$W F-0450 t-1$ & 042152 & 0 & 8951 & 12.25 & 12.25 & & 1. \\
\hline$W F^{\prime}-04506-2$ & 042132 & 8951 & 13800 & 8.5 & 0 & & 0 \\
\hline$W F-04509-1$ & 10215 & 0 & 11187 & 9.5 & 9.5 & & 1 \\
\hline$W F-04509-2$ & 10215 & 14.74 & 14.774 & 6.5 & 0 & & 0 \\
\hline$W F-0450$ & 112123 & & LIH: & U.t: & 0 & & 0 \\
\hline$W F-04523$ & 21213 & & UH: & UF: & 0 & & 0 \\
\hline$W F-04529-1$ & 312122 & 0 & 1014 & 8.75 & 0 & & 0 \\
\hline$W F-04529-2$ & $\therefore 12122$ & 1014 & 3918 & 7.203 & 7.203 & & 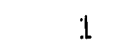 \\
\hline$W F-(15540-1$ & 062251 & 0 & \pm 700 & L.t: & 0 & & 0 \\
\hline$W F-(14540-2$ & $06 \quad 22 \quad 31$ & 3700 & 10400 & 9.5 & 0 & & () \\
\hline$W F-04540-3$ & 062231 & 10400 & 11405 & 6.5 & 0 & & 0 \\
\hline$W F-04544-1$ & 02220 & 0 & 405 & 22 & 0 & & 0 \\
\hline$W F-04544-2$ & $02 \quad 22 \quad 3$ & 405 & 5657 & 17 & 17 & & 1 \\
\hline$W F-04544-I$ & 0220 & $\therefore 657$ & 7490 & 9.875 & 0 & & 0 \\
\hline$W F-04544-4$ & 02230 & 7490 & 12205 & 9.875 & 0 & & 0 \\
\hline$W F-04544-5$ & 022230 & 12205 & 14259 & 6.25 & 0 & & 0 \\
\hline
\end{tabular}




\section{WELL NO. LDCATION \\ Sec. T. Fi \\ from DEFTH to BIT DIA. EIT DIA., WELL COUNT}

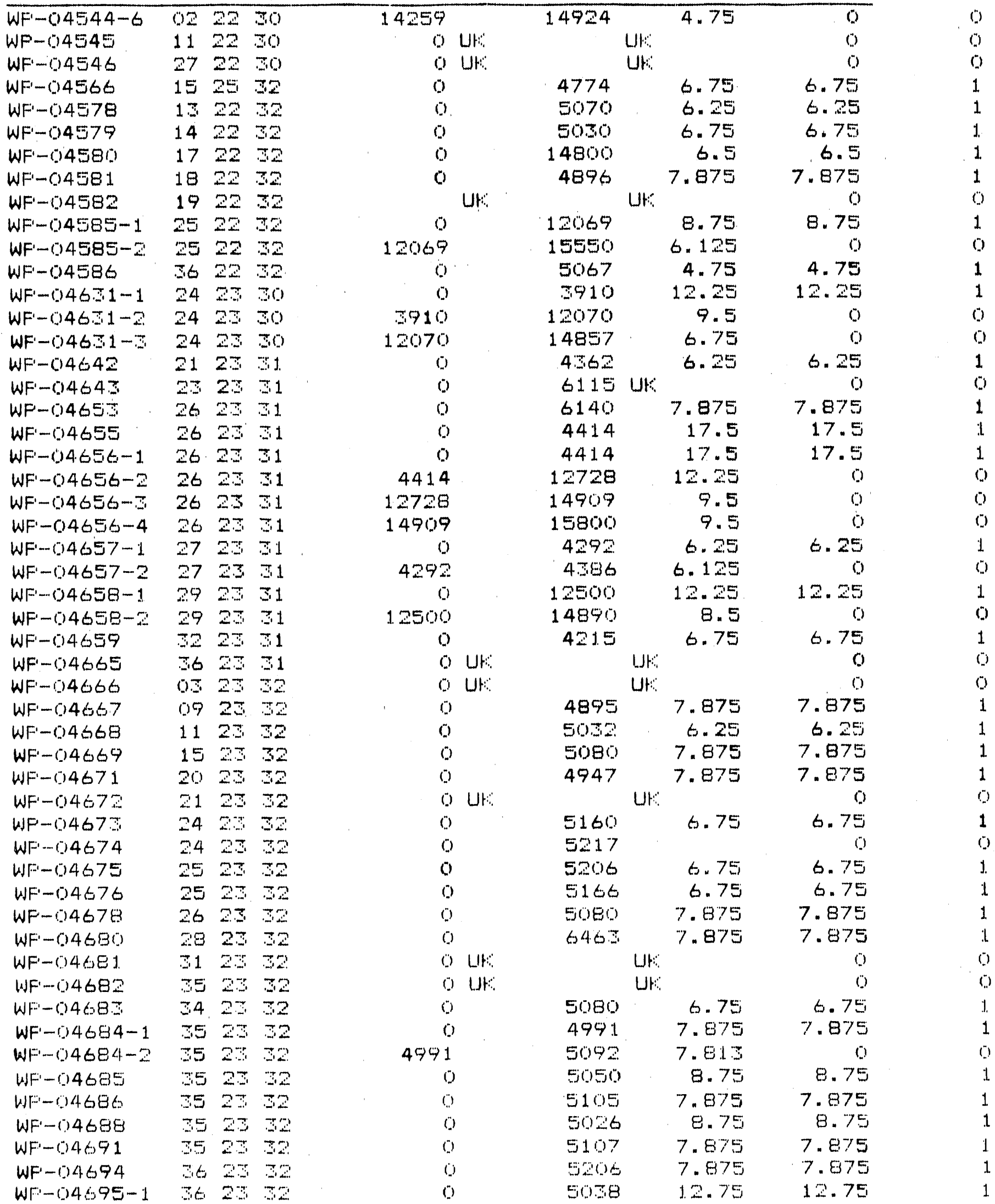




WEI.L WO. LOCATION DEFTH
SEC.T.FI from EIT DIA. EIT DIA. WELL COUNT

\begin{tabular}{|c|c|c|c|c|c|c|c|c|c|}
\hline$W F-04695-2$ & 36 & 23 & 32 & 50.68 & & 12727 & 12.25 & () & 0 \\
\hline$W F-04695-3$ & 36 & $2 \pi$ & 3 & 12727 & & 16825 & 9.5 & 0 & 0 \\
\hline$W F-04695-4$ & 56 & 23 & 92 & 16825 & & 17649 & 6.5 & 0 & 0 \\
\hline$W F-04699$ & 18 & 23 & 32 & 0 & Ut: & \multicolumn{2}{|c|}{ UK } & 0 & 0 \\
\hline$W F^{\prime}-014796$ & 07 & 24 & 29 & 0 & & 2779 & 5.5 & 5.5 & 1 \\
\hline$W F=-04806$ & 27 & 24 & 29 & 0 & & 3031 & 6.25 & 6.25 & 1 \\
\hline$W F-018812$ & 29 & 24 & 30 & 0 & & 3805 & 6 & 6 & 1 \\
\hline$W F-0481 \Sigma-1$ & 02 & .24 & 31 & 0 & & 12534 & 9.5 & 9.5 & 1 \\
\hline$W F-04812-2$ & 02 & 24 & 31 & 12544 & & 15120 & 6.5 & 0 & 0 \\
\hline$W F^{\prime}-0.4817$ & 03 & 24 & $\Xi 1$ & 0 & & 4526 & 7.875 & 7.875 & 1 \\
\hline$W F=-014818$ & 03 & 24 & $\Xi 1$ & 0 & & 4450 & 4.75 & 4.75 & 1 \\
\hline$W F^{\prime}-04819$ & 04 & 24 & $\Xi 1$ & 0 & & 4400 & 7.875 & 7.875 & 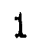 \\
\hline$W F-04820$ & 11 & 24 & \pm 1 & 0 & & 4656 & 7.875 & 7.875 & 1 \\
\hline$W F^{\prime}-04822-1$ & 04 & 24 & $\$ 1$ & 0 & & 12500 & 12.25 & 12.25 & 1 \\
\hline$W F-04822-2$ & 04 & 24 & 31 & 12500 & & 14200 & 8.5 & 0 & 0 \\
\hline$W F-04822-3$ & 04 & 24 & $\Xi 1$ & 14200 & & 15200 & 6.5 & 0 & 0 \\
\hline WF-01482J & 21 & 24 & \pm 1 & 0 & & 4540 & 7.875 & 7.875 & 1 \\
\hline$W F^{\prime}-0.04824$ & 20 & 24 & 31 & 0 & & 4423 & 6.75 & 6.75 & 1 \\
\hline$W F-04825-1$ & 24 & 2.4 & $\Xi 1$ & 0 & & 750 & 15.575 & 0 & 0 \\
\hline$W F-04825-2$ & 24 & 24 & $\$ 1$ & 750 & & 4476 & 9.625 & 9.625 & 1 \\
\hline$W F-04825-3$ & 24 & 24 & : 1 & 4476 & & 8545 & 8.75 & 0 & 0 \\
\hline$W F-04.827-1$ & 04 & 24 & 31 & 0 & & 571 & 9.875 & 0 & 0 \\
\hline$W F-04827-2$ & 04 & 24 & 31 & 571 & & 4400 & 6.25 & 6.25 & 1 \\
\hline$W F-048 \geq 8$ & 17 & 24 & 31 & 0 & & 4500 & 8.625 & 8.625 & 1 \\
\hline$W F-04829$ & 20 & 24 & $\Xi 1$ & 0 & & 4502 & 6.25 & 6.25 & 1 \\
\hline$W F-04830-1$ & 35 & 24 & 31 & 0 & & 12500 & 9.625 & 9.625 & 1 \\
\hline$W F-04830-2$ & 55 & 24 & 31 & 12500 & & 15060 & 6.5 & 0 & 0 \\
\hline$W F^{\prime}-04879$ & 26 & 23 & 32 & 0 & & 5210 & 7.875 & 7.875 & 1 \\
\hline$W F-04882$ & 09 & 25 & 52 & 0 & & 4850 & 6.75 & 6.75 & 1 \\
\hline$W F-04883$ & 10 & 25 & 32 & 0 & & 4910 & 6.75 & 6.75 & 1 \\
\hline$W F-04884$ & 10 & 25 & 32 & 0 & & 4896 & 6.75 & 6.75 & 1 \\
\hline$W F-04892-1$ & 10 & 25 & 2 & 0 & & 4685 & 6.75 & 6.75 & 1 \\
\hline$W F-04892-2$ & 10 & 25 & 3 & 4685 & & 4787 & 6.688 & 0 & 0 \\
\hline$W F-04853-1$ & 10 & 25 & 2 & 0 & & 4685 & 7.875 & 7.875 & 1. \\
\hline$W F-04893-2$ & 10 & 25 & 32 & 4685 & & 4820 & 7.813 & 0 & 0 \\
\hline$W F-04894$ & 10 & 25 & 32 & 0 & & 4775 & 6.75 & 6.75 & 1 \\
\hline$W F-04895$ & 10 & 25 & 20 & 0 & & 4777 & 6.75 & $6.75 j$ & 1 \\
\hline$W F-04896$ & 10 & 25 & 2 & 0 & & 4815 & 6.75 & 6.75 & 1 \\
\hline WF- -04897 & 10 & 25 & 32 & 0 & & 4791 & 6.75 & 0.75 & 1 \\
\hline$W F-04.898$ & 10 & 25 & 32 & 0 & & 4850 & 6.25 & 6.25 & 1 \\
\hline$W F-0,007$ & 26 & 25 & 29 & 0 & Ur: & & & 0 & 0 \\
\hline$W F^{\prime}-0,50,59$ & 1 & 25 & 2 & 0 & & 4610 & 8. 25 & 8.25 & 1 \\
\hline$W F=015062$ & 30 & 25 & 29 & 0 & & 3000 & 7.875 & 7.875 & 1 \\
\hline$W F^{\prime}-0,006 \Omega$ & 29 & 25 & 29 & 0 & & $\$ 450$ & 7.875 & 7.875 & 1 \\
\hline$W F-05076$ & 07 & 24 & $\therefore 1$ & 0 & & 4393 & 7.875 & 7.875 & 1 \\
\hline$W F-05077-1$ & 06 & 24 & $\because 1$ & 0 & & 4145 & 1.7 .5 & 17.5 & 1. \\
\hline$W F-050177-2$ & 06 & 24 & 31 & 41.45 & & 12570 & 12.25 & 0 & 0 \\
\hline$W F-05077-3$ & 06 & 24 & 31 & 12570 & & 14570 & 8.5 & 0 & 0 \\
\hline$W F-05077-4$ & 06 & 24 & $\Xi 1$ & 14570 & & 15520 & 6.5 & 0 & 0 \\
\hline$W F-05088$ & 01 & 24 & 2 & 0 & & 5110 & 7.875 & 7.875 & 1 \\
\hline$W F-05089$ & 06 & 24 & 3 & 0 & & 4797 & 7.875 & 7.875 & 1 \\
\hline$W F-05098$ & 15 & 25 & 29 & 0 & & 3190 & 6.375 & $6 . .75$ & 1 \\
\hline
\end{tabular}


WELL NO. LOCATION DETH
SEC. T. FI FIT DIA. EIT DIA. WELL COUNT

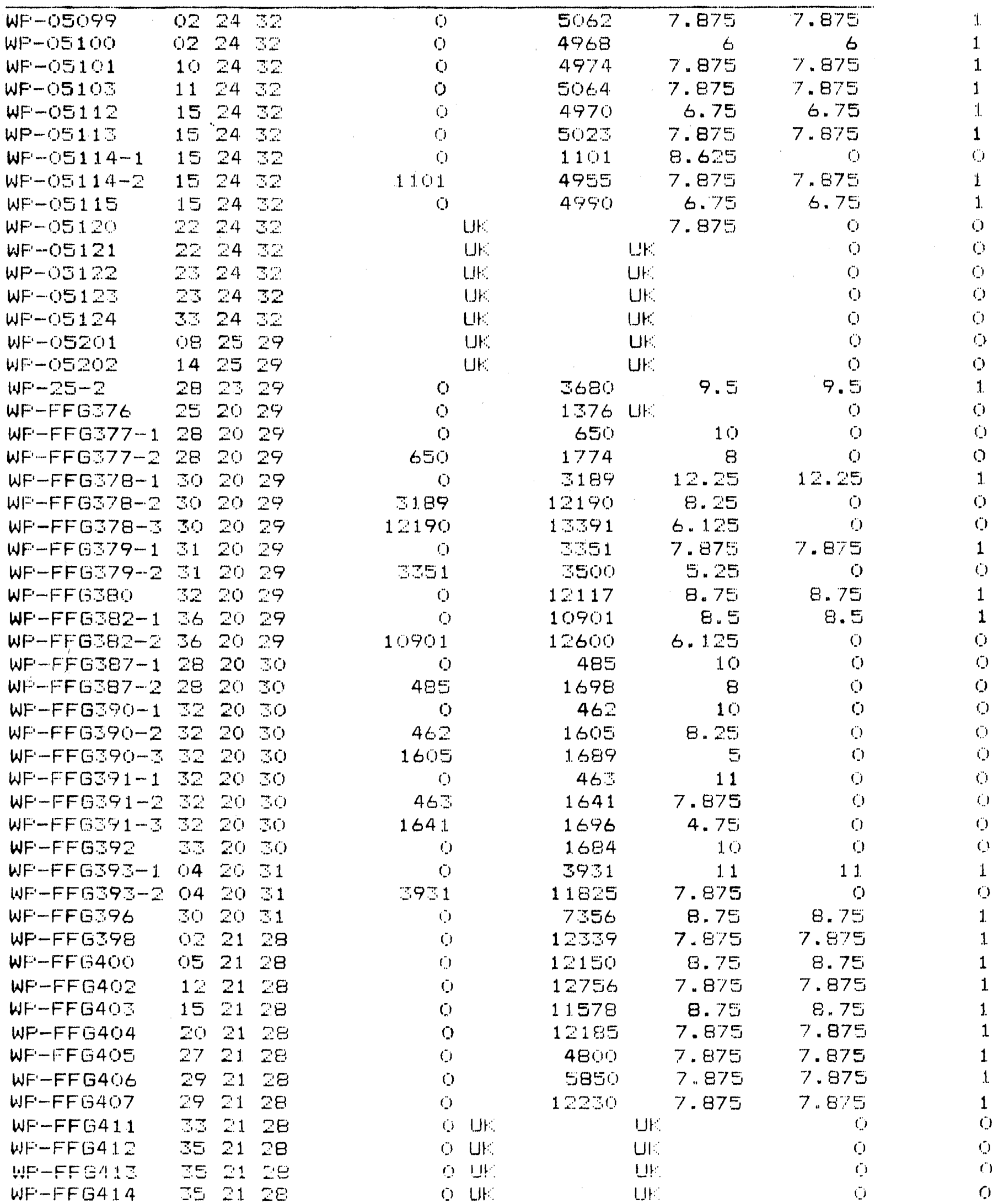




\begin{tabular}{|c|c|c|c|c|c|c|c|c|c|}
\hline \multirow[t]{2}{*}{ WELL ND. } & \multicolumn{3}{|c|}{ L..OCATION } & \multicolumn{2}{|r|}{ DEFTH } & \multirow{2}{*}{$\begin{array}{c}\text { BIT DIA. } \\
\text { IN. }\end{array}$} & \multirow{2}{*}{$\begin{array}{l}\text { EIT DIA. } \\
\text { (d) } 2150^{\circ}\end{array}$} & \multirow[t]{2}{*}{ WE:LL } & \multirow[t]{2}{*}{ COUN } \\
\hline & & & & from & to & & & & \\
\hline WF-FFG418-1 & 03 & 21 & 29 & 0 & 4117 & 11. & 11 & & 1. \\
\hline WF-FFG418- ב & 03 & 21 & 29 & 4117 & 12520 & 7.075 & 0 & & 0 \\
\hline WF $-F F G 41.9$ & 0.4 & 21 & 29 & 0 & Lt: & Ut: & 0 & & 0 \\
\hline WF-FFG426 & 1.9 & 21 & 29 & 0 & Ut: & (U) & 0 & & 0 \\
\hline WF-FFG4S3 & 0 & 22 & 28 & 0 & 985 & 7.875 & 7.875 & & 1 \\
\hline WF-FFG44T-1 & 21 & 22 & 28 & 0 & J. 84 & 12.5 & 0 & & $a$ \\
\hline$W F-F F[-144-2$ & 21 & 22 & 28 & 184 & 1200 & 10 & 0 & & 0 \\
\hline WF-FFG443... & 21 & 22 & 28 & 1200 & 2500 & 9.625 & 8.625 & & 1. \\
\hline$W F-F F G 44 \div-4$ & 21. & 22 & 20 & 2050 & 2745 & 6.25 & 0 & & 0 \\
\hline$W F-F F=5444$ & 22 & 22 & 28 & 0 & 4816 & 9.5 & 5.5 & & 1 \\
\hline$W F-F F G 445-1$ & 25 & 22 & 28 & 0 & 9200 & 8.5 & 8.5 & & 1 \\
\hline$W F-F F G 445-2$ & 25 & 22 & 28 & 9200 & 15101 & 8.5 & 0 & & 0 \\
\hline$W F-F F G 446$ & 27 & 22 & 28 & 0 & 3752 & 11 & 11. & & 1. \\
\hline WF-FFGE4S-1 & 28 & 19 & 30 & 0 & 295 & 11 & 0 & & o \\
\hline$W F-F F G 542$ & $2 E$ & $1 \%$ & 50 & 395 & 1697 & 7.875 & () & & 0 \\
\hline WF-FFG544-1 & 29 & 19 & 30 & 0 & 555 & 9.625 & 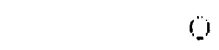 & & 1 \\
\hline$W F-F F G 54.4-2$ & 28 & 19 & 30 & 355 & 1592 & 8 & 0 & & 0 \\
\hline$W F-F F G 544-\Xi$ & 29 & 19 & 30 & 1592 & 1717 & 6.125 & 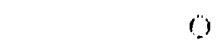 & & 0 \\
\hline WF-FFG545 & 30 & 19 & 30 & 0 & 1815 & 8 & 0 & & 0 \\
\hline$W F-F F[; 5 ; 46$ & 31 & 19 & 0 & 0 & 1697 & 8.5 & 0 & & 0 \\
\hline WF:-FFG547-1 & 3 & $1 \%$ & 50 & 0 & 383 & 1. 1 & 0 & & 0 \\
\hline WF-FFG547-2 & 32 & 19 & 80 & 383 & 1695 & $\Xi$ & 0 & & 0 \\
\hline$W F-F F(-1548 \cdots 1$ & 35 & 19 & 30 & 0 & 646 & 10 & 0 & & 0 \\
\hline$W F-F F G 54 E-2$ & 6 & 19 & 30 & 640 & 2047 & G & 0 & & () \\
\hline WF-FFES48-3 & 36 & 19 & 30 & $204 \%$ & 2055 & 6.25 & 0 & & 0 \\
\hline$W F-F F B \theta 5-\cdots 1$ & 0 & 19 & 31 & 0 & 900 & 10 & 0 & & 0 \\
\hline WF-FFG652-2 & 9 & 19 & 31 & 900 & 2700 & 8 & e & & 1 \\
\hline WF-FFG652- & 02 & 19 & 31 & 2700 & 4120 & 6.25 & 0 & & 0 \\
\hline WF-FFG & 0 & 19 & 31 & 0 & 3900 & $6.75 j$ & 6.75 & & 1. \\
\hline$W F-F F G 654$ & 0.4 & 19 & 31 & 0 & 4145 & 7.875 & 7.875 & & 1 \\
\hline$W F-F F G 655-1$ & 04 & 19 & $\therefore 1$ & 0 & 4150 & 12.25 & 12.25 & & \rfloor \\
\hline WF-FFE $-555-2$ & 04 & 1.9 & 1 & 4150 & 13510 & 8.5 & 0 & & 0 \\
\hline$W F-F F G 656-1$ & 04 & 19 & 31 & 0 & 3475 & 5.5 & 5.5 & & 1 \\
\hline$W F-F F G t 5 t-2$ & 04 & 19 & 31 & 3475 & 1606 & 5 & 0 & & () \\
\hline WF-FFGG7B & 29 & 19 & 31 & 0 & 2218 & 7.875 & 7.875 & & 1. \\
\hline$W F-F F G 6>7-1$ & 29 & 19 & 31 & 0 & 2087 & 8 & 0 & & 0 \\
\hline$W F-F F(6679-2$ & 29 & 19 & 31 & 2087 & 2177 & 6.5 & 6.5 & & 1 \\
\hline$W F-F F G 6 \theta 0-1$ & 30 & 19 & 31 & 0 & 2144 & 6.25 & 0 & & 0 \\
\hline WF- - 11 & 26 & 21 & 30 & 0 & 3680 & Uト: & 0 & & () \\
\hline$W F-510$ & 07 & 24 & 31 & 0 & 4.92 & 7.875 & 7.875 & & 1 \\
\hline$W F-S 11-1$ & 18 & 24 & 31 & 0 & 4300 & 7.875 & 7.875 & & 1 \\
\hline$W F-511-2$ & 18 & 24 & 31 & 4300 & 4.370 & 7.813 & 0 & & o \\
\hline$W F-S 12$ & 21 & 24 & $\Xi 1$ & 0 & 44831 & 7.875 & 7.875 & & 1 \\
\hline$W F-51 \Xi-1$ & 28 & 24 & $\Xi 1$ & 0 & 12557 & 12.25 & 12.25 & & 1 \\
\hline$W F-51 \Xi-2$ & 28 & 24 & 31 & 12557 & $16 \pm 61$ & 8.5 & 0 & & 0 \\
\hline$W F-51 \circlearrowleft-3$ & 28 & 24 & 31 & 16361 & 16600 & 5.875 & 0 & & 9 \\
\hline$W F-514$ & 23 & 22 & 31 & (i) & 4766 & 7.875 & $7.8 \% 5$ & & 1. \\
\hline WF- -515 & 15 & 22 & $\Xi 1$ & 0 & 4340 & 13.875 & $1 \div .875$ & & 1 \\
\hline$W F-516$ & 01 & 22 & 31 & 0 & 4510 & 7.875 & $7.8 \% 5$ & & 1 \\
\hline WF $-517-1$ & \pm 6 & 22 & 30 & 0 & 12065 & 9.625 & 9.625 & & 1 \\
\hline$W F-51 \%-2$ & $x$ & 22 & 30 & 12065 & 15506 & 6.625 & 0 & & 0 \\
\hline $\begin{array}{c}W F-5 \pm T-3 \\
A-136\end{array}$ & ت̇́ & 22 & 30 & 1.550 & 16271 & 4.5 & 0 & & $\therefore$ \\
\hline
\end{tabular}




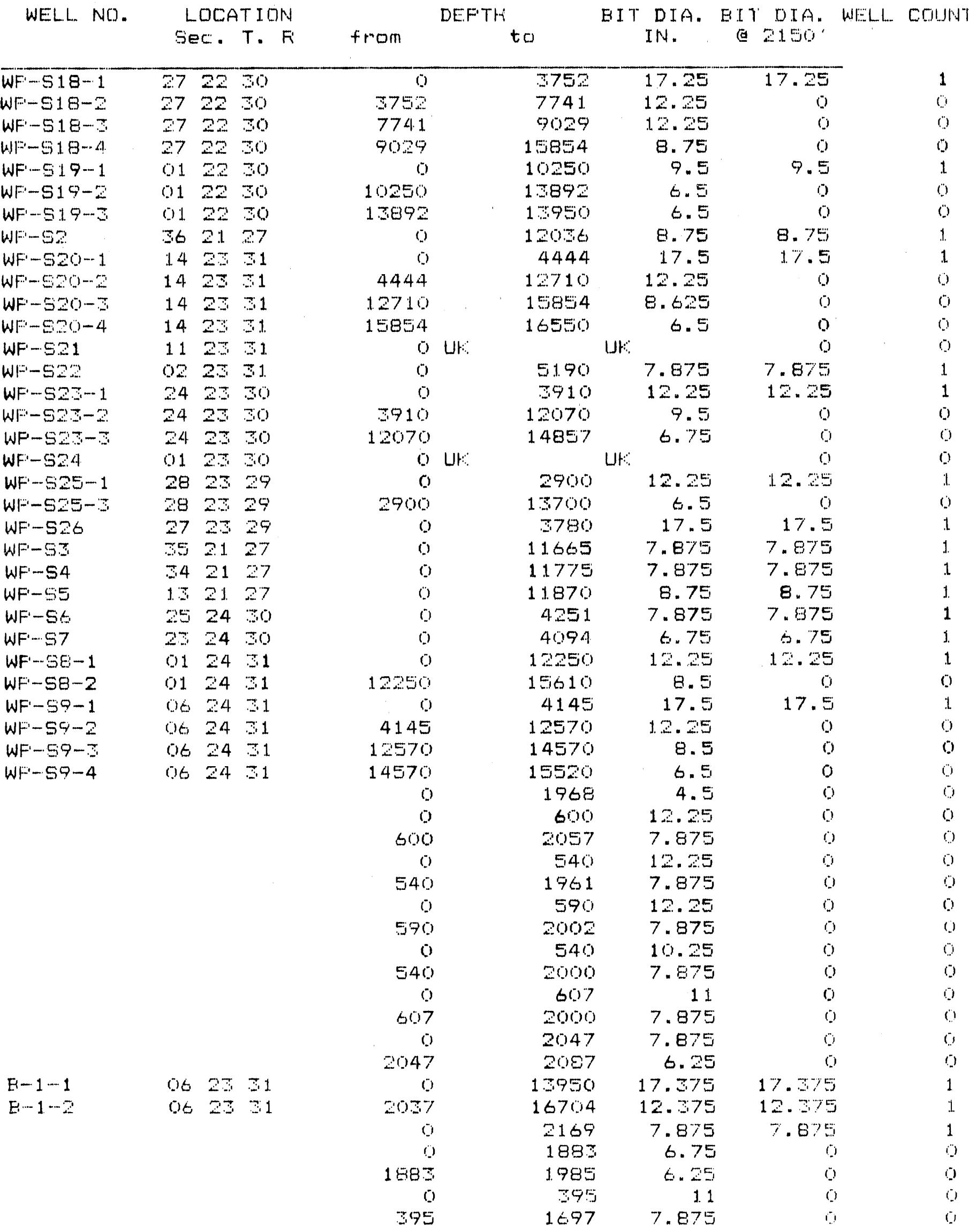




\begin{tabular}{|c|c|c|c|c|c|c|c|}
\hline \multirow{2}{*}{ WE:LL NO. } & \multirow{2}{*}{$\begin{array}{l}\text { LOCATIONV } \\
\text { SEC. T. Fi }\end{array}$} & \multicolumn{2}{|c|}{ DEF'TH } & \multirow{2}{*}{$\begin{array}{c}\text { EIT DIA. } \\
\text { IN. }\end{array}$} & \multirow{2}{*}{$\begin{array}{c}\text { BIT DIA. } \\
\text { \& } 2150 .\end{array}$} & \multirow[t]{2}{*}{ WEI..L } & \multirow[t]{2}{*}{ EOIUNT } \\
\hline & & from & to & & & & \\
\hline & & 0 & 355 & 9.625 & 0 & & 0 \\
\hline & & 355 & 1592 & 8 & 0 & & 0 \\
\hline & & 1592 & 1717 & 6.125 & 0 & & 0 \\
\hline & & 0 & 1810 & 8 & 0 & & 0 \\
\hline & & 0 & 1687 & 8.5 & 0 & & 0 \\
\hline & & 0 & 383 & 1. 1 & 0 & & 0 \\
\hline & & 88 & 1685 & 8 & 0 & & 0 \\
\hline & & 0 & 646 & 10 & 0 & & 0 \\
\hline & & 646 & 2047 & 8 & 0 & & 0 \\
\hline & & 2047 & 2055 & 6.25 & 0 & & \% \\
\hline & & 0 & $90 \%$ & 10 & 0 & & 0 \\
\hline & & 900 & 2700 & 8 & 8 & & 1 \\
\hline & & 2700 & 4120 & 6.25 & 0 & & 0 \\
\hline & & 0 & 3900 & 6.75 & 6.75 & & 1 \\
\hline & & 0 & 41.45 & 7.875 & 7.875 & & 1 \\
\hline & & 0 & 4150 & 12.25 & 12. & & 1 \\
\hline & & 4150 & 13510 & 8.5 & 0 & & 0 \\
\hline & & 0 & 475 & 5.5 & 5.5 & & 1 \\
\hline & & 3475 & 3606 & 5 & 0 & & 0 \\
\hline & & 0 & 2218 & 7.875 & 7.875 & & $\mathrm{t}$ \\
\hline & & 0 & 2087 & 8 & 0 & & 0 \\
\hline & & 2087 & 2177 & 6.5 & 6.5 & & 1 \\
\hline & & 0 & 55 & 8 & 0 & & 0 \\
\hline & & 5.55 & 2150 & 6.25 & 0 & & $\%$ \\
\hline & & 0 & 2125 & 4.5 & 0 & & 0 \\
\hline & & 0 & 2205 & 8 & 8 & & 1 \\
\hline & & 0 & 2221 & 5.5 & 5.5 & & 1 \\
\hline & & 0 & 1.1913 & 9.5 & 9.5 & & 1 \\
\hline & & 1.913 & 14569 & 6.25 & 0 & & 0 \\
\hline
\end{tabular}




\section{Memo 11}

Date: $\quad 11 / 19 / 90$

To: R. P. Rechard, 6342

From: P. B. Davies (6344) and A. M. LaVenue (6344, INTERA)

Subject: Additional Data for Characterizing 2-Phase Flow Behavior in Waste-Generated Gas Simulations and Pilot Point Information for Final Culebra 2-D Model (SAND89-7068/1) 
Date: $\quad$ November 19,1990

To:

R.P. Rechard (6342)
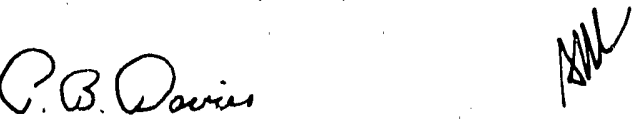

From:

P.B. Davies (6344) and A.M. I.aVenue (6344, INTERA)

Subject: $\quad$ Additional Data for Characterizing 2-Phase Flow Behavior in Waste-Generated Gas Simulations and Pilot Point Information for Final Culebra 2-D Model (SAND89$7068 / 1)$

In response to your request, this memo provides additional data for 2-phase modeling of waste generated gas and pilot point information for the final Culebra 2-D model that is presented in LaVenue et al. (1990) SAND89-7068/1.

\section{2-Phase Data}

In order to provide a complete discussion, this memo includes the information on capillary pressure and relative permeability for Salado salt that was transmitted in the Davies and LaVenue memo of $8-1-90$.

Experimental data on capillary pressure and relative permeability of Salado Fm. halite, Salado Fm. interbeds, and the waste-backfill mixture in disposal rooms do not exist. Given the very low permeability of the Salado lithologies, the possibility of fracture-controlled pore space in the interbeds, and complexity in the evolution of the waste-backfill mixture during consolidation, direct measurements of 2-phase properties is a complex task. Therefore, experimental data for WIPP materials will not be available in the near future. Given this situation, our evaluation of 2-phase properties has focused on two approaches. The first approach is to select approximate analogue materials for which complete two-phase measurements have been made. This approach assures that the capillary pressure and relative permeability relations are internally consistent with each other. The second approach is to work on theoretically-based pore structure models that provide the basis for calculating theoretical capillary pressure and relative permeability relations given basic information about the nature of the pore structure in each of the pertinent materials at WIPP. Our ultimate objective is to assemble a suite of capillary pressure and relative permeability relations that will provide the basis for examining the impact of a variety of assumptions about the 2-phase characterization of both the room and the Salado Formation.

We have completed selection of the first analogue group and the data from that group has been used in most of our simulations to date. Given their higher permeabilities and lower threshold pressure, the Salado interbeds are expected to be the primary units controlling gas release (Davies, in prep). Also, because of the high threshold pressure in intact halite, significant gas penetration into the halite may not occur. For the anhydrite interbeds, the analogue material that has been selected is based on the lowest permeability material that we could find for which the complete capillary pressure and relative permeability has been measured. The analogue material is a tight gas sand from the multi-well experiment with an intrinsic permeability on the order of a few tens of microdarcies (Morrow et al., 1985). The dominant pore geometry consists of intergranular cracks, small solution 
pores partially filled with dolomite, and some :mall fractures. Data from the laboratory measurements on this material have been incorporated in tis a slightly modified version of the Brooks and Corey (1964) model to produce the complete capillary pressure and relative permeability relations presented in Table 1 , and Figures 1 and 2.

As noted previously, the high threshold pressure in intact halite means that significant gas penetration into the halite may not occur. The most important 2-phase parameter for the halite is the threshold pressure. Threshold pressures for pure and impure halite have been estimated based on an empirical correlation between intrinsic permeability and threshold pressure (Davies, in prep). This type of correlation is commonly used in the analysis of caprock materials for underground gas storage reservoirs (Thomas et al., 1968). Based on this correlation, estimated threshold pressure for Salado halite is $4.6 \mathrm{MPa}$ for $10^{-20} \mathrm{~m}^{2}, 10 \mathrm{MPa}$ for $10^{-21} \mathrm{~m}^{2}$, and $23 \mathrm{MPa}$ for $10^{-22} \mathrm{in}^{2}$ halite. For our simulations to date, we have used $\mathrm{k}=10^{-20} \mathrm{~m}^{2}$ and $\mathrm{Pt}=4.6 \mathrm{MPa}$ as representing impure halite and $\mathrm{k}=10^{-22} \mathrm{~m}^{2}$ as representing pure halite. Because the halite is of secondary importance for gas flow, what is assumed for the capillary pressure curve and for relative permeability is of less importance. Therefore, we use the same analogue properties for halite that were used for anhydrite, except that the capillary pressure curves have been computed using the higher threshold pressure values for pure and impure halite. The resulting capillary pressure and relative permeability relations are presented in Table 2 and Figures 3, 4 and 5.

Because there are no measured relative permeability or capillary pressure data for any of the waste-disposal room materials, a similar analogue approach has been used. The analogue used is a heterogeneous, unconsolidated mix of fragmented clay, sandstone, and volcanic sand (Brooks and Corey, 1964). This material is characterized by a well aggregated structure with secondary as well as primary porosity. Data from laboratory measurements on this material have been incorporated in the Brooks and Corey (1964) model to produce the complete capillary pressure and relative permeability relations presented in Table 3, and Figures 6 and 7.

\section{Pilot Points}

The calibration procedure employed for the final 2-D Culebra flow model (LaVenue et al., 1990) utilized a geostatistical approach for adjusting the transmissivity field. The M.I.T. kriging code, AKRIP, was modified to allow for uncertainties assigned to the data and to calculated block-averaged estimates and estimate errors. Calibration points, referred to as "pilot points", were added to the observed transmissivity data set which was used during the kriging process. The locations of the pilot points were guided by the code GRASP Il, an adjoint sensitivity post-processor to the flow code, SWIFT II. GRASP II allows for the identification of areas where changes to the boundary conditions or transmissivity values in the model domain will reduce a performance measure defined by the modeler (e.g., differences between calculated and observed heads at selected borehole locations at selected times). The $\log 10$ transmissivity data set (used as input to AKRIP) for the transient calibrated model is presented in Table 4.

For additional details on the specifics of the kriging generalized-covariance model used during the calibration procedure one should review (LaVenue et al., 1990). 


\section{References}

Brooks, R.H. and Corey, A.T., 1964, Hydraulic properties of porous media: Hydrology Papers, No. 3, Colorado State University, Fort Collins, Colorado, 20 p.

Davies, P.B., (in prep), Evaluation of the role of threshold pressure in controlling the flow of wastegenerated gas into the bedded salt surrounding the WIPP repository: SAND report in preparation.

Davies, P.B. and LaVenue, A.M., 1990, Comments on model implementation and data for use in August performance assessment calculations: 8-1-90 memo to E.D. Gorham, 12 p.

LaVenue, A.M., Cauffman, T.L., and Pickens, J.F., 1990, Ground-water flow modeling of the Culebra Lolomite, volume I: model calibration: SAND89-7068/1, Sandia National Laboratories, Albuquerque, New Mexico, var. pag.

Mo:row, N.R., Ward, J.S., and Brower, K.R., 1986, Rock matrix and fracture analysis of flow in western tight gas sands: 1985 Annual Report, DOE/MC/21179-2032 (DE86001055), U.S. Department of Energy, Morgantown, West Virginia.

Thomas, L.K., Katz, D.L., and Tek, M.R., 1968, Threshold pressure phenomena in porous media: Society of Petroleum Engineers Journal, vol. 8, no. 2, p. 174-184. 
TABLE 1. Caplllary Pressure and Relative Permeability for Interbeds

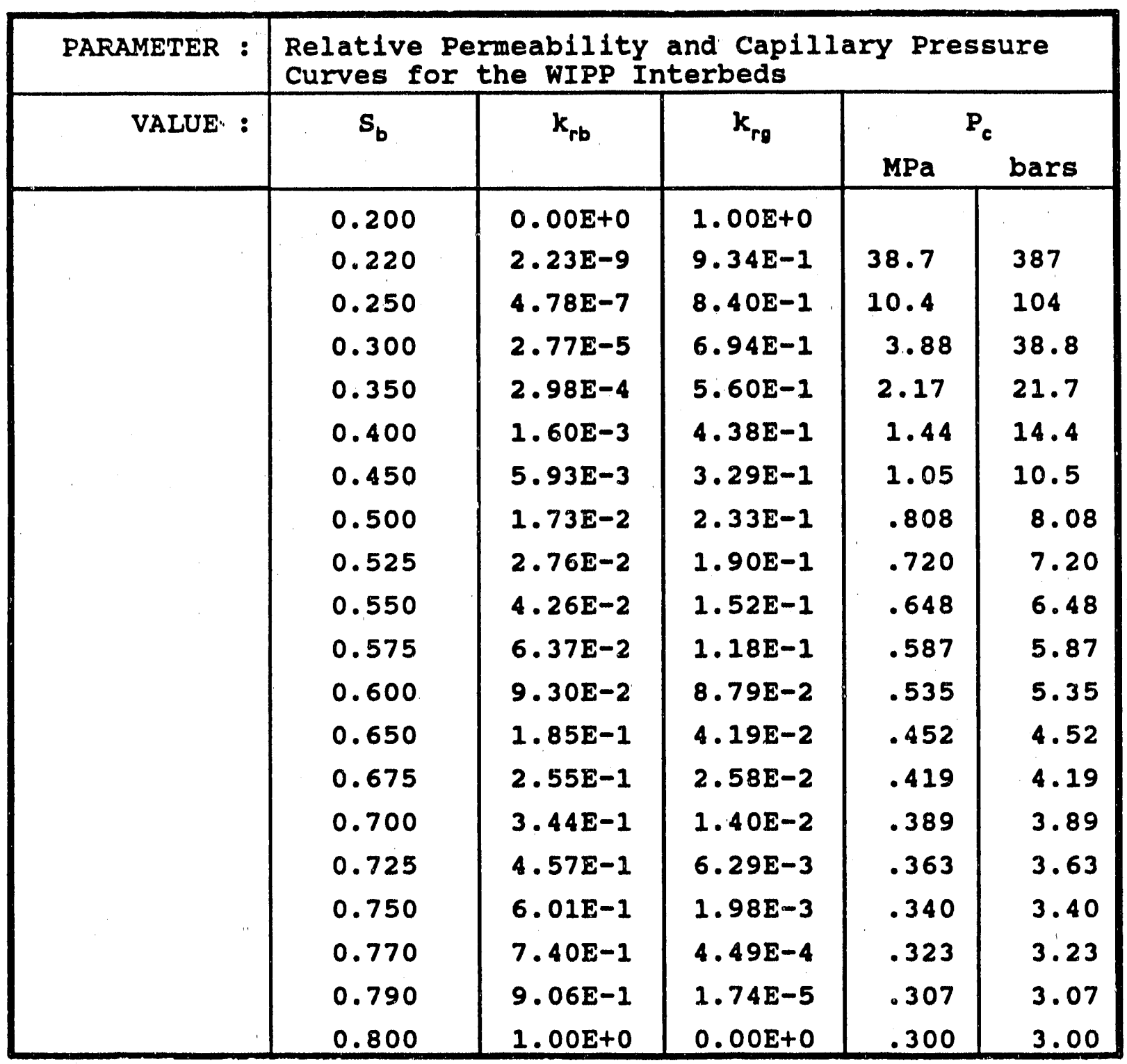


TABle 2. Capillary Pressure and Relative Permeability for Pure and Impure Halite

\begin{tabular}{|c|c|c|c|c|c|c|c|}
\hline PARAMETER : & \multicolumn{7}{|c|}{$\begin{array}{l}\text { Relative Permeability and Capillary Pressure } \\
\text { Curves for Relatively Pure and Impure Halite }\end{array}$} \\
\hline \multirow[t]{3}{*}{ VALUE : } & \multirow{3}{*}{\multicolumn{3}{|c|}{$x_{r o}$}} & \multicolumn{4}{|c|}{$\mathbf{P}_{c}$} \\
\hline & & & & \multicolumn{2}{|c|}{$\begin{array}{c}\text { pure } \\
\text { hallte }\end{array}$} & \multicolumn{2}{|c|}{$\begin{array}{l}\text { impure } \\
\text { halitee }\end{array}$} \\
\hline & & & & $\mathrm{MPa}$ & bars & $\mathrm{MPa}$ & bars \\
\hline & 0.200 & $0.00 E+0$ & $1.00 E+0$ & & & & \\
\hline & 0.220 & $2.23 E-9$ & $9.34 \mathrm{E}-1$ & 2960 & 29600 & 593 & 5930 \\
\hline & 0.250 & $4.78 E-7$ & $8.40 \mathrm{E}-1$ & 801 & 8010 & 160 & 1600 \\
\hline & 0.300 & $2.77 E-5$ & $6.94 \mathrm{E}-1$ & 297 & 2970 & 59.5 & 595 \\
\hline & 0.350 & $2.98 E-4$ & $5.60 E-1$ & 167 & 1670 & 33.3 & 333 \\
\hline & 0.400 & $1.60 \mathrm{E}-3$ & $4.38 E-1$ & 110 & 1100 & 22.1 & 221 \\
\hline & 0.450 & $5.93 E-3$ & $3.29 E-1$ & 80.3 & 803 & 16.1 & 161 \\
\hline & 0.500 & $1.73 E-2$ & $2.33 E-1$ & 61.9 & 619 & 12.4 & 124 \\
\hline & 0.525 & $2.76 \mathrm{E}-2$ & $1.90 E-1$ & 55.2 & 552 & 11.0 & 110 \\
\hline & 0.550 & $4.26 E-2$ & $1.52 \mathrm{E}-1$ & 49.7 & 497 & 9.93 & 99.3 \\
\hline & 0.575 & $6.37 E-2$ & $1.18 \mathrm{E}-1$ & 45.0 & 450 & 9.00 & 90.0 \\
\hline & 0.600 & $9.30 E-2$ & $8.79 E-2$ & 41.0 & 410 & 8.21 & 82.1 \\
\hline & 0.650 & $1.85 \mathrm{E}-1$ & $4.19 E-2$ & 34.7 & 347 & 6.94 & 69.4 \\
\hline & 0.675 & $2.55 E-1$ & $2.58 E-2$ & 32.1 & 321 & 6.42 & 64.2 \\
\hline & 0.700 & $3.44 E-1$ & $1.40 \mathrm{E}-2$ & 29.8 & 298 & 5.97 & 59.7 \\
\hline & 0.725 & $4.57 E-1$ & $6.29 E-3$ & 27.8 & 278 & 5.57 & 55.7 \\
\hline & 0.750 & $6.01 E-1$ & $1.98 \mathrm{E}-3$ & 26.0 & 260 & 5.21 & 52.1 \\
\hline & 0.770 & $7.40 \mathrm{E}-1$ & $4.49 E-4$ & 24.7 & 247 & 4.95 & 49.5 \\
\hline & 0.790 & $9.06 \mathrm{E}-1$ & $1.74 \mathrm{E}-5$ & 23.6 & 236 & 4.71 & 47.1 \\
\hline & 0.800 & $1.00 \mathrm{E}+0$ & $0.00 \mathrm{E}+0$ & 23.0 & 230 & 4.60 & 46.0 \\
\hline
\end{tabular}


TABLE 3. Capillary Pressure and Relative Permeabllity for Waste Disposal Room

\begin{tabular}{|c|c|c|c|c|c|}
\hline \multirow{2}{*}{$\begin{array}{l}\text { PARAMETER : } \\
\text { VALUE : }\end{array}$} & \multicolumn{5}{|c|}{$\begin{array}{l}\text { Relative Permeability and Capillary Pressure } \\
\text { Curves for the Waste Disposal Room (initial, } \\
\text { intermediate, and final states) }\end{array}$} \\
\hline & $s_{b}$ & $k_{r b}$ & $\mathbf{k}_{\mathrm{rg}}$ & (MPa) & (bars) \\
\hline . & $\begin{array}{l}0.276 \\
0.290 \\
0.300 \\
0.350 \\
0.400 \\
0.450 \\
0.500 \\
0.550 \\
0.600 \\
0.650 \\
0.700 \\
0.750 \\
0.800 \\
0.850 \\
0.900 \\
0.925 \\
0.950 \\
0.970 \\
0.980\end{array}$ & $\begin{array}{l}0.00 \mathrm{E}+0 \\
5.23 \mathrm{E}-7 \\
3.82 \mathrm{E}-6 \\
2.44 \mathrm{E}-4 \\
1.64 \mathrm{E}-3 \\
5.74 \mathrm{E}-3 \\
1.46 \mathrm{E}-2 \\
3.07 \mathrm{E}-2 \\
5.70 \mathrm{E}-2 \\
9.68 \mathrm{E}-2 \\
1.54 \mathrm{E}-1 \\
2.32 \mathrm{E}-1 \\
3.36 \mathrm{E}-1 \\
4.71 \mathrm{E}-1 \\
6.41 \mathrm{E}-1 \\
7.41 \mathrm{E}-1 \\
8.51 \mathrm{E}-1 \\
9.49 \mathrm{E}-1 \\
1.00 \mathrm{E}+0\end{array}$ & $\begin{array}{l}1.00 \mathrm{E}+0 \\
9.59 \mathrm{E}-1 \\
9.30 \mathrm{E}-1 \\
7.83 \mathrm{E}-1 \\
6.43 \mathrm{E}-1 \\
5.14 \mathrm{E}-1 \\
3.98 \mathrm{E}-1 \\
2.98 \mathrm{E}-1 \\
2.13 \mathrm{E}-1 \\
1.44 \mathrm{E}-1 \\
9.11 \mathrm{E}-2 \\
5.21 \mathrm{E}-2 \\
2.57 \mathrm{E}-2 \\
9.96 \mathrm{E}-3 \\
2.38 \mathrm{E}-3 \\
7.85 \mathrm{E}-4 \\
1.29 \mathrm{E}-4 \\
4.83 \mathrm{E}-6 \\
0.00 \mathrm{E}+0\end{array}$ & $\begin{array}{l}6.54 \mathrm{E}-3 \\
5.43 \mathrm{E}-3 \\
3.68 \mathrm{E}-3 \\
3.07 \mathrm{E}-3 \\
2.73 \mathrm{E}-3 \\
2.51 \mathrm{E}-3 \\
2.34 \mathrm{E}-3 \\
2.20 \mathrm{E}-3 \\
2.10 \mathrm{E}-3 \\
2.01 \mathrm{E}-3 \\
1.93 \mathrm{E}-3 \\
1.87 \mathrm{E}-3 \\
1.81 \mathrm{E}-3 \\
1.76 \mathrm{E}-3 \\
1.73 \mathrm{E}-3 \\
1.71 \mathrm{E}-3 \\
1.69 \mathrm{E}-3 \\
1.69 \mathrm{E}-3\end{array}$ & $\begin{array}{l}6.54 \mathrm{E}-2 \\
5.43 \mathrm{E}-2 \\
3.68 \mathrm{E}-2 \\
3.07 \mathrm{E}-2 \\
2.73 \mathrm{E}-2 \\
2.51 \mathrm{E}-2 \\
2.34 \mathrm{E}-2 \\
2.20 \mathrm{E}-2 \\
2.10 \mathrm{E}-2 \\
2.01 \mathrm{E}-2 \\
1.93 \mathrm{E}-2 \\
1.87 \mathrm{E}-2 \\
1.81 \mathrm{E}-2 \\
1.76 \mathrm{E}-2 \\
1.73 \mathrm{E}-2 \\
1.71 \mathrm{E}-2 \\
1.69 \mathrm{E}-2 \\
1.69 \mathrm{E}-2\end{array}$ \\
\hline
\end{tabular}


TABLE 4. Pilot Points for Culebra Flow Model (LaVenue et al., 1990)

The pilot points are denoted by the name PP- $n$, where $n$ is the pilot point number.

\begin{tabular}{|c|c|c|c|c|}
\hline $\begin{array}{l}\text { UTM CORD. } \\
\text { EAST }(\mathrm{m})\end{array}$ & $\begin{array}{l}\text { UTM CORD. } \\
\text { NORTH }(m)\end{array}$ & LOG $10 \mathrm{~T}$ & $\begin{array}{l}\text { SIGMA } \\
\text { OF LOG } 10 \mathrm{~T}\end{array}$ & $\begin{array}{l}\text { WELL } \\
\text { NAME }\end{array}$ \\
\hline 613423. & 3581684 & -6.02900 & 0.50 & $\mathrm{H}-1$ \\
\hline 612651 & 3581651 . & -6.20050 & 0.25 & $\mathrm{H}-2$ \\
\hline 613729. & 3580895 & -5.60890 & 0.25 & $\mathrm{H}-3$ \\
\hline 612380 & 3578483. & -5.99600 & 0.25 & $\mathrm{H}-4$ \\
\hline 616872 & 3584801 & -7.01150 & 0.25 & $\mathrm{H}-5$ \\
\hline 610594 & 3585008 & -4.45000 & 0.25 & H-6 \\
\hline 608124 & 3574648 . & -2.81250 & 0.25 & $\mathrm{H}-7$ \\
\hline 608683. & 3563556 & -5.05470 & 0.25 & H-8 \\
\hline 613989. & 3568261 & -3.90190 & 0.25 & H-9 \\
\hline 622975 & 3572473 & -7.12340 & 0.50 & $\mathrm{H}-10$ \\
\hline 615346. & 3579130 & -4.50570 & 0.25 & $\mathrm{H}-11$ \\
\hline 617023 & 3575452 & -6.71320 & 0.50 & $\mathrm{H}-12$ \\
\hline 612341. & 3580354. & -6.48420 & 0.50 & $H-14$ \\
\hline 615315. & 3581859. & -6.38040 & 0.50 & $H-15$ \\
\hline 613369 & 3582212 & -6.11490 & 0.50 & $H-16$ \\
\hline 615718 & 3577513 & -6.63610 & 0.50 & $\mathrm{H}-17$ \\
\hline 612264. & 3583166 & -5.77750 & 0.25 & H- 18 \\
\hline 609084 & 3581976. & -3.55710 & 0.41 & P- 14 \\
\hline 610624. & 3578747. & -7.03540 & 0.50 & $P-15$ \\
\hline 613926. & 3577466 & -5.96850 & 0.50 & $P-17$ \\
\hline 618367. & 3580350 & -10.12340 & 0.50 & $P-18$ \\
\hline 613710 & 3583524 & -6.96850 & 0.50 & $W-12$ \\
\hline 612644 & 3584247 & -4.12960 & 0.50 & $W-13$ \\
\hline 613735 & 3583179 & -6.49130 & 0.50 & $W-18$ \\
\hline 613739 & 3582782 . & -6.19030 & 0.50 & $W-19$ \\
\hline 613743. & 3582319. & $-6 . .7050$ & 0.50 & $W-21$ \\
\hline 613739. & 3582653. & -6.40030 & 0.50 & $W-22$ \\
\hline 606385 & 3584028 & -3.54120 & 0.25 & $W-25$ \\
\hline 604014 & 3581162 & -2.91360 & 0.25 & $W \cdot .26$ \\
\hline 604426 & 3593079. & -3.36920 & 0.25 & W-27 \\
\hline 611266. & 3594680. & -4.68390 & 0.25 & W-28 \\
\hline 596981. & 3578694. & -2.96850 & 0.25 & W-29 \\
\hline 613721. & 3589701 & -6.60230 & 0.50 & $W-30$ \\
\hline 621126 & 3589381. & -6.55350 & 0.50 & AEC-7 \\
\hline 613696 & 3581958. & -6.29640 & 0.50 & ER-9 \\
\hline 613191 & 3578049. & -6.52130 & 0.50 & $\mathrm{CB}-1$ \\
\hline 614953. & 3567454. & -4.33500 & 0.25 & ENGLE \\
\hline 606462 & 3569459. & -3.25840 & 0.25 & USGS1 \\
\hline 615203. & 3580333. & -4.42710 & 0.25 & DOE-1 \\
\hline 613683 & 3585294. & -4.01910 & 0.25 & DOE-2 \\
\hline 608702 & 3578877. & -5.68970 & 0.50 & $D-268$ \\
\hline 605250 & 3587600 & -2.07000 & 1.01 & $P P-1$ \\
\hline 606500 & 3587600 & -2.25000 & 0.98 & PP-2 \\
\hline 607750 & 3588600 & -2.32000 & 0.99 & PP-3 \\
\hline
\end{tabular}




\section{TABLE 4. [Continued]}

The pilot points are denoted by the name $P P-n$, where $n$ is the pilot point number.

\begin{tabular}{|c|c|c|c|c|}
\hline $\begin{array}{l}\text { UTM CORD. } \\
\text { EAST }(m)\end{array}$ & $\begin{array}{l}\text { UTM CORD. } \\
\text { NORTH }(\mathrm{m})\end{array}$ & LOG $10 \mathrm{~T}$ & $\begin{array}{l}\text { SIGMA } \\
\text { OF LOG } 10 \mathrm{~T}\end{array}$ & $\begin{array}{l}\text { WELL } \\
\text { NAME }\end{array}$ \\
\hline 608000 & 3576750 & -3.62000 & 0.74 & PP -4 \\
\hline 608000 & 3577750 . & -3.58000 & 0.72 & PP-5 \\
\hline 612520 & 3576550. & -6.02000 & 0.75 & PP-6 \\
\hline 613585 & 3576550 . & -6.42000 & 0.68 & PP -7 \\
\hline 613950 & 3576000 & -3.41000 & 0.63 & PP-8 \\
\hline 614950 & 3577500 . & -2.71000 & 0.51 & PP-9 \\
\hline 614950 & 3583000 & -7.72000 & 0.61 & PP-11 \\
\hline 613950 & 3581500 & -8.08000 & 0.41 & PP- 12 \\
\hline 612950 & 3582500 & -5.64000 & 0.41 & $P P-13$ \\
\hline 611900. & 3580620. & -8.34000 & 0.62 & $P P-14$ \\
\hline 613450 & 3579500. & -6.49000 & 0.54 & PP- 15 \\
\hline 610450 & 3580000 & -5.13000 & 0.60 & $P P-16$ \\
\hline 610450 & 3577500. & -6.60000 & 0.66 & PP-17 \\
\hline 609100 & 3587990. & -2.63000 & 0.81 & $P P-18$ \\
\hline 609600 & 3587990. & -2.86000 & 0.83 & PP-19 \\
\hline 614200 & 3574500 & -2.94000 & 0.84 & PP-20a \\
\hline 616200 & 3574500 . & -3.00000 & 0.79 & PP-21a \\
\hline 615700 & 3576500 . & -3.85000 & 0.56 & PP-23 \\
\hline 613725 & 3580900. & -3.50000 & 0.33 & PP-24 \\
\hline 614100 & 3580100 & -6.00000 & 0.46 & PP-25 \\
\hline 612900 & 3582100 & -5.50000 & 0.36 & $P P-26$ \\
\hline 615300 & 3581300 & -4.25000 & 0.48 & PP-27 \\
\hline 615700 & 3581300. & -3.50000 & 0.54 & PP-28 \\
\hline 615700 & 3579700 . & -3.25000 & 0.47 & PP-29 \\
\hline 614100 & 3578500 & -6.10000 & 0.50 & PP-30 \\
\hline 614500 & 3578500 & -5.87000 & 0.50 & $P P-31$ \\
\hline 613575 & 3582200 & -5.00000 & 0.31 & PP-32 \\
\hline 612675 & 3584390 & -3.59000 & 0.41 & PP-34 \\
\hline 612675 & 3584240 & -2.67000 & 0.41 & PP-35 \\
\hline 613300 & 3580900 & -5.17000 & 0.39 & PP-36 \\
\hline 613300 & 3587500 & -4.31000 & 0.74 & PP-37 \\
\hline 613700 & 3589100 & -3.90000 & 0.62 & PP-38 \\
\hline 613725 & 3589700 & -3.90000 & 0.62 & PP-39 \\
\hline 612675 & 3582945 & -5.93000 & 0.41 & PP-40 \\
\hline 613412 & 3583520 & -4.00000 & 0.41 & $P P-41$ \\
\hline 615125 & 3580300 & -3.50000 & 0.47 & $P P-42$ \\
\hline 612375 & 3581895 & -5.00000 & 0.41 & $P P-43$ \\
\hline 611250. & 3579430 & -5.00000 & 0.41 & PP-44 \\
\hline
\end{tabular}


FIGURE 1. Relative Permeability Curves for Interbeds

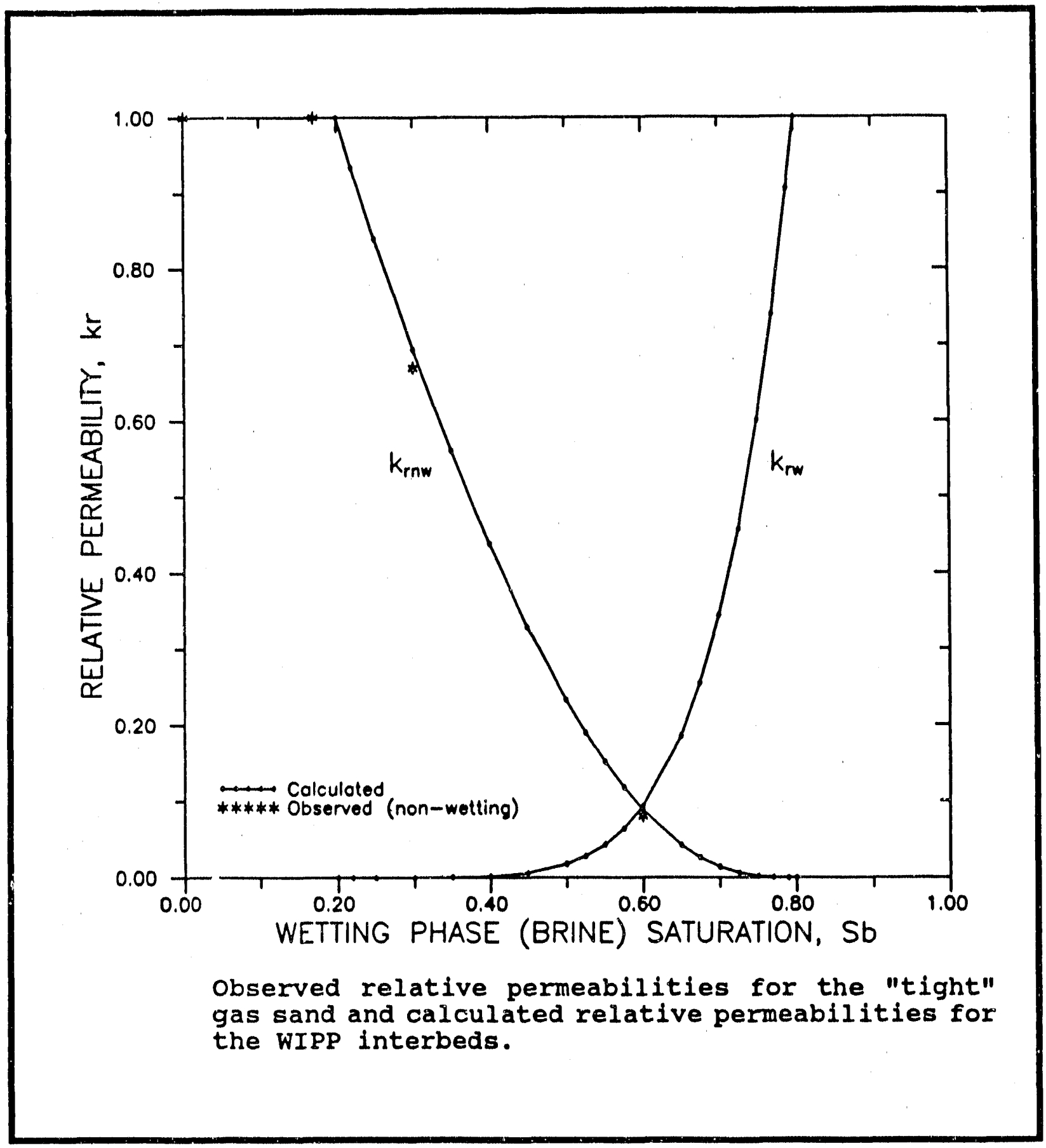


FIGURE 2. Capillary Pressure Curve for Interbeds

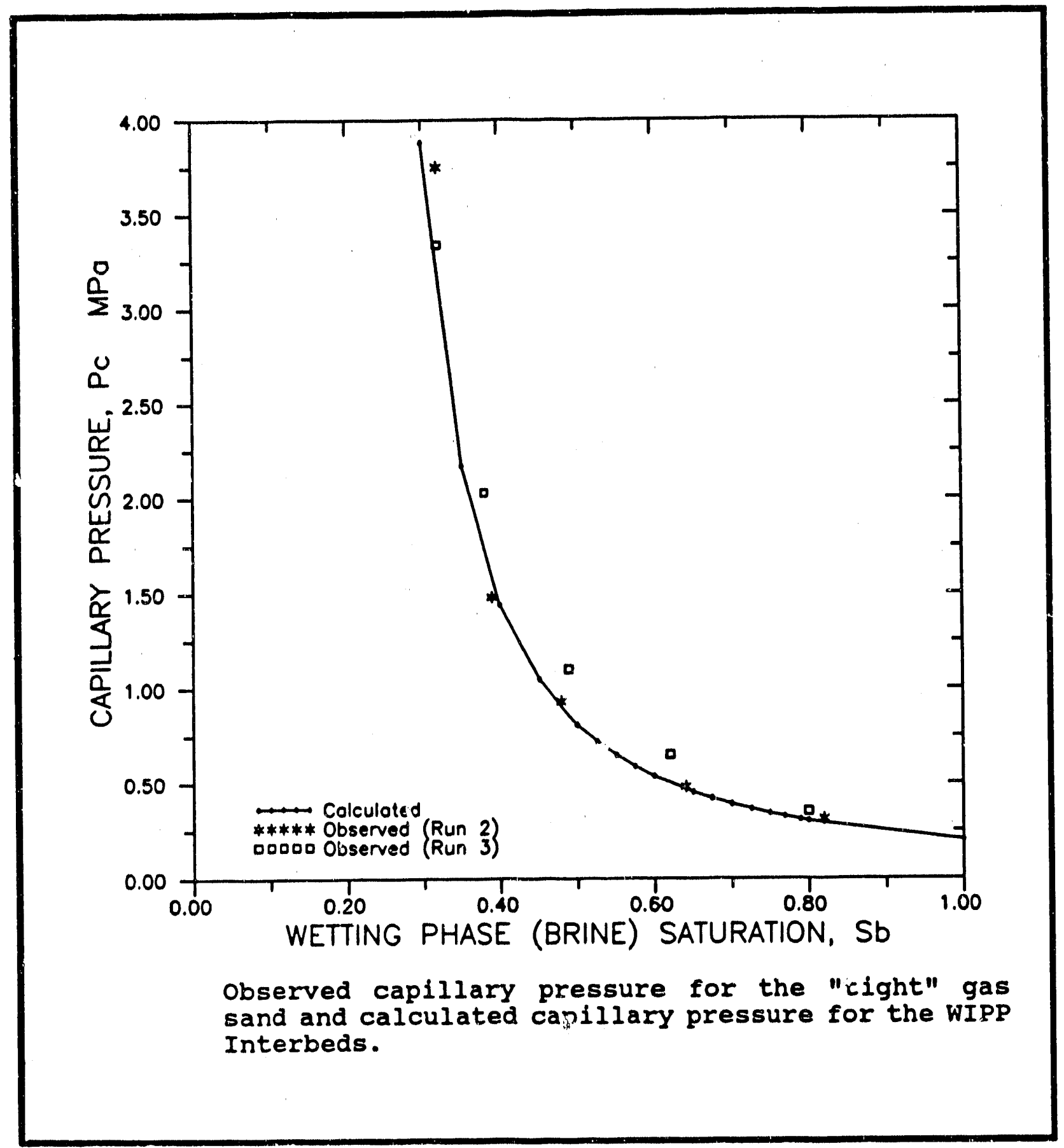


FIGURE 3. Relative Permeability Curves for Pure and Impure Halite

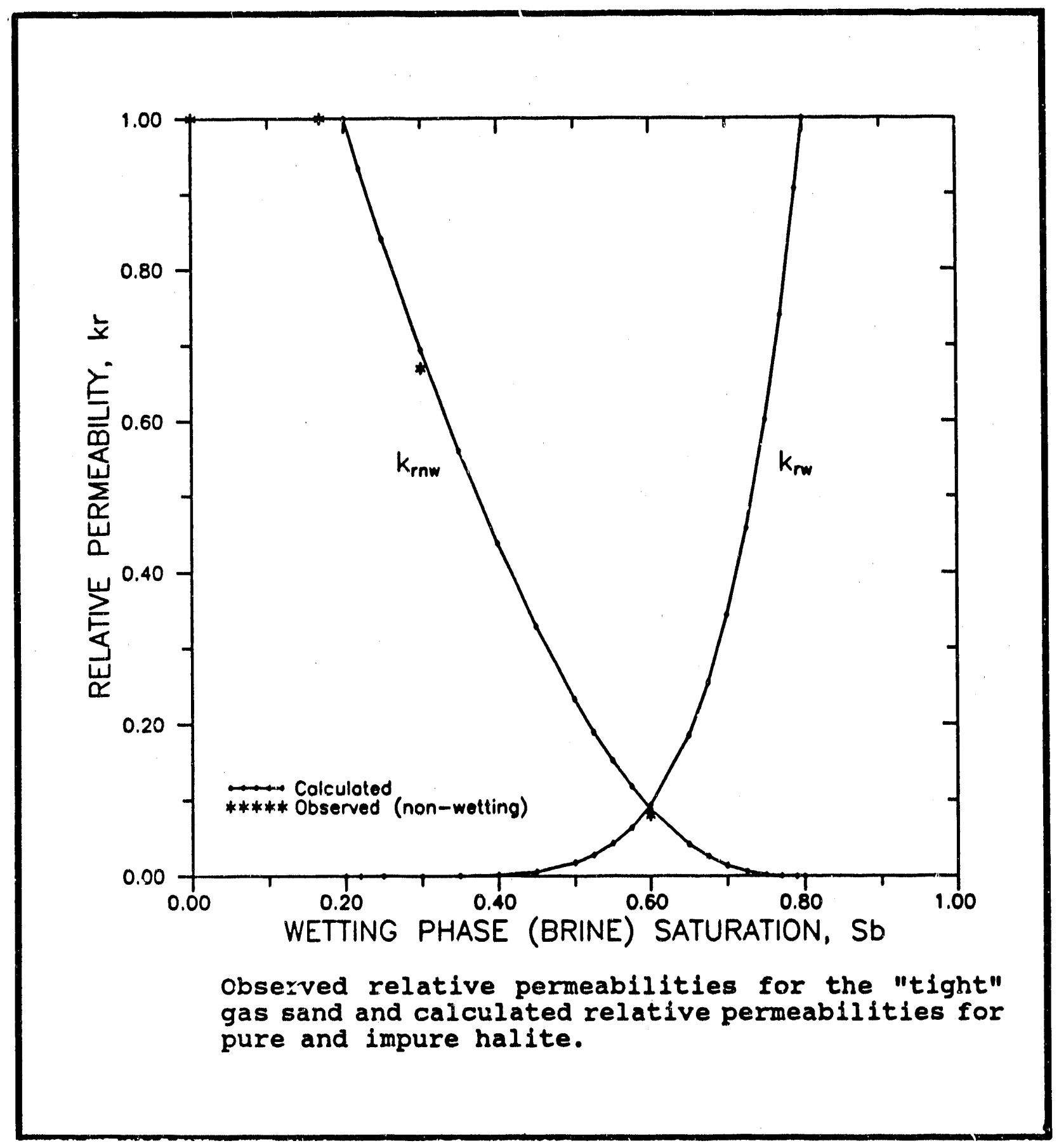


FIGURE 4. Capillary Pressure Curve for Pure Halite

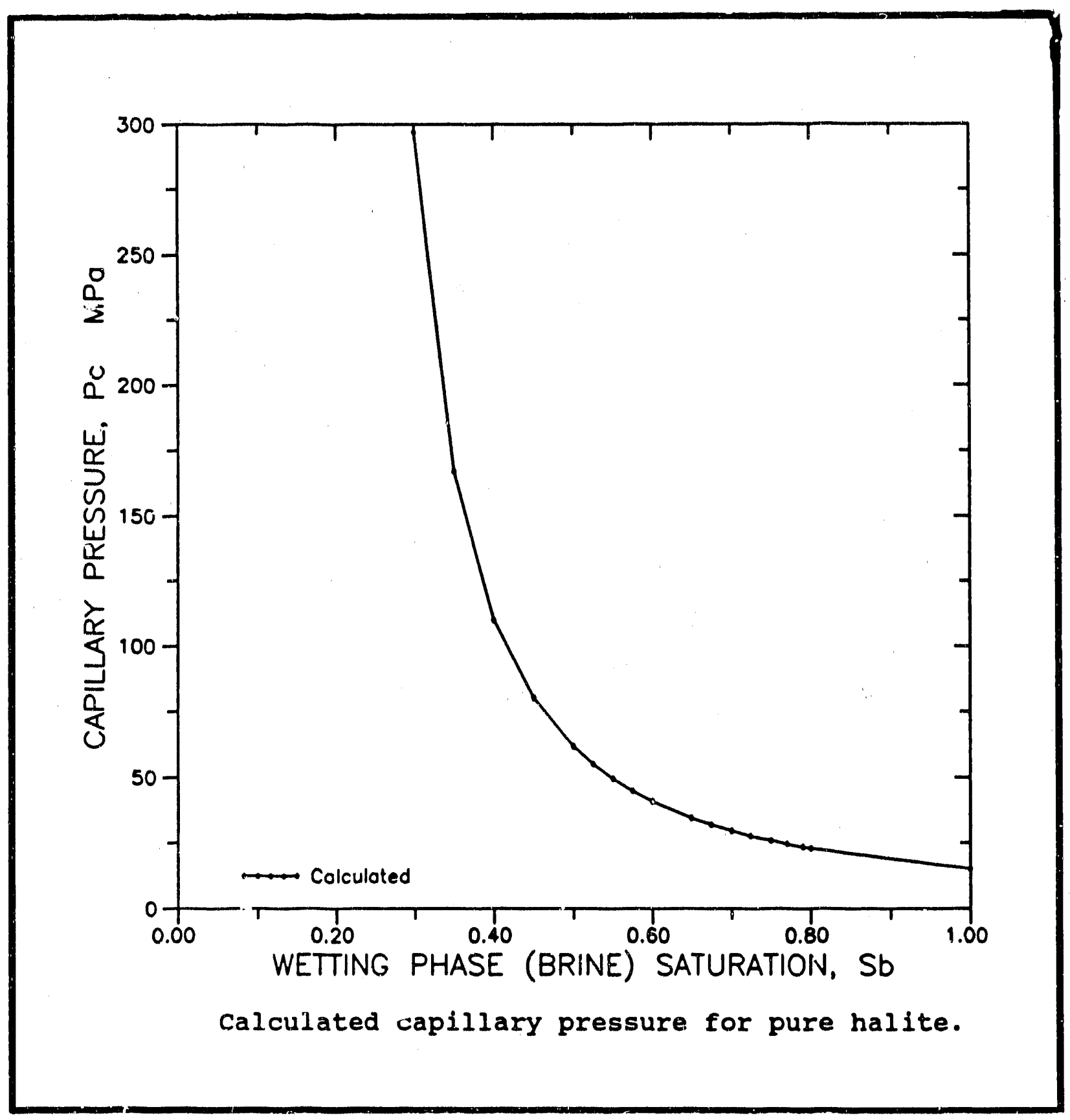


FIGURE 5. Capillary Pressure Curve for Impure Halite

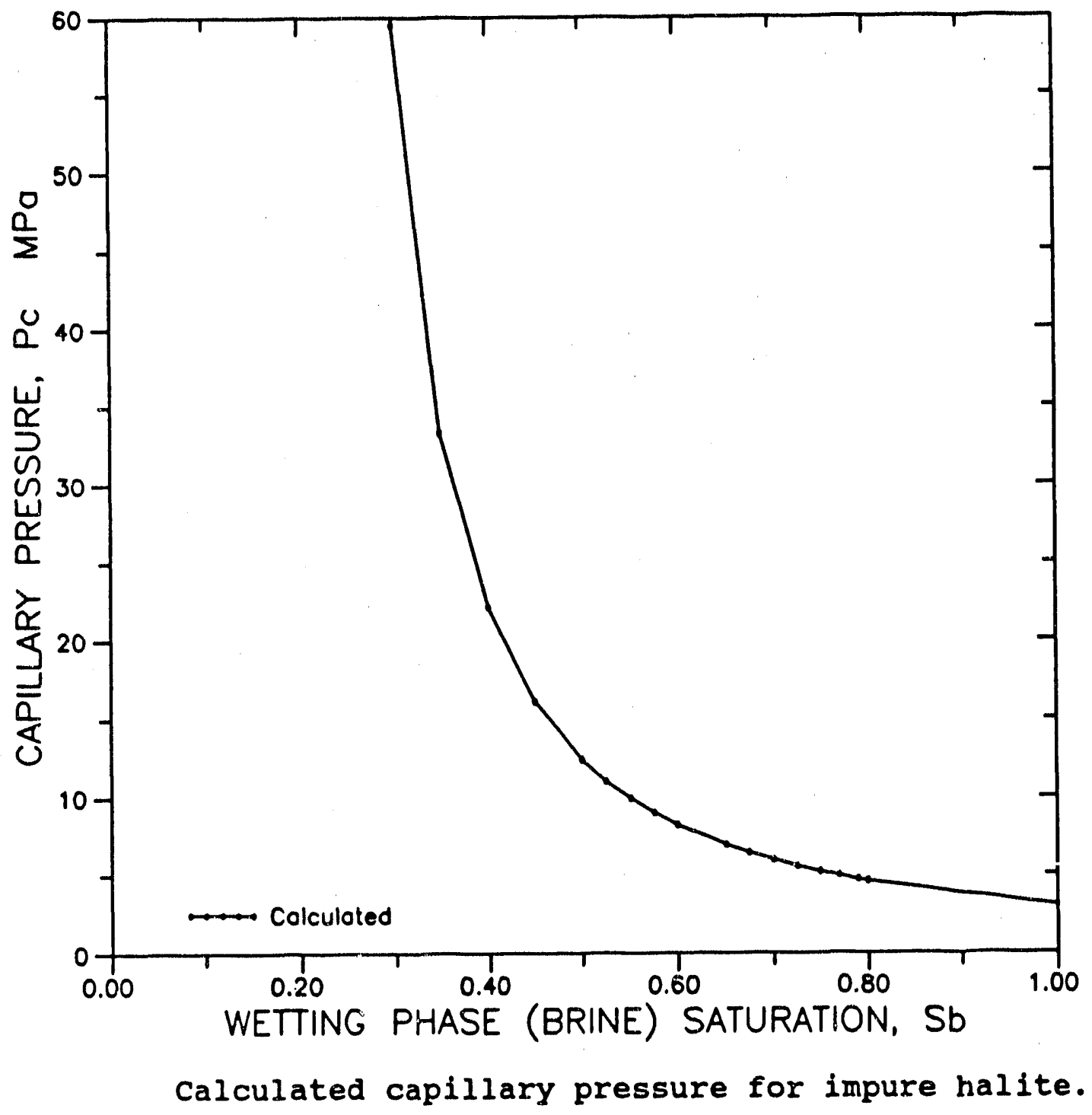


FIGURE 6. Relative Permeability Curves for Waste Disposal Room

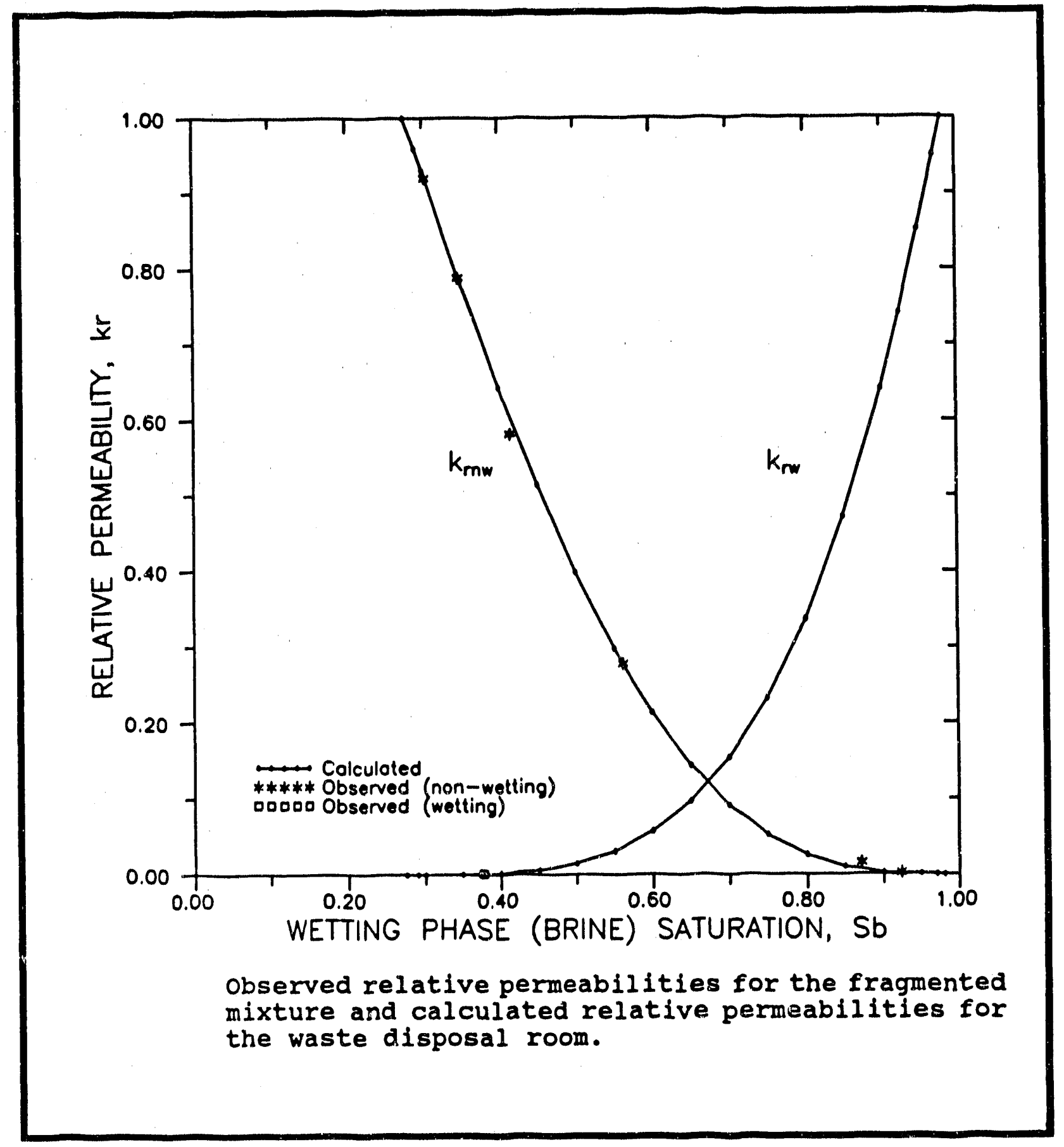


FIGURE 7. Capillary Pressure Curve for Waste Disposal Room

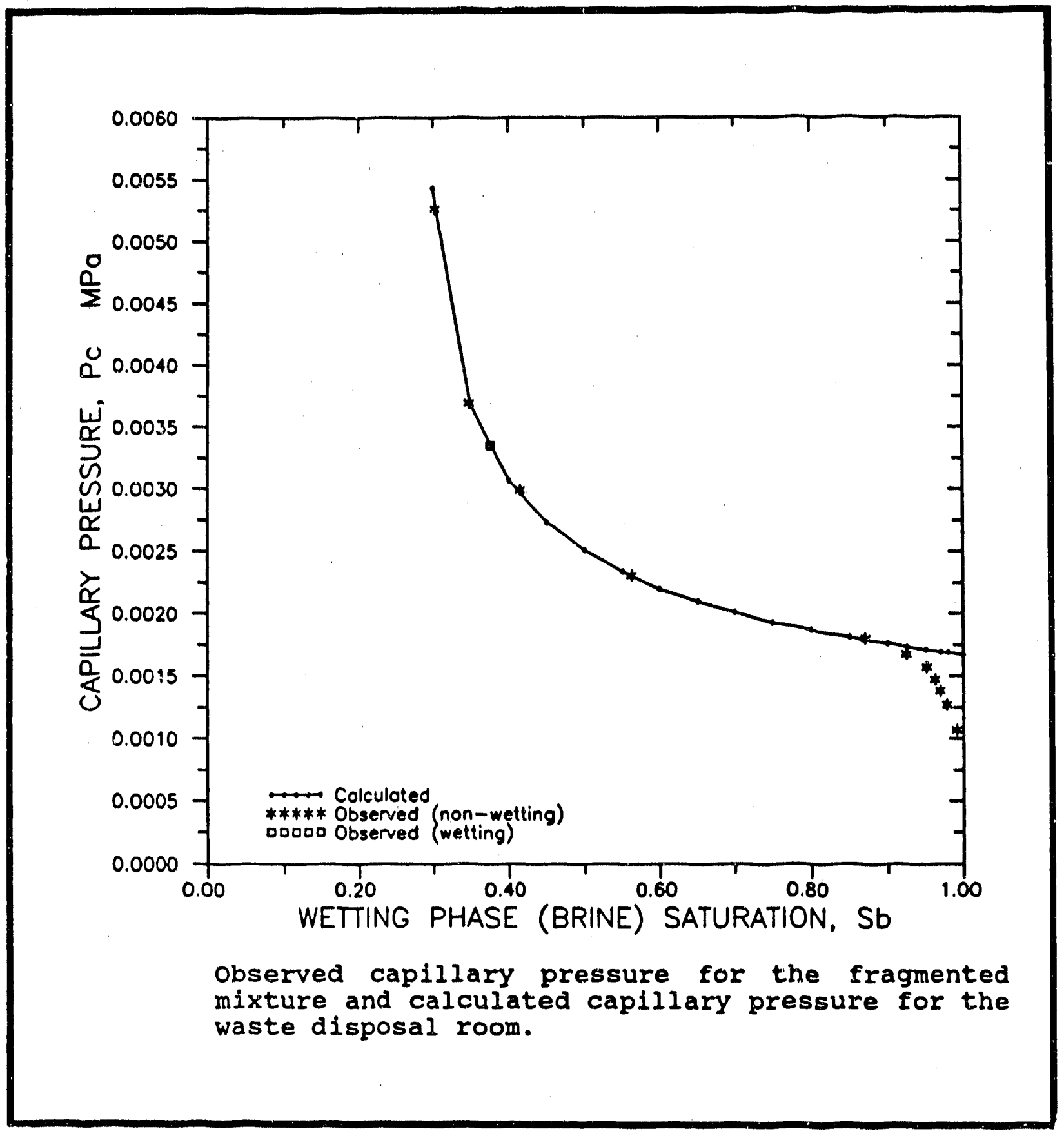


Appendix A

cc: W.D. Weart (6340)

D.R. Anderson (6342)

M.G. Marietta (6342)

E.D. Gorham (6344)

R.L. Beauheim (6344)

S.J. Finley (6344)

S.M. Howarth (6344)

S.W. Webb (6344)

File 5.2 


\section{Letter 1a}

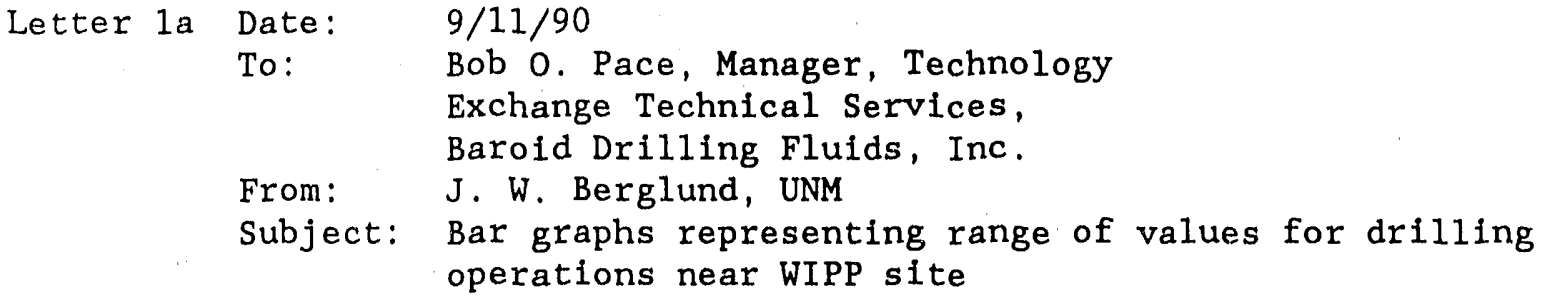




\section{Letter $1 \mathbf{a}$

Bob O. Pace

Manager, Technology Exchange

Technical Services

Baroid Drilling Fluids, Inc.

3000 N. Sam Houston Pkwy. E. (77032)

\section{P.O. Box 1675}

Houston, Texas 77251

\section{Dear Mr. Pace:}

I wish to thank you for the very informative "class" that you gave for us in Albuquerque on current drilling procedures. The information that you provided will be very valuable in assessing the vulnerability of the WIPP repository to a future drillhole intrusion.

As I explained during your seminar we are currently performing a series of calculations that will ultimately determine the probable quantity of radioactive material that would be brought to the ground surface by a drilling operation sometime in the distant future. The variables that have to be considered in such an estimate are quantities such as drill speed and drilling mud properties.

During the last part of the seminar you provided to me some probable ranges for these variables and these are currently being used in our calculations. I have plotted some of the variables as bar graphs and attached them to this letter. To ensure that I have not misinterpreted any of the data that you provided, and to further document our discussion, I would liked to ask you if the attached bar graphs are in your opinion representative of the probable range of values that might be expected for drilling operations at or near the WIPP site. I would greatly appreciate your sending me a note confirming the data given in the graphs or suggesting any appropriate changes. I am also including a WIPP location map and a cross-section of the geology.

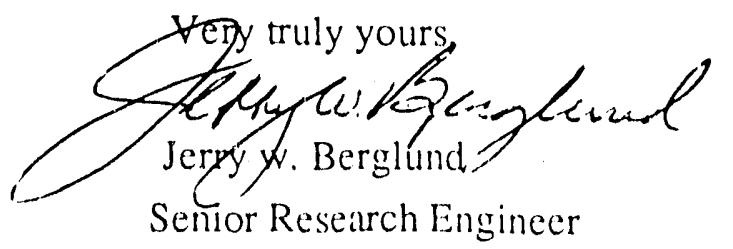




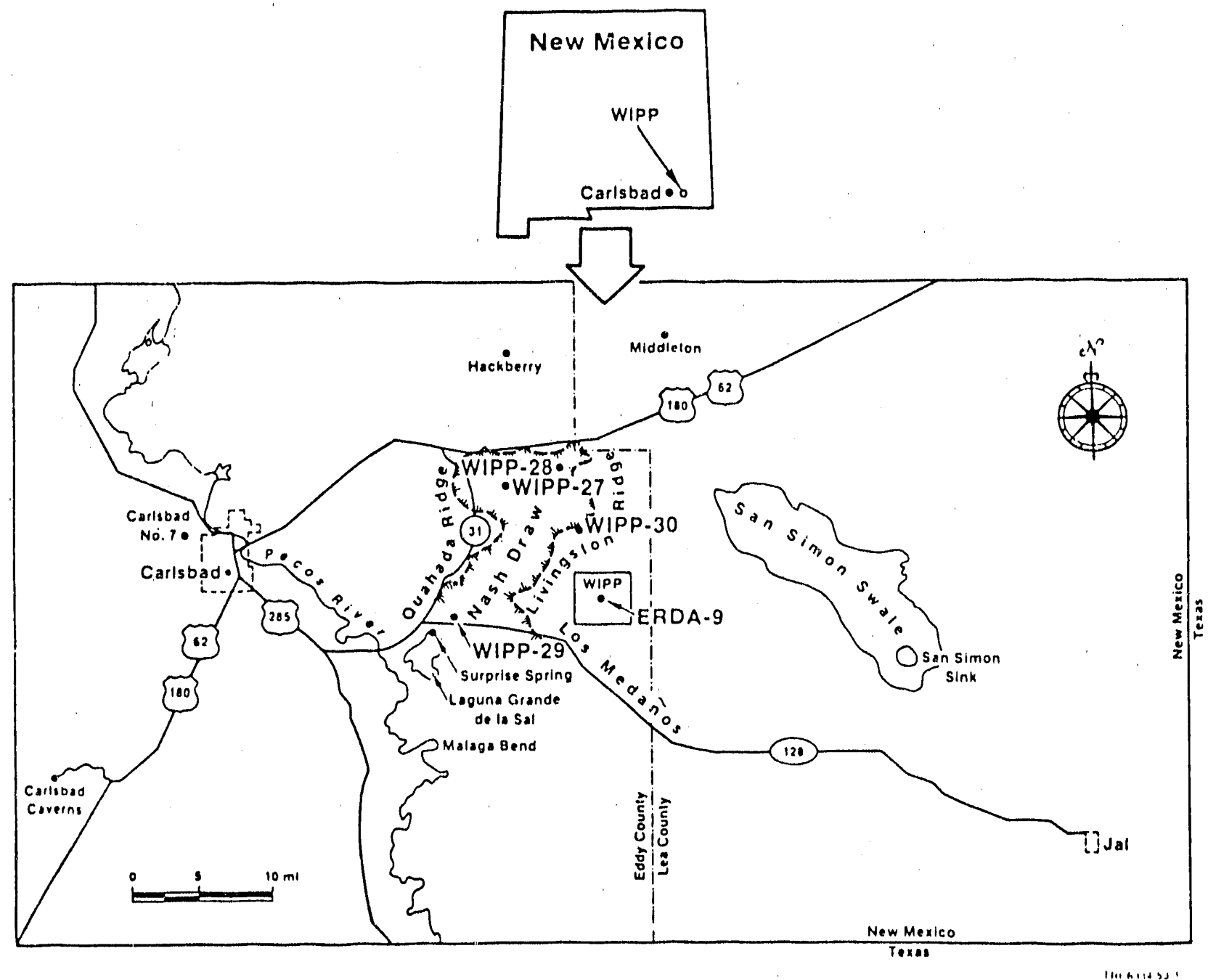

Figure 1-1. WIPP Location in Southeastern New Mexico (after Rechard, 1989). 

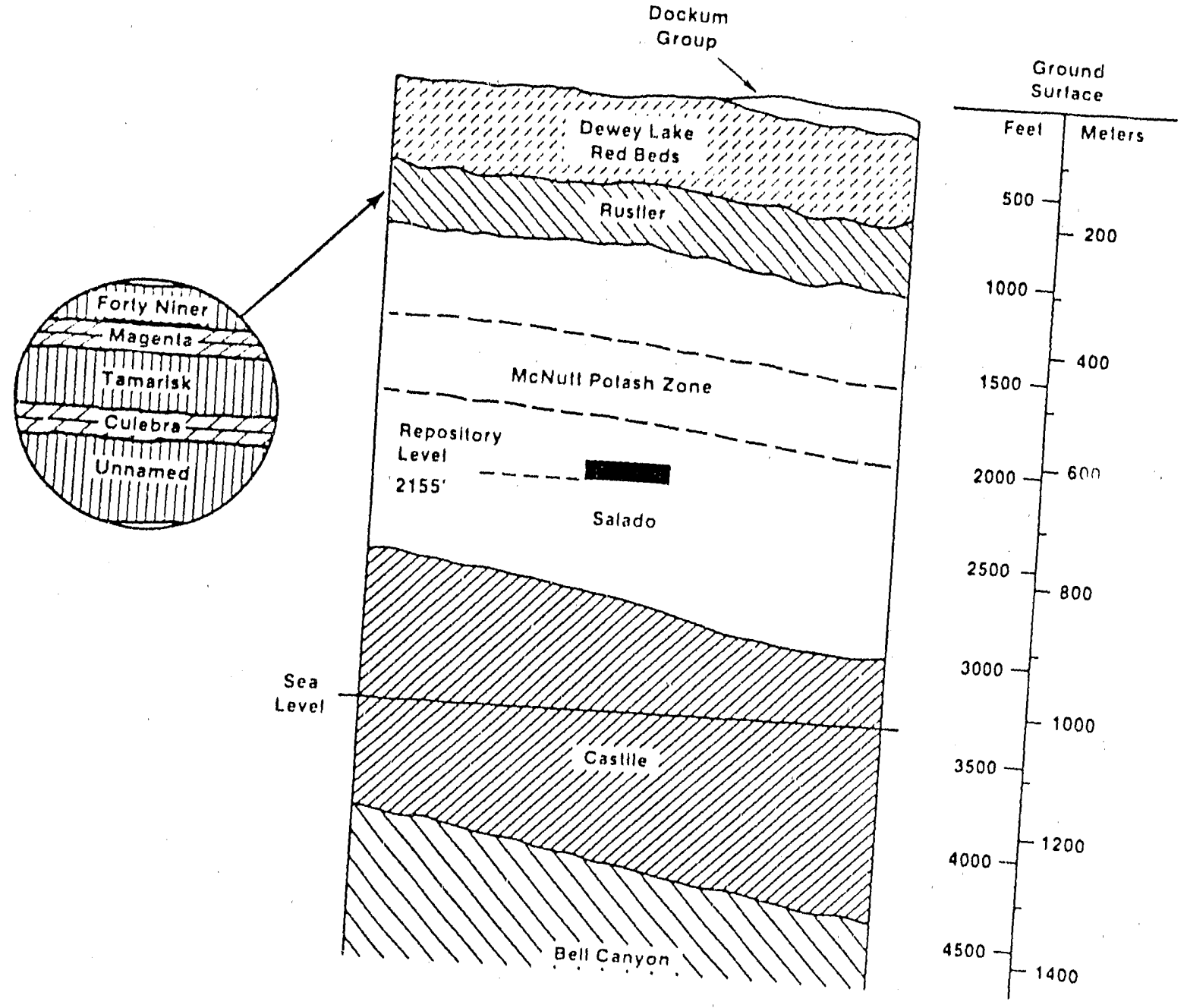

Figure 1-2 Level of WIPP Repository, Located in the Salado Formation. The Salado Formation is
composed of thick halite with thin interbeds of clay and anhydrite deposited as marine
evaporites about 255 million years ago (Permian period) (Rechard, 1989). 
Appendix A Distribution of Drilling Speeds ( $\mathrm{rpm}$ )

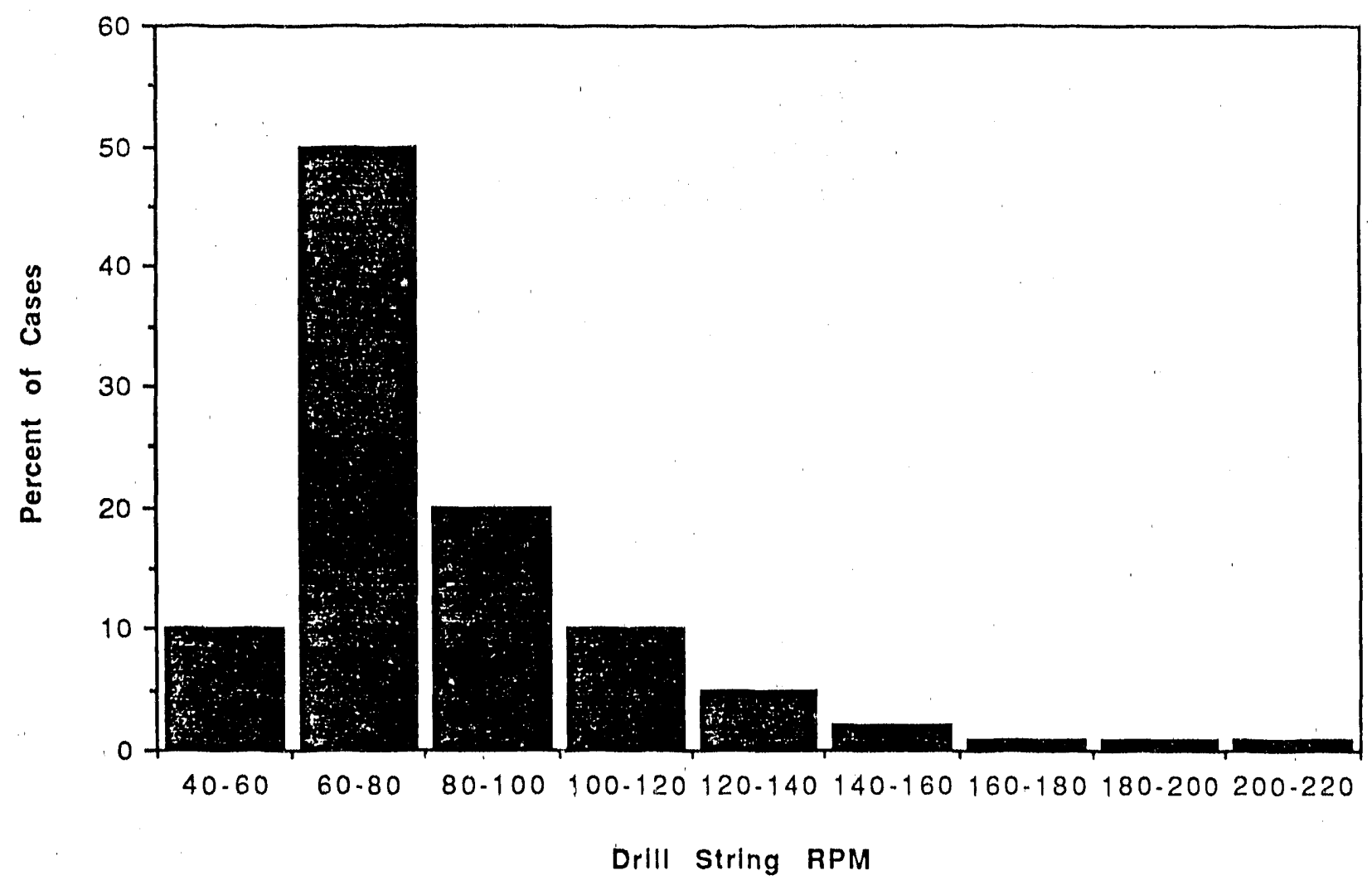

Drilling mud velocity adjacent to collars as a percent of critical velocity

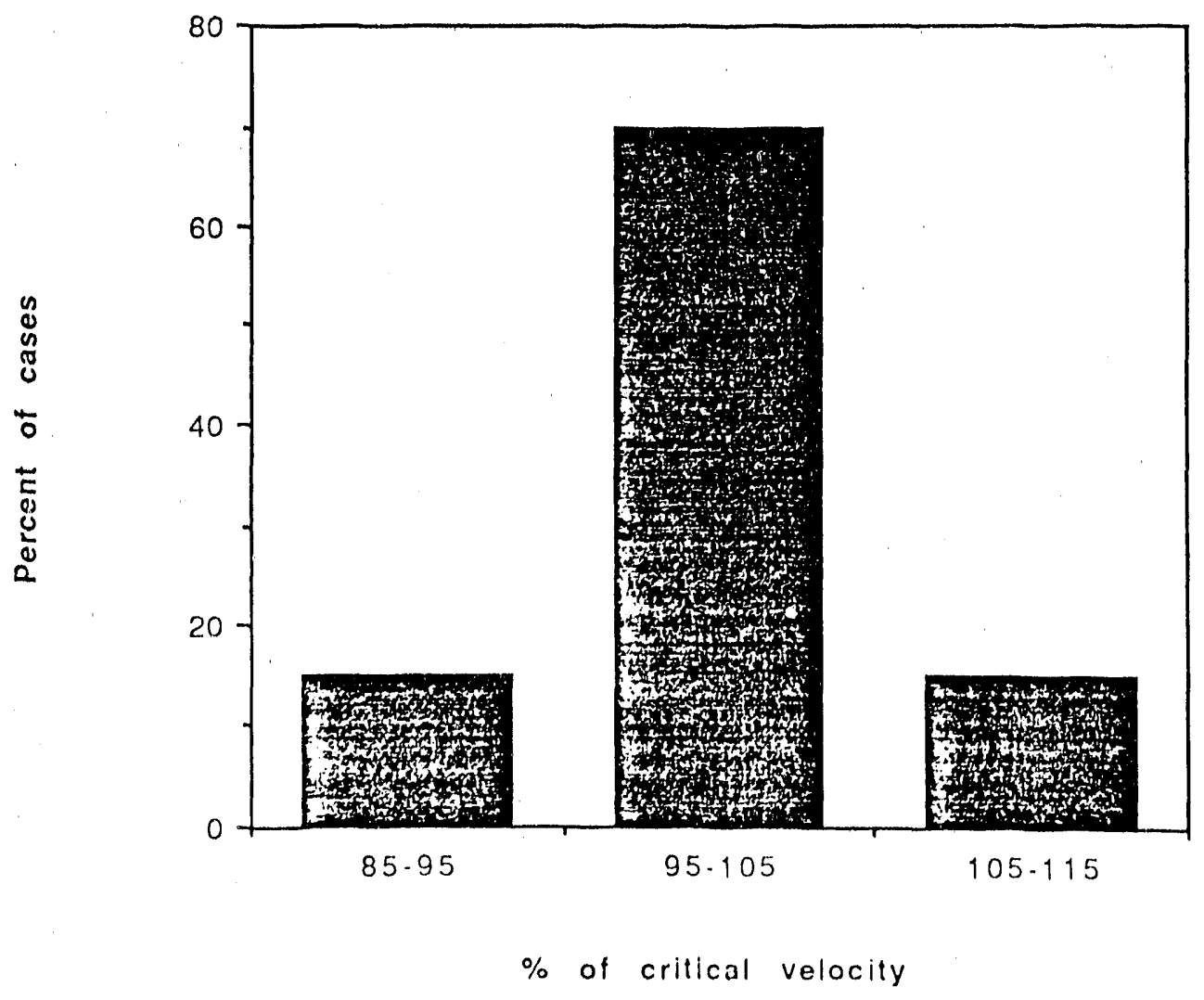


Drilling Mud Yield Point

(mainly saturated brine)

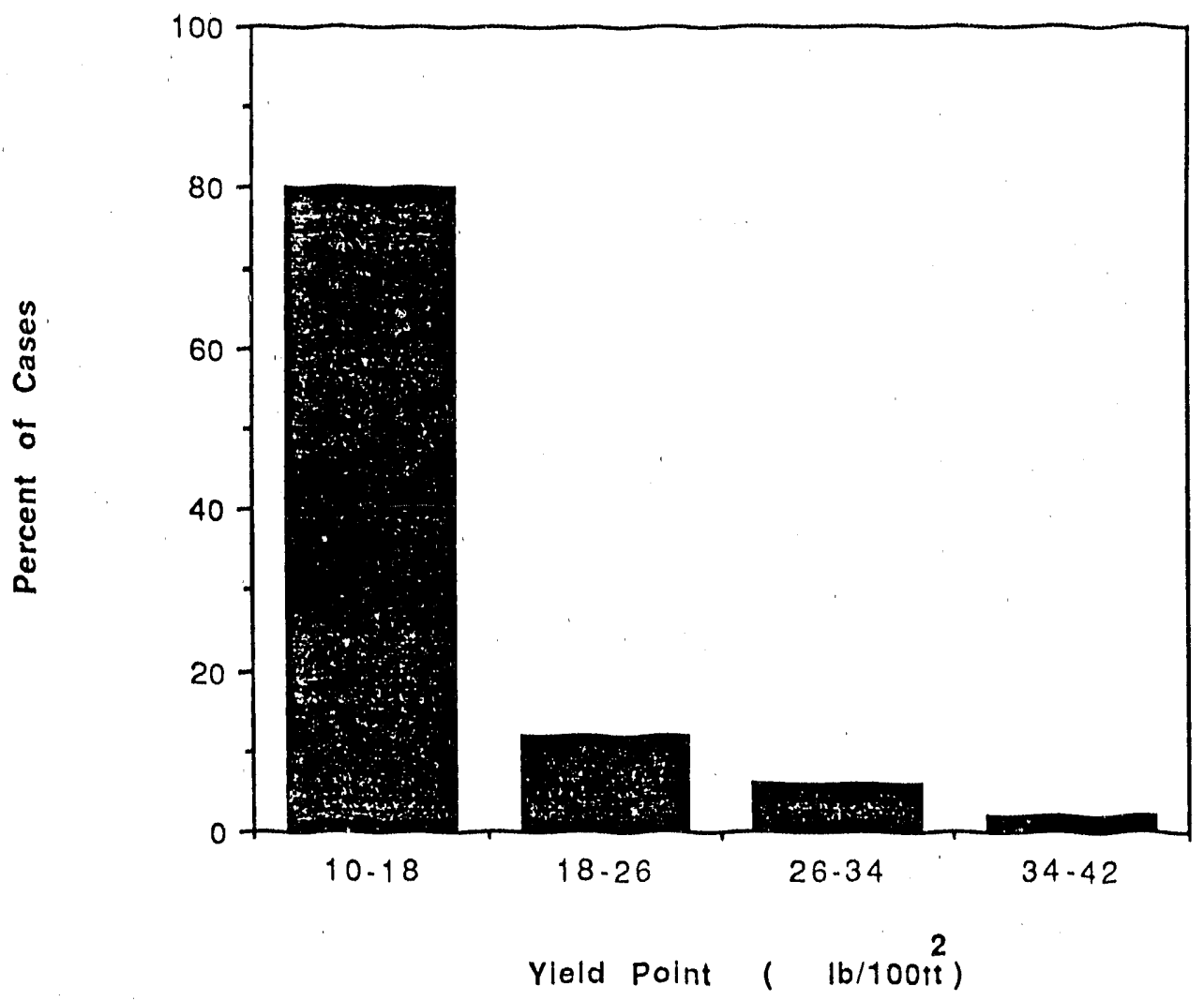

Drilling Mud Plastic Viscosity

(mainly saturated brine)

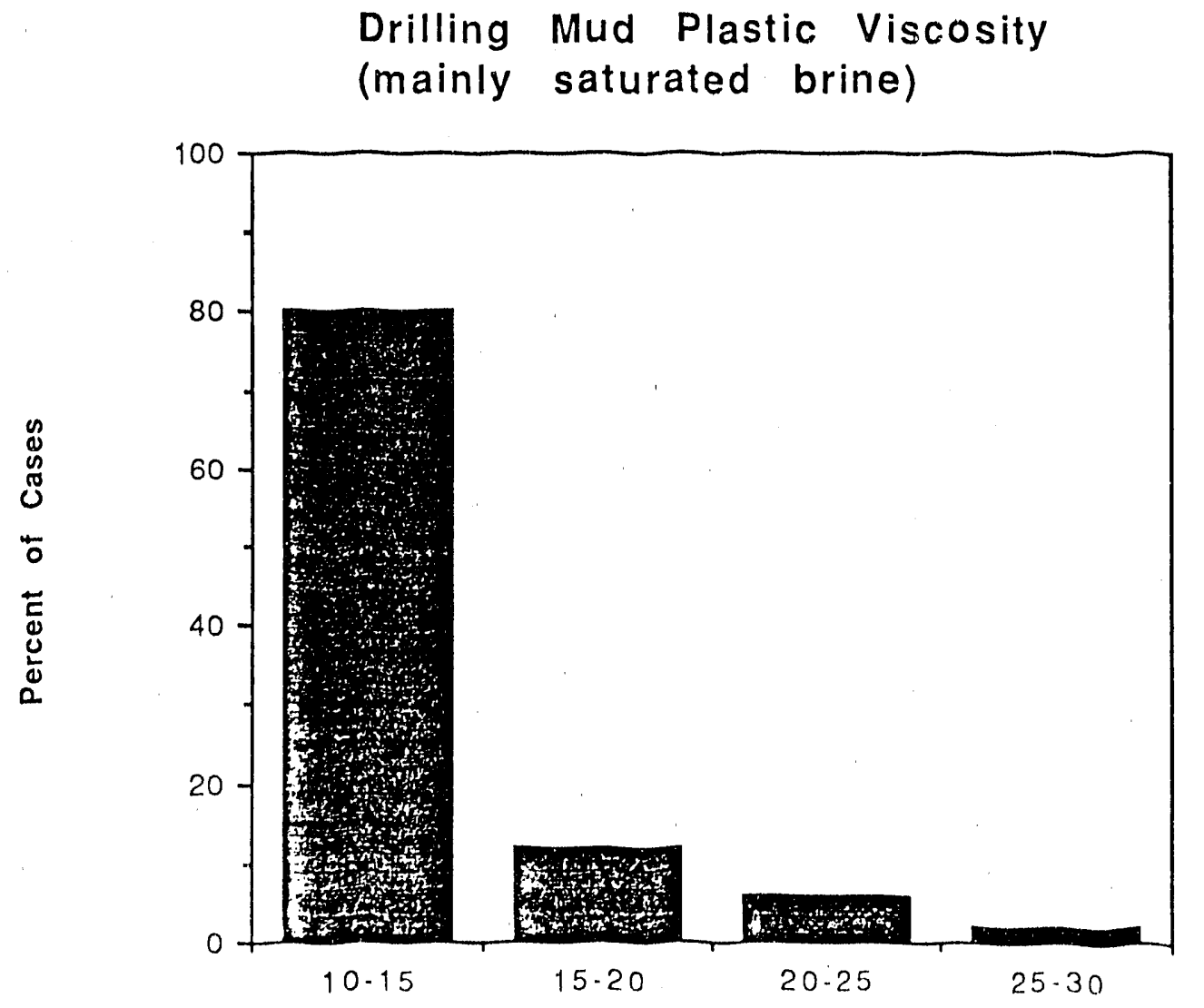

Plastic Viscosity (cp) 
Drilling Mud Density (mainly saturated brine)

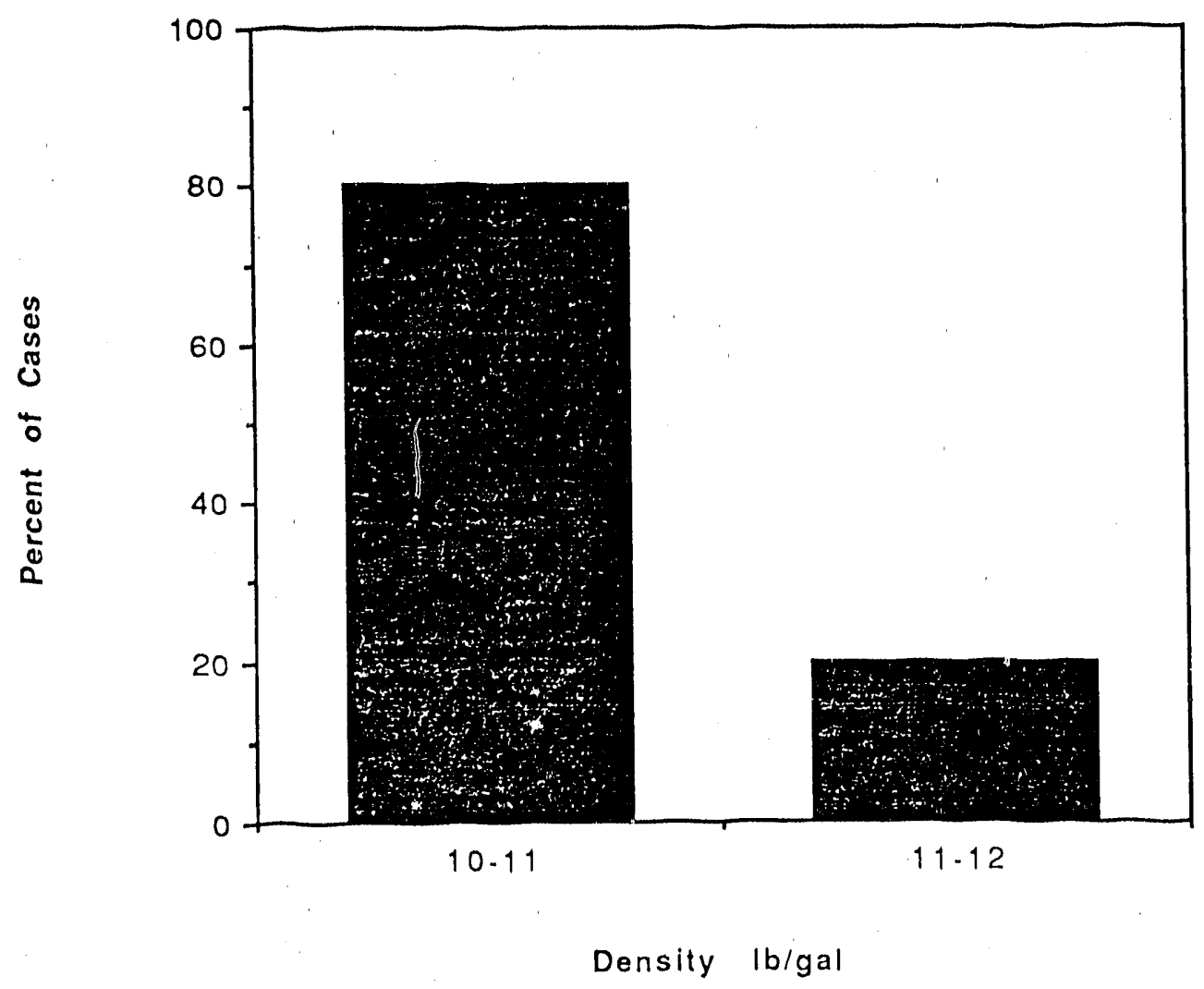




\title{
Letter $1 b$
}

\author{
Lette:: 1b Dite: $\quad 9 / 18 / 90$ \\ J. W. Berglund \\ m: Bob 0. Pace \\ Subject: Changes to bar graphs
}




\section{Baroid Drilling Fluids, Inc.}

Septembe; 18,1990

Jerry W. Berglund

NEW MEXICO ENGINEERING RESEARCH INSTITUTE

Campus Post Office Box 25

Albuquerque, New Mexico 87131

Dear Mr. Berglund:

After talking to one of our field engineers, 1 altered the percentages slightly so that they are closer to what is currently being used.

If I were to look into the immediate future, I think that in the next 10 to 25 years, operating pressures for drilling will rise with an increase in annular velocities being a part of it. I would not be surprised at increases of 100 to 200 percent.

Attached are copies of your slides with my recommended changes.

If I can be of further assistance, please let me know.

Sincerely yours,

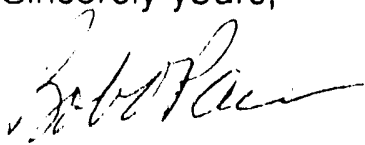

Bob O. Pace

Enc: 


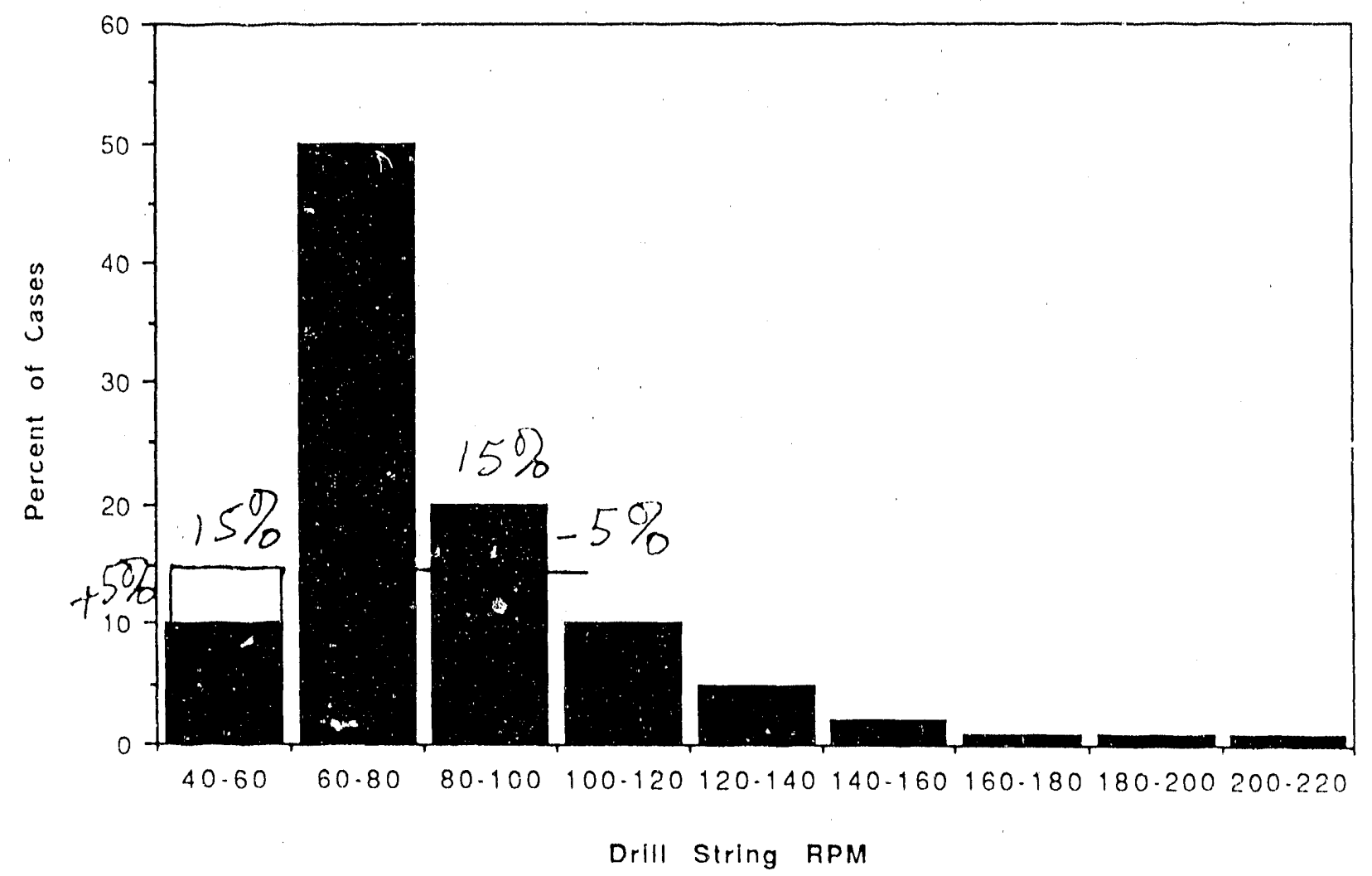

Drilling mud velocity adjacent to collars as a percent of critical velocity

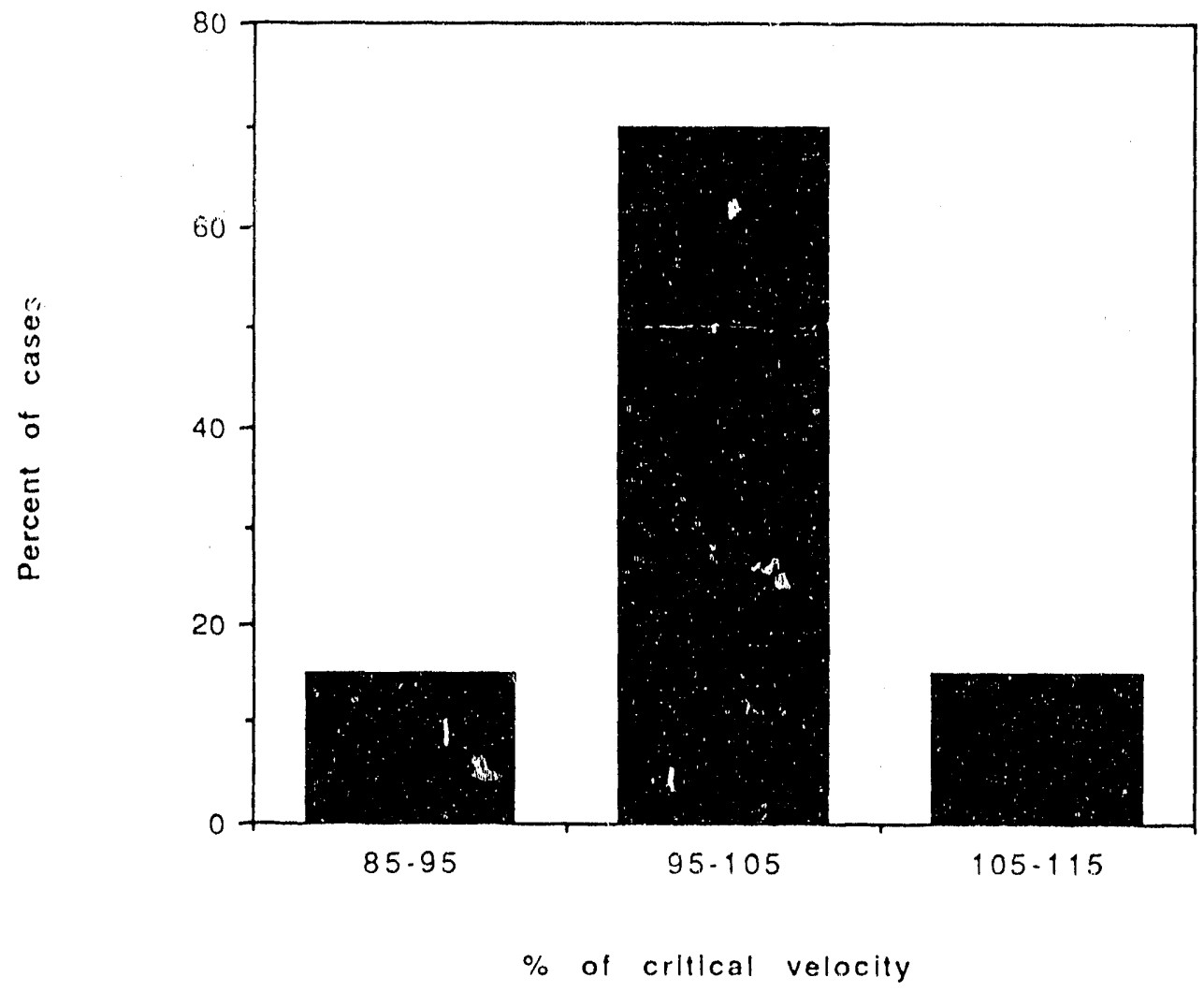


(mainly saturated brine)

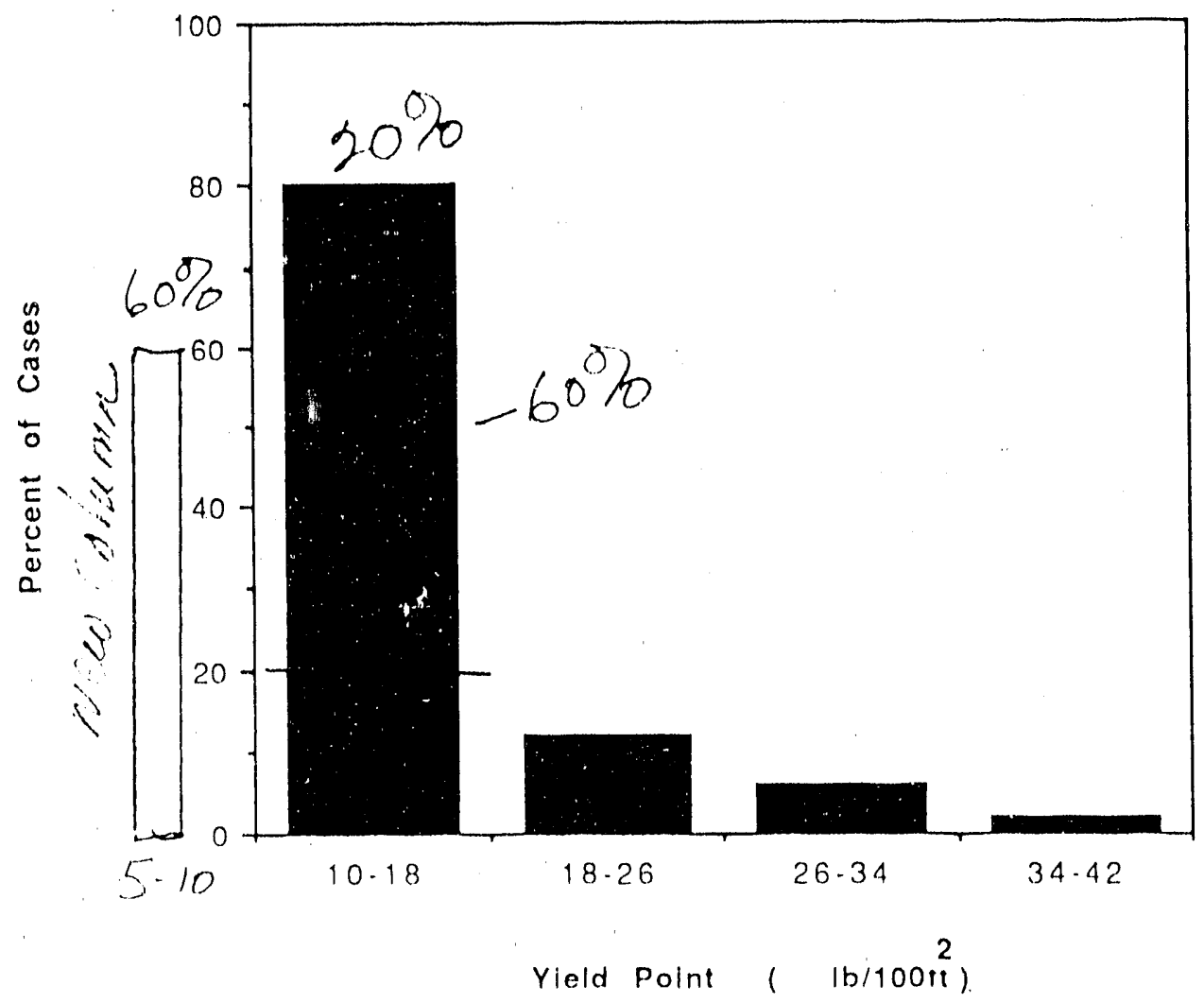

Drilling Mud Plastic Viscosity (mainly saturated brine)

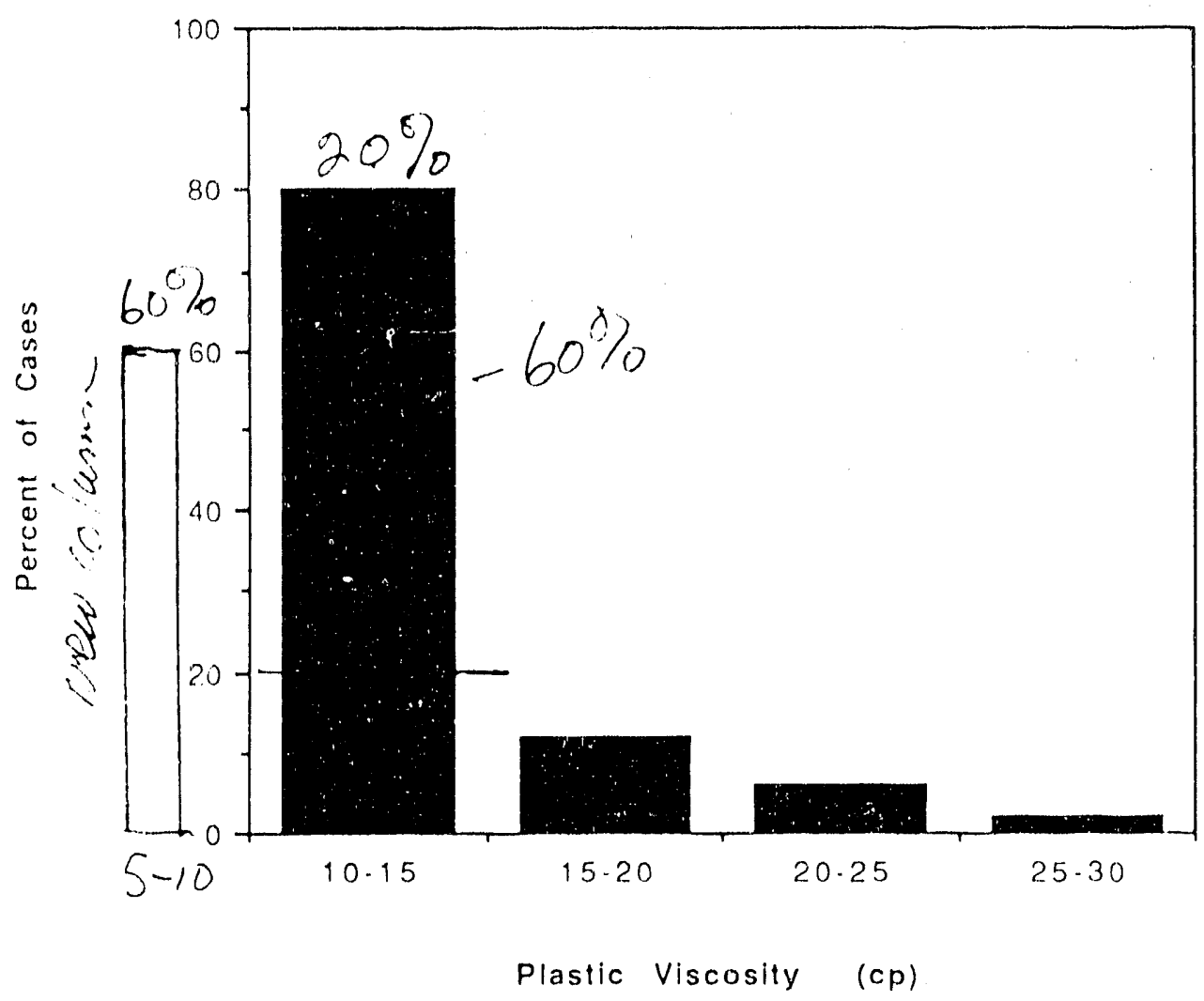


Appendix A

Drilling Mud Density (mainly saturated brine)

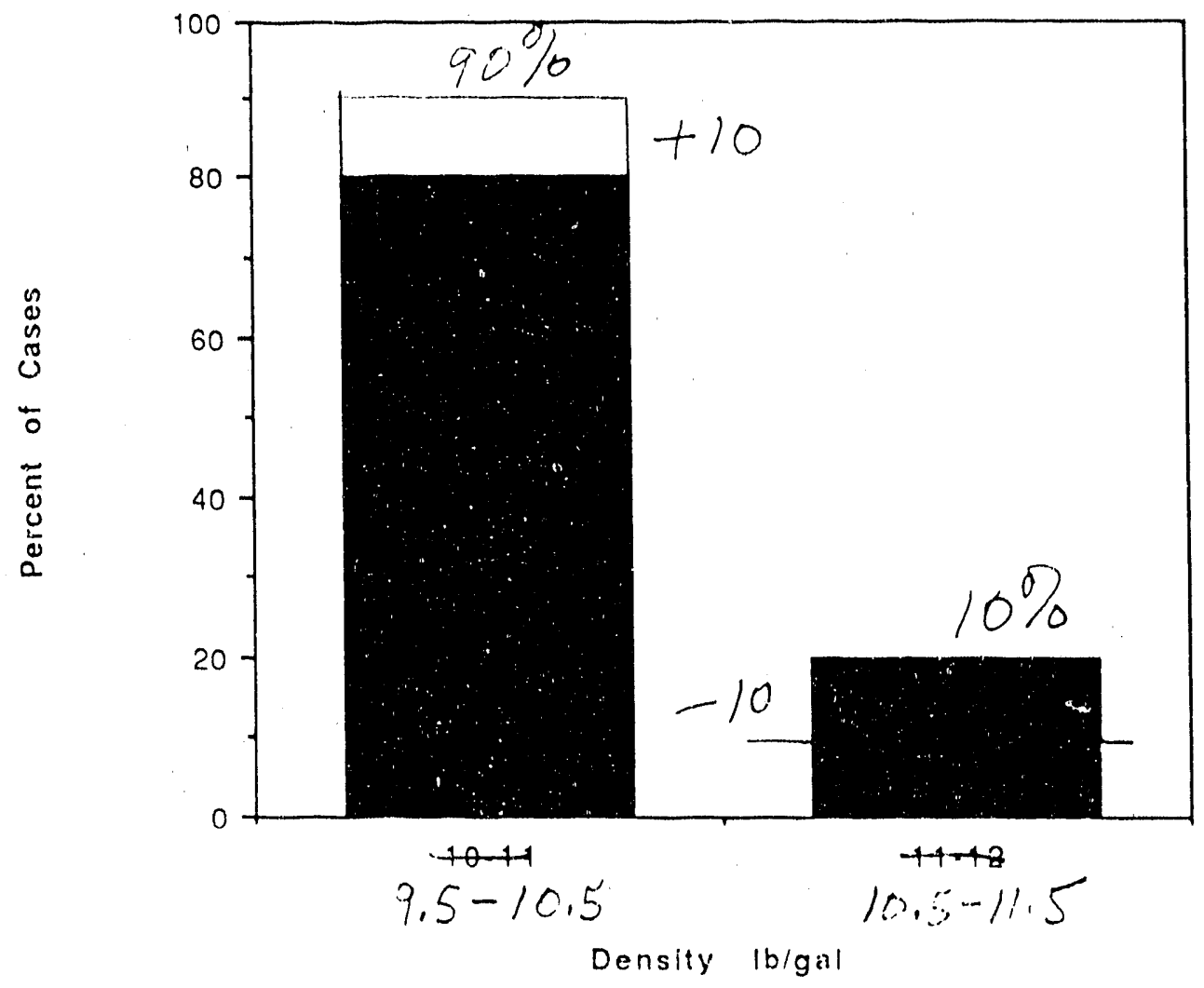

density of the saturated brine

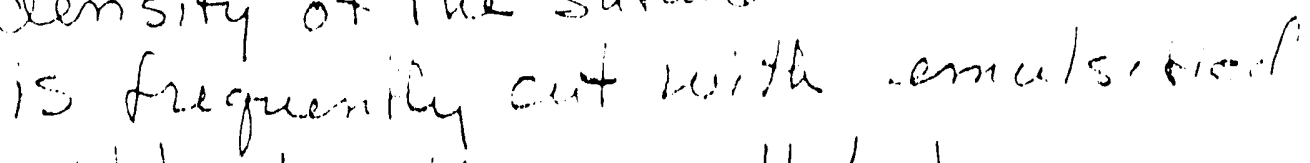
oiltolosilina $1 \mathrm{lb} / \mathrm{gal}$

A -170 


\section{GLOSSARY}

accessible environment - The accessible environment means (1) the atmosphere, (2) land surfaces, (3) surface waters, (4) oceans, and (5) all of the lithosphere that is beyond the controlled area (40 CFR 191.12[k]).

alpha particle - A positively charged particle emitted in the radioactive decay of certain nuclides. Made up of two protons and two neutrons bound together, it is idurtical to the nucleus of a helium atom. It is the least penetrating at the three common types of radiation - - alpha, beta, and gamma."

anhydrite - A mineral consisting of anhydrous calcium sulfate $\left(\mathrm{CaSO}_{4}\right)$. It is gypsum without water, and is denser, harder, and less soluble.

arenaceous - An adjective for rocks that are derived from sand or that contain sand.

argillaceous - Containing clay-sized particles or clay minerals.

backf111 - Material placed around the waste containers, filling the open space in the room.

Bel1 Canyon Formation - A sequence of rock strata that form the topmost formation of the Delaware Mountain Group (Early Permian).

bentonfte - A commercial term applied to clay materials containing montmorillonite (smectite) as the essential mineral.

borehole - A hole drilled from the surface for purposes of jeologic or hydrologic testing, or to explore for resources; sometimes referred to as drillhole.

brine occurrence - Hydraulically isolated stagnant pocket of pressurized fluid in the Castile Formation; also referred to as "brine pocket" or "brine reservoir."

brine pocket - see brine occurrence.

CAMCON - Compliance Assessment Methodology CONtroller; controller (driver) for compliance evaluations developed for the WIPP.

CAMDAT - Compliance Assessment Methodology DATa base; computational data base developed for the WIPP.

capacitance - In hydrology, the combined compressibility of the sollid porous matrix and the fluid within the pores.

Cast:1e Formation - A stratigraphic unit of evaporite rocks (interbedded halite and anhydrite) of Permian period that immediately underlies the Salado Formation (in which the WIPP disposal level is being built). 


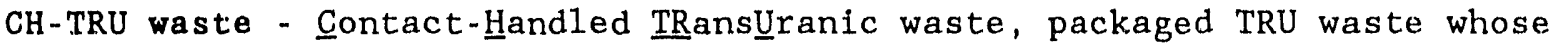
external surface dose rate does not exceed 200 mrem per hour.

complementary cumulative distribution function (CCDF) - One minus the cumulative distribution function.

compressibility - A measure of the ability to be reduced in volume by application of pressure; quantitatively, the reciprocal of the bulk modulus.

conceptual model - The set of hypotheses and data that postulate the description and behavior of the disposal system (e.g., structural geometry, material properties, and all significant physical processes that affect behavior) (Silling, 1983). For WIPP, the data pertinent for a conceptual model are stored in the secondary data base. Several secondary data bases exist because each scenario may have a slightly different conceptual model.

controlled area. - The controlled area means (1.) a surface location, to be identified by passive institutional controls, that encompasses no ore that $100 \mathrm{~km}$ and extends horizontally no more than $5 \mathrm{~km}$ in any direction from the outer boundary of the original location of the radioactive wastes in a disposal system; and (2) the subsurface underlying such a surface location (40 CFR 191.12[g]).

Culebia Dolomite Member - The lower of two layers of dolomite within the Rustler Formation that are locally water bearing.

cumulative distribution function - The sum (integral) of the probability density of frequency values that are less than or equal to a specified value.

Delaware Basin - The part of the Permian Basin in southeastern New Mexico and adjacent parts of Texas where a sea deposited large thicknesses of evaporites some 200 million years ago. It is partially surrounded by the Capitan Reef.

Dewey Lake Red Beds - A formation of the Permian Period that overlies the Rustler Formation and is composed of reddish brown marine mudstones and siltstones interbedded with fine-grained sandstone.

disposal system - Any combination of engineered and natural barriers that isolate spent nuclear fuel or radioactive waste after disposal (40 CFR 191.12(a)). The natural barriers extend to the accessible environment. The WIPP disposal system comprises the underground repository, shafts, and controlled area.

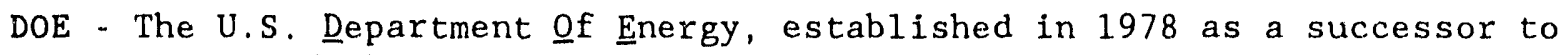
ERDA and the AEC.

drift - A horizontal passageway in a mine. 
E1 - An event used to develop scenarios: intrusion of a borehole through a disposal panel into a pressurized brine occurrence in the Castile Formation, or a simplified notation for a scenario in which event $\mathrm{E} 1$ occurs and other events do not ( $\overline{\mathrm{TS}}, \mathrm{E} 1, \overline{\mathrm{E} 2})$.

E2 - An event: intrusion of a borehole into a disposal panel, or a simplified notation for a scenario in which event E2 occurs and other events do $\operatorname{not}(\overline{\mathrm{TS}}, \overline{\mathrm{E} 1}, \mathrm{E} 2)$.

E1E2 - A scenario: intrusion of a borehole through a disposal panel into a pressurized brine occurrence in the vastile Formation (E1) and another intrusion of a borehole into the same pane1 (E2), without the occurrence of other events. Simplified notation for scenario $\overline{T S}, E 1$, E2, $\overline{\mathrm{E} 3}$.

El'A - Environmental Protection Agency of the U.S. Government.

evaporite - A sedimentary rock composed primarily of minerals produced by precipitation from a solution that has become concentrated by the evaporation of a solvent, especially salts deposited from a restricted or enclosed body of seawater or from the water of a salt lake. In additior, to halite ( $\mathrm{NaCl}$ ) these salts include potassium, calcium, and magnesium chlorides and sulfates.

half-1ife - The time required for the activity of a group of identical radioactive nuclei to decay to half its initial value.

interbeds - Sedimentary beds that 1 ie between or alternate with other beds having different characteristics.

Latin Hypercube Sampling - A Monte Carlo sampling technique that divides the distribution into intervals of equal probabil:ty and samples from each interval.

11thostatic pressure - Subsurface pressure caused by the weight of overlying rock or soil, about $14.9 \mathrm{MPa}$ at the WIPP repository level.

MB139 - Marker Bed 139: One of 45 siliceous or sulfatic units within the Salado Formation consisting of about $1 \mathrm{~m}$ of polyhalitic anhydrite and anhydrite. MB139 is located within the WIPP horizon.

panel - A group of several undergrounc rooms bounded by two pillars and connected by drifts. Within the WIPP, a panel usually consists of seven rooms connected by $10-m$-wide drifts at each end.

performance assessment - The process of assessing the compliance of a deep, geologic, waste repository with the Containment Requirements of 40 CFR 191, Subpart B. Performance assessment is defined by Subpart $B$ as an analysis that (1) identifies the processes and events that might affect the disposal system, (2) examines the effects of these processes and events on the performance of the disposal system, and (3) estimates the 
Glossary

cumulative releases of radionuclides, considering the associated uncertainties, caused by all significant processes and events. These estimates are incorporated into an overall probability distribution of cumulative release to the extent practicable (40 CFR 191.12(q)).

permeability - A measurement of the ability of a rock or soil to allow fluid to pass through it.

Permian Basin - A region in the south-central United States, where during the Permian Period ( 245 to 286 million years ago), there were many shallow sub-basins in which vast beds of marine evaporites were deposited.

polyhalite - An evaporite mineral: $\mathrm{K}_{2} \mathrm{MgCa}_{2}\left(\mathrm{SO}_{4}\right)_{4} \cdot 2 \mathrm{H}_{2} \mathrm{O}$; a hard, poorly soluble mineral.

radioactive waste - Solid, liquid, or gaseous material of negligible economic value that contains radionuclides in excess of threshold quantities.

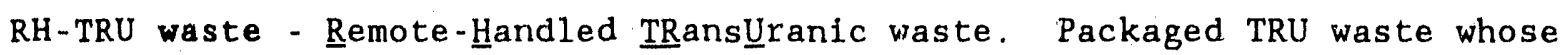
external surface dose rate exceeds 200 mrem per hour, but not greater than 1,000 rem per hour.

room - An excavated cavity underground. Within the WIPP, a room is $10 \mathrm{~m}$ wide, $4 \mathrm{~m} \mathrm{high}$, and $91 \mathrm{~m}$ long.

Rustler Formation - A sequence of Late Permian age clastic and evaporite sedimentary rocks that contains two dolomite marker beds and overlies the Salado Formation.

sealing - Formation of barriers within man-made penetrations (shafts, boreholes, tunnels, drifts).

shaft - A man-made hole, either vertical or steeply inclined, that connects the surface with the underground workings of a mine.

storativity - The volume of water released by an aquifer per unit surface area per unit drop in hydrologic head.

tortuosity - Measurement of actual path of flow through a porous medium.

transmissivity - The rate at which water of the prevailing kinematic viscosity is transmitted through a unit width of the aquifer under a unit hydraulic gradient.

transuranic radioactive waste (TRU Waste) - Waste that, without regard to source or form, is coltaminated with more than $100 \mathrm{nCi}$ of alphaemitting transuranic isotopes with half-lives greater than $20 \mathrm{yr}$, per gram of waste, except for: (1) HLW; (2) wastes that the DOE has determined, with the concurrence of the EPA Administrator, do not need

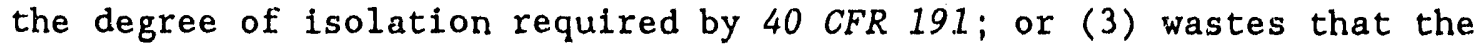
NRC Commission has approved for disposal on a case-by-case basis in accordance with 10 CFR 61. Heads of DOE field organizations can determine that other alpha-contaminated wastes, peculiar to a specific site, must be managed as TRU waste. 


\section{NOMENCLATURE}

\section{MATHEMATICAL SYMBOLS}

A

b

$b_{c}$

$\mathrm{C}^{\circ}$

c

$D^{\circ}$

D*

g

K

$\mathrm{K}_{\mathrm{d}}$

$\mathrm{k}$

$\mathrm{k}_{\mathrm{rg}}$

$\mathrm{k}_{\mathrm{rw}}$

$\ell$

M

$\mathrm{p}$

R

$R_{m}, R_{f}$

$\overline{\mathrm{K}}$

S

$\mathrm{S}_{\mathrm{S}}$

$\mathbf{s}$
- cross-sectional area $\left(\mathrm{m}^{2}\right)$

- fracture aperature

- thickness of minerals lining boths sides of fracture

- solubility mass fraction $(\mathrm{kg} / \mathrm{kg}) ; \overline{\mathrm{C}}^{\circ}$ solubility concentration $\left(\mathrm{kg} / \mathrm{m}^{3}\right)$

- capacitance $\left(\mathrm{S}_{\mathrm{S}} / \gamma\right)\left(\mathrm{Pa}^{-1}\right)$

- molecular diffusion in fluid $\left(\mathrm{m}^{2} / \mathrm{s}\right)$

- molecular diffusion in porous media $\left.\left(\mathrm{m}^{2} / \mathrm{s}\right) D^{*}=r D^{\circ}\right)$

- gravity constant, $9.79 \mathrm{~m} / \mathrm{s}^{2}$ at repository level

- hydraulic conductivity $(\mathrm{m} / \mathrm{s})$

- partition (or distribution) coefficient $\left(\mathrm{m}^{3} / \mathrm{kg}\right)$

- permeability $\left(\mathrm{m}^{2}\right)$

- relative permeability for gas

- relative permeability for water

- length

- molecular weight

- pressure (Pa)

- retardation

- retardation of matrix and fracture, respectively

- universal gas constani

- coefficient of storage

- specific storage coefficient $\left[\mathrm{m}^{-1}\right]$

- saturation 


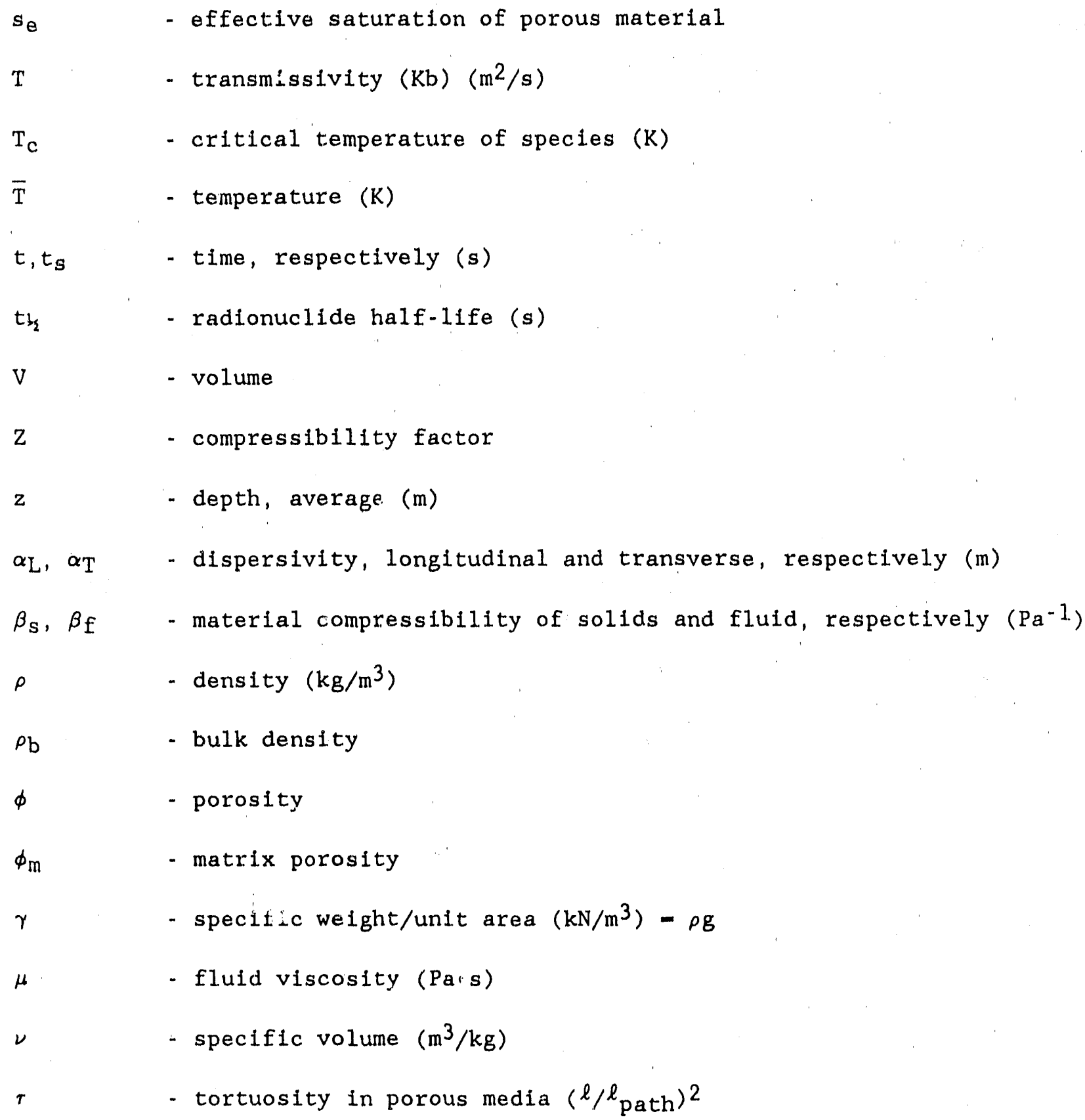



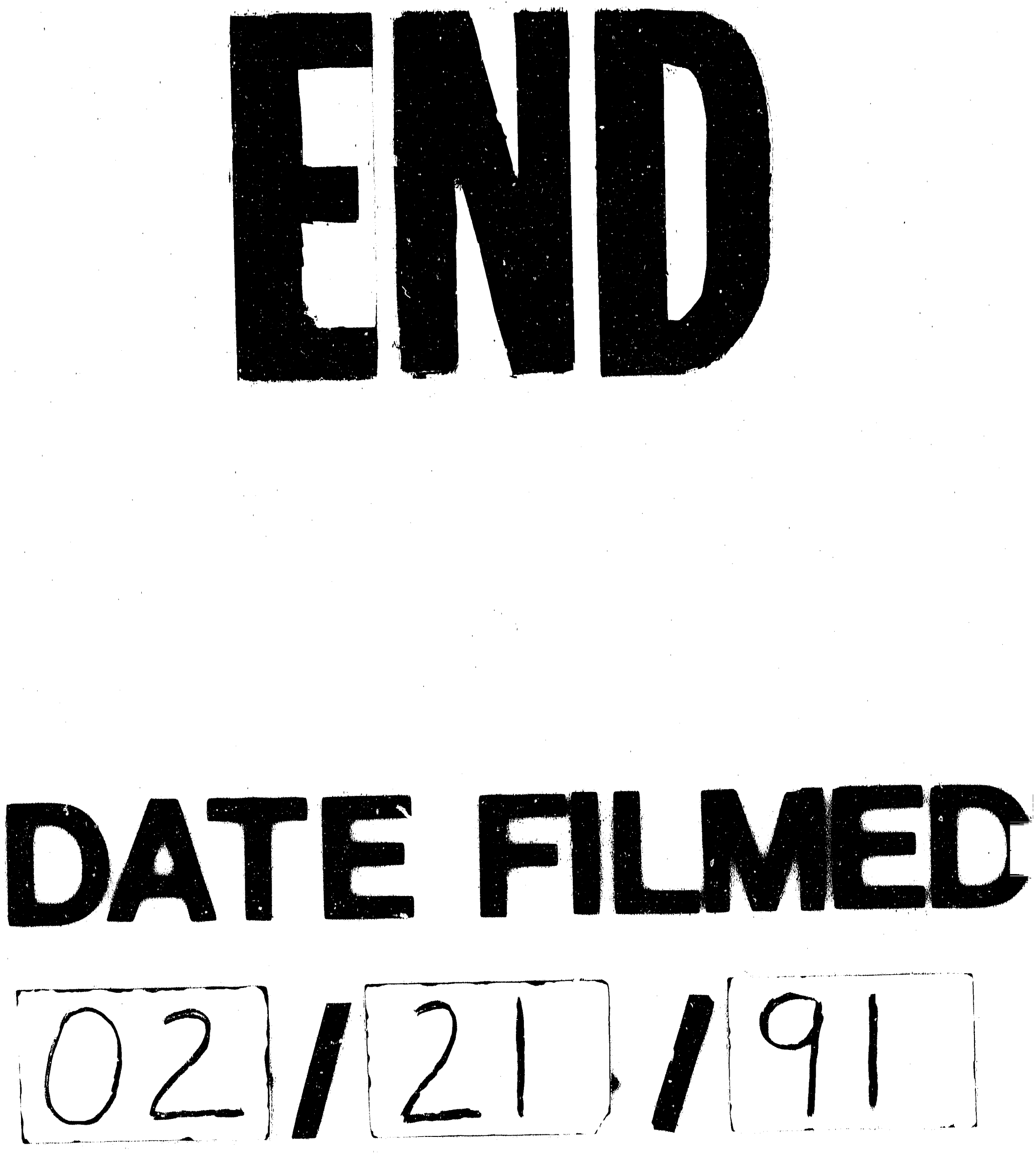
